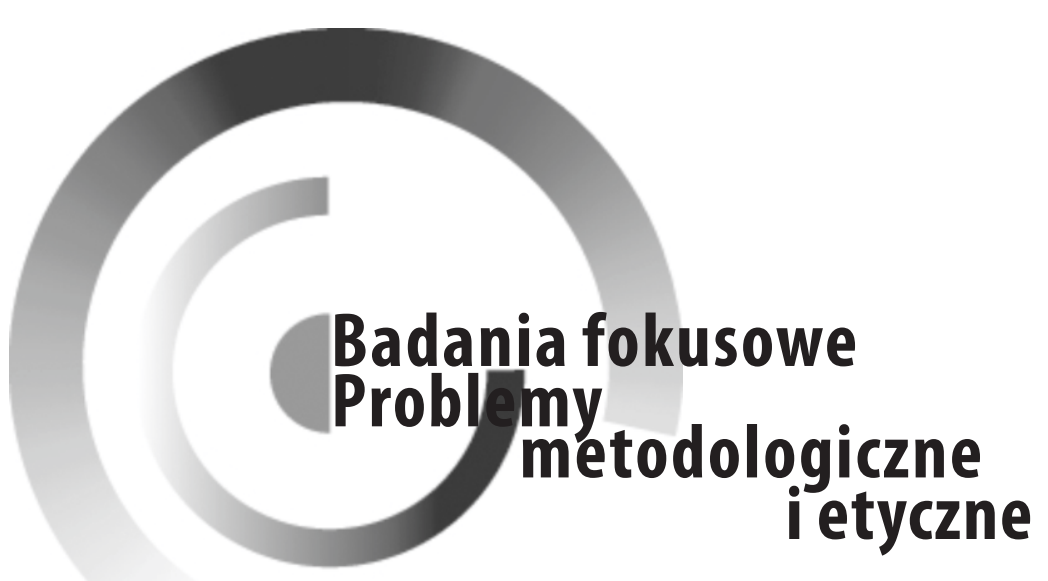


$\frac{3}{40}$ 


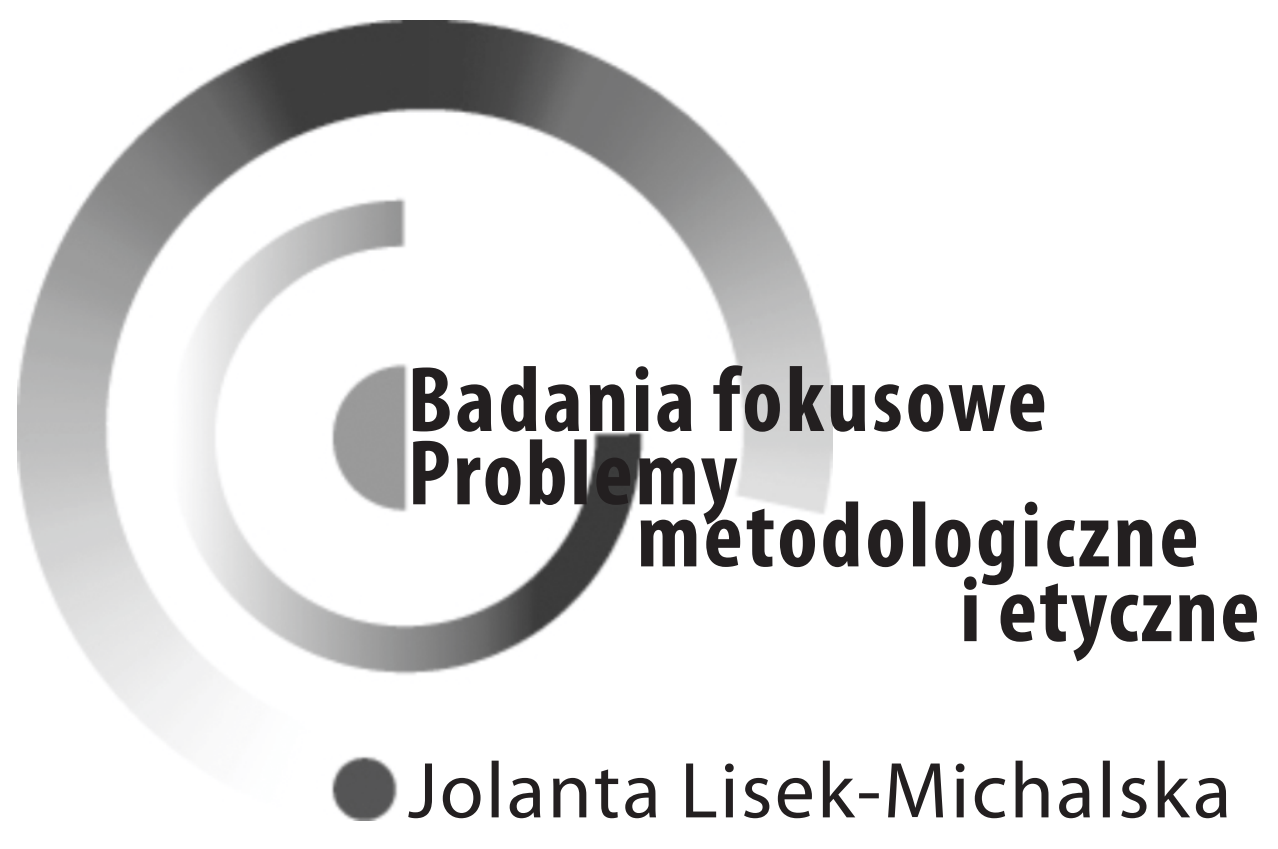

kÓDŹ 2013 
Jolanta Lisek-Michalska - Katedra Metod i Technik Badań Społecznych

Uniwersytet Łódzki, 90-214 Łódź, ul. Rewolucji 1905 r., nr 41/43

\section{RECENZENT}

Mieczysław Gałuszka

REDAKCJA JĘZYKOWA

Magdalena Kqqcicka

SKŁAD I ŁAMANIE

Magdalena Kqqcicka

PROJEKT OKŁADKI

Dorota Jary

Wydrukowano z gotowych materiałów dostarczonych do Wydawnictwa Ut

(C) Copyright by Uniwersytet Łódzki, Łódź 2013

Wydane przez Wydawnictwo Uniwersytetu Łódzkiego

Wydanie I. W.06250.13.0.H

ISBN (wersja drukowana) 978-83-7525-896-7

ISBN (ebook) 978-83-7969-347-4

Wydawnictwo Uniwersytetu Łódzkiego

90-131 Łódź, ul. Lindleya 8

www.wydawnictwo.uni.lodz.pl

e-mail:ksiegarnia@uni.lodz.pl

tel. (42) 66558 63, faks (42) 6655862 
mojemu Synowi 



\section{WSTȨP}

Praktyka badań fokusowych ${ }^{1} \mathrm{w}$ Polsce ma już ponad dwudziestoletnią historię. Po sukcesach, jakie fokus odniósł w naszym kraju w latach dziewięćdziesiątych w dziedzinie badań rynkowych, ugruntował także swoją pozycję w repertuarze warsztatowym nauk społecznych, w tym socjologii. Pomimo wielkiej ilości badań z wykorzystaniem tej metody, tylko dla nielicznych polskich badaczy² zogniskowany wywiad grupowy stał się obiektem pogłębionej refleksji metodologicznej.

Celem tej książki jest choćby częściowe uzupełnienie braków w tym zakresie. Wprawdzie tytuł sugeruje, że jest ona poświęcona w sposób symetryczny zarówno metodologii, jak i etyce badań fokusowych, ale zdecydowanie punkt ciężkości został położony na kwestie etyczne. Jest to zabieg celowy, wynikający z trzech przesłanek. Po pierwsze, problemy metodologii badań fokusowych zostały szczegółowo rozpoznane przez licznych autorów, głównie amerykańskich — odwołania do wielu spośród nich znajdzie Czytelnik w tej książce. Po wtóre, w zogniskowanym wywiadzie grupowym, ze względu na jego specyfikę, występuje wyjątkowo wiele elementów „etycznie wrażliwych" i są one znacznie bardziej złożone, niż ma to miejsce w przypadku innych metod badawczych. Tym samym zasługują na wnikliwą uwagę. Po trzecie wreszcie, jest to rezultat przekonania, iż postawa etyczna badacza w przypadku badań fokusowych w znacznym stopniu determinuje ich metodologię. Jest to antyteza wobec obowiązującego przez kilkadziesiąt lat pozytywistycznego podejścia do uprawiania badań w naukach społecznych, w którym dla rozważań o charakterze etycznym nie było miejsca. Motto tego modelu sprowadzało się do stwierdzenia: „Moja etyka to moja metodologia". (Amsterdamski, 1983, s. 134-135)

\footnotetext{
${ }^{1}$ Autorka traktuje synonimicznie określenia fokus, zogniskowany wywiad grupowy i FGI.

2 Zob. np.: Nawrocki, 1996; Nikodemska-Wołownik, 1999; Maison, 2001; Malinowski, 2004; Lisek-Michalska, Daniłowicz, 2004; Lisek-Michalska i in., 2012.
} 
W następnych latach kwestie etyki badań były podejmowane raczej jako swoiste didaskalia refleksji metodologicznych, skoncentrowanych głównie na metodach standaryzowanych. Znakomitym tego przykładem są chociażby prace socjologów reprezentujących łódzką szkołę metodologiczną Krystyny Lutyńskiej (Lutyńska, 1993), Zygmunta Gostkowskiego (Gostkowski, 1992), Anny Kubiak (Kubiak i in., 1992), Andrzeja W. Rostockiego (Rostocki, 1992), Krzysztofa Kistelskiego (Kistelski, 1985). Ich analizy weryfikacyjne, mimo że skupione na wartości uzyskiwanych informacji, uzupełniały obraz metody (w tym wypadku - wywiadu kwestionariuszowego) namysłem nad człowiekiem - podmiotem badań w kategoriach jego godności i autonomii. Przyjęta $w$ tej książce perspektywa natomiast łączy na równorzędnych prawach obydwa aspekty - metodologiczny i etyczny. Takie podejście z jednej strony stanowi logiczną konsekwencję procesu rozwoju metod badawczych, a z drugiej strony wpisuje się w analityczną tradycję łódzkiej szkoły metodologicznej, z której Autorka się wywodzi. Jednak nade wszystko stanowi ono rezultat przemyśleń własnych i wieloletnich doświadczeń empirycznych zarówno badawczych $^{3}$, jak i dydaktycznych ${ }^{4}$. Naturalnie ujawnia także wprost przyjętą humanistyczną, podmiotową koncepcję badanego jako podmiotu w pełni autonomicznego i kreatywnego.

Przyznanie etyce badań fokusowych takiego samego znaczenia jak ich metodologii, wymagało przedstawienia dwóch obszarów problemowych. W rozdziale I starano się zatem możliwie dokładnie i szczegółowo zrekonstruować metodę zogniskowanego wywiadu grupowego, przyjmując za oś opisu poszczególne elementy procedury badawczej. Odniesiono się tutaj także do powszechnie panujących stereotypów dotyczących badań fokusowych oraz dokonano porównania zogniskowanego wywiadu grupowego z wybranymi elementami wywiadu indywidualnego i badań surveyowych. Rozdział II z kolei stanowi przegląd regulacji etycznych zawartych w rozmaitych kodeksach postępowania badawczego, szczególnie tych, które są obligatoryjne dla naukowych badań społecznych i socjologicznych. Zasygnalizowano tu także problemy etyczne charakterystyczne dla innych niż fokus metod badawczych. Wreszcie w rozdziale III połączono obie per-

\footnotetext{
${ }^{3}$ Przez lata fascynacji fokusem Autorka zrealizowała kilkadziesiąt badań fokusowych od fazy konceptualnej poczynając, poprzez ich realizację, na opracowaniu raportów kończąc. Miała okazję moderować kilkaset sesji FGI z przedstawicielami bardzo licznych i zróżnicowanych kategorii społecznych, którzy dyskutowali o bardzo odmiennych zagadnieniach. Wykorzystane w tej pracy przykłady badań w znakomitej większości zaczerpnęła z własnej praktyki badawczej.

${ }^{4}$ Od kilku lat Autorka prowadzi zajęcia warsztatowe poświęcone metodzie FGI. Trudności i wątpliwości, z jakimi zmagają się studenci realizujący badania fokusowe, stawiane przez nich pytania, stanowiły istotną inspirację zarówno do przemyślenia rozmaitych aspektów zogniskowanego wywiadu grupowego, jak i do napisania tej książki.
} 
spektywy i zanalizowano poszczególne elementy składowe badań fokusowych przez pryzmat potencjalnych problemów etycznych. Starano się wykazać, w jaki sposób i w jakim stopniu dokonywane przez badacza wybory etyczne modyfikują samą metodę. Osobne miejsce w tej pracy zajmuje - wsparta licznymi ilustracjami empirycznymi - refleksja na temat badań fokusowych prowadzonych z jedną z najbardziej wrażliwych etycznie kategorii społecznych, mianowicie z dziećmi i młodzieżą. Kwestii tej poświecony jest rozdział IV. Ostatni rozdział ma zaś na celu prezentację potencjału badań fokusowych w zakresie analiz etyczno-metodologicznych dotyczących sposobów badania osób starszych. Wydaje się, że realizacja zarysowanego tu metodologicznego schematu postępowania może dostarczyć wielu niezwykle użytecznych wskazówek nie tylko dla fokusa, lecz także dla innych metod badawczych.

Głębokie przemiany społeczne, technologiczne i mentalne zachodzące w ostatnich dekadach, wywołują i wymuszają także ustawiczną rewizję metodologicznych i etycznych reguł badań społecznych i socjologicznych. $\mathrm{W}$ procesie podążania za tymi zmianami nie tylko stale wzrasta ranga etyki, ale rozszerza się także zakres zjawisk podlegających etycznym regulacjom. Jest to proces nieskończony i dynamiczny, za którym nie są w stanie nadążyć kolejne ustalenia etycznych kodeksów badawczych. Świadectwem znaczenia, jakie współcześnie przyznaje się kwestiom etycznym są chociażby dwie polskie inicjatywy kodyfikacyjne z 2012 roku - sformułowanie Kodeksu Etyki Pracownika Nauki i Kodeksu Etyki Polskiego Towarzystwa Socjologicznego. Jednak kodeksy są dość stabilne, bowiem zinstytucjonalizowana procedura wprowadzania w nich zmian jest bardzo rozciągnięta w czasie. Ponadto kodeksy ze swojej istoty są ogólnikowe, często pozbawione wystarczająco szczegółowych wskazówek wykonawczych, nie dają tym samym odpowiedzi na wiele istotnych pytań o charakterze etycznym nurtujących badaczy. Ta książka ma za zadanie pokazać, jak w zgodzie z istniejącymi ogólnymi ustaleniami kodeksowymi traktować szczegółowe problemy badawcze i jak złożonym i wielowymiarowym zagadnieniem jest etyka współczesnych badań fokusowych. Wiele poruszonych tu wątków, mimo że dotyczą bezpośrednio zogniskowanego wywiadu grupowego, znajduje swoje odpowiedniki w innych metodach badawczych. W tym sensie Autorka ma nadzieję, że książka ta okaże się przydatna także dla tych Czytelników, którzy nie stosują FGI w swojej działalności badawczej. 


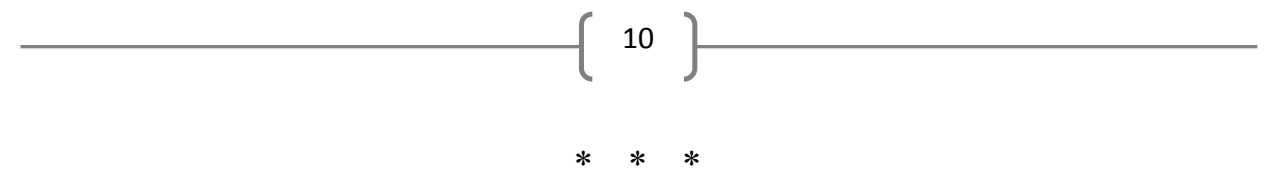

Opracowanie to jest efektem mojej trwającej wiele lat przygody fokusowej. Jednak pewnie nigdy by nie powstało, gdyby nie wsparcie, jakie uzyskałam w swoim otoczeniu. Zdecydowanie bardziej bowiem wolę napięcie, emocje i pokonywanie problemów towarzyszące kolejnym projektom badawczym, niż pisanie o nich. Dlatego w tym miejscu pragną złożyć serdeczne podziękowania prof. Annie Kubiak za konsekwentne i uporczywe motywowanie mnie do podjęcia tego wyzwania. Mojemu przyjacielowi dr. Andrzejowi W. Rostockiemu dziękuję, że zechciał być pierwszym uważnym i krytycznym Czytelnikiem tej pracy. Wyrażam także ogromną wdzięczność prof. Mieczysławowi Gałuszce za życzliwą recenzję wydawniczą. Dziękuję również Magdalenie Kącickiej, która panowała nad aspektami formalnymi tej książki oraz moim Kolegom z Katedry Metod i Technik Badań Społecznych Instytutu Socjologii Uniwersytetu Łódzkiego, którzy wykazali nadzwyczajną cierpliwość, słuchając kolejny raz o badaniach fokusowych... 


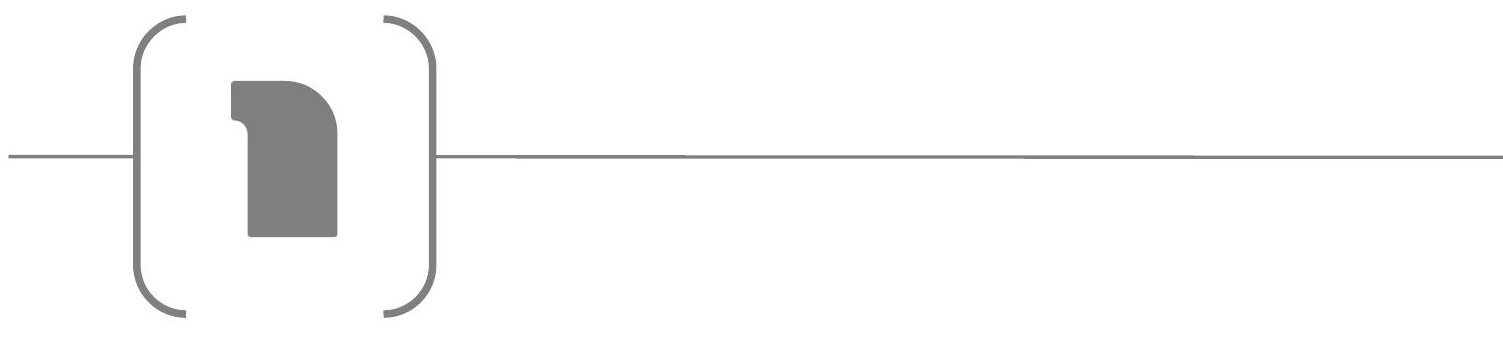

ZOGNISKOWANY

WYWIAD

GRUPOWY

CHARAKTERYSTYKA METODY 



\section{WPROWADZENIE}

Ten rozdział poświęcony jest charakterystyce przede wszystkim tych elementów metody badań fokusowych, których związek z decyzjami etycznymi stanowi przedmiot rozważań w rozdziale II i IV. Dlatego pominięto w nim niektóre bardzo istotne zagadnienia metodologiczne - jak chociażby kwestię opracowania zgromadzonych danych, czy ocenę ich wartości - co w żadnym razie nie oznacza, iż dla całościowej oceny FGI są bez znaczenia. Przedstawiona niżej analiza zogniskowanego wywiadu grupowego koncentruje się kolejno na zagadnieniu doboru uczestników do badania, na fenomenie grupy fokusowej, rolach odgrywanych przez uczestników w trakcie sesji, dynamice grupowej i osobie moderatora. Ponadto podjęto próbę ustosunkowania się do rozmaitych powszechnie występujących opinii na temat fokusa, starając się wykazać iluzoryczność poglądu wielu badaczy o prostocie, niskich kosztach i szybkości badań fokusowych. 


\section{FOKUS - GENEZA}

Zogniskowany wywiad grupowy (focus group interview, FGI) należy obecnie do grupy najbardziej popularnych sposobów zbierania danych w naukach społecznych w wielu krajach na świecie. Początki kariery tej metody sięgają lat czterdziestych XX wieku (Merton, Kendall, 1990), a sam Morgan (1988) jej prototypu upatruje w opisanych w 1926 roku przez Bogardusa wywiadach grupowych (Bogardus, 1926). Jej powstanie poprzedziło opisywane wielokrotnie w literaturze (Stewart, Shamdasani, 1990 i inni) badanie przeprowadzone na uniwersytecie Columbia, gdzie Merton wraz z Lazarsfeldem po raz pierwszy zorganizowali sesję fokusową i nadali jej nazwę (the focussed interview). Studium zlecone przez rząd miało za zadanie zbadać wpływ mediów na postawy Amerykanów wobec zaangażowania Stanów Zjednoczonych w II wojnie światowej (Merton, 1987). Zaproszeni uczestnicy w trakcie odsłuchiwania za pośrednictwem indywidualnych słuchawek zarejestrowanej wcześniej audycji radiowej byli zobowiązani naciskać jeden z dwóch przycisków zamontowanych w oparciach krzeseł. Klawisz zielony służył do zaznaczenia jakiejkolwiek pozytywnej reakcji na dźwięki w słuchawkach (treść, ton, słowo), natomiast naciśnięciem klawisza czerwonego uczestnik dawał wyraz odczuciu negatywnych emocji. Każde naciśnięcie guzika było rejestrowane na specjalnym urządzeniu. Następnie uczestnicy spotkania zdjęli z uszu słuchawki, ponownie odtworzono nagranie radiowe, przerywając je w tych wszystkich momentach, w których aparat zarejestrował naciśnięcie guzika przez uczestnika. Odpowiednią osobę proszono o szczegółowe wyjaśnienie przyczyny i rodzaju swojej reakcji. Rezultaty tego badania posłużyły do opracowania materiałów propagandowych przeznaczonych na potrzeby armii amerykańskiej. Później posługiwano się tą metodą do analizy propagandy komunistycznej. Mimo że fokus narodził się jako akademicka metoda badawcza, od lat 50. ubiegłego stulecia stał się synonimem badań marketingowych (Munday, 2006). I to głównie dzięki badaniom marketingowym, po wielu latach zapomnienia, przeżył swój naukowy came back w wielkim stylu w latach osiemdziesiątych XX wieku.

W 1988 roku ukazały się pierwsze wydania książek Morgana i Kruegera, które wzbudziły zainteresowanie fokusem jako narzędziem w badaniach ewaluacyjnych (Morgan, 1988; Kreuger, 1988). Od tego momentu datuje się rosnąca popularność fokusa jako metody gromadzenia danych jakościowych. W końcu XX wieku metody oparte na wykorzystaniu grup fokusowych stały się popularne jako albo dodatkowe, albo zasadnicze podejście do gromadzenia danych także w naukach społecznych, w tym szczególnie w obszarze nauk o zdrowiu i badań ewaluacyjnych. Z obliczeń Morgana (1997) wynika, że pod koniec XX wieku w periodykach prezentujących wyniki badań empirycz- 
nych ukazywało się ponad 100 artykułów rocznie powołujących się na rezultaty zogniskowanego wywiadu grupowego. Analiza treści materiałów socjologicznych wykazała, że ponad $60 \%$ badań empirycznych odbyło się przy połączeniu metody grup fokusowych z inną metodą. Roczny odsetek studiów opierających się wyłącznie na grupach fokusowych także zaczął systematycznie rosnąć. W tym samym okresie notuje się także znaczącą liczbę publikacji książkowych dotyczących tej metody (Agar, MacDonald, 1995; Catterall, Maclaran, 1997; Frey, Fontana, 1991; Kingry, Tiedje, Friedman, 1990; Kitzinger, 1994; Krueger, 1988, 1997, 1997a, 1997b; Krueger, King, 1997; Merton, 1987; Morgan, 1988, 1993, 1995, 1996, 1997, 1997a; Stewart, Shamdasami, 1990; Straw, Marks, 1995; Straw, Smith, 1995).

Mimo że pomysłodawcami i twórcami zogniskowanego wywiadu grupowego byli wybitni reprezentanci empirycznej socjologii Robert K. Merton i Paul Lazarsfeld, fokus nie spotkał się z entuzjastycznym przyjęciem ze strony socjologii akademickiej. Zdecydowanie szybciej zadomowił się w komercyjnych ośrodkach badawczych jako metoda w badaniach rynkowych, marketingowych i społecznych nastawionych na realizację rezultatów praktycznych. Krueger (1988), Morgan $(1993,1995,1996)$ i inni badacze wykonali ogromną pracę na rzecz odzyskiwania tej metody dla nauk społecznych. We wprowadzeniu do książki Mertona (1990) Albert Gollin podkreślił, że fokus jest jedyną metodą, którą warto rekomendować zarówno ze względu na jej walory historyczne, jak i współczesną użyteczność. W rezultacie fokus na stałe zagościł wśród innych metod empirycznych badań jakościowych, choć często forma i sposób zastosowania z pewnością zaskoczyłaby jego twórców.

Na rynku badań marketingowych fokusy ostatecznie ugruntowały swoją pozycję, co więcej - obszar zastosowań tej metody badawczej znacznie się poszerzył. To właśnie w marketingu FGI osiągnął swoją dojrzałą postać (Morgan, 1988; Templeton, 1987) i ciągle poddawany jest kolejnym modyfikacjom $^{5}$. Jego zastosowanie w tej dziedzinie systematycznie rośnie od lat 70. XX wieku. Świadczą o tym chociażby kwoty wydatkowane na świecie na ten typ badań (Stewart, Shamdasani, Rook, 2007). Także w Polsce od kilkunastu

\footnotetext{
5 Dzisiejszy fokus w niewielkim stopniu przypomina to, co fokusem nazwali jego twórcy Merton i Lazarsfeld. Obecnie badanie fokusowe, które naprawdę ma pogłębić temat, dotrzeć do tego, co nieświadome i nieoczywiste, to wywiad prowadzony w małych grupach (np. 4-6 osób), dłuższy (trwający nawet ponad 3 godziny) i wykorzystujący wiele technik projekcyjnych i wspomagających. Nie ma już wyraźnej granicy między wywiadem grupowym a indywidualnym. Jest to raczej kontinuum na osi badania jakościowego. „Określenie minigrupa zmieniło zupełnie swoje znaczenie - to, co było minigrupą jeszcze 10 lat temu (np. 6 uczestników), dzisiaj stało się standardem. To, co jeszcze niedawno było wywiadem przedłużonym, obecnie często stanowi wariant podstawowy." (Katalog 2010/2011, edycja XV).
} 
lat rysuje się w tej kwestii wyraźna tendencja wzrostowa. W 2010 roku tylko wśród firm zrzeszonych w PTBRiO (Katalog 2010/2011, edycja XV) badania FGI stanowiły 12,0\% wielkości sektora badawczego, jego wartość wynosiła 60818783 PLN, a liczba badanych osiągnęła 105143 osób. Dla porównania badania IDI stanowiły 4,5\% wielkości sektora, warte były 22666186 PLN, a przebadano łącznie w tym samym roku 19325 osób.

Zatem, uwzględniając dość długą, bo ponadsiedemdziesięcioletnią historię badań fokusowych, w żaden sposób nie można zgodzić się $\mathrm{z}$ autorem pewnego artykułu w czasopiśmie „Newsweek”, który opisuje wywiad zogniskowany jako przemijającą modę w zakresie badań rynku z lat 80 . XX wieku (Kaufman, 1997).

\section{FOKUS - DEFINICJA I RODZAJE}

David Morgan (1997) definiuje fokus jako technikę badawczą, w której poprzez współdziałanie, interakcję grupy uczestników, badacz zbiera niezbędne dla jego celów informacje. Ta definicja składa się z trzech podstawowych elementów. Po pierwsze, wyraźnie zaznacza, że grupy fokusowe to metoda badawcza poświęcona zbieraniu danych. Po drugie, wskazuje na interakcję w dyskusji grupowej jako źródło pozyskiwania danych. Po trzecie, podkreśla aktywną rolę badacza w tym procesie. Mimo że ta definicja jest bardzo ogólna, to jednak poprzez wyróżnienie trzech elementów składowych pozwala wykluczyć inne metody badawcze, które czasami określa się tym mianem.

Przede wszystkim grupy fokusowe należy odróżnić od grup, których główny cel jest inny niż realizacja badania (grupy terapeutyczne, edukacyjne, decyzyjne), choć elementy terapii, edukacji, procesu podejmowania decyzji występują w trakcie sesji. Dalej pozwala odróżnić grupy fokusowe od innych taktyk, które zakładają obecność wielu uczestników, ale nie przewidują żadnej interakcji czy też dyskusji między nimi (chociażby ankieta audytoryjna). Wreszcie grupy fokusowe należy odróżnić od metod, które polegają na gromadzeniu danych generowanych $w$ trakcie naturalnie występujących dyskusji grupowych, gdzie nie funkcjonuje osoba prowadząca (moderator), jak to ma miejsce $w$ badaniach antropologicznych czy obserwacji zewnętrznej.

Przy próbie określenia, czym tak naprawdę są grupy fokusowe rodzą się pytania, czy grupy fokusowe należy odróżnić od innych typów wywiadów grupowych i na jakiej podstawie można to zrobić. Autorzy opracowań poświęconych zogniskowanemu wywiadowi grupowemu nie osiągnęli $w$ tej kwestii porozumienia. Część z nich opowiada się za traktowaniem większo- 
ści form wywiadów grupowych jako wariantów grup fokusowych (tzw. podejście inkluzyjne). Inni natomiast promują traktowanie grup fokusowych jako bardzo wąską technikę, której nie należy mylić z innymi rodzajami grupowych wywiadów (tzw. podejście ekskluzywne, charakterystyczne raczej dla badań marketingowych). Frey i Fontana (1991, s. 175-187) zaproponowali typologię, która lokalizuje sesję fokusową jako jedną z kategorii wywiadów grupowych. Według nich wywiady grupowe nie są wywiadami fokusowymi jeżeli: prowadzone są w nieformalnych warunkach, brakuje moderatora lub zawierają niestrukturalizowane pytania. Jednak ta propozycja także nie została powszechnie zaakceptowana, ponieważ ocena poziomu ustrukturalizowania pytań jest trudna i możliwa tylko w kontekście danego badania, a decyzja o poziomie strukturalizowania pytań $\mathrm{w}$ fokusie zależy od bardzo wielu czynników - celu badania, tematu, uczestników. Ponadto poziom strukturyzacji pytań może podlegać modyfikacji w trakcie sesji, zatem nie jest to wygodne i precyzyjne kryterium graniczne. Pytanie, czy socjologowie powinni używać ekskluzywnych czy też inkluzyjnych definicji grup fokusowych, nadal nie jest rozstrzygnięte. Tym bardziej, że zogniskowany wywiad grupowy nie jest techniką jednorodną, w praktyce badawczej występują różne jego odmiany, wyodrębnione ze względu na bardzo rozmaite kryteria:

\section{Czas trwania badania}

a) Brief group

Spotkanie, które trwa zazwyczaj krócej niż godzinę, a uczestnicy dyskutują na jeden, szczegółowo określony temat. Udział bierze tylko kilka osób (4-5), precyzyjnie wyselekcjonowanych. Oczekuje się, że badani posiadają wyraźnie sformułowane przekonania dotyczące przedmiotu rozmowy, dlatego też można spotkanie przeprowadzić bardziej dynamicznie. Brief group organizuje się często jako formę podsumowania bardziej rozbudowanego przedsięwzięcia badawczego.

b) Extended group

Spotkanie tak zwanej „grupy rozszerzonej” trwa znacznie dłużej, nawet 6-7 godzin z przerwą na posiłek. Taka strategia organizacji sesji jest przydatna wówczas, gdy w scenariuszu przewidziano konieczność zastosowania dodatkowych technik badawczych (projekcyjnych lub technik twórczego myślenia), które znacznie wydłużają czas spotkania. Ten sposób badania wybiera się również ze względu na wysoki poziom trudności lub/i drażliwości tematu. Należy zainwestować sporo czasu w fazę wprowadzającą do zasadniczej dyskusji, aby uczestnicy się poznali, nabrali do siebie zaufania i poczuli bezpiecznie. Długi czas trwania spotkania, różnorodność i inten- 
sywność zadań stawianych przed uczestnikami, wspólne ich wykonywanie obniża poziom samokontroli badanych i generuje wiele pozytywnych mechanizmów w dynamice grupowej.

\section{Liczba uczestników}

a) Mini group

W sesji uczestniczy mniej osób, zwykle ich liczba nie przekracza 4-5. Ze względu na oczekiwania zleceniodawcy lub rodzaj poruszanych zagadnień czasami konieczne jest stworzenie bardziej kameralnej sytuacji badawczej, w większym stopniu sprzyjającej dyskutowaniu na tematy trudne, drażliwe. W mini grupach można bardziej szczegółowo, dogłębnie omówić zagadnienie, wypytując drobiazgowo uczestników. To sprawia, że ten sposób badania przypomina wywiady indywidualne, ale zachowuje interakcje pomiędzy badanymi. Mini grupy szczególnie przydatne są wówczas, gdy badacz spodziewa się wielkiego zaangażowania ze strony uczestników, bo, albo są ekspertami w jakiejś dziedzinie, albo mają do tematu osobiste silne nastawienie emocjonalne, albo dyskutowane zagadnienie jest złożone, kontrowersyjne. Do udziału w takich sesjach zapraszani są zazwyczaj przedstawiciele tak zwanych "trudnych" kategorii oraz eksperci, na przykład przedstawiciele kadry menedżerskiej, lekarze, prawnicy. Mini grupy stwarzają uczestnikom możliwość artykułowania częstszych i dłuższych wypowiedzi, niż klasyczne grupy fokusowe.

b) Focus group

Klasyczna wersja sesji, w której uczestniczy zwykle 6-9 osób (w Europie) lub $10-12$ (w USA) 6 .

\section{Częstotliwość badania}

a) Reconvent group (grupa powtarzana)

Sesje odbywają się dwukrotnie z udziałem tych samych osób. Zazwyczaj taki zabieg ma na celu ustalenie, czy pomiędzy spotkaniami nastąpiły zmiany postaw i opinii uczestników na skutek jakichś nowych doświadczeń. Formuła taka stosowana jest głównie w badaniach marketingowych (kiedy pomiędzy spotkaniami badani testują nowy produkt), ale znajduje swoje zastosowanie także w innych obszarach. (Przykładem mogą być opisane w tej pracy, w rozdz. IV badania w projekcie Speak up!) Powtórne zaangażowanie

\footnotetext{
${ }^{6} \mathrm{~W}$ literaturze czasem pojawia się w takim zestawieniu wywiad fokusowy z parą lub trójką respondentów (dyads/paired interview i triads). Tutaj zdecydowano się je pominąć, ponieważ — zdaniem Autorki - nie można ich traktować jako wariantów badania fokusowego. Diady lub triady z udziałem osoby prowadzącej (badacza) stosuje się wówczas, gdy osoby badane posiadają jednakową moc decyzyjną, a jednocześnie prezentują odmienne poglądy wobec jakiegoś zjawiska.
} 
do udziału w badaniu tych samych osób ma swoje uzasadnienie także wówczas, gdy badani reprezentują w jakimś sensie kategorię „trudną”, która nie odnajduje się łatwo w sesji fokusowej.

b) Sensitivity panels (panel wrażliwości)

Odmiana grup powtarzanych, polegająca na przeprowadzeniu kilku sesji z tymi samymi uczestnikami. Za każdym razem badani poddawani są działaniu różnych technik dodatkowych. Ta postać dyskusji grupowej datuje swój początek na lata 60. XX wieku. Intencją twórcy tego podejścia - Billa Schlackmana było uzyskanie danych, w jak największym stopniu odpowiadających potrzebom poznawczym zleceniodawcy. Wielokrotna analiza tego samego zagadnienia z różnych punktów widzenia i z zastosowaniem różnych technik rozwija świadomość uczestników i zwiększa ich zrozumienie (wyczucie) badanych kwestii.

c) Klasyczna sesja pojedyncza

Najczęściej występująca w praktyce fokusowej. Często w procesie rekrutacji uczestników badacz przyjmuje jako istotne kryterium poprzednie doświadczenia badawcze swoich potencjalnych badanych i eliminuje ze składu grupy fokusowej tych spośród nich, którzy wcześniej uczestniczyli już w sesji (sesjach) fokusowych.

\section{Kryteria doboru uczestników}

a) Clash group (grupa konfliktowa, spierająca się) Typ sesji, na którą albo zaprasza się równą liczbę osób prezentujących sprzeczne poglądy konfrontowane w trakcie spotkania (np. zwolennicy przeciwnicy aborcji), albo uczestników dzieli się na dwie antagonistyczne frakcje, które mają za zadanie przedstawić stronie przeciwnej swoje argumenty. Taki rodzaj spotkania ma zwykle bardzo dynamiczny przebieg, dlatego często uczestniczy w nim dwóch moderatorów.

b) Affinity group (grupa skoligacona)

Przeznaczona jest do badania osób, które doskonale znają się wzajemnie, np. uczniowie tej samej klasy, członkowie rodziny. Wcześniejsza znajomość uczestników ułatwia poruszanie tematów, o których nie rozmawia się z obcymi ludźmi, zwiększa poczucie bezpieczeństwa badanych, sprzyja takiemu poziomowi szczerości, jaki obowiązuje miedzy nimi w warunkach naturalnych. Występuje także w odmianie mini (affinity mini group).

c) Encounter groups (wywiady konfrontacyjne)

Stosowane w badaniach marketingowych, w których uczestniczą przedstawiciele dwóch stron, na przykład osoby reprezentujące producenta i konsumenci. 


\section{Sposób traktowania narzędzia badawczego}

a) Concept-lab (grupa dynamiczna)

Odmiana badań fokusowych, w której z założenia przewiduje się modyfikację scenariusza moderatora na podstawie informacji uzyskanych w poprzedniej sesji. Stosowana głównie w badaniach marketingowych, niewystarczająco doceniana w naukach społecznych.

\section{Cel}

a) Creativity focus group (grupa kreatywna)

Sesja przypomina twórczy warsztat, w trakcie którego rygorystycznie zrekrutowania badani wspólnie wypracowują jakiś całościowy koncept (na przykład strukturę społecznej kampanii medialnej) lub znajdują nowe rozwiązania postawionych problemów.

\section{Sposób organizacji sesji}

a) Two-way focus group

Polega na tym, że jedna grupa obserwuje dyskusję innej grupy, a później sama omawia poczynione spostrzeżenia. Zasłyszane w trakcie obserwacji poglądy uczestników pierwszej grupy stanowią dobry bodziec do generowania bardziej rozbudowanych informacji i czasami taka strategia prowadzi do sformułowania przez grupę obserwatorów zupełnie odmiennych konkluzji.

b) Dual moderator focus group

Wymaga obecności dwóch moderatorów w trakcie sesji, którzy dzielą się obowiązkami. Jeśli sesję prowadzi tylko jeden moderator, istnieje większe ryzyko, że - skupiony na atmosferze panującej w grupie, dbając o dobre samopoczucie uczestników - pozwoli na odejście od wymiaru zadaniowego spotkania. Ponadto obecność dwóch prowadzących, którzy mogą na przemian moderować te obszary dyskusji, w których posiadają większe kompetencje merytoryczne urozmaica przebieg spotkania i zmniejsza niebezpieczeństwo udzielania przez uczestników odpowiedzi, które antycypują jako akceptowane przez moderatora.

c) Dueling moderator focus group

Rodzaj sesji, w której dwóch moderatorów polemizuje ze sobą, co ma za zadanie prezentację sprzecznych punktów widzenia po to, by uczestnicy na tej podstawie mogli wygenerować jakieś nowe pomysły.

d) Respondent moderator focus group

W trakcie sesji jeden lub, na zmianę, kilku uczestników wciela się tymczasowo w rolę moderatora. Zabieg ten ma za zadanie osłabić (zróżnicować) wpływ osoby prowadzącej na uzyskiwane odpowiedzi. 


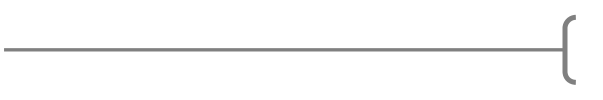

21

Fokus - definicja i rodzaje

e) Client participant focus group

W trakcie sesji obecni są — jawnie lub nie — reprezentanci klienta/zleceniodawcy badania (jeden lub kilku). Taka formuła daje klientom większą kontrolę nad przebiegiem dyskusji, mogą wychwycić i rozbudować interesujące ich wątki.

\section{Rodzaj kontaktu badacza $\mathrm{z}$ badanymi}

a) Teleconference focus group

Technika stosowana, kiedy niemożliwe jest zgromadzenie w jednym czasie i miejscu potencjalnych uczestników. Nie daje możliwości obserwowania informacji pozawerbalnych.

b) Online focus groups, virtual group

W internetowych sesjach fokusowych wszyscy uczestnicy mają możliwość równoczesnego obserwowania się i rozmawiania za pośrednictwem komputera. Oprócz moderatora i uczestników, sesje mogą obserwować inne osoby, na przykład przedstawiciele zleceniodawcy, eksperci. Obserwatorzy mają możliwość porozumiewania się między sobą za pomocą zamkniętego czatu (back room), do którego nie mają dostępu badani i moderator.

W oparciu o powyższe zestawienie można stwierdzić, że badanie fokusowe ma "wiele twarzy”, wymyka się precyzyjnej, jednoznacznej definicji. Różnorodność form, jakie przyjmują badania fokusowe sprawia, że znajdują one swoje zastosowanie dla osiągania bardzo różnych celów badawczych i stanowią użyteczne narzędzie zarówno dla socjologów, jak i przedstawicieli innych dyscyplin - pedagogów, psychologów, specjalistów z zakresu edukacji, zdrowia, pracy socjalnej, polityki społecznej, zarządzania, i oczywiście - marketingu.

W dalszej charakterystyce poszczególnych elementów metody skoncentrowano się wyłącznie na fokusie realizowanym w kontakcie bezpośrednim - twarzą w twarz, pominięto te wszystkie odmiany badań fokusowych, które są zapośredniczone przez rozmaite komunikatory. Decyzja ta wynika z przekonania, że zbyt wiele jest różnic metodologicznych, organizacyjnych, psychologicznych i etycznych pomiędzy tymi postaciami FGI, aby można było analizować je łącznie.

\section{Dobór uczestników}

W wariancie klasycznym grupa fokusowa to 6-10 osób zaproszonych do udziału w spotkaniu prowadzonym przez moderatora-członka zespołu badawczego. Ostateczna decyzja dotycząca liczebności grupy zawsze powinna być ściśle związana zarówno z celem badania, jak i jego tematyką, cechami 
respondentów i kwalifikacjami moderatora. Najbardziej ogólna dyspozycja nakazuje znaleźć złoty środek pomiędzy dążeniem do powiększenia grupy w oczekiwaniu na wygenerowanie większej ilości informacji, a jednocześnie niedopuszczeniem do sytuacji, w której uczestnicy nie wezmą aktywnego udziału w rozmowie, zostaną z niej wykluczeni. Ostatnio obserwowane praktyki wyraźnie wskazują na tendencje do zmniejszania liczby uczestników w grupie fokusowej. Doświadczenia badawcze potwierdzają słuszność sugestii Morgana (1997, s. 54), który zalecał, aby w przypadku, kiedy dyskusja dotyczy bardziej angażującego emocjonalnie zagadnienia, zmniejszać liczebność grupy, aby każdy z uczestników miał możliwość i czas na swobodną wypowiedź. Natomiast kiedy temat jest mało atrakcyjny większa grupa daje szansę na uniknięcie impasu w sesji i krępujących chwil milczenia. Znaczenie „wagi” sprawy dla osoby badanej w kontekście planowania, realizacji i opracowania badania ponad pół wieku temu podkreślał Z. Gostkowski (1957).

Uczestnicy zazwyczaj stanowią grupę względnie homogeniczną (Hoffman, 1959, s. 27-39; Hoffman, Maier, 1961, s. 401-407; Krueger, Casey, 2000), co ułatwia likwidowanie barier we wzajemnej komunikacji, zwiększa poczucie bezpieczeństwa i w rezultacie skłania badanych do ujawniania swoich poglądów wobec osób, których (w większości przypadków) prawdopodobnie nigdy więcej nie spotkają. Przypomina to znany „syndrom przedziału kolejowego". Postulat homogeniczności grup ma swoje uzasadnienie w mechanizmach psychologicznych - interakcje z osobami postrzeganymi jako podobne sprzyjają większej otwartości, skłaniają do dzielenia się doświadczeniami, zmniejszą wstyd i zażenowanie oraz obawę o ocenę. I odwrotnie, uczestniczenie $\mathrm{w}$ dyskusji z osobami odbieranymi jako inne, niepodobne pod względem jakiejś cechy, np. antycypowanej pozycji społecznej, poziomu wykształcenia lub zamożności (grupy heterogeniczne) zwiększa poczucie dystansu i obawę przed oceną, a tym samym blokuje wypowiadanie własnych poglądów, ogranicza spontaniczność i otwartość.

Do udziału w badaniu dobiera się zatem zarówno grupy poprzez określenie ich specyfiki, jak i poszczególnych uczestników spełniających zaplanowane parametry doboru. Poza wszystkimi społeczno-demograficznymi kryteriami selekcyjnymi podstawowe znaczenie przy doborze osób badanych ma wspólnota doświadczeń, a zatem uzyskanie pewności, że każdy z nich spełnia pewien typ kryterium merytorycznego, na przykład przebywał w zakładzie karnym, wychował się w rodzinie zastępczej, bądź w przypadku badań marketingowych - od określonego czasu kupuje interesujący zleceniodawcę gatunek mydła.

Rozstrzygnięcia badacza, który określa strukturę grupy fokusowej mają również konsekwencje o charakterze etycznym, choć podstawę jego decyzji 
stanowią przesłanki psychologiczne. Bowiem jego celem jest wypracowanie takiej metodologii projektu, która zapewni uzyskanie możliwie najcenniejszych informacji. Badacz musi na przykład zdecydować: w jakim kontekście, składzie grupy będzie najbardziej komfortowo dla uczestników mówić o określonych sprawach; czy lepiej, żeby mężczyźni i kobiety dyskutowali osobno; czy młode osoby nawet tej samej płci będą z właściwym szacunkiem traktowane przez starszych uczestników lub czy młodzi nie będą lekceważyć starszych; czy zróżnicowanie dochodów lub poziomu wykształcenia nie doprowadzi do zdominowania grupy przez jej niektórych uczestników i nie wyłączy z dyskusji innych; czy obecność w jednej grupie osób zajmujących różne pozycje w strukturze organizacji/instytucji nie doprowadzi do pozabadawczych negatywnych konsekwencji.

Kryteria rekrutacji powinny być zatem szczegółowo przemyślane i rygorystycznie przestrzegane, a przede wszystkim dostosowane do celu badania. Najczęściej badacz opracowuje kwestionariusz selekcyjny stanowiący narzędzie dla ankieterów-rekruterów. Ale nie zawsze tak musi być. Czasem, jeśli wszyscy potencjalni badani spełniają w jednakowym stopniu kryteria selekcyjne i jednocześnie wyrażają ochotę na udział w sesji, można przeprowadzić losowanie. W innym przypadku może zdarzyć się tak, że całe grupy istniejące naturalnie stanowią jednocześnie grupy fokusowe, np. wielopokoleniowe rodziny, grupy rówieśnicze.

Zwykle dobrze jest zaprosić więcej osób, niż docelowo ma uczestniczyć w sesji. Wszyscy potencjalni badani powinni być uprzedzeni o możliwości rezygnacji z ich udziału w spotkaniu i o formie rekompensaty za wyrażoną przez nich gotowość do badania. Dla pozostałych respondentów także należy przygotować jakiś rodzaj wynagrodzenia - najczęściej są to pieniądze, choć stosuje się także różne bony zakupowe, bilety, upominki.

Zaproszonym potencjalnym uczestnikom ankieter-selekcjoner pozostawia pisemną informację na temat planowanego przedsięwzięcia, miejsca i czasu spotkania, kontaktu z badaczem w celu wyjaśnienia ewentualnych wątpliwości wraz z treścią oświadczenia o świadomej zgodzie na udział. $\mathrm{W}$ dniu poprzedzającym spotkanie dobrze jest potwierdzić telefonicznie gotowość zaproszonych uczestników.

\section{Grupa fokusowa}

Stosowany w praktyce i w literaturze termin grupa fokusowa wymaga choćby krótkiego komentarza (Hare, 1976; Shaw,1981). Jest to bowiem twór, który nie spełnia rygorystycznie żadnej socjologicznej ani psychologicznej definicji grupy społecznej (Lisek-Michalska, 2004, s. 53), bowiem charakte- 
ryzuje go bardzo krótkie istnienie, nieczytelne dla członków normy, niejasny skład, brak struktury, niepewność celu.

Hubert Malinowski (2004) pisze: „Istnieją dwa podejścia do definiowania grup. W pierwszym wymienia się warunek lub warunki, które musi spełniać dana zbiorowość, aby miano grupy jej przysługiwało, w drugim proponuje się zbudowanie kontinuum grupowości, gdzie natężenie określonej cechy pozwala dany agregat jednostek umiejscawiać na kontinuum "nie-grupa - "grupa« bliżej krańca prawego." Przykładem pierwszego stanowiska jest definicja zaproponowana przez P. Hare'a (1976): „Istnieje (...) pięć cech, które różnią grupę od zbioru jednostek. Członkowie grupy wchodzą ze sobą we wzajemne interakcje. Mają wspólny cel oraz zespół norm, które nadają kierunek i określają granice ich działalności. Wytwarzają oni także zespół ról oraz sieć atrakcyjności osobniczej, które służą do oddzielania ich od innych grup". Według autora grupą jest ten agregat jednostek, który posiada wszystkie te cechy, gdy którejś zabraknie - nie możemy mówić o grupie, ale o tworze, dla którego należałoby stworzyć inną nazwę. Kolejni badacze akcentują inne warunki dla zbiorowości pretendującej do miana grupy, a są to między innymi:

1. Komunikacja

„Przez grupę rozumiemy grupę osób, które się ze sobą komunikują, często przez dłuższy czas, a których jest wystarczająco niewiele, aby możliwa była rozmowa każdej osoby z każdą twarzą w twarz, bez wymiany komunikatów z drugiej ręki." (Homans, 1950, s. 1)

2. Wpływ

„Grupą są dwie lub więcej jednostek, które wchodzą ze sobą w interakcję w taki sposób, że każda osoba wpływa i podlega wpływowi każdej innej osoby." (Shaw, 1981, s. 454)

3. Interakcja

„Grupa jest systemem społecznym, w którym dokonują się interakcje członków i istnieje wspólna wszystkim tożsamość. Oznacza to, że w grupie jest poczucie "nas «, które uzdalnia członków do identyfikowania się z odrębną całością." (Johnson, 1995, s. 125)

4. Współzależność

„Grupa jest zbiorem jednostek będących ze sobą w relacjach, które czynią je do pewnego stopnia zależnymi od siebie nawzajem." (Cartwright, Zander, 1968, s. 46)

5. Wzajemne relacje

„Grupa jest zbiorem dwóch lub więcej osób, które są do pewnego stopnia w zmieniającej się wzajemnej relacji." (McGrath, 1984, s. 8) 


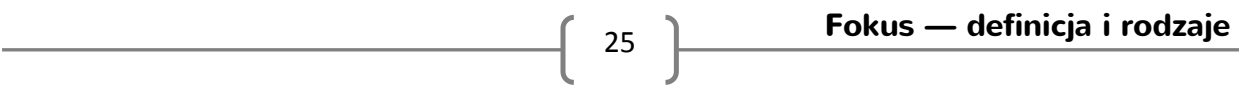

\section{Znaczenie psychologiczne}

„Grupa psychologiczna to taka grupa, która jest przez każdego członka subiektywnie uznawana za znaczącą, która stanowi obszar odniesienia, porównywania się, która dostarcza norm i wartości akceptowanych przez jednostkę, i która wreszcie wpływa na postawy i zachowania swoich członków." (Turner, 1987, s. 1-2)

7. Identyfikacja

„Grupa istnieje, jeśli dwie lub więcej osób definiuje siebie jako jej członków i jeśli jej istnienie jest uznane przez choć jedną osobę spoza tej grupy" (Brown, 1993, s. 2). Podobnie grupę definiuje Tajfel (1986), twierdząc, że wystarczy wyróżnić dane osoby z szerszej zbiorowości i powiedzieć o nich „wy”, aby uruchomić w nich przekonanie o istniejącej między nimi wspólnocie.

8. Struktura

„Grupa jest społeczną jednostką, która zawiera kilku członków będących we wzajemnych relacjach (lepiej lub gorzej określonych) w zakresie statusu i roli, i w której istnieje zestaw norm i wartości regulujących zachowanie członków przynajmniej w zakresie grupy." (Sherif, Sherif, 1956, s. 144)

Wydaje się, że wśród wielu propozycji, w odniesieniu do specyfiki grupy fokusowej najbardziej adekwatne są definicje porządkujące, które za punkt wyjścia przyjmują istnienie continuum grupowości, rozciągającego się pomiędzy dwoma krańcami: „grupą” z jednej strony i „nie-grupą” na przeciwstawnym krańcu. To, gdzie na tym continuum ulokuje się dana struktura zależy od intensywności prezentowanych przez nią atrybutów grupowości. Należą do nich na przykład propozycje porządkujące, opracowane m.in. przez D.T. Campbella, a podzielane w Polsce przez J. Szmatkę (1989). Campbell (1958) utrzymywał, że każdą zbiorowość społeczną można ulokować na continuum grupowości, a jej pozycja na tym continuum zależy od postrzeganych przez członków tej zbiorowości trzech wymiarów: poczucia bliskości, podobieństwa oraz wspólnoty losu. W takim rozumieniu grupowość to antycypowana przez członków spójność zbiorowości. Dwa krańce continuum grupowości dla J. Szmatki stanowią „efemeryczne i amorficzne zbiorowości” oraz „zbiorowości o wykrystalizowanych strukturach wewnętrznych, określonych systemach wartości, trwałych stanach świadomościowych i specyficznej kulturze."

Jak dalej pisze Malinowski (2004, s. 71): „Według J. Szmatki twierdzenia i prawa określające prawidłowości zachodzące w "grupach w całej pełni« są nie do zastosowania do owych quasi-grup, do których należałoby zaliczyć zbiorowość osób zebranych podczas fokusa.” Uznaje, że „całkowicie odmienne są $w$ tych rodzajach grup stosunki i relacje pomiędzy grupą a jej 
członkami. (...) W świetle powyższych rozważań można mówić o czymś takim, jak potencjalność grupowa dla danej zbiorowości, czyli zdolność do uruchomienia procesu grupotwórczego. Termin odnosi się do zdolności zbioru określonych osób do wystąpienia wśród nich interakcji. Podczas fokusa mamy do czynienia z przejściem od potencjalności grupowej zebranych jednostek o określonej charakterystyce do aktualizacji grupy przez stymulowanie respondentów do wzajemnego oddziaływania na siebie w zakresie tematu, na którym zogniskowany jest wywiad. Poszczególni członkowie wpływają na siebie przez komunikowanie swoich myśli, uczuć i doświadczeń".

Zestawy parametrów koniecznych do oceny stopnia grupowości są różnie skonfigurowane. Na przykład Król i współautorzy (Król i in., 2002) wymieniają tu następujące aspekty: podobieństwo członków potencjalnej grupy, doświadczanie tej samej trajektorii zdarzeń czy wyników podjętych działań, przepuszczalność grupy, wielkość grupy, czas trwania grupy, wspólne cele, ważność przynależności. Przy zastosowaniu continuów dla poszczególnych wymiarów można byłoby przyjąć, że grupa fokusowa spełnia cechy grupy społecznej, szczególnie w warstwie odnoszącej się do podobieństwa członków grupy, doświadczania tej samej trajektorii zdarzeń czy wyników podjętych działań. W przypadku grupy fokusowej możliwość rozwoju niektórych wyżej wymienionych cech jest silnie ograniczona czasem istnienia grupy oraz brakiem czytelnych przesłanek, umożliwiających uczestnikom oszacowanie chociażby stopnia przepuszczalności grupy i ważności przynależności. Kryterium wspólnoty celu także jest dość dyskusyjne, ale abstrahując od rzeczywistych zróżnicowanych celów poszczególnych uczestników, można uznać, że ten wspólny cel dotyczy zadania postawionego przed uczestnikami przez moderatora. Skoro zadanie postawione przed zbiorem jednostek ma tak istotne znaczenie, można grupę fokusową rozpatrywać w kategoriach grupy zadaniowej. Grupa zadaniowa to „(...) grupa powołana przez organizację do osiągnięcia względnie wąskiego zakresu celów w określonym lub domyślnym czasie" (Griffin, 1996, s. 623). Charakterystyczne cechy grupy zadaniowej to krótkotrwałe istnienie, kontraktowy charakter uczestnictwa, impersonalny charakter relacji, czytelna hierarchizacja pozycji poszczególnych jednostek i wyodrębniona z kontekstu społecznego (instytucyjnego) struktura. Więzi pomiędzy członkami takiej grupy mają charakter rzeczowy. Komunikacja w takim typie grupy przebiega według określonych zasad i przyjmuje przewidziane formy. Sformułowanie zadania i uświadomienie sobie przez poszczególnych uczestników faktu, iż możliwe jest jego wykonanie tylko wówczas, jeśli wszyscy wniosą jakiś wkład, uruchamia procesy strukturyzowania się działań pomiędzy nimi w oparciu o określony schemat zachowań organizacyjnych. 
Według koncepcji H.J. Bertchera (1996) grupa zadaniowa nie jest zainteresowana kształtowaniem jednostki według pożądanego z jej perspektywy modelu, bo taki model po prostu nie istnieje. Podstawowym ogniwem scalającym taki zbiór osób jest konieczność realizacji zadania, zatem jedyne oczekiwania wobec uczestników takiego zespołu dotyczą ich aktywności w tym zakresie. Kontrolę nad wykonaniem zadania i motywowaniem jednostek sprawuje lider (w przypadku fokusa - moderator). Mimo że propozycja postrzegania grupy fokusowej w kategoriach grupy zadaniowej wydaje się adekwatna i atrakcyjna (chociażby dlatego, że zmalałoby znaczenie wpływu konformizmu grupowego na uzyskiwane informacje), to przyjęcie takiego rozwiązania skutkuje nadmiernym ograniczeniem bogactwa wymiarów analitycznych, jakie faktycznie w grupie fokusowej mają miejsce. Ponadto trudno byłoby zgodzić się z założeniem, że uczestnicy grupy fokusowej podzielają $\mathrm{w}$ jednakowym stopniu potrzebę realizacji postawionego zadania i rezygnują z innych indywidualnych celów (chociażby uzyskania sympatii ze strony innych osób). Zatem ulokowanie grupy fokusowej w kategorii grup zadaniowych także ma swoje słabe strony.

\section{Role grupowe}

Jeśli przyjąć, że role społeczne stanowią zbiór przywilejów oraz obowiązków wynikających z zajmowanej pozycji społecznej, rozumianej jako miejsce jednostki w określonej strukturze (Sztompka, 2006, s. 110), to w takiej postaci nie mają one szansy ukonstytuować się w trakcie sesji fokusowej. Wydaje się zatem, że do analizy fokusów bardziej użyteczne jest postrzeganie uczestników nie przez pryzmat ról społecznych, a pełnionych ról grupowych, czyli inwestycji, jaką ponosi dana jednostka na rzecz funkcjonowania grupy. Przyjmuje się, że ten wkład stanowi wypadkową cech osobowości, zachowań oraz oczekiwań jednostki (Adams, Galanes, 2008, s. 196). W przeciwieństwie do wywiadów indywidualnych, każdy uczestnik rozpoczyna interakcje w grupie, przyjmując taką rolę, jaka jest dla niego wygodna, w jakiej czuje się najbardziej komfortowo w tej sytuacji (Silverman, 2012). Literatura dostarcza wielu propozycji zarówno definiowania pojęcia roli grupowej, jak i rozmaitych typologii ról grupowych. Wspomniany tu Silverman na przykład wyróżnia między innymi następujące ich rodzaje: przewodzący, innowacyjny, wyjaśniający, komplikujący, pytający, spekulujący, dominujący, wspomagający, upraszczający, integrujący, przeszkadzający, poszukujący, emocjonalny, perswadujący, opóźniający. Z kolei Belbin (2003) w swojej koncepcji ról grupowych opisał następujące role: realizatora, koordynatora, lokomotywę, myśliciela, poszukiwacza źródeł, krytyka wartościującego, duszę zespołu oraz skrupulatnego wykonawcę. Wiele spo- 
śród ról grupowych, jakie przyjmują uczestnicy nie sprzyja sprawnemu prowadzeniu dyskusji. Należą do nich na przykład osoby, które prezentują się jako: dominujące, nieśmiałe, agresywne, generujące problemy, przyjmujące pozę ekspertów lub kozłów ofiarnych. Z kolei pozytywnie na przebieg sesji i wartość uzyskanych informacji wpływają:

- myśliciel - osoba, która wykorzystując swój intelekt oraz wyobraźnię, generuje największą pulę pomysłów oraz rozwiązań, przyczyniając się do zwiększenia wartości informacyjnej fokusa,

- krytyk wartościujący - uczestnik, który poprzez analizę problemu oraz sugestii ze strony grupy dokonuje pewnego rodzaju oceny oraz wartościowania wypowiedzi dyskutantów, prowokując pozostałych uczestników spotkania do obrony swoich racji oraz zaprezentowania kontrargumentów, powodujących rozwój dyskusji,

- dusza zespołu - dyskutant skoncentrowany na relacjach a nie na zadaniu, który przez swoje prospołeczne zachowanie wzmacnia poczucie bezpieczeństwa i komfortu wśród pozostałych uczestników dyskusji, kreując klimat sprzyjający występowaniu pozytywnych efektów grupowych.

W trakcie sesji każdy uczestnik wchodzi w szeroko rozumiane relacje (oczekiwania względem innych osób, interakcje, przekonania, oceny i emocje) z wszystkimi innymi obecnymi osobami. W rezultacie $\mathrm{w}$ dziewięcioosobowej konfiguracji (ośmiu uczestników i moderator) pojawiają się $8 \times 9=72$ relacje pomiędzy uczestnikami plus te, które kształtują się pomiędzy podgrupami (Silverman, 2012). Ponieważ nikt nie potrafi utrzymać jednocześnie takiej liczby aktywnych relacji, grupa dokonuje wewnętrznej koniecznej organizacji. Zdaniem Silvermana istotny jest sposób, w jaki uczestnicy podtrzymują określone relacje, ponieważ odzwierciedla on ich postępowanie w prawdziwym życiu i staje się ważnym aspektem gromadzonych danych. Uważa on, że role grupowe są podstawowym fenomenem grupowym, ponieważ $\mathrm{w}$ trakcie interakcji pomiędzy uczestnikami, którzy przyjęli na czas sesji określone role, ujawniają się istotne dla badacza informacje. Badaczowi zależy bowiem nie tylko na usłyszeniu opinii, ale także na ustaleniu, jakie typy ludzi te opinie podzielają, w jaki sposób je wyrażają i jakie mają one znaczenie dla ich postaw.

\section{Dynamika grupowa}

Zasadniczym fenomenem grup fokusowych jest ich dynamika, będąca skutkiem interakcji pomiędzy uczestnikami. Dynamika determinuje wypowiedzi uczestników badania, nadaje dyskusji kierunek i warunkuje jej bieg (Nikodemska-Wołownik, 1999). 
Wchodzenie we wzajemne relacje ułatwia wyrażanie emocji, sprawia, że w dyskursie ujawniają się treści pozaświadome, które nie były wcześniej przedmiotem racjonalnych rozważań uczestników. David Morgan (1997a) pisał, że badania surveyowe zakładają, że ludzie wiedzą, co czują. Jednak w rzeczywistości często tak nie jest. Czasami przydaje się im wysłuchanie opinii innych osób w małej i bezpiecznej grupie, zanim sami sformułują swoje myśli i opinie. Grupy fokusowe stwarzają taką możliwość. Kiedy są dobrze realizowane, stwarzają badanym warunki do swobodnego, nieskrępowanego wyrażania własnymi słowami swoich skomplikowanych systemów przekonań. Istotą fokusa jest obecność innych uczestników badania. W trakcie sesji ludzie nie tylko wchodzą ze sobą w interakcje, lecz także stymulują się wzajemnie, a to coś znacznie więcej. Nie chodzi tylko o możliwość komentowania cudzych wypowiedzi, lecz także o aktywizowanie do zaangażowania się w dyskusję. Stymulacja wytwarza się przez emocje, wsparcie grupowe, wyzwania, nowe pomysły i inne cechy interakcji. W dyskusji grupowej pojawia się prawie nieodparty impuls, by mówić nawet o sprawach, jakich się wcześniej nie poddawało racjonalnemu przemyśleniu. Sprzyjają temu procesy zachodzące w trakcie spotkania, bowiem uczestnicy:

- reagują na wypowiedzi innych,

- zwracają się do siebie nawzajem,

- zadają sobie pytania,

- wspólnie tworzą pomysły,

- inspirują się,

- przywołują wspomnienia,

- modyfikują wzajemne wypowiedzi,

- uzupełniają nawzajem swoje wypowiedzi,

- kontrolują nawzajem stereotypowe myślenie,

- przyjmują odmienne stanowiska,

- przekonują się wzajemnie,

- zmieniają swoje opinie.

Pozytywne efekty grupowe. Wszystkie te rodzaje interakcji o charakterze werbalnym i niewerbalnym, wzmocnione silnym zapleczem emocjonalnym składają się na dynamikę grupy, która z kolei wyzwala określone efekty grupowe, a te determinują jakość uzyskanego materiału. Rezultaty dynamiki grupowej przejawiają się także $\mathrm{w}$ występowaniu $\mathrm{w}$ trakcie dyskusji specyficznych, unikalnych i korzystnych procesów, które napędzają tę dynamikę (Malinowski, 2007). Mowa tu o tzw. „5S” od pierwszych liter angielskich słów: synergy (synergia), snowballing (efekt kuli śniegowej), stimu- 
lation (stymulacja), security (bezpieczeństwo) oraz spontanity (spontaniczność zachowań). Autorzy prac poświęconych wywiadom grupowym już kilka dziesięcioleci temu uznali istnienie grupy w sytuacji badawczej za generator silnej synergii (Hess, 1968), stymulacji (Goldman, 1962), spontaniczności (Hess, 1968) oraz docenili jej rolę w osłabianiu i przełamywaniu oporów osób badanych (Merton, 1956), a także zwiększaniu poczucia bezpieczeństwa (Hess, 1968). Już Goldman (1962) twierdził, że uzyskana w ten sposób jakość jest odmienna (lepsza) od sumy rezultatów wywiadów indywidualnych. [W opozycji do tych przekonań lokują się rezultaty analizy porównującej wyniki badań fokusowych i indywidualnych wywiadów grupowych, wskazujące, że IDI jest techniką dostarczającą lepsze materiały niż fokusy (Fern, 1982)].

Efekt synergii. Rezultat stanowiący wypadkową pracy całej grupy, a nie prosta suma indywidualnych nakładów poszczególnych uczestników włożonych w finalny efekt wspólnego działania. Można byłoby zapisać ten proces jako: $1+1+1+1>4$. Efekt synergii wskazuje na zalety współpracy grupy w porównaniu z pracą indywidualną poszczególnych osób. Jednak nie zawsze przynosi takie rezultaty. Okazuje się bowiem, że w pewnych sytuacjach grupa szczególnie inteligentnych i asertywnych osób uzyskuje dużo gorsze wyniki, aniżeli jej poszczególni członkowie działający samodzielnie. Zjawisko to zwane jest Syndromem Apollo (The Apollo Syndrome) i zostało opisane przez Mereditha Belbina. Matematycznie można je przedstawić jako: $1+1+1+1<4$. Dzieje się tak wówczas, gdy każdy z członków grupy jest bardziej skoncentrowany na przekonaniu innych do swoich racji niż na rozwiązaniu problemu. Przy okazji jest to cenna wskazówka dla badacza planującego sesje fokusowe: należy unikać udziału w nich silnych indywidualności. Częściowo stanowi także wyjaśnienie eliminowania $\mathrm{z}$ badań fokusowych (poza szczególnymi przypadkami) uczestników, co do których istnieje przypuszczenie, iż z powodu treningu zawodowego mogą przyjąć role dominujące - dotyczy to na przykład specjalistów z branży marketingowej, dziennikarzy, psychologów. Przy zachowaniu właściwego doboru osób badanych i sprawnego kierowania dyskusją efekt synergii w badaniu fokusowym sprzyja uzyskaniu materiału wysokiej jakości.

Hess (1968) wyjaśniał efekt synergii występujący w grupie, odwołując się do teorii wpływu społecznego. Według niego można przewidzieć, o ile zwiększy się zakres uzyskiwanych informacji, ich wnikliwość, szczegółowość i nowatorstwo w miarę zwiększania liczby osób uczestniczących w badaniu od jednej do ośmiu.

Efekt kuli śnieżnej. W nazwie tego zjawiska wykorzystuje się metaforę, by obrazowo opisać proces, w którym coś początkowo niewielkiego i bez znaczenia w krótkim czasie urasta do takich rozmiarów, że zagarnia wszyst- 
ko na swojej drodze. W odniesieniu do fokusa efekt ten polega na tym, że badani uwzględniają $w$ swoich wypowiedziach informacje zawarte $w$ wypowiedzi poprzednika, rozbudowują je, pogłębiają ich znaczenie. W publikacjach marketingowych czasem zwraca się uwagę na konieczność odróżnienia efektu kuli śnieżnej od efektu domina lub efektu motyla, jednak w kontekście zogniskowanego wywiadu grupowego nie wprowadza się takich dystynkcji.

Efekt stymulacji. Związek przyczynowo-skutkowy między zachowaniem (werbalnym lub pozawerbalnym) jednego uczestnika a reakcją innego. Stymulacja rozwija dyskusję, wprowadzając do niej kolejne wątki. Z badań Edwarda Ferna (1982, s. 1-13) wynika, że wraz ze zwiększeniem liczby uczestników z 4 osób do 8 znacząco zwiększyła się liczba wypracowanych w grupie pomysłów.

Efekt bezpieczeństwa. Merton (1956) wskazywał, że obecność innych sprzyja odblokowaniu własnych zahamowań i w rezultacie prowadzi do zwiększenia otwartości i tym samym wzrostu wartości uzyskanych informacji. Efekt bezpieczeństwa to także poczucie wsparcia grupowego sprzyjające osłabieniu poczucia osobistej odpowiedzialności uczestnika. Z tym efektem silnie wiąże się zjawisko przesunięcia ryzyka - w większości przypadków grupy podejmują decyzje bardziej radykalne niż te same osoby podjęłyby indywidualnie.

Efekt spontaniczności. Polega na bezpośrednim reagowaniu uczestników na obserwowany i przeżywany emocjonalnie rozwój wydarzeń w trakcie sesji. Spontaniczność i szczerość dla Goldmana to główne przyczyny uzyskiwania w dyskusji grupowej rezultatów bogatszych i jakościowo odmiennych od tych, jakie są możliwe do zdobycia w wywiadach indywidualnych (Goldman, 1962, s. 61-68).

Negatywne efekty grupowe. Naturalnie obecność wielu badanych to nie same zalety dla materiału empirycznego. Należy bowiem liczyć się z możliwością wystąpienia negatywnych efektów grupowych. Wiele czynników ma wpływ na pojawienie się niekorzystnych zmian w dynamice grupowej i w rezultacie na wygenerowanie wyników o niewielkiej wartości. Dzieje się tak na przykład wówczas, gdy w trakcie sesji wyłania się zdecydowany lider lub frakcja, z różnych powodów narzucające pozostałym uczestnikom własny punkt widzenia. Tylko odpowiednio przygotowany i doświadczony moderator może skutecznie przeciwdziałać takim procesom. Ale to nie wszystkie okoliczności, w jakich może dojść do wystąpienia negatywnych efektów grupowych, zmniejszających efektywność pracy grupy fokusowej. 
W odniesieniu do dyskusji fokusowej najczęściej podnosi się ryzyko wystąpienia myślenia grupowego, polaryzacji grupowej, próżniactwa społecznego (Oyster, 2002, s. 179) i konformizmu społecznego. Rozmaite koncepcje zarządzania uzupełniają tę listę o wiele innych niekorzystnych zjawisk, które jednak przy bliższej analizie okazują się szczególnymi odsłonami wymienionych wyżej negatywnych efektów grupowych. Należą do nich na przykład:

1. Syndrom „wielogłowego zwierzęcia” występujący, gdy grupa nie jest wystarczająco zdyscyplinowana i jej uczestnicy w tym samym czasie dyskutują na różne tematy.

2. Konfliktowe cele drugorzędne dające o sobie znać wówczas, gdy dyskusja przeradza się w jakiś rodzaj rywalizacji o zwycięstwo w sferze emocjonalnej, o zdobycie prestiżu, o realizację ambicji.

3. Automatyczne „wyrównywanie” opinii i preferencji indywidualnych zachodzące, gdy zadaniem grupy jest wypracowanie wspólnego stanowiska, osiągnięcie consensusu. W rezultacie uczestnicy koncentrują się na osiągnięciu tego porozumienia i rezygnują $\mathrm{z}$ analizy ewentualnych różnic pomiędzy dyskutantami.

4. Skłonność do konformizmu prowadząca do ujednolicenia poglądów $\mathrm{w}$ grupie. Postawa nonkonformistyczna przejawia się w działaniach skoncentrowanych na obronie własnej tożsamości i oporowaniu wobec grupy.

5. Wzrost poziomu radykalizmu (skrajności) wynikający między innymi z rozproszenia odpowiedzialności.

6. Możliwość zafiksowania się na jednym pomyśle, rezygnacja $\mathrm{z}$ uwzględnienia innych idei.

Syndrom grupowego myślenia. Został zdefiniowany przez I. Janisa (Akert, Aronson, Wilson, 2004, s. 380) jako sposób myślenia, który charakteryzuje ludzi głęboko zaangażowanych w funkcjonowanie swojej grupy o wysokiej spójności. Wtedy dążenie do zachowania grupowej spójności i solidarności jest ważniejsze od realistycznego liczenia się $\mathrm{z}$ faktami. Tendencja do uzyskania jednomyślności pod wpływem nacisków wewnątrzgrupowych postępuje równocześnie ze zmniejszeniem efektywności psychicznej, zdolności do osądu moralnego i realizmu. Wobec braku innych czytelnych punktów odniesienia sama grupa się nim staje. Prawdopodobieństwo wystąpienia tego syndromu wzrasta wówczas, gdy członkowie grupy mają silne motywacje do przynależenia do niej. Z uwagi na antycypowane oczekiwania innych, zwiększa się poziom konformizmu uczestników.

Janis (1972) poszukiwał wyjaśnienia przyczyn sprawiających, że dyskusje polityczne o wyjątkowym znaczeniu (np. decyzja o inwazji na Kubę w Zatoce Świń, zlekceważenie informacji sugerujących możliwość ataku Japończyków na Pearl Harbor, zatuszowanie afery Watergate przez Nixo- 
na i jego doradców) prowadziły do podejmowania złych decyzji. W tym celu na początku lat osiemdziesiątych XX wieku poddał analizie dokumentację o charakterze politycznym i bezpośrednie relacje uczestników spotkań. $\mathrm{Na}$ tej podstawie wskazał okoliczności sprzyjające wystąpieniu syndromu myślenia grupowego. Zaliczył do nich:

1. Wysoką spójność grupy, opartą nie tyle na postrzeganiu wyjątkowości zadania grupowego, ile na wzajemnej percepcji atrybutów członków grupy jako atrakcyjnych; grupa zapewnia prestiż i przynależność do niej staje się pożądana.

2. Izolację grupy od otoczenia zewnętrznego, co zabezpiecza ją przed dostępem alternatywnych rozwiązań.

3. Monopolizację przestrzeni dyskusji przez najbardziej aktywnego werbalnie rozmówcę.

4. Autorytatywny styl przywództwa przejawiający się w kontrolowaniu innych i w narzucaniu innym własnych przekonań.

5. Brak wypracowanych procedur podejmowania decyzji i metod rozpatrywania alternatywnych poglądów.

6. Presję czasu wymuszającą szybkie podjęcie decyzji.

7. Kolektywne doświadczanie poczucia zagrożenia lub iluzję omnipotencji wzmocnioną przez dotychczasowe osiągnięcia. (Akert, Aronson, Wilson, 2004, s. 381)

Do przejawów syndromu grupowego myślenia zalicza się:

1. Poczucie iluzji podzielanie przez większość lub wszystkich członków grupy, wyrażające się wspólnym przekonaniem o sukcesie, będącym rezultatem wypracowania przez grupę jednomyślnej decyzji ograniczającej ryzyko błędu. Takie przekonanie wpływa na osłabienie odczuwania lęku i jednocześnie wzmacnia poczucie pewności siebie poszczególnych członków grupy. Działa stymulująco na gotowość grupy do podjęcia skrajnego ryzyka. Wyzwala nastrój optymizmu, poczucie wszechmocy a zmniejsza poziom samokrytycyzmu i samokontroli.

2. Silne przekonanie członków grupy o bezdyskusyjnej wyższości moralnej własnej grupy, co prowadzi do bagatelizowania lub całkowitego ignorowania etycznych i moralnych konsekwencji własnych decyzji. Taka postawa sprawia, że członkowie grupy blokują możliwość wystąpienia poczucia winy i wstydu za przyczynienie się do podjęcia decyzji, które są sprzeczne $\mathrm{z}$ indywidualnymi zasadami moralnymi. Przekonanie takie jest wzmacniane przez zabiegi dyskredytujące przeciwników (chociażby poprzez pozostawanie wyłącznie w kontekście stereotypu), co ułatwia podejmowanie wobec nich amoralnych działań. 
3. Iluzoryczne poczucie jednomyślności członków grupy, oparte na autocenzurze i grupowej cenzurze tych spośród uczestników, którzy werbalizują odmienne poglądy. Skłonność do wypracowania zgodności (jednomyślności) determinuje wszystkie działania grupy.

4. Wyłonienie osoby (osób), która chroni pozostałych przed dostępem informacji niepożądanych z punktu widzenia spójności grupy. Rolę tę określa się mianem „samozwańczego strażnika myśli”. Zablokowanie dopływu obcych idei zapewnia grupie bezkrytyczne funkcjonowanie.

5. Cenzurowanie, czyli wywieranie bezpośredniego nacisku na poszczególnych uczestników dyskusji w celu skłonienia ich do przeformułowania własnych przekonań w kierunku zgodnym z poglądami grupy. Zespół dysponuje szerokim zestawem dotkliwych środków represyjnych, np. może zakwestionować kompetencje intelektualne, psychiczne i moralne dyskutanta, który zagraża jednomyślności albo go po prostu wykluczyć ze swojego składu.

6. Autocenzurowanie polegające na poddawaniu w wątpliwość własnych przekonań różniących się od grupowych. Po przepuszczeniu własnego poglądu przez filtr zgodności/niezgodności z przekonaniami grupy uczestnik decyduje się na rezygnację lub powstrzymanie się od ujawniania sądów odmiennych, ponieważ grupa dysponuje zestawem sankcji (uznanie za zdrajcę, awanturnika, czy manipulatora).

7. Wspólną obronę atrakcyjności przyjętych ustaleń przejawiającą się w lekceważeniu informacji ostrzegawczych, sugerujących potrzebę rewizji. Grupa ma skłonność do absolutyzowania własnego pomysłu, do taktowania go jako jedyny słuszny i prawdziwy, wobec czego jest zainteresowana wytworzeniem i utrzymaniem dystansu wobec argumentacji innych (przeciwstawienie poglądów eksperci - laicy/amatorzy).

Spośród wskazanych przez Janisa konsekwencji aktywacji syndromu myślenia grupowego dla zmniejszenia produktywności grupy zadaniowej, w przebiegu sesji fokusowych szczególnie istotne wydają się: dyskusja nieuwzględniająca alternatywnych rozwiązań, zablokowanie dostępu opozycyjnych poglądów, selekcja informacji, cenzura i autocenzura.

Literatura dostarcza sugestii na temat sposobów przeciwdziałania syndromowi grupowego myślenia. $\mathrm{W}$ odniesieniu do grup fokusowych skuteczne może być zwłaszcza odpowiednie przygotowanie moderatora, który potrafi zablokować rozwój niepożądanych mechanizmów i dysponuje umiejętnością bezstronnego formułowania podsumowań i wniosków, zachęca do krytyki sformułowanych idei, przyjmuje lub zachęca któregoś z dyskutantów (albo kolejno wszystkich) do przyjęcia roli „,adwokata diabła”. Każdy uczestnik powinien być zobowiązany do wyraźnego sformułowania swoich wątpliwości (w celu uniknięcia wpływu grupy można to zrobić, korzystając 
na przykład z techniki „niedokończonych zdań”). Pomaga również przeprowadzenie kilku sesji z różnymi uczestnikami.

Polaryzacja grupowa. Przejawia się w skłonności grupy do podejmowania decyzji bardziej radykalnych oraz formułowania opinii bardziej skrajnych niż poszczególni członkowie prezentowali przed sesją (Wallach, Kogan, Bern, 1962). Porównania indywidualnych i grupowych zachowań decyzyjnych w sytuacji ryzyka podjął się James Stoner (1961). Jak pisał, analizując uzyskane wyniki, „nie należy abstrahować od możliwego wpływu na te decyzje dwóch czynników, po pierwsze faktu, iż wszyscy badani byli mężczyznami, a po drugie, że byli przedstawicielami uczelni biznesowej, gdzie funkcjonuje stereotyp człowieka biznesu jako gotowego do podejmowania ryzyka." Stoner poszukiwał wyjaśnienia fenomenu polaryzacji grupowej w zjawisku rozproszenia odpowiedzialności. Stwierdził, że grupa daje złudzenie anonimowości, zatem jej członkowie dają sobie przyzwolenie na zachowania mniej odpowiedzialne i moralne a bardziej radykalne. Jednakże inne badania nie potwierdziły słuszności tych wyjaśnień. Współcześnie poszukuje się wytłumaczenia zjawiska polaryzacji grupowej poprzez odwołanie się do mechanizmów autowaloryzacji, perswazji i familiaryzacji. Ludzie dążą do podtrzymania wysokiej samooceny - autowaloryzacji (w tym oceny swoich poglądów) i w chwili konfrontacji indywidualnych przekonań z innymi, dokonują ich korekty, aby utrzymać tę wysoką ocenę. Udaje się to na przykład poprzez zradykalizowanie poglądów. Za pomocą perswazji przekonują innych, nie do końca zdecydowanych do zaakceptowania pewnych poglądów. W efekcie następuje wzajemne utwierdzanie się w słuszności, które sprzyja radykalizacji postaw. Teoria familiaryzacji z kolei zakłada, że w miarę upływu czasu i liczby powtórzeń poglądy (lub zachowania) postrzegane początkowo jako ekscentryczne powszednieją i wzrasta poziom ich akceptacji (Oyster, 2002, s. 188-189).

Próżniactwo grupowe. Opisane po raz pierwszy przez francuskiego inżyniera Maximiliena Ringelmanna, który analizował siłę, z jaką ludzie ciągną linę, w zależności od tego, czy robią to sami, czy też w grupie. W tych klasycznych eksperymentach jednostka ciągnąca linę robiła to przeciętnie z siłą $63 \mathrm{~kg}$, grupa trzyosobowa ciągnęła linę z przeciętną siłą $53 \mathrm{~kg}$ na osobę, grupa ośmioosobowa - $31 \mathrm{~kg}$ na osobę. Można zatem obliczyć, że wydajność grupy ośmioosobowej w porównaniu do grupy trzyosobowej spadła o $(53-31) / 53$, czyli prawie $42 \%$, natomiast w porównaniu z pojedynczą osobą produktywność spadła o ponad 50\%. Ringelmann (1913) ustalił, że w miarę zwiększania liczebności grupy wzrasta jej nieefektywność i tym samym obalił tezę mówiącą o oczywistej skłonności członków zespołów (grup) do zwiększania wysiłków na rzecz grup, do których należą. 
Wskazał także dwa podstawowe mechanizmy odpowiedzialne za ten rezultat: utratę motywacji jednostki i ograniczenie możliwości sprawnej koordynacji działania. Dzisiaj w psychologii społecznej to zjawisko nazywa się „efektem Ringelmanna”.

Kolejne badania (Ingham, Levinger, Graves, Peckham, 1974) potwierdziły te wyniki także wówczas, gdy tylko jeden uczestnik grupy był rzeczywisty a pozostali jedynie imitowali wysiłek. Mimo że praktycznie nie występowała żadna współpraca i porozumienie pomiędzy osobą badaną a współpracownikami badacza, a koordynacja wysiłków była sprowadzona do minimum, to badany wyraźnie ograniczał swój wkład w ostateczny rezultat działań grupowych. Dlatego Ingham i jego współpracownicy podtrzymali tezę Ringelmanna o zmniejszeniu motywacji do działania przekładającym się na indywidualny spadek wydajności, gdy badany funkcjonuje jako członek zespołu. Dla wszystkich przedsięwzięć, których wyniki uzależnione są od współpracy zespołowej, konsekwencje tego mechanizmu są bardzo znaczące. Rezultaty próżniactwa społecznego stanowią zatem swoisty kontrapunkt dla korzyści wynikających z działania mechanizmu synergii.

W badaniach fokusowych można w pewnym zakresie ograniczyć skutki próżniactwa poprzez działania moderatora sugerujące kontrolowanie indywidualnego wysiłku (na przykład przez „wywoływanie do odpowiedzi” uczestników mniej angażujących się w dyskusję), podkreślanie znaczenia indywidualnego wkładu każdego uczestnika i zwiększanie poczucia odpowiedzialności za ostateczny wynik pracy całego zespołu oraz wzmacnianie przekonania o ważności zadania, jakie grupa fokusowa realizuje.

Występowanie próżniactwa społecznego zwykle wiąże się z rozproszeniem odpowiedzialności oraz postępującą deindywiduacją. Rozproszenie odpowiedzialności pojawia się, gdy jednostka w grupie ma poczucie, iż jej osobisty nakład pracy jest niemożliwy lub bardzo trudny do oszacowania i oceny. Deindywiduacja natomiast to „utrata samoświadomości i lęku przed oceną społeczną, do jakiej dochodzi w grupach sprzyjających anonimowości i odciągających uwagę od jednostki" (Myers, 2003, s. 370). W efekcie jednostka działa i traktuje siebie jako element konkretnej grupy społecznej, pozostając pod jej przemożnym wpływem, spada jej poczucie odpowiedzialności za własne postępowanie i wzrasta gotowość do podejmowania działań radykalnych, często szkodliwych.

Konformizm grupowy. W psychologii społecznej konformizm rozumie się jako zmianę zachowania $\mathrm{w}$ wyniku faktycznego lub antycypowanego oddziaływania (nacisku) innych. W jednostce będącej członkiem grupy pojawia się skłonność do uległości wobec poglądów czy wartości charakterystycznych dla tej grupy społecznej. Przyjmuje się, że u podstaw konformizmu grupowego leży głównie wpływ normatywny oraz informacyjny. 
Wpływ normatywny wynika z potrzeby akceptacji oraz przynależności do danej grupy i skutkuje podporządkowywaniem działań i decyzji jednostki normom obowiązującym w grupie. Natomiast wpływ informacyjny polega na zmianie zachowania jednostki pod wpływem docierających do jednostki informacji (Oyster, 2002, s. 160-161).

Konformizm grupowy $w$ fokusie prowadzi zatem do uniformizacji wygłaszanych opinii, a tym samym do pozbawienia materiału badawczego niezwykle cennych odmiennych idei. Dlatego należy dążyć do ograniczenia warunków sprzyjających wystąpieniu tego zjawiska.

Moderator może podjąć następujące działania (Maison, 2001, s. 131-134):

- podkreślać obowiązywanie zasady braku jednomyślności celem ośmielenia osób, których poglądy pozostają w opozycji do wypowiedzi pozostałych członków grupy,

- w pierwszej kolejności kierować pytania do uczestników wykazujących się najmniejszą aktywnością werbalną oraz tendencją do potwierdzania opinii osób, które zmonopolizowały dyskusję,

- korzystać z indywidualnych technik zbierania materiału, w celu uchwycenia opinii danego dyskutanta, niezmodyfikowanej pod wpływem wypowiedzi pozostałych uczestników spotkania,

- aktywnie odbierać komunikaty niewerbalne, które mogą być wyrazem sprzeciwu pojedynczych osób względem zdania większości.

Dynamika grupowa, która generuje wystąpienie zarówno pozytywnych, jak i negatywnych efektów grupowych warunkuje zatem informacje gromadzone w trakcie sesji fokusowej. Dlatego też warto wykorzystać dostępne $w$ fokusie metody zadbania o jak najkorzystniejszy dla oczekiwanego materiału rozwój tej dynamiki. W tym celu moderator powinien (NikodemskaWołowik, 1999, s. 104-105):

- kontrolować właściwy poziom aktywności poszczególnych uczestników, czyli ograniczać udział osób zbyt dominujących i jednocześnie motywować, zachęcać do zabrania głosu uczestników wycofanych;

- dbać o zachowanie relacji typu badany - grupa i nie dopuścić do przekształcenia jej w układ badany - moderator, by fokus nie zatracił swojej specyfiki na rzecz kilku równolegle prowadzonych wywiadów indywidualnych;

- wypracować atmosferę, w której uczestnicy odczują swobodę w wyrażaniu swoich emocji;

- doprowadzić do pojawienia się ze strony uczestników samodzielnej inicjatywy w kierunku polemizowania z innymi badanymi;

- zadbać o życzliwą postawę badanych wobec siebie. 
Mając na uwadze decydujące znaczenie dynamiki grupowej dla uzyskiwanego w wyniku badań fokusowych materiału, podjęto próbę (Lisek-Michalska, Lipiec, Olczyk, 2012) skonstruowania strategii oceniania metodologicznej i praktycznej (merytorycznej) jakości badań fokusowych. Przyjęto za punkt wyjścia fakt, że uzyskiwany przez badacza materiał jest produktem grupy, czyli właśnie zachodzących w niej dynamicznych procesów wyzwalających wspomniane efekty grupowe. „W badaniu przyjęto dwie przesłanki wyjściowe: 1) metodologiczna jakość fokusa jest ujmowana jako stopień nasilenia efektów grupowych, 2) efekty grupowe są bezpośrednim następstwem dynamiki grupowej, można stwierdzić, że metodologiczna jakość FGI jest dokonywaną przez badacza oceną poprawności dynamiki grupowej. Dynamika ta jest tym bardziej prawidłowa, im rejestruje się większą siłę aktywacji pozytywnych efektów grupowych imniejsze nasilenie efektów negatywnych z zastrzeżeniem, że nadmiarowa siła aktywacji efektów emocjonalnych może skutkować redukcją nasilenia efektu stymulacji oraz śnieżnej kuli. Ocena poprawności dynamiki grupowej powinna zatem uwzględniać przejawy tej dynamiki, czyli pozytywne i negatywne efekty grupowe, a ściślej ich siłę aktywacyjną. Z kolei ocena stopnia nasilenia wybranych efektów powinna bazować na częstości obserwowanych zachowań dyskutantów, np. częstości artykulacji odmiennych przekonań." Rozumowanie to miało za zadanie wykazać wyraźnie „(...) dystynkcje zaznaczające się między pojęciami metodologicznej jakości FGI, dynamiki grupowej i efektów grupowych. Zatem dynamika grupowa i jej następstwa - efekty grupowe - są »dziełem« grupy, a metodologiczna jakość FGI (podobnie jak jakość praktyczna) jest konstruktem tworzonym przez badacza, który opisuje poprawność dynamiki grupowej oraz stopień nasilenia efektów grupowych."

Autorzy tej propozycji stwierdzili w oparciu o zgromadzony materiał empiryczny, iż metodologiczna i praktyczna jakość fokusa są ze sobą wyraźnie powiązane. Badanie doprowadziło do konkluzji, że na jakość merytoryczną badania FGI wpływa siła aktywacji poszczególnych efektów grupowych.

„Po pierwsze stwierdzono, że wyższa siła aktywacji efektów emocjonalnych, tj. efektu bezpieczeństwa i spontaniczności może stymulować dyskutantów z grup FGI do generowania bardziej różnorodnych lub unikalnych wypowiedzi. Emocje kontrolujące (np. lęk) zawężają zakres uwagi podmiotu do świata wewnętrznych przemyśleń, z kolei emocje adaptacyjne (np. ożywienie, zapał) ukierunkowują uwagę na bodźce działające w otoczeniu zewnętrznym. Przenosząc to ogólne założenie psychologiczne na pole badań FGI, można stwierdzić, że dyskutant przeżywający lęk, np. przed krytyką rozmówców lub odrzuceniem ze strony grupy, może być nadmiernie zaabsorbowany antycypacją potencjalnych kosztów i strat wiążących się z wprowadzeniem do dyskusji nowego wątku tematycznego lub z publiczną arty- 
kulacją niekonwencjonalnych lub odmiennych od interlokutorów przekonań. Silniejsza tendencja do przeżywania emocji kontrolujących aktywowanych na myśl o przystąpieniu do badania może skłonić dyskutanta do rezygnacji z wygłoszenia własnej opinii lub zachęcić do dokonania treściowej replikacji poprzednich poglądów, które nie wzbudziły w grupie oporu w ten sposób badany nie przyczynia się do wzrostu liczby wypowiedzi unikalnych i treściowo zróżnicowanych.

Po drugie, również wyższa siła aktywacyjna syndromu grupowego myślenia może powstrzymywać przed artykulacją niekonwencjonalnych lub nowych w aspekcie treściowym wypowiedzi. Osiowym symptomem powyższego efektu jest dążenie do utrzymania życzliwej i bezkonfliktowej atmosfery oraz zachowania spójności grupowej, a każdy pogląd, zwłaszcza niekonwencjonalny generuje ryzyko ujawnienia się w grupie różnych stanowisk, mieszanych nastawień. W rezultacie taki pogląd może stać się przyczynkiem do zawiązania się konfliktu i rozpadu grupy.

Po trzecie, mniejsze nasilenie pozytywnych efektów zadaniowych, tj. efektu stymulacji i śnieżnej kuli, może być barierą powstrzymującą przed pozyskaniem bardziej pogłębionych wypowiedzi, szczególnie gdy dyskutanci przejawiają słabszą tendencję do postrzegania rozmówców jako atrakcyjnych interpersonalnie. Im mniejsza skłonność do przypisywania członkom własnej grupy fokusowej atrybutów atrakcyjności interpersonalnej, np. inteligencji, tendencji do oryginalnego myślenia, umiejętności przekonującego argumentowania własnych poglądów, tym słabsza motywacja do intensywnego lub długotrwałego angażowania zasobów uwagi oraz pamięci długotrwałej umożliwiających odnoszenie się do spostrzeżeń innych na drodze komentowania, uzupełniania i klaryfikowania wypowiedzi innych i zadawania pytań.

Po czwarte, można zauważyć, że istnieje przełożenie między metodologiczną a praktyczną jakością badania FGI, dlatego wysiłki badawcze warto ukierunkować na poszukiwania czynników regulujących oraz modyfikujących stopień nasilenia efektów grupowych. Wyniki tego projektu badawczego mogą inicjować ważny z praktycznego punktu widzenia trend w badaniach FGI trend, którego celem jest identyfikacja regulatorów siły aktywacji efektów grupowych pośrednio wpływających na różnorodność, unikalność i nasycenie informacji pozyskanych z wykorzystaniem metody zogniskowanego wywiadu grupowego." (Lisek-Michalska, Lipiec, Olczyk, 2012)

Badanie, z którego pochodzą powyższe rezultaty miało niewielki zakres, jednak wyniki wydają się bardzo obiecujące i zasługują na dalszą penetrację w oparciu o zaproponowane schematy postępowania analitycznego. Bez 
wątpienia potwierdzają jednak niezwykłe znaczenie kontekstu grupowego dla uzyskiwanych $w$ fokusie informacji.

\section{Moderator}

W trakcie dyskusji, sesji fokusowej, zaproszeni uczestnicy w swobodnej atmosferze wypowiadają się na tematy poruszane kolejno przez osobę prowadzącą (moderatora), który czuwa nad sprawnym przebiegiem wywiadu, dba o utrzymanie odpowiedniego poziomu aktywności każdego z uczestników oraz o to, by uzyskać materiał dotyczący wszystkich pytań zawartych w narzędziu badawczym (interview guide).

Zadaniem moderatora jest wygenerowanie możliwie wielu zróżnicowanych i zinterpretowanych idei, pomysłów. Powinien czynić to $w$ toku swobodnej, spontanicznej dyskusji, możliwie zbliżonej do sposobu, w jaki zaproszeni uczestnicy w życiu codziennym formułują swoje opinie.

Kluczem do zrozumienia roli moderatora jest uznanie faktu, iż konwersacja w trakcie sesji fokusowej jest zupełnie czymś innym niż wywiad indywidualny. Nie jest to także kilka wywiadów prowadzonych jednocześnie, ale płynna dyskusja kierowana i stymulowana przez moderatora. 0 optymalnym przebiegu sesji mówi się wówczas, gdy rola moderatora ogranicza się do dyskretnego nadawania kierunku rozmowie (zgodnie ze znaczeniem moderate - wyciszać, łagodzić, powściągać), a uczestnicy wchodzą ze sobą w żywe interakcje, stymulując się wzajemnie. Wobec tego za najlepsze dla fokusa uważa się zachowanie równowagi pomiędzy działaniami moderatora a nieskrępowaną dyskusją, która pozostaje w związku z problematyką badania (Williams, 2003, s. 67).

Zasadniczy wpływ moderatora na przebieg sesji i w konsekwencji na jakość uzyskanego materiału badawczego jest bezsporny7. Jeżeli nie kwestionuje się występowania wielokierunkowego i wieloaspektowego wpływu ankietera na przebieg i rezultaty wywiadu kwestionariuszowego, to analogicznie do efektu ankieterskiego uznać należy, że możliwości moderatora w badaniu fokusowym są w tym wymiarze nieporównanie większe, a potencjalne strefy ingerencji badacza bardziej rozległe. Każde jego działanie przekłada się na rozwój sytuacji w grupie. Jeśli moderator zostanie odebrany jako osoba zagrażająca bezpieczeństwu badanych, rozmówcy stronić będą od wypowiadania się. Jeśli grupa spostrzeże go jako postać niepanującą nad rozwojem wydarzeń, przejmie kontrolę nad przebiegiem sesji. Jeśli moderator będzie zbyt aktywny i dominujący, grupa ograniczy swoje zaangażowanie i zmniejszy się intensywność dynamiki grupowej, bowiem to on stanie się centrum, do któ-

\footnotetext{
${ }^{7}$ Ale wyniki badań (Fern, 1982) pokazują, że obecność moderatora nie zwiększa ilości generowanych pomysłów w porównaniu z grupami niemoderowanymi.
} 


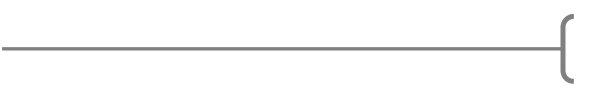

41

Fokus - definicja i rodzaje

rego poszczególni uczestnicy kierować będą swoje wypowiedzi i sesja fokusowa przekształci się w kilka jednocześnie prowadzonych wywiadów pomiędzy moderatorem i poszczególnymi uczestnikami. Jasno wynika z tego, że z zadaniem moderowania sesji wiąże się wiele wyzwań i wymaga to różnorodnych umiejętności.

$\mathrm{Z}$ uwagi na fakt, że to od zachowania moderatora w ogromnym stopniu uzależniony jest sukces sesji fokusowej, nie może to być przypadkowa osoba. Od idealnego moderatora oczekuje się, że będzie posiadał na przykład następujące cechy:

- potrafi słuchać z uwagą i empatią,

- potrafi słuchać i myśleć (zapamiętywać) jednocześnie,

- jest przekonany, że każdy uczestnik niezależnie od poziomu wykształcenia, czy doświadczenia ma coś ważnego i interesującego do powiedzenia i daje temu wyraz,

- posiada wiedzę na temat, którego dotyczy spotkanie,

- potrafi powstrzymać się od ujawniania własnych przekonań,

- potrafi zarządzać grupą i swobodnie prowadzić dyskusję.

Greenbaum (1998, s. 76-79) uzupełnia tę listę o konieczność posiadania przez moderatora:

- zdolności do szybkiego i adekwatnego reagowania na bodźce, także nieoczekiwane

- umiejętności podtrzymywania rytmu dyskusji,

- inteligencji,

- doświadczenia pozwalającego na właściwe kierowanie dyskusją,

- odpowiedniego poziomu kompetencji komunikacyjnych, aby był w stanie zainicjować i podtrzymywać właściwy rodzaj relacji z badanymi.

Praktyka badawcza wskazuje, że generalnie rzecz ujmując, moderator powinien posiadać określone kompetencje (cechy) zarówno osobiste, jak i badawcze/przywódcze. Wśród cech osobistych szczególnie przydatne są:

- autentyczne zainteresowanie myślami i uczuciami innych ludzi, dociekliwość i potrzeba zadawania pytań, aby zaspokoić głód wiedzy,

- ekspresyjność w sferze emocji wyrażająca się zdolnością do (kontrolowanego) ujawniania osobistych reakcji,

- spontaniczność korzystna dla wysokiej dynamiki grupowej,

- wyrazistość, szczególnie istotna dla działań o charakterze stymulującym,

- poczucie humoru pozbawione agresji i złośliwości,

- zdolność do empatii, która sprzyja właściwemu zrozumieniu sposobu, w jaki uczestnicy postrzegają rzeczywistość, 
- zdolność do introspekcji niezbędna do poznania i zrozumienia własnych poglądów i emocji a tym samym ograniczeń związanych $\mathrm{z}$ badaniem i wyrobienie w sobie odpowiedniego dystansu ${ }^{8}$,

- umiejętność jasnego i szybkiego formułowania myśli,

- elastyczność - musi być zdolny do szybkiego reagowania na wykryte nieefektywne elementy narzędzia badawczego,

- niski poziom lęku w sytuacjach społecznych,

- umiejętność improwizacji,

- zdolność do utrzymania własnego wysokiego poziomu nastawienia zadaniowego.

Z kolei moderator jako lider powinien posiadać umiejętności:

- takiego formułowania problemu, aby wzbudzić w uczestnikach gotowość i chęć do jego konstruktywnego rozwiązywania,

- właściwego selekcjonowania przekazywanych uczestnikom informacji, aby wystarczająco dokładnie wyjaśniały zadanie, ale nie zawierały sugestii rozwiązania,

- kontrolowania i kierowania rozwojem dynamiki grupowej,

- radzenia sobie z przerwami i ciszą,

- sformułowania pomysłów grupy w sposób bardziej precyzyjny, jasny niż uczynili to sami członkowie grupy,

- zadawania pytań stymulujących rozwiązanie problemu,

- podsumowania wyników pracy całej grupy.

W rezultacie okazuje się, że idealny moderator poza wyposażeniem w określoną wiązkę cech osobowościowych, powinien łączyć w sobie dociekliwość badacza naukowego, pragmatyzm marketingowca i determinację działacza społecznego.

Często zaleca się, aby moderatorowi towarzyszył asystent, ale w praktyce z powodu dodatkowych kosztów często rezygnuje się z zaangażowania takiej osoby. Asystent zajmuje się sprawami organizacyjnymi, obsługą sprzętu rejestrującego i sporządza notatki, służy radą w przypadku różnych komplikacji. Jego obecność zmniejsza obciążenie moderatora i tym samym stwarza warunki do tego, aby moderator był skoncentrowany wyłącznie na swoim zasadniczym zadaniu.

\footnotetext{
8 Zdaniem Nikodemskiej-Wołowik (1999, s. 118-122) świadomość własnych opinii związanych z przedmiotem rozmowy jest niezbędna do tego, aby moderator mógł wypracować wobec niego możliwie obiektywną postawę wyrażającą się w merytorycznym i rzeczowym podejściu do dyskusji.
} 


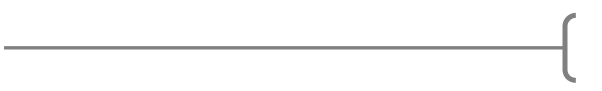

43

\section{Sesja - organizacja}

Sesja fokusowa zazwyczaj trwa 1,5-2 godziny, przy czym czas przeznaczony na spotkanie zawsze powinien być dostosowany do antycypowanych możliwości uczestników. Ten czas można w uzasadnionych przypadkach wydłużyć, jednak wówczas moderator powinien dysponować środkami pozwalającymi na podtrzymanie aktywności i koncentracji uczestników. Chodzi tu przede wszystkim o stosowanie dynamicznie zmieniających się rodzajów zadań stawianych przed badanymi, o zabiegi relaksujące, odprężające badanych, wreszcie o dbałość o poczęstunek i napoje.

Sesje przeprowadzane są w specjalnie dostosowanych pracowniach fokusowych, chociaż dzięki rozwojowi technologii informatycznej możliwe jest ich przeprowadzanie praktycznie wszędzie bez konieczności rezygnacji z zapisu przebiegu spotkania oraz z możliwości jego oglądania „na żywo”. Wystarczy w sąsiednim pomieszczeniu podłączyć monitor, na który przekazywany jest bezpośrednio obraz z kamery. Jest to szczególnie istotne udogodnienie, gdy sesje organizuje się w małych miejscowościach, gdzie nie funkcjonują profesjonalne pracownie fokusowe. Poza tym te techniczne usprawnienia dają możliwość organizowania sesji w miejscach bardziej naturalnych, postrzeganych jako przyjazne przez zaproszonych uczestników (na przykład w wiejskiej szkole, klubie studenckim). Przebieg sesji jest rejestrowany przy pomocy kamery i/lub dyktafonu. Bez względu na rodzaj pomieszczenia i jego lokalizację, należy zwrócić uwagę na następujące aspekty organizacji scenografii:

1. Lokalizacja zapewniająca dogodny dojazd komunikacją lokalną.

2. Parking dostępny dla uczestników.

3. Właściwe (widoczne) oznakowanie drogi prowadzącej do pomieszczenia badawczego (szczególnie istotne w dużych budynkach).

4. Wystarczająco cicha okolica pomieszczenia badawczego (ruchliwa ulica, trwająca budowa, boisko szkole).

5. Wystarczająco przestronne pomieszczenie.

6. Wystarczająca liczba miejsc siedzących.

7. Odpowiednia temperatura $\mathrm{w}$ pomieszczeniu.

8. Miejsce na okrycia wierzchnie uczestników.

9. Odpowiednio duży stół/blat do dyspozycji, szczególnie jeśli planuje się zadania wymagające pisania, oglądania różnych przedmiotów.

10. Odpowiednio ulokowane kamera i mikrofony — zamocowane dyskretnie, ale w sposób gwarantujący możliwie najlepszą jakość nagrania.

11. Podłączenie sprzętu multimedialnego (jeśli planuje się prezentacje materiałów audiowizualnych).

12. Przygotowane materiały i rekwizyty potrzebne do realizacji scenariusza. 
13. Napoje, ewentualnie jakieś przekąski i właściwe naczynia do ich podania. W szczególnych sytuacjach — organizacja dla badanych obiadu lub innego ciepłego posiłku.

14. Odpowiednio przygotowane upominki lub koperty z pieniędzmi dla uczestników.

W określonych sytuacjach organizator badania zobowiązany jest do zapewnienia dodatkowych usług na czas trwania sesji. Na przykład: zorganizowanie opieki nad małymi dziećmi, jeśli w badaniu uczestniczą młode matki, zadbanie o obecność lekarza, gdy uczestnikami są osoby dotknięte jakimś rodzajem choroby, psychologa, jeśli tematy są trudne, tłumacza (także języka migowego) itd.

Komuś, kto nie spotkał się w swojej praktyce fokusowej z niedostatecznym zadbaniem o któryś z powyższych elementów organizacji sesji, zalecenia te mogą wydać się banalne. Jednak niedopilnowanie któregoś z nich w rzeczywistości może sprawić, że sesja stanie się porażką.

W jednym projekcie należy zaplanować najlepiej 3-5 sesji fokusowych. Zresztą dość łatwo można zorientować się, czy należy organizować jeszcze następną sesję — jeśli moderator na kolejnym spotkaniu nie dowiedział się niczego nowego, prawdopodobnie temat został wysycony.

\section{Sesja - przebieg}

Sesja fokusowa ma swoją czytelną strukturę, składa się zasadniczo z 3 części - w każdej z nich pojawiają się inne rodzaje stawianych pytań. Pytania we wstępnej, wprowadzającej fazie badania mają za zadanie rozluźnić atmosferę, zwiększyć poczucie bezpieczeństwa i przygotować do zasadniczej dyskusji. Ponieważ uczestnicy nie otrzymują wcześniej do wglądu tematów, które zostaną poruszone w trakcie sesji (powiadamiani są jedynie ogólnie o przedmiocie rozmowy), pytania zadawane im w części zasadniczej sesji powinny być konkretne, krótkie, zrozumiałe, dotyczące każdorazowo tylko jednego aspektu, otwarte. Powinny być formułowane w taki sposób, aby niemożliwe było udzielenie odpowiedzi tylko tak lub nie. Do rozbudowanych odpowiedzi skłaniają pytania rozpoczynające się od: w jaki sposób..., dlaczego..., w jakich okolicznościach... W ostatniej fazie sesji pytania moderatora sprowadzają się głównie do ustalenia, czy wszystko zostało powiedziane i właściwie zrozumiane, czy niczego nie pominięto, czy któryś z uczestników nie chciałby czegoś dodać, zmienić, wyjaśnić. Trójelementowa struktura sesji znajduje swoje odzwierciedlenie w konstrukcji scenariusza.

Zarówno moderator, jak i jego pomocnik powinni powitać uczestników, pomóc im w rozlokowaniu się oraz, jeśli jest taka potrzeba, w wypełnieniu dodatkowych dokumentów rekrutacyjnych. 
W części wprowadzającej moderator ma obowiązek dokonać prezentacji siebie jako przedstawiciela instytucji realizującej badanie, wyjaśnić jego cel, temat i zasady (poinformować o prawie do rezygnacji, o tym, że spotkanie jest rejestrowane, podkreślić wartość wszystkich wypowiedzi, poprosić o zachowanie wzajemnego szacunku poprzez nieprzerywanie sobie wzajemnie), określić czas trwania spotkania i sformułować oczekiwania względem uczestników. Zapewnia także o nieujawnieniu nagrania nikomu spoza zespołu badawczego, gwarantuje poufność danych i osób. Zobowiązuje także innych uczestników do zachowania dla siebie usłyszanych opinii.

Po udzieleniu odpowiedzi na ewentualne pytania uczestników moderator upewnia się, że wszystko zostało właściwie zrozumiane i prosi o podpisanie oświadczenia o świadomie podjętej decyzji uczestnictwa. W dalszej kolejności moderator powinien zastosować jakiś rodzaj formuły prezentującej uczestników względem siebie. Często stosuje się imienne identyfikatory ułatwiające wzajemne komunikowanie się, które są także przydatne podczas sporządzania transkrypcji z przebiegu sesji. Ta część sesji ma charakter integracyjno-organizacyjny, bowiem z jednej strony zmniejsza dystans pomiędzy uczestnikami spotkania, z drugiej - ustanawia porządek dyskusji i charakter relacji między moderatorem a dyskutantami.

Jeśli zachodzi taka potrzeba, w tym momencie można prosić o wypełnienie krótkich ankiet, których wyniki są przydatne później do analizy ich wypowiedzi. Taki kwestionariusz powinien być krótki, wypełnienie go powinno zająć badanym 3-4 minuty. Jeśli moderator wyczuwa, że pomimo upływu kilku-kilkunastu minut uczestnicy spotkania nie czują się wystarczająco naturalnie (Kruger, Casey, 2000), nie są rozluźnieni, może wprowadzić jakiś rodzaj techniki dodatkowej, ułatwiającej odprężenie i osłabiającej nadmierną kontrolę ze strony respondentów (zob. np. Lisek-Michalska, 2004, s. 155-194).

Wreszcie moderator przechodzi do zadawania pytań zgodnie z opracowanym wcześniej scenariuszem. Dyskusja w grupie koncentruje się wokół starannie przygotowanych wcześniej pytań badawczych. Zwykle nie jest ich wiele, zaledwie kilka. Niektórzy praktycy uważają, że liczba pytań badawczych w jednej sesji powinna ograniczać się do 8-9 (Eliot i in., 2005). Zresztą sama nazwa focused interview oznacza skupienie, zogniskowanie jak w optycznej soczewce uwagi uczestników na konkretnym obiekcie/zjawisku badanym po to, aby obejrzeć ten obiekt/zjawisko możliwie dokładnie, szczegółowo i ze wszystkich stron.

Początkowe pytania są zwykle łatwe, ogólne, by wraz ze wzrostem dynamiki spotkania przejść do spraw bardziej szczegółowych i często trudniejszych. Moderator jest zobowiązany do uzyskania informacji dotyczących 
wszystkich pytań zamieszczonych w narzędziu badawczym w przewidzianym czasie. Odpowiada za to, by wszyscy uczestnicy w jednakowym stopniu mieli możliwość wyrażenia swoich poglądów. Dba o precyzyjne i jednoznaczne wyjaśnienie i uzasadnienie formułowanych sądów. Do tego celu służy mu wiele pytań dodatkowych, sondujących, na przykład: Proszę powiedzieć o tym coś więcej, Proszę podać jakiś przykład, Proszę poprawić mnie, jeśli coś niewłaściwie zrozumiałem i wiele innych. Ta ostatnia formuła, kiedy moderator, parafrazując i podsumowując jakąś długą i skomplikowaną wypowiedź, prosi o jej krytyczną ocenę uczestników, spełnia dodatkową bardzo pożyteczną funkcję, mianowicie pozwala innym badanym właściwie zrozumieć przebieg dyskusji. Jednocześnie moderator prezentuje się jako osoba zainteresowana, uważnie słuchająca, co stanowi doskonały bodziec stymulujący dla uczestników.

Dobry scenariusz i doświadczony moderator potrafią zadbać o płynne przejście pomiędzy ogólną dyskusją a szczegółowymi pytaniami. Podobnie jak pod koniec spotkania następuje powrót do spraw bardziej ogólnych, podsumowujących. Taka procedura zbierania informacji, w przeciwieństwie do badania surveyowego, daje badanemu czas na mentalne i emocjonalne przygotowanie się do udzielania odpowiedzi. Poza tym w fokusie oczekuje się od badanych odpowiedzi rozbudowanych i uzasadnionych, a nie tylko wyboru odpowiedniej alternatywy z przygotowanej wcześniej listy. Dlatego, inaczej niż w przypadku surveyu, materiał do analizy wymaga odpowiedniego przygotowania, czyli sporządzenia transkrypcji, zanim zostanie poddany obróbce. W wywiadzie standaryzowanym układ ról pomiędzy badaczem a badanym jest stały i sztywny. Dopuszczone i oczekiwane w sytuacji badawczej zachowania obu podmiotów są dość rygorystycznie określone. Zupełnie inna sytuacja jest w fokusie. Często zdarza się (i jest to ze wszech miar pożądane), że moderator przestaje być postrzegany przez uczestników jako przedstawiciel badacza, staje się po prostu jednym z nich. Mogą mu zadawać pytania, wspólnie się śmieją, oddziałują na siebie silnie za pomocą sygnałów niewerbalnych. Czasem dyskusja zbacza z założonego nurtu, ale jeśli moderator postrzega tę sytuację jako pożyteczną z badawczego punktu widzenia, może akceptować takie zachowania uczestników. W zamian ma szansę usłyszeć coś, czego nie przewidziano w scenariuszu, a co okaże się niezwykle pomocne przy opisie badanego zjawiska. I zostaje wykorzystane do następnej sesji. Jest to możliwe wyłącznie dzięki zapewnieniu badanym warunków do swobodnego wypowiadania się w bezpiecznym środowisku. Takich odkryć nie uda się uzyskać w badaniach surveyowych9.

\footnotetext{
${ }^{9}$ W efekcie grupowej dyskusji pojawiają się informacje, które nie miałyby szansy zaistnieć także w wywiadzie indywidualnym. Obecność innych osób („podobnych”), wysłuchanie ich
} 
FGI w większym stopniu niż inne metody, pozwala na uzyskanie zaskakujących informacji. Tematy mogą być modyfikowane z sesji na sesję, a nawet w czasie jej trwania. Doświadczony moderator może opierać się na pomysłach i spostrzeżeniach poprzednich grup, docierając do bardziej szczegółowych informacji. Zatem zupełnie inaczej niż w badaniach standaryzowanych, moderator może kreatywnie i swobodnie korzystać z narzędzia i, podobnie jak ma to miejsce w wywiadzie swobodnym, dostosowywać taktykę prowadzenia dyskusji do konkretnych okoliczności. Naturalnie zobligowany jest do uzyskania informacji pozwalających odpowiedzieć na postawione pytania problemowe - te nie ulegają modyfikacji (Lindlof, Taylor, 2002).

Moderator poza warstwą merytoryczną spotkania musi także kontrolować jego wymiar psychologiczny (dynamikę grupową). Do jego zadań należy mobilizowanie uczestników pozostających poza głównym nurtem rozmowy, powstrzymywanie tych, którzy mają tendencje do monopolizowania dyskusji. Dysponuje w tym celu bogatym warsztatem technik. Jednocześnie musi powstrzymać się od wyrażania zarówno werbalnie, jak i pozawerbalnie akceptacji lub dezaprobaty wobec pojawiających się wypowiedzi i komentarzy. Czasem jest to zadanie niezwykle trudne, kiedy uczestnik w oczekiwaniu potwierdzenia zwraca się do moderatora na przykład z następującym stwierdzeniem: Przecież każdy się ze mna zgodzi, że aby właściwie wychować dziecko, trzeba je bić od maleńkości. Musi mieć szacunek do ojca. Prawda?

Obecność grupy i zachodzących w niej procesów (stymulacji, synergii i in.) pomaga badanym uruchamiać skojarzenia, które prawdopodobnie wcale nie wystąpiłyby w wywiadzie indywidualnym. Mechanizm ten powoduje, że wypowiedzi uczestników stają się bardziej rozbudowane. Jednocześnie moderator ma możliwość interweniować w dowolnym momencie i prosić ouszczegółowienie, uzupełnienie bądź wyjaśnienie wypowiedzi badanych. Ma także wyjątkową sposobność do zapoznania się ze specyfiką języka (vernacular speech), jakim posługują się badani, bowiem w trakcie dyskusji uczestnicy odkrywają i uzgadniają język, przy pomocy którego opisują podobne doświadczenia.

Końcowa faza sesji zwykle zawiera pytania łatwiejsze, podsumowujące, korygujące i uzupełniające. Po uzyskaniu odpowiedzi na wszystkie przygotowane pytania i upewnieniu się, że wszystko zostało już powiedziane

opowieści, wspomnień, poznanie doświadczeń pobudza twórczą aktywność, kreatywność, o jaką nie podejrzewaliby się sami badani (Lindlof, Taylor, 2002, s. 182). Ujawnianiu takich obszarów sprzyjają techniki dodatkowe, w tym w szczególności techniki projekcyjne (LisekMichalska, 2004) oraz różne techniki twórczego myślenia (Nęcka, Brocławik, 1984; Nęcka, 1994), twórczego rozwiązywania problemów i wiele innych (na przykład burza mózgów) (Osborn, 1959), technika winiety, „sześć kapeluszy” (de Bono, 1999). 
i poprawnie zinterpretowane, moderator zobowiązany jest do podziękowania uczestnikom sesji oraz do przekazania im prezentów lub ustalonych sum pieniędzy.

Bezpośrednio po opuszczeniu przez badanych pomieszczenia moderator wraz z asystentem sprawdzają jakość nagrania, odpowiednio identyfikują zebrane materiały, podsumowują najważniejsze idee, porządkują pomieszczenie. Następnie w możliwie krótkim czasie sporządza się transkrypcję z nagrania, według reguł obowiązujących w zaplanowanym sposobie opracowania: albo jest to zapis dosłowny, rejestrujący, albo z transkrypcji usuwa się wszelkie zbędne z punktu widzenia zapotrzebowania informacyjnego kwestie, pozostawiając jedynie merytorycznie istotne wypowiedzi. W zależności od potrzeb, czasem identyfikuje się autora wypowiedzi poprzez podanie jego symbolu kodu, a czasem nie opisuje się poszczególnych wypowiedzi w ten sposób.

Dalsze opracowanie zależy od potrzeb i możliwości badaczy oraz od celu, jakiemu ma służyć. W różnym stopniu na przykład wykorzystuje się do analizy komunikaty pozawerbalne. Natomiast zasadniczo obiektem analizy są słowa (w szczególnych sytuacjach używane w różnych znaczeniach), albo różne określenia opisujące, zdaniem badanych, to samo zjawisko, kontekst wypowiedzi, sposób, w jaki została wyrażona, poziom jej szczegółowości, podawane przykłady, uzasadnienia, stopień przekonania osoby wypowiadającej się, ilość i rodzaj reakcji (akceptacja, dezaprobata), jakie wypowiedź wywołała.

Istotą opracowania wyników badania fokusowego są słowa i konteksty, w jakich zostały użyte przez uczestników, odtwarzające ich sposób postrzegania zjawiska i logikę rozumowania.

Coraz częściej stosuje się oprogramowanie do komputerowej analizy danych jakościowych (OpenCode 3.6, Atlas.ti oraz NVivo) (Niedbalski, Ślęzak, Bieliński, Iwańska, Rosińska-Kordasiewicz, 2007, s. 89-114; Wilk, 2001, s. 49-63), ale także przy niewielkiej liczbie sesji można prowadzić analizę metodą „wytnij-wklej", łącząc poszczególne wypowiedzi w szersze znaczeniowo lub bardziej wysycone kategorie i ich podkategorie. Każda kategoria otrzymuje swoją nazwę. Dalej następuje proces syntezy. Sformułowane wnioski i rekomendacje odnoszą się do informacji uzyskanych od grupy/grup, a nie od pojedynczych uczestników. Możliwości uogólnienia wniosków są bardzo ograniczone, można co najwyżej mówić o generalizacjach typologicznych, w żadnym razie zaś statystycznych. Pojawiły się co prawda sugestie poddania danych uzyskanych w badaniach fokusowych opracowaniu ilościowemu przy użyciu statystyki małych prób, jednak poglądy badaczy na kwestię zasadności i metodologii tych działań są podzielone; jak pisze Maciej Karwowski (2003) postępowanie takie „(...) zdaniem niektórych specjalistów (Maison 2001, s. 105) jest (...) dużym błędem, zdaniem innych (Kruszewski, 2000) jest zupełnie dopuszczalne". 


\section{MITY NA TEMAT FOKUSA ${ }^{10}$}

Przedstawiona wyżej charakterystyka badania fokusowego, nawet tak ogólna, stanowi dobrą okazję do przyjrzenia się obiegowym opiniom na jego temat. W odniesieniu do fokusów funkcjonuje powszechnie wiele nieporozumień. Chyba żadna inna technika zbierania materiałów nie zapracowała sobie na taką „sławę".

Współcześnie FGI jest stosowany w bardzo wielu obszarach i służy rozmaitym celom, poczynając od opracowania kampanii reklamowych dla pasty do zębów do analizy wizerunków polityków, z prezydentami Stanów Zjednoczonych włącznie. Rysunki na temat FGI pojawiają się na stronach wysokonakładowych wiodących gazet i czasopism. Na niektórych wizualizacjach widać dyskutującą grupę fokusową, ale podpis temu przeczy, za to inne przedstawiają Jezusa w otoczeniu swoich uczniów jako „pierwszą sesję fokusową". Już choćby taka praktyka publicystyczna skłania do refleksji na temat błędnych opinii o fokusie.

Do najczęściej powtarzanych nieprawdziwych poglądów należy opinia, że FGI to badania:

- szybkie,

- latwe,

- niewymagające specjalnych kwalifikacji,

- niewymagające specjalnych przygotowań,

- tanie,

- nadające się do badania wszystkich problemów i wszystkich kategorii respondentów.

A rezultaty są rzekomo łatwe do zrozumienia i bardziej przystępne dla zleceniodawców, odbiorców lub decydentów, niż wyniki złożonych analiz statystycznych danych ilościowych.

Jak pisze George Silverman (2012), zdaniem laików FGI to tylko grupa osób reagujących na koncept, bądź dyskutujących na dany temat. Każdy może znaleźć grupę ludzi, zadać pytania i rozpocząć konwersację. Co jest tutaj do interpretowania? Wystarczy słuchać, co mówią uczestnicy i uogólnić to na populację.

Z drugiej strony, do bezrefleksyjnie eksponowanych w kategoriach wad cech FGI zalicza się na przykład:

- ograniczenie możliwości uogólniania uzyskanych wyników,

- wytwarzanie chaotycznych danych trudnych do interpretacji,

10 Tytuł tego podrozdziału został zaczerpnięty z tekstu Davida Morgana i Richarda A. Kruegera (1993, s. 4), którzy użyli sformułowania: some common myths about focus groups. 
- niebezpieczeństwo wpływu moderatora na odpowiedzi uczestników,

- niemożność ustalenia faktycznego znaczenia wyartykułowanych poglądów.

Potencjalny badacz skuszony obietnicą szybkich, łatwych i tanich badań w konfrontacji z powyższymi ograniczeniami (traktowanymi jako nieprzezwyciężalne) poczuje się oszukany i zawiedziony, a jego zleceniodawca najpewniej odstąpi od realizacji projektu badawczego.

Już wiele lat temu klasycy badań fokusowych, Morgan i Krueger (1993, s. 3-19) podkreślali, że powyższe opinie są nieprawdziwe oraz, że także w przypadku FGI, jakość rezultatów wprost zależy od zainwestowanych w nie środków intelektualnych i finansowych. Autorzy wyraźnie dementowali pogląd, że grupy fokusowe są tanim i szybkim sposobem gromadzenia wysokiej klasy informacji. Twierdzili, że organizowanie i prowadzenie grup dyskusyjnych a następnie analizowanie i przekazywanie ich wyników jest niezwykle pracochłonne. Jakość wyników badań fokusowych może znacząco się zmniejszyć, jeśli zbyt oszczędza się na zasobach (ludzkich i finansowych).

FGI nie są także badaniami niewymagającymi specjalnych kwalifikacji. Moderator musi przejść odpowiednie szkolenie, aby efektywnie prowadzić sesję fokusową. Chociaż dobre umiejętności ułatwiające pracę grupy są ważne, niezbędne jest również, aby moderator posiadał wiedzę na temat osób w grupie oraz na temat dyskutowanych zagadnień. George Silverman na stronie swojego Centrum Badań Fokusowych (Focus Group Center) wyraźnie pisze: „Prawdą jednak jest, że grupy zogniskowane wymagają przy projektowaniu, realizacji i interpretowaniu znacznej ilości profesjonalnych metod. Ich elastyczność mylona jest z luzem i niedbałością. Powierzchowne podobieństwo między zogniskowanymi grupami a zwykłymi grupowymi dyskusjami powoduje, że są one traktowane często jak proste grupowe dyskusje. Jednak w FGI istnieją nadzwyczajne wymagania, podczas ekstremalnych ograniczeń czasowych. W celu prawidłowego przeprowadzenia wywiadów grupowych potrzebne są lata treningów, doświadczenia nie tylko w tradycyjnej psychologii, lecz także w odrębnych dziedzinach jak socjologia, grupy dynamiczne i biznes (w tym marketing, sprzedaż i dystrybucja)". (Silverman, 2012)

Niektórzy badacze uważają, że fokusy nie są przydatne do badania problemów, z którymi badani wiążą zbyt silne emocje, że dla takich wyzwań lepsze są wywiady indywidualne. Sesja fokusowa wymaga od osób badanych pewnego stopnia odsłonięcia się w obecności innych, zatem nie można wykluczyć, że wybrane tematy będą nie do przyjęcia przez niektórych uczestników. Obecnie jednak takie twierdzenia są oparte bardziej na intuicji niż na danych, ponieważ nie prowadzi się badań empirycznych dotyczących zakresu tematów, które nie mogą lub nie powinny być poruszane w fokusie. Także zdaniem Morgana i Kruegera (1993, s. 3-19) przekonanie to nie jest 
prawdziwe. W rzeczywistości grupy fokusowe mogą i często stanowią bezpieczne środowisko sprzyjające ujawnianiu spraw drażliwych, czego dowodem są chociażby bardzo liczne projekty w zakresie nauk o zdrowiu (badania z niepełnosprawnymi, chorymi na raka), czy badania dotyczące kontroli urodzeń i stosowania środków zapobiegających ciąży, homoseksualistów i transwestytów, fokusy z wdowami, które niedawno straciły mężów (Morgan, 1988, s. 18 i nast.).

Coraz częstsze stosowanie badań fokusowych na przykład w odniesieniu do środowisk zmarginalizowanych (mniejszości kulturowych, gejów, sierot, ludzi ubogich) pokazuje, że doświadczenie i praktyka badawcza najlepiej określa obszar tematyczny, w którym fokusy będą lub nie będą się sprawdzać.

Nie jest także bezdyskusyjny pogląd mówiący o tym, że rezultaty badań fokusowych są łatwe do zrozumienia dla zleceniodawców, odbiorców lub decydentów, ponieważ często $\mathrm{w}$ praktyce z ich strony pojawia się zapotrzebowanie na dodatkowe wyjaśnianie i interpretację uzyskanych wyników.

Kolejny mit mówi o tym, że rezultaty dyskusji grupowych są w sposób konieczny wypaczone, ponieważ stanowią efekt konformizmu grupowego. Jednak doświadczeni moderatorzy potrafią stworzyć w trakcie sesji bezpieczny klimat dla różnorodnych opinii, wielokrotnie wyraźnie podkreślając, że celem spotkania jest zebranie różnych punktów widzenia i ewentualnie wypracowanie tylko pewnych obszarów konsensusu.

Wreszcie Morgan (1988) przeciwstawia się także poglądowi mówiącemu, że rezultaty badań fokusowych nie powinny stanowić jedynej podstawy do podejmowania decyzji. Według niego mogą pełnić taką funkcję, choć wartość rezultatów znacznie wzrasta, gdy konfrontuje się je z danymi uzyskanymi przy pomocy innych metod.

Wiele mylnych przekonań dotyczy także poszczególnych elementów samej procedury badawczej. Na przykład Morgan (1988) obala pogląd mówiący o tym, że członkowie grup nie mogą się znać wzajemnie. Choć pewien poziom anonimowości może sprzyjać ujawnianiu prawdziwych opinii i odczuć, to jednak w wielu przypadkach rekrutacja uczestników zupełnie obcych względem siebie nie jest możliwa (na przykład w sytuacji badania mieszkańców małych społeczności lokalnych, niewielkich organizacji). Takie okoliczności nie są wystarczającym argumentem na rzecz rezygnacji z realizacji badania fokusowego. Współczesna praktyka badawcza wypracowała nawet specjalny rodzaj fokusów, tak zwane affinity focus groups, w których z założenia spotykają się osoby doskonale znające się.

Często zaleca się skrupulatne przestrzeganie homogenicznego składu grup fokusowych. Znaczące różnice pomiędzy uczestnikami ze względu na ich osobiste doświadczenia, prezentowane struktury poznawcze, sposoby percepcji 
wydają się obiecujące dla uzyskania bardziej różnorodnych i twórczych rozwiązań. Jednakże nadmierna heterogeniczność uczestników może wywołać między nimi wiele sprzeczności, ograniczyć produktywność grupy i prowadzić do pojawienia się gorszego materiału. I rzeczywiście na przykład Goldman (1962) podkreśla znaczenie wspólnych obszarów interesów wszystkich uczestników sesji, a Merton (1956) uważa, że grupa pracuje lepiej wtedy, gdy jej członkowie są społecznie i intelektualnie podobni, szczególnie pod względem wieku, wykształcenia i wykonywanego zajęcia. Także Axelrod (1976) namawia do zachowania jak najdalej posuniętej jednorodności uczestników i sugeruje, aby dobierać ich tak, aby posiadali podobne potrzeby, cele i style życia. Wells (1974, s. 133-146) z kolei w jednorodności reprezentowanej pozycji społecznej, etapu w cyklu życia rodziny i korzystania z tych samych produktów upatruje warunków sukcesu sesji fokusowej. Ale z kolei badania Hoffmana (1959) i jego następców (Hoffman, Maier, 1961) dostarczają przykładów świadczących o większej produktywności grup niejednorodnych. Dlatego warto zachować pewien dystans wobec rygorystycznych zaleceń dotyczących homogeniczności grupy fokusowej. Praktyka badawcza wskazuje na bezwzględną konieczność zadbania o jednorodność członków grupy fokusowej zaledwie w jednym wymiarze - we wspólnocie pewnego doświadczenia. Pozostałe parametry strukturalne grupy powinny uwzględniać konkretny cel badawczy.

Obiegowy pogląd (podzielany zresztą przez wielu badaczy) mówi, że idealna grupa fokusowa powinna składać się z 8-12 uczestników. Jednak na przykład Sampson (1972) uważa, że nie istnieje coś takiego, jak jedyna poprawna liczebność grup fokusowych. Liczba uczestników może wahać się pomiędzy 5 a 12, w zależności od tego, jaką kompetencją werbalizacyjną wykazują się badani. Według Wellsa (1974) wielkość grupy fokusowej jest uzależniona od uzgodnień badaczy i od indywidualnego stylu pracy moderatora. Hess z kolei (Hess, 1968) postuluje organizowanie grup około dwudziestoosobowych, bowiem większe mają zbyt silny efekt synergii. Smith (1977) uznaje liczebność 8 do 10 osób za adekwatną, bowiem większe grupy trudno prowadzić, a mniejsze mogą nie dostarczyć oczekiwanej ilości pomysłów, rozwiązań. Zdaniem Payne’a (1976) w żadnej dyskusji grupowej nie powinno uczestniczyć więcej niż 8 uczestników, zaś 6 lub 7 jest liczbą doskonałą. Fern (1982) z kolei ustalił, że produktywność poszczególnych uczestników (liczba pomysłów, idei wygenerowana przez każdego pojedynczo) spada w miarę wzrostu liczebności badanych. Zatem po raz kolejny okazuje się, że sztywne przywiązanie do pokutujących opinii na temat fokusa (w tym przypadku liczebność uczestników) prowadzi do ograniczenia badaczy i tym samym do organizacji badania w sposób mniej adekwatny do konkretnych okoliczności. 
Do kwestii dyskusyjnych można zaliczyć także przekonanie, że rola moderatora w badaniu fokusowym jest kluczowa, a jego umiejętności, doświadczenie i osobowość są decydujące dla wzbudzenia interakcji grupowej (Axelrod, 1976; Caruso, 1976). Podkreśla się znaczenie jego kompetencji w zakresie psychologii społecznej i klinicznej, zakres doświadczenia w prowadzeniu grup oraz otwartą osobowość, cechującą się autentycznym zainteresowaniem ludźmi i tym, co mają do powiedzenia. Agar i MacDonald (1995) zastosowali analizę dyskursu w celu porównania interakcji werbalnej między moderatorami i uczestnikami w grupie fokusowej i pomiędzy ankieterami a badanymi w szeregu indywidualnych wywiadów. Stwierdzili, że dynamika wywiadów indywidualnych w wyraźnie większym stopniu obciąża uczestnika odpowiadającego badaczowi, a zachowania moderatora w grupie fokusowej zakłócały naturalną interakcję pomiędzy uczestnikami. Saferstein (1995) wyraża wręcz przekonanie, że to moderator, a nie grupa, określa porządek i formę dyskusji. Chociaż kwestie poruszane przez Agara i MacDonalda (1995) i Safersteina (1995) zależą od stylu moderowania, to nie ma wątpliwości, że zachowanie moderatora ma wpływ na charakter wywiadu grupowego. Jednakże Fern (1982) poddaje i to przekonanie w wątpliwość, bowiem w jego badaniu grupy moderowane nie wyprodukowały większej ilości pomysłów, niż grupy niemoderowane.

\section{WADY I ZALETY BADAŃ FOKUSOWYCH}

Bezkrytyczne powielanie obiegowych nieprofesjonalnych opinii na temat badań fokusowych nie ułatwia tej metodzie badawczej ekspansji w obszarze badań naukowych. Jest to bez wątpienia jeden z powodów, dla których w tych krajach, które nie prowadzą tak intensywnej fokusowej działalności badawczej w naukach stosowanych, jak ma to miejsce w USA, nadal środowiska akademickich socjologów i psychologów prezentują swoisty dystans i powściągliwość wobec takiej strategii pozyskiwania danych pierwotnych. A fokus, tak jak wszystkie inne metody uzyskiwania informacji w naukach społecznych, ma po prostu swoje wady i zalety (Maison, 2001, s. 23; Babbie, 2003, s.331; Nikodemska-Wołownik, 1999, s.140-141), których właściwe rozpoznanie może uczynić go narzędziem przydatnym do rozwiązywania problemów naukowych. 
Po stronie potencjalnych ${ }^{11}$ zalet warto wymienić:

- oszczędność czasu poprzez uzyskiwanie informacji od kilku a nawet kilkunastu osób jednocześnie,

- bogactwo informacyjne uzyskanych danych, obejmujące także specyfikę języka i stosowanych przez uczestników struktur argumentacyjnych,

- prospołeczny charakter badania, który sprzyja pojawieniu się informacji w warunkach zbliżonych do naturalnego procesu wymiany interakcji,

- względnie symetryczną relację badacz - badany, znoszącą formalizm tego kontaktu typowy dla innych metod badawczych,

- elastyczność pozwalającą na zróżnicowanie struktury badania na etapie planowania scenariusza sesji badawczej,

- możliwość modyfikacji scenariusza w trakcie sesji, oraz z sesji na sesję,

- relatywnie szybko uzyskane rezultaty,

- szansę na pojawienie się wątków, które nie zostały uwzględnione przez badacza i być może nie miałyby miejsca podczas wywiadu indywidualnego,

- pozytywne efekty grupowe wpływające na dynamikę grupy.

Natomiast ewentualne ograniczenia tej metody mogą pojawić się zarówno na skutek niewłaściwych zachowań badacza, jak i wynikać z okoliczności od niego niezależnych. Warto zatem wziąć pod uwagę ryzyko:

- uzyskania powierzchownych, niepogłębionych lub niedostatecznie argumentowanych informacji ze względu na błędy moderatora,

- negatywnego wpływu moderatora na przebieg dynamiki grupowej prowadzący do zmniejszenia wartości uzyskanego materiału,

- możliwości uzyskania danych zasugerowanych przez moderatora lub dominującego uczestnika,

- popełnienia błędów interpretacyjnych w fazie analizy uzyskanych danych,

- subiektywizmu analityka opracowującego materiał empiryczny,

- braku możliwości zagwarantowania poufności przez uczestników sesji,

- braku anonimowości, który może zniekształcać wypowiedzi uczestników,

- trudności ze skompletowaniem grup fokusowych,

- zastosowania nieadekwatnych parametrów rekrutacji uczestników,

- formułowania przez uczestników poglądów o charakterze deklaratywnym, które nie znajdują odzwierciedlenia w ich rzeczywistych zachowaniach,

- braku właściwości prognostycznych - badania FGI są bardziej pomocne w uzyskiwaniu informacji o doświadczeniach, uczuciach i poglądach dyskutantów aniżeli w przewidywaniu ich przyszłych zachowań,

\footnotetext{
11 Zarówno wady, jak i zalety FGI należy traktować w kategoriach potencji tej metody, bowiem wadliwa realizacja badania może spowodować osłabienie zalet, a przy odpowiednich kompetencjach i wysiłku można ograniczyć pojawienie się wad.
} 
- pojawienia się wielu nakładających się negatywnych efektów grupowych i brak możliwości oszacowania w tym kontekście faktycznej wartości uzyskanych informacji.

Powyższy wykaz z pewnością nie jest kompletny. Douglas Rushkoff (2005) twierdzi wręcz, że ze względu na zasięg i kaliber ograniczeń badań fokusowych stają się one bezużyteczne i często generują więcej problemów niż te, do których rozwiązania zostały powołane. Dla ilustracji tej tezy w literaturze często przywołuje się spektakularną porażkę amerykańskiego koncernu w projekcie „New Coke” z 1980 roku, do jakiej przyczyniły się badania fokusowe. Na 77 dni wprowadzono na rynek nowy napój z nową nazwą, co spotkało się z gwałtownym sprzeciwem społeczeństwa amerykańskiego, zarzucającego producentom wręcz atak na podstawowe wartości amerykańskie. W 2002 roku prezydent The Coca-Cola Company - Donald Keough ujawnił film dokumentalny Trouble at the top special - People v Coke (2003) obrazujący skalę społecznego niezadowolenia i potwierdzający słuszność decyzji o reaktywacji „starej” coli.

Zatem, podobnie jak w przypadku innych metod badawczych wykorzystywanych w naukach społecznych, FGI ma swoje mocne i słabe strony. Najbardziej doniosłe zalety i największe ograniczenia tej metody dotyczą tego samego zjawiska, czyli charakteru interakcji pomiędzy uczestnikami. A te z kolei w znacznym stopniu zależą od moderatora i samej grupy. Kwestia wpływu subiektywizmu badacza zarówno na przebieg sesji, jak i na opracowanie uzyskanych materiałów występuje we wszystkich innych technikach jakościowych. Fokusy mają także swoją unikalną specyfikę. I tak, jak to ma miejsce wtedy, gdy badacz stosuje survey, obserwację czy wywiad indywidualny, ostateczny efekt wszystkich starań w ogromnej mierze zależy od jego kompetencji metodologicznych, doświadczenia, nakładu pracy oraz zdolności do krytycznej analizy własnych działań.

\section{FGI A SURVEYE}

Trwające od lat osiemdziesiątych ubiegłego stulecia zainteresowanie potencjałem badań fokusowych w sposób oczywisty przejawiało się także w poszukiwaniu podobieństw i różnic pomiędzy nimi a innymi technikami otrzymywania materiałów. Zasadnicze pytanie wyznaczające te kierunki analiz sprowadzało się do próby ustalenia, na ile różne bądź podobne są generowane przy ich zastosowaniu dane. Niektórzy badacze oczekiwali, aby wyniki sesji fokusowych odtwarzały rezultaty badań standaryzowanych, 
a inni domagali się od nich generowania wyników nowatorskich, niepowtarzalnych, niemożliwych do uzyskania na innej drodze. Morgan (1997) zwrócił uwagę na pewien tkwiący tu paradoks: jak grupy fokusowe mogą dostarczać wyników takich samych, jak te uzyskane za pośrednictwem innych metod badawczych i jednocześnie różnych? Niemniej jednak, zdaniem wspomnianego autora, te dwa odmienne poglądy są przydatne do podsumowania mocnych i słabych stron wywiadów fokusowych.

Szczególnie wiele rzekomych ograniczeń badań fokusowych wynika z porównywania ich do badań ilościowych. Greenbaum (1998) uważał, że jedną z zasadniczych przyczyn dezawuowania roli i znaczenia badań fokusowych jest historyczne i biograficzne (w odniesieniu do edukacji poszczególnych badaczy) pierwszeństwo metod ilościowych. Fokus pojawił się później, niż miał miejsce rozwój badań surveyowych opartych na metodach statystycznych oraz zwykle potencjalni badacze poznają jego tajniki po uznaniu atrakcyjności surveyu. Może to powodować, że nie są oni zdolni do właściwego prowadzenia badań fokusowych (ani nie są nimi szczególnie zainteresowani).

Zarówno wady, jak i zalety fokusa stają się bardziej wyraziste wówczas, gdy dokonuje się porównania FGI do innych metod badawczych. Grupa fokusowa jako generator informacji oraz rola moderatora, od którego w ogromnej mierze zależy przebieg interakcji grupowych należą do podstawowych aspektów metody, które skupiają na sobie uwagę analityków dokonujących porównania FGI do innych metod badawczych.

Evelyn Folch-Lyon w 1981 roku jako jedna z pierwszych zamieściła w swoim raporcie uwagi dotyczące porównania badań fokusowych do badań surveyowych. W Meksyku przebadano postawy mieszkańców wobec planowania rodziny w ogóle i w kontekście programów rządowych, poglądy na optymalną wielkość rodziny, opinie na temat męskich i kobiecych ról w życiu rodziny i różnych metod antykoncepcji. Dwa niezależne zespoły badawcze zastosowały $\mathrm{w}$ tym projekcie dwie różne metody gromadzenia informacji. I tak przy pomocy wysoko wystandaryzowanych wywiadów zbadano 2000 gospodarstw domowych, a około 300 osób uczestniczyło w 44 sesjach fokusowych, w grupach liczących od 6 do 12 osób. Autorzy opracowania podkreślili znaczenie badań fokusowych dla tego typu przedsięwzięć. Zdaniem Autorki, ponieważ członkowie tej samej grupy kulturowej mają podobne struktury poznawcze, zbliżony sposób postrzegania swojej sytuacji społecznej i podzielają podobne wartości normatywne, w dyskusji grupowej zinternalizowane wpływy czynników kulturowych i system wartości grup społecznych, do których przynależą uczestnicy i w oparciu, o które modyfikują swoje zachowanie, ulega silnemu wzmocnieniu i z łatwością się manifestuje. Dzięki możliwości identyfikacji wspólnoty cech, przekonań, motywacji, podejście jakościowe daje dostęp do procesów myślowych i emocji badanych; zbieżne jest to z koncepcją charakteru społecz- 
nego, ale traktowanego nie jako wysoko zindywidualizowanego, unikalnego charakteru struktury społecznej przejawiającej się w jednostce, lecz jako rodzaj matrycy (character matrix), która rozwija się jako wynik adaptacji do ekonomicznych, społecznych i kulturowych warunków u dominującej większości społeczeństwa. W opozycji do bardziej ustrukturyzowanych technik badawczych, akcentują znaczenie rezultatów zależnych od nieformalnej dyskusji $\mathrm{w}$ bezpiecznym, tolerancyjnym środowisku.

Ward i in. (1991) porównywali wyniki badań surveyowych i badań fokusowych w trzech badaniach nad planowaniem rodziny - analizowali postawy mieszkańców wobec metod sterowania płodnością. W Gwatemali i Zairze projekt dotyczył postaw wobec zabiegu podwiązywania jajowodów, a w Hondurasie - wobec wazektomii. Podczas każdego z trzech badań stosowali jednocześnie dwie metody gromadzenia informacji na ten sam temat. Porównanie łącznie 60 zmiennych wykazało, że wyniki obu metod były:

- bardzo podobne dla $30 \%$ zmiennych,

- podobne, ale grupy fokusowe dostarczyły więcej informacji w przypadku $42 \%$ zmiennych,

- podobne, ale badania surveyowe dostarczyły, więcej informacji dla $17 \%$ zmiennych,

- niepodobne dla $12 \%$ zmiennych.

Łącznie dla 88\% zmiennych rezultaty uzyskane przy pomocy surveyów i fokusów były podobne, przy czym w odniesieniu do połowy tych zmiennych zogniskowane wywiady grupowe dostarczyły bardziej szczegółowych informacji.

Zaś Saint-Germain i in. (1993) przeprowadzili systematyczne porównanie wyników uzyskanych przy pomocy surveyów i grup fokusowych na temat przyczyn niechęci poddania się badaniom na wykrycie raka piersi wśród starszych latynoskich kobiet. Okazało się, że w obu metodach uzyskano bardzo zbliżoną hierarchię przyczyn tej niechęci; w większości przypadków informacje z wywiadów fokusowych pokryły się z danymi surveyowymi.

David Morgan (1988) podkreślał zalety występującej w obszarze badań praktyki łączenia fokusów z innymi metodami badawczymi, głównie z surveyami. Wyróżnił trzy podstawowe taktyki:

1. Fokus może poprzedzać badanie surveyowe, a jego rezultaty są pomocne przy konstrukcji narzędzia standaryzowanego, pozwalają bowiem budować bardziej adekwatne pytania z uwzględnieniem specyfiki języka potencjalnych respondentów. Zatem fokusy mogą być interesującą alternatywą dla wywiadów indywidualnych, które często służą podobnym celom. 
Szczegółowe korzyści wynikające z zastosowania FGI przed rozpoczęciem badań surveyowych mogą mieć bardzo różny charakter. Zogniskowany wywiad grupowy okazuje się bowiem użyteczny również dla lepszego doprecyzowania celu badawczego w surveyu. Można go wykorzystać do zbadania określonych wątków tematycznych, jakie zostaną poruszone w surveyu, do oglądu mechanizmów generowania danych kontekstualnych lub do poznania specyfiki kalk językowych używanych przez badanych.

Szczególnie przydatna może być taka formuła wykorzystania FGI w badaniach środowisk stosunkowo słabo znanych badaczowi (Vaughn i in., 1996), gdzie dotychczas prowadzono niewiele badań oraz w odniesieniu do takich zbiorowości, które nie ujawniają powszechnie wiedzy na swój temat. To odnosi się chociażby do każdego pokolenia młodzieży, które na nowo i na swój użytek kształtuje, wciela w życie i ogranicza upublicznianie własnych norm regulujących zachowania grupowe.

Badania Frankland i Bloor (1999) w szkołach Południowej Walii stanowiły element ewaluacji projektu zakładającego wykorzystanie współpracy przeszkolonych liderów środowiskowych do skutecznej interwencji zniechęcającej ich rówieśników do palenia papierosów. Frankland przeprowadziła 12 sesji fokusowych z uczniami w wieku 8 lat i 9 sesji z uczniami 12-14 lat. Struktura grupy uczestników poszczególnych sesji była zróżnicowana, bowiem zorganizowano spotkania zarówno z samymi chłopcami, samymi dziewczynkami oraz z grupami heterogenicznymi ze względu na płeć. Dodatkowo w doborze poszczególnych składów manipulowano natężeniem zmiennej „palenie papierosów” (okazjonalne lub regularne). Badania te dostarczyły empirycznego potwierdzenia faktu, iż w badanej kategorii wiekowej palenie papierosów i eksperymentowanie z paleniem papierosów ma bardzo silny związek z normami obowiązującymi w konkretnych grupach rówieśniczych. Z punktu widzenia praktyki profilaktycznej rezultaty te wskazały na konieczność podjęcia działań zmierzających w kierunku wywierania wpływu na te normy grupowe.

Funkcję pomocniczą $w$ fazie poprzedzającą survey zogniskowany wywiad grupowy może spełnić doskonale także wówczas, gdy zachodzi potrzeba uzyskania danych kontekstualnych. W trakcie sesji fokusowej badacz ma możliwość zaobserwowania, w jaki sposób uczestnicy rozmawiają z sobą na tematy, które mają być poruszone w kwestionariuszu ankiety czy wywiadu. Przykładem takiego zastosowania są badania fokusowe, w których wykorzystano technikę winiety (Barbour, 1999). Polega ona na przedstawieniu badanym hipotetycznych sytuacji, w odniesieniu do których uczestnicy proponują własną interpretację lub opisują prawdopodobny dalszy przebieg działania bohaterów tych opowiastek. Zabieg taki często stosowany jest w badaniach standaryzowanych (West, 1982). Uczestnicy sesji fokusowych, ustalając ten praw- 
dopodobny rozwój wydarzeń w sytuacjach opisanych w winiecie umożliwiają badaczowi dokonanie wglądu w kontekst ich codziennych doświadczeń. W oparciu o tak uzyskane dane pojawia się szansa na zbudowanie adekwatnych pytań do narzędzi standaryzowanych. Możliwość tę wykorzystano w badaniach ryzykownych zachowań osób przyjmujących dożylnie narkotyki (McKeganey, 1995, s. 749-751). Uczestnicy sesji dzięki zastosowaniu winiety dostarczyli badaczom wiedzy o potocznym języku, przy pomocy którego takie zachowania są wśród tego rodzaju osób nazywane. Warto dodać, że z takich możliwości FGI należy korzystać w sposób przemyślany i krytyczny. Mays (Mays i in., 1992, s. 425-434) w związku ze swoimi badaniami dotyczącymi seksualnych zachowań czarnoskórych gejów zastanawiał się, czy w konstruowaniu pytań surveyowych należy wykorzystać język codzienny stosowany przez potencjalnych badanych i w jakim stopniu. Czy lepiej używać w surveyu w odniesieniu do zachowań seksualnych określeń neutralnych, czy terminów $\mathrm{z}$ obszaru slangu używanego przez to środowisko? Czy intencja pytania kwestionariuszowego zostanie odczytana bardziej adekwatnie w językowej wersji neutralnej czy specyficznej dla środowiska? I wreszcie, czy terminy pochodzące ze slangu zostaną zrozumiane przez wszystkich potencjalnych badanych w surveyach?

2. W drugiej kombinacji fokusy są podstawową metodą zbierania informacji, podczas gdy surveye pełnią wobec nich funkcję pomocniczą. W zogniskowanym wywiadzie grupowym badacz ma możliwość ujawnienia tymczasowego i dynamicznego charakteru indywidualnych opinii, jakie uczestnicy prezentują podczas dyskusji grupowej. Jest to taki aspekt postawy, który pozostaje poza możliwościami odkrycia przez badania surveyowe. Znakomitym przykładem takiej funkcji FGI są badania Nawrockiego (1995, s.75-99), w których autor poprzez wprowadzenie do sesji swojego współpracownika („prowokatora”) poddał w wątpliwość oczywistość prezentowanej przez uczestników normy tolerancji i wykazał jej deklaratywny charakter. Również Wynne (1996, s. 44-83) dzięki fokusom ujawnił, że postawy lokalnych mieszkańców wobec przemysłu jądrowego były znacznie bardziej skomplikowane i tymczasowe niż wykazały to badania surveyowe.

3. Trzeci rodzaj fuzji ponownie wykorzystuje badania surveyowe jako podstawową metodę, ale grupy fokusowe są teraz określone jako metoda równoległa - taka, która pomaga w interpretacji wyników badania. Ilustracją takiego połączenia obu metod była na przykład próba wyjaśnienia zaskakujących dla badaczy wyników badań ilościowych, z których wynikało, że kobiety dobrze wykształcone, samodzielne finansowo, mieszkanki wielkich polskich miast czę- 
ściej niż kobiety nisko wykształcone z regionów wiejskich stwierdziły stosowanie wobec nich przemocy domowej. Na sesjach fokusowych okazało się, że kluczem do zrozumienia tych rezultatów było zupełnie odmienne rozumienie terminu „przemoc" przez obie kategorie kobiet. Te wysoko wykształcone zaliczały do aktów przemocy domowej na przykład podniesiony głos partnera i kłótnie, podczas gdy dla kobiet wiejskich granica, od której zaczyna się przemoc była przesunięta znacznie dalej, czasem nawet niekoniecznie obejmowała akty użycia siły fizycznej.

Innego przykładu dostarczają badania pod kierunkiem Jenny Kitzinger (1994, 1994a) dotyczące reakcji społecznej na medialne doniesienia na temat HIV/AIDS. Z wcześniejszych badań surveyowych wynikało, że przez niektórych ludzi krwiodawstwo jest postrzegane jako mechanizm rozprzestrzeniania się HIV. Wzbudziło to zrozumiały niepokój Scottish Blood Transfusion Service, które obawiało się ograniczenia dotacji na swoją działalność. Jednak rezultaty FGI pokazały, że uczestnicy sesji nie obawiali się infekcji jako skutku oddania krwi, a nawet przeciwnie, wykazali dużą gotowość do takich działań. Uznali, że występuje ryzyko przeniesienia HIV w krwi przyjętej, ale nie wiąże się ono $\mathrm{z}$ aktem jej oddawania. Po prostu we wcześniejszych badaniach surveyowych nie uwzględniono na poziomie języka pytań zadawanych respondentom konieczności rozróżnienia czasowników, których silne zróżnicowanie występuje w mowie potocznej (donating i receiving). Na tej samej zasadzie większość populacji różnicuje w mowie potocznej znaczenie czasownika „pożyczać” (to lend i to borrow). W obu przedstawionych wyżej przypadkach fokus pozwolił ujawnić możliwe sposoby interpretowania terminów występujących w narzędziach standaryzowanych, dzięki czemu uzyskane w badaniach ilościowych rezultaty stały się zrozumiałe.

W szczególnych sytuacjach survey pozwala także wypreparować specyficzną kategorię osób, którym badacz proponuje udział w sesjach fokusowych. Jak pisze Morgan, mimo że takie podejście z perspektywy badacza wydaje się bardzo atrakcyjne, niewiele jest udokumentowanych w literaturze przedmiotu przypadków wykorzystania tej taktyki. Dobrym przykładem takiej strategii mogą być badania metodologiczne zrealizowane w 2011 roku w Katedrze Metod i Technik Badań Społecznych Instytutu Socjologii UŁ (Lisek-Michalska, Lipiec, Olczyk, 2012). Ich celem była analiza zależności między (non)konformistycznym profilem osobowości uczestników a metodologiczną i praktyczną jakością badania FGI. Chodziło o ustalenie, czy udział w sesji osób o nonkonformistycznym profilu osobowości przyczynia się do uzyskania bardziej różnorodnego i pogłębionego materiału, niż wówczas, gdy badanych cechuje konformizm lub równowaga konformizmu — nonkonformizmu. 
Stosunkowo najrzadziej w praktyce badawczej spotyka się takie łączenie surveyów i wywiadów grupowych, które sytuuje FGI w roli metody podstawowej, a badania standaryzowane traktowane są jako źródło dodatkowych, „zapasowych” danych. Być może jednym z powodów jest obawa badaczy realizujących FGI przed posądzeniem ich o konieczność wzmocnienia rezultatów jakościowych przy pomocy „twardych” danych.

Natomiast powszechność występowania w praktyce badawczej pierwszej strategii, gdzie grupy fokusowe są pomocne w tworzeniu ankiet i trzeciej, gdzie fokus wspiera interpretację ich wyników pokazuje potencjał, jaki tkwi w łączeniu FGI i metod ilościowych. Być może w wielu przypadkach triangulacyjne wykorzystanie fokusów w projektach badawczych stanowi efekt postrzegania takiego podejścia jako respektującego wymogi metodologicznego rygoru i pewnej swoistej mody wśród badaczy. Jednak uzyskiwane efekty są co najmniej zadowalające i można przypuszczać, że ta tendencja będzie wzrastać.

$\mathrm{Z}$ dotychczasowych doświadczeń badawczych wynika bowiem, że w zdecydowanej większości przypadków, podobnie jak Evelyn Folch-Lyon, badacze w różnym stopniu ostatecznie potwierdzają zalety łączenia obu tych metod. Tom Greenbaum (1977) pisał, że wsparcie badań ilościowych materiałem uzyskanym $w$ fokusie sprawi, iż całościowy obraz staje się zrozumiały. Wolff, Knodel i Sittitrai (1993, s. 119) stwierdzili w swoim artykule, że chociaż survey i fokus pochodzą z różnych tradycji teoretycznych, nie ma w tych metodach niczego, co zabraniałoby stosować je łącznie. W rzeczywistości słabe i mocne strony obu tych strategii mogą się doskonale uzupełnić i — stosowane łącznie - podnieść jakość badania.

Czasem triangulacja metod ilościowych i fokusów staje się wręcz konieczna. Takim przykładem są opisane przez badaczy Uniwersytetu Chińskiego w Hong Kongu (Lam i in., 2012) badania z uczestnikami, dla których język kwestionariusza ankiety jest drugim językiem. W Polsce podobne badania (od strony metodologicznej, nie merytorycznej) przeprowadzono w ramach projektu poświęconego imigrantom, realizowanego przez Instytut Polityki Społecznej UW pod kierunkiem prof. dr hab. Jolanty Supińskiej (2003).

Liczni autorzy proponują, by surveye stosować wówczas, gdy badaczowi zależy na uzyskaniu odpowiedzi typu JAK. Natomiast gdy chce odkryć DLACZEGO, powinien wykorzystać badania fokusowe. W konkluzji formułują oni przekonanie, że decyzja pomiędzy wyborem podejścia jakościowego czy ilościowego sprowadza się do oszacowania wartości uzyskanych danych, a prawdziwym wyzwaniem jest określenie adekwatnej do problemu badawczego metodologii i zintegrowanie w jednym przedsięwzięciu badawczym różnych metod gromadzenia materiału. Nie oznacza to jednak, że fokusy nie mogą pełnić funkcji samodzielnej metody badawczej. Wręcz przeciwnie, powszechnie wykorzysty- 
wane są samodzielnie w wielu dyscyplinach. Szczególnie interesujące wydaje się badanie Morgana, który wykorzystał FGI do generowania (i śledzenia) procesów myślowych, które prowadzą do ustanowienia opinii. Uznał, że bez współdziałania z innymi, ludzie często nie są świadomi swoich poglądów. Pragnienie, aby wyjaśnić własną perspektywę rozumowania komuś z potencjalnie innym punktem widzenia jest dobrą motywacją do formułowania, artykułowania i argumentowania opinii (Morgan, 1988). Na podobne aspekty badania fokusowego zwracali uwagę także inni autorzy. Interakcja grupowa jest definicyjną cechą badań fokusowych. Podczas spotkania moderator ma możliwość obserwować, w jaki sposób ludzie formułują swoje opinie i jak proces konfrontacji własnych opinii z poglądami innych kształtuje ostateczny sąd. (Kruger, 1988; Morgan, 1988; Templeton, 1987).

Innym niezwykle interesującym przykładem zastosowania FGI jako metody samodzielnej jest wykorzystanie go do poznania systemów normatywnych, jakimi ludzie kierują się w swoim postępowaniu (Bloor, 2001). Systemy te są częścią naszej ugruntowanej wiedzy (Schütz, Luckmann, 1974; Bloor, Frankland, Thomas, Robson, 2001). W życiu codziennym podstawy normatywne wyznaczające ludzkie zachowanie są niezwykle rzadko artykułowane expressis verbis. Warunki, w jakich ludzie pozwalają na testowanie, opisywanie swoich podstaw normatywnych zwykle są wyjątkowe. W normalnych okolicznościach i normalnych interakcjach tylko odnosimy się do tych norm w sposób aluzyjny — nie ma powodów do ich eksponowania. A umiejętność rozpoznawania/rozumienia tych aluzji (the indexical expressions of methodology) (Garfinkel, 1967) jest znakiem rozpoznawczym kompetencji członka zbiorowości. Te nastawienia normatywne stają się dostępne jedynie dla etnografów funkcjonujących w danej społeczności i nawet wówczas są one w większości indukcyjne a nie rejestrowane bezpośrednio. Sytuacja na sesjach FGI daje okazję i stymuluje członków zbiorowości do nazywania tych zazwyczaj nieartykułowanych nastawień normatywnych. Grupa fokusowa daje społecznie akceptowaną okazję do uruchomienia retrospektywnej introspekcji (retrospective introspection) wcześniej przyjętych i głęboko zakorzenionych nastawień. To ujawnienie (leasing out) może być tylko częściowe i dyskusyjne, ale może dostarczyć tak bogatych danych o normach, jak długi okres pobytu badacza etnografa w środowisku. Oczywiście - jak stwierdzają autorzy - należy liczyć się z wystąpieniem wielu problemów dotyczących jakości uzyskanych danych i ich analizy. FGI nie tylko obnaża te zasady, ale uświadamia (zarówno prowadzącemu, jak i uczestnikom), że ich stabilność jest iluzoryczna i pokazuje, że są wewnętrznie niejednoznaczne. Dlatego fokus jest najlepszą metodą pozwalająca na dotarcie do norm grupowych i do demonstrowania, że te ujawnione normy grupowe nie mogą być bezrefleksyjnie zastosowane 
w podejmowaniu decyzji w organizacji lub w polityce społecznej. Jednym z zadań dla badaczy fokusowych jest znalezienie sposobu na inkorporowanie fokusów do społecznego podejmowania decyzji, zamiast traktować je tylko jako zasób/źródła informacji dla deliberacji ekspertów (CunninghamBurley i in., 1999; Johnson, 1996). Oczywiście wymaga to szczególnych procedur interpretacyjnych, rozumienia, ale nie jest ono jakieś niezwykłe, bowiem to rozumienie jest podzielane z innymi, jest częścią społecznej wiedzy. Jest także podstawą społecznego działania. Dyskusja w grupie FGI dostarcza bogatych danych na temat grupowego rozumienia przedmiotu badania. Ale każdy akt ujawniania znaczenia grupowego dla badanego zagadnienia obnaża prowizoryczny charakter takiej interpretacji. Tak jak dane uzyskane w FGI dotyczące norm grupowych pokazują niejednoznaczność tych norm, tak dane fokusowe dotyczące rozumienia/nadawania znaczenia mogą ukazywać niezbędną ambiwalencję interpretacji. Ten raczej chaotyczny charakter rezultatów nie jest efektem wady metody, ale jest wiernym odbiciem badanego zjawiska (Bloor i in., 2001).

Ponadto należy pamiętać, że grupy fokusowe odzwierciedlają wewnętrzne procesy grupowe i formalną oraz nieformalną strukturę grupy, dlatego, jak mało które inne dostępne socjologom metody, pozwalają je także badać. Ten atrybut fokusów może znaleźć zastosowanie przy poznawaniu nieformalnych układów hierarchicznych w różnych typach zespołów (pracowniczych, organizacyjnych, towarzyskich).

Rezultatem badań ilościowych są wykresy i tabele oparte na rozbudowanych analizach statystycznych, pokazujące zazwyczaj wyniki dla populacji szerszej niż ta, która została poddana badaniom. Wnioski w raporcie $\mathrm{z}$ badań fokusowych mają jedynie charakter sprawozdawczy, dotyczą tylko tych, którzy wzięli udział w sesjach. Czasami uczestnicy są traktowani jako reprezentanci pewnych typów (mieszkańców, konsumentów, rodzin) i wówczas rezultaty mogą być reprezentatywne w sensie typologicznym. Fokus nie jest przeznaczony do konstruowania generalizacji statystycznych i żadne jego cechy nie pozwalają osiągnąć takiego rezultatu. Jednak nie warto z niego rezygnować, bowiem badania fokusowe dostarczają wiarygodnych danych, które również prowadzą do istotnych spostrzeżeń na temat ludzkich zachowań (Fern, 2001). Zatem oba podejścia badawcze różnią przede wszystkim możliwe do osiągnięcia przy ich pomocy cele badawcze. FGI umożliwia wgląd w motywacje, znaczenia ukryte poza faktami, emocje, a badanie surveyowe dostarcza danych, na podstawie których można formułować generalizacje, budować trendy, przewidywać. 

64

\section{FOKUS A WYWIAD INDYWIDUALNY}

W przeciwieństwie do wywiadów indywidualnych, grupy dyskusyjne umożliwiają obserwowanie dynamiki zmian w procesie kształtowania i formułowania opinii (Morgan, 1988) oraz są przydatne do poznawania wspólnych zakresów czy kontekstów znaczeniowych różnych pojęć. Z kolei zdaniem wielu autorów stają się mniej użyteczne do poznawania drażliwych, trudnych fragmentów biografii uczestników. Zdaniem Morgana (1988) zogniskowany wywiad grupowy nie jest tak skuteczny dla poznania bogactwa kontekstu fenomenów społecznych, jak obserwacja uczestnicząca, ani tak produktywny w docieraniu do indywidualnych sposobów rozumienia osób badanych, jak pogłębiony wywiad indywidualny. Jednakże żadna inna samodzielna metoda nie pozwala na tak efektywne połączenie obu tych celów.

Niestety, niewiele badań relacjonuje w sposób systematyczny efekty porównania danych uzyskanych za pomocą fokusa z danymi zgromadzonymi pomocy innych metod jakościowych, dlatego trudno odwołać się do tego typu argumentacji.

Decyzja, czy w danym projekcie zastosować fokus, czy lepiej jakąś liczbę wywiadów indywidualnych, nie jest oczywista. Zależy od wielu czynników, przede wszystkim zaś od pytania, na jakie badacz poszukuje odpowiedzi. Przydatna wydaje się analiza elementów, które mogą mieć na nią wpływ.

Jeżeli badaczowi zależy na uzyskaniu od badanych możliwie wielu idei, pomysłów na jakiś temat, mogłoby się wydawać, że dobrym kryterium do podjęcia decyzji jest potencja obu technik w tym zakresie. Jednak wyniki badań nie są tu jednoznaczne. Z analiz Ann Lewis (1992, s. 413-421) wynika, że grupa fokusowa może generować większą ilość takich idei niż wywiad indywidualny, jednak twierdzenie to jest kwestionowane przez rezultaty stosunkowo najbardziej pogłębionych badań metodologicznych Edwarda Ferna (1982, s. 1-13), który dokonał w sposób systematyczny porównania liczby unikalnych pomysłów wygenerowanych przez równą liczbę osób badanych w trakcie sesji fokusowych i w wywiadach ${ }^{12}$. Z Rysunku 1. wynika, że IDI dostarczają badaczowi więcej takich idei niż fokusy (moderowane i niemoderowane). Fern uzyskany rezultat tłumaczył występowaniem w FGI procesów grupowych, które powodują zmniejszenie produktywności poszczególnych uczestników (opisany wcześniej w tej pracy efekt rozproszenia odpowiedzialności).

\footnotetext{
12 Prawdopodobnie na uzyskanie tak sprzecznych rezultatów ma wpływ fakt, iż Ann Lewis przeprowadzała swoje analizy w oparciu o materiały zgromadzone w badaniach dzieci, a Fern badał osoby dorosłe. Znaczna część aktywności życiowej dzieci dokonuje się w grupach rówieśniczych, dlatego też wiele ich zachowań wynika z przyjęcia i respektowania znanych, oswojonych, norm grupowych. Grupa jest dla dzieci środowiskiem naturalnym i bezpiecznym, dlatego poznawanie ich poglądów w kontekście grupy najpewniej ma istotne znaczenie dla przejawianej gotowości dzielenia się informacjami.
} 
Jednocześnie jednak w podsumowaniu autor stwierdza, że brakuje dostatecznych powodów do tego, by uznać IDI za technikę bardziej efektywną niż FGI, ponieważ występujący w trakcie wywiadu indywidualnego efekt ankietera jest równie znaczący dla uzyskanych danych, jak efekt moderatora w fokusie.

Rysunek 1. Liczba wygenerowanych idei jako funkcja liczebności badanych osób (Fern, 1982, s. 6)

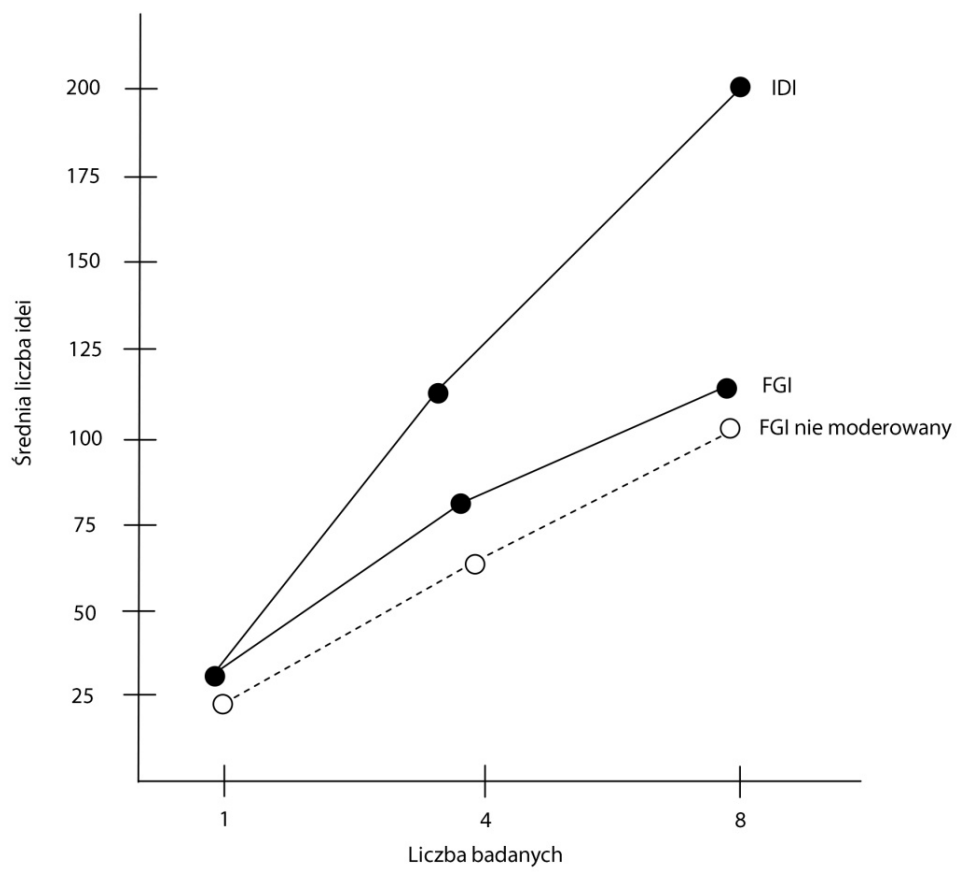

Dalej Fern konkluduje, że wobec tak dyskusyjnych rezultatów i braku badań metodologicznych w tym zakresie wydaje się, że kryterium oczekiwanej liczby unikatowych rozwiązań, pomysłów, propozycji nie powinno stanowić nie tylko wystarczającej miary wartości dla FGI, lecz także jedynej podstawy do rozstrzygnięcia, czy w danym projekcie wykorzystać grupowe czy indywidualne metody zbierania danych. Są bowiem inne powody, chociażby natury praktycznej, które skłaniać mogą do wyboru FGI zamiast IDI. Dwie sesje ośmioosobowe dostarczają tyle materiału, ile dziesięć wywiadów swobodnych, co ma znaczenie dla tempa realizacji fazy terenowej badania i czasu koniecznego na analizę materiału.

Jednak nie zawsze przecież chodzi w badaniach fokusowych o zgromadzenie jak największej liczby oryginalnych rozwiązań czy punktów widzenia. Zasadniczo, akceptując konkluzje Ferna, w badaniach przeprowadzo- 

66

nych w Instytucie Socjologii UŁ zaproponowano nieco bardziej rozbudowaną procedurę oceny jakości merytorycznej badań fokusowych ${ }^{13}$, uwzględniającą dodatkowe kryteria, poza liczbą unikalnych idei.

W diagnozie praktycznej jakości badania FGI przyjęto jako jednostkę analizy każdą wypowiedź dyskutanta wygenerowaną na przestrzeni całego badania i zgodną z intencją pytania moderatora. Uwzględniono wypowiedzi wygenerowane przez badanych w toku tradycyjnej konwencji fokusowej, ponieważ w przekonaniu autorów różne wymiary praktycznej jakości fokusa (różnorodność, nasycenie i unikalność) w większym stopniu zależą od zdolności oraz preferencji poznawczo-intelektualnych badanych niż od przyjętego przez moderatora stylu kierowania dyskusją.

$\mathrm{Z}$ analizy wyłączono wypowiedzi zgodne z problematyką dyskusji, ale niezgodne z intencją pytania moderatora. Dla przykładu, w toku dyskusji moderator zadaje pytanie: co sq̨dzicie na temat dodatkowych możliwości, jakie oferuje wam szkoła?, jeden z dyskutantów odpowiada: uważam, że w szkole jest za dużo zajęć i należałoby skrócić plan lekcji. W takim przypadku pomimo że wypowiedź dyskutanta dotyczy szkolnictwa licealnego, to nie będzie poddana analizie, gdyż nie jest ona zgodna z intencją pytania moderatora. Powyższy przykład ilustruje sytuację, w której wypowiedzi dyskutantów stanowią rodzaj odpowiedzi, a ich zakres tematyczny pozostaje w związku z problematyką badania, ale nie jest zgodny z intencją pytania moderatora. Co za tym idzie, są to wypowiedzi wyłączone $z$ dalszej analizy, podobnie jak wątki dygresyjne, czyli wypowiedzi badanych, które oprócz tego, że nie są zgodne $\mathrm{z}$ intencją pytania moderatora, to nie pozostają w związku z problematyką dyskusji. Przykładem wątku dygresyjnego jest poniższa sekwencja wypowiedzi badanych, stanowiąca fragment transkrypcji:

B: Ono [fiat seicento] potrafi wiele przetrwać, no. Podczas, gdy kiedyś jechaliśmy do Warszawy z chłopakami, to dwie sarny zabiliśmy, ale mimo tego jakoś tam dojechaliśmy.

B: To trzeba było przykleić taką sarenkę i odkreślić dwie kreski [śmiech w grupie]

B: Będzie straszyło następne sarny.

B: A na kolację gulasz z dziczyzny.

B: Nie, jechaliśmy dalej, a później do McDonalda [śmiech w grupie].

B: Nie ma, jak McDonald, no nie.

B: Ciekawe swoją drogą, skąd oni mają zapasy w tym McDonaldzie?

B: No właśnie, może to wywożą do McDonalda.

13 Zamieszczony tu opis procedury badawczej stanowi wierną parafrazę fragmentu szerszego tekstu (Lisek-Michalska, Lipiec, Olczyk, 2012). 
Ponadto na potrzeby projektu badawczego zdecydowano się na wyłączenie $\mathrm{z}$ analizy każdej wypowiedzi, której treść jest na tyle wieloznaczna lub niesprecyzowana, że groziłaby dokonaniem interpretacji nieadekwatnej. Zatem analizie poddano tylko jednoznaczne wypowiedzi dyskutantów, które w swojej treści ściśle odpowiadają intencji pytania moderatora.

Aby zdiagnozować praktyczną jakość materiału zebranego z poszczególnych sesji FGI, należy dokonać operacjonalizacji „bogactwa informacyjnego". W tym celu skonstruowano 3 wskaźniki - zróżnicowania, nasycenia oraz unikalności.

1. Wskaźnik zróżnicowania (WZ).

Liczba kategorii odpowiedzi wyodrębnionych przez badacza woparciu o treść wypowiedzi wygenerowanych przez grupę FGI w następstwie pytania moderatora. W tym miejscu warto odwołać się do sposobu definiowania kategorii w ramach metodologii teorii ugruntowanej. W powyższej orientacji zakłada się, że „kategoria powstaje w procesie różnicowania elementów obserwowalnej rzeczywistości bądź zjawisk według jakiegoś kryterium" (Konecki, 2000, s. 29). Dokonawszy przeniesienia powyższej definicji na potrzeby projektu uznano, iż kategorie odpowiedzi dyskutantów powstają poprzez różnicowanie ich wypowiedzi według kryterium zawartego w pytaniu moderatora. Przy tym podkreślenia wymaga fakt, że warunkiem wyodrębnienia danej kategorii jest istnienie argumentów, które ją uzasadniają. W opinii autorów taki, a nie inny sposób wyróżnienia poszczególnych kategorii odpowiedzi jest bardziej uzasadniony niż proste sumowanie odpowiedzi dyskutantów, prowadzące z reguły do mnożenia synonimicznych wypowiedzi nie zwiększających wiedzy badacza. Ilustruje to następujący przykład:

M: Jakim samochodem mogłaby być uczelnia?

B: Zardzewiały Polonez. Moja uczelnia to stara kamienica.

M: Dlaczego zardzewiały?

B: Bo moja uczelnia przecieka. I w niektórych salach nie można używać światła, bo grozi to spięciem.

M: Jakim samochodem mogłaby być uczelnia?

B.: Wołga, ponieważ Wołga była z założenia takim samochodem, który miał być takim wschodnim mercedesem, takim ekskluzywnym, ale ciągle po takiej starej radzieckiej myśli technologicznej. A wiem, że studia są takie, że starają się być takie nowoczesne, starające się być takie dostosowane, podciągnięte pod Zachód, jeśli chodzi powiedzmy o taki sprzęt, wygląd tego 
wszystkiego, ale jednak ciągle gdzieś jest coś takiego, co nam się kojarzy z taką swojską, wschodnią częścią Europy.

Na podstawie tego materiału można wyodrębnić dwie kategorie odpowiedzi rozumiane jako dwa różnego rodzaju znaczenia nadane uczelni na drodze metaforyzacji - porównania jej do samochodu. Pierwszą kategorią jest szkoła jako budynek o niezadowalającym stanie technicznym, a drugą jest szkoła jako instytucja bezskutecznie aspirująca do zachodnich standardów. Z kolei, jeśli w odpowiedzi na postawione wyżej pytanie dyskutanci wskazują poloneza, malucha i trabanta, za każdym razem uzasadniając swoje odpowiedzi w podobny sposób, to mimo tego, że wypowiedzi dyskutantów odwołują się do różnych modeli samochodów, na ich podstawie tworzy się tylko jedną kategorię, bowiem uzasadnienie wyboru każdego z wyżej wymienionych samochodów odnosi się do równoważnych treściowo argumentów, czyli nie zwiększa bogactwa informacyjnego. Tym samym, im wyższa wartość WZ, tym większe zróżnicowanie odpowiedzi dyskutantów. Autorzy rezygnują z analizy materiału, która bazowałaby tylko na samych prostych operacjach arytmetycznych. Specyfika zogniskowanego wywiadu grupowego wymaga przyjęcia podejścia uwzględniającego przede wszystkim treść, a nie liczbę wypowiedzi dyskutantów.

2. Wskaźnik nasycenia kategorii (WN).

Określa liczbę rozłącznych, tzn. zróżnicowanych treściowo argumentów (uzasadnień lub przykładów) przytoczonych przez badanych, aby wyjaśnić swoje wypowiedzi. Sparafrazowane uzasadnienia, niosące tę samą treść są traktowane jako jeden argument uzasadniający konkretną kategorię.

Wskaźnik WN obliczano według poniższego wzoru:

$$
W N X=\frac{n A K_{1}+n A K_{2}+n A K k}{n K}
$$

$\mathrm{X}$ - numer grupy fokusowej,

nAK 1 - łączna liczba argumentów uzasadniających pierwszą kategorię,

nAK 2 - łączna liczba argumentów uzasadniających drugą kategorię,

nAKk — łączna liczba argumentów uzasadniających $n$ kategorię,

nK - łączna liczba kategorii wygenerowanych przez dyskutantów, a wyodrębnionych przez badacza. 
Zatem wskaźnik WN jest ilorazem sumy łącznej liczby argumentów uzasadniających wszystkie wygenerowane przez badacza kategorie i łącznej liczby tych kategorii. Wskaźnik WN skonstruowano w oparciu o średnią arytmetyczną. Zabieg ten uznano za rodzaj uproszczenia, które posłużyło do relatywizacji wyników otrzymanych dla poszczególnych sesji FGI. Nie zdecydowano się na zastosowanie średniej ważonej ze względu na to, że dany argument może nie zwiększać bogactwa informacyjnego materiału, a mimo to inspiruje kolejną wypowiedź. Dlatego hierarchizacja argumentów wydaje się nieuzasadniona. Reasumując, za miarę nasycenia kategorii uznano różnorodność argumentów w postaci uzasadnień lub przykładów przytoczonych przez dyskutantów w nawiązaniu do określonej wypowiedzi. Im wyższa wartość wskaźnika WN, tym wyższy stopień nasycenia kategorii.

\section{Wskaźnik unikalności (WU).}

Zdefiniowany jako liczba odpowiedzi unikatowych na pytanie moderatora. Przez określenie „unikatowa" autorzy rozumieją taką wypowiedź dyskutanta, która we wszystkich sesjach pojawiła się tylko podczas jednego fokusa. Wskaźnik WU informuje o tym, na ile materiał uzyskany podczas danej dyskusji jest nieszablonowy, oryginalny i wychodzący ponad utarte schematy myślenia. Im wyższy wskaźnik WU, tym bardziej niekonwencjonalne spojrzenie na problem będący przedmiotem dyskusji.

Nie sposób stwierdzić, na ile pełne jest zróżnicowanie odpowiedzi dyskutantów lub nasycenie wybranej kategorii, ani też na ile materiał zebrany podczas dyskusji jest unikalny. Celem badaczy była relatywizacja uzyskanych wskaźników - porównanie wielkości wskaźnika właściwego dla danej sesji ze wskaźnikami otrzymanymi dla pozostałych sesji. Innymi słowy, interpretacja tych trzech wskaźników pozwala wnioskować, czy stopień różnorodności, nasycenia lub unikalności kategorii wyodrębnionych przez badacza dla konkretnej sesji jest większy, mniejszy lub porównywalny z innymi sesjami.

Zaprezentowane wskaźniki autorzy sugerują wyliczać rozłącznie dla pytań zasadniczych oraz pytań projekcyjnych. Rozróżnienie to podyktowane jest odmienną charakterystyką pytań postawionych badanym. Pytania projekcyjne bardziej niż pytania zasadnicze angażują myślenie twórcze, którego istotą jest giętkość, plastyczność, zdolność do realizacji operacji intelektualnych na materiale abstrakcyjnym, wieloznacznym i słabo ustrukturalizowanym. Tym samym powyższe zadania mogą być zróżnicowane pod względem trudności i w efekcie mogą one różnicować stopień różnorodności i uzasadnienia wypowiedzi dyskutantów. 
W celu zidentyfikowania sesji, która w porównaniu z pozostałymi pozwoliła na zebranie najbogatszego materiału przyjęto, że im wyższe wskaźniki zróżnicowania, nasycenia oraz unikalności, tym lepsza merytoryczna (czyli praktyczna ze względu na cel badania) jakość danego fokusa. Tym samym, uwzględniając przyjęte wskaźniki bogactwa informacyjnego, można sprecyzować, że im większa liczba kategorii, rozłącznych argumentów uzasadniających daną kategorię oraz wypowiedzi unikatowych, tym wyższa merytoryczna jakość fokusa.

Opisana tu procedura wydaje się bardzo obiecująca i z pewnością warta dalszych analiz metodologicznych. Być może pozwoli w przyszłości na bardziej jednoznaczne porównanie zysków informacyjnych uzyskiwanych $\mathrm{w}$ fokusie i w wywiadzie indywidualnym.

Kolejnym elementem istotnym w kontekście porównania obu technik badawczych zdaniem Kidd i Parschall (2000, s. 293-308) jest fakt, iż w przeciwieństwie do wywiadów indywidualnych, uczestnicy grup fokusowych relacjonują swoje doświadczenia i reakcje wśród osób, co do których zakłada się, że mają podobny status, z którymi dzielą pewien wspólny zakres odniesienia. Członkowie grupy fokusowej komentują wzajemnie swoje punkty widzenia, często podważając motywy i działania innych członków grupy ze wskazaniem, do kogo się zwracają i o kim mówią. W opinii tych autorów, „(...) gdyby wywiad indywidualny był tak konfrontacyjny, bardzo prawdopodobne jest, że prowadziłby do alienacji osoby, z jaką wywiad byłby prowadzony. W przypadku zogniskowanych wywiadów grupowych, porozumienia albo ich brak są procesami o fundamentalnej roli, które wpływają na naturę i zawartość odpowiedzi w miarę, jak grupa odbywa wywiad. Wywiady indywidualne i grupowe mogą dostarczać dowodów ambiwalencji, niekonsekwencji, zgodności poglądów, myślenia na głos w gronie osób dostarczających informacji. Jednakże, z definicji, indywidualne osoby dostarczające informacji ani nie osiągają porozumienia, ani nie ponoszą porażki w procesie osiągania porozumienia, nie negocjują, nie konfrontują, nie antagonizują ani nie poddają się bezpośredniej krytyce, nie wyrażają także współczucia wobec siebie nawzajem."

Z powodów merytorycznych i praktycznych warto także zwrócić uwagę na fakt, iż w wywiadach indywidualnych oczywiste jest, kto wypowiada daną opinię. W trakcie sesji fokusowej nie zawsze jest to możliwe do ustalenia nawet przez moderatora obecnego na spotkaniu. Czasem dyskusja przybiera tak żywiołowy przebieg, że uczestnicy przekrzykują się wzajemnie i mimo zapisu audio i video, może nie tylko nie udać się zidentyfikowanie poszczególnych głosów i przyporządkowanie ich do konkretnych osób, ale także niektóre wypowiedzi mogą stać się zupełnie niezrozumiałe i niemożliwe do zapisu w transkrypcji. Innym powodem utraty części materiału jest fakt, iż 
niektórzy rozmówcy wymieniają informacje pomiędzy sobą, poza głównym obszarem rozmowy. Te wypowiedzi ani nie podlegają konfrontacji z poglądami pozostałych uczestników, ani nie zostają nagrane. Transkrypcja, w oparciu o którą badacz opracowuje zgromadzony materiał, nie oddaje także emocji, jakie towarzyszyły osobom wypowiadającym się. Zresztą podobnie wygląda to w przypadku indywidualnych wywiadów swobodnych.

Istotne znaczenie ma także fakt, iż ponowne zebranie grupy fokusowej w późniejszym okresie jest często nierealne, a nawet jeżeli się uda, to dynamika grupy nie będzie już taka sama. A zatem większość czynności weryfikacyjnych z udziałem członków grupy (Denzin, Lincoln, 1994) musi zostać wykonana w czasie rzeczywistym, podczas prowadzenia wywiadu z każdą grupą fokusową. Dlatego jedynym właściwie rozwiązaniem jest zaprezentowanie przez moderatora pod koniec każdej sesji wstępnej wersji interpretacyjnej w celu jej potwierdzenia i uzupełnienia.

\section{Podsumowanie}

Gdyby nauki społeczne dysponowały w swoim warsztacie jedynie fokusem jako metodą badawczą, najpewniej ich współczesna kondycja byłaby dramatycznie zła. Wobec braku innych alternatyw bez wątpienia uległyby wyostrzeniu wszystkie wady i ograniczenia tej metody. Brak surveyu wyeksponowałby przede wszystkim niemożność prowadzenia analiz statystycznych i brak szans na generalizowanie. Niekorzystanie z indywidualnych wywiadów pogłębionych ograniczyłoby dostęp do poznania szczególnie drażliwych i złożonych zjawisk. Fokus został włączony do repertuaru metod badawczych później niż survey i później niż IDI, co nie jest bez znaczenia dla jego akulturacji w środowisku samych badaczy. Na szczęście FGI jest jednym z wielu narzędzi w warsztacie badawczym socjologa, narzędziem, które - właściwe stosowane - pomaga także niwelować ograniczenia innych metod badawczych. 



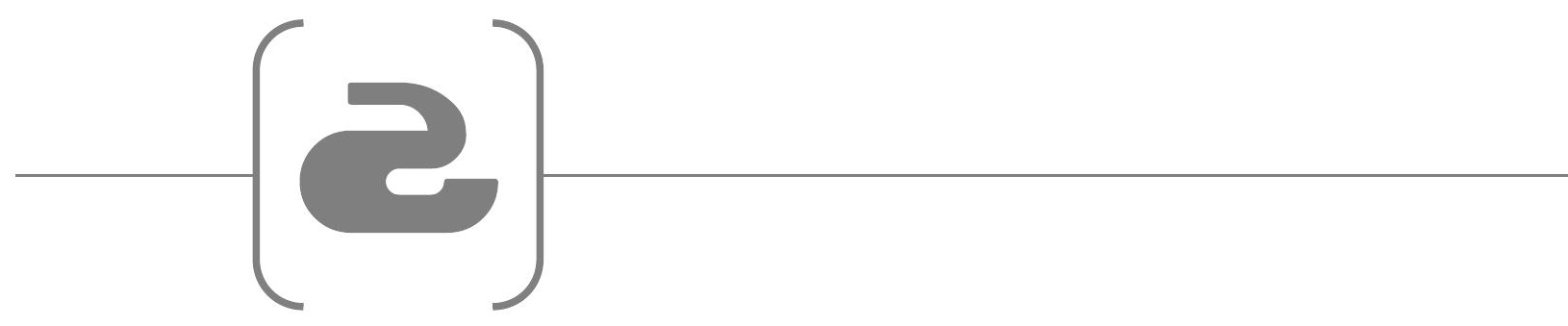

ETYKA W NAUCE

I BADANIACH SPOtECZNYCH 



\section{WPROWADZENIE}

Od przeszło tysiąca lat zagadnienia dobra i zła oraz akceptowanych i niegodziwych uczynków stanowią obszar refleksji filozofów. Poczynając od najdawniejszych myślicieli, filozofowie formułują różne koncepcje dobra, jego źródeł oraz sposobów osiągania. Dla św. Augustyna o jakości życia duchowego człowieka decyduje jego wolna wola, która zawsze dąży do realizacji dobra. Wolną wolę wspierają prawdy moralne (zasady), które wyposażają człowieka w poczucie prawa i moralnego obowiązku. Ta kontrowersyjna koncepcja predestynacji zwalniała człowieka od odpowiedzialności za czyny, wpisane wcześniej w jego los. Św. Tomasz z kolei podstawą swoich rozważań w tym zakresie uczynił godność osoby ludzkiej, która zawiera w sobie prawość sumienia i jej się domaga. W doskonaleniu człowieka w wykonywaniu dobrych moralnie czynności wspierają go liczne sprawności moralne. Czyn moralnie dobry to taki, w którym dobro jednocześnie dotyczy przedmiotu, celu i okoliczności. Zatem cel nie uświęca zastosowanych środków (Piechowiak, 2003, s. 219-242; Tatarkiewicz, 2001). Zarówno systemy deontologiczne (powinnościowe), zakładające, iż kryterium oceny moralnej zawarte jest w motywach i zachowaniach, niezależnie od ludzkich intencji, jak i systemy konsekwencjonalistyczne (teleologiczne, celowościowe), które przyjmują, iż kryterium oceny moralnej stanowią skutki działań, przechodziły przez stulecia różne modyfikacje.

Przez te kilkanaście wieków teoretyczna myśl etyczna wypełniła kontinuum pomiędzy nihilizmem a absolutyzmem, czy wręcz fundamentalizmem etycznym. Najogólniej rzecz ujmując, można wskazać trzy modelowe stanowiska wobec dylematów o charakterze etycznym. Rygoryzm etyczny zakazuje narażania człowieka na jakikolwiek dyskomfort w jakimkolwiek obszarze. Indyferentyzm moralny polega na pomniejszaniu znaczenia negatywnych efektów dla jednostki, zaś realizm etyczny zaleca dążenie do unikania w miarę możliwości sytuacji odbieranych przez jednostkę jako zagrażające i sugeruje poszukiwanie metod alternatywnych, mniej inwazyjnych (Frączek, 1979). Naturalnie u podłoża tych przewartościowań leży zmieniająca się koncepcja człowieka. 
Współcześnie Zygmunt Bauman (1994a) przypisuje etykę w wersji absolutyzmu etycznego wiekowi nowoczesności, w ponowoczesności zaś dostrzega miejsce dla relatywizmu etycznego, będącego rezultatem społecznych interakcji ${ }^{14}$. Zwraca uwagę, że „elastyczne normy i zmienne wartości w płynnej nowoczesności muszą ustąpić normom sumienia chroniącym godność dru-

\begin{abstract}
14 „Prawo odgradzało ład od chaosu, istnienie ludzkie od zwierzęcego catch-as-catch-can, świat zamieszkały od nienadającego się do osadnictwa, sens od bezsensu. Prawo dla każdego i na każdą okoliczność; także i dla wszystkiego, co ktokolwiek zrobić może komukolwiek innemu. Nieustępliwe poszukiwania zasad etycznych były częścią składową (łatwą do przewidzenia a nieodzowną) ustawodawczego szału. Należało ludzi uświadomić, że czynienie dobra jest ich obowiązkiem, i że spełnienie obowiązku jest dobrem. I nie można się było po ludziach spodziewać, że spełniać będą obowiązek z własnej inicjatywy — jeśli się ich wpierw do tego nie skłoni; obowiązków trzeba nauczyć, do ich spełnienia popychać, łagodnie lub brutalnie, w zależności od siły napotkanego oporu. Nowoczesność była zatem, i musiała być, Wiekiem Etyki; nie byłaby nowoczesnością w przeciwnym przypadku. Podobnie jak prawo poprzedzało wszelki ład, etyka musiała poprzedzać moralność. Moralność nie mogła być pomyślana inaczej niż jako wytwór etyki; zasady etyczne były narzędziami jej produkcji; etyka była technologią przemysłu moralnego, dobro zamierzonym produktem, zło odpadem lub brakiem fabrycznym.
\end{abstract}

Dla każdego, kto przywykł myśleć o moralności jako o produkcie końcowym przemysłu etycznego (a więc dla nas wszystkich, nauczonych tak właśnie o moralności myśleć), zmierzch Wieku Etyki (a więc wieku ferowania praw dla moralności) zwiastuje zmierzch (kres?) moralności. Wraz z rozmontowaniem taśm produkcyjnych dostawa dóbr musi wszak ustać? Na miejsce świata trzymanego w ryzach przez przykazania Boże i świata administrowanego przez Rozum, nadciąga oto świat zaludniony przez mężczyzn i kobiety zdane na własny spryt i pomysłowość. Mężczyźni, kobiety puszczone luzem... Mężczyźni i kobiety luźnych obyczajów? Życie, jak w Hobbesowej prehistorii, na powrót nieznośne, brutalne i krótkie?

Takich właśnie następstw nauczyła nas spodziewać się groźbami żonglująca era ustawodawstwa etycznego. Projekt budowy ładu, zważywszy jego koszty, nie mógł się przecież obejść bez przekonywania wszystkich, których przekonać należało (i unaoczniania tym, którzy przekonać się nie dawali), że wybór w istocie rzeczy nie istnieje, że polityka ładu nie posiada alternatywy, że ład zapewnić można tylko w ten jeden jedyny sposób, że dylemat kondycji ludzkiej wyznacza opozycja między cywilizacją a barbarzyństwem." (Bauman, 1994, s. 73) „Być może prawo etyczne obwarowane sankcjami karnymi i wspierane przez szantaż intelektualny było nie tyle ramą, jaka ratowała standardy moralne przed rozpadnięciem się, co stalową klatką, uniemożliwiającą owym standardom rozwój, do jakiego były zdolne, osiągnięcie rozmiarów, jakie osiągnąć mogły i przejście próby, jaka dla wszelkiej etyki i moralności jest próbą obowiązkową i decydującą: próby, jaka polega na zawiązywaniu i odtwarzaniu wspólnoty międzyludzkiej. Być może po rozpadnięciu się ramy jej zawartość nie rozleci się i nie rozpłynie, lecz przeciwnie, zewrze się, uściśli i nabierze prężności, skazana teraz na własne tylko siły i nie zniewalana przez zewnętrzne naciski. Być może z chwilą, gdy ich uwagi nie będzie już pochłaniać troska o ustawodawstwo etyczne i przestrzeganie litery stanowionego prawa, ludzie będą mogli — będą musieli — stanąć oko w oko z nie dającym się już ukryć czy zamazać faktem ich moralnej autonomii, a i tym faktem, że autonomia moralna oznacza moralną od powie dzialność - nie odbieralną ale też i niezbywalną. Być może, w tym samym sensie, w jakim nowoczesność zapisała się w historii jako wi e k e ty ki, nadchodząca era ponowoczesna zapisze się jako wiek moralności?" (Bauman, 1994, s. 78) 
giego człowieka. Szanować w innych ludziach należy to, co w sobie samym nauczyło się uważać za godne szacunku" (Bauman, 2007, s. 242).

Głębokie przemiany, jakie w ciągu ostatnich dziesięcioleci dokonały się w sposobie myślenia o moralności ogólnej znalazły swoje odzwierciedlenie w bogatej literaturze przedmiotu, a etyki szczegółowe przybrały postać rozmaitych kodeksów etycznych.

\section{KODEKSY ZAWODOWE - ZA I PRZECIW}

W latach pięćdziesiątych XX wieku, w znacznej mierze za przyczyną procesu norymberskiego, dyskusje etyczne przeniosły się poza gabinety filozofów i zagościły także wśród praktyków, przedstawicieli różnych dyscyplin zawodowych. Jak pisze Lenk (1995, s. 180-181), ujawnione przed światem straszliwe praktyki dokonywane przez ludzi na ludziach wywołały potrzebę sformułowania kodeksu etycznego postępowania przede wszystkim w obszarze medycyny: „Dopiero skrajne, równoznaczne $\mathrm{z} »$ odczłowieczeniem « nadużycia, uprzedmiotawiające osoby poddawane eksperymentom w obu dziedzinach, biomedycznej i psychologiczno-społecznej, wywołały w skali światowej dyskusje na temat etycznych wątpliwości i podejrzanych manipulacji. Proces norymberski w dramatyczny sposób zaalarmował opinię publiczną. Aby móc wymierzyć sprawiedliwość i etycznie ocenić te eksperymenty na ludziach, trzeba było sformułować [nowe] punkty odniesienia i wytyczyć kryteria. Te nowe reguły (...) dość precyzyjnie sformułowane, antycypowały już większość późniejszych unormowań i mogą być uważane za punkt wyjścia w etycznej dyskusji na temat eksperymentów na ludziach nie tylko w sferze biomedycyny, ale i w obszarze nauk społecznych i humanistycznych". (Lenk, 1995, s. 189)

Wkrótce „śladem norymberskim” podążyli przedstawiciele innych dyscyplin - między innymi psychologowie ${ }^{15}$, prawnicy, dziennikarze, socjologowie, a pod koniec XX wieku badacze rynkowi i społeczni. Każde z tych środowisk (i inne również)opracowało własny, specyficzny kanon właściwego etycznie postępowania zawodowego ${ }^{16}$.

\footnotetext{
15 Amerykańscy psychologowie już w 1953 roku zrealizowali potrzebę ustalenia określonych reguł postępowania w badaniach z udziałem ludzi w postaci kodeksu APA (American Psychological Association). W niedługim czasie podobne regulacje pojawiły się winnych krajach, także w Polsce w 1992 r.

${ }^{16}$ Jako uczeni mamy obowiązki, których nie majq kupcy. Obowiązki przemysłowca sq różne od żołnierza, a tego ostatniego od kapłana... jest tyle form moralności, ile jest różnych zawodów. (Durkheim, 1957, s. 3-4)
} 
Jednocześnie powstawać zaczęły liczne instytucje stawiające sobie za cel bądź to formułowanie, propagowanie, bądź to kontrolowanie respektowania zasad etycznych w poszczególnych środowiskach zawodowych.

Intensywna działalność kodyfikacyjna w zakresie etyki w drugiej połowie XX wieku stała się także obiektem wielu krytycznych dyskusji i komentarzy. 0 ile bowiem takie unormowania początkowo powstawały głównie w odniesieniu do zawodów o wyjątkowym poziomie odpowiedzialności lekarzy, prawników, nauczycieli, czyli takich profesji, w których ryzyko wyrządzenia szkody jest wysokie i w których, z powodu społecznego oczekiwania, uchybienia zawodowe są poddawane szczególnej krytyce i napiętnowaniu, otyle wkrótce zaczęto formułować zalecenia kodeksowe dla przedstawicieli innych profesji - sprzedawców ${ }^{17}$, księgowych ${ }^{18}$, komorników ${ }^{19}$, pracowników muzeów ${ }^{20}$. Na dwie możliwe przyczyny tej skłonności do konstruowania zawodowych dyrektyw etycznych zwróciła uwagę A. Jawłowska (1994, s. 194-195): „Ożywienie to może świadczyć o destrukcji dotychczasowych form ładu aksjonormatywnego; otym, że praktyka w zawodach bardzo ważnych dla ludzkiej codzienności rozmija się z oczekiwaniami społecznymi związanymi z określoną rolą zawodową". Ponadto (...) „potrzeba tworzenia kodeksów etycznych może być również świadectwem bezradności wobec nowych problemów, które nie dadzą się ani wyartykułować, ani tym bardziej rozwiązać w obrębie znanych systemów etycznych.” Autorka wiąże zatem tę tendencję „kodeksotwórczą” z jednej strony z przejawami patologii środowisk zawodowych, a z drugiej strony z koniecznością regulacji wynikającą z zaistnienia nowych, nieznanych wcześniej okoliczności, w jakie wikłają się poszczególne profesje.

Znacznie głębiej przyczyn tego zjawiska upatruje Z. Bauman (1994, s. 79). Jego przytoczone niżej rozważania dotyczą, co prawda, moralności w ogólnym rozumieniu tego terminu, a nie bezpośrednio procedur kodyfikacji norm szczegółowych, jednak wydaje się, że opisane mechanizmy odnaleźć można także w intencjach formułowania przykazań etyki zawodowej: „Teraz, dla odmiany, to właśnie elita panująca potrzebowała norm i kodeksów - i to drobiazgowych. Przepisów surowych, o ile to możliwe niedwuznacznych, skutecznych - takich, jakich przestrzegania powszechnego, lub niemal powszechnego, dałoby się dopilnować. Elita panująca potrzebowała kodeksu etycznego: zbioru wskazówek dla każdego i na każdą okazję — kontroli wszędobylskiej i natrętnej,

\footnotetext{
17 Kodeks Etyki Zawodowej Sprzedawców.

18 Kodeks Etyki Zawodowej w Rachunkowości.

${ }^{19}$ Kodeks Etyki Zawodowej Komornika Sądowego.

${ }^{20}$ Kodeks Etyczny Pracowników Muzeum Etnograficznego im. Marii Znamierowskiej-Prüfferowej $w$ Toruniu.
} 
wnikającej w każdy szczegół życia i każdą szczelinę społecznego układu, kierującej każdym poczynaniem (lub, gdy po temu zajdzie potrzeba, zapobiegającej ruchom niepożądanym) wszystkich, którzy znajdą się na terenie, nad którym rozciąga się panowanie. Nic i nikogo nie wolno było pozostawić żywiołowi czy przypadkowi; odstępstwo od tej zasady, lub choćby jej złagodzenie, groziłoby efektywności władzy, a już na pewno stawiałoby pod znakiem zapytania jej trwałość. Wymogiem panowania było okiełznanie sił groźnych a tajemniczych emanujących z nowopowstałych mas, nie podległych już tradycyjnej rutynie, której korzenie nowoczesność podcięła, i dlatego nieprzewidywalnych w tym, co czynią i uczynić mogą; trzeba było "poskromić bestię«, trzymać na wodzy niesforny tłum: nadać światu na powrót to, co utracił — monotonność, jaka czyniłaby go przewidywalnym i podatnym na manipulację.

Nie każdy jednak kodeks odpowiadałby zamówieniu elity panującej. Potrzebne było takie prawo, jakie ukazałoby ład istniejący (ład utożsamiony z trwałością jej zwierzchnictwa) nie w kategoriach wyjątkowości elity i jej prerogatyw, ale w kategoriach powszechności zasad, które tylko mimochodem, bez uprzedniej intencji, i nie tracąc nic ze swych walorów uniwersalnych, czynią panujących panującymi atych, nad którymi panują podległymi i nakazują jednym i drugim trwać w kondycji, w jakiej się znaleźli.”

Zatem zawodowe kodeksy etyczne postrzegać można zarówno jako zaspokojenie potrzeby wsparcia konkretnych środowisk wskazówkami dającymi im poczucie zabezpieczenia w sytuacji bezradności, jak i jako instrument sprawowania kontroli nad nimi.

Zagadnienie etyki różnych zawodów i powstałych kodeksów budzi wiele kontrowersji, które za przedmiot mają zarówno istotę etyk szczegółowych i ich relacje do moralności ogólnej, jak i rolę, jaką takie kodyfikacje faktycznie odgrywają oraz oczywiście szczegółowe rozstrzygnięcia w nich zawarte. Mnogość kwestii spornych w tym obszarze ujawniła w Polsce w połowie lat dziewięćdziesiątych (XX wieku) ożywiona dyskusja zainicjowana przez pismo „Etyka”21 (Ale naturalnie sprawy te podnoszono w naszym kraju wcześniej). Uczestniczący w tej debacie Zygmunt Bauman zwrócił uwagę na nieusuwalną sprzeczność pomiędzy wyraźnie odczuwaną przez człowieka potrzebą posiadania czytelnych drogowskazów moralnych, a jego naturalną skłonnością do dystansowania się wobec repertuaru reguł moralnych postrzeganych jako narzucone z zewnątrz: „W naszym życiu częściej i pilniej potrzebujemy wiedzy i umiejętności moralnych niż wiedzy o »prawach natury« czy umiejętno-

21 W dyskusji redakcyjnej „Wokół etyki zawodowej” głos zabrali: Magdalena Środa, Barbara Skarga, Wojciech Pawlik, Krzysztof Kiciński, Ija Lazari-Pawłowska, Henryk Jankowski, Jan Wileński, Joanna Górnicka, Robert Piłat, Marek Wichrowski, Aldona Jawłowska, Grzegorz Hansen, Janusz Kraszewski; „Etyka” 1994:27. 
ści technicznych. Jednakże nie wiemy, skąd moglibyśmy je czerpać, zaś gdy są nam oferowane, rzadko mamy pewność, że możemy do końca im zawierzyć" (Bauman, 1994, s. 9-10). Ta antynomia w żadnym razie nie czyni kontrowersji wokół zagadnień etycznych i moralnych łatwiejszą.

Problem dotyczy już samego sposobu definiowania terminu etyka zawodowa. Wyłącznie dla zilustrowania, nie angażując się w szczegółowe analizy, przywołano tu przykładowe propozycje interpretowania tych kwestii. Dla I. Lazari-Pawłowskiej (1969, s. 77) etyki zawodowe wyznaczają wzory zachowań ludzi będacych w roli wykonawców danego zawodu; etyka zawodowa to „(...) spisane normy odpowiadające na pytanie, jak — ze względów moralnych - przedstawiciele danego zawodu powinni, a jak nie powinni postępować" (Lazari-Pawłowska, 1969, s. 58). W takim znaczeniu etyka zawodowa pełni funkcję programu, niekoniecznie pokrywającego się $\mathrm{z}$ faktycznymi postawami moralnymi przedstawicieli różnych środowisk zawodowych. Zdaniem tej autorki, reguły zawarte w kodeksach etyki zawodowej należy wyraźnie odgraniczyć od moralności ogólnej, przede wszystkim z powodu niezliczonej ilości pełnionych przez ludzi ról społecznych, których nie można zawrzeć kompleksowo i bezkolizyjnie w ramach moralności ogólnej (Lazari-Pawłowska, 1969, s. 70).

Według Słownika etycznego z kolei „zawodowe kodeksy etyczne tworzone są (...) poprzez konkretyzację i uszczegółowienie norm etyki ogólnej, funkcjonującej w danym społeczeństwie, dostosowując ją do specyfiki danego zawodu" (Jedynak, 1990, s.71), zatem zakłada się tutaj wyraźnie większą ogólność, wspólność i powszechność formułowanych reguł. W podobnym duchu odnosi się do tej kwestii K. Kiciński. Jego zdaniem etyki zawodowe odnoszą się do zbioru doświadczeń „(...) grup zawodowych, które dopracowały się własnej etycznej podkultury, stanowiącej swego rodzaju operacjonalizację norm i wartości etyki ogólnej, dokonaną pod kątem sytuacji i zachowań specyficznych dla danego zawodu" (Kiciński, 1994, s. 175), ale nadmierna liczba i szeroki zakres reguł z obszaru etyki ogólnej sprawiają, że w tej postaci nie znajdują zastosowania do rozwiązywania specyficznych dylematów konkretnych zawodów.

Nie tylko kwestie definicyjne budzą kontrowersje. Także relacja pomiędzy etyką zawodową a obowiazującymi regulacjami prawnymi nie wydaje się oczywista: „Etyce przypada także rola uzupełnienia prawa w sytuacjach, w których nie jest ono wystarczająco precyzyjne, a zachowanie zgodne z prawem byłoby nieetyczne $=$ złe. $(. ..) \mathrm{W}$ szczególnych sytuacjach etyka zmusza do postępowania wbrew prawu dla wypełnienia powinności czynienia dobrze. W warunkach cywilizowanych powinno to stanowić zdecydowany wyjątek, w systemach o niesprawiedliwych prawach może stanowić nakaz permanentny. Sprawiedliwi Wśród Narodów Świata, to właśnie 
Osoby łamiące prawa III Rzeszy. Aczkolwiek z prawami komunistycznymi nie stało się to jeszcze tak jednoznaczne. A i chyba nie wszystkie akty z czasów III Rzeszy przestały obowiązywać." (Marczewski, 2007)

Tworzenie kodeksów zawodowych ma swoich zwolenników i przeciwników22, wśród których nie brak etyków (Przyłuska-Fiszer, 2007). Przeciwnicy generalnie stoją na stanowisku, że problemy wynikające z wykonywanych czynności zawodowych można rozwiązywać za pomocą zasad i wartości etyki ogólnej. Stawiają oni m.in. zarzut relatywizmu i partykuralizmu wynikający $\mathrm{z}$ faktu, iż normy ograniczają się tylko do określonego zawodu. Ponadto, ich zdaniem, podmiotem etyk zawodowych nie jest człowiek całkowity, ale zredukowany do konkretnej roli społecznej, a etyka zawodowa jest jedynie rezultatem umowy i konwencji, nie zaś przejawem głęboko zinternalizowanych wartości - ma stanowić substytut przy braku tych ostatnich (Środa, 1994, s. 167). Etyka zawodowa nie jest bezinteresowna poprzez swoje prakseologiczne cele, a tym samym przestaje być częścią moralności ogólnej. Zoperacjonalizowanie etyki zawodowej do postaci kodeksów stwarza złudzenie bezpiecznego przewodnika moralnego, a postępowanie zgodne z przyjętymi zasadami kodeksowymi eliminuje przydatną i wskazaną autorefleksję, dostarczając ludziom $\mathrm{w}$ zamian poczucie samozadowolenia $\mathrm{z}$ „bycia w porządku”. Kolejne zastrzeżenia dotyczą procedury ustanawiania etyki zawodowej - tego kto ${ }^{23}$, dlaczego i dla kogo (w czyim imieniu) miałby to robić. Wskazuje się również na silne uwikłanie etyki zawodowej w realia kulturowe, społeczne, polityczne i technologiczne, co sytuuje ją w jeszcze większym oddaleniu od tego, co nazywa się moralnością ogólną.

Kwestionuje się wobec tego także wpływ kodeksów etycznych na prawdopodobieństwo zmniejszenia zachowań uznanych za nieetyczne (Łukaszewski, 2000, s. 97-98): „(...) tymczasem wcale nie brak rozterek, czy wiele zachowań uznanych za etyczne ( $w$ świetle kodeksów) nie niesie z sobą więcej zagrożeń,

22 „Kodeksy etyki mają swoich wrogów. Także kodeksy etyki lekarskiej. Nieżyczliwość, a w każdym razie nieufność, budzi już sama ich amfibijna, dwoisto-nieczysta natura, sytuująca je gdzieś na pograniczach etyki i prawa. Niektórzy widzą w nich tylko pokraczne krzyżówki, twory hybrydyczne, lub co gorsza - usiłujące łączyć własności gatunków, których nie sposób ze sobą skrzyżować. Uważają je więc za konstrukty z istoty chybione, gdyż niezgodne z samym pojęciem etyki, nie dającej się wtłoczyć w ramy żadnego »kodeksu«, w najbardziej nawet liberalnym sensie uporządkowanego zbioru pryncypiów i reguł, które miałyby regulować określoną dziedzinę ludzkiej aktywności (...)." (Galewicz, 2007)

23 „Kodeksy są często pisane, aby coś komuś nakazać lub zakazać. Ich twórcy nie zawsze zdają sobie sprawę z praktycznych skutków swojej działalności, czasami nawet nie bardzo chcą, a często ich szlachetna postawa i wiek nie pozwalają na takie badania, bo ich wyniki mogłyby być zbyt okrutne. W każdym razie nie słyszałem, aby ktoś opracowywał kodeks w oparciu o badania naukowe, zwłaszcza empiryczne. A szkoda!" (Marczewski, 2007) 
niż niektóre zachowania (znów w świetle kodeksów) nieetyczne" oraz wskazuje na ryzyko ich wykorzystywania do „(...) odłączenia odpowiedzialności za własne postępowanie od »ja« i przeniesienia odpowiedzialności na kodeksy właśnie" (Łukaszewski, 2000, s. 100). Jeszcze ostrzej formułuje ten zarzut B. Skarga (1994, s. 170): „Wykonywanie zawodu jest działaniem, a działanie powinno być skuteczne. Etyka zawodowa ma więc usprawiedliwić to wszystko, co sprzeczne jest z wyznawanymi w kulturze europejskiej wartościami, ale co bywa nieodzowne dla skuteczności zawodowej." B. Skarga jest zdania, że istnieje potrzeba usprawiedliwiania mającego często miejsce łamania zasad ogólnie uznanej moralności na gruncie działalności zawodowej i w związku z tym kodeksy zawodowe są usankcjonowaniem „społecznie nieodzownej moralnej niecnoty" (Staniszewska, 2000, s. 68).

Zwolennicy formułowania etyk zawodowych z kolei argumentują, że skoro zadaniem moralności ogólnej jest regulacja stosunków międzyludzkich, to z pewnością może dotyczyć ona także normowania relacji i postępowania w konkretnych środowiskach zawodowych. Wskazują na historyczną genezę takich działań, przywołując etykę rycerską i kodeks Hipokratesa. Podkreślają, że etyka zawodowa nie stoi w konflikcie z moralnością ogólną, ale adaptuje jej normy do określonych, rutynowych dla danej profesji praktyk, poprzez wskazanie dopuszczalnych odstępstw od tych norm. Pełni zatem funkcje informacyjne (poprzez wylistowanie zachowań dozwolonych i niedozwolonych) i ostrzegawcze (wskazuje na sankcje, przewidziane w sytuacji postępowania niezgodnego z kodeksem) (Łukaszewski, 2000, s. 96). Innymi słowy, opisuje pożądany dla danej profesji wzór osobowy. Z kolei zarzut dotyczący „interesowności”, wynikający z funkcji prakseologicznych, odpierany jest przez argument, iż celem postępowania zgodnego z kodeksem jest dbałość o prestiż czy godność (zawodu i jego przedstawicieli). Zazwyczaj stronnicy konstruowania kodeksów zawodowych wskazują, iż powinny one powstawać szczególnie w odniesieniu do takich zawodów, w których występuje niebezpieczeństwo wyrządzenia innemu człowiekowi szkody, których wykonawcy wpływają na ludzkie życie, zdrowie, wolność, godność, własność. „Ograniczenie dowolności i pewien rygoryzm wydają się w praktyce niektórych zawodów niezbędne. Tylko takie ograniczenie daje szanse na przewidywalność zachowań. Ludzie zaś słusznie pragną mieć minimum gwarancji, że np. lekarz, który jest równocześnie badaczem nie potraktuje ich w sposób instrumentalny". Pawłowska ogranicza jednak tę pozytywną rolę kodeksu, gdy stwierdza: „Nie można przesądzać, że posiadanie lub nieposiadanie przez daną grupę wypracowanej etyki zawodowej w pełni wyznacza rzeczywisty poziom moralny przedstawicieli danego zawodu. Wolno jednak przypuszczać, że w jakiejś mierze, niekiedy znacznej, na ten poziom wpływa" (Lazari-Pawłowska, 1994, s. 177-180). 
W intencji twórców kodeksy zawodowe mają za zadanie pełnić kilka istotnych funkcji. Jedną z podstawowych jest regulowanie systemów wartości i przełożenie ich na zachowania (czy szerzej — postawy) pożądane w konkretnym środowisku zawodowym oraz wskazanie potencjalnych zagrożeń etycznych, typowych dla określonych kategorii zawodowych, co można określić mianem funkcji edukacyjnej. Często zawiera się w nich wskazania dotyczące obowiązku dbałości o reputację profesji i jej przedstawicieli24. Z reguły przywołuje się ich funkcję motywacyjną, profilaktyczną i integracyjną, choć zarówno nazewnictwo w tym zakresie, jak i proponowane klasyfikacje różnią się między sobą, niekiedy zasadniczo. Jednak krytyce poddaje się także efektywność tych funkcji, podkreślając ich fasadowość i deklaratywność 25 . Wiesław Łukaszewski, na przykład, w odniesieniu do funkcji informacyjnej, która jego zdaniem polega na dostarczeniu opisu niedopuszczalnych zachowań, stwierdza: „[Kodeksy] określają pewien zakres zachowań dozwolonych i nierzadko znacznie większy zakres zachowań niedozwolonych. Najczęściej kodeksy nazywają i definiują to, co jest negatywnie oceniane, zabronione itp., tym samym pozwalając na domniemanie, że wszystko pozostałe jest dozwolone" (Łukaszewski, 2000, s. 96). Funkcja ostrzegawcza według tego autora ma polegać na uświadomieniu wykonawcom zawodu całego spektrum możliwych sankcji negatywnych, przewidzianych $\mathrm{w}$ danym środowisku $\mathrm{w}$ reakcji na zachowania potępiane przez normy kodeksu: „Od dezaprobaty, poprzez potępienie, aż do eliminacji ze środowiska społecznego. Podkreślenia wymaga jednak, że konsekwencje te w przypadku kodeksów etycznych są możliwe, ale najczęściej bynajmniej nie są konieczne". Funkcja samouspokojenia sprawia, że jeśli przedstawiciele zawodu znają kodeks i respektują jego wymagania, to „(...) w ten właśnie sposób otrzymują świadectwo zawodowej moralności. Nietrudno jednak przyjąć, że mało prawdopodobne jest, aby kodeks (jakikolwiek) przewidywał wszystkie możliwe odstępstwa od dobrego obyczaju. Zatem jest wysoce prawdopodobne, że zachowania nie wchodzące w kolizje z kodeksem, mogą być równie obciążające, przykre dla innych — badanych, uczniów, klientów. Mogą być sprzeczne z dobrym obyczajem czy prawami jednostki". I w końcu funkcja moralnej dezorientacji, która skłania do wyboru działań akceptowanych przez zapisy kodeksu, ale o małej wartości i rezygnacji z działań

\footnotetext{
24 „Kodeksy spełniają niewątpliwie pewną rolę dekoracyjno-konstytutywną, tj. podnoszą rangę środowiska. Zapewne nie tylko dlatego powstały liczne kodeksy, ale coś jest na rzeczy (...)" (Marczewski, 2007).

25, „(...) kodeksy etyki zawodowej pełnią często rolę deklaratywną i nie przekładają się na rzeczywistą praktykę moralną, szczególnie wówczas, jeśli zawarte w nich normy nie są powszechnie akceptowane w środowisku, lub gdy wśród osób wykonujących dany zawód jest ktoś, kto nie ma wykształconego zmysłu moralnego i poczucia odpowiedzialności moralnej i zawodowej." (Przyłuska-Fiszer, 2007)
} 
nieoczywistych z punktu widzenia skodyfikowanych norm, ale za to znaczących. Może to w rezultacie „(...) prowadzić do postawy cynizmu poznawczego: działania błahe nabierają wysokiej rangi, bo są moralnie korzystne lub moralnie obojętne, zaś działania ważne, jako niezgodne z kodeksami powinny być eliminowane na margines (...)" (Łukaszewski, 2000, s. 96).

Rzeczywiście trudno byłoby znaleźć kodeks zawodowy na tyle precyzyjny, drobiazgowy i kazuistyczny, którego zapisy byłyby w stanie rozstrzygać wszystkie występujące $\mathrm{w}$ ramach poszczególnych obszarów praksis dylematy. Ale też nie zawsze komentatorzy mają wobec nich takie oczekiwania. Dla jednych kodeksy: „Powinny być jednak formułowane nie tylko w oparciu o tradycję moralną zawodu, ale także brać pod uwagę akceptowane społecznie wartości, zachować zgodność z obowiązującym prawem i konwencjami międzynarodowymi i nie starać się rozstrzygać spornych kwestii etycznych, co do których istnieją zasadnicze różnice zdań" (PrzyłuskaFiszer, 2007), a dla innych powinny zawierać jednoznaczne, konkretne reguły postępowania: „(...) ograniczenia dowolności w rozwiązywaniu konfliktów wydają (...) się w praktyce niektórych zawodów niezbędne. Tylko takie ograniczenie daje szansę na przewidywalność zachowań" (LazariPawłowska, 1994, s. 177-180).

Przegląd rozmaitych kodeksów zawodowych pozwala uznać, że zawodowe normy etyczne ze swojej istoty mają jednak dość ogólny charakter, raczej wskazują pożądany kierunek postępowania, niż regulują jego szczegóły26. Czyli w pewnym sensie ich praktyczna realizacja uzależniona jest jednak od postawy moralnej przedstawicieli poszczególnych środowisk zawodowych.

Jeśli zaś chodzi o drugą kategorię ludzi, dla której normy kodeksowe mają istotne znaczenie, czyli o pacjentów, klientów i wszelkich beneficjentów wchodzących w relacje z przedstawicielami poszczególnych zawodów wyposażonych w regulacje kodeksowe, to sądzić należy, że świadomość zobligowania profesjonalistów do postępowania zgodnego z przyjętymi zaleceniami podnosi ich poziom zaufania do wykonawców tych zawodów. Prawdopodobnie biorcy różnorodnych profesjonalnych czynności często mają poczucie, że celem tych regulacji normatywnych jest ochrona ich interesów, a nie danego środowiska zawodowego ${ }^{27}$, stanowi rodzaj gwarancji w obszarze etycznym.

\footnotetext{
${ }^{26}$ Kodeksy odnoszą się jedynie do takich zagadnień, które są stosunkowo niezmienne i często występujące. „Jak wiadomo, nawet najbardziej szczegółowe wskazówki nie mogą wyczerpać wszystkich okoliczności i uwzględnić wszystkich konfliktów, jakie mogą się wyłonić. Jednakże sytuacje odczuwane jako szczególnie ważne, kodeksy z reguły uwzględniają, pozostawiając rozstrzygnięcia w kwestiach mniej ważnych indywidualnemu poczuciu słuszności." (Lazari-Pawłowska, 1969, s. 72-73)

27 „Kodeksy etyczne stanowią próbę zapisania czegoś, co nie do końca jest prawem, ale pretenduje do roli regulującej, najczęściej na potrzeby jakiegoś środowiska, np. lekarzy, i często
} 


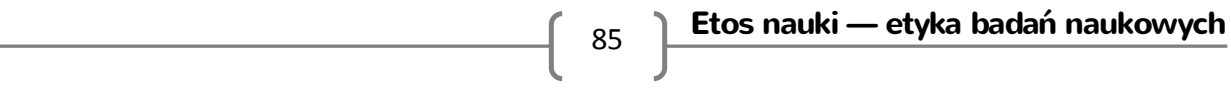

Rozstrzygnięcia kodeksowe w ramach rozmaitych profesji nie są stałe wraz ze zmianą okoliczności wykonywania zawodu (społecznych, politycznych, ekonomicznych, technologicznych) poszczególne zapisy tracą swoją zasadnośćc ${ }^{8}$. Wiele wskazuje na to, że w najbliższych latach ta dynamika zmian przepisów kodeksowych znacznie przyspieszy ${ }^{29}$. Jednak zawartość nawet nieaktualnych kodeksów jest bardzo cenna poznawczo: „Analiza treści poszczególnych kodeksów ujawnia przemiany, jakie dokonywały się w ramach określonych zawodów, ale także pozwala uzyskać wgląd w społeczne warunki wykonywania zawodu, organizacji instytucjonalnej, czynnościach traktowanych jako właściwe i zabronione" (Koralewicz-Zębik, 1969, s. 152).

Spory toczone wokół kodeksów etycznych stanowią refleks fundamentalnych wątpliwości dotyczących etyki w ogólności, wyrażonych chociażby przez wspomnianego już Zygmunta Baumana, który napisał, że we współczesnym (ponowoczesnym), niezwykle zróżnicowanym i dynamicznym społeczeństwie sama możliwość dokonania rozróżnienia pomiędzy dobrem i złem przestała być oczywista: „(...) teraz wiemy, że zawsze już będziemy mierzyć się z moralnymi dylematami nie znajdując jednoznacznie dobrych (to znaczy: powszechnie akceptowanych, nie kwestionowanych) rozwiązań i że nigdy nie będziemy pewni, gdzie mamy takich rozwiązań poszukiwać, nigdy też nie będziemy wiedzieć, czy dobrze byłoby je znać" (Bauman, 1994, s. 23).

\section{ETOS NAUKI - ETYKA BADAŃ NAUKOWYCH}

Problemy etyki stanowią istotny obszar zainteresowania ludzi nauki. Nawiązując do wyżej przedstawionych rozważań, można przyjąć, że potrzeba wypracowania jednolitych norm etycznych w nauce także, w jakimś stopniu, wynika z rozbieżności poglądów akademików na to, co jest moralnie właściwe, a co nie. Mimo że w Polsce naukowiec cieszy się bardzo wysokim prestiżem społecz-

bywa przez wyłonione z tegoż grona gremia uchwalane współcześnie w drodze mniej lub bardziej demokratycznych procedur." (Marczewski, 2007)

28 „Niektórzy współcześni lekarze przeżywają frustrację, ponieważ postęp technologii, zmiany w systemie opieki zdrowotnej, zachodzące niemal we wszystkich krajach uprzemysłowionych, zagrażają etycznym zasadom wykonywania ich zawodu i związanym z nimi wartościom. Zmiany zachodzące w naszych społeczeństwach, stanowią zagrożenie dla zobowiązań środowiska medycznego wobec pacjentów. (...) Jednocześnie istotna jest też polemika z niektórymi »zaleceniami« czy »sformułowaniami«, które w istocie nie mają nic wspólnego z etosem lekarskim." (Szymańska, 2007)

29 „Ciekawe, co zmieni informatyzacja i w ogóle postęp nauki, ale nie można wykluczyć, że powstaną kodeksy pisane przez komputer (program) w oparciu o szczegółowe dane i ogólne zasady. Nam pozostanie pięknie różnić się w sporze o pryncypia a resztę zrobią maszyny." (Marczewski, 2007) 
nym $^{30}$, trudno założyć, że całe środowisko naukowe bez dodatkowych uzgodnień będzie podzielało identyczne przekonania etyczne (szczególnie takie środowisko, w którym funkcjonują potężne autorytety opiniotwórcze). Zatem także do tej specyficznej kategorii można odnieść słowa Davida B. Resnika (2011): „Większość ludzi uczy się norm etycznych w domu, w szkole, w kościele, czy innych okolicznościach społecznych. Mimo że ludzie nabywają świadomości dobra i zła w okresie dzieciństwa, ich rozwój moralny dokonuje się w ciągu całego życia, a ludzie w trakcie dojrzewania przechodzą przez różne jego etapy. Normy etyczne są tak wszechobecne, że można byłoby pokusić się traktować je w sposób zdroworozsądkowy. Z drugiej strony, jeśli moralność jest niczym więcej niż zdrowym rozsądkiem, to dlaczego jest tak wiele sporów i kwestii etycznych w naszym społeczeństwie? (...) prawdopodobnym wyjaśnieniem tych rozbieżności jest to, że wszyscy ludzie uznają pewne wspólne normy etyczne, ale różnie je interpretują i stosują w zależności od ich własnych systemów wartości i życiowych doświadczeń."

Działalność akademików wkomponowana jest w kontekst etosu nauki, rozumianego jako zestaw norm regulujących procedury badawcze, rozpowszechnianie wyników, funkcjonowanie wspólnoty uczonych. Etos nauki to zatem coś znacznie więcej, niż tylko dopuszczalne etycznie postępowanie w ramach procedur badawczych, obejmuje bowiem także aspekt relacji pomiędzy członkami środowiska naukowego oraz powinności nauki wobec społeczeństwa. Decyzja o włączeniu się do wspólnoty naukowców zmusza automatycznie do akceptacji obowiązujących w tym środowisku wartości (Lekka-Kowalik, 2008).

Jednak rozstrzygnięcia przyjęte dla etosu nauki nie zawsze obejmowały tak szerokie spektrum zagadnień. Na przykład etos według Robera Mertona (2002, s. 581-591) obejmuje cztery typy nakazów ${ }^{31}$ :

- nakaz uniwersalizmu, który zakłada, że te twierdzenia, które ubiegają się o uzyskanie statusu wiedzy naukowej podlegać powinny jednakowym standardom krytyki i oceny;

- komunizm, zalecający, aby wszelkie odkrycia naukowe stawały się dostępne dla innych badaczy;

- bezinteresowność z kolei polegać ma na akceptacji tylko poznawczych motywów badaczy, z wyłączeniem ich indywidualnych celów ${ }^{32}$;

\footnotetext{
30 W badaniach CBOS z 2009 r. 84\% ankietowanych stwierdziło, że darzy naukowców (profesorów uniwersyteckich) dużym poważaniem. Autorzy raportu zwracają uwagę, że polskie społeczeństwo wysoko ceni ludzi wykształconych, których działalność zawodowa jest postrzegana w kategoriach „służby społecznej”. (Komunikat 4073, 2009)

31 Tzw. normy CUDOS od: communalism, universalism, disinterestedness i organized skepticism.

32 „Uczony nie powinien tracić czasu na realizowanie celów praktycznych. Zapewne, zrealizuje on je, ale trzeba, by osiągnął to na marginesie swojej zasadniczej działalności. Nie powinien on nigdy zapominać, że badany przezeń poszczególny przedmiot jest tylko częścią wielkiej całości,
} 
- zorganizowany sceptycyzm przejawiający się w gotowości do metodologicznej krytyki osiągnięć i do rezygnacji z tych, które nie zostaną pozytywnie zweryfikowane w oparciu o przyjęte kryteria.

Widać wyraźnie, że powyższe nakazy ograniczają odpowiedzialność badaczy do odpowiedzialności za naukę i za organizacją wspólnotową, a wartością fundamentalną jest autoteliczna wiedza. To typowo scjentystyczne, w rozumieniu Stefana Amsterdamskiego, podejście do uprawiania nauki. Scjentyzm bowiem według tego autora, to „(...) zespół tez dotyczących społecznej wartości nauki i metody naukowej. W tym sensie [jest równoznaczny] z określoną opinią wartościującą rolę nauki w kulturze. (...) mówiąc najogólniej, jest to opinia, że nauka jest dobrem nieproblematycznym". Amsterdamski (1983, s. 132-133) pisze dalej, że „(...) ze względu na taki właśnie charakter nauki jakakolwiek metoda konstytuować może kodeks etyczny nauki, stanowi ową dystynktywną cechę wszelkich stanowisk scjentystycznych. (...) Właśnie dlatego, że scjentyzm traktuje naukę jako dobro nieproblematyczne, postulował on, by społeczeństwo w całości akceptowało ten system wartości, którego realizacja stworzy najlepsze warunki dla rozwoju nauki - ściśle: do urzeczywistniania określonego jej ideału. Stąd wynikała też swoista agresywność myśli scjentystycznej, domagającej się podporządkowania całości życia społecznego takiej lub innej wykładni metody naukowej."

Akceptacja w postawie scjentystycznej koncepcji autonomicznego podmiotu poznającego, który nie zakłóca rezultatów poznania żadnymi własnymi indywidualnymi cechami i przyjęcie określonej wizji nauki jako dostarczycielki „moralnych i materialnych dobrodziejstw dla ludzkości” upoważnia uczonego do stwierdzenia: „(...) moja etyka to moja metodologia. Póki nie grzeszę przeciwko regułom gry obowiązującym w nauce, a kodyfikowanym przez metodologię, spełniam zarazem i mój zawodowy obowiązek uczonego, i etyczny obowiązek człowieka. (...) skoro cel (...) działalności [uczonego] jest z góry usankcjonowany moralnie, jest jednoznacznym dobrem, to jest on odpowiedzialny jedynie za to, by właściwymi drogami dążyć do tego celu. (...) swoją odpowiedzialność za dzieje ludzkości mógł on po prostu utożsamiać z odpowiedzialnością za dzieje nauki." (Amsterdamski, 1983, s. 134-135)

która nieskończenie ten przedmiot przerasta; umiłowanie tej wielkiej całości oraz zainteresowanie nią winny być jedynym motywem poczynań uczonego. Nauka ma cudowne zastosowania; ale nauka, która by dążyła tylko do zastosowań, nie byłaby już nauką, byłaby kuchnią. Nie ma innej nauki, niż nauka bezinteresowna." Henri Poinkare (Amsterdamski, 1983, s. 130) 
Jednak nieuniknione zmiany sposobu postrzegania nauki, $w$ tym przede wszystkim jej uwikłanie w kontekst polityczny i ekonomiczny ${ }^{33}$ (Krimsky, 2006; Guston, 2000), silne powiązanie nauki z techniką oraz redefinicja podmiotowości człowieka, usytuowanie go wroli adresata dobra płynącego z nauki doprowadziły do tego, że „Wiek XX odebrał im [uczonym] moralną pewność, że uprawiając naukę świadczą ludzkości wyłącznie dobro, a tym samym podważył przekonanie, iż przestrzeganie reguł metodologicznych starcza za kodeks etyczny uczonego." Ale w zamian zaproponował harmonijny rozwój nauki otwarty na wartości humanistyczne. Nauka, technika i kultura to naczynia połączone, które wzajemnie mogą czerpać z korzyścią ze swoich dokonań. „(...) Tylko w ten sposób będziemy mieć naukę, która będzie w stanie sprostać wymaganiom sumienia i moralność zdolną objąć to, czego wymaga nasza wiedza naukowa i świat stworzony przez technikę." (Agazzi, 1997, s. 270)

Współczesny etos uczonego nie lokuje go zatem w pozycji wyjątkowej względem innych członków społeczeństwa ${ }^{34}$, a przynajmniej z pewnością nie w takim znaczeniu i stopniu, jak ta uznawana w scjentyzmie. Współczesność obarcza go odpowiedzialnością nie tylko za naukę i wspólnotę uczonych, ale także za społeczeństwo i za pojedynczego człowieka, z którym uczony nawiązuje relację badawczą ${ }^{35}$. Sytuacja taka generuje potrzebę wy-

\footnotetext{
${ }^{33}$ Na złożoność kontekstu, w jakim funkcjonuje współczesny naukowiec wskazuje także Ewa Chmielecka: „Dzisiejsze opisy presji wywieranej na uczelnie związane są przede wszystkim ze zmianą ich społecznego usytuowania, z coraz silniejszą instytucjonalizacją formalną i wynikającym z tego zderzeniem tradycyjnej misji opisanej w kategoriach wartości akademickich z interesami: od szeroko pojętego interesu społecznego po zwykłą efektywność ekonomiczną uczelni, instytucji zarządzającej swymi finansami. Sprzyjają temu różne zjawiska społeczne: umasowienie edukacji wyższej; coraz silniejsze związanie badań z bezpośrednimi problemami i potrzebami praktycznym (np. innowacyjnością); potrzeba rozliczania uczelni - na niespotykaną uprzednio skalę - ze spożytkowania funduszy publicznych (accountability) oraz innych pożytków, jakie powinna ona przynieść swym interesariuszom. W ostatnich latach w Europie mamy także do czynienia z podporządkowaniem systemów edukacji wielkim strategiom ponadnarodowym, takim jak strategia lizbońska czy proces boloński. To ostatnie przedsięwzięcie owocuje jednym z najlepiej znanych przykładów owego konfliktu dwóch postaw - zderzeniem środowiska akademickiego i jego tradycyjnego etosu ze środowiskiem decydentów politycznych i administracyjnych odpowiedzialnych za szkolnictwo wyższe oraz badania". (Chmielecka, 2008, s. 23-36)

34 Tadeusz Styczeń, SDS, w swoim eseju zastanawia się, czy istnieje etyka dla naukowca i analizuje dwie możliwości: jedna przewiduje, że wszystkich ludzi obowiązuje jedna etyka, a druga nakłada na naukowca etykę szczególną. (Styczeń, 1998)

35 „Wartości etyczne, standardy rzetelności naukowej oraz dobre praktyki w nauce uwydatniają etyczną i społeczną odpowiedzialność naukowców. Podkreślając społeczno-etyczny kontekst badań oraz problemy dotyczące rzetelności w nauce, należy rozróżnić ich dwie kategorie: te, które odnoszą się do samej nauki i jej rzetelności oraz te, które wynikają ze związków nauki ze społeczeństwem. Nie ma, rzecz jasna, idealnej granicy podziału pomiędzy tymi kategoriami. Pytania
} 
pracowania adekwatnych do tych oczekiwań treści etosu i ich zinstytucjonalizowania w postaci kodeksów.

Poza tym nigdy wcześniej uczony nie musiał funkcjonować w tak złożonych konfiguracjach z ekonomią i polityką. Porozumienie zawiązane między nauką i polityką w połowie lat 40. stało się niedostosowane i nieaktualne; ani polityka, ani nauka nie są takimi, jakimi były wówczas ${ }^{36}$ (Guston, Keniston, 1994, s. 1-41). Ta okoliczność stanowi potencjalne źródło różnego rodzaju pokus, czemu kodeksy mają zapobiegać.

Naturalnie mówi się także o innych przyczynach stojących za potrzebą opracowania kodeksów nauki - dotyczy to sytuacji zagrażających lub naruszających obowiązujący etos: „(...) potrzeba wprowadzenia regulacji zewnętrznych i wewnętrznych, które zapewnią prawidłowe funkcjonowanie instytucji akademickiej i odpowiedzialne wypełnianie przez nią funkcji, pojawia się wraz z sygnałami zauważalnego naruszania etosu. Mówiąc po heglowsku: "Sowa Minerwy wylatuje o zmierzchu« — kiedy powstają zagrożenia dla tożsamości wspólnoty akademickiej pojawia się potrzeba przemyślenia, czym ona jest. (...) im wyższa świadomość i wola przestrzegania etosu w środowisku - tym mniej potrzebne jest odwołanie do kodeksów i podpieranie się regułami zabezpieczającymi prawidłowość funkcjonowania instytucji. Im zagrożenie etosu większe, tym bardziej potrzebne są regulacje dodatkowe (...). (...) w obliczu zagrożeń stosować można różne rozwiązania, od »odświeżenia« listy wartości etosowych po wprowadzenie regulatorów zapobiegających w trybie mniej lub bardziej restrykcyjnych nakazów patologiom związanym z upadkiem etosu."37 (Chmielecka, 2008, s. 23-36)

etyczne pojawiają się wtedy, gdy naukę rozpatruje się właśnie w szerszym, społecznym kontekście. Naukowcy muszą być bowiem świadomi swej szczególnej odpowiedzialności względem społeczeństwa i dobra ogółu ludzkości." (Kodeks etyki pracownika..., 2012, pkt.2. Preambuła)

36 „Dobre obyczaje w nauce stanowią kolejne ogniwo w tym łańcuchu reakcji społecznej i zawodowej naukowców na niespotykane wcześniej tempo rozwoju nauki (i związaną z tym nieprzewidywalność odległych skutków dziś podejmowanych wyborów i działań, które, być może, zaważą na dalszych losach cywilizacji i kultury ludzkiej), ale także - na zagrożenia płynące z nowych form organizacji i finansowania badań naukowych przez biznes, politykę konkurencji międzynarodowej czy nawet, w sporadycznych przypadkach, działania kryminalno mafijne. Cechą wspólną tych propozycji jest próba budowania fundamentów dobrej obyczajowości, która rozszerza zakres dostrzeganych i uwzględnianych powinności moralnych człowieka, a zarazem, nie likwidując różnorodności systemów etycznych, koncentruje się na podstawowych wartościach i normach obecnych w różnych systemach etycznych, wypracowanych przez wieki doświadczeń ludzkich." (Promieńska, 2005)

$37 \mathrm{O}$ ile jedni autorzy podkreślają dramatyczny upadek norm moralnych w środowisku naukowców, o tyle inni wskazują na nieznaczny rozmiar tego zjawiska. Na przykład Shamoo i Resnik, powołując się na wyniki analiz, twierdzą, że (mimo różnic w szacunkach) wykroczenie w badaniach naukowych jest bardzo rzadkim zjawiskiem. Według tych autorów na podstawie potwierdzonych przypadków uchybień w badaniach finansowanych z pieniędzy 
Bez względu na to, która grupa powodów była bardziej znacząca, rzeczywiście, poczynając od drugiej połowy XX wieku, daje się obserwować dynamiczny proces instytucjonalizacji etyki nauki i badań naukowych. Przybiera on różne formy:

1. Unormowania prawne $w$ ramach krajowych ${ }^{38}$ i międzynarodowych systemów legislacyjnych.

2. „Sądy naukowe”, których zadanie polega na rozwiązywaniu konfliktów natury etycznej między nauką a społeczeństwem i jego instytucjami39.

3. Centra badawcze lub zespoły w ramach istniejących instytucji, które monitorują naukę i opracowują ogólne zalecenia o charakterze etycznym.

4. „Kodeksy dobrych praktyk” tworzone przez różne organizacje zajmujące się nauką.

5. Komitety etyczne.

6. Kodeksy zawodowe poszczególnych dziedzin nauki dostarczające naukowcom rekomendowane dla reprezentowanych przez nich dyscyplin normy i wartości.

7. Włączenie jako obowiązkowego przedmiotu „Etyka badań naukowych" do programu zajęć na studiach wyższych.

Spośród wielu przyjętych w Polsce skodyfikowanych unormowań etycznych postulowanych dla przedstawicieli nauki warto bliżej przyjrzeć się najnowszemu opracowaniu z tego zakresu, mianowicie Kodeksowi etyki pracownika naukowego, przyjętemu na Zgromadzeniu Ogólnym PAN 13 grudnia 2012 (Kodeks, 2012), który powstał $\mathrm{w}$ odpowiedzi na dostrzeżone przejawy patologii polskiego środowiska naukowego ${ }^{40}$. Kodeks jest wyrazem zarysowanego wyżej nowoczesnego

federalnych zarzuty takie dotyczą od 0,01\% naukowców rocznie do 1\% wtedy, gdy analiza uchybień jest prowadzona innymi metodami (Shamoo, Resnik, 2009).

38 W Polsce ten aspekt instytucjonalizacji etyki naukowej znajduje wyraz w opracowaniu rozmaitych krajowych i środowiskowych kodeksów etycznych. Do tych pierwszych należą przede wszystkim: Zbiór zasad i wytycznych. Dobre obyczaje w nauce; Kodeks Etyki Pracownika Naukowego; Dobre praktyki w szkołach wyższych; Dobra praktyka badań naukowych. Rekomendacje; Kodeks Etyki Państwowej Komisji Akredytacyjnej. Swoje kodeksy mają także poszczególne uczelnie, na przykład Uniwersytet Jagielloński, Politechnika Wrocławska, Uniwersytet Gdański, AGH oraz studenci wielu polskich szkół wyższych.

39 Taką funkcję pełni w skali ogólnopolskiej przede wszystkim Komitet Etyki w Nauce PAN, ale istnieje także Komisja ds. Etyki przy Konferencja Rektorów Zawodowych Szkół Polskich. Ponadto komisje powołały liczne uczelnie, a nawet poszczególne instytuty w ramach uczelni (np. Komisja ds. Etyki Badań Naukowych przy Instytucie Psychologii UJ).

40 Kilka miesięcy wcześniej, w sierpniu 2012 roku Ministerstwo Nauki i Szkolnictwa Wyższego opublikowało dokument pt: Rzetelność w badaniach naukowych, opracowany przez Zespół do Spraw Dobrych Praktyk Akademickich. Ta „(...) broszura stanowi przegląd najczęstszych przewinień popełnianych przez badaczy, uchybień w procedurach grantowych czy wreszcie 
poglądu na rolę uczonego, opisuje zarówno powinności środowiskowe, jak i wynikające ze społecznej odpowiedzialności naukowców. Jednak szczególną wagę przykłada się w Kodeksie nie tyle do kontekstu społeczno-etycznego, w jakim funkcjonuje uczony, ile do zagadnienia rzetelności badawczej.

Podstawowe wartości i przyjęte zasady wyjaśnia Preambuła Kodeksu, w której stwierdza się:

1. „Kodeks opiera się na podstawowych ogólnych zasadach etyki, uznanych w naszym kręgu kulturowym za naturalne i powszechnie obowiązujące. Uznanie tych zasad zostało przyjęte jako fundament, bez potrzeby analizy źródła tego przeświadczenia. Za podstawowe zasady etyki uznaje się tu poszanowanie godności człowieka oraz życia we wszystkich jego przejawach, prawdomówność, uczciwość, obowiązek przestrzegania przyjętych zobowiązań oraz uznanie prawa do wolności przekonań i prawa własności ${ }^{41}$. Należy uznać, że strażnikiem i sędzią w sprawach etycznych jest indywidualne sumienie oraz sumienie zbiorowe.

2. Wartości etyczne, standardy rzetelności naukowej oraz dobre praktyki w nauce uwydatniają etyczną i społeczną odpowiedzialność naukowców. Podkreślając społeczno-etyczny kontekst badań oraz problemy dotyczące rzetelności w nauce, należy rozróżnić ich dwie kategorie: te, które odnoszą się do samej nauki i jej rzetelności oraz te, które wynikają ze związków nauki ze społeczeństwem. Nie ma, rzecz jasna, idealnej granicy podziału pomiędzy tymi kategoriami. Pytania etyczne pojawiają się wtedy, gdy naukę rozpatruje się właśnie w szerszym, społecznym kontekście. Naukowcy muszą być bowiem świadomi swej szczególnej odpowiedzialności względem społeczeństwa i dobra ogółu ludzkości.

3. Kodeks etyki pracownika naukowego prezentuje zasady samoregulacji społeczności naukowej, która wprowadza je w przeświadczeniu, że podstawowym obowiązkiem środowiska naukowego jest przestrzeganie ustalonych przez siebie zasad i cnót pracy naukowej. Kodeks definiuje kryteria właściwej praktyki w prowadzeniu pracy badawczej oraz ustanawia procedury dla postępowań, które należy stosować w przypadku ujawnienia zagrożenia rzetelności w nauce. Kodeks ten obejmuje wszelką pracę naukową, niezależnie od miejsca jej wykonywania.

naruszeń atrybucji autorstwa publikacji naukowych. Jest to jednocześnie zbiór cennych wytycznych odnoszących się do kwestii własności intelektualnej, uczciwości autorskiej i zachęta do piętnowania wszelkich przypadków łamania tych zasad" - ze Słowa wstępnego Ministra Nauki i Szkolnictwa Wyższego, prof. Barbary Kudryckiej.

41 Treść dokumentu Rzetelność w... sugeruje, że przestrzeganie reguł etyki zawodowej $\mathrm{w}$ środowisku naukowym pozostawia wiele do życzenia. Być może w jakimś stopniu wynika to z nie tak powszechnej, jak należałoby oczekiwać, znajomości tych zasad. Dlatego zdecydowano się przywołać dość obszerny fragment omawianego Kodeksu. 
4. Wysokie standardy rzetelności i skrupulatne przestrzeganie właściwego dla nauki systemu wartości muszą stanowić nieodłączny atrybut pracy naukowej, której główną inspiracją jest pogłębianie potwierdzonej wiedzy i poszerzanie jej horyzontu poza granice tego, co jest już znane a także dzielenie się nią z innymi. Zachowywanie tych standardów ma zasadnicze znaczenie nie tylko dla utrzymania wewnętrznej spójności nauki, ale i dla jej społecznego autorytetu i wiarygodności. System nauki jest szczególnie wrażliwy na najmniejszy nawet przejaw nieuczciwości, a prowadząc badania naukowe lub je wykorzystując, wciąż opieramy się na świadectwie innych, w związku z czym powinniśmy mieć do tego świadectwa zaufanie.

5. Nauka, obejmująca swym zakresem nauki ścisłe, przyrodnicze, społeczne i humanistyczne, stanowi usystematyzowaną wiedzę uzyskiwaną przez obserwację i eksperymentowanie, badanie i rozmyślanie. Chęć zrozumienia otaczającego nas świata, jak również poznania umysłu człowieka i jego wytworów, zakorzeniona jest głęboko w ludzkiej naturze i mimo że pomiędzy dyscyplinami nauki występują niejednokrotnie bardzo istotne różnice zarówno w zakresie stosowanych metod, jak i przyjętych praktyk, to wszystkie nauki posiadają podstawową cechę wspólną: opierają się na racjonalnej argumentacji i przedstawianiu sprawdzalnych dowodów materialnych lub rozumowych, a więc polegają na obserwacji przyrody lub ludzi oraz badaniu ich działań i wytworów.

6. Nauka nie jest działaniem, które może być prowadzone wodizolowaniu. Badań i dociekań naukowych nie da się bowiem uprawiać bez czerpania z pracy poprzedników. Wymagają one ponadto dyskusji i współpracy z innymi naukowcami. Współpraca ta musi być otwarta na świat, gdyż nauka stanowiąc dobro globalne, nie posiada narodowości. Ponadto to właśnie szerokie środowisko naukowe decyduje o adekwatności przyjmowanych metod badań, a zarazem weryfikuje wiarygodność wyników i odkryć. Badania naukowe przyczyniają się do poszerzenia wiedzy tylko wtedy, gdy ich wyniki zostaną zaprezentowane $w$ sposób pozwalający na ich powtórzenie, a postawione hipotezy zostaną ocenione przez innych. Postęp w nauce jest więc ściśle uwarunkowany sprawnym iszybkim przekazywaniem informacji między kolegaminaukowcami oraz dobrze działającym systemem peer review. Dlatego podstawowe standardy stosowane w prowadzeniu badań i publikowaniu ich wyników muszą być wspólne dla całej, międzynarodowej społeczności naukowej.

7. Nauka ma silny, dwukierunkowy związek ze światem zewnętrznym. Nie tylko siły społeczne i polityczne wpływają na podejmowane kierunki badań, ale również nauka sama z siebie wywiera ogromny wpływ na rozwój cywilizacyjny i społeczny, chociaż jej wyniki mogą być i były niejednokrotnie spożytkowane niewłaściwie. Obowiązkiem naukowców jest uczynienie wszystkiego, co jest w ich mocy, by prowadzone przez nich badania służyły ogólnemu dobrobytowi ludzkości i dobru społeczeństwa. 
8. Presja światopoglądowa bądź polityczna, interes ekonomiczny czy finansowy mogą się przyczynić do pojawienia się w działalności naukowej korupcji i jej uzależnienia od pozanaukowych wpływów. Dlatego też, dla utrzymania wiarygodności nauki pracownicy naukowi muszą strzec swej bezinteresowności i dbać o to, aby pozostać zawsze niezależnymi oraz bezstronnymi i zachować swobodę stosowania uznanych wspólnie praw i kryteriów. Jednocześnie należy być świadomym, że naukowcy działają w kontekście ograniczonym przez wartości, to znaczy, że wybór przedmiotu badań i stawiane hipotezy, sposób gromadzenia danych i wpływ dokonanych odkryć na społeczeństwo, wszystko to odnosi się do etycznego i społecznego kontekstu, w którym nauka funkcjonuje.

9. Kodeks etyki pracownika naukowego nie zajmuje się szerszym, społeczno-etycznym kontekstem nauki, lecz skupia wyłącznie na odpowiedzialnym i rzetelnym prowadzeniu badań. Ma służyć utrzymywaniu integralności nauki, przez stosowanie zasad dobrej praktyki naukowej."

Część 2. Kodeksu informuje o zasadach i wartościach, których przestrzegania oczekuje się od przedstawicieli wszystkich dyscyplin naukowych. Są one obowiązujące także dla innych osób, z którymi uczony wchodzi w relacje badawcze, czyli instytucji, w ramach których badania są prowadzone oraz tych, które te badania finansują i rozpowszechniają ich wyniki. Kodeks obliguje pracodawców (szczególnie te jednostki, które prowadzą studia doktoranckie i mają prawo do nadawania tytułów i stopni naukowych) do dbałości o przestrzeganie tych zasad przez pracowników poprzez promowanie zasad dobrej praktyki naukowej i zasad etyki w nauce oraz poprzez uwrażliwianie na każdym etapie kariery na etykę badań naukowych. Kodeks do tych zasad uniwersalnych zalicza:

1. „Sumienność w prezentowaniu celów i intencji zamierzonych czy prowadzonych badań, w przedstawianiu metod i procedur badawczych oraz interpretacji uzyskanych wyników, a także w przekazywaniu informacji na temat możliwych zagrożeń oraz dobrze uzasadnionych, niepochopnych przewidywaniach odnośnie do możliwych zastosowań i korzyści.

2. Wiarygodność w prowadzaniu badań, krytycyzm wobec własnych rezultatów, skrupulatność, troska o szczegóły i pieczołowitość w uzyskiwaniu, zapisywaniu i przechowywaniu danych oraz w przedstawianiu wyników badań. A też nie wykorzystywanie swojego naukowego autorytetu przy wypowiadaniu się poza obszarem własnej kompetencji.

3. Obiektywizm: opieranie interpretacji i wniosków wyłącznie na faktach, sprawdzalnym rozumowaniu i danych, które są możliwe do potwierdzenia przez innych. 
4. Bezstronność $\mathbf{w}$ podejściu do badanego lub prezentowanego problemu czy zjawiska i w przekazywaniu wiedzy.

5. Niezależność od zewnętrznych wpływów na prowadzenie badań, zarówno wobec zlecających badania czy ekspertyzy, jak i od wpływów ze strony politycznych, ideologicznych lub biznesowych grup nacisku.

6. Otwartość $w$ dyskusjach na temat własnych badań $\mathrm{z}$ innymi naukowcami, co stanowi jeden z kluczowych warunków postępu w nauce oraz w przyczynianiu się do gromadzenia wiedzy przez publikowanie tych wyników, jak również w uczciwym przekazywaniu tej wiedzy ogółowi społeczeństwa.

7. Przejrzystość w zakresie zbierania, analizowania i interpretowania danych, co wymaga aby dane doświadczalne były właściwie przechowywane i po opublikowaniu stały się dostępne.

8. Odpowiedzialność przejawiana wobec uczestników badań oraz obiektów badań, w tym również wobec środowiska czy dóbr kultury. Badania, których przedmiotem jest istota żywa mogą być prowadzone jedynie wówczas, kiedy jest to niezbędne oraz zawsze z poszanowaniem godności człowieka i praw zwierząt, na podstawie zgody wyrażonej przez odpowiednie komisje bioetyczne.

9. Rzetelność w uznawaniu osiągnięć naukowych tych, którym się ono rzeczywiście należy, wyrażająca się poprzez właściwe podawanie źródeł i uczciwe uznawanie udziału należnego innym badaczom, niezależnie od tego czy są to współpracownicy, konkurenci czy poprzednicy.

10. Troska o przyszłe pokolenia naukowców przejawiająca się wpajaniem swoim uczniom i podopiecznym obowiązujących standardów oraz norm etycznych.

11. Odwaga w sprzeciwianiu się poglądom sprzecznym z wiedzą naukową oraz praktykom niezgodnym z zasadami rzetelności naukowej."

Część 3. Kodeksu poświęcona jest dobrym praktykom w badaniach naukowych. Termin ten „(...) obejmuje szczegółowe, powszechnie zrozumiałe i możliwe do wprowadzenia w poszczególnych jednostkach naukowych reguły rzetelnego postępowania odnoszące się do prowadzenia, prezentowania i oceniania badań naukowych, które mają zapewnić spełnienie etycznych wymogów."

Kodeks zaleca pracownikom znajomość tych reguł i konsekwencji w wypadku ich naruszenia, a odpowiedzialność za ich stosowanie składa na ręce całej społeczności naukowej, czyli uczestników procesu badawczego (studentów, doktorantów, pracowników i kierowników zespołów badawczych), instytucji naukowych, agend rządowych i pozarządowych działających w obszarze nauki. 


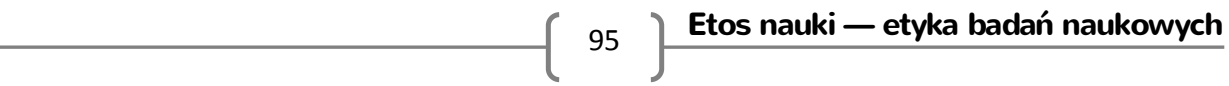

W Kodeksie wyróżniono poniższe kategorie dobrych praktyk:

1. „Postępowanie $\mathrm{z}$ danymi naukowymi.

2. Procedury badawcze.

3. Autorstwo oraz publikowanie wyników badań.

4. Recenzowanie.

5. Formowanie młodej kadry.

6. Współpraca międzynarodowa.

7. Unikanie konfliktu interesów."

Ze względu na różnice w praktykach badawczych występujące pomiędzy dyscyplinami naukowymi Kodeks sugeruje potrzebę wypracowania w ich obrębie własnych zestawów dobrych praktyk; postuluje także, aby takie wewnętrzne zasady wypracowały wydawnictwa i instytucje sponsorujące badania.

Ze względu na przedmiot dalszych rozważań, w tym miejscu zostaną przytoczone jedynie zasady dobrych praktyk odnoszące się do dwóch pierwszych kategorii ${ }^{42}$.

We fragmencie dotyczącym postępowania z danymi naukowymi Kodeks zaleca, aby: „Wszystkie oryginalne dane źródłowe, a więc pierwotne wyniki badań, na których zostały lub zostaną oparte publikacje, a w niektórych przypadkach również próbki czy materiały pochodzące z prowadzonych badań, powinny być skrupulatnie udokumentowane i bezpiecznie zarchiwizowane w sposób uniemożliwiający manipulowanie nimi i zapewniający po opublikowaniu tych badań ich dostępność przez okres właściwy dla danej dyscypliny, ale nie krótszy niż 6 lat od zakończenia badań."

Paragraf 3.2. Kodeksu prezentuje zalecenia dotyczące procedur badawczych:

1. „Wszystkie badania powinny być prowadzone skrupulatnie, z zachowaniem koniecznej ostrożności. Powinny być poprzedzone analizą towarzyszącego im ryzyka oraz skutków, jakie wyniki badań wywierać mogą na społeczeństwo i środowisko.

2. Podczas ubiegania się o fundusze na badania powinno się składać realne obietnice i dokładać wszelkich starań dla zrealizowania deklarowanych celów.

3. W przypadku badań prowadzonych na ludziach należy dbać o zachowanie godności człowieka i okazywać im szacunek, uwzględniając wiek, płeć, kulturę, religię, przynależność etniczną czy pochodzenie społeczne.

\footnotetext{
42 W części końcowej Kodeks definiuje nierzetelność w badaniach naukowych, wskazuje konkretne działania uznane za przewinienia oraz formułuje zasady postępowania w przypadku wykrycia nierzetelności.
} 
4. Badania z udziałem człowieka należy prowadzić zgodnie z przyjętymi zasadami Deklaracji Helsińskiej, Karty Praw Podstawowych Unii Europejskiej, Konwencji o Prawach Człowieka i Biomedycynie Rady Europy, a także innymi szczegółowymi wytycznymi, jak np. prawa farmaceutycznego i dyrektywy Komisji Europejskiej dotyczącej badań klinicznych.

5. Szczególne obiekty badań, takie jak organizmy żywe, dobra kultury i środowisko naturalne powinny być traktowane z należnym im poszanowaniem i troską.

6. Zdrowie, bezpieczeństwo oraz dobro zarówno współpracowników, jak i innych osób nie związanych z prowadzonymi badaniami nie mogą być zagrożone.

7. Badacze powinni być świadomi potrzeby wyważonego gospodarowania środkami przeznaczonymi na badania. Oznacza to efektywne i oszczędne zarządzanie zasobami (finansowymi i innymi) oraz minimalizację odpadów i strat.

8. Zleceniodawcy lub sponsorzy badań powinni być uświadomieni o etycznych i prawnych zobowiązaniach, które wiążą naukowców oraz wynikających z tego ewentualnych ograniczeń, jak również o zasadniczym znaczeniu publikowania wyników badań.

9. W szczególnych, uzasadnionych innymi przepisami przypadkach, naukowiec powinien uszanować poufność danych lub wyników badań, jeśli takie wymagania stawiane są przez zleceniodawcę lub pracodawcę."

Przywołany tu Kodeks zajmuje stanowisko wobec wszystkich zagadnień uznanych przez A. Shamoo i D. Resnika (2009, s. 28-29) jako podstawowe dla etyki badawczej. Autorzy ci przyznają fundamentalną rolę następującym zasadom:

- uczciwość, nakazująca szczerze i otwarcie informować o cechach zgromadzonych danych, zastosowanych metodach i procedurach, zakazująca jednocześnie jakiegokolwiek oszukiwania współpracowników, zleceniodawców lub społeczeństwa,

- obiektywność polegająca na dążeniu do unikania stronniczości (także samooszukiwania) w prowadzeniu badania, analizie i interpretacji danych, wzajemnej ocenie, decyzjach personalnych, składaniu wniosków badawczych i in.,

- integralność, czyli zalecenie dążenia do spójności myśli i działania zespołu badawczego,

- otwartość sprowadzająca się do udostępniania danych, wyników, idei, narzędzi i gotowości do przyjęcia krytyki i nowych propozycji, 
- poufność obejmująca nakaz ochrony wszelkich informacji mogących narazić badanych lub współpracowników na jakiekolwiek negatywne konsekwencje (dane osobowe, finansowe, handlowe i in.),

- ostrożność przejawiająca się w staraniach o unikanie zaniedbań we wszystkich czynnościach badawczych (np. właściwe gromadzenie danych, archiwizowanie korespondencji dotyczącej projektów),

- szacunek dla kolegów i sprawiedliwe ich traktowanie,

- poszanowanie własności intelektualnej wymagające wskazania autora oraz zgody autora na upowszechnienie niepublikowanych informacji,

- poszanowanie prawa obejmujące zrozumienie odpowiednich przepisów,

- poszanowanie obiektu badania, nakazujące ostrożność i uważność w postępowaniu ze zwierzętami, a w przypadku badań ludzi - ochrona jednostki ludzkiej poprzez poszanowanie ludzkiej godności, prywatności i autonomii zaleca podjęcie specjalnych środków ostrożności przy badaniu populacji „wrażliwych” (vulnerable): dzieci, niepełnosprawnych, biednych,

- odpowiedzialność społeczna polegająca na dążeniu do promowania dobra społecznego i zapobieganie lub łagodzenie szkód społecznych poprzez badania, edukację publiczną i rzecznictwo,

- właściwe zarządzanie polegające na odpowiednim wykorzystywaniu zasobów ludzkich, finansowych i technologicznych; w tym dbałość o materiały i urządzenia,

- wolność - instytucje badawcze i rządowe nie powinny ingerować w swobodę myśli.

Do właściwego traktowania osób badanych przykłada się wielką wagę także $\mathrm{w}$ pozostałych formach instytucjonalizacji etyki w nauce, czyli w działalności komisji etycznych, monitoringu i audycie etycznym badań, akademickich programach nauczania: „Badania naukowe należy prowadzić w sposób nie uwłaczający godności człowieka i nie naruszający zasad humanitarnych. Badania, których przedmiotem jest człowiek, należy prowadzić zgodnie z przyjętymi zasadami Deklaracji Helsińskiej i jej kolejnymi uzupełnieniami. W postępowaniu z człowiekiem jako przedmiotem badań należy przestrzegać zasady dobrowolnej i świadomej zgody na uczestnictwo w badaniach oraz zasady poufności i anonimowości wyników badań. Jeżeli badany jest małoletni, to należy dodatkowo uzyskać zgodę jego rodziców lub prawnych opiekunów. Osobie badanej trzeba przyznać prawo do wycofania się z uczestnictwa w trakcie prowadzonych badań. W przypadku badań dolegliwych obowiązkiem pracownika nauki jest analiza konieczności takich badań, ograniczenie ich rozmiaru, zminimalizowanie stopnia ich dolegliwości i przywrócenie osób badanych do stanu sprzed podjęcia badań. Osoba badana powinna być w pełni uświadomiona co do charakteru, celu i skutków badań. Naruszenie tej normy jest dopuszczalne 
tylko w tych szczególnych sytuacjach, gdy uprzednia pełna informacja o badaniach mogłaby zniweczyć wartość wyników badań. W tych przypadkach zatajoną informację pracownik nauki powinien ujawnić osobie badanej po zakończeniu badań i uznać jej prawo do odmowy zgody na wykorzystanie uzyskanych od niej danych." (Dobre obyczaje..., 2001)

Profesor Włodzimierz Galewicz określa powinności badacza - przedstawiciela nauki wobec badanego przy pomocy reguły z obszaru etyki ogólnoludzkiej: „Wartościowe badania naukowe, przeprowadzane na jakichś osobach, służą dobru nauki i dobru ogółu. To powszechne dobro, do którego przyczyniają się takie badania, nie musi jednak przypadać i często też nie przypada w udziale akurat osobom, na których są one przeprowadzane. Stąd też naukowiec, który podejmuje badania na pewnych osobach lub innych czujących istotach żywych, staje się poniekąd dłużnikiem tych istot lub osób, i już choćby z tego względu powinien otaczać je należytą troską. Badacz, który nie troszczy się o swoich probantów, lecz zamiast tego wyrządza im taką lub inną krzywdę, odnosi się zatem do nich w sposób nielojalny. $\mathrm{Z}$ tego punktu widzenia interesujące nas reguły, zakazujące wyrządzania krzywdy w toku badań naukowych, można by więc nazywać regułami lojalności - lojalności wobec uczestników badań." (Galewicz, 2009, s. 48-57)

Działalność przedstawiciela nauki, który realizuje w swojej pracy zawodowej badania społeczne dodatkowo jest regulowana przez liczne kodeksy etyki badawczej.

\section{ETYKA W BADANIACH SPOtECZNYCH ${ }^{43}$}

Od kilkudziesięciu lat następuje stały wzrost liczby inicjatyw badawczych, coraz to nowe obszary społecznej rzeczywistości są poddawane analizie empirycznej i nic nie wskazuje na to, aby ta tendencja miała ulec zmianie czy za-

\footnotetext{
${ }^{43} \mathrm{~W}$ przyjętym tu rozumieniu badania społeczne są realizowane w oparciu o naukowe metody postępowania badawczego. Termin „badania społeczne” jest bardzo szeroki; obejmuje niezliczoną ilość różnorodnych praktyk badawczych z obszaru wielu dyscyplin — socjologii, pedagogiki, psychologii, politologii, edukacji, pracy socjalnej, polityki społecznej, antropologii, etnografii, nauk o zdrowiu i in. Wiele badań społecznych przekracza umowne granice wymienionych dziedzin, korzystając zdorobku merytorycznego i metodologicznego innych nauk. W najszerszym sensie przedmiotem ich zainteresowania są zjawiska społeczne. Wspólną cechą tych badań jest to, że podstawowym podmiotem tych badań jest człowiek; często staje się on także istotnym źródłem informacji koniecznych dla rozwiązania problemu badawczego. Przede wszystkim jednak uporządkowana, konceptualnie konsekwentna i spójna procedura badawcza wymaga przyjęcia określonych, czytelnych założeń, także w odniesieniu do uznanej przez badaczy koncepcji człowieka. Dlatego przyjęto tu, że niżej zarysowane kwestie etyki badawczej dotyczą całej „rodziny” nauk społecznych, choć szczegółowe rozwiązania konkretnych kwestii mogą się pomiędzy nimi różnić.
} 
hamowaniu. Wyniki badań stały się powszechnym składnikiem doniesień medialnych i weszły na stałe do publicznego dyskursu. Jednocześnie przynajmniej od zakończenia II wojny światowej obserwuje się wzmożoną refleksję nad etycznymi aspektami takiej działalności, w której wraz z rosnącą wrażliwością na ludzkie wartości pojawiają się coraz to nowe wątki ${ }^{4}$. Także przewartościowania $w$ ramach samej nauki ${ }^{45}$ oraz szeroko rozumiane dynamiczne zmiany społeczne i technologiczne ${ }^{46}$ wymuszają ustawiczną rewizję uznanych wcześniej norm w etyce postępowania badawczego. W tym kontekście na przykład nie jest bez znaczenia rozwój technologii cyfrowej, bowiem pojawiły się nowe, jeszcze niedawno nieznane, a obecnie powszechnie stosowane sposoby rejestracji aktu czy procesu kontaktu $\mathrm{z}$ badanym, ewidencjonowania i przechowywania jego danych oraz związana z tym pokusa i łatwość ich ujawnienia (np. badania CATI, CAWI).

Znaczenie etyki w działalności badaczy społecznych wielokrotnie podkreślali liczni autorzy, uznając $w$ tym zakresie jej rangę jako porównywalną do tej, jaką pełni w badaniach o charakterze eksperymentalnym w naukach medycznych: „Nie tylko badacz, podejmujący medyczne i farmakologiczne eksperymenty na ludziach, staje wobec dylematu i pokusy, by w interesie postępu nauki i/lub własnej kariery zawodowej ignorować, czy wręcz odrzucić, odpowiedzialność, jaka na nim spoczywa wobec powierzonego jego pieczy pacjenta czy osób poddawanych eksperymentom. Również badacze społeczeństwa i psychologowie stają często wobec podobnego dylematu choć na ogół mniej niebezpiecznego, bo nie decydującego o życiu lub śmierci, nie powodującego widocznych i trwałych szkód fizycznych. Taki dylemat

\footnotetext{
${ }^{44} \mathrm{~W}$ najbliższej przyszłości ze względu na tendencje demograficzne widoczne w krajach wysoko rozwiniętych, socjologowie najpewniej staną wobec konieczności zrewidowania adekwatności (również w wymiarze etycznym) powszechnie używanych metod do badania ludzi starych. Autorka rozpoczęła (dotychczas na niewielką skalę) prowadzenie analiz zmierzających do zbadania odbioru fokusa, wywiadu swobodnego i wywiadu kwestionariuszowego przez badanych w wieku 65+. Pierwsze rezultaty zdają się wskazywać, że fokus jest postrzegany przez taką kategorię osób jako szczególnie atrakcyjna i przyjazna metoda badań. ${ }^{45}$ Chodzi tu przede wszystkim o, najogólniej rzecz ujmując, krytykę obiektywistycznego modelu uprawiania nauk społecznych, w tym przede wszystkim socjologii i alternatywę proponowaną przez podejście konstruktywistyczno-interpretatywne (zob. Zybertowicz, 1995).

46 Zdaniem Davida Resnika, amerykańskiego filozofa, bioetyka, przewodniczącego zarządu NIEHS Institutional Review Board, który zajmuje się nadzorowaniem aspektów etycznych $\mathrm{w}$ badaniach przeprowadzonych z udziałem ludzi, na przemiany w obrębie etyki mają znaczący wpływ także procesy i wydarzenia polityczno-gospodarcze. Na rządowej stronie National Institues of Health (NIH) zamieścił obszerne kalendarium wydarzeń, które jego zdaniem dowodzą konieczności prowadzenia ustawicznej pracy wzakresie ustanawiania i kontrolowania norm etycznych. Każde z nich bowiem w nowym świetle ukazywało zagadnienia etyczne. Kalendarium wydaje się tak interesujące i inspirujące, że zdecydowano się zamieścić je w Aneksie. (Aneks, Załącznik 1)
} 
etyczny czy pokusa nie jawi się jednak tym badaczom jako mniej brzemienny w skutki; często jest on nawet bardziej bulwersujący, ponieważ w tych humanistycznych dyscyplinach nauki osoby poddawane eksperymentom wcale nie są pacjentami i w związku z tym nie oczekuje się tu (zarówno dla samych tych osób, jak i innych ludzi znajdujących się w podobnym położeniu) żadnych terapeutycznych korzyści. Często bowiem z punktu widzenia eksperymentatora szkodzenie, narażanie na nieprzyjemności, czy choćby oszukiwanie osoby poddawanej eksperymentowi nie jest potrzebne i dlatego - etycznie niedopuszczalne. $W$ badaniach psychologicznych, zwłaszcza zaś psychospołecznych, problem oszukiwania wynikający ze stosowania określonych metod występuje o wiele ostrzej niż w większości eksperymentów medycznych" (Lenk, 1995, s. 180-181).

Można wskazać wiele powodów, dla których tak istotne znaczenie ma stosowanie się do norm etycznych w badaniach przeprowadzanych z udziałem ludzi. David Resnik (2011) zalicza do nich propagowanie wartości, takich jak wiedza i prawda, co jest równoznaczne z zakazem wytwarzania fałszywych danych. Ponadto - co szczególnie ważne w badaniach zespołowych, także transdyscyplinarnych - normy etyczne promują wartości niezbędne dla właściwego przebiegu pracy grupowej, takie jak wzajemne zaufanie, szacunek, odpowiedzialność i uczciwość. Po trzecie, normy etyczne mogą być użyteczne w sytuacji, kiedy społeczeństwo domaga się pociągnięcia badaczy do odpowiedzialności w przypadku ich naruszenia. Dalej, obecność czytelnych norm etycznych zwiększa poziom społecznego zaufania wobec badań i tym samym stanowi rodzaj gwarancji dla zleceniodawców finansujących te przedsięwzięcia. Etyczne normy badawcze są także dobrym pretekstem do propagowania i rozpowszechniania innych istotnych wartości moralnych i społecznych - praw człowieka, ochrony zwierząt, poszanowania prawa.

Zagadnienia etyczne badań społecznych od połowy XX wieku stanowią przedmiot zarówno dyskusji podejmowanych w społeczności akademickiej i wśród praktyków, nie związanych z badaniami akademickimi, jak i licznych będących ich rezultatem publikacji.

Wiodące motywy tych rozważań koncentrują się wokół zagadnień, takich jak akceptowalne granice dociekliwości poznawczej w badaniach empirycznych przeprowadzanych z udziałem ludzi, kwestia zapewnienia poufności danych, anonimowości badanych i katalogu ich praw. Jednak mimo wsparcia tej debaty przez wiele naukowych autorytetów, nie wydaje się, aby udało się ostatecznie wypracować reguły etyczne badań w taki sposób, żeby zostały zaakceptowane (nie tylko deklaratywnie) przez całe środowisko badaczy społecznych. Przyczyn tego stanu rzeczy jest wiele. Jedną z nich, kto wie, czy nie najbardziej decydującą, jest niezwykła różnorodność prowa- 
dzonych w tym obszarze badań, przejawiająca się w ich tematyce, metodologii, celach, kategoriach osób badanych, tradycji i szkołach, jakie reprezentują badacze. W rezultacie w podręcznikach czytelnik zazwyczaj może znaleźć jedynie opis ogólnych zasad postępowania i ewentualnie sytuacji, w których autorzy dopuszczają odstępstwo od powyższych (Kowalski, 2005). Dodatkowym bodźcem, poza wszelkimi innymi okolicznościami, podgrzewającym debaty etyczne w obszarze badań społecznych, są różne spektakularne projekty badawcze, które uruchamiają lawinę komentarzy, czego przykładem mogą być choćby historyczne już eksperymenty psychologiczne Asha, Milgrama (Hock, 2003; Aronson, 2002), Zimbardo (2008) czy Humphreysa (1970). Kontakty intymne, jakie badacz Erich Goode (2002) utrzymywał (i opisał!) z respondentkami wywołały ogromne i uzasadnione oburzenie. Dzienniki Bronisława Malinowskiego wywołały wrzenie wśród kilku pokoleń badaczy (Malinowski, 2002). Na gruncie polskim spore zamieszanie etyczne związane było na przykład z badaniami M. Stefanowskiej (1988), P. Moczydłowskiego (1989), M. Kamińskiego (2006).

Źródłem problemów etycznych w badaniach społecznych może stać się zarówno sam cel poszukiwań, jak i służąca do tego metoda, a także cały kontekst sytuacyjny badania (dom samotnej matki, szpital) i specyfika badanej populacji (osoby nieletnie, niepełnosprawne, doświadczone na skutek traumatycznych przeżyć) oraz charakter uzyskanych materiałów.

Wśród badań społecznych szczególną pozycję zajmują badania socjologiczne. Można wskazać co najmniej dwie istotne przyczyny tego stanu rzeczy. Po pierwsze, to przede wszystkim na gruncie socjologii, a właściwie metodologii socjologicznej dokonuje się najwięcej analiz służących poprawie metod badawczych, stosowanych później z powodzeniem przez przedstawicieli innych dyscyplin ${ }^{47}$. Po drugie zaś, spektrum zainteresowań socjologii jest tak zróżnicowane, że znajdują się w nim także problemy specyficzne dla pozostałych dziedzin.

Regulacja zachowań etycznych w zawodzie socjologa przebiega na kilku płaszczyznach, poczynając od podstaw socjalizacyjno-wychowawczych, które prowadzą do internalizacji norm i wartości społecznych, a kończąc na prawnie obligujących aktach normatywnych o różnym charakterze.

W obrębie tych ostatnich wskazać można różne formy instytucjonalne, jakie przybierają zalecenia etyczne. Są wśród nich rozmaite szkolenia etyczne, komisje etyki, audyty etyczne, przewodniki, poradniki etyczne dla badaczy i wreszcie relatywnie szczegółowe kodeksy etyczne dotyczące działalności

\footnotetext{
${ }^{47}$ Autorka w żadnym razie nie ma na celu dyskredytowania osiągnięć metodologicznych pozostałych dyscyplin społecznych (psychologii, pedagogiki i in.), jednak uważa, że socjologiczny wkład do rozwoju metod badawczych jest szczególnie znaczący.
} 
badawczej, które są wyrazem starań zmierzających z jednej strony do uwrażliwienia na pułapki etyczne podmiotów uczestniczących w badaniach, a z drugiej strony do upowszechnienia standardów postępowania w tej dziedzinie.

Do najważniejszych regulacji etycznych standardów badawczych w Polsce należy zaliczyć Międzynarodowy Kodeks Badań Rynku i Badań Społecznych ICC/ESOMAR oraz w kontekście najbardziej tu istotnych badań socjologicznych - uchwalony w 2012 roku Kodeks Etyki Polskiego Towarzystwa Socjologicznego ${ }^{48}$.

Intencją twórców Kodeksu ESOMAR było dostarczenie badaczowi (bo to on jest głównym adresatem dokumentu) wskazań etycznych, do których przestrzegania jest zobowiązany, w celu wzmocnienia zaufania członków społeczeństwa do badań rynku, poprzez wyartykułowanie praw i gwarancji zapewnionych im przez Kodeks. Dokument ten nakłada na badaczy szczególną odpowiedzialność $w$ badaniach dzieci i młodzieży a także formułuje prawa badaczy rynku do poszukiwania, otrzymywania i rozpowszechniania informacji.

W relacjach z respondentami badacze są zobowiązani mocą ustaleń Kodeksu do przestrzegania kilku fundamentalnych zasad. Obowiązuje ich przestrzeganie zasady uczciwości (art. 2. Kodeksu), rozumianej jako zakaz nadużywania zaufania respondentów oraz zakaz wykorzystywania ich braku wiedzy lub doświadczenia. Zapis zabrania także składania respondentom nieprawdziwych oświadczeń o umiejętnościach, doświadczeniu lub działaniach swoich bądź swojej organizacji. W art. 3. Odpowiedzialność zawodowa podkreśla się całkowitą dobrowolność współpracy respondentów $\mathrm{z}$ badaczem na każdym etapie badania. Badacz jest zobowiązany do poinformowania badanych o tym fakcie, a także do podejmowania wszelkich racjonalnych działań w celu ochrony respondentów przed szkodą lub negatywnymi konsekwencjami ich udziału w badaniu. Dalej Kodeks wprowadza zasadę przejrzystości (art. 4.), rozumianą jako konieczność autoidentyfikacji badacza i prawdziwego celu badania. Respondenci powinni mieć możliwość weryfikacji tych deklaracji. W części dotyczącej zasad rejestracji i technik obserwacji (art. 6.) wymaga się od badacza, aby poinformował respondentów o zastosowaniu technik obserwacji lub sprzętu rejestrującego, o ile nie jest on jawnie umieszczony w miejscach publicznych. Na życzenie respondenta zapis, który dotyczy go osobiście, powinien zostać zlikwidowany. W przypadku braku wyraźnej zgody zainteresowanych na ujawnienie tożsamości, badacz ma obowiązek ją chronić. Od badacza oczekuje się także, aby (art. 7.) był gotów wyjaśnić respondentowi procedurę ochrony prywatności, jaka jest stosowana w jego firmie. Zatem w stosunku do respondenta badacz jest zobowiązany do podjęcia wszelkich działań, które spowodują, że

48 Polskie Towarzystwo-Socjologiczne - Kodeks Etyki Socjologa. 
badani zrozumieją i uświadomią sobie własne prawa do tego, że mogą odmówić udziału w badaniu na każdym jego etapie, że mogą zastrzec prawo do udostępniania innym użytkownikom własnych danych osobowych oraz że mogą domagać się usunięcia lub sprostowania danych, które ich dotyczą. Ponadto (art. 8.) badacze są zobligowani do zachowania szczególnej ostrożności wtedy, gdy respondentami są osoby niepełnoletnie. Przed przystąpieniem do zbierania danych należy uzyskać zgodę rodzica lub opiekuna takiego badanego.

Kodeks Etyki PTS w obszarze relacji z uczestnikami badań nakłada na socjologów wiele szczegółowych powinności i zobowiązań w odniesieniu do: zasady dobrowolności uczestnictwa, zasady świadomej zgody, zasady niewyrządzania krzywdy badanym (także w sensie emocjonalnym), zasady anonimowości, poufności i prawdy.

Zgodnie z rozstrzygnięciami Kodeksu badacz-socjolog powinien zdawać sobie sprawę, iż nawiązywane w procesie badawczym relacje z różnymi osobami i grupami mają charakter etyczny (par. 5.) oraz że jest on bezpośrednio odpowiedzialny ( $w$ ramach możliwości sytuacyjnych) za sposób wykorzystania i skutki rozpowszechniania wyników swoich badań (par. 6.). Do obowiązków socjologów należy dążenie do ochrony praw badanych, ich interesów, wrażliwości i prywatności, nawet, jeśli wyważenie sprzecznych interesów może okazać się trudne. Mają także obowiązek zadbać, by prowadzone badania nie miały negatywnego wpływu na stan fizyczny, społeczny i psychiczny ich uczestników (par. 7.), co wiąże się z koniecznością oszacowania poziomu i rodzaju ewentualnego ryzyka (par. 13.) oraz opracowaniem najmniej dolegliwego dla badanych wariantu (par. 15.). W relacjach z badanymi ich postępowanie powinno cechować się uczciwością, bezstronnością i odpowiedzialnością (par. 8.). Kodeks zobowiązuje badacza do przestrzegania zasady dobrowolnej i świadomej zgody uczestników badania ${ }^{49}$. Ta świadomość ma być gwarantowana poprzez

${ }^{49}$ Poprawnie przeprowadzona procedura wyrażania świadomej zgody zawierać musi cztery komponenty:

1. Kompetencja, która przejawia się w tym, iż na podstawie podanych przez badacza przesłanek (dotyczących celu, przebiegu itp. badania) decyzje podejmują osoby dojrzałe i sprawne intelektualnie w stopniu, który umożliwia im właściwe zrozumienie planowanego przedsięwzięcia. We wszystkich innych sytuacjach (badanie dzieci, osób z ograniczonymi kompetencjami intelektualnymi) procedura przewiduje konieczność uruchomienia indywidualnie, sytuacyjnie adekwatnych strategii.

2. Dobrowolność - zadbanie o zniwelowanie wpływu okoliczności zewnętrznych na podejmowanie decyzji o uczestnictwie w badaniu. W praktyce badawczej zdarza się, że ten warunek jest zagrożony (np. wpływ autorytetu badacza, badania w instytucjach o charakterze autorytarnym).

3. Pełna informacja, czyli taka, która zawiera elementy bezwzględnie konieczne (prawo do odmowy, do wycofania się, określenie potencjalnego ryzyka szkód, jeśli badacz potrafi je 
wyraźne i dostosowane do percepcji badanego wyjaśnienie mu jego praw oraz celu, zasad, przebiegu, możliwych dla badanego skutków badania (par. 9.). Generalnie Kodeks zobowiązuje socjologa do zagwarantowania możliwie najwyższego stopnia anonimowości i poufności50 (par. 10.), a we wszystkich sytuacjach, w których przewiduje się konieczność udostępnienia materiału innym badaczom, obowiązkowe jest poinformowanie o tym badanych i uzyskanie ich zgody (par.11.). Socjolog na mocy tego dokumentu zobowiązany jest do zachowania szczególnej uwagi w badaniach prowadzonych z udziałem osób starszych, niepełnosprawnych, chorych fizycznie i psychicznie i uważności w uzyskiwaniu od takich osób świadomej zgody (par. 15.).

Badacz-socjolog musi bezwzględnie przestrzegać zasady anonimowości, szanować prywatność uczestników procesu badawczego, zachować poufność ich danych osobowych (par. 19.), oszacować ewentualne ryzyko naruszenia tych reguł (par. 20.) i zastosować wszelkie środki gwarantujące bezpieczne przechowywanie danych badawczych (par. 21.). Osobny zestaw zasad reguluje relacje ze sponsorami i podmiotami finansującymi badania.

Przywołane tu kodeksy formułują ustalenia w odniesieniu do podstawowych problemów etycznych potencjalnie możliwych do wystąpienia w relacji badacz - badany, czyli regulują kwestię dobrowolnego uczestnictwa respondentów, zakazują ich krzywdzenia, gwarantują anonimowość i poufność badanych. Perspektywa badacza-praktyka często jednak znosi tę wyjątkową rangę kwestii deontologicznych na rzecz sprawności metodologicznej badania, jego wartości poznawczej, przydatności wyników dla diagnozy lub prognozy społecznej. Takie podejście jednak staje się tym bardziej dyskusyjne, im bardziej metoda badania ingeruje w prywatność osób badanych, im bardziej jest ona inwazyjna. A badanie jakościowe, jakim jest zogniskowany wywiad grupowy, bez wątpienia ma taki charakter. Przynajmniej, jeśli bierze się pod uwagę jego zastosowanie w badaniach socjologicznych, a nie marketingowych. Zagadnieniom tym poświęcono rozdział III.

przewidzieć), ale jednocześnie taka, która przez zbytnią drobiazgowość nie skomplikuje obrazu badania w percepcji uczestnika.

4. Zrozumienie sprowadza się do konieczności dostosowania sposobu przekazywania badanym treści do ich poziomu percepcji, do dbałości o to, by wszelkie informacje zostały właściwie zrozumiane przez potencjalnych uczestników badania. (Frankfort-Nachmias, Nachmias, 2001, s. 96-98)

${ }^{50} \mathrm{Ch}$. Frankfort-Nachmias i D. Nachmias traktują anonimowość i poufność jako techniki mające na celu ochronę osób badanych. Anonimowość to oddzielenie danych personalnych czy umożliwiających ustalenie tożsamości badanego od informacji od niego uzyskanych. Służą temu wypracowane, powszechnie znane strategie postępowania badawczego. Poufność zaś odnosi się do nieujawniania publicznie informacji identyfikujących osoby badane. (Frankfort-Nachmias, Nachmias, 2001, s. 102-104) 


\section{Problemy etyczne W technikach BadaWCzych}

Etyczny kontekst badań społecznych uwidacznia się na każdym etapie postępowania, od fazy koncepcyjnej poczynając, na rozpowszechnieniu wyników kończąc. Sam wybór zjawisk poddanych badaniu nie jest obojętny w wymiarze etycznym, czego licznych przykładów dostarcza historia badań. Dobór metod i technik badawczych automatycznie uruchamia związane $\mathrm{z}$ nimi dylematy, o czym szerzej $\mathrm{w}$ dalszej części. Bezpośredni kontakt $\mathrm{z}$ badanymi osobami w sposób oczywisty uruchamia aspekty etyczne. Faza opracowania i interpretacji zebranego materiału także nie jest wolna od takich wątpliwości, wynikających chociażby z analizowania wypowiedzi artefaktualnych, odpowiedzi na pytania sugerujące lub szerzej - z oglądu materiału poprzez pryzmat systemu wartości badacza. Jeszcze inne kwestie mogą pojawić się w opublikowanym raporcie $\mathrm{z}$ badania (na przykład nieuprawniona zamiana terminów użytych w treści pytań zadawanych respondentom na inne, nie synonimiczne wyrażenia, nieujawnienie słabości metodologicznej badania, zamieszczanie nieneutralnych komentarzy).

Etyczny kontekst badań jest bardzo złożoną, niejednorodną i zmienną materią, bowiem badania prowadzi się w różnych warunkach kulturowych, a zatem $w$ różnych systemach wartości i w rezultacie badanie, które w danym momencie, w konkretnym środowisku w żaden sposób nie narusza godności i bezpieczeństwa osób badanych, powtórzone w innym czasie lub w innych realiach może uruchomić lawinę etycznych problemów. Ponadto często relacje pomiędzy normami etycznymi a przepisami prawa nie są jednoznaczne „Mimo że w większości społeczeństw wykorzystuje się przepisy prawa do egzekwowania powszechnie przyjętych norm moralnych i etycznych, należy pamiętać, żeby odróżniać normy prawne od etycznych. Działanie może być legalne, ale nieetyczne lub nielegalne, ale etyczne." (Resnik, 2011)

W sposób oczywisty w dyskusjach dotyczących etyki badawczej pojawia się kwestia stosowanych metod i procedur badawczych, głównie tych o charakterze interakcyjnym. Analiza pożądanego układu sił pomiędzy badaczem a badanym, w zależności od przyjętych przez autorów różnych koncepcji człowieka, zaowocowała bogatą literaturą. Ponadto w każdej technice zbierania informacji, w której dochodzi do kontaktu badanego z badaczem tkwi źródło możliwych do wystąpienia specyficznych dla tej techniki problemów etycznych. Szczególnie wiele uwagi poświęcono obserwacji uczestniczącej i quasi-uczestniczącej (Tarkowska i in., 1994, Chomczyński, 2006, Doktór, 1961), ale standaryzowane techniki badawcze także doczekały się wielu krytycznych analiz z perspektywy etyki.

W odniesieniu do tych ostatnich znakomitym przykładem jest analiza autorstwa E. Neyman-Mascarou. Zdaniem tej autorki, praktycznie każdy element 
wywiadu przebiegającego pomiędzy ankieterem a respondentem niesie ze sobą problem etyczny. Wywiad „(...) jest grą specyficzną o tyle, że już w samym założeniu tylko jedna strona może ją wygrać. Zdobycie niezbędnych informacji oznacza zwycięstwo ankietera (...). W odróżnieniu od ankietera, respondent jest graczem mimo woli: osobnikiem, któremu narzuca się sytuację gry i którego ustawia się w roli partnera, nie informując o jej stawce ani o zasadach. Wywiad przypomina więc raczej corridę, niż sugerowany przez metodologów "pojedynek «" (Kahn, Cannell, 1957); „(...) scenariusz wywiadu przewiduje grę dwóch partnerów opierającą się na sprzecznych wobec nich oczekiwaniach. Ankieter ma przez cały jej czas zachować maskę na własnej twarzy, usiłując równocześnie zedrzeć maskę z twarzy respondenta. Ów zaś nie powinien mu w tym przeszkadzać" (Neyman-Mascarou, 1985, s. 82). Przedmiotem krytyki tej autorki jest również sytuacja wywiadu, określona przez nią jako sztuczna, całkiem nieprzystająca do tego, co w życiu potocznym uważa się za rozmowę naturalną (Denzin, 1970, s. 142), dająca całkowitą przewagę ankieterowi, który zresztą jest jedynie anonimowym wykonawcą wywiadu; z perspektywy badacza jest traktowany jako narzędzie, zobowiązane do redukcji swojej indywidualności. Sprzyja temu wystandaryzowane narzędzie badawcze, które mając za zadanie zapewnienie porównywalności, skutecznie ogranicza spontaniczność respondenta i reguły ankieterskiego savoir-vivru, zafiksowane na skuteczność kontaktu z badanym (chodzi tu także o instrumentalną funkcję działań zmierzających do wypracowania dobrej atmosfery w wywiadzie, czyli na przykład okazywanie przyjacielskiej postawy i zainteresowania respondentem, co ma spowodować, że chętniej przekaże on pożądane informacje). (Goode, Hatt, 1952, s. 190; Gopal, 1970, s. 317)

Neyman-Mascarou przywołuje w swoim eseju, opublikowane na łamach „American Journal of Sociology” w 1929 roku, wyniki analiz (Hyman, Cobb, 1975, s. 27-28) zaleceń kierowanych przez autorów różnych podręczników pod adresem ankieterów. Okazało się, że żadne z nich nie było podyktowane dbałością o dobro badanego. Zdaniem Autorki, przez następne półwiecze nic się w tej kwestii nie zmieniło, nie pojawiły się na przykład wymagania wyrażania szacunku wobec respondenta, niegwałcenia sfery jego intymności i in.

Nie tylko respondent $\mathrm{w}$ kontakcie $\mathrm{z}$ ankieterem traktowany jest przedmiotowo. Także ten drugi jest zobligowany do odłączenia swojej indywidualności, bowiem „(..) funkcja ankietera wymaga podporządkowania się badaczowi i ślepego posłuszeństwa roli przewidzianej przez scenariusz wywiadu. Owa rola ${ }^{51}$ należy do najbardziej odhumanizowanych ról, jakie znamy. Ankieter nie ma prawa funkcjonować jako osoba, skazany jest na stały wysiłek zapominania

\footnotetext{
51 Ija Lazari-Pawłowska także problematykę etyk zawodowych analizowała poprzez socjologiczną kategorię roli społecznej (Lazari-Pawłowska, 1971, s. 41).
} 
siebie." (Neyman-Mascarou, 1985, s. 92) Ta rola wyznacza sposób ubierania ankietera i styl zachowania - nie wolno mu wykazać spontaniczności, wyrażać własnych postaw, okazywać sympatii respondentowi, dyskutować z nim, udzielać rad, choćby każde z tych zachowań było jak najbardziej oczekiwane $\mathrm{w}$ trakcie interakcji z respondentem. Generalnie nie wolno mu robić czegokolwiek, co mogłoby zniekształcić pożądany metodologicznie wzór ${ }^{52}$.

W przypadku nieoczekiwanego rozwoju sytuacji w wywiadzie, ankieter jest zobowiązany do posłużenia się jedynie wyuczonymi strategiami, nie wolno mu stosować własnych osobistych taktyk służących rozwikłaniu problemów interakcyjnych, gdyż byłoby to niezgodne z zasadami roli. W rezultacie: „Ankieter jest szczególnie narażony, gdy atakuje się go $\mathrm{w}$ trakcie spotkania jako osobę, ponieważ przepisy jego zadania nie pozwalają mu wystąpić w tej roli. To w ten sposób respondent może w największym stopniu wywrzeć swoją władzę" (Brenner, 1978, s. 135). Można w tym kontekście uznać, że song Jacka i Michała Tarkowskich z przełomu lat sześćdziesiątych i siedemdziesiątych ma znacznie bogatszą konotację, niż mogłoby się na pozór wydawać:

Ankieterska dolo, dolo ankieterska

Aniś ty niemiecka, ani holenderska

Jenoś tyś jest polska, polska z krwi i ciała

Polska Szkoła Socjologiczna cię wydała.

Jak konstatuje Neyman-Mascarou, silne przywiązanie do obiektywistycznego modelu nauki i oferowanych w nim metod badawczych prowadzi w rezultacie do dominacji metodologii nad zagadnieniami etycznymi: „Ankieta urosła w świadomości społecznej do rangi zawodowej identyfikacji oraz profesjonalnej własności — za jedynych kompetentnych w ustalaniu jej standardów, $w$ jej ocenie, w jej ulepszaniu, realizowaniu oraz nauczaniu, za jedynych upoważnionych do tych działań uważa się socjologów. Licencja i mandat na ankietę umożliwiają autonomizację metodologii wobec powszechnie uznanych zasad etycznych oraz krystalizację specyficznej moralności zawodowej nastawionej na doskonalenie aktu poznania jako na dobro naczelne, nawet kosztem strat psychicznych i moralnych jego przedmiotu (respondentów) czy wykonawcy (ankieterów). Ujmowanie społeczeństwa jako »rezerwuaru informacji«, materii do »eksploracji«, nieliczenie się z potrzebami i interesami respondentów, jak i z chroniącymi ich ogólnie uznanymi zasadami etycznymi, fetyszyzacja i mistyfikacja roli badacza przejawiająca się $\mathrm{w}$ profesjonalnych racjonalizacjach,

$52 \mathrm{~W}$ podobnym duchu instrumentalną odmianę roli ankietera opisuje Krzysztof Kistelski, (1985). Zob. też: Daniłowicz, 1992; Skawiński, Sztabiński, Sztabiński, 2000. 
wszystkie te zjawiska stanowią integralne elementy socjologicznego profesjocentryzmu." (Neyman-Mascarou, 1985, s. 100)

Nie może zatem dziwić negatywna reakcja niektórych badaczy na działania zmierzające do prawnej regulacji ich działalności. Neyman-Mascarou przywołała w swoim tekście artykuł K.J. Bergena (1973, s. 907) pt: Kodyfikacja etyki zawodowej. Punkt widzenia wątpiq̨cego Tomasza, w którym autor jednoznacznie sprzeciwia się wprowadzeniu dodatkowych norm na działalność badaczy. Sekunduje mu w tym także T.N. Greenstein (1980, s. 113), który na wprowadzenie prawnej ochrony respondentów zareagował w sposób następujący: „Większość naukowców reprezentujących dyscypliny społeczne zgodziłaby się, że strategie badań terenowych (włączając eksperymentowanie terenowe, jak również obserwacje uczestniczącą i nieuczestniczącą) odgrywają istotną rolę w naszych próbach wyjaśniania i przewidywania ludzkich zachowań i że próby (...) jakiejkolwiek instytucji rządowej podejmowane w celu zbiurokratyzowania badań terenowych jeszcze nie istniejących powinny spotkać się z silnym sprzeciwem".

$\mathrm{Na}$ brak przestrzegania reguł etycznych zwracano uwagę także w odniesieniu do wywiadów jakościowych. Stwierdzono, iż „(...) techniki i taktyki wywiadu (...) są tak naprawdę metodami manipulacji respondentami i jednocześnie traktowania ich przedmiotowo, zamiast widzieć w nich indywidualne jednostki" (Oakley, 1981). Dostrzeżono, że przedmiotowe traktowanie respondenta i instrumentalna wersja roli ankietera prowadzą do oddzielenia danych od kontekstu, w jakim zostały wytworzone i w rezultacie powodują zubożenie i wypaczenie uzyskiwanego materiału (Schwandt, 1997, s. 79). Otwarcie wyartykułowano silne i różnorodne powiązania pomiędzy działalnością badawczą a badaną rzeczywistością ${ }^{53}$. Na skutek burzliwej i wieloletniej dyskusji zdecydowana większość współczesnych badaczy jakościowych krytycznie odnosi się do paternalistycznego traktowania badanych osób.

Szczególnie wielu analiz uwzględniających etyczny wymiar przedsięwzięcia doczekała się obserwacja uczestnicząca, która ma charakter niejawny, w odróżnieniu od obserwacji quasi-uczestniczącej. Autorzy zwracają uwagę na mnogość zagrożeń, jakie w tym aspekcie ta metoda generuje. Źródłem dylematów etycznych jest tu przede wszystkim wyjątkowo złożona, wielowymiarowa i nasycona emocjonalnie relacja pomiędzy badaczem i badanym. W trakcie długotrwałej obserwacji uczestniczącej dochodzi do wypracowania pewnego poziomu zaufania, znajdującego wyraz w gotowości do zwierzeń, do przyzwalania badaczowi na przekroczenie pewnych granic prywatności i intymności. Proces

\footnotetext{
53 „Teraz już rozumiemy, że obywatelski badacz jakościowy posługuje się zbiorem praktyk, które wywierają wpływ na badany świat. Te praktyki nie są neutralnymi narzędziami." (Denzin, Lincoln, 2010, s. 627)
} 
ten prowadzi często do zmiany statusu badanych - stają się badaczowi bliscy, ważni dla niego jako ludzie, a nie tylko obiekty obserwacji. Jednocześnie wymóg zachowania emocjonalnej i behawioralnej neutralności staje się dla badacza bardzo trudny, a konieczność ustawicznego lawirowania pomiędzy obowiązkiem zachowania profesjonalizmu z jednej strony, a potrzebą „zachowania się po ludzku" z drugiej, prowadzi do poważnych dylematów wewnętrznych (Chomczyński, 2006). Chyba żaden badacz terenowy nie może z pełną odpowiedzialnością zagwarantować, która z jego tożsamości - trwała czy tymczasowa - zwycięży w sytuacjach kryzysowych. Wbrew pozorom, procedura „odkłamania” sytuacji, czyli ujawnienia po przeprowadzeniu obserwacji uczestniczącej jej prawdziwych celów i odsłonięcie faktycznej roli badacza wcale nie poprawia komfortu tego ostatniego, bowiem stawia go wobec konieczności przyznania się do oszustwa i zagraża utratą zdobytego zaufania. Nie sprzyja także dobremu samopoczuciu badanych, a wręcz przeciwnie - zmusza do uświadomienia sobie, że zostali w pewien sposób wykorzystani. Ponadto badacz musi podjąć decyzję, w jakim zakresie i w jaki sposób wykorzysta najbardziej osobiste zwierzenia (Doktór, 1964; Miszewski, 2007; Hryciuk, 2009; Chrsitians, 2009, s. 207-240; Wosińska, 2010; Kleszcz, 2004; Angrosino, 2010; Moczydłowski, 1988; Doktór, 1961, s. 7689; Chomczyński, 2006; Kamiński, 1990, s. 247-250; 1993, s. 115-138).

Wiele problemów etycznych charakterystycznych dla opisanych wyżej technik badawczych dotyczy także zogniskowanych wywiadów grupowych, o czym mowa w rozdziale III.

\section{Podsumowanie}

Badania społeczne to taki fragment społecznego życia, który od wątpliwości etycznych nie jest wolny, a wręcz przeciwnie, ze względu na wyjątkowy obiekt badania - człowieka, generuje problemy, jakie nie występują $\mathrm{w}$ innych dyscyplinach. Jako że zgodnie z jednoznacznym stanowiskiem etyków, badanie społeczne należy do obszaru zjawisk podległych ocenie moralnej w taki sam sposób jak każdy inny przejaw ludzkiego działania, to kwestie etyczne determinują (a przynajmniej powinny) także postępowanie badacza społecznego. Każda z metod badawczych zawiera w sobie potencjalne ryzyko, że przy niewłaściwym lub nieuważnym postępowaniu badacza może przekształcić się z neutralnego narzędzia w źródło problemów etycznych. Mimo najlepszych intencji ich twórców, temu niebezpieczeństwu nie są w stanie zapobiec kolejne akty normatywne w postaci kodeksów etyki. Poziom ogólności zawartych w nich dyrektyw jest bardzo odległy od konkretnych sytuacji występujących w praktyce badawczej. 



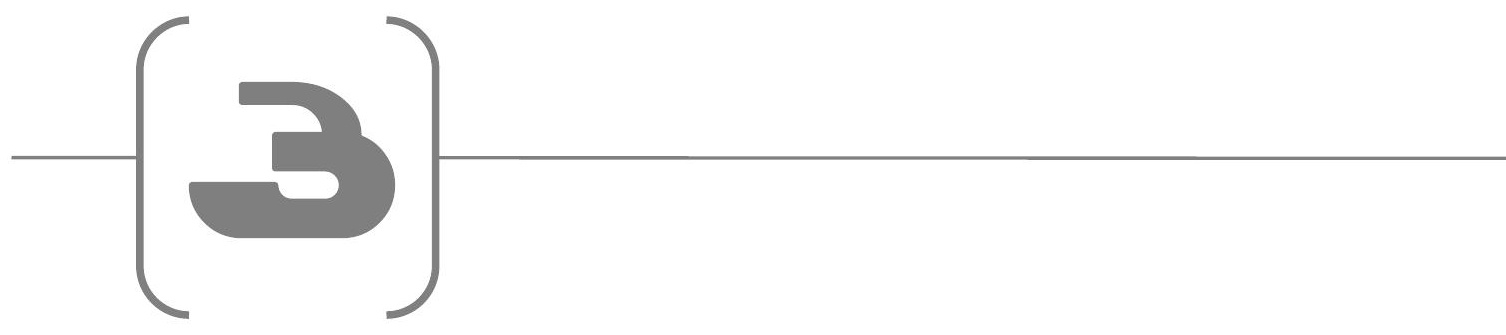

ETYKA

BADAŃ FOKUSOWYCH

W KONTEKŚCIE

ELEMENTÓW

METODY BADAWCZEJ 



\section{WPROWADZENIE}

Celem tego rozdziału jest uzasadnienie tezy mówiącej, że zagadnienia etyczne w badaniach fokusowych są znacznie bardziej złożone i wielowymiarowe niż w przypadku innych technik zbierania danych opartych na interrogacji. Literatura przedmiotu nie traktuje z należytą powagą tego aspektu badań fokusowych, a przecież chociażby w odniesieniu do wywiadu kwestionariuszowego czy wywiadu swobodnego wątki etyczne doczekały się wnikliwych analiz.

Jak starano się to przedstawić w poprzednim rozdziale, kodeksy zawodowe formułują ustalenia w odniesieniu do podstawowych problemów etycznych, możliwych w relacji badacz - badany, czyli regulują kwestię dobrowolnego uczestnictwa respondentów, zakazują ich krzywdzenia, gwarantują anonimowość badanych i poufność54. Oczywiście, w zależności od stosowanych technik otrzymywania materiału, realizacja praktyczna tych zasad etycznych przebiega nieco inaczej.

Warto przyjrzeć się zatem, jakie pułapki zagrażające przestrzeganiu zasad obowiązujących w kontekście przywołanych kodeksów kryją się w badaniach fokusowych. Problemy etyczne zogniskowanego wywiadu grupowego omówione zostaną przez pryzmat podmiotów bezpośrednio zaangażowanych w realizację przedsięwzięcia badawczego, czyli badanych i badacza (i jego współpracowników).

Badanego, uczestnika sesji, z perspektywy etycznej, mogą dotyczyć problemy wynikające z:

1. Elementów procedury - nagrywanie, podgląd, obecność innych uczestników.

\footnotetext{
${ }^{54}$ Specyfika badań marketingowych i ich powszechność wymuszają konieczność uwzględnienia wstandardach badawczych dodatkowych wątków, szczególnie istotnych wobec wszechobecnych praktyk o charakterze marketingu bezpośredniego (np. przesyłki bezpośrednie - direct mail), telemarketing, marketing poprzez Internet). Kodeksy obligują badaczy i zleceniodawców do wykorzystywania wyników tych badań (i wszelkich materiałów empirycznych) zgodnie z obowiązującymi zasadami etycznymi. W związku z tym zakazują m.in. gromadzenia poprzez działalność badawczą baz danych adresowych dla pozabadawczych celów (reklama, promocja), zdobywania informacji pozwalających oszacować wiarygodność kredytową respondentów oraz prowadzenia działalności handlowej.
} 
2. Charakteru badanego zagadnienia: różnice między badaniami socjologicznymi a rynkowymi/marketingowymi (drażliwość tematyki, trudność, kontrowersyjność). Problemy związane z treścią wypowiedzi uczestników: możliwość modyfikacji opinii innych uczestników, konsekwencje dla samooceny badanych.

3. Formy interrogacji - relacje pomiędzy uczestnikami, funkcja terapeutyczna fokusów.

4. Charakteru narzędzia (scenariusza moderatora) - rodzaj pytań i zadań dla uczestników, techniki projekcyjne.

5. Relacji między uczestnikami a moderatorem.

W przypadku badacza (bądź jego współpracowników) omówienia wymagają problemy:

1. Ankieterów związane z selekcją/rekrutacją uczestników sesji, rezygnacja z nadliczbowych uczestników.

2. Związane $\mathrm{z}$ pełnieniem funkcji moderatora.

3. W relacjach ze zleceniodawcą.

4. W kontekście konsekwencje dla przedmiotu badania.

5. Związane z badaniem szczególnych kategorii uczestników (tu omówione zostaną na przykładzie dzieci i niepełnoletniej młodzieży).

\section{Problemy etyczne WrNikające $Z$ elementóW Procedury}

Procedura badań fokusowych jest stosunkowo skomplikowana. Z punktu widzenia uczestnika sytuacja badawcza jest znacznie bardziej złożona niż w przypadku techniki wywiadu swobodnego czy badań ankietowych, które prowadzone są najczęściej w czasie dogodnym dla badanego i w miejscu wybranym przez respondenta, a zatem przyjąć należy, że w znanym i bezpiecznym. Dlatego także w fokusie pojawia się więcej, niż w przypadku wymienionych technik, możliwości naruszenia podstawowych zasad etycznych obowiązujących wobec uczestników. Ponadto, co nie jest bez znaczenia dla analizowanego tu problemu, poziom akulturacji zogniskowanego wywiadu grupowego w polskim społeczeństwie jest relatywnie niski. (Daniłowicz, 2004)

\section{Lokalizacja badania}

Badanie fokusowe (jeśli ma miejsce w profesjonalnej pracowni) jest przeprowadzane $\mathrm{w}$ pomieszczeniu, $\mathrm{z}$ jakim zdecydowana większość uczestników nigdy wcześniej się nie zetknęła. Pierwsze wrażenie często wiąże się $\mathrm{z}$ odczuwaniem lęku. Stan emocjonalny towarzyszący badanym na początku 
sesji dobrze ilustruje wypowiedź jednego z uczestników, uzyskana w wywiadzie swobodnym, przeprowadzonym po zakończeniu fokusa ${ }^{55}$ : „Najtrudniejsze zawsze są początki, więc pewnie to pierwsze wrażenie, jak do tego pierwszego pokoju wchodzenie, zamknięcie i od razu człowiek jest wystraszony, że go coś tam czeka."

Zdjęcie 1. Pracownia fokusowa w Toruniu

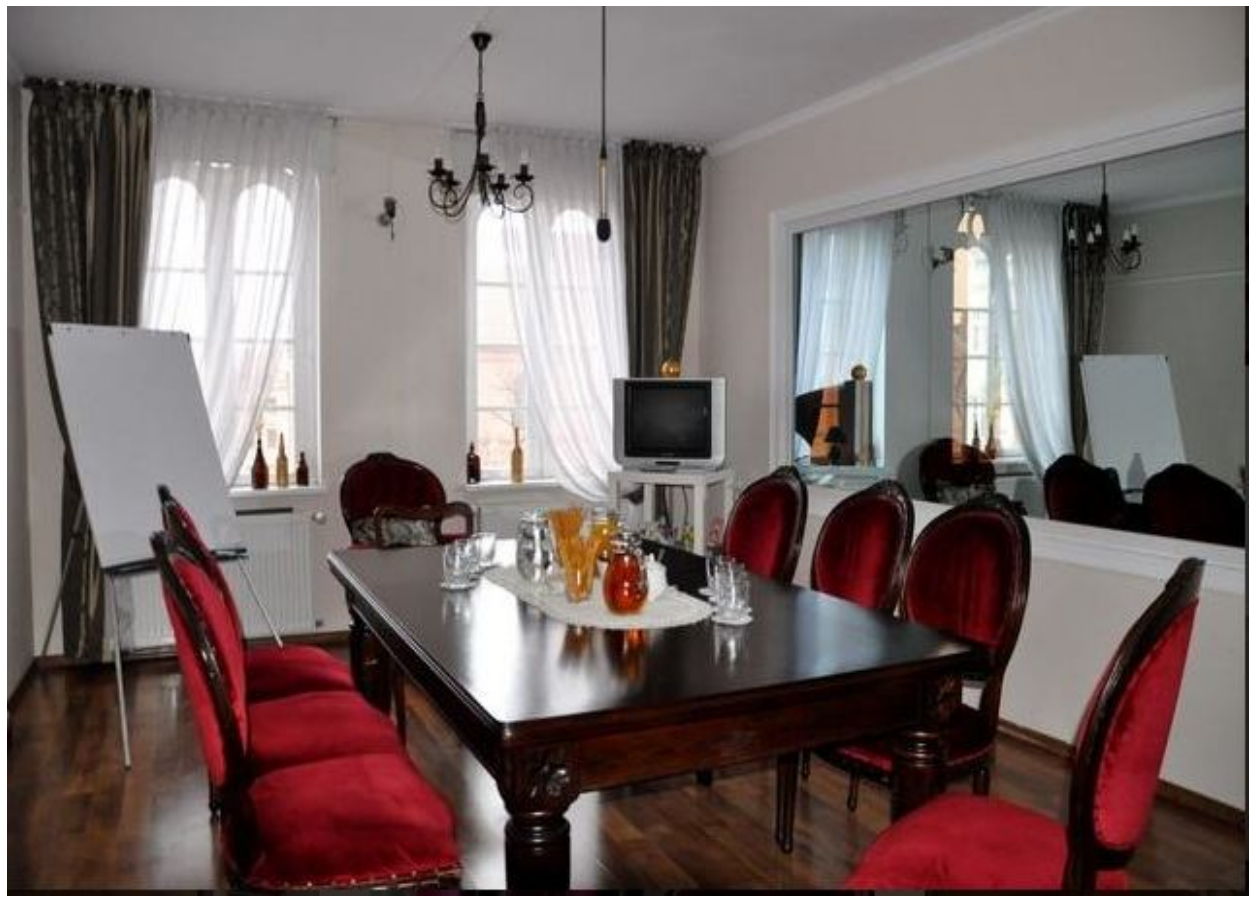

Źródło: http://www.fokusstudio.exe.pl/torun/ na dzień 22.02.13

Oczywiście, wiele zależy tu od sposobu aranżacji wnętrza, ale bez względu na to, czy ma ono bardziej (Zdjęcie 1.), czy mniej oficjalny (Zdjęcie 2.) charakter (a można taki osiągnąć na przykład przez ustawienie w sali fokusowej kwiatów, obrazów, odpowiednich mebli), to i tak centralne miejsce zajmuje lustro weneckie, mikrofon(y), kamera, tablica, a czasem także inne urządzenia (rzutnik, ekran, sprzęt nagrywający). Ale jeżeli nawet studenci odbywający kolejny

55 Cytowane tu fragmenty wypowiedzi pochodzą z badań „Zogniskowany wywiad grupowy. Studia nad metodą" (Grant KBN; kierownik: Jolanta Lisek-Michalska), których jednym z elementów były wywiady swobodne przeprowadzone $\mathrm{z}$ badanymi bezpośrednio po zakończeniu sesji fokusowych, w których brali udział. Narzędzie do wywiadu swobodnego zamieszczono w Aneksie, Załącznik 2. 
raz zajęcia w pracowni fokusowej twierdzą, że nie czują się zbyt komfortowo w tym miejscu, ponieważ nie mają pewności, czy przebieg konwersatorium nie jest nagrywany, to nie można oczekiwać od badanych, że w krótkim czasie trwania sesji oswoją się z tym wnętrzem na tyle, żeby poczuć się $\mathrm{w}$ nim zupełnie swobodnie.

W tradycji angielskiej organizowane były sesje fokusowe w prywatnych mieszkaniach uczestników. Ideą tej koncepcji było prowadzenie badania w okolicznościach znajomych dla respondentów, postrzeganych jako bezpieczne, a jednocześnie nie kojarzących się z badaniem, ale z sytuacją naturalną, z wizytą u znajomych.

\section{Zdjęcie 2. Sesja fokusowa w mieszkaniu prywatnym}

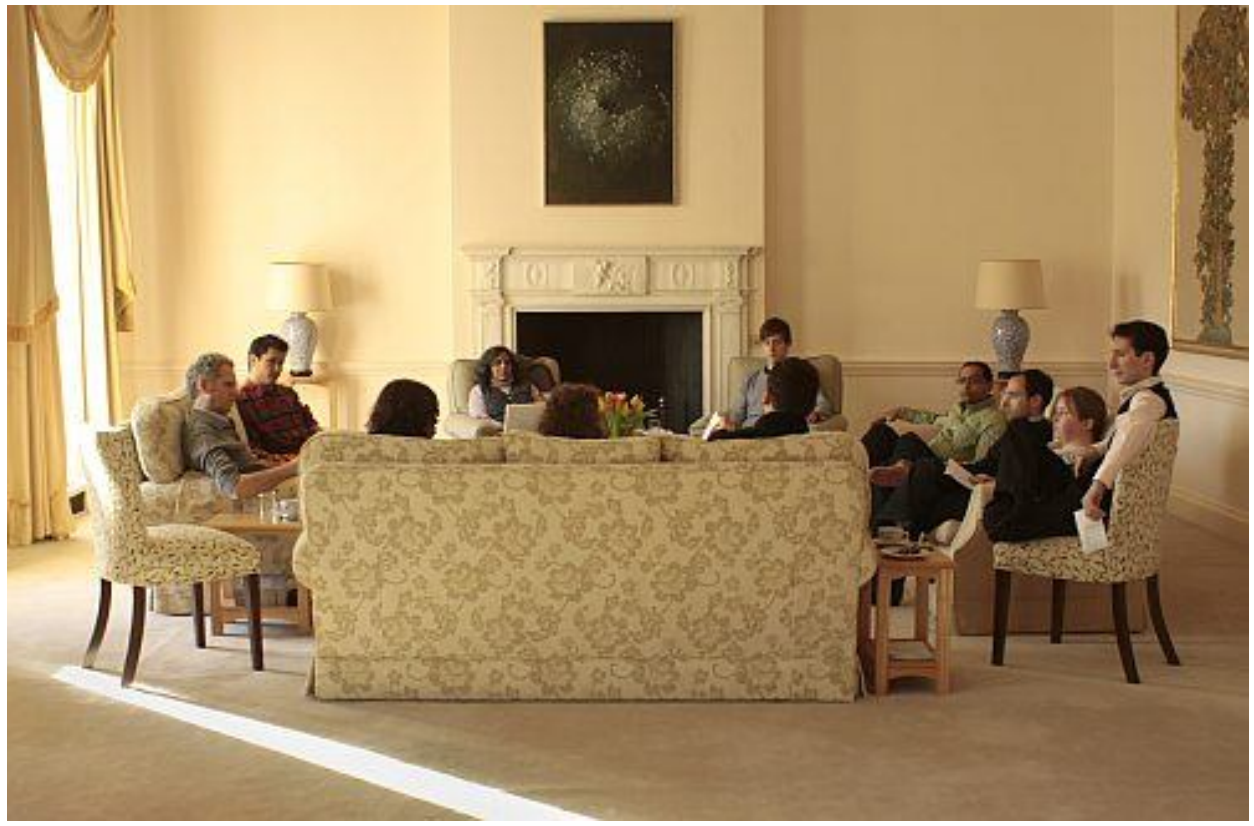

Źródło: http://blog.brockwood.org.uk/2011/02/26/inspiring-alumni-focus-group/

Pomysł ten testowano również w Polsce. Jednak wydaje się, że taka formuła nie przystaje zarówno do oczekiwań polskich badanych, jak i badaczy. Z doświadczeń empirycznych wynika ${ }^{56}$, że pomimo tak zwanej polskiej gościnności, nikt z uczestników nie czuł się w tych obcych mieszkaniach swobodnie, z właścicielem włącznie.

\footnotetext{
56 Autorka moderowała takie sesje w ramach współpracy z Sopocką Pracownią Badań Społecznych.
} 
Zdjęcie 3. Sesja fokusowa w mieszkaniu prywatnym

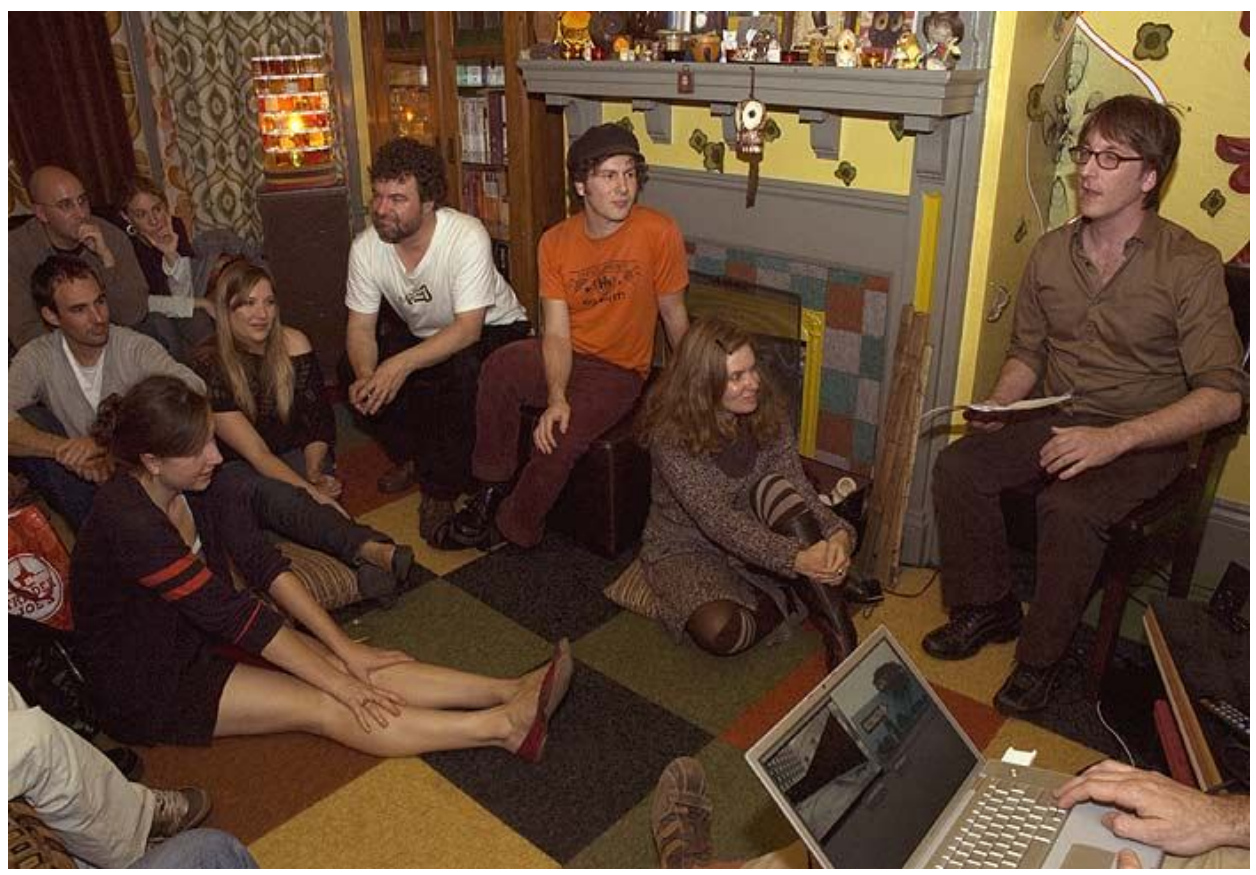

Źródło http://meganwilson.com/sub/focus-group-jeff-foye-gordon-winiemko

Dla gospodarza był to poważny stres - ludzie, u których organizowano badanie sprzątali mieszkania „jak na święta”, obawiali się, że ktoś zechce skorzystać z łazienki, w której nie wszystko było tak, jak być powinno. Doszły do tego jeszcze problemy organizacyjne - zbyt mała przestrzeń, za wysoka temperatura, konieczność otwarcia okien zza których dobiegał hałas ulicy, wymagający podniesienia głosu przez osoby mówiące. Bywało i tak, że w mieszkaniu, w którym odbywała się sesja, nie było wystarczająco dużego stołu, który mógłby pomieścić wygodnie 8-9 osób. Uczestnicy siadali na różnych kanapach, fotelach, krzesłach, pożyczonych na tę okoliczność przez właściciela mieszkania od sąsiadów. Odpowiednie zainstalowanie kamery graniczyło z cudem. No i taka aranżacja sytuacji badania praktycznie eliminowała możliwość skorzystania zleceniodawcy z podglądu. Ponieważ zwykle moderatorowi towarzyszył inny członek zespołu badawczego, zajmujący się sprzętem i kontrolujący (w przedpokoju!) zgodność kwestionariuszy rekrutacyjnych z przybywającymi uczestnikami, to w trakcie badania przebywał on zwykle w kuchni mieszkania przeistoczonego na ten krótki czas na pracownię badawczą. Cała ta aranżacja sytuacji badawczej nie tylko niczego nie ułatwiła, ale wręcz pogorszyła komfort badanych 
(i moderatora). Warunki mieszkaniowe w Polsce są, jakie są i nie sprzyjają prowadzeniu takich badań. Ponadto zbyt wiele rzeczy rozprasza badanych - przyglądają się, jak mieszkają inni ludzie, jak się urządzili, jakie mają sprzęty i przedmioty. To nie sprzyja koncentracji na realizacji celów badawczych. Z kolei wybór mieszkania dużego, wygodnego, odpowiednio urządzonego także pewnie nie byłby dobry z punktu widzenia uczestników, których warunki domowe są zdecydowanie gorsze.

\section{Zdjęcie 4. Sesja prowadzona poza pracownią fokusową}

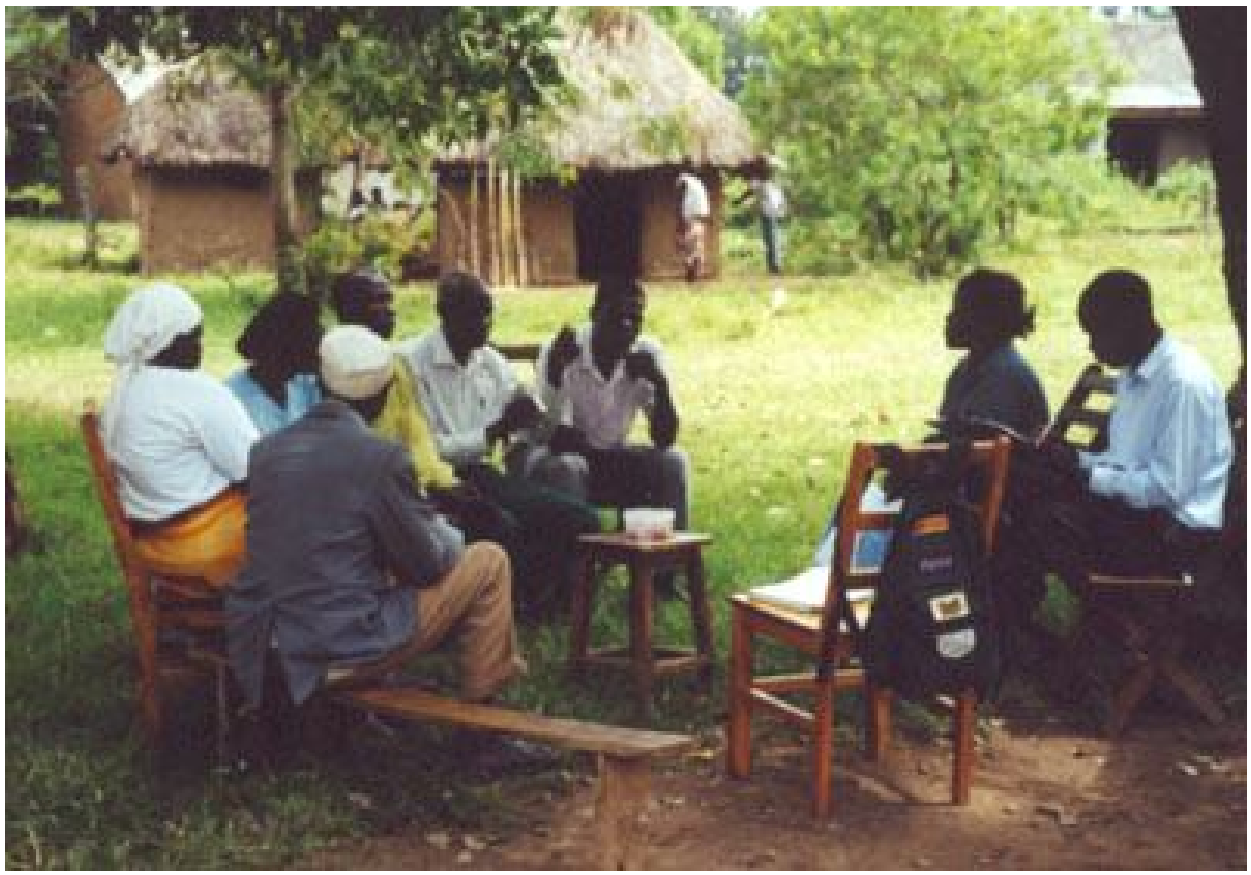

Sesja fokusowa w wiosce Sumba, Dystrykt Siaya, Kenia, w ramach projektu Program on Health and Society in Africa realizowanego przez Center for Health, Culture and Society Uniwersytetu Emory $w$ Atlancie; autor zdjęcia: Peter Oyloe;

Źródło: http://www.emory. edu/CHCS/p_africa_studentResearchReport.htm

Alternatywą dla tego rozwiązania są fokusy prowadzone w miejscach publicznych, takich jak szkoły, lokale gastronomiczne, kluby. Wydaje się, że jest to dobry kompromis, tym bardziej, że często jest to jedyne wyjście, ponieważ sieć profesjonalnych pracowni fokusowych obejmuje właściwie wyłącznie wielkie miasta, a przecież ogromną ilość sesji prowadzi się „w terenie”.

Oczywiście z perspektywy badacza i klienta takie badania są mniej wygodne (pomijając konieczność dojechania na miejsce), bowiem należy spo- 
dziewać się chociażby problemów z zainstalowaniem podglądu komputerowego, sprzętu nagrywającego, trzeba zabierać ze sobą rzutnik, ekran (jeśli są potrzebne) itd. Jednak wieloletnie doświadczenia w tym zakresie pozwalają sformułować spostrzeżenie, że taka organizacja badania fokusowego przysparza badanym najmniej stresu. Zwykle w przeszłości mieli okazję bywać w tej szkole, kawiarni; jest to wysoce prawdopodobne szczególnie w niewielkich miejscowościach. Zmiany polegające na zamontowaniu kamery i mikrofonu nie robią już takiej różnicy.

Zdjęcie 5. Sesja prowadzona poza pracownią fokusową

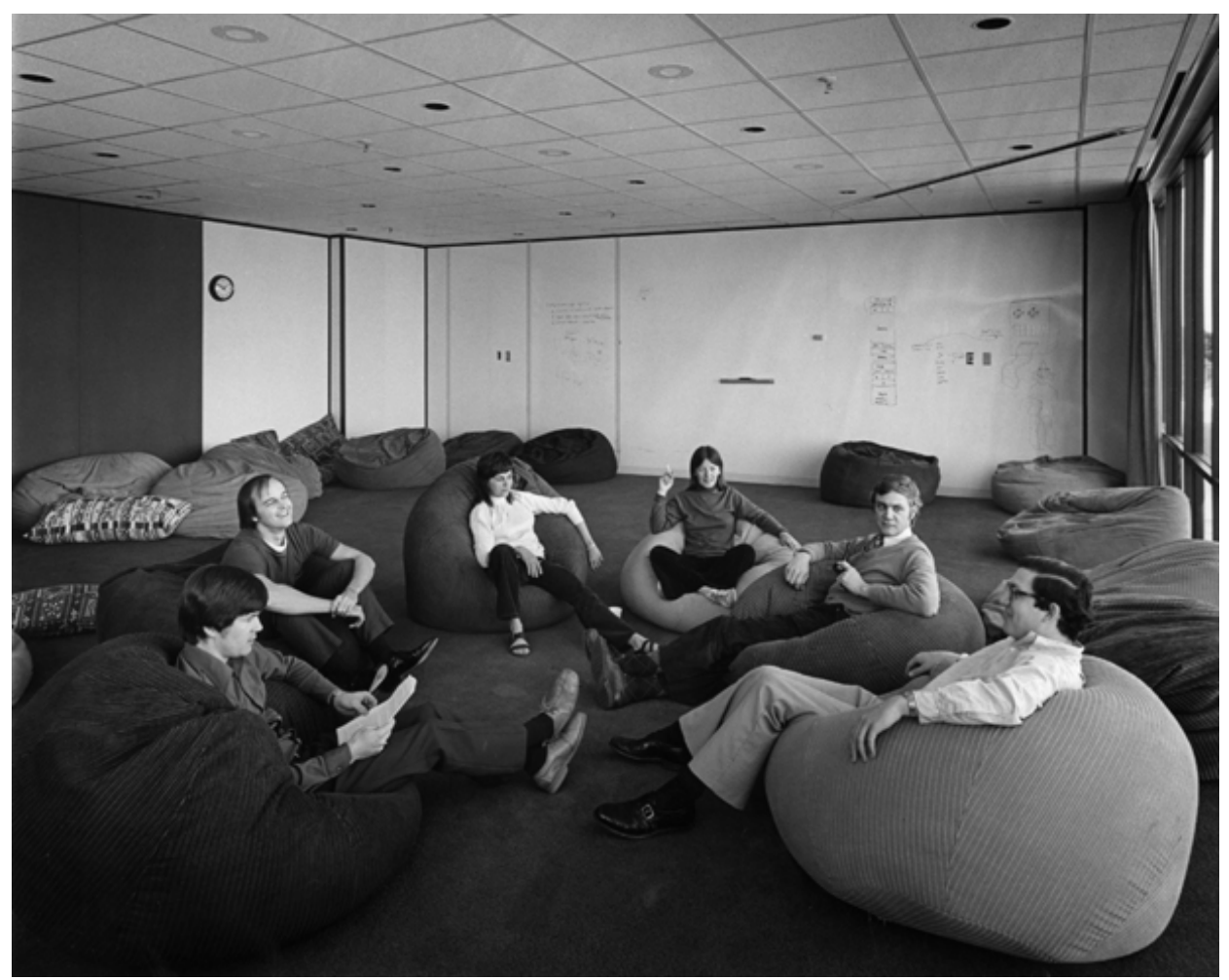

Zdjęcie zamieszczone dzięki uprzejmości Xerox PARC $w$ artykule Ravi Sawhneya Why Designers Need to Focus on Focus Groups z dnia 7 lipca 2009;

Źródło: www.fastcom pany.com/1305749/why-designers-need-focus-focus-groups 


\section{Rejestracja przebiegu sesji}

Wiadomo, że przebieg sesji jest rejestrowany przy pomocy kamery, a często także drugiego urządzenia, zapisującego jedynie dźwięk. Zarówno obraz, jak i nagranie dźwiękowe mogą posłużyć do identyfikacji badanego i do odkrycia jego tożsamości. Badacz poprzez swoich ankieterów rekrutujących do udziału w badaniu ma obowiązek poinformować potencjalnych uczestników o nagrywaniu badania. W praktyce nie zawsze tak się dzieje. Wielu ankieterówselekcjonerów w obawie przed odmową osoby spełniającej kryteria rekrutacyjne nie powiadamia ich o rejestracji. Badany dowiaduje się o tym dopiero na miejscu, od moderatora. Stawia to uczestnika w trudnej sytuacji - przełamał już wiele własnych barier, decydując się na udział w sesji, odczuwa ze strony moderatora oczekiwanie, iż pozostanie na badaniu, jednocześnie o nagraniu dowiaduje się w obecności kilku nieznanych sobie osób, które, być może w przeciwieństwie do niego, miały podane pełne informacje o przebiegu spotkania. Zatem także ich uwaga koncentruje się na reakcji tego uczestnika i w obawie, żeby nie pokazać się w negatywnym świetle, podejmuje on decyzję o własnym udziale na zmienionych zasadach w krótkim, pełnym napięcia czasie. Raczej nie można w tej sytuacji mówić o jego komforcie psychicznym i oczekiwać bezkonfliktowego wejścia w na nowo zdefiniowaną rolę. A co z tymi, którzy teoretycznie wiedzieli o fakcie nagrywania sesji? Moderatorzy wielokrotnie bywają świadkami napięć, jakie w uczestnikach wywołuje obecność kamery i mikrofonu. Przyjęcie do wiadomości informacji o nagrywaniu od ankietera-selekcjonera nie musi oznaczać świadomości okoliczności tej rejestracji. Ludzkie wyobrażenia o tym, jak to może wyglądać, są bardzo różne. W wywiadach prowadzonych z uczestnikami sesji po ich zakończeniu, często mówili, że spodziewali się, iż będzie to tak, jak na uroczystościach rodzinnych, to znaczy kamerzysta od czasu do czasu sfilmuje ich postać. Nie sądzili, że będą obserwowani przez kamerę przez cały czas.

A zatem zarówno w pierwszym, jak i w drugim przypadku nie została zrealizowana właściwie zasada przekazania badanym kompletnych informacji, które stanowiłyby przesłanki do podjęcia przez nich świadomej decyzji o uczestnictwie w badaniu. Ich zgoda na dobrowolne uczestnictwo została oparta na fałszywym obrazie przedsięwzięcia, w którym biorą udział. Każdy z potencjalnych uczestników przybywa na badanie z jakimś wyobrażeniem tego, co go czeka. Czasem jest ono bliższe, a czasem bardziej odległe od rzeczywistości. Ta druga sytuacja dowodzi zaniedbań lub uproszczeń $\mathrm{w}$ fazie rekrutacyjnej. 
Zdjęcie 6. Sesja fokusowa w warunkach naturalnych dla uczestników

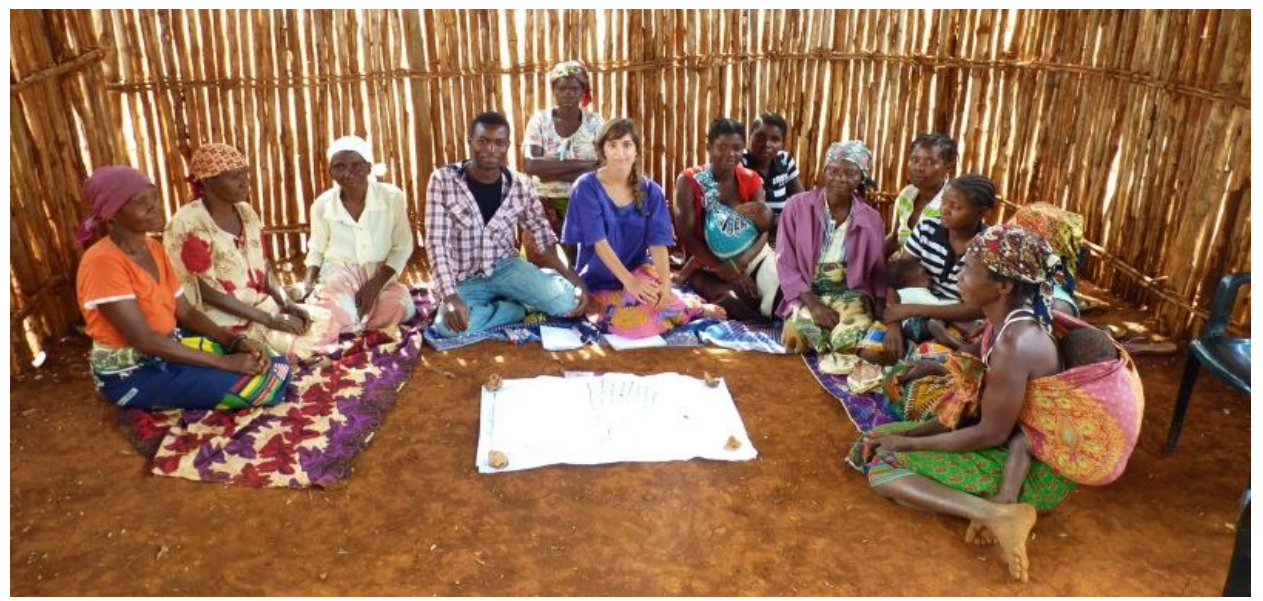

Yvane Marble prowadzi sesję fokusową z kobietami - hodowcami kóz na temat terenów wypasu. Autor: Yvane Marble (maj 2012);

Źródło: http://imgoats.files.word press.com/2012/07/women-focus-group.jpg

\section{Informacje przekazywane badanym w fazie rekrutacji a ich wyobrażenia o przebiegu sesji}

Z wywiadów po sesjach w przeprowadzonych w projekcie metodologicznym ${ }^{57}$ dotyczącym zogniskowanego wywiadu grupowego, gdzie szczególnie zadbano o przekazanie zapraszanym osobom kompletu informacji o przebiegu sesji, wynikało, że oczekiwania badanych na temat liczby uczestników oraz zasad prowadzenia spotkania były odmienne od treści przekazanych przez ankieterów-selekcjonerów. Jedna z osób myślała, że grupa będzie większa, więc zabierający głos będzie się musiał wcześniej zgłaszać lub będzie „typowany”, inna stwierdziła, że taka grupa powinna być większa, „żeby nadać echa spotkaniu”, bo z „gadania” ośmiu osób nic nie wynika. Ktoś wyobrażał sobie bardziej swobodną i chaotyczną dyskusję, w której uczestnicy będą pozostawieni sami sobie, „puszczeni na głęboką wodę” i był mile zaskoczony obecnością moderatora kontrolującego przebieg dyskusji. Jeden z uczestników był przekonany, że spotkanie będzie miało charakter wywiadu ankieter — respondent. Inny wyobrażał je sobie „bardziej jako wykład — ktoś będzie stał i mówił".

57 „Zogniskowany wywiad grupowy. Studia nad metodą”, kierownik: Jolanta Lisek-Michalska. 
Rozbieżności pomiędzy tym, co przekazywali ankieterzy w trakcie rekrutacji, a tym, jak te informacje zostały zrozumiane i przyjęte przez uczestników dotyczyły praktycznie każdego elementu spotkania.

Użytecznym sposobem na oswojenie osób badanych z nową dla nich sytuacją i zmniejszenie ich niepewności jest dokładne wyjaśnienie formuły spotkania na samym początku sesji. To bardzo pomaga uczestnikom uporządkować wyobrażenia o czekającym ich doświadczeniu. Moderator powinien szczegółowo przedstawić wszystkie istotne cechy spotkania - cel, organizację, zasady, czas trwania oraz upewnić się, że uczestnicy właściwie zrozumieli uzyskane informacje. Badani zwykle przestrzegają zasad, wprowadzonych przez moderatora i cenią je wysoko: „Na początku było ustalone coś takiego, żeby nie mówić wszyscy razem, bo tu chodziło właśnie (...) żeby tego bełkotu się nie zrozumie i raczej tak się wszyscy stosowali do tego, że jeżeli ktoś coś mówil, no to reszta milczała, słuchała”, „Każdy kto chciał powiedzieć, to mógł powiedzieć i ... tak sprawnie było to prowadzone wszystko. Nie zakrzyczeliśmy się nawzajem i nie było tak, że... to, co mi się bardzo podobało, co jest rzadkością w takich dyskusjach, że nikt nikomu nie mówił, że, że mówił bzdury, czy... na przykład, że nie ma racji, że on uważa to, że on uważa tamto, że jak gdyby każdy szanował, to mi się bardzo podobało. Każdy szanował stanowisko drugiej osoby". Zwracali uwagę, że chętnie i aktywnie uczestniczyli w dyskusji prowadzonej zgodnie z przyjętymi zasadami: „Rwali się wszyscy do dyskusji, ale jakoś... jakoś każdy mógł swobodnie się wypowiedzieć do końca”, „Nie było żadnego przerywania, ewentualnie dyskusja, ale w momencie, kiedy ja kończyłam, ktoś się włączał i wymiana jak gdyby poglądów"58.

Sposób rozlokowania uczestników sesji także często nie jest bez znaczenia dla ich samopoczucia. Można to zaobserwować w momencie, kiedy badani przekraczają próg pracowni fokusowej. Wielu z nich ma skłonność do poszukiwania miejsc „bezpiecznych”, zdarza się, że siadają na postawionych pod ścianą pustych krzesłach, a nie zajmują miejsc przy stole. Jeśli z rozłożenia przedmiotów lub pozycji prowadzącego jest możliwe do ustalenia, które miejsce należy do niego, krzesło tuż obok moderatora jest zajmowane zwykle jako ostatnie. Również nie cieszą się zainteresowaniem miejsca na wprost moderatora. W rozmowach prowadzonych z uczestnikami sesji po ich zakończeniu pojawiają się informacje świadczące o zakłopotaniu badanych, a nawet o chęci ucieczki z miejsca badania, która pojawia się w chwili wejścia do pracowni fokusowej. Obserwując ich sposób radzenia sobie z tym wyzwaniem (a także wypytując po badaniu), można wyrazić przypuszczenie, że zupełnie

\footnotetext{
58 Fragmenty wypowiedzi uzyskanych od uczestników badania fokusowego w wywiadach swobodnych przeprowadzonych po zakończeniu sesji. „Zogniskowany wywiad grupowy. Studia nad metodą", kierownik: Jolanta Lisek-Michalska.
} 
nie uaktywnia się w nich świadomość prawa do rezygnacji z udziału w badaniu. Niepełne zrozumienie całej sytuacji sprawia, że decydują się na postępowanie oparte na wewnętrznej dyrektywie, nakazującej zaprezentować się zgodnie $\mathrm{z}$ antycypowanymi przez nich regułami roli. W wywiadach swobodnych prowadzonych po zakończeniu fokusów, chociaż wszyscy twierdzili, że nie czuli się zmuszani do zabierania głosu, to pojawiły się uwagi, że sama zgoda na udział w badaniu obligowała do aktywnego uczestnictwa: „To znaczy ten przymus ja określam w ten sposób, że starałem się jednak coś wymyślić, nie, czyli coś do tego dołożyć. Nie na zasadzie jakiejś tam strachu, że muszę coś powiedzieć, czy ... czy jakieś tam napięcie, tylko, po prostu tylko to, że jednak, jeśli przyszedłem na to zebranie, czyli coś muszę dołożyć od siebie, nie. (...) że jednak do czegoś muszę być przydatny”, „Wiedziałem, że będę musiał zabrać głos, bo przecież to dotyczyło mnie, (...) innych, no i po to tu przyszedłem, żeby powiedzieć coś na ten temat". Zatem badani czują się zobligowani do kontynuowania przyjętej $w$ fazie rekrutacji roli, której specyfikę przewidzieli tylko w pewnym stopniu. Znowu można powtórzyć już wcześniej postawione tu pytanie: na ile jest świadoma ich zgoda na udział w badaniu? W jakim stopniu wiedzą, na co się decydują?

\section{Świadoma zgoda na udział w badaniu}

To jedna z fundamentalnych zasad badań społecznych. Jej geneza sięga procesu norymberskiego, gdzie przyjęto ją jako istotną regułę etyczną dla badań medycznych, która później została implementowana na grunt nauk społecznych.

W środowisku etyków, w tym głównie bioetyków, toczy się dyskusja na temat aspektów prawnych, psychologicznych, praktycznych uzyskiwania świadomej zgody59 (Manson, O'Neill, 2007). Badacze społeczni także aktywnie wniej uczestniczą. Ich poglądy na temat procedury uzyskiwania zarówno świadomej zgody od badanych, jak i sposobu uzyskiwania podpisu oraz wpływu tej czynności na jakość materiałów są bardzo zróżnicowane. Autorzy przeprowadzonego przeglądu literatury przedmiotowej w tym zakresie (Wiles, Heath, Crow, Charles, 2005) twierdzą, że procedura ta jest jeszcze daleka od doskonałości i postulują, by badacze przywiązywali wielką wagę zarówno do udzielanych potencjalnym badanym informacji, jak i do procesu uzyskiwania zgody, włączając $w$ to kwestię stylu, a także formę kwestionariusza ${ }^{60}$. Podkreślają również wyraźnie, że kon-

\footnotetext{
59 Procedurze uzyskiwania świadomej zgody od badanych poświęcono nawet specjalny projekt pt.: Informed Consent and the Research Process zrealizowany na Uniwersytecie w Southampton; http://www.sociology.soton.ac.uk/Proj/Informed_Consent/project.htm

${ }^{60} \mathrm{Nie}$ bez znaczenia jest także moment uzyskiwania zgody od badanych. Wskazuje się na przykład, że prośba o podpisanie formularza świadomej zgody przed badaniem, w fazie re-
} 
tekst zawodowy, w jakim funkcjonuje badacz oraz jego osobista orientacja etyczna wpływają na sposób, w jaki badacz podchodzi do kwestii świadomej zgody. Ich zdaniem decyzje dotyczące procedury uzyskiwania świadomej zgody mają swoje podstawy w strukturach prawnych, etycznych i ustawowych, w jakich funkcjonują badania społeczne oraz - w równym stopniu w skomplikowanym oddziaływaniu wciąż rosnących wpływów politycznych, prawnych, moralnych i instytucjonalnych.

Większość badaczy społecznych podziela przekonanie, że kwestia uzyskania świadomej zgody od badanych ma charakter kluczowy dla etyki badawczej. Niemniej jednak zagadnienie to wywołuje liczne spory i wątpliwości związane przede wszystkim z istotą procedury. Liczni autorzy podkreślają, że uzyskanie podpisu badanego na dokumencie zgody jest jedynie materialnym dowodem pewnych procesów psychicznych, jakie w nim zaszły, ale niczego o tych procesach nie mówi. A przecież może się zdarzyć, że zgodę wyraziła osoba z silnym poczuciem lęku, brakiem umiejętności odmawiania, zerową asertywnością, skłonna do ulegania antycypowanej presji społecznej. W badaniach społecznych nie praktykuje się kontrolowania uczestników pod kątem posiadania przez nich właściwych zdolności rozumowania, czyli nie ustala się na przykład poziomu ich intelektualnej czy psychicznej dojrzałości lub innych okoliczności uniemożliwiających adekwatne podjecie decyzji (na przykład pozostawanie pod wpływem leku lub substancji o działaniu psychotropowym), co stanowi konieczny element analogicznych procedur sądowych i przyjmuje się, że uczestnik właściwie zrozumiał wszelkie istotne warunki. Założenie to niestety nie daje badaczowi żadnej gwarancji, że rzeczywiście tak jest. Na szczęście jednak poziom ryzyka w badaniach społecznych jest nieporównanie mniejszy niż ten, który w przypadku wystąpienia wadliwego (merytorycznie lub psychicznie) rozumienia warunków świadomej zgody może mieć miejsce w medycynie61, czy procedurach sądowych. (Warto dodać, że w obu wymienionych tu dziedzinach uzyskiwanie świadomej zgody podmiotu często ma charakter procesualny, odbywa się etapami wraz z rozwojem sytuacji, natomiast w przypadku badania społecznego jest to decyzja jednorazowa, obejmująca wszelkie konsekwencje udziału w przedsięwzięciu badawczym).

Wśród badaczy brak także porozumienia co do tego, czy takie same zasady i treści procedury świadomej zgody powinny być stosowane w odniesieniu do różnych badanych środowisk i różnych ram metodologicznych

\footnotetext{
krutacji, wywołuje niepokój potencjalnych uczestników i w związku z tym sugeruje się, aby o pisemne potwierdzenie gotowości do uczestnictwa zwracać się dopiero w trakcie samego badania, w jego fazie początkowej. (Singer, 1978)

61 Przykładem może być chociażby wyrażenie świadomej zgody na aborcję lub eutanazję.
} 
badania. Mimo że uzyskiwanie świadomej zgody generalnie wywołuje wiele pytań, to szczególnego (drażliwego) charakteru nabierają one w tych badaniach społecznych, w których podejmuje się na przykład problematykę relacji uczestników z matką we wczesnym dzieciństwie, procesu starzenia się, problemów zdrowotnych i wielu innych.

Brak także wśród badaczy zgodności w ustalaniu, jak daleko sięgają granice świadomej zgody. Interesujących przykładów dostarcza artykuł Wiles i in. (2005), w którym autorzy przedstawiają następujące przypadki:

1. Badacz zrealizował badanie na grupie starszych osób na temat ich doświadczeń w zakresie opieki zdrowotnej. W tym celu przeprowadził 10 sesji fokusowych w domach opieki. Jako element procedury świadomej zgody wysłał do wszystkich uczestników kopie transkrypcji i poprosił ich, żeby poinformowali go w przypadku, gdy zechcą usunąć z tych zapisów jakieś fragmenty swoich wypowiedzi. Opracował swój raport i pół roku po zakończeniu badania uzyskał od jednej z uczestniczek informację, iż nie życzy ona sobie dalej uczestniczyć w tym przedsięwzięciu i domaga się usunięcia treści swoich wypowiedzi $\mathrm{z}$ transkrypcji i opracowania. Pojawia się zatem pytanie - czy prawo do wycofania się $\mathrm{z}$ badania powinno mieć jakieś ograniczenia czasowe?

2. Badacz w ramach swojego projektu prosił uczestników, by sfotografowali obiekty poza ich własnymi domami, które uważają za ważne dla siebie. Na tych zdjęciach, robionych przez uczestników badania w miejscach publicznych, widoczni są różni ludzie w różnych okolicznościach: w klubach, pubach, sklepach. Czy można wykorzystać ten materiał do analizy, skoro nie uzyskano zgody uwiecznionych na fotografiach ludzi? Jak daleko musi posunąć się badacz w uzyskiwaniu zgody?

3. Badacz analizował doświadczenia młodych ludzi, których rodzice umarli na chorobę nowotworową. Uczestnicy badania byli rekrutowani przez hospicjum. Jako element procedury świadomej zgody gwarantowano uczestnikom i hospicjom anonimowość poprzez użycie w materiałach badawczych jedynie pseudonimów. Jednak kilkoro z badanych wyraziło silny sprzeciw wobec tej propozycji. Domagali się możliwości używania nazw własnych swoich i rodziców i innych informacji ułatwiających identyfikację, traktując to jako dbałość o pamięć rodziców. Jednak to oznaczało, że rozpoznawalne będzie także każde konkretne hospicjum. Interesy obu podmiotów (dzieci i hospicjów) okazały się sprzeczne na etapie procedury świadomej zgody.

Mimo że świadoma zgoda nie ma jednoznacznego statusu, jednak procedura jej uzyskania jest stosowana w znakomitej większości badań społecznych. Formularz świadomej zgody spełnia bowiem kilka funkcji - przede wszystkim wyraźnie i jednoznacznie informuje potencjalnych uczestników o przysługujących im prawach, wyjaśnia przebieg i możliwe konsekwencje 
badania. Jest to rodzaj zobowiązania badacza wobec badanego, gwarantujący temu ostatniemu na piśmie określony zestaw uprawnień. Z drugiej strony stanowi zabezpieczenie dla badacza w przypadku wystąpienia problemów $\mathrm{z}$ etyczną oceną całego przedsięwzięcia ${ }^{62}$. W wielu krajach stanowi podstawowy dokument dla komisji etycznych nadzorujących badanie. Dlatego także w interesie badacza jest, aby formularz zawierał wszelkie ważne informacje.

Generalnie przyjmuje się, że w procesie uzyskiwania świadomej zgody istotne są trzy elementy. Po pierwsze, badacz jest zobowiązany do ujawnienia wszelkich informacji o badaniu ${ }^{63}$, które mają znaczenie z perspektywy uczestnika dla podjęcia przez niego decyzji. Informacje te muszą być sformułowane językowo w sposób dostosowany do uczestników. Po drugie, badacz powinien starać upewnić się, że zostały one zrozumiane zgodnie z jego intencją i zgoda jest udzielana w oparciu o rzeczywistą świadomość konsekwencji. Po trzecie wreszcie, zasadniczą cechą tej procedury jest całkowita dobrowolność oznaczająca prawo badanego do odmowy, a także unikanie jakichkolwiek metod wywierania presji czy manipulacji64.

W przypadku niektórych badań potencjalne ryzyko narażenia badanego na negatywne konsekwencje uważa się za tak marginalne, że badacze odstępują od komplikowania przebiegu sesji procedurą uzyskiwania świadomej zgody. Dzieje się tak często na przykład w badaniach marketingowych (List, 2008), w których korzyści z uzyskania świadomej zgody są znikome, a koszty mogą być znaczące.

Wszystkie powyżej sformułowane wątpliwości dotyczą także badań fokusowych. Dodatkowo pojawia się bardzo istotny aspekt współuczestnictwa w badaniu kilku, kilkunastu osób jednocześnie, który musi zostać uwzględniony w treści świadomej zgody. Dlatego w treści formularza badacze zwykle uprzedzają uczestnika, że jego tożsamość nie będzie dla pozostałych badanych zagadką i że organizatorzy nie mogą zagwarantować, iż wszystkie obecne na sesji osoby będą przestrzegały zasady poufności. Jednocześnie zobowiązują każdego badanego indywidualnie do nieujawniania poufnych informacji z przebiegu sesji osobom postronnym. W przypadku braku zgody uczestnika na tak sformułowany zapis, należy poinformować go, że nie będzie mógł wziąć udziału w sesji. Do tak rozumianych informacji

\footnotetext{
62 W niektórych praktycznych przewodnikach badań fokusowych zaleca się, aby bezwzględnie rejestrować procedurę podpisywania przez uczestników formularzy na nagraniu audiowizualnym. 63 Wbrew pozorom ta kwestia także może budzić wątpliwości. (Fins, del Pozo, 2011)

640 problemach i ograniczeniach występujących w praktykowaniu uzyskiwania świadomej zgody od pacjentów medycznych związanych z nieujawnianiem przez badacza wszystkich istotnych informacji, $\mathrm{z}$ nieadekwatnym rozumieniem ustaleń zgody oraz z manipulowaniem informacją pisze np. Nancy M. Kettle (2002).
} 
poufnych zazwyczaj zalicza się wiedzę lub materiały, w których posiadanie może wejść uczestnik sesji fokusowej, czyli wszelkie:

- informacje na temat każdego uczestnika grupy fokusowej, który nie jest osobą publiczną lub powszechnie znaną w danym środowisku,

- dane osobowe lub inne informacje, które mogą doprowadzić do identyfikacji uczestników,

- informacje dotyczące technik, pomysłów, procesów, tajemnic handlowych, innowacji, strategii i prognoz ujawnione badanym.

Dane, które są powszechnie znane, nie są traktowane jako poufne.

W tradycji amerykańskiej procedura podpisywania przez uczestników zapraszanych do udziału w fokusie formularzy-oświadczeń świadomej zgody (Singer, 1978, s. 144-162) praktykowana jest już od kilkudziesięciu lat. Dalej przedstawiono przykładowy dokument Oświadczenia świadomej zgody, zamieszczony w The focus group guidebook (Morgan, 1997a).

Mimo wskazanych wyżej wątpliwości, wobec braku alternatywnych rozwiązań należy przyjąć, że oświadczenie o świadomej zgodzie na udział w badaniu, którego kopia powinna pozostać do dyspozycji badanego, zwiększa prawdopodobieństwo uzmysłowienia sobie przez uczestników przysługujących im praw i specyfiki przedsięwzięcia, na które się decydują. Ważne jest jednak, aby badacze w pełni zdawali sobie sprawę z faktu, iż „świadoma zgoda” w jednakowym stopniu dotyczy świadomego wyboru i świadomie podejmowanej decyzji, jak i świadomej odmowy na udział w badaniu. 


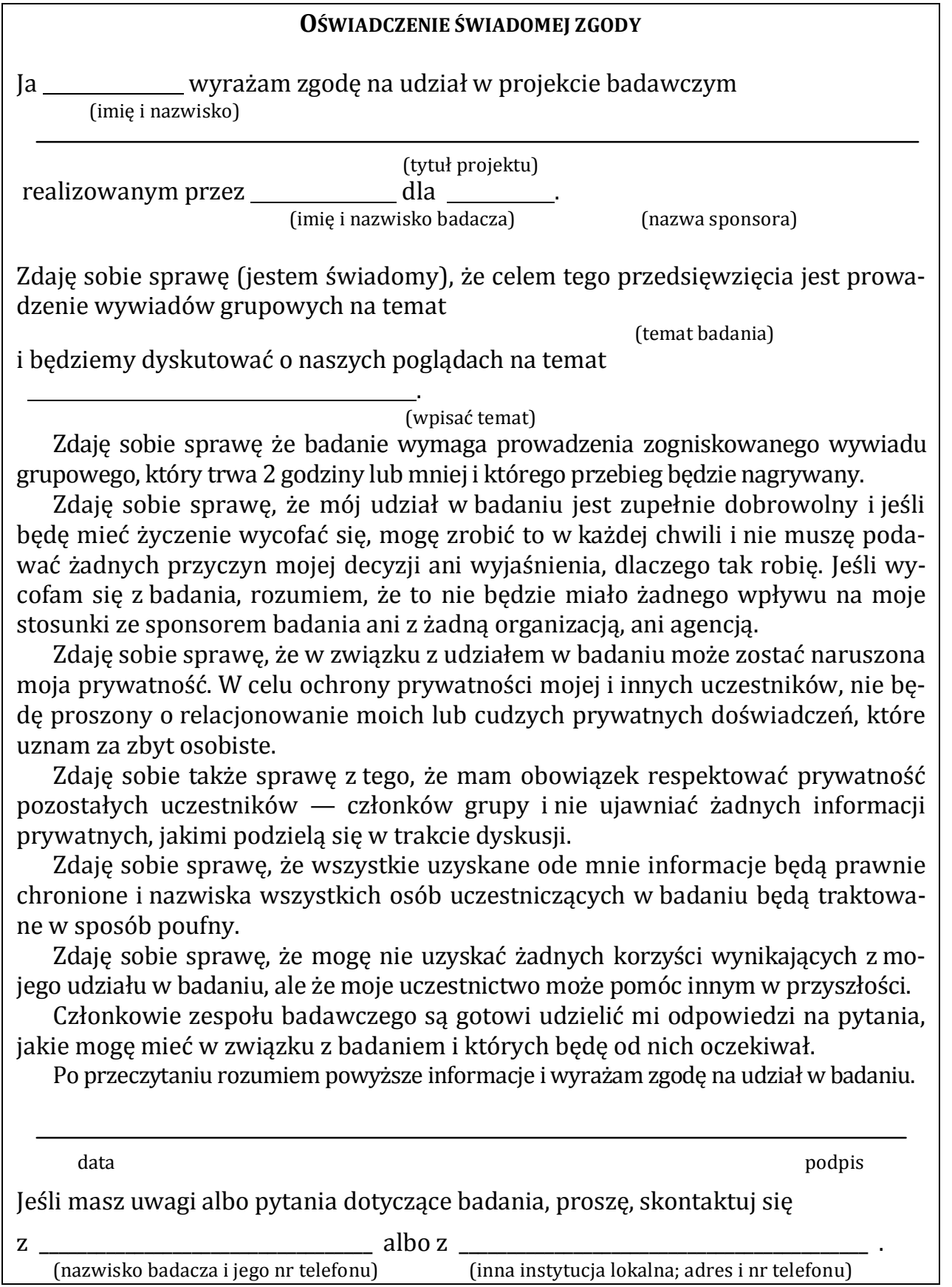




\section{Rejestracja i podgląd przebiegu sesji}

Kolejny element procedury, który warto omówić w kontekście problemów etycznych badań fokusowych, to rejestracja przebiegu sesji. Wiążą się z nią przynajmniej dwie istotne kwestie: po pierwsze, jest to kolejny element stresogenny dla wielu uczestników, a po drugie, utrwalenie sesji na nośnikach cyfrowych umożliwia identyfikację osób badanych. Najpierw omówiona zostanie ta druga kwestia.

$\mathrm{O}$ ile $\mathrm{w}$ formularzu świadomej zgody badany akceptuje narzucone przez badacza warunki udziału w projekcie, o tyle badacz także przyjmuje na siebie liczne zobowiązania. $W$ tym kontekście na uwagę zasługuje przede wszystkim jego zobligowanie do przestrzegania wszelkich przepisów prawa regulujących kwestie poufności i prywatności uczestników, obejmujące konieczność zadbania o to, by materiały: notatki, dokumenty, zapisy, nagrania, zawierające jakiekolwiek informacje poufne nie dostały się w niepowołane ręce. Prawo do nich ma jedynie badacz, a w odniesieniu do niektórych materiałów - zleceniodawca badania. Z tego punktu widzenia materiałem bardzo szczególnym jest zapis przebiegu sesji.

Zdjęcie 7. Podglądownia w pracowni fokusowej w Kielcach

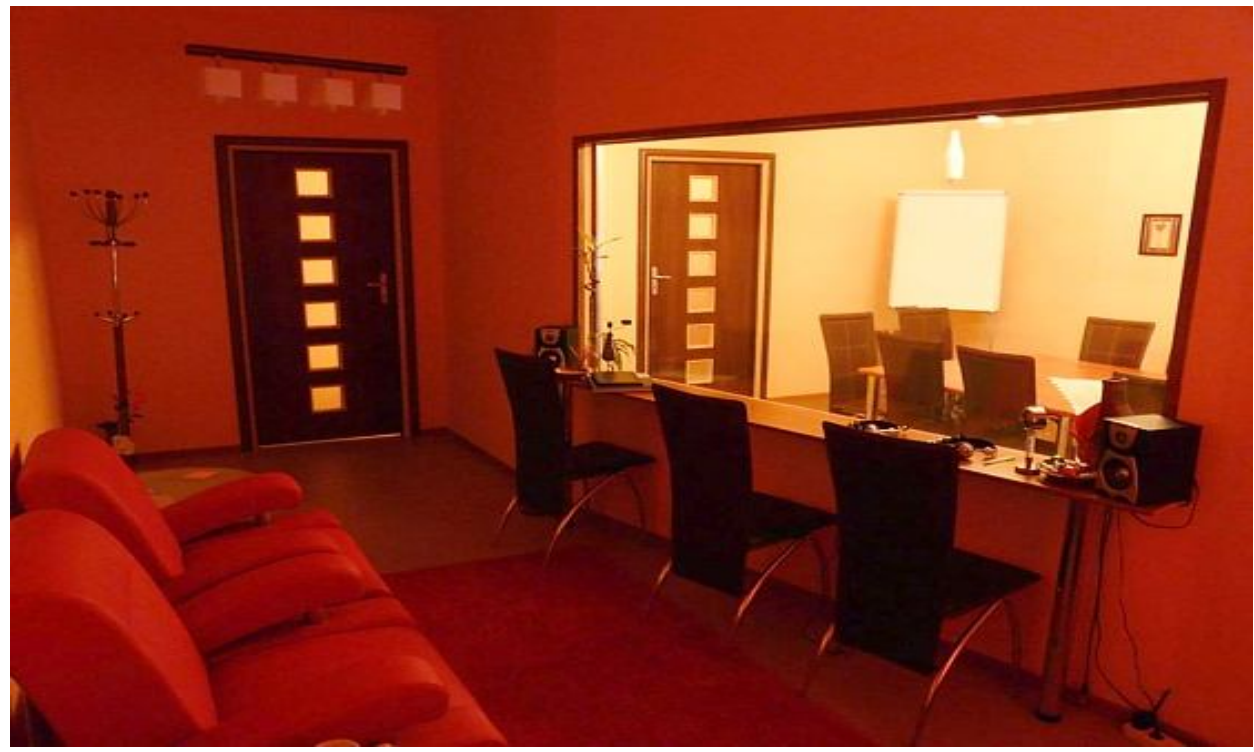

Źródło: http://www.kielce.fokusstudio.exe.pl/ na dzień 22.02 .13

Nagranie jest przekazywane zazwyczaj do transkrypcji i wobec tego badacz bierze na siebie odpowiedzialność za postępowanie osoby, która tego przepisania dokonuje. Musi mieć gwarancje, że plik nie zostanie skopiowany 
ani w żaden sposób w całości lub we fragmentach udostępniony osobom postronnym. Dlatego tak istotne jest, aby badacz mógł w pełni zaufać swoim współpracownikom, tak, jak od uczestników oczekuje, że zaufają jego deklaracjom w kwestii poszanowania ich prawa do zachowania poufności. Trudno nie dostrzec, że przesłanki, jakie pozwalają badaczowi na powierzenie członkom zespołu badawczego materiałów z sesji mają znacznie silniejsze podstawy, niż te, którymi mogą posłużyć się badani. Badacz zazwyczaj zna osoby, którym zleca transkrypcję, sporządził z nimi umowę obligującą ich do określonego postępowania. Uczestnikom badań pozostaje zawierzyć badaczowi (moderatorowi) „na słowo”.

Zdjęcie 8. Obserwacja sesji fokusowej zza lustra weneckiego

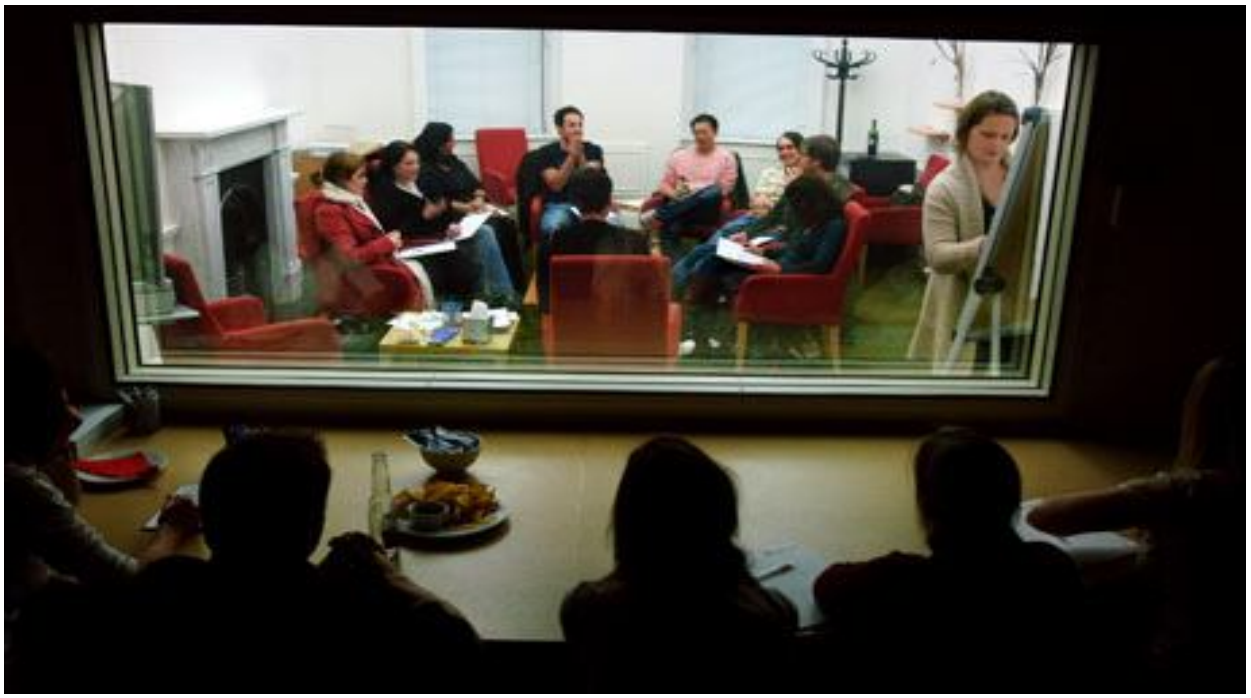

Źródło:http://static.guim.co.uk/sysimages/Guardian/Pix/pictures/2011/1/1/ 129856665814/Focus-Group-003.jpg

Obecność kamery nie jest naturalnym elementem codziennego życia osób badanych, jest czymś zazwyczaj nowym, szczególnie w połączeniu z całą sytuacją badania. Mimo powszechności stosowania w życiu publicznym rozmaitych sposobów rejestracji danych (chociażby kamery drogowe, kamery w sklepach itd.), udział w intencjonalnie nagrywanej sesji jest dla wielu ludzi zupełnie szczególnym przeżyciem. Już wiele lat temu Stanisław Ossowski (1962) pisał: „(...) jednostki tworzące jakąś społeczność mniej lub bardziej zdają sobie sprawę z tego, że są lub mogą być poznawane. Badacz nie powinien więc pozostawać obojętny na to, jaką postawę wobec poznawania siebie zajmą członkowie społeczności. Kiedy mówi się, że badana 
rzeczywistość społeczna może zostać przekształcona przez proces badawczy i to tak daleko, iż uniemożliwia osiągnięcie miarodajnych wyników, to często dzieje się tak za sprawą świadomości bycia badanym i nastawień z tym związanych". W przypadku fokusa ta uwaga nabiera szczególnego znaczenia - uczestnicy sesji nie tylko nie mają wątpliwości, że biorą udział w badaniu, ale ponadto wiedzą, że zostanie to utrwalone.

Nadal na sesjach padają pytania świadczące o braku zrozumienia powodów rejestracji, na przykład: kiedy to będzie emitowane w telewizji? Innym przejawem traktowania rejestracji badania w sposób wyjątkowy jest, szczególnie w małych miejscowościach, przejawiana przez uczestników dbałość o wygląd zewnętrzny („no, bo jak mam być na nagraniu, to trzeba jakoś wyglądać, prawda?"). W zasadzie cały ciężar zlikwidowania lub zmniejszenia tego stresu spoczywa na osobie moderatora. Od niego zależy, czy potrafi na tyle oswoić uczestników z obecnością urządzeń (kamery i mikrofonu), że przestanie to być dla nich czynnik regulujący ich zachowanie, treść i formę wypowiedzi.

Sesje fokusowe nie tylko są rejestrowane na rozmaitych nośnikach, ale także bardzo często obserwowane przez przedstawicieli zleceniodawcy i reprezentantów ośrodka badawczego w tak zwanej podglądowni, zza weneckiego lustra.

Nawet jeśli sesja odbywa się w prowizorycznie zaaranżowanym dla tego celu innym pomieszczeniu, to i tak istnieje prosty technicznie sposób na przesłanie obrazu na monitor ulokowany w innym pomieszczeniu. Zdarzają się sesje, w których liczba uczestników jest mniejsza, niż liczba osób „na podglądzie". Często, szczególnie w badaniach marketingowych, podglądownia jest także miejscem pracy tłumaczy symultanicznych. I o ile w praktyce przestrzega się zasady informowania badanych o fakcie rejestrowania przebiegu sesji, o tyle o obecności „podglądaczy” raczej się nie mówi.

A zdaniem wielu badaczy taka praktyka jest niedopuszczalna, bowiem ludzie będący obiektem badań społecznych powinni posiadać kompletną i prawdziwą wiedzę na temat przedsięwzięcia, w jakim uczestniczą, oraz dobrowolnie wyrazić na nie zgodę. Część autorów stoi na stanowisku, że badań prowadzonych w sposób ukryty nie sposób usprawiedliwić w żadnym albo prawie żadnym przypadku. Podłożem takich zarzutów jest przekonanie, że tego rodzaju badania gwałcą prawo człowieka do prywatności i godności. Jak piszą Hammersley i Atkinson (Warwick, 1982), pojawiają się opinie, iż badania społeczne prowadzone z użyciem podstępu i manipulacji, sprzyjają powstawaniu społeczeństwa cyników, kłamców i oszustów oraz podkopują zaufanie, które stanowi podstawę sprawiedliwego ładu społecznego (Miszewski, 2007). 
Także kodeksy etyczne dość jednoznacznie regulują tę kwestię, przyznając badanym prawo do informacji o tym, że ich zachowanie będzie obserwowane i rejestrowane, z wyjątkiem obserwacji w miejscach publicznych. W sytuacjach eksperymentalnych, na przykład w badaniach wykorzystujących techniki symulowanej sprzedaży zaleca się, aby po zakończeniu aktu obserwacji wyjaśnić badanemu specyfikę zdarzenia, w jakim uczestniczył.

To, czym się zajmują się osoby zgromadzone w podglądowni to przecież nic innego, jak klasyczna obserwacja niejawna. Niejawność obserwacji (bez względu na jej rodzaj) polegać może albo na ukryciu faktu badania, albo jego prawdziwego celu (Frankfort-Nachmias, 2001). W przypadku fokusa mogą wystąpić obie te sytuacje, jednak teraz zajmijmy się tylko pierwszą z nich.

Według Michaela Pattona (1997) „Zdania na temat etycznych i moralnych stron obserwacji niejawnej (w tym uczestniczącej) są mocno podzielone." Na jednym krańcu kontinuum znajduje się Edward Shils, negujący całkowicie wszelkie formy obserwacji ukrytej. Shils sprzeciwia się jakiejkolwiek technicznie wykonalnej obserwacji zachowań prywatnych bez wiedzy i wyraźnej zgody osób obserwowanych. Jest zdania, że cel badań nigdy nie powinien być tajemnicą, a więc technika obserwacji uczestniczącej jest „moralnie naganną manipulacją", jeśli obserwator zaraz na wstępie nie wyłoży uczestnikom badań swoich pytań badawczych (Miszewski, 2007).

Przeciwne stanowisko reprezentuje Jack Douglas (1976). Proponuje on podejście nazwane „śledztwem społecznym” (investigative social research). Dowodzi, że tradycyjne metody antropologicznych badań terenowych opierają się na jednomyślnym założeniu, że ludzie są z gruntu gotowi do współpracy i niesienia pomocy, że pragną, by ich punkt widzenia był rozumiany i podzielany przez innych. W przeciwieństwie do tego modelu opartego na konsensusie społecznym, Douglas proponuje paradygmat wychodzący od konfliktu społecznego. Paradygmat śledczy Douglasa opiera się na przesłance, że życie społeczne przenika głęboki konflikt interesów, wartości, uczuć i działań. „Trzeba przyjąć jako coś oczywistego, że wiele osób - być może w mniejszym lub większym stopniu wszyscy - ma coś do ukrycia, a nawet oszukuje innych. Zamiast wierzyć każdemu i oczekiwać, że on nam uwierzy, jesteśmy podejrzliwi wobec innych ludzi, tak jak oni mogą być podejrzliwi wobec nas. Konflikt jest rzeczywistością naszego życia, podejrzliwość zaś jego wiodącą zasadą. (...) Jest to wojna wszystkich przeciwko wszystkim i nikt nie daje nikomu niczego za darmo, a przede wszystkim prawdy." (Miszewski, 2007). Paradygmat ten pozwala Douglasowi wierzyć, że wszystkie niejawne metody badawcze, które zbliżają badacza do prawdy, powinny być uznane i zaakceptowane jako dopuszczalne (Miszewski, 2007).

W przypadku badań społecznych, w tym także oczywiście tych prowadzonych przy pomocy zogniskowanego wywiadu grupowego, badacz musi 
rozstrzygnąć, czy etycznie właściwe pełne ujawnienie wszystkich własnych działań (zarówno ich słuszności, jak i celu całego przedsięwzięcia) nie zmniejszy wartości gromadzonych danych. Wprowadzanie badanych w błąd jest niezgodne ze standardami etycznymi. Ale rygorystyczne zachowanie standardów w badaniach społecznych może prowadzić do gromadzenia nieużytecznych materiałów, które nie znajdą zastosowania dla formułowania diagnoz czy prognoz. Zatem w obawie przed uzyskaniem mało wartościowych danych, badacz poddaje badanego pewnym manipulacjom i oszustwom. Proporcje takich zabiegów zwykle zależą od samego badacza. W badaniach fokusowych badacz ma szczególnie dogodne warunki do choćby częściowego rozwiązania tej kwestii, ponieważ może bezpośrednio po zakończeniu właściwej sesji przeprowadzić debriefing i wyjaśnić zarówno przyczyny, jak i sposoby wprowadzenia badanych w błąd 65 .

\section{Obecność innych uczestników badania}

Bardzo wiele napisano o trudnościach, z jakimi musi się zmierzyć respondent w wywiadzie prowadzonym przez ankietera (Rostocki, 1992). Analizowano różne aspekty tej sytuacji, wskazując między innymi na znaczenie antycypowanej przez badanego oceny jego osoby przez prowadzącego wywiad. W kontekście badania grupowego, ten argument ulega znacznemu wzmocnieniu. Badani kontrolują nie tylko to, jak odbiera ich moderator, ale także śledzą uważnie reakcje pozostałych uczestników na siebie. Sytuacja komplikuje się jeszcze bardziej, jeśli w grupie wyłania się lider (Bales, 1970) lub jeśli grupa dzieli się na frakcje. Stosunek ujawniany przez lidera wobec innego dyskutanta może być podzielany przez pozostałych uczestników dyskusji, gdyż występują oni w roli obserwatora interakcji rozgrywających się między nimi, a także lider reprezentujący najwyższy status socjometryczny może wywierać największy wpływ na to, jak poszczególni dysku-

65 Zgodnie z Ethical principles in the conduct of research with human participants dopuszcza się okłamywanie badanych jedynie w następujących sytuacjach: 1. Badacz uważa, że problem, którym się zajmuje jest bardzo ważny. 2. Można udowodnić, że bez zastosowania instrukcji maskującej nie będzie możliwe przeprowadzenie badania. 3. Można przyjąć, że jeśli osoba badana zostanie poinformowana o celu badania po przeprowadzeniu eksperymentu to nie wpłynie na jej opinię na temat prawości, rzetelności i wiarygodności badacza. 4. Osoba badana ma stworzoną przez badacza możliwość wycofania się wdowolnym, przez nią wybranym momencie $\mathrm{z}$ dalszego udziału w badaniu, albo możliwość anulowania wyników badania po uzyskaniu od badacza pełnej, prawdziwej informacji całym badaniu. 5. Badacz ponosi pełną odpowiedzialność za wywołane, stresujące efekty eksperymentu u badanych i ich neutralizację. Jednak także w odniesieniu do procedury ujawniania/odsłaniania prawdziwych informacji o badaniu, opinie różnych badaczy są podzielone. Pojawiają się wśród nich i takie, które wskazują na większe skutki negatywne tego odkrycia badacza przed badanym, niż gdyby uczestnik nie został o niczym po fakcie poinformowany. 
tanci są percypowani przez grupę. Nie można bowiem wykluczyć sytuacji, że wyobrażenia i odczucia wygenerowane na polu interakcji lider - dyskutant staną się również wyobrażeniami obserwatorów tej interakcji. Lider może zatem wywierać przemoc symboliczną — jego odczucia wobec poszczególnych dyskutantów, komunikowane werbalnie lub niewerbalnie mogą zostać odczytane, przejęte przez innych badanych, a czynnikiem facylitującym jest atrakcyjność interpersonalna lidera. Z kolei, jeśli grupa jest podzielona na frakcje, istnieje ryzyko wzbudzenia w polu świadomości jednostki stanu dysonansu skutkującego poczuciem dezorientacji, napięciem frustracyjnym, nasileniem lęku lub dyskomfortu psychicznego. Źródłem owego dysonansu może być ścieranie się w polu świadomościowym dwóch sprzecznych struktur poznawczych - pozytywnych wyobrażeń o Ja antycypowanych z reakcji członków własnej grupy, oraz tych negatywnych odczytywanych z reakcji członków grupy obcej.

Badany w miarę możliwości stara się kontrolować rozwój sytuacji i dostosowywać swoje zachowanie do własnego o niej wyobrażenia. Jeśli dodać do tego konieczność śledzenia merytorycznych wątków dyskusji i oczekiwanie, że on także weźmie w niej udział, można sobie zdać sprawę z trudności zadania, przed jakim staje uczestnik sesji fokusowej. Dla wielu ludzi jest to wielki wysiłek i wyzwanie, niewspółmierne do tego, z jakim są zmuszeni poradzić sobie $\mathrm{w}$ wywiadzie prowadzonym twarzą $\mathrm{w}$ twarz.

$\mathrm{Z}$ drugiej strony nie można zapominać o korzyściach, jakie w tym samym wymiarze psychologicznym dostarcza uczestnikom badanie w grupie. Chodzi tu przede wszystkim o rozproszenie odpowiedzialności i możliwość „schowania się za innymi”, przeniesienie na pozostałych uczestników trudu odpowiadania na pytania moderatora i zyski wynikające z pozytywnych efektów grupowych:

„Bardzo była sympatyczna rozmowa, wszyscy zachowywali się bardzo luźno, swobodnie wydaje mi się, że każdy z uczestników wypowiadał się naprawdę sensownie. Nie było żadnego kręcenia, żadnego wymyślania. Każdy mówił w pełni swobodnie, trochę żeśmy się pośmiali. Było naprawdę miło." „W sumie osiem osób, z którymi widziałem się po raz pierwszy, ale ja przynajmniej tak odczułem, być może to moja subiektywna ocena, że nie było kamuflaży, każdy się naturalnie zachowywał."

„Otwartość i właściwie brak zahamowań ludzi. Zupełnie bez skrępowania wyrażali swoje poglądy. Bardzo sympatycznie.”,Dobra jest taka forma właściwie spotkania się osób po raz pierwszy w życiu, mogące się może nie 


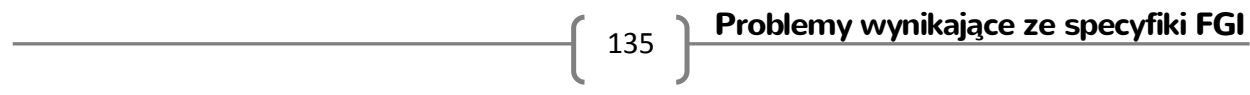

spotkać już i akurat myślę, że chyba każdy z nas podchodził do tego... w sposób taki prawdziwy, uczciwy. $66^{\prime \prime}$

Duża część badanych respondentów wyraziła w wywiadach swobodnych zadowolenie z obecności pozostałych osób, choć wielu z nich nie potrafiło wytłumaczyć, w jaki sposób im to pomagało. Wśród podanych uzasadnień pojawiły się opinie, że w grupie badany czuje się pewnie i wypowiada się bardziej otwarcie i szczerze, że lubi współpracować z ludźmi lub, i to była najczęstsza uwaga, że w toku dyskusji łatwiej jest sobie pewne rzeczy przypomnieć, skojarzyć:

„Raczej pomagało, bo każda osoba wtedy mówi i ja sobie mogę wysłuchać i też mogę coś powiedzieć, ale w którejś tam części, a jak jestem ja sama z osobą prowadzącą, to ja muszę mówić albo osoba mnie pyta a ja odpowiadam, to, to jest tak jak wywiad, a to już jest coś zupełnie innego. W grupie czuję się bardziej pewnie."

„No na pewno w trakcie dyskusji coś tam wychodzi, prawda, człowiekowi coś się przypomina i wtedy ma szansę jeszcze się wykazać, może coś jeszcze dopowiedzieć."

„(Obecność innych) pomagała raczej, bo, jak mówię, prawdopodobnie nie powiedziałabym aż tyle $w$ indywidualnej rozmowie".

Uczestnicy zwracali uwagę, że pracując w grupie czuli się raźniej, pewniej, bardziej otwarcie i odważnie zabierali głos:

„W grupie jest człowiek chyba bardziej anonimowy, więc szybciej się uzewnętrznia, szybciej jest w stanie, łatwiej jest w stanie swoje sądy wypowiedzieć."

Część respondentów stwierdziła, że dzięki pracy w grupie efekt był dużo lepszy - cechowało go większe bogactwo i różnorodność określeń, wynikających z różnych doświadczeń poszczególnych osób:

"Co dwie głowy, to nie jedna."

„Jest taka chwila, że... że robi się pustka, a tak, to każdemu coś tam się nasunie i z tego się tworzy obraz."

„Nie no podpowiadamy sobie nawzajem i wtedy jest prościej dojść do jakiegoś tam słowa, które no pomoże przy tym wszystkim. Każdy ma tam jakiś pomysł i można to potem ująć w jedno."

„Ja lubię pracować w grupie. Wtedy łatwiej i więcej można się dowiedzieć. Więcej uzyskać informacji, osoba która prowadzi może oczywiście uzyskać więcej informacji."

${ }^{66}$ Fragmenty wypowiedzi uzyskanych od uczestników badania fokusowego w wywiadach swobodnych przeprowadzonych po zakończeniu sesji. „Zogniskowany wywiad grupowy. Studia nad metodą", kierownik: Jolanta Lisek-Michalska 
„Wspólnie więcej pomysłów, zresztą każdy ma inne skojarzenia, każdemu się ta korupcja inaczej kojarzy."

„Moim zdaniem grupowo jest lepiej, bo jednak grupa ludzi to jest grono, które po prostu wymyśli, ze tak powiem, czy sięgnie pamięcią gdzieś dalej i będzie więcej określeń."

Dzięki wypowiedziom pozostałych łatwiej było im sobie przypomnieć pewne sprawy, skojarzyć, odblokować pamięć, pokonać pustkę w głowie. Poza tym forma grupowej rozmowy jest, według wielu respondentów, bardziej efektywna:

„W grupie chyba większe są korzyści z takiego spotkania, dlatego, że na jeden problem było wiele odpowiedzi. Nie wszyscy żeśmy się zgadzali z danym jakimś problemem, były osoby za, przeciw."

„Takie forum dyskusyjne jest lepsze od indywidualnych jakichś spowiedzi.”

Wspominali też, że dzięki współpracy mogli zaspokoić swoją ciekawość, tzn. poznać doświadczenia pozostałych osób oraz że taka formuła zadania pobudza do myślenia. Obecność innych nie przeszkadzała im, ale pomagała - czuli się pewniej, byli bardziej rozluźnieni, odważniej zabierali głos:

„W grupie lepiej się rozmawia. Bo to może po prostu nawet w trakcie rozmowy po prostu jak ten coś opowiada, ten coś opowiada, to człowieka zachęca, przekonuje, że jednak można coś tam powiedzieć."

Ktoś wspomniał, że w grupie, gdy wszyscy opowiadają o swoich doświadczeniach, nie czuje się osamotniony, ma poczucie, że są też inni, którzy znaleźli się w podobnej sytuacji. Respondenci uważali, że w grupie mówi się więcej i bardziej otwarcie niż w rozmowie sam na sam, że grupa mobilizuje do szczerej wypowiedzi:

„Indywidualnie, to wie pan, człowiek zaczynałby ubarwiać, cudować, wie pan, do tego. A tak, to człowieka mobilizuje. (...) Obecność osób trzecich jest, wie pan, powiedziałbym, że konieczna, wie pan, rozwiązuje języki w dyskusji." 67

Inni podkreślali, że praca w grupie sprawiła, że dyskusja była żywa, sprawnie przebiegała i szybciej poradzili sobie z tym zadaniem, dodawali, że atmosfera była bardzo sympatyczna. Niektórzy zauważyli, że grupa ośmiu osób była „akurat”, jeżeli chodzi o liczbę uczestników, stwierdzając że w liczniejszej grupie współpraca byłaby utrudniona.

Zatem obecność innych osób postawionych w tej samej sytuacji, osób postrzeganych przez badanego jako podobne do niego, w pewnym stopniu rekompensuje inne trudne aspekty badań fokusowych.

\footnotetext{
${ }^{67}$ Fragmenty wypowiedzi uzyskanych od uczestników badania fokusowego w wywiadach swobodnych przeprowadzonych po zakończeniu sesji. „Zogniskowany wywiad grupowy. Studia nad metodą", kierownik: Jolanta Lisek-Michalska.
} 


\section{Czas trwania sesji}

Na koniec tego wątku rozważań warto wspomnieć o jeszcze jednym formalnym aspekcie badania fokusowego, które może wywołać niekorzystny rezultat w postaci negatywnych emocji osób badanych. Chodzi tu o dość sztywne ramy czasowe sesji. Abstrahując od poszczególnych odcinków czasowych przeznaczonych na realizacje kolejnych modułów problemowych scenariusza, należy dodać, że bardzo często zdarza się, że uczestnicy nie chcą zakończyć spotkania.

Oczywiście, jeśli to jest ostatnia sesja w danym dniu i jeśli moderatora nie czeka kilkusetkilometrowa droga powrotna do domu, nic nie stoi na przeszkodzie, żeby jeszcze przez jakąś chwilę porozmawiać z badanymi i nie domagać się stanowczo opuszczenia sali fokusowej. Ale jeśli w poczekalni czekają już następni zaproszeni uczestnicy, trzeba umiejętnie rozwiązać tę sytuację. Bardzo przydaje się wówczas współpracownik moderatora, który może zająć się tymi, z którymi sesja zakończyła się, a moderator powinien punktualnie rozpocząć nowe spotkanie.

Zdjęcie 9. Uczestniczki grupy fokusowej

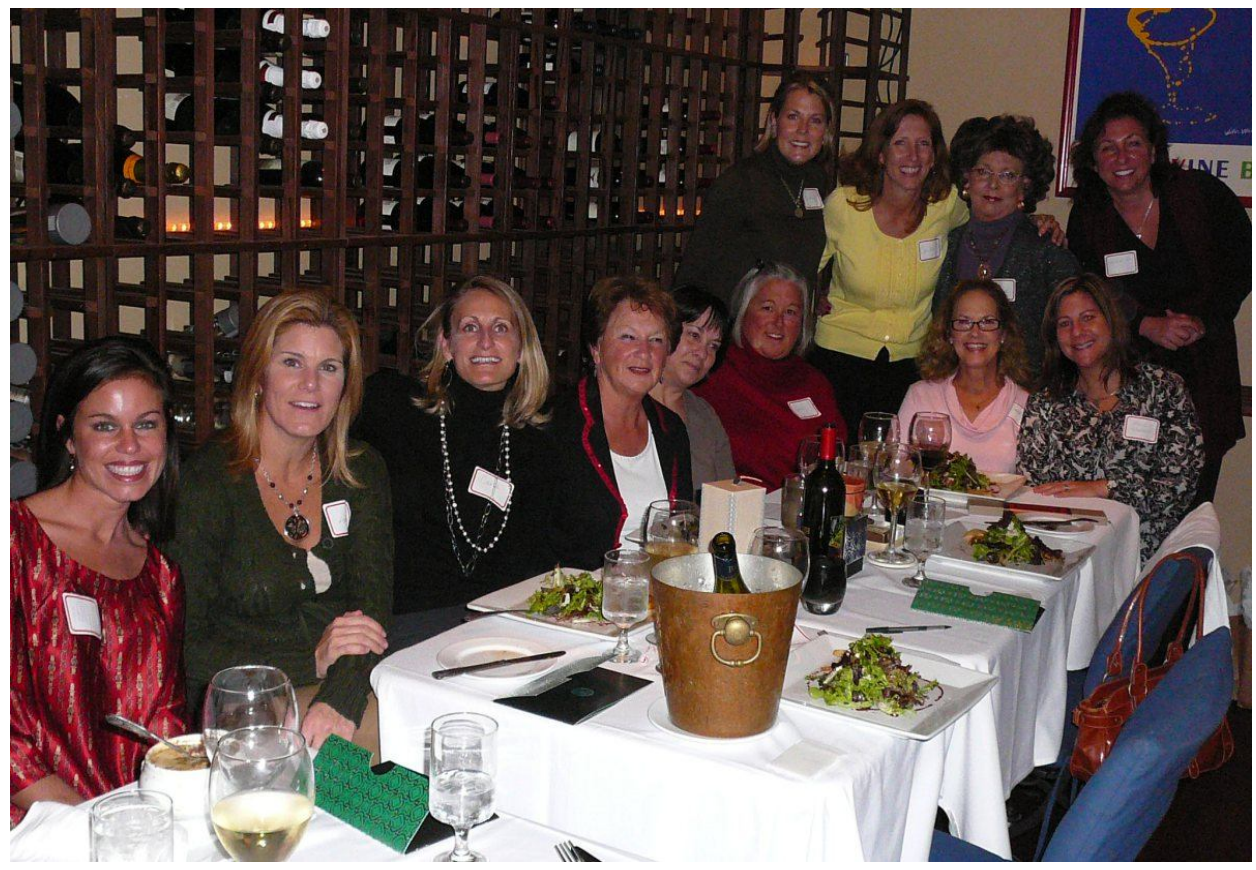

Źródło: http://votivo.wordpress.com/ 
Dobrze jest też zaplanować odpowiednio dłuższą przerwę pomiędzy sesjami realizowanymi w tym samym dniu. Szkoda byłoby, gdyby badani zgodnie z działaniem efektu świeżości jako ostatnią emocję związaną z udziałem $\mathrm{w}$ sesji zapamiętali swoje niezadowolenie. Na pewien niedosyt $\mathrm{w}$ tym względzie skarżyli się także uczestnicy badań metodologicznych, w wywiadach po sesjach mówili, że: „przeszkadzały czasowe ograniczenia i zabrakło czasu, by powiedzieć wszystko, co chcieli."68 Kilka osób przyznało, że chętnie podjęłoby wątki, dla których w czasie spotkania zabrakło miejsca lub nie zostały w pełni rozwinięte. Zatem zabiegi zmierzające do zadbania o uczestników pod względem etycznym (w tym przypadku o ich nastrój po badaniu) przekładają się na tak wydawałoby się drobne elementy metody zogniskowanego wywiadu grupowego, jak planowanie długości przerw miedzy sesjami.

\section{Problemy etyczne Wrnikająe ze SPeCyfiki metody FGI}

\section{Tematyka badania (drażliwość, trudność, kontrowersyjność)}

W przypadku badań rynkowych, obiekt będący przedmiotem dyskusji (produkt, marka, logo, reklama) zwykle jest dla uczestników neutralny emocjonalnie (poza szczególnymi przypadkami ${ }^{69}$ ). Zupełnie inna sytuacja ma miejsce w większości badań socjologicznych, które koncentrują się na sprawach bezpośrednio związanych z życiem osób badanych. W końcu już wiele lat temu Peter L. Berger pisał: „Socjolog (...) jest to osoba intensywnie, stale, bezczelnie zainteresowana poczynaniami ludzi. Można by to samo rzec bardziej obcesowo. Moglibyśmy powiedzieć, że socjolog to człowiek, który (...) musi wbrew sobie wysłuchiwać plotek, który jest skłonny do zaglądania przez dziurki od klucza, czytania listów innych ludzi, otwierania zamkniętych sekretarzyków. Socjolog będzie się zajmował sprawami, które inni uważają za zbyt uświęcone bądź też wstrętne, by poddać je obiektywnemu badaniu" (Berger, 1999).

W zogniskowanych wywiadach grupowych na poziomie rekrutacji do udziału w sesjach poza parametrami społeczno-demograficznymi stosuje się tak zwane kryteria merytoryczne, na podstawie których uznaje się konkretną osobę za „eksperta w sprawie”, czyli do badań o biedzie z punktu wi-

\footnotetext{
${ }^{68}$ Fragmenty wypowiedzi uzyskanych od uczestników badania fokusowego w wywiadach swobodnych przeprowadzonych po zakończeniu sesji. „Zogniskowany wywiad grupowy. Studia nad metodą", kierownik: Jolanta Lisek-Michalska.

${ }^{69}$ Chodzi tu o takie badania, w których na przykład przedstawiciele partii politycznej dyskutują nad wygenerowanymi wcześniej propozycjami haseł do kampanii wyborczej, albo członkowie zarządów banków planujących fuzję wybierają wspólne logo.
} 
dzenia biednych zaprasza się osoby spełniające kryteria „bycia biednym”, do badań o przemocy w szkole - dzieci i młodzież ze szkół, w których to zjawisko występuje itd. Zatem już na etapie konceptualizacji projektu badacz ma świadomość, że w wielu badaniach tematyka dyskusji zogniskowanej ma charakter drażliwy, angażuje uczestników emocjonalnie, ponieważ dotyczy ich osobiście (Rostocki, 1992) ${ }^{70}$. W kontekście badań nad ubóstwem Elżbieta Tarkowska (2000, s. 42-44) i Krystyna Lutyńska (2000, s. 208-219) przypomniały opisany wcześniej przez Marię Ossowską $(1985)^{71}$ mechanizm kłamstwa obronnego, umożliwiający zachowanie godności, gdy pytania dotykały sfery osobistej, spraw drażliwych bądź wstydliwych, jakich badany wolałby nie ujawniać, np. alkoholizmu lub przemocy w rodzinie. Podobne mechanizmy uruchamiają się w badaniach fokusowych. (Rostocki, 1992a)

Pytania dotyczące bezrobocia, reakcji małoletniego dziecka na rozwód rodziców, funkcjonowania służby zdrowia, dochodów, planów życiowych mogą okazać się bolesne dla badanego. Badacz często liczy na to, że uzyska od uczestnika informacje prywatne, takie, do których ten nie dopuszcza nawet osób bliskich. W sytuacji badań fokusowych badacz nie tylko spodziewa się, że te informacje zostaną ujawnione, ale jeszcze oczekuje, że stanie się to w obecności innych obcych osób. Podstawową kwestią staje się w takich przypadkach absolutne przekonanie badacza o niezbędności poszukiwanych informacji i umiejętność przekonania o tym badanego. Poza tym w takich sytuacjach badacz powinien dokonać przeglądu całego arsenału narzędzi, żeby sposób postawienia pytania łagodził jego dolegliwość dla osób badanych. Z wielu doświadczeń badawczych wynika, że drażliwość (czy domniemana drażliwość) przedmiotu dyskusji nie jest cechą, która nieodwołalnie dyskwalifikuje dany obszar zagadnień z badań fokusowych. Gdyby tak było, fokusy nadawałyby się wyłącznie do badań marketingowych. Uświadomiona badanym wspólnota doświadczeń uczestników, podobieństwo sytuacji życiowej są czynnikami, które - umiejętnie i z wielką

\footnotetext{
70 Ponad 50 lat temu Z. Gostkowski zwracał uwagę na to, w jaki sposób „waga” sprawy dla respondenta przekłada się na jego odpowiedzi w wywiadzie kwestionariuszowym. (Gostkowski, 1960)

71 „(...) Na ogół, w opinii ludzi znanych nam z druku czy żywego słowa, istnieją okoliczności, wolno nam od prawdomówności odstąpić, przy czym rozgrzeszenie może być częściowe, lub nawet zupełne. I tak np. dopuszczamy, jak wiadomo, kłamstwo obronne w stosunku do wroga, który chce dobyć z nas jakieś informacje na to, by nam szkodzić. Wprowadzanie w błąd prowokatora wydaje się w pełni usprawiedliwione nie tylko wtedy, gdy chronimy dobro cudze, ale i wtedy, gdy zabezpieczamy własne. Odmianą dozwolonego kłamstwa obronnego jest kłamstwo w obronie własnej zagrożonej prywatności. Wolno nam odmówić odpowiedzi albo skłamać w przypadku czyjejś niewczesnej familiarności czy natarczywej niedyskrecji." (Ossowska, 1985, s. 115)
} 
uważnością wykorzystane przez badacza, często stanowią element wyzwalający gotowość do dzielenia się własnym życiem z innymi. W przywoływanych tutaj badaniach metodologicznych z uczestnikami sesji fokusowych na temat korupcji badanym także towarzyszyło wiele napięć. Podczas opowiadania o sytuacjach łapowniczych wielu z nich odczuwało niepokój, zakłopotanie, niesmak. Dla niektórych przyczyną tych emocji była konieczność zwierzeń wobec obcych ludzi z upokarzających, przykrych momentów w ich życiu: „No, sama sytuacja już jest drażliwa, a wspominanie o tym... to jest ciężka rzecz, mimo wszystko człowiek czuje się tam trochę niezręcznie, nie, w tej sytuacji. (...) chyba nikt nie lubi się przyznawać do tego", dla innych zaś bezradność wobec korupcji stającej się coraz częściej jedynym sposobem załatwienia pewnych spraw ${ }^{72}$.

Doskonałym przykładem badania, w którym udało się pogodzić niezwykle drażliwą problematykę z zadbaniem o uczestników, jest projekt zrealizowany przez Morgana i współpracowników. W sesjach przygotowanych przez badaczy uczestniczyły kobiety, które owdowiały nie dalej, niż pół roku przed badaniem. Rozmowa koncentrowała się na ich doświadczeniach wyniesionych z tego niezwykle trudnego okresu. Organizatorzy zadbali o obecność psychologów, gotowych w każdej chwili udzielić kobietom wsparcia, wielokrotnie przypominali o przynależnym im prawie do przerwania udziału w sesji, jeśli uznają one, że ponoszą zbyt duże koszty emocjonalne. Przypominali, że priorytetem jest zaopiekowanie się sobą i innymi wokół, zatem bez względu na okoliczności nie powinny narażać się na stres w celu udzielenia pomocy (informacji) badaczom. Wyrazem uznania dla wysiłku, jaki kobiety włożyły w uczestnictwo w sesjach, były przygotowane dla nich broszury zawierające informacje o instytucjach i organizacjach mogących służyć im pomocą (Morgan, 1989).

W takiej sytuacji badacz balansuje na granicy ryzyka przeistoczenia się sesji fokusowej w sesję terapeutyczną. Utrzymanie się w regułach fokusa jest wtedy niezwykle trudne. Ale z wielu powodów groźniejsze i niedopuszczalne jest przekroczenie tej bariery. Po pierwsze, badacz nie dysponuje odpowiednimi kwalifikacjami do wyprowadzenia uczestników ze stanu nadmiernego pobudzenia emocjonalnego. Po drugie, nie taki był deklarowany przez niego w trakcie rekrutacji cel, zatem intencjonalna czy wynikająca z utraty kontroli moderatora zmiana formuły spotkania byłaby rodzajem oszukiwania bada-

\footnotetext{
72 Fragmenty wypowiedzi uzyskanych od uczestników badania fokusowego w wywiadach swobodnych przeprowadzonych po zakończeniu sesji. „Zogniskowany wywiad grupowy. Studia nad metodą", kierownik: Jolanta Lisek-Michalska.
} 
nych. Po trzecie, decyzja o udziale badanego w terapii, w jaką przeistacza się sesja, z całą pewnością nie należy do badacza73.

Pewne cechy terapeutyczne badania fokusowego dostrzegli także uczestnicy sesji na temat korupcji: „Wręcz zauważyłam, że ludzie bardzo lubią o tym mówić... i myślę, że gdyby pozwolić, to bardzo dużo by mówili, bo, mimo, że to jest takie zjawisko niemiłe, to jednak ludzie są zmuszani do tych sytuacji i tu mogli dać upust własnemu jakiemuś takiemu... właśnie sprzeciwowi przeciwko temu, mimo, że to robią, ale się z tym nie zgadzają. A tutaj ten żal można było na forum jakimś nareszcie wypowiedzieć"74.

\section{Treść wypowiedzi uczestników: możliwość modyfikacji opinii in- nych uczestników, konsekwencje dla samooceny badanych}

Jeśli zgodzić się ze stanowiskiem sformułowanym przez W.A. Rostockiego (1992, s. 84) w odniesieniu do techniki surveyu: „Chodzi bowiem o to, że wbrew utrzymywanemu w pozytywistycznym wzorze założeniu o neutralności stosowanych narzędzi badawczych, ingerują one w społeczny i psychiczny świat respondenta (badanego), wprowadzają w nim jakieś krótko- lub długotrwałe zmiany. Stawiając zagadnienie nieco inaczej, chodzi o to, że sytuacja po badaniu nie jest już taka sama jak przed badaniem. Stosowana procedura badawcza pozostawia w świadomości respondenta jakiś ślad, nie zawsze pozytywny", to warto zdać sobie sprawę, że w badaniu fokusowym takie konsekwencje mają zdecydowanie silniejszy charakter.

Sesja w przeciwieństwie do większości standaryzowanych wywiadów trwa długo, co najmniej półtorej godziny, a często jeszcze dłużej. Zazwyczaj określony problem jest analizowany bardzo szczegółowo. Typ aktywności w trakcie sesji znacznie bardziej angażuje wiele wymiarów funkcjonowania uczestnika, nie sprowadza się do wyuczalnej umiejętności wyboru odpowiedzi spośród zaproponowanych. Poza tym obecność grupy nieznanych osób czyni całą sytuację bardziej złożoną niż wtedy, kiedy badany utrzymuje kontakt tylko z jednym ankieterem. Zatem szansa na uświadomienie sobie przez uczestnika własnych poglądów i ograniczeń jest nieporównywalnie większa,

73 Trudno byłoby dzisiaj zgodzić się ze stanowiskiem sformułowanym przez I. Kołodziej: „(...) Jak powiedziałam wyżej, badany daje siebie: mniejszą lub większą, mniej lub bardziej ważną część swojej osobowości. Przekazuje opinie, informacje o uczuciach, marzeniach, dążeniach, działaniach. W zamian ? oferujemy mu satysfakcję, że służy rozwojowi nauki. W moim odczuciu jest to zbyt licha zapłata za „obnażanie się (...) Jedynie [cel terapeutyczny i reformatorski wywiadu] są wystarczającym usprawiedliwieniem indagacji badaczy". (Kołodziej, 1980)

${ }^{74}$ Fragmenty wypowiedzi uzyskanych od uczestników badania fokusowego w wywiadach swobodnych przeprowadzonych po zakończeniu sesji. „Zogniskowany wywiad grupowy. Studia nad metodą" (Grant KBN), kierownik: Jolanta Lisek-Michalska. 
niż w standaryzowanych badaniach opartych na interrogacji. Przy czym te konsekwencje nie muszą nastąpić w trakcie sesji, ale mogą pojawić się po zakończeniu badania ina przykład przejawiać się wobniżonej samoocenie uczestnika. Bez przesady można w tym sensie uznać fokus za badanie znacznie bardziej inwazyjne niż inne typy wywiadów.

Dobrym przykładem ilustrującym ten rodzaj konsekwencji dla badanych (i ryzyko badacza) jest badanie Jana Nawrockiego (1996, s. 75-99) nad zjawiskiem tolerancji. W jego projekcie wśród uczestników sesji znajdował się niejawny współpracownik badacza. Jego zadaniem było „zawieszanie” oczywistości normy tolerancji przez wygłaszanie, w odpowiednich momentach dyskusji, poglądów noszących silne znamiona nietolerancji. Zabieg ten miał na celu zbadanie stopnia internalizacji normy tolerancji przez te osoby badane, które określały się jako tolerancyjne. Sam autor paradoksem nazywa efekt tej operacji, polegający na tym, że: „(...) badani dość starannie konstruowali tło, którym były poglądy przypisywane »nietolerancyjnemu polskiemu społeczeństwu«, następnie deklarowali swą otwartość i tolerancję, po czym niespodziewanie łatwo, na poziomie wyobrażonych sytuacji kontaktu z Obcymi, stawali się nietolerancyjni. Oczywiście zjawisko to nie dotyczyło wszystkich badanych osób, niemniej jednak była to znacząca większość. Niewątpliwie katalizatorem niechętnych reakcji wobec Obcych mogły być wypowiedzi współpracującego z moderatorem członka grupy, zawieszające niejako normę tolerancji. Jest jednak zadziwiające, jak niewielkim wysiłkiem udawało się ją zawiesić." (Nawrocki, 1996).

Odkrycie dzięki interwencji „fałszywego” uczestnika rzeczywistych intencji osób badanych dostarczyło badaczowi odpowiedzi na jedno z kluczowych w tym projekcie pytań problemowych ${ }^{75}$. Czy jednak można mieć pewność, że wiedza ta była pożądana przez badanych? Ludzie przecież nie zawsze i nie w odniesieniu do wszystkich spraw pragną poszerzenia własnej

\footnotetext{
75 Zachowania uczestników nastąpiły pod wpływem nieuświadomionej prowokacji badacza, a zabieg taki jest bardzo dyskusyjny z etycznego punktu widzenia: „Prowokacja jest środkiem wyjątkowo wątpliwym pod względem etycznym. Wiąże się z oszustwem, które stanowi grzech wobec normy prawdomówności. (...) Kolejna zasada etyczna, która została zdeptana przez prowokatora, zakłada uzyskanie dobrowolnej i świadomej zgody osób badanych na udział w eksperymencie. Nie można bowiem dokonać skutecznej prowokacji, uprzednio powiadomiwszy jej uczestników o swoim zamiarze. Kodeksy etyczne w przypadkach, gdy wcześniejsze podanie uczestnikom badania pełnej informacji na jego temat grozi rozbiciem eksperymentu, dopuszczają rozwiązanie, w myśl którego eksperymentator podaje osobom badanym odnośne informacje dopiero po zakończonym badaniu. Jednocześnie badacz musi zaakceptować prawo uczestników eksperymentu do sprzeciwu wobec wykorzystania zebranych przez niego danych." (Gustaw, Brocławik, 2008, s. 329-335) Mimo, że powyższy cytat nie odnosi się wintencji autorów do badań fokusowych, to dobrze ilustruje etyczny problem wprowadzenia badanych w błąd.
} 
samoświadomości. Czasem ważniejsze jest dla nich „dobre myślenie” o sobie ${ }^{76}$. A wracając do punktu wyjścia — jakie przekonanie o własnej tolerancji wypowiadać będą po badaniu? Czy — jeżeli powrócą do artykułowania swojej powierzchownej, deklaratywnej tolerancyjności - towarzyszyć temu będzie jakiś dysonans? (Lisek-Michalska, 2004).

W trakcie sesji fokusowych nawet bez udziału jakiegoś prowokatora może dojść do krytycznej i niezamierzonej przez badacza rewizji obrazu siebie osób badanych. Taka sytuacja miała na przykład miejsce w trakcie badań, przeprowadzonych z osobami, które na szczeblu władz gminnych i powiatowych były postrzegane jako eksperci od problemów społecznych dotyczących kobiet ${ }^{77}$ (Lisek-Michalska, 2008, s. 205-224). Rekonstrukcja mapy kłopotów kobiet wiejskich miała bardzo ożywiony charakter, uczestnicy prześcigali się we wskazywaniu dotykających je ograniczeń i trudności. Na przykład za jedno z podstawowych zjawisk negatywnych uznano nikły odsetek kobiet wiejskich pracujących zarobkowo. Argumentowano, że $\mathrm{w}$ tradycyjnej rodzinie wiejskiej nie istniała potrzeba specjalnego organizowania opieki nad małymi dziećmi, ponieważ w sytuacji wspólnego zamieszkiwania wielu pokoleń rodziny, uzyskiwania dochodów z własnego gospodarstwa, bez konieczności podejmowania pracy zarobkowej przez kobiety, problem w zasadzie się nie ujawniał. Wieś nie miała wcześniej potrzeby wypracowania instytucjonalnych form opieki nad dziećmi i obecnie jest to jedna z barier powstrzymujących młode kobiety wiejskie przed podjęciem pracy zarobkowej. $W$ wielu wsiach przedszkola nie istnieją i młode matki muszą same zapewnić dzieciom opiekę. Ale jeden z modułów scenariusza dotyczył opinii osób badanych na temat działań własnych i innych podmiotów w rozwiązywaniu tych problemów i przeciwdziałaniu im. Uczestnicy musieli przyznać, że władze lokalne (czyli oni sami) nie są w stanie takiej opieki zapewnić. Mało tego, zdaniem badanych również dowożenie dzieci do przedszkoli w innych miejscowościach przy wszechobecnych na wsi problemach komunikacyjnych w zasadzie nie wchodzi w rachubę. W opinii lokalnych liderów kłopoty z dojazdem do innych miejscowości skutecznie zniechęcają mieszkańców wsi, w tym kobiety, do większej aktywności zarówno edukacyjnej, zawodowej, jak i towarzyskiej, czy rekreacyjnej (korzystanie z sal gimnastycznych, basenów), pomijając leczenie

\footnotetext{
${ }^{76} \mathrm{~W}$ badaniach przemyślanych pod względem etycznym opracowuje się na etapie konceptualizacji procedury decepcji. Badacz opisuje szczegółowo elementy procedury wprowadzające osobę badaną w błąd, uzasadnia potrzebę zastosowania opisanej procedury oraz wyjaśnia sposób odkłamania.

77 Projekt Polskiego Towarzystwa Polityki Społecznej wramach SPO RZL 1.6. (B) Diagnoza sytuacjispołeczno-zawodowej kobiet wiejskich w Polsce (projekt realizowany we współpracy z Ministerstwem Pracy i Polityki Społecznej) Moduł I: Władza lokalna i jej polityka wobec kobiet wiejskich.
} 
i profilaktykę zdrowotną (dentysta, ortodonta, badania, konsultacje). Wystarczająco uciążliwe są dla nich dojazdy traktowane jako konieczne, związane z załatwianiem formalności administracyjnych, skarbowych itp. A problemom komunikacyjnym badani (przedstawiciele władz) także nie są w stanie zaradzić w żaden sposób. I mimo że w trakcie prowadzonych sesji próbowali sobie poradzić z dotkliwie odczuwaną bezsilnością i nieefektywnością własnych działań poprzez wskazywanie, że istotną barierę w przezwyciężaniu problemów kobiet wiejskich stanowi ich własna mentalność, której elementami są: bierność, brak aktywności, podporządkowanie mężczyźnie "głowie rodziny”, skrytość, lęk, wstyd, przywiązanie do gospodarstwa i tradycyjnie pojmowanej roli kobiety wiejskiej, to i tak nie pozbyli się tych obniżających samoocenę uczuć. W rezultacie przedstawiciele władz i instytucji lokalnych stwierdzili, że kobiety wiejskie nie są traktowane jako odrębny podmiot zainteresowania przez lokalnie prowadzoną politykę społeczną. Uczestnicy sesji mieli świadomość tego faktu i braku konkretnych, ukierunkowanych na tę kategorię społeczną programów pomocowych. Badani nie tylko nie kwestionowali potrzeby opracowania takich projektów, a wręcz przeciwnie, na miarę własnych możliwości sporadycznie podjęli takie próby. Zdaniem lokalnych liderów społecznych i politycznych, działalność edukacyjna często nie trafia $w$ autentyczne zapotrzebowanie i zainteresowania potencjalnych beneficjentów. Nie wzbudzają zainteresowania kursy i szkolenia dotyczące zagadnień niepraktycznych z punktu widzenia mieszkańców wsi. Kobiety wiejskie chętniej uczestniczą w takich zajęciach i programach edukacyjnych, które dostarczają im umiejętności i wiedzy bezpośrednio możliwej do zastosowania w ich życiu, znajdują bezpośrednie przełożenie na działanie. Atrakcyjne są także takie szkolenia, których ukończenie traktowane jest jako warunek (jeden z warunków) uzyskania innych korzyści, np. dostępu do tanich pożyczek, kredytów. Władze przyznają, że ich działania są nieskuteczne, nieadekwatne do potrzeb, że niewłaściwie współpracują ze sobą instytucje pomocowe, że problemami kobiet zajmuje się zbyt mała liczba osób o niedostatecznych kwalifikacjach, że nie wypracowano sensownych sposobów współpracy, że ograniczają ich zbyt sformalizowane przepisy, że z powodu ograniczonych kompetencji podejmują działania w ograniczonym zakresie, że interwencje w sytuacjach kryzysowych podejmują zbyt późno itd. Dyskusja ujawniła i uświadomiła wszystkim obecnym niedostatek i nieadekwatność podejmowanych przez nich, jako przedstawicieli władz lokalnych, działań o charakterze naprawczym czy zapobiegawczym. Ujawniła ich niemoc i pozorność działania. A takie odkrycie, dokonane publicznie, nie pozostaje bez wpływu na samoocenę.

Czasem może zdarzyć się i tak, jak w trakcie badań pt.: Rozwiązania systemowe skierowane do dziecka i rodziny, które zrealizowano z inicjatywy 
Urzędu Marszałkowskiego w Łodzi. Uczestnikami były osoby zajmujące się zawodowo problematyką dzieci i młodzieży w kontekście szeroko rozumianej pomocy społecznej. Dyskusja była bardzo burzliwa, wywołała wiele emocji i ku zaskoczeniu samych zainteresowanych ujawniła nigdy wcześniej nie wyartykułowane przez nich potrzeby środowiska, które reprezentowali. Osoby zaproszone do udziału w sesji stwierdziły, że „(...) zainteresowanie pomocą społeczną rodzi się wtedy, gdy dochodzi do tragedii. Natomiast, jeśli chodzi o normalny czas, to za mało się pokazuje tego, co udaje nam się zdziałać." Zatem jako niewłaściwy postrzegają sposób podejścia do ich pracy mediów i osób publicznych. Media ich zdaniem mogą odegrać pozytywną rolę nie tylko w odniesieniu do ich zawodu, ale także wprost do problemów, którymi się zajmują, choćby poprzez „(...) pokazywanie dobrych wzorców i zmianę obrazu rodzin. Zmiana na przykład określenia »rodzina patologiczna « na »rodzina, w której występują zjawiska patologiczne «". Ponadto badani zwracają uwagę na to, że oczekiwania pod adresem pomocy społecznej są często zbyt wygórowane i niewłaściwe: „Od nas się oczekuje bardzo dużo. (...) Jakoś się utarło, że my jesteśmy w stanie załatwić wszystko, dlatego wszystko, z czym gmina nie może dać sobie rady, daje do pomocy społecznej. Było tak ostatnio z suszami, które nas na 2 miesiące zmusiły do zostawania po pracy i nie widziałyśmy nic, poza protokołami." Taka sytuacja nie podnosi komfortu ich pracy. A w zderzeniu z ogromem problemów „(...) Czujemy się często bezsilne, wypalone, dlatego potrzebne są takie spotkania" a nawet, jak uznała jedna z dyskutantek, przy aprobacie kilku innych osób: „wskazane byłoby objęcie pomogą psychiatryczną każdego pracownika opieki społecznej." Być może taką rolę mogłyby odgrywać jakieś cykliczne spotkania profesjonalistów, bo, jak stwierdził jeden z uczestników sesji: „(...) dyskusja jest bardzo ciekawa i dochodzimy do wniosku, że dla nas też są potrzebne takie spotkania, żebyśmy mogli wymieniać miedzy sobą doświadczenia, bo są niestety sytuacje, w których jesteśmy bezradni." (LisekMichalska, 2006) Długo po zakończeniu sesji badani nie rozchodzili się, mimo że mieszkali w odległości co najmniej kilkudziesięciu kilometrów od Łodzi. Byli zafascynowani wzajemnym odkrywaniem podobieństw problemów emocjonalnych, których dotąd nie ujawniali i z którymi dotychczas mierzyli się w samotności, kładąc je na karb własnego zmęczenia, bądź braku wystarczających kompetencji zawodowych. Wymienili się numerami telefonów i umawiali na kolejne spotkanie. Pytali moderatora, czy zechciałby w nim uczestniczyć i je poprowadzić. Fokus w tym przypadku stał się katalizatorem, dzięki któremu uczestnicy uświadomili sobie wspólnotę odczuwania niesprawiedliwego społecznego traktowania ich profesji, rozmiar własnych frustracji i potrzebę wsparcia psychologicznego. 
Także w relatywnie bezpiecznym badaniu następują zmiany w postawach/poglądach osób badanych. Wiele takich sytuacji miało miejsce w projekcie dotyczącym korupcji ${ }^{78}$. W wywiadach swobodnych respondenci przyznawali, że skojarzenia (wymagane w technice projekcyjnej) im samym nie przyszły na myśl, a były bardzo ciekawe i celne, ale w trakcie sesji często nie mogli ich sobie przypomnieć. Jedna z uczestniczek była zdziwiona, że wśród skojarzeń z korupcją znalazł się neutralny „prezent”: „Oświeciło mnie takie stanowisko kategoryczne jednego z panów na temat określenia "prezent«, nie przypuszczałam, że ktoś tak kategorycznie negatywnie może określać pojęcia, które, moim zdaniem, funkcjonują normalnie w życiu w sposób bardzo prosty." Inna osoba uznała za trafne i dające do myślenia określenie „uzależnienie”, dające, według niej, inne spojrzenie na dających i biorących łapówki. Jedna kobiet z przykrością uświadomiła sobie, że coraz więcej ludzi daje łapówki, żeby poprawić sobie samopoczucie i uspokoić sumienie, że zrobili wszystko, co w ich mocy w danej sprawie. Dla jednego $\mathrm{z}$ badanych udział $\mathrm{w}$ tym zadaniu wiązał się $\mathrm{z}$ następującym wnioskiem: „dowiedziałem się jednego, że wszyscy się zgadzamy, że zjawisko jest naganne i trzeba z tym zjawiskiem walczyć i tępić. Sprowadza się sprawa do jednego, że... że to jest patologią w naszym społeczeństwie." Niektórzy dyskutanci podczas oceniania historii łapowniczych uświadomili sobie trudność jednoznacznej oceny korupcji, zauważyli, że ustosunkowanie się do konkretnych sytuacji nie jest proste i oczywiste, jak im się wydawało: „Kiedyś byłem taki, że twierdziłem, że z każdej sytuacji jest wyjście i że można wykluczyć dać łapówki, ale już wcześniej zaczęło do mnie docierać, że jednak są sytuacje, gdzie nie da się tego uniknąć, no i tu miałem tego przykłady." Czasem wiązało się to z zyskaniem nowego spojrzenia na łapownictwo: „Ja zawsze to oceniałem źle biorącego. Nigdy nie starałem się może, bo nigdy nie zastanawiałem się też, że jednak dający też robi błąd, nie. Czyli... czyli... ja tutaj oceniałem tylko i wyłącznie do tej pory od... od strony brania, nie od dawania. A teraz, po tym spotkaniu zaczynam myśleć, że to jednak trzeba dających też źle oceniać. Może nie doszedłem jeszcze do tego, żeby ich tak samo, na równi jeszcze oceniać, ale to też jest naganne." Dla wielu osób czymś nowym i cennym była możliwość poznania poglądów na temat korupcji tych uczestników, którzy mieli do czynienia z łapownictwem. Jedna z osób badanych była zaskoczona, że można korupcję traktować po prostu jako sposób załatwienia sprawy stosowany na co dzień: „nie przypuszczałam, że dla ludzi jest to takie normalne." Respondenci przyznawali, że dys-

\footnotetext{
${ }^{78}$ Fragmenty wypowiedzi uzyskanych od uczestników badania fokusowego w wywiadach swobodnych przeprowadzonych po zakończeniu sesji. „Zogniskowany wywiad grupowy. Studia nad metodą", kierownik: Jolanta Lisek-Michalska.
} 
kusja i postawy innych skłoniły ich do wielu przemyśleń i niekiedy do pewnej zmiany swoich poglądów.

Poza ewentualną modyfikacją opinii dotyczących badanych zagadnień, udział $\mathrm{w}$ fokusie może dostarczyć uczestnikom informacji, które są dla nich ważne. Badacz zwykle nie bierze pod uwagę takiej możliwości. $W$ badaniach, które realizowano we wrześniu 2010 r. w Łodzi, Piotrkowie Trybunalskim, Sieradzu i Skierniewicach uczestniczyli przedstawiciele różnych typów rodzin zastępczych tj. 1) spokrewnionej z dzieckiem, 2) niespokrewnionej, 3) zawodowej niespokrewnionej z dzieckiem, 4) rodziny zastępczej o charakterze pogotowia rodzinnego, 5) zawodowej niespokrewnionej wielodzietnej, 6) zawodowej niespokrewnionej specjalistycznej.

Sesje były bardzo intensywne pod względem psychologicznym, ponieważ badani opowiadali o dramatycznych doświadczeniach związanych czy to $\mathrm{z}$ okolicznościami przejęcia opieki nad dzieckiem (śmierć rodziców biologicznych, popadnięcie ich w uzależnienia, wyroki sądowe), czy z procedurami sądowymi lub problemami emocjonalnymi dzieci ${ }^{79}$.

W trakcie każdej sesji zdarzyło się, że uczestnicy wzajemnie od siebie dowiadywali się o sposobach rozwiązania własnych problemów, których inni badani doświadczyli wcześniej. Taki niedobór informacji dotyczył najrozmaitszych zagadnień, od opieki zdrowotnej poczynając, poprzez problemy natury prawnej, na kwestiach finansowych kończąc. Na przykład jedna z osób badanych dowiedziała się o pieniądzach, które przysługują rodzicom zastępczym: „(...) To znaczy mnie też to powiedziała sąsiadka z klatki, która też wychowuje wnuczka. Wcześniej mieliśmy ją 3 lata i nie korzystaliśmy z tych pieniędzy, bo nikt nie wiedział, że ona jest u nas."

Inny dyskutant dopiero na sesji usłyszał o dofinansowaniu do zakupu podręczników:

„(...) Są wyprawki szkolne, bez względu na dochód. (...) Ja nic nie wiem. (...) Szkoła powinna informować. (...) Ja wiem, bo sama załatwiałam. U nas w gimnazjum jest. U nas to kryterium, to $351 \mathrm{zł}$, jest bardzo niskie, ale są pieniądze dla tych, co idą nowym programem. W szkole podstawowej oni chyba dawali 250 złotych. Każda szkoła z ministerstwa coś takiego miała dostać podobno. (...) Ja nie wiem czy nie do końca września są te stypendia.

79 „Do momentu zapadnięcia prawnej decyzji, rodzic zastępczy, nawet jeśli już od długiego czasu wychowuje dziecko, nie ma wobec niego żadnych uprawnień. Problemem staje się na przykład zabieg chirurgiczny, na który należy mieć zgodę rodziców biologicznych. Tylko, co wtedy, gdy zabieg należy wykonać szybko, a nie można ustalić miejsca pobytu takich rodziców? Albo gdy nie są w stanie podpisać zgody? Lub nie chcą? Albo żądają od opiekuna pieniędzy za wyrażenie zgody na operację?" (Lisek-Michalska, 2010). Raport powstał w ramach projektu „Lokalny system opieki nad dzieckiem w opiniach przedstawicieli rodzin zastępczych i instytucji pomocy społecznej”, kierownik: Jerzy Krzyszkowski. 
(...) Nie, nie. One były do 3 września. Stypendia do 15 września. Były ogłoszenia na stornie internetowej."

Kolejny uczestnik dowiedział się o możliwości skorzystania ze specjalnych zajęć dla dziecka nadpobudliwego: „(...) U nas w szkole od roku są takie zajęcia różne, może się pani zainteresuje. Są jakieś baseny z piłeczkami, są lampki świecące."

Zatem w pewnych sytuacjach sesje fokusowe mogą pełnić bardzo szczególną funkcję - nie tylko badacz uzyskuje pożądane informacje, lecz także z nową wiedzą opuszczają je uczestnicy. Przytoczony przykład wydaje się „bezpieczny” pod względem etycznym, ale warto zdawać sobie sprawę $\mathrm{z}$ takich, zwykle nieplanowanych, ewentualnych efektów. Nie zawsze można pozostawić to poza kontrolą badacza.

Takie same rezultaty ujawniły się $\mathrm{w}$ trakcie sesji z przedstawicielami podmiotów ekonomii społecznej. Wśród uczestników nie było osób, które współpracują ze sobą w ramach działań prowadzonych przez ich instytucje na rzecz osób zagrożonych wykluczeniem społecznym, natomiast taka potrzeba i chęć pojawiły się w trakcie dyskusji i uczestniczki wymieniły pomiędzy sobą kontakty. „My się przymierzamy do tworzenia CIS-u od 2012 roku. Skromnie, na 20-24 osoby. To jest mała gmina. Trochę ponad 27 tysięcy ludzi ze wsiami, a samo miasto 20 tysięcy, więc troszeczkę się boję zaszaleć. W tym projekcie systemowym chcę to zrobić dwumodułowo. Myśleliśmy o trzech profilach. Sprzątanie, sprzedawca w wielkopowierzchniowym sklepie i gastronomia. Mamy też restauracje, gdzie można pokusić się o praktyki. Bardzo mnie zainteresowała ta pracownia krawiecka (o której mówił inny uczestnik). Ja się boję wejść w układ z firmą prywatną." (LisekMichalska, 2011) Sesja fokusowa uświadomiła badanym zyski płynące z wymiany doświadczeń między przedstawicielami różnych podmiotów ekonomii społecznej, podczas gdy w codziennej praktyce na porządku dziennym relacje pomiędzy nimi cechuje niechęć do dzielenia się informacjami i rywalizacja.

Jeszcze inny charakter mają problemy pojawiające się w przypadku badań fokusowych dotyczących patologii społecznych zahaczających o konflikt z prawem. Taki rodzaj problematyki generuje wiele problemów etycznych w badaniach fokusowych. Jedną $\mathrm{z}$ najbardziej istotnych kwestii jest zapewnienie poufności informacji. W takiej sytuacji wskazane jest zastosowanie dodatkowych procedur zabezpieczających. Przykładem mogą być badania nad sektami działającymi w Polsce ${ }^{80}$. Już na etapie konceptualizacji

\footnotetext{
${ }^{80}$ Autorka realizowała ten projekt na zlecenie Jolanty Sochy, polskiej przedstawicielki Europejskiej Federacji Stowarzyszeń Badania Nadużyć Psychomanipulacji.
} 
przedsięwzięcia wiadomym było, że badanie takiego środowiska i takich zagadnień ma wyjątkowy charakter.

W polskim ustawodawstwie pojęcie sekty nie występuje, stosuje się określenia „kościoły i związki wyznaniowe”. Ta terminologia wydaje się łagodzić grozę praktyk występujących w sektach ${ }^{81}$. Dlatego w badaniu posłużono się pojęciem „grupy psychomanipulacyjnej”, które, chociaż bywa różnie definiowane, zwykle wskazuje na stosowanie przez te grupy właśnie mechanizmów psychomanipulacji, którą D. Zarębska-Piotrowska (1999) określa jako „Intencjonalny proces wywierania wpływu na ludzkie indywidualne/grupowe/zbiorowe/masowe - zachowania, postawy, motywacje, specyfikę procesów percepcyjnych, ale także wyobrażeniowych i pamięciowych, obejmujących funkcjonowanie na poziomie zarówno intelektualnym, jak i emocjonalnym oraz szeroko rozumianą osobowość - skutkujący realizacją obcych, narzuconych jednostce/grupie - celów i obcych jej zamierzeń — bez wiedzy i zgody podmiotu manipulacji".

Do udziału w badaniu zostały zaproszone osoby, którym w krótkim czasie przed realizacją projektu udało się opuścić sekty oraz ludzie zawodowo trudniący się pomaganiem tym, którzy pozostają pod wpływem sekt i ich rodzinom. Ze względu na bezpieczeństwo tej pierwszej kategorii uczestników sesje nie były rejestrowane przy pomocy kamery, dokonano jedynie rejestracji audio, przy czym badacz został zobowiązany do tego, że transkrypcję z nagrania wykona osobiście. Samo nagranie zostało zniszczone przez zleceniodawcę w obecności badacza, bezpośrednio po spisaniu treści.

Interesującego przykładu zadbania przez badacza o bezpieczeństwo badanych dostarcza projekt Kertha O'Briena, który zrealizował sesje z udziałem homo- i biseksualnych mężczyzn. Dyskusja dotyczyła ich nastawienia wobec epidemii AIDS. Ponieważ uczestnicy ujawniali swoją orientację seksualną, podstawową kwestią było zapewnienie im konfidencjonalności. Pierwszym krokiem w tym kierunku była rezygnacja badacza z uzyskiwania tradycyjnych podpisanych kwestionariuszy, wyrażających zgodę uczestników na badanie. Zamiast tego badacz przeprowadzał rekrutację telefonicznie, rozpoczynał każdą nagrywaną przez siebie rozmowę od odczytania wszystkich informacji potrzebnych do podjęcia świadomej decyzji o przystąpieniu do badania, pozwalał badanym posługiwać się tylko imieniem, albo pseudonimem, upewniał się, że badany właściwie wszystko zrozumiał i wyraża zgodę na swój udział. Ponadto wszystkie materiały rekrutacyjne,

81 Składane w Polsce doniesienia i prowadzone postępowania przeciwko przedstawicielom sekt dotyczyły między innymi przestępstw takich, jak: zabójstwa, udział w bójce z udziałem niebezpiecznego przedmiotu, pozbawienie wolności, stosowanie przemocy, gwałt, nadużycie seksualne, znieważanie zwłok, fałszerstwo dokumentów. 
nagrania były przechowywane w sejfie ulokowanym poza biurem badacza (Morgan, 1997, s. 88).

W mniejszym stopniu, ale ten sam typ problemów wystąpił w badaniach dotyczących korupcji, gdzie uczestnicy byli proszeni o szczegółową rekonstrukcję okoliczności, w jakich przyjęli, bądź wręczyli łapówkę. I pomimo że w badaniach fokusowych nie sposób mówić o anonimowości uczestników względem siebie, to przecież m.in. zarówno policjant, jak i pielęgniarka drobiazgowo odtworzyli moment przyjęcia nienależnej im korzyści. Po zakończeniu sesji kilka osób zauważyło, że powiedzieli więcej niż sobie wyobrażali, że powiedzą: ,ja powiedziałam o rzeczach, o których właściwie nie powinnam może... znaczy... o tym, że... To była taka kwestia, że ja, na przykład mówiłam, że pracuję w urzędzie i... i zdarzało mi się, że ja sama przyjmowałam jakieś czekolady, czy tam coś w tym stylu. No, nie wiem, czy powinnam o tym mówić, ale to...", atmosfera spotkania i szczerość innych sprawiły, że uczestnicy wypowiadali się swobodnie, „rozkręcili się”. „Z wypowiedzi wszystkich tam obecnych można było wyczuć, że jest to szczerze, nikt nie, bo jak ktoś zmyśla, kombinuje, coś tam chce zataić, to się zastanawia, myśli, kombinuje, a tu widać było, że wszyscy mówią tak wylewnie, od siebie." Niektórzy wyznawali nawet, że powiedzieliby dużo więcej, ale powstrzymywały ich ograniczenia czasowe: „Tylko wiadomo, że można tam dużo przykładów podać, ale to czasu nie ma. Trzeba każdemu pozwolić się wypowiedzieć." Chociaż temat nie był drażliwy dla uczestników, to, jak zauważyli badani, dla tych, których doświadczenia związane $\mathrm{z}$ łapownictwem były zbyt świeże lub dotyczyły bliskich osób, ich choroby lub śmierci, konieczność zwierzeń mogła być przykra i denerwująca, co jednak nie wpłynęło na ich szczerość.

Była też inna argumentacja własnej szczerości i otwartości. Część respondentów stwierdzała, że nie ma nic do ukrycia i powodu do wstydu, gdyż albo nie mieli do czynienia z korupcją: „Wypowiadałam się szczerze. Nigdy nie miałam z tym do czynienia i mam nadzieję, że nigdy nie będę miała i w ogóle to bardzo potępiam", albo ich sytuacja łapownicza miała miejsce dawno temu i nie wiążą się z nią już żadne emocje, albo przypadki korupcji z własnego życia uznawali za nieznaczące: „Nie zajmuję eksponowanego stanowiska, nie jestem urzędnikiem państwowym... moje życiowe doświadczenia nie były korupcją wysokiego rzędu.” „Ja w życiu nie miałam dużo takich doświadczeń korupcyjnych, jestem takim szaraczkiem, więc nic specjalnie nie miałam, więc nie było to dla mnie takie bardzo trudne. 0 wszelkich typowych sytuacjach, takich jak mandaty, czy kanary, to nie miałam innych, więc nie było to dla mnie jakieś krępujące.” „Ponieważ nie miałam aż tak bardzo drastycznych powodów do opowiadania, nie kontrolowałam się, mówiłam szczerze”, ,Ja bezpośrednio nie miałem styczności z bardzo drastycznym przypadkiem korupcji. Czyli, powiedzmy, płacenia, mówię przykładowo, płacenia, powiedzmy, dużo pieniędzy 
za jakąś tam, na przykład, tą, poradę lekarską, czy operację, gdzie jest to, że tak powiem, o dużej wadze korupcja, czy tam powiedzmy przepłacenie jakiegoś polityka za coś tam, nie. Gdzie ja mam sprawę wysokości, powiedzmy dziesięciu, dwudziestu złotych przepłacenia jakiegoś tam urzędnika, strażnika miejskiego, to... ja się nie muszę bać, nie, tego powiedzieć, bo to jest, dla mnie osobiście jest to zbyt niski poziom, nie, tego... tego... grzechu". Niektórzy mówiąc o swojej szczerości, braku zahamowań i wstydu, byli przekonani o podobnej postawie pozostałych uczestników sesji.

Jedna tylko osoba przyznała się do ocenzurowania swojej historii, tłumacząc to trudnością z ustosunkowaniem się do własnego postępowania i niechęcią wobec bycia ocenianą przez innych:

„M: Wspominała Pani, że ocenzurowała Pani swoje oświadczenie i tylko o niektórych mówiła w grupie, a dlaczego nie chciała Pani mówić o wszystkich doświadczeniach?

B.: Dlatego że, być może nie mam własnego zdania i jakieś oceny wyrobionej, a poza tym obawiam się, że gdybym do takiej oceny doszła, to ta ocena jest dla mnie negatywna, w związku z tym naturalnym biegiem rzeczy jest to, że ja o tym nie będę mówić, po to żeby być ocenianą negatywnie (...) Ja obawiam się, że moja ocena wypadnie negatywnie własnych zachowań, w związku z tym ujawnienie tego spowoduje, że ja sama będę musiała to przyznać, nie chcę tego robić w obecności obcych osób."

Ktoś stwierdził, że o pewnych sytuacjach nie opowiedział, gdyż pokryłoby się to $\mathrm{z}$ historiami innych, a inna osoba zasugerowała, że pewne historie zachowała dla siebie, choć w tych, o których opowiedziała była całkowicie szczera ${ }^{82}$.

Rzetelność badacza jest zasadą fundamentalną w badaniach socjologicznych, ale w takich sytuacjach nabiera dodatkowego niezwykle istotnego znaczenia. Zresztą zadbanie o bezpieczeństwo badanych i przekonanie ich o tym procentuje uzyskaniem wartościowszych informacji, zatem tak naprawdę jest to działanie w interesie własnym badacza. Badani na te same zabiegi perswazyjne reagują różnie, czego dowodzą ich wypowiedzi uzyskane w wywiadach swobodnych po sesjach fokusowych. Pytani, czy takie zapewnienie o konfidencjonalności, jakie usłyszeli od moderatora było wystarczające i przekonujące, w większości udzielili odpowiedzi pozytywnej. Jedna z uczestniczek zaznaczyła, że przekonuje ją fakt prowadzenia badania przez Uniwersytet Łódzki, będący dla niej poważną, godną zaufania i szacunku instytucją: „Ja myślę, że szacunek dla Uniwersytetu, bo gdyby to była inna instytucja, jakaś mniej znana to może nawet bym się nie zgodziła, natomiast wierzę, że będzie tajne." Ale

82 Fragmenty wypowiedzi uzyskanych od uczestników badania fokusowego w wywiadach swobodnych przeprowadzonych po zakończeniu sesji. „Zogniskowany wywiad grupowy. Studia nad metodą", kierownik: Jolanta Lisek-Michalska. 
w kilku wypowiedziach pojawił się sceptycyzm i wątpliwości, co do zachowania konfidencjonalności badania i wykorzystania uzyskanych informacji dla celów naukowych: „Jeżeli mam być szczery, to rozumiem, że to jest anonimowe, ale do końca to nie wiadomo”, „Ktoś tam ma do tego wgląd, także do końca anonimowe to nie jest, prawda?”, „Na przykład ktoś ci mówi, no miało być całkowicie anonimowo, macie nasze nazwiska, daty urodzenia, czyli już nie jest anonimowa ta ankieta całkowicie, tak, że mi się wydaje, że mogą postronne osoby też z tego korzystać w jakiś tam sposób." A zatem, jeśli w projekcie, w którym przykładano szczególną wagę do dbałości o etyczne strony przedsięwzięcia i który był firmowany przez cieszącą się autorytetem uczelnię pojawiły się opinie sceptyczne co do zachowania poufności uzyskanych danych, to tym bardziej takich wątpliwości można się spodziewać w pozaakademickich projektach badawczych.

Inny rodzaj drażliwości ma miejsce wówczas, gdy dyskusja koncentruje się wokół zagadnień niekoniecznie bezpośrednio związanych z życiem uczestnika, ale takich, o których on nie zwykł wypowiadać się publicznie, na przykład preferencje seksualne (Lutyńska, 2000, s. 51-64).

Nadal $w$ wielu środowiskach istnieją przecież rozmaite tematy tabu, o których nie powinno się rozmawiać nie tylko z obcymi, ale nawet $\mathrm{z}$ bliskimi. A w fokusie wszystkie wypowiedzi są rejestrowane... Jak w takiej sytuacji sprostać oczekiwaniom moderatora i pozostałych badanych? Oczywiście można próbować łagodzić dyskomfort uczestników w takiej sytuacji poprzez zastosowanie technik projekcyjnych. Ale warto mieć na uwadze, że nie wszyscy jednakowo sprawnie i bez wątpliwości uruchamiają mechanizmy projekcji. Zawsze mogą na sesji znaleźć się tacy uczestnicy, dla których bariera tematu tabu jest nieprzekraczalna pomimo użycia rozmaitych zabiegów technicznych i którzy silnie odczują dyskomfort całej sytuacji.

Podobny proces może zajść w badaniach, które dotyczą zagadnień kontrowersyjnych, takich, co do których sami badani mają świadomość, iż poglądy różnych osób w tej sprawie są odmienne, na przykład: czy należy w Polsce wprowadzić karę śmierci, czy aborcja powinna być kwestią prywatnej decyzji, czy należy odebrać byłym pracownikom bezpieki przywileje finansowe itd. Nie dość, że często sami nie mają jednoznacznie sprecyzowanych opinii na dany temat, to jeszcze nie wiedzą, jakie poglądy w tym zakresie posiadają inni uczestnicy sesji. I znowu okazuje się, że badani postawieni są w sytuacji trudnej, niejednoznacznej, w której ujawnienie opinii sprzecznych z pozostałymi dyskutantami wystawia respondenta na niebezpieczeństwo otwartej krytyki ze strony pozostałych uczestników. W przytaczanych tu wywiadach swobodnych dwoje uczestników przyznało się na przykład do świadomego powstrzymania się od wypowiedzi w sytuacji, gdy byli odmiennego zdania niż ich przedmówcy, gdyż nie wiedzieli, jak owe osoby zareago- 
wałyby na słowa krytyki. Nie wszyscy potrafią bronić swoich racji otwarcie. Dla wielu z nich upublicznienie własnego sądu w sytuacji, kiedy może się on spotkać z dezaprobatą pozostałych badanych jest niezwykle stresujące, budzi opór przed werbalizacją opinii i obawę przed odrzuceniem przez grupę. $\mathrm{W}$ rezultacie może pojawić sie tendencja do wycofania, co z kolei nie pozostaje bez wpływu na samoocenę takiego uczestnika.

Pozostaje mieć nadzieję, że powyższe rozważania dostatecznie ilustrują tezę, iż charakter badanego zagadnienia, drażliwość tematyki, trudność poruszanych zagadnień, kontrowersyjność przedmiotu dyskusji mogą stanowić elementy potencjalnie wyzwalające w uczestnikach socjologicznych badań fokusowych stany mentalne i emocjonalne, które pod znakiem zapytania stawiają zachowanie zasady niewyrządzania krzywdy badanym.

\section{CHARAKTER NARZĘDZIA (SCENARIUSZ MODERATORA) - RODZAJ PYTAŃ I ZADAŃ STAWIANYCH UCZESTNIKOM, TECHNIKI PROJEKCYJNE}

Inny rodzaj drażliwości (Rostocki, 1992, s. 84; 1975; Lutyńska, 2000, s. 5164) ma miejsce wówczas, gdy stawiane przed badanymi w trakcie sesji zadania są dla nich zbyt trudne. W oparciu o materiał empiryczny zgromadzony w przywoływanym tu badaniu metodologicznym należy stwierdzić, że prawie wszyscy w sesjach doświadczyli czegoś, co uznali za trudne. Tylko kilka osób spośród przebadanych 96 stwierdziło, że żadna część spotkania nie sprawiła im problemów. W wypowiedziach pozostałych uczestników zostały wymienione wszystkie fragmenty sesji, nawet takie, co do których badacz zupełnie nie przypuszczał, że mogą przysporzyć uczestnikom kłopotów.

Abstrahując już od samej treści pytań, bądź użytych w nich sformułowań, z których zrozumieniem badani mogą mieć kłopoty, w zogniskowanych wywiadach grupowych często używa się rozmaitych technik wymagających myślenia abstrakcyjnego lub hipotetycznego lub stawia zadania wymagające dużych kompetencji, na przykład - językowych. A nie dla wszystkich taki rodzaj rozumowania jest czymś naturalnym, dlatego w sytuacji, kiedy uczestnik nie radzi sobie z zadaniem, bo jest ono dla niego zbyt trudne, istnieje możliwość pogorszenia jego samooceny. Badacze często przewidują w scenariuszach rozmaite techniki dodatkowe, w tym na przykład projekcyjne. Przydatność tego typu zabiegów (w określonych sytuacjach badawczych) jest niekwestionowana, jednak warto pamiętać o tym, by likwidując jedno niebezpieczeństwo, na przykład unikając zadawania pytań bezpośrednich, które mogą wprawiać uczestników w zakłopotanie, nie narazić ich 
na dyskomfort trudnością stawianych zadań. Nie wszystkim badanym udaje się uruchomić w sobie zdolność do wymyślania w technikach personifikacji, jakim człowiekiem jest proszek do prania lub kawa. A i tak te przykłady typowe dla badań marketingowych nie są wcale najtrudniejsze. Więcej wysiłku, chociaż opierającego się na tych samych mechanizmach, wymaga wyobrażenie sobie, jaką osobą jest np. konkretna partia polityczna. Technika winiety z kolei (opis przypadku) wymaga od badanego umiejętności postawienia się $w$ roli bohatera historii i znalezienia rozwiązania, jakie $w$ takiej wyobrażonej sytuacji byłoby najwłaściwsze. Technika niedokończonych zdań wymaga gotowości do szybkiego myślenia, chiński portret zaś do myślenia dywergencyjnego, generowania skojarzeń, dokonywania personifikacji, a technika kolażu opiera się na zdolności „myślenia obrazami”, wyrażania poprzez obrazy swoich poglądów lub stanów emocjonalnych.

W przywoływanym tu badaniu metodologicznym dotyczącym od strony merytorycznej zjawiska korupcji, w scenariusz fokusa wprowadzono technikę circeptu (Lisek-Michalska, 2007). "Circept” to sztuczne słowo utworzone z dwóch pojęć circulus (krąg) i koncept. Jest to metoda aktywizująca, która służy rozwiązywaniu problemów w sposób twórczy. Przy jej pomocy powstaje obraz danego pojęcia, problemu, tematu w wyniku intensywnej wymiany myśli i zbierania pomysłów. Circept to ćwiczenie polegające na wykorzystaniu analogii i metafor. W dużym skrócie i uproszczeniu jego realizacja sprowadza się do tego, że w pierwszej fazie badani tworzą analogie lub metafory dotyczące problemu badawczego, a później dokonują ich uporządkowania według uznanych przez nich kryteriów. Jak pisze Nęcka (1994) „(...) Podejście takie opiera się na założeniu, że głębsze zrozumienie problemu wymaga odwołania się do obszarów wiedzy lub doświadczeń bezpośrednio z nim nie związanych - w przeciwnym wypadku będziemy zbyt ograniczeni rutyną, schematem i stereotypowym widzeniem problemu. Próbując zgłębić temat, powinniśmy oderwać się od wiedzy bezpośrednio związanej z tematem i spróbować wykorzystać wiedzę z zupełnie innych dziedzin, np. pszczelarstwa lub ziołolecznictwa np. przy rozwiązywaniu problemu usprawnienia funkcjonowania firmy. Takie przenoszenie wiedzy nie może być przypadkowe, bo niewiele by dało. Dlatego wykorzystujemy podobieństwa i metafory, czyli - zgodnie z klasyczną definicją Arystotelesa — »struktury umożliwiające mówienie o jednej rzeczy w terminach właściwych zupełnie innej rzeczy« (...) Technika ta pozwala uzyskać wgląd w ukryte cechy obiektu, a tym samym - lepiej go zrozumieć. Poza tym dzięki niej zdajemy sobie sprawę $\mathrm{z}$ przeciwieństw tkwiących $\mathrm{w}$ wielu pozornie mało skomplikowanych obiektach. Jest to więc technika z natury dialektyczna, tym bardziej, że przeciwieństwa, które ujawnia, ułożone są w harmonijnej strukturze kołowej. Zatem circept pokazuje jedność obiektu w jego przeciwieństwach, co stanowi rdzeń 
dialektyki. Ponadto jest atrakcyjny dla uczestników. Stanowi też dobre przygotowanie do rozwiązywania problemów, zwłaszcza, gdy sprawiają wrażenie trudnych i złożonych".

Pełna procedura tego ćwiczenia jest dość skomplikowana i — co bardzo istotne z punktu widzenia realizacji badania empirycznego — zajmuje wiele czasu. Spodziewano się także, że takie zadanie może okazać się nużące i bardzo trudne dla uczestników, dlatego dokonano pewnych modyfikacji w przedstawionej tu wersji circeptu, dzięki czemu w przekonaniu badacza zmniejszył się wyraźnie poziom trudności ${ }^{83}$. Informacje uzyskane od badanych przy pomocy wywiadu swobodnego znacznie zmieniły jednak to wyobrażenie. Badani co prawda różnili się w ocenie trudności zadania - część z nich nie uznała go za trudne czy skomplikowane, ktoś porównał je do układania puzzli czy rozwiązywania krzyżówki. Inni jednak zwrócili uwagę, że to polecenie nie było dla nich zrozumiałe, mieli trudności ze zorientowaniem się, o co w nim chodzi i co mają robić:

„Ja właściwie nie wiedziałam, czy to mają być antonimy czy synonimy korupcji." „Początkowo to takie miałem jakieś niezbyt przejrzyste powiedzmy na to jakieś takie spojrzenie, później troszeczkę już tak jakoś bardziej to do mnie dotarło." Zapisanie określeń kojarzących się z korupcją nie było dla większości problemem, bo, jak wyjaśniali, zjawisko korupcji jest tak powszechne i tyle się o nim mówi, że każdemu nasuwa się mnóstwo skojarzeń. Niektórzy wspominali jednak, że trudno im było znaleźć odpowiednie słowo. Natomiast dla wielu badanych trudność sprawiało segregowanie tych określeń, znalezienie określeń przeciwstawnych, umieszczenie ich wszystkich na osi. Wynikało to z tego, że było ich dużo i że często były to wyrażenia bliskie znaczeniowo. Jedna z dyskutantek przyznała, że zaskoczyło ją znalezienie wśród nich słów skrajnych, gdyż wydawało jej się to niemożliwe:

„Hasła, które żeśmy tam podali były podobne do siebie, no bo nie dało się, przynajmniej ja miałam problem ztakimi przeciwnościami, dla mnie to wszystko było do jednego garnka, bo jest to temat taki no przykry. Ciężko było nam ustalić, po jakimś tam czasie dopiero żeśmy tę oś ułożyli." „Dla mnie to było, że to było wszystko jednakowe, nie że to jest przeciwstawne. Jak były dwa hasła, to ja mówię, że to jedno i to samo."

83 Po przeanalizowaniu różnych możliwości uznano, że najlepszym sposobem osiągnięcia celu badawczego będzie zastosowanie zabiegu, łączącego w sobie cechy circeptu iprojekcyjnej techniki niedokończonych zdań. Z techniki niedokończonych zdań zaczerpnięto treść bodźca inicjującego Korupcja jest to..., zamiast występującego w technikach odwołujących się do metafor i analogii: Korupcja jestjak... Natomiast pozostałe zadania stawiane przed badanymi (czyli wybór par określeń przeciwstawnych, układanie pozostałych określeń na utworzonych osiach, opisanych przez terminy przeciwstawne) zostały zainspirowane circeptem (Lisek-Michalska, 2007). 
„Gorzej z tym umieszczeniem, rozmieszczeniem. Niektóre kartki pasowały do wszystkiego w zasadzie."

Niektórzy zwracali uwagę, że każdy z uczestników inaczej rozumiał pewne określenia, więc pojawiał się problem z umieszczeniem ich na osi. Często jedna osoba rzucała jakąś propozycję, a inni ją akceptowali, bo nikt nie miał lepszego pomysłu: „Dziwne było bym powiedziała (to zadanie). Bo jakby wszyscy nie bardzo zrozumieliśmy, bo pisaliśmy te karteczki, te tytuły i potem trzeba było to jakoś przyporządkować. W pewnym sensie, te kartki najpierw zostały rozdzielone na boki i później pan ze wszystkich boków zebrał je na środek, bo mówi, że na dobrą sprawę pasuje i tu, i tu, i tu. Wszyscy się jakoś na to zgodzili. Ja to potraktowałam tak jak podejrzewam wszyscy, tak nie bardzo zrozumiałe to było. Że ktoś powiedział i reszta się z tą osobą zgadzała i nie miała swojego zdania na ten temat." Można więc stwierdzić, że dla części badanych circept okazał się trudnym, nie do końca zrozumiałym zadaniem. W kilku zaledwie wypowiedziach pojawiły się uwagi, że było to zadanie wymagające myślenia i przez to ciekawe dla uczestników. Pozostali respondenci mieli z nim wiele problemów:

„Początkowy (fragment) był dość trudny, skomplikowany, bo mieliśmy rożne zdania z tymi właśnie słowami, z ułożeniem, z segregowaniem tego, ale wszystko do przeskoczenia, ja bym tam niektóre inaczej ustawił, ale niektórzy mieli inne zdania, tak, że decyzję podejmowaliśmy większością głosów." „Najtrudniejszy? To może ułożenie tych karteczek, na tym diagramie, w kolejności no takiej.... każdy po prostu inaczej to widział wszystko."

Dla niektórych problemem było samo podanie określeń, ponieważ trudno im było znaleźć właściwe słowa lub mieli zbyt wiele pomysłów, a musieli ograniczyć się do kilku: „Najtrudniejszym fragmentem, to było to pierwsze zadanie, kiedy trzeba było na kartkach wypisać, co się kojarzy z korupcją. Jeżeli ktoś chciałby wypisać wszystko, to byłyby stosy chyba tego. I później dopasować te grupy do siebie bo... na tej kartce to było na cztery podzielone i trzeba było to zgrupować. I ciężko jest to zgrupować, ponieważ jest to temat rzeka i wszystko się do tej korupcji praktycznie nadawało, to, co było napisane na kartkach. Uważam, że to zadanie było takie dyskusyjne bardzo."

Były osoby, którym trudność sprawiło opowiadanie własnej historii łapowniczej a przede wszystkim wymyślenie dla niej tytułu - niektórzy stwierdzali, że nie mają zdolności do rozwiązywania tego typu zadań, inni, że nigdy wcześniej czegoś takiego nie robili. Wreszcie sporo respondentów narzekało na trudność oceny zjawisk korupcyjnych, ze względu na zbyt małą skalę ocen, wskazywało na problem jednoznacznego ustosunkowania się do pewnych sytuacji lub niejasność tego zadania: 
„Najtrudniejszy był moment tej oceny, powiedzenie swojego zdania, bo to się wiąże, jeżeli jedne sytuacje są takie bardzo codzienne, no to nie ma wtedy problemu z oceną."

„(...) jeżeli w grę wchodzą jakieś takie sytuacje bardziej drastyczne to wtedy po prostu mnie osobiście było trudniej powiedzieć o tym, czy się ustosunkować."

„Pisaliśmy na kartce punkty pozytywne, negatywne i obojętne, no i ciężko było wybrać, ustalić podzielić."

Jeden z badanych stwierdził, że miał za mało czasu na przemyślenie i zastanowienie się przy wymyślaniu hasła i ocenie korupcji. Inna osoba wspomniała, iż dla niej trudnością był fakt, że uczestnicy różnie rozumieli treść poleceń i zadań.

Wymienione tu techniki to zaledwie mały fragment wielkiego repertuaru zabiegów technicznych stosowanych wbadaniach fokusowych (Billson, 1989). Często w ramach fazy aranżacyjnej moderator inicjuje jakiś zabieg mający na celu przełamanie barier pomiędzy uczestnikami, proponując na przykład typowo dziecięcą zabawę w "głuchy telefon”, „pomidora” lub dokończenie zdania: gdybym był psem, to byłbym (tu oczekiwano podania nazwy rasy psów), ponieważ.... Nie wszystkie tego typu zabiegi są jednakowo neutralne dla wszystkich badanych. Czasem można osiągnąć efekt odwrotny od zamierzonego, ponieważ odczuwany przez uczestnika poziom zaskoczenia i niedowierzania przekłada się w sposób trwały na cały jego udział w sesji. Pojawia się poczucie lekceważenia, niepoważnego traktowania zaproszonych uczestników, bądź po prostu badany kompletnie nie jest w stanie zdefiniować sytuacji, w jakiej się znalazł. Żadne z tych odczuć nie sprzyja jego dobremu samopoczuciu.

W relacjonowanym tu badaniu metodologicznym w celach integracyjnych na początku sesji zastosowano zabieg, co do którego badacz był przekonany, że jest on bardzo bezpieczny pod względem generowania nieprzyjemnych stanów emocjonalnych. Respondenci byli proszeni o opowiedzenie, co dobrego zdarzyło się im w ostatnim czasie. Na podstawie materiałów uzyskanych od respondentów w wywiadach swobodnych należało jednak zrewidować to początkowe przekonanie. Niektórzy badani oceniali tę część pozytywnie, uważali, że pozwoliło to na rozluźnienie się, otworzenie się. Stwierdzali, że przecież każdy znajdzie coś przyjemnego, miłego, o czym mógłby powiedzieć. Jednocześnie wypowiedzi innych skłaniały do pewnych refleksji, że są także ludzie niezbyt pozytywnie nastawieni do życia, że jako naród chętniej i częściej opowiadamy o smutkach niż o radościach. Byli jednak także uczestnicy, dla których konieczność takich zwierzeń była denerwująca i stresująca; jedną z badanych dotknęło pytanie o przyjemne zdarzenia, gdyż boryka się $\mathrm{z}$ samymi problemami, druga wolałaby nie być zmuszana do wypowiedzi już na samym początku spotkania: „To chyba nie jest potrzebne, bo jak wchodzi- 
my, to każdy jest spięty i takie kazanie mówić od razu, to jest takie trochę, no to jest tak jak ktoś się pyta jak się pani czuje, jakie tam uczucia, emocje, to nie jest potrzebne. Powinno być tak, że jak ktoś chce, to niech mówi, jak ktoś nie chce, to niech milczy. Bo pierwsza osoba zawsze musi zacząć, a nie wie co powiedzieć, czy: Nazywam się, czy coś jeszcze, więc to takie trochę... można się wystraszyć jak ktoś nie lubi mówić."

Bardziej ujednolicone opinie badani wyrazili w związku ze sposobem prezentowania się osób biorących udział w sesjach. Respondenci zgadzali się co do tego, że przedstawienie się uczestników i wzajemne poznanie było ważne i potrzebne dla dalszego przebiegu spotkania. Gdy znali już swoje imiona, łatwiej było im się do siebie zwracać. Choć pojawiły się uwagi, że same imiona to za mało, że badani nadal pozostali dla siebie anonimowi. Któryś z respondentów chciałby wiedzieć także coś o pracy i zajmowanych stanowiskach innych, co wydawało mu się znaczące w dyskusji na temat korupcji. Dyskutanci często podkreślali, że zarówno przedstawianie się, jak i opowiadanie o ostatnich przyjemnych zdarzeniach w życiu zbliżyło do siebie uczestników, wpłynęło na pewną integrację grupy, rozładowało napięcie i podenerwowanie i sprawiło, że atmosfera stała się sympatyczna, miła, ciepła:

„To jest bardzo potrzebne i wprawdzie ja myślę, że była wyjątkowo... jakaś taka... no nie - luzacka, bo to może by było źle powiedziane, ale sympatyczna i rozluźniona, że... ale nieraz ludzie są spięci, zamknięci i... i jest to jak najbardziej potrzebne. A komunikowanie się, w momencie, kiedy my mamy w dwie minuty do siebie się zwracać, to te karteczki były jak najbardziej... To taka szkolna, szkolna metoda. Natomiast, natomiast takie opowiedzenie, to... no tak rozluźnia atmosferę. W moim odczuciu. Jest to chyba konieczne."

„Jeżeli mieliśmy karteczki, gdzie ja widziałam, że to jest pani Genia a to jest pani Basia na pewno, w jakiś sposób spowodowało taką, może za duże słowo, ale rodzinną atmosferę."

„Widziałem w samej tej zabawie, odczuwałem to, że jest takie rozładowanie, taka pomoc, że tak jak w konsolidacji tego zebrania."

„Te karteczki z imionami, które... wręcz zwracaliśmy się właściwie w niektórych przypadkach zupełnie po imieniu. No i takie rozluźniające było, co się tam komu zdarzyło miłego, tak, że troszeczkę takie... odskocznia jakby od właściwego tematu."

„No musi być na przełamanie bariery, żeby ludzie się otworzyli, powiedzieli coś o sobie, bo tak to... W osiem osób obcych, no nie ma innej możliwości. Trzeba jakoś po prostu towarzystwo rozbujać."

„Każdy się tam otworzył i jakieś tam lody zostały przełamane.”

Ktoś zwrócił uwagę, że zwracanie się do siebie w formie „pani Basiu”, „panie Marku" jest dziś już bardzo powszechne, jest czymś naturalnym, normal- 
nym. Inny respondent wolałby nawet używać po prostu samych imion, tym bardziej, że uczestnicy byli mniej więcej w jednym wieku.

Zatem z pełną pokorą należy przyjąć, że nie ma technik integracyjnych, dodatkowych, projekcyjnych, które miałyby charakter uniwersalny i pasowały do wszystkich tematów badań i wszystkich kategorii respondentów. Naturalnie nie chodzi tu jedynie o oczywiste modyfikacje techniki ${ }^{84}$, ale samej jej istoty. Jest to niewątpliwie stwierdzenie banalne, ale wielu badaczy ma pewne własne przyzwyczajenia, wręcz nawyki, przekonania o tym, że pewne baterie technik, używając żargonu praktyków - „dobrze chodzą” w fokusach. Zresztą, automatyczne, bezrefleksyjne wprowadzanie stałego zestawu technik dodatkowych do treści scenariusza owocuje nie tylko etycznymi, lecz także poważnymi konsekwencjami merytorycznymi dla wartości uzyskanych danych. W tym nurcie rozważań aspekt jednak zostanie pominięty.

Konkludując, mimo że powyższe rozważania podporządkowane są perspektywie etycznej, konsekwencje dla samego sposobu uzyskiwania danych, dla metody fokusowej są wyraźnie widoczne. Żaden wysiłek wynikający z przesłanek deontologicznych włożony przez badacza w konstrukcję scenariusza dla moderatora nie jest zbyt duży. Warto dokładnie przemyśleć nie tylko to, jakie informacji potrzebuje uzyskać, lecz także to, w jaki sposób zamierza to zrobić, zawsze w kontekście jego wiedzy o konkretnej kategorii badanych. W innym przypadku niestety trzeba się liczyć z tym, że atrakcyjnie pod względem technicznym skonstruowane narzędzie zupełnie nie sprawdzi się empirycznie, a stanowić będzie jedynie źródło stresów dla badanych i oczywiście także dla moderatora, bo to on zmierzy się bezpośrednio z wycofaniem uczestników, a nie zawsze będzie rozumiał jego przyczyny.

\section{RELACJE MIȨDZY UCZESTNIKAMI I POMIȨDZY UCZESTNIKAMI A MODERATOREM}

\section{Porównanie pod kątem zagadnień etycznych kontaktu ankieter - respondent w wywiadzie kwestionariuszowym i uczestnicy - moderator w fokusie}

To, jakie relacje wytworzą pomiędzy sobą uczestnicy FGI ma fundamentalne znaczenie dla ich funkcjonowania jako grupy generującej informacje, o czym pisano tu już wcześniej. Wiele lat temu Z. Gostkowski (1961) napisał: „Z psychologii społecznej i psychosocjologii badających zachowanie ludzkie w małych grupach wiadomo, że zachowanie to - zarówno zachowania bezpośred-

\footnotetext{
${ }^{84}$ Modyfikacja ma miejsce, gdy w technice chińskiego portretu badacz prosi nastolatki o opowiedzenie, jakim pubem byłaby partia X, a osoby dorosłe $\mathrm{z}$ wyższym wykształceniem — o wyobrażenie sobie partii X jako przyjęcia lub koncertu.
} 
nie, jak i symboliczne - jest funkcją sytuacji grupowej, w której znajduje się jednostka. Inaczej mówiąc - w jednych sytuacjach człowiek będzie się wypowiadać inaczej, niż w drugich. Zależy to od tego, jakie afiliacje i identyfikacje grupowe wzbudza dana sytuacja w jego umyśle, czyli innymi słowy, jak definiuje on stosunek społeczny ze swoim rozmówcą. Dlatego też (...) należy przyjąć, że wypowiedź jest funkcją, czy też »korelatem《 danej sytuacji społecznej. Wszelkie wypowiedzi mają walor jako materiał socjologiczny tylko ze względu na sytuację społeczną, układ ról społecznych, w obrębie których zostały wygłoszone" (Gostkowski, 1961)85. Ogromną zaletą badań fokusowych jest to, że formuła wywiadu grupowego jest zbliżona do sytuacji występujących w codziennym życiu, zatem na artykułowane opinie uczestników mają wpływ inni badani i cały kontekst badania. Nie można więc przecenić znaczenia takich relacji pomiędzy badanymi, które są odpowiedzialne za zaistnienie pozytywnych procesów grupowych. Jednocześnie może to być największą słabością wywiadu grupowego, bowiem na badaczu/moderatorze spoczywa odpowiedzialność za charakter tych relacji, za coś, co można nazwać atmosferą spotkania ${ }^{86}$.

Niektóre elementy uruchamiające problemy natury etycznej w relacjach pomiędzy samymi uczestnikami zostały poruszone nieco wyżej, jednak oczywiście nie wyczerpano wszystkich możliwości. Jednym z najsilniejszych i jednocześnie najbardziej powszechnych źródeł dyskomfortu psychicznego badanych jest ich niepokój o to, jak zostaną odebrani przez pozostałych uczestników. Ludzie obawiają się, jak wypadną na tle innych, czy nie okaże się, że są w jakikolwiek sposób gorsi. Przykładem takiej sytuacji może być realizowane przez Autorkę badanie marketingowe. Projekt dotyczył tanich gatunków papierosów ido udziału w sesjach zostali zaproszeni mężczyźni o niskich dochodach, deklarujący się jako palacze takich właśnie marek. W trakcie spotkania, kiedy moderator pozwolił na zapalenie papierosów, badani wyciągnęli z kieszeni opakowania markowych, drogich papierosów. (A w podglądowni przebywali pracownicy działu marketingu, reprezentujący sponsora. Natychmiast zareagowali decyzją o przerwaniu sesji ze względu na niewłaściwy dobór uczestników). Moderator po chwili konsternacji wyjął

\footnotetext{
85 Problem społecznego zakotwiczenia opinii stanowił także przedmiot analiz z perspektywy zjawiska tożsamości grupowej związanej z rolą społeczną (Sztabiński, 1992).

86 Fakt, że FGI jest wykreowany i prowadzony przez badacza stanowi dla krytyków tej metody zasadnicze jej ograniczenie, gdyż staje się on przez to wyraźnie różny od sytuacji naturalnej, co przekłada się na jakość materiału, który jest oceniany z tego względu jako mniej wartościowy, niż na przykład dane zebrane w obserwacji uczestniczącej. Podnosi się, że istnieje ryzyko, iż moderator, aby osiągnąć swój cel, może wywierać wpływ na uczestników. Jednak wydaje się, że w praktyce wpływ moderatora na uzyskany materiał nie jest większy, niż w przypadku obserwacji uczestniczącej lub IDI.
} 
własną paczkę (przygotowaną dla celów badania) niedrogich, zwyczajnych papierosów. Został natychmiast poproszony o poczęstowanie takim papierosem przez mężczyznę, który miał w dłoni jakiś drogi gatunek. Zapytany, czemu nie zapali swojego ekskluzywnego papierosa udzielił wyjaśnienia, że on i kilku innych panów zakupili je specjalnie na spotkanie, bo nie chcieli, aby inni widzieli, że palą tani gatunek. Sesja była kontynuowana.

Nie wolno zatem zapominać, że uczestnicy sesji fokusowej mają mniej lub bardziej wyraźną świadomość bycia ocenianym przez innych badanych i moderatora. Pierwsze spotkanie z grupą zupełnie obcych ludzi jest obciążone szczególnie dużym zagrożeniem wystąpienia postawy lękowej. Poziom odczuwanego lęku jest większy przy licznym (choćby dziesięcioosobowym) audytorium niż w trakcie interakcji z pojedynczą obcą osobą. Może jeszcze wzrosnąć, jeśli badany zidentyfikuje pozostałych uczestników jako kompetentnych i atrakcyjnych społecznie. Nie bez znaczenia jest także skala zaangażowania w interakcje własnej prawdziwej tożsamości - im bardziej otwarcie uczestnik odsłania siebie, tym można oczekiwać, że niepokój o percepcję jego osoby będzie rosnąć. Ta obawa przed oceną wywiera bezpośredni wpływ na ujawniane zachowania werbalne i niewerbalne. W rezultacie każdy z obecnych na spotkaniu dokonuje różnych zabiegów autoprezentacyjnych polegających na manipulowaniu wrażeniem wywieranym na innych. W zależności od tego, jak badany interpretuje reakcje na swoje zachowanie, ten lęk przed oceną rośnie lub maleje. Niebagatelną rolę w obniżaniu poziomu lęku może odegrać moderator pod warunkiem, że jest w stanie trafnie zidentyfikować psychologiczne podłoże interakcji. Ma on do dyspozycji praktycznie nieskończony repertuar tak zwanych „łamaczy lodu” (ice breaking exercises), które mogą zostać wykorzystane do wypracowania lepszego samopoczucia badanych poprzez wzmocnienie ich przekonania, że pozostali uczestnicy są bardzo do nich podobni, tacy sami. Można na przykład poprosić badanych o znalezienie 10 wspólnych dla wszystkich obecnych cech. Zwykle sporządzaniu takiej listy towarzyszy sporo śmiechu, a jednocześnie zadanie to spełnia funkcję integracyjną i osłabiającą poziom lęku przed oceną.

Dowiedziono empirycznie, że badani lepiej czują się w zespole, którego uczestników postrzegają jako zbliżonych do siebie. Stąd zwykle do udziału w sesji zaprasza się osoby „podobne”, chociażby w zakresie kilku cech - dookreśla się przedział wiekowy zapraszanych gości, ich poziom wykształcenia, zamożności, ustala proporcje udziału kobiet i mężczyzn, bądź kompletuje grupę homogeniczną pod względem płci. Wszystkie te zabiegi mają zasadniczy cel — sprawić, żeby zewnętrzne różnice pomiędzy badanymi nie zaciążyły na ich samopoczuciu i nie spowodowały na przykład wycofania się z dyskusji albo, w sytuacji, kiedy komuś zostanie przypisana wyjątkowo wysoka pozycja (status), nie doprowadziły do jej zmonopolizowania przez jednego uczestnika. 
Jest to także jeden z powodów, dla których warto zadbać o to, by w sesji uczestniczyły albo wyłącznie osoby nieznające się nawzajem, albo (jak to się dzieje w małych miejscowościach i na wsiach) tylko takie, które się wzajemnie znają. Jeśli wśród zaproszonych osób obcych znajdzie się chociaż jedna para badanych, którzy dobrze się znają, ich pozycja w grupie natychmiast ulega wzmocnieniu, co bardzo komplikuje wypracowanie dalszych właściwych relacji. Naturalnie może okazać się, że mimo podobieństwa parametrów społeczno-demograficznych i tak występują ogromne różnice pomiędzy uczestnikami (np. dwie kobiety w tym samym wieku mogą wyglądać jak przedstawicielki dwóch pokoleń), ale na to już badacz nie ma żadnego wpływu. Co najwyżej, jeśli na spotkanie przyszło zbyt wielu zaproszonych uczestników, może przed rozpoczęciem sesji podziękować niektórym za wykazaną gotowość i nie wprowadzić ich na spotkanie.

W trakcie dyskusji pomiędzy uczestnikami dochodzi często do konfrontacji poglądów i eskalacji emocji. Oczywiście większe jest prawdopodobieństwo takiego efektu wtedy, gdy przedmiot dyskusji ma dla nich istotne znaczenie i co za tym idzie, gdy angażują oni wartości osobiste, posługują się argumentami, kontrargumentami lub konkretnymi ilustracjami empirycznymi, broniąc słuszności znaczących dla siebie wartości. Jak pisze Krueger, w przeciwieństwie do wywiadów indywidualnych, uczestnicy grup fokusowych relacjonują swoje doświadczenia w obecności osób, co do których zakłada się, że mają podobny status, z którymi dzielą pewien wspólny zakres odniesienia. Członkowie grupy fokusowej komentują także wzajemnie swoje punkty widzenia, często kwestionując opinie, motywy i działania innych, konkretnych członków grupy. W wywiadzie swobodnym do takich konfrontacji nigdy nie dochodzi. W przypadku zogniskowanych wywiadów grupowych, porozumienia albo ich brak są procesami o fundamentalnej roli, które wpływają na naturę i zawartości odpowiedzi w miarę, jak grupa odbywa wywiad. W toku dyskusji, a ściślej werbalizacji poglądów, zostaje odkryty aksjologiczny kontekst funkcjonowania badanego. Co więcej, każda wypowiedź ujawniona podczas dyskusji może generować zagrożenie dla wartości podzielanych przez danego rozmówcę, jeśli dostarcza ona argumentów lub empirycznych ilustracji kwestionujących słuszność zinternalizowanych przez nich wartości. Wywiady indywidualne i grupowe mogą dostarczać dowodów ambiwalencji, niekonsekwencji, zgodności poglądów, albo myślenia na głos w gronie osób, dostarczających informacji. Jednakże, z definicji, indywidualne osoby, dostarczające informacji, nie osiągają porozumienia, ani nie ponoszą porażki $\mathrm{w}$ procesie osiągania porozumienia, i nie negocjują, nie konfrontują, nie antagonizują ani nie poddają bezpośredniej krytyce, nie wyrażają też współczucia wobec siebie nawzajem i nie idą na kompromis wimię dobrych układów z innymi uczestnikami (Krueger, 1997). Wszystkie te procesy są bez wyjątku 
procesami wpływu społecznego, które mogą mieć krytyczne znaczenie dla akceptacji albo odrzucenia nowego albo zmienionego programu albo produktu (Schindler, 1992). Fakt, że takie procesy zachodzą w grupach fokusowych, może rodzić uzasadnioną troskę o wiarygodność wyników, ale nie oznacza to, że dezawuuje je całkowicie - sesja fokusowa stanowi doskonałe laboratorium do badania takich zjawisk.

Wpływ społeczny, oddziałujący w trakcie sesji fokusowej, poza konsekwencjami dla zawartości merytorycznej wypowiedzi uczestników, wywołuje także skutki natury emocjonalnej. Niekiedy te emocje przybierają postać nieoczekiwaną i szczególnie niebezpieczną. W badaniach dotyczących bezpieczeństwa dzieci w Łodzi (Lisek-Michalska, 2010a), szerzej opisanych w następnym rozdziale, odbyły się sesje z uczniami szkół podstawowych, gimnazjów, szkół zawodowych ponadgimnazjalnych i liceów ogólnokształcących. W każdej sesji spotkali się uczniowie przynajmniej dwóch szkół $\mathrm{z}$ danego poziomu, które zajęły ostatnie miejsca w rankingu tych placówek pod względem bezpieczeństwa (ranking został opracowany na podstawie wcześniejszych badań ankietowych) (Michałowska, Daniłowicz, Szymczak, 2008). Jeden z wątków problemowych wprowadzonych do scenariusza moderatora przewidywał konieczność rekonstrukcji cech lidera rówieśniczego i agresora oraz porównanie obu tych „autorytetów” (zob. Aneks, Załącznik 6., cz. III i IV). Podczas dyskusji z uczniami gimnazjów, w trakcie wypowiedzi jednej z uczestniczek, druga - przekonana o tym, że jest liderką dla swoich kolegów - w sposób niewidoczny dla moderatora, ale czytelny dla wszystkich pozostałych zakazała wypowiadania się na temat szkolnego przywódcy. Wykonała gest podrzynania gardła i położyła palec na ustach. Dzieci nie były świadome, że po drugiej stronie lustra weneckiego ktoś je obserwuje. A siedzieli tam studenci z Instytutu Socjologii UŁ i to oni dostrzegli ten niewerbalny komunikat. Uczestniczka, do której została skierowana ta niema informacja przerwała swoją wypowiedź i do końca sesji pozostała milcząca. Oczywiście żaden z pozostałych uczestników spotkania nie dał moderatorowi nawet najmniejszego sygnału na temat zajścia. W interpretacji tego zachowania pomogła wiedza uzyskana w trakcie sesji od badanych uczniów. Wśród gimnazjalistów generalnie obowiązuje zasada, że wtrudnych sytuacjach, w przypadku konfliktu z innymi rówieśnikami, nie zwracają się po pomoc do dorosłych, ponieważ: „Wtedy może być gorzej”. Dorosłych informuje się dopiero wówczas: „jak jest naprawdę źle. (...) Jak zaczynają bić albo coś”. Uczniowie twierdzą, że o zagrożeniu ze strony określonych rówieśników nauczyciele wiedzą, ale nie reagują, ponieważ:

„(Oni) sami się boją... (...) No czasem było tak, że jak koleś nie mógł zdać, to kolegów nasyłał na dyrektorkę." 
„No u mnie nauczycielka mieszkała w wolnostojącym domku i tam w niego rzucali jajkami. Ona dzwoniła na policję, ale ich to nie obchodzi. (...) No, bo oni byli tyle razy zatrzymywani, że ich puszczają już po prostu. Potem zaczęli pisać graffiti, że ją zabiją i w końcu ona sama się powiesiła. (...) Oni się zaczęli chwalić po roku tym."

Można przypuszczać, że ujawnienie poglądów przez uczestniczkę „przywołaną do porządku" przez liderkę, stało się dla tej pierwszej źródłem problemów w rzeczywistości pozaszkolnej. Zobowiązanie etyczne „nie zaszkodzić badanemu" i obietnica (sformułowana w amerykańskim modelu „świadomej zgody"), że jego udział nie przełoży się na przyszłe relacje z innymi, nie zostały w tym przypadku dotrzymane. I pomimo że można tu znaleźć mnóstwo okoliczności usprawiedliwiających moderatora, nie zmienia to faktu, że jedna z osób badanych przeżyła silny lęk, który przeniósł się na jej życie poza salę fokusową. Kodeksy nie regulują precyzyjnie odpowiedzialności badacza za konsekwencje dla badanego wykraczające poza obszar badania. Ale to nie zwalnia z tej odpowiedzialności.

Jednym z niezwykle istotnych warunków dla osiągnięcia sukcesu badawczego w zogniskowanym wywiadzie grupowym jest akceptacja w roli moderatora osoby prowadzącej sesję. Chodzi tu o „dopasowanie” moderatora do antycypowanych oczekiwań badanych, o wybór takiego prowadzącego, z którym określona kategoria uczestników będzie najbardziej skłonna rozmawiać o konkretnym problemie. Oczywiście nie zawsze jest to możliwe, zwykle prowadzenie sesji powierza się osobom sprawdzonym w takim charakterze, których kompetencji badacz jest pewien. Ale w praktyce badawczej zdarzają się także dość kuriozalne sytuacje - na przykład sesje poświęcone trudnościom, z jakimi muszą zmierzyć się kobiety w okresie menopauzy, moderowane przez młodego, niespełna trzydziestoletniego badacza. Nie dość, że sam przedmiot spotkania był bardzo drażliwy, to osoba prowadzącego skutecznie uczyniła porozumienie wręcz niemożliwym. W tym przypadku obu stronom nie było czego zazdrościć - zażenowany moderator i dojrzałe kobiety przeświadczone o tym, że prowadzący nie ma pojęcia, o co pyta.

Moderator jest jedynym łącznikiem pomiędzy badaczem a badanymi. Odbiór osoby i zachowania moderatora ma fundamentalne znaczenie dla fazy terenowej badania. To od niego i jego kompetencji w znacznym stopniu zależy, jakie materiały do analizy uzyska badacz. Jest to jednocześnie postać niezwykle ważna dla uczestników. Dowodzą tego wypowiedzi uczestników sesji fokusowych uzyskane w wywiadzie swobodnym w przywoływanym tu już badaniu metodologicznym. Respondenci zwracali uwagę na sposób bycia prowadzącej i jej podejście do uczestników — „miła, sympatyczna, budząca zaufanie" - podkreślając jej pozytywny wpływ na ich dobre samopo- 
czucie, rozluźnienie, aktywny udział w dyskusji i swobodną, przyjemną atmosferę spotkania:

„Jakoś tak przyjaźnie do nas podeszła. I jakoś tak, dzięki temu, to myślę, że chyba my żeśmy się dobrze czuli."

„Wprowadziła bardzo dobry nastrój i wszystko bardzo dobrze wytłumaczyła."

„Bardzo dobrze poprowadziła. Wprowadziła taki raczej spokój, luz.”

Wiele osób było zdania, że dzięki moderatorowi dyskusja przebiegała sprawnie, bez zakłóceń, nie było poczucia jakiegoś chaosu, bałaganu:

„Doskonale dawała sobie radę z grupą."

„Przygotowana była bardzo dobrze, panowała nad wszystkim.”

Niektórzy podkreślali dyskrecję prowadzącej, dzięki czemu dyskusja sprawiała wrażenie bardzo swobodnej, luźnej, spontanicznej. Dla badanych ważna była możliwość swobodnego, pełnego wypowiedzenia się, którą stworzyła im prowadząca:

„Po kilku minutach stwierdziłam, że to jest odpowiednia osoba na odpowiednim miejscu. Bardzo, bardzo miło. Czekała ładnie, wysłuchała, aż ostatnia osoba skończyła, chwila przerwy i dopiero ona coś tam powiedziała. Nie wchodziła w słowo, a to jest bardzo ważne."

„Starała się zachować neutralną pozycję i po prostu nie wpływała na to, co ludzie mówili. Po prostu słuchała jako obojętna i według mnie to się dobrze wywiązała z tego, bo to była taka jej rola."

„Nie narzucała jakiegoś toku myślenia, tylko każdy mówił to, co właściwie uważał.”

Respondenci w tym badaniu mieli poczucie, że nie są do niczego zmuszani, że moderator niczego im nie narzuca i nie sugeruje a w razie jakichś problemów będzie służył im pomocą: „Panowała nad dyskusją, spokojnie, była opanowana, wiedziała, o co chodzi, jeżeli był jakiś kłopot to usilnie nie wymagała odpowiedzi jak ktoś nie wiedział, zagubił się, to nie było, że na siłę musi, to jest ważne, nie byliśmy w szkole, że musieliśmy, ktoś może się zaciąć, ktoś może się chwilę zastanowić, albo nie może znaleźć pewnych słów, żeby wypowiedzieć swoje myśli to nie było to natarczywe i pani nie nalegała na siłę." Byli zadowoleni ze sposobu wprowadzania ich w kolejne etapy sesji przez prowadzącą i wyjaśniania przez nią zadań: „umiała wytłumaczyć, mówiła zrozumiałym językiem"87. Uważali ją za osobę konkretną, rzeczową, „znającą się na rzeczy”, kompetentną.

Zadanie moderatora w zogniskowanym wywiadzie grupowym ma znacznie bardziej skomplikowany charakter, niż to, do czego zobowiązany jest

87 Fragmenty wypowiedzi uzyskanych od uczestników badania fokusowego w wywiadach swobodnych przeprowadzonych po zakończeniu sesji. „Zogniskowany wywiad grupowy. Studia nad metodą" (Grant KBN), kierownik: Jolanta Lisek-Michalska. 
ankieter $\mathrm{w}$ wywiadzie z pojedynczym respondentem. 0 ile $\mathrm{w}$ wywiadzie indywidualnym ankieter poza skupieniem się na wymiarze merytorycznym rozmowy, śledzi uważnie reakcje swojego badanego, o tyle moderator nadzoruje nie tylko to, co dzieje się z jego aktualnym rozmówcą, ale także kontroluje relacje $w$ grupie jako całości. Jeśli zgodzić się, że w wywiadzie indywidualnym czasem ankieterowi trudno zachować właściwą neutralność ze względu na poglądy czy osobowość badanego, to wyzwanie, przed którym staje moderator, konfrontując się jednocześnie z ośmioma czy dziesięcioma osobami, jawi się jako znacznie trudniejsze. Oczywiście chodzi tu przede wszystkim o badania społeczne, a nie marketingowe, w których przedmiot dyskusji jest znacznie mniej emocjonalnie angażujący. Mimo że moderator zwraca się na początku sesji do badanych z prośbą, aby zabierali głos pojedynczo, to przecież $\mathrm{w}$ ferworze dyskusji rzadko kiedy taki postulat jest przestrzegany. Moderator poza kontrolowaniem kontaktu z aktualnym rozmówcą musi wsłuchiwać się także w głosy pozostałych i wychwytywać spośród nich takie wypowiedzi, do których będzie chciał za moment się odwołać. Zdarza się bowiem, że bardzo interesujące wątki czy argumenty pojawiają się w rozmowach prowadzonych pomiędzy uczestnikami w czasie, kiedy moderator jest skupiony na konkretnym rozmówcy. Często tak zachowują się uczestnicy, którzy, gdy są „wywołani” do wypowiedzi i uwaga całej grupy koncentruje się na nich, nie wyrażają swoich opinii, „uciekają” od takiej sytuacji, a jednocześnie, jako „aktorzy drugiego planu” są autorami istotnych idei. $\mathrm{W}$ takich sytuacjach działania moderatora można porównać do ewolucji akrobaty cyrkowego: aby zadbać o dobre samopoczucie aktualnego rozmówcy powinien go wysłuchać lub przerwać mu w sposób taktowny, powinien poradzić sobie z tymi, którzy właśnie koniecznie chcą podzielić sie z nim własnymi opiniami i powinien skłonić tego istotnego uczestnika do publicznego powtórzenia wypowiedzianych "na boku” kwestii. I to wszystko z dbałością o komfort psychiczny zainteresowanych. To zdecydowanie więcej do opanowania niż w wywiadzie indywidualnym. Dużo łatwiej o jakieś niedopatrzenia. Dlatego bardzo użyteczne jest stosowanie przez moderatora w trakcie sesji specjalnej słuchawki, za pośrednictwem której osoby przebywające w podglądowi mogą zwrócić uwagę prowadzącego na jakieś przeoczone przez niego wypowiedzi. Jeśli ankieter $w$ wywiadzie indywidualnym popełni jakieś poważne błędy, które zakłócą przebieg komunikacji, zawsze może, nauczony zdobytym doświadczeniem, zadbać o to, by następny wywiad był wolny od tych wad. W przypadku badań ankietowych takich indywidualnych kontaktów $\mathrm{z}$ badanym jest kilkadziesiąt lub kilka tysięcy. W badaniach z wykorzystaniem wywiadów swobodnych robi się ich przynajmniej kilkanaście. Ale błędów popełnionych w trakcie sesji zwykle już nie można naprawić. W projekcie fokusowym bowiem takich spotkań 
jest zaledwie kilka, czasem nawet tylko dwa lub trzy. Dlatego warto powierzać prowadzenie sesji moderatorom z dużym doświadczeniem, sprawdzonym - wtedy ryzyko utraty materiału z sesji zdecydowanie maleje.

Pozostając przy porównaniu pracy ankietera w badaniach surveyowych i moderatora $w$ fokusach, warto przyjrzeć się jeszcze jednej kwestii, mianowicie, korzystając $\mathrm{z}$ analogii do efektu ankieterskiego $\mathrm{w}$ wywiadach kwestionariuszowych - efektowi moderatorskiemu. Efekt ankieterski88 jest definiowany jako wpływ, jaki ankieter wywiera na respondenta podczas realizacji wywiadu. Może on mieć charakter intencjonalny, ale częściej - niecelowy. Jest wówczas wynikiem mimowolnych sygnałów ankietera, którymi daje wyraz swojej akceptacji, bądź dezaprobaty treści/formy odpowiedzi i/lub osoby respondenta. Im bardziej respondentowi zależy na określonym sposobie spostrzegania go przez ankietera, tym ten efekt jest silniejszy.

Przyjmuje się, że efekt ankieterski ma swoje źródła: po pierwsze, w cechach społeczno-demograficznych ankietera, czyli jego płci, wieku, wykształceniu i pozycji społecznej, po drugie, w jego cechach osobowości i postawach i po trzecie, w jego zachowaniach. Badany kształtuje w oparciu o te przesłanki swoje wyobrażenie o partnerze interakcji i w większym lub mniejszym stopniu stara się, aby jego własne zachowania zostały odebrane przez badacza przychylnie. Takie same procesy zachodzą u uczestników wywiadów grupowych. I choć w przeciwieństwie do wcześniej wspomnianych błędów popełnianych przez moderatora te rezultaty są od niego w znacznej mierze niezależne, to nie oznacza to, że nie powinny być przedmiotem analizy, najlepiej prowadzonej wraz $\mathrm{z}$ badaczem $\mathrm{w}$ oparciu o zapis DVD. Analiza taka powinna uwzględniać także wymiar etyczny badania, a nie tylko jego warstwę merytoryczną.

\section{Problemy etyczne zWiazane Z rola moderatora}

Moderator w badaniu fokusowym może stanowić zarówno przyczynę, jak i obiekt etycznych problemów. Osoba, która prowadzi wiele sesji, staje w obliczu sytuacji zupełnie niestandardowych, do których nie przygotowuje żaden kurs czy szkolenie. Dobrze ilustrują to poniższe przypadki: we

\footnotetext{
88 Krystyna Lutyńska rozróżnia termin „wpływ ankieterski” i „efekt ankieterski”; ten pierwszy polega na pozytywnym lub negatywnym wpływie ankietera na wyniki badań. Ten drugi zaś to różnica między wynikami uzyskiwanymi przez różnych ankieterów, a wiec różnica miedzy rezultatami tego oddziaływania. W takim ujęciu powyższe uwagi dotyczyłyby „wpływu ankieterskiego”. (zob. też Lutyńska, 1978, s. 143-175; 1993, s. 95-126; 1998, s. $17-$ 37; 1999, s. 32-47) Zdecydowano się jednak na użycie określenia „efekt ankieterski” ze względu na jego powszechne rozumienie w opisanym w tekście znaczeniu.
} 
wspominanym wcześniej projekcie dotyczącym działalności sekt religijnych w Polsce, jeden z uczestników (nomen omen - lekarz psychiatra, specjalizujący się w problematyce praktyk manipulacji stosowanych w sektach) przyszedł na spotkanie pod wpływem alkoholu. W sesji uczestniczyli także inni specjaliści reprezentujący różne ośrodki prowadzące działalność na rzecz ludzi opuszczających sekty oraz rodzin tych, którzy weszli w struktury sekciarskie oraz osoby, którym udało się w okresie 6 miesięcy poprzedzających badanie odejść z sekty. Wspomniany uczestnik co kilkanaście minut wychodził z pomieszczenia, w którym odbywało się spotkanie i wracał coraz bardziej nietrzeźwy. Wszyscy obecni w pokoju uczestnicy byli świadomi jego postępowania. Moderator odczuwał potrzebę wyjaśnienia tej sytuacji. Wyproszenie tego uczestnika wiązało się z narażeniem go na wstyd (nawet, gdyby uznać, że byłaby to bardzo łagodna i w pełni zasłużona konsekwencja), a przyzwolenie na to, żeby pozostał, czyniło całą sytuację niekomfortową dla pozostałych uczestników i odciągało ich uwagę od celu spotkania. Należy dodać, że wszyscy badani przyjechali na sesję bez żadnej rekompensaty finansowej ze strony organizatora, nawet bez zwrotu kosztów podróży i czekała ich droga powrotna m.in. do Krakowa, Warszawy i Gdańska. Tylko ten lekarz był z Łodzi, zatem poniósł relatywnie najmniejsze koszty dotarcia na badanie (finansowe, czasowe i wszelkie inne), ale też, jak wszyscy pozostali, nie oczekiwał żadnych materialnych korzyści. W czasie, kiedy kolejny raz opuścił pomieszczenie, moderator zwrócił się do uczestników sesji z zapytaniem, czy życzą sobie, aby podziękować temu uczestnikowi za udział w spotkaniu, czy też, ich zdaniem, powinien pozostać do końca, zakładając, że wytrwa. Ku zaskoczeniu moderatora wszyscy opowiedzieli się za tym, aby ten mężczyzna pozostał na sesji. (Wkrótce okazało się, że dla celu badania była to bardzo korzystna decyzja, ponieważ sprowokował jedną swoją wypowiedzią wielkie emocje, które zaowocowały bardzo interesującym materiałem badawczym. Inna sprawa, czy etycznie było to właściwe.).

Inne zdarzenie spotkało studenta, który w ramach zajęć specjalizacyjnych moderował pierwszą w swoim życiu sesję fokusową. W podglądowi przebywali wszyscy koledzy z tej grupy studenckiej i nauczyciel akademicki. Badanie dotyczyło zasiłku rodzinnego, tak zwanego „becikowego”. W sesji uczestniczyły kobiety, które były matkami przynajmniej czworga dzieci. Dwie z nich przyszły na spotkanie z dziećmi - jedno było niemowlęciem. Akurat ta kobieta usiadła tuż przy moderatorze. W pewnym momencie w sposób dla niej (i pozostałych pań) zupełnie naturalny, odsłoniła pierś i zaczęła karmić niemowlę. Moderator, dwudziestodwuletni mężczyzna zasłabł z wrażenia. Przez kilka minut zupełnie nie był w stanie wydobyć z siebie głosu, stał się bardzo blady. Po zakończeniu sesji drżały mu ręce, nogi, był tak wyczerpany tym przeżyciem, że został zawieziony do domu taksówką. 
Moderatorzy $\mathrm{z}$ dużym doświadczeniem badawczym zgodzą się ze stwierdzeniem, że nie ma dwóch takich samych sesji, nawet, jeśli projekt przewiduje ich kilkanaście (przynajmmniej w badaniach społecznych). Zawsze może zdarzyć się coś nietypowego, zaskakującego, trudnego dla moderatora. Dlatego należy także jego rolę rozważyć w kontekście reguł etyki, jakie powinny być zachowane w badaniach fokusowych.

Dla moderatora zaangażowanego $\mathrm{w}$ projekt prowadzenie sesji fokusowej jest bardzo intensywnym wysiłkiem intelektualnym i psychicznym. W praktyce badawczej częste są przypadki nadmiernej eksploatacji moderatorów, czyli planowanie dwóch albo nawet trzech sesji w ciągu jednego dnia, $\mathrm{z}$ krótkimi tylko przerwami. Jeśli dyskusja koncentruje się na marce mydła, to wyczerpanie moderatora ma głównie charakter fizyczny. Choć naturalnie jest to znaczne uproszczenie, bo $w$ fokusie neutralny przedmiot dyskusji nie jest równoznaczny z tym, że moderator nie odczuwa emocji i nie koncentruje się mentalnie. Oba te procesy występują jednak zdecydowanie silniej w badaniach społecznych, szczególnie zogniskowanych wokół zagadnień drażliwych. Wtedy emocje i napięcie odczuwane przez uczestników w sposób oczywisty obejmują także moderatora, który musi kontrolować proporcje pomiędzy zadaniem, jakie ma do zrealizowania (uzyskanie informacji) a samopoczuciem badanych i relacjami w grupie. Dla zewnętrznego obserwatora wysiłek, jaki wkłada doświadczony moderator w prowadzenie sesji, jest zwykle niedostrzegalny. Ale to nie oznacza, że nie jest odczuwany przez niego samego. Warto pamiętać o tym, że moderator w badaniach społecznych często jest zmuszony do wysłuchania opinii kompletnie niezgodnych z własnym światopoglądem i jednocześnie, inaczej niż pozostali uczestnicy, zwykle nie ma możliwości komentowania, wyrażenia swojego krytycznego stanowiska. Czasem wysłuchuje relacji, które dla niego samego mogą być wstrząsające. I znowu musi powstrzymać się od wyrażenia własnego poglądu, bądź ujawnienia stanu emocjonalnego. Nadmierne skumulowanie takich przeżyć prowadzi do wypalenia zawodowego.

Każdy, kto kiedykolwiek przeprowadzał standaryzowany wywiad w oparciu o kwestionariusz, w którym występowały pytania obciążone różnymi wadami (na przykład pytania niedostosowane do respondenta, świadczące o braku dostatecznej wiedzy badacza o przedmiocie, zawierające wadliwie skonstruowane alternatywy itp.) wie, że ankieterzy stosują w takich sytuacjach różne strategie. Jedynie ci bardziej odporni (lub obojętni) na reakcje respondenta decydują się odczytać bez zmian takie ułomne pytanie. Pozostali wybierają jedno $\mathrm{z}$ dwóch rozwiązań: albo po prostu pomijają je zupełnie, albo zmieniają jego treść lub formę. W taki sposób postępowała zdecydowana większość studentów, którzy po raz pierwszy w życiu występowali $\mathrm{w}$ charakterze ankieterów w badaniu realizowanym w oparciu o niedos- 
konały kwestionariusz ich autorstwa. Uznali, że w bezpośrednim kontakcie $\mathrm{z}$ badanym bardziej zależało im na pozytywnym odbiorze przez niego własnej osoby, niż na rzetelnym przestrzeganiu instrukcji ankieterskiej. Nie wydaje się, aby doświadczeni ankieterzy, którzy przeprowadzają setki wywiadów, postępowali inaczej. Ujawnienie takich odstępstw od procedury praktycznie jest niemożliwe, czego ankieterzy mają świadomość.

Sytuacja moderatora w przypadku pracy $\mathrm{z}$ wadliwym scenariuszem jest inna. Wprowadzane przez niego do narzędzia badawczego modyfikacje są zarejestrowane i z pewnością o takim fakcie dowie się badacz - kierownik projektu i często także autor scenariusza. Moderator jest zatem zmuszony do rozstrzygnięcia, czy bezkrytycznie przestrzegać zapisów narzędzia badawczego, czy, dostrzegając negatywne reakcje uczestników skierowane pod jego adresem wówczas, gdy zadaje z ich punktu widzenia niewłaściwe (niestosowne) pytania, zrezygnować z tego w kolejnej sesji. Nie zawsze bowiem pertraktacje $\mathrm{z}$ autorem scenariusza są możliwe i skuteczne.

Warto poruszyć jeszcze jeden wątek związany z rolą moderatora. Otóż $\mathrm{w}$ wywiadach standaryzowanych prawie bez znaczenia jest to, czy ankieter ma wiedzę merytoryczną o przedmiocie wywiadu. Jakieś podstawowe kwestie można zresztą wyjaśnić w opracowanej na jego potrzeby instrukcji. W badaniach fokusowych (szczególnie społecznych) rzecz wygląda zupełnie inaczej - sam scenariusz nie jest wystarczający do tego, by prowadzić dyskusję z „ekspertami w sprawie” (jakakolwiek by ona była), a brak kompetencji moderatora w kwestiach będących tematem dyskusji jest natychmiast wychwytywany przez uczestników, którzy mogą odebrać to jako przejaw lekceważenia. A takie zdefiniowane sesji nie tylko łamie podstawowe zasady etyczne, ale niszczy jej wartość pod względem informacyjnym.

\section{Problemy etyczne realizatora badań}

\section{Selekcja/rekrutacja uczestników sesji}

Ponieważ dobór badanych nie ma charakteru reprezentatywnego w sensie statystycznym, materiał nie daje szansy na formułowanie generalizacji, warto jest zadbać o to, aby konkluzje odnosiły się do precyzyjnie określonych i poprawnie dobranych kategorii respondentów. W praktyce ten ostatni warunek nie zawsze bywa spełniany. Do takiej sytuacji może dojść co najmniej na dwa sposoby: albo ankieter zrekrutuje osobę, która nie spełnia określonych parametrów doboru, albo zaprasza uczestników ze zbyt mało zróżnicowanych środowisk, często ciągle z tych samych.

Powszechna pokusa, którą odczuwają ankieterzy-selekcjonerzy, to dążenie do minimalizowanie wysiłku wkładanego w proces rekrutacji uczestni- 
ków sesji fokusowych. Stąd w sposób bez mała naturalny pojawiać się może tendencja do ułatwiania sobie tego zadania przy pomocy rozmaitych strategii własnego autorstwa. To zagadnienie tylko z pozoru ma charakter metodyczny, czy też inaczej mówiąc, techniczny. W rzeczywistości dotyka postaw etycznych współpracowników badacza wobec całego przedsięwzięcia.

Przy okazji realizacji projektów badawczych ze studentami specjalizacji metodologiczno-badawczej (studenci Socjologii - I i II roku studiów magisterskich) rekonstruowano ścieżki, jakimi poruszali się w celu dotarcia do potencjalnych uczestników sesji fokusowych. Pomimo braku wcześniejszych doświadczeń w tym zakresie i zalecenia, aby nie porozumiewali się ze sobą $w$ tej kwestii, okazało się, że uruchamiali podobne procedury. Na przykład, kiedy należało zaprosić na sesje nauczycieli, kierowali się do szkół, które sami ukończyli. Jeśli w projekcie przewidziano kilka sesji, zapraszali kilkoro nauczycieli z tej samej szkoły, przyporządkowując ich do różnych terminów spotkań, odległych od siebie o kilka dni, zatem istniała doskonała możliwość wymiany informacji pomiędzy tymi, którzy już brali udział w spotkaniu, a tymi, którzy się na nie dopiero wybierali. Podobną regułę stosowali także przy rekrutacji innych kategorii badanych.

Znacznie sprawniejsze sposoby wypracowują sobie na własny użytek ankieterzy-selekcjonerzy na stałe wykonujący takie zajęcie. Posiadają swoje sieci znajomych, dzięki którym wielokrotnie zapraszają osoby z tych samych środowisk. Docierają do potencjalnych uczestników, również korzystając z rekomendacji osób, które wyraziły już zgodę na udział w tym konkretnym badaniu. Proszą wówczas o kontakt z kimś spośród znajomych rekrutowanego uczestnika, z kimś, kto spełnia wymagane kryteria. Szczególnie powszechny jest ten proceder $w$ badaniach marketingowych, gdzie lista parametrów doboru osób do badania nie jest zbytnio rozbudowana. Rezultat dla całego przedsięwzięcia oczywisty - ograniczenie różnorodności środowisk reprezentowanych przez uczestników i zmniejszenie w ten sposób urozmaicenia uzyskanych informacji.

Nie jest to jedyna pokusa ankieterów-selekcjonerów. W przypadku rozbudowanych kryteriów rekrutacyjnych albo krótkiego czasu przewidzianego na zgromadzenie uczestników, pojawia się skłonność do ułatwiania sobie zadania i albo ankieter zaznacza właściwą wartość cechy, która kwalifikuje osobę do badania bez jej wiedzy, albo wprost umawia się z nią, żeby zafałszowała określony parametr. Oczywiście nie dotyczy to cech społecznodemograficznych, łatwych do weryfikacji, ale kryteriów merytorycznych, na przykład deklarowanego poparcia dla jakiegoś ugrupowania politycznego, ilości czasu spędzanego przed telewizorem czy ulubionych napojów. Albo, jeśli takie są oczekiwania badacza, ankieter zobowiązuje potencjalnych 
uczestników, będących znajomymi, bądź członkami tej samej rodziny, aby w trakcie sesji udawali, że się nie znają. Wtedy nie tylko sam oszukuje, ale jeszcze skłania do tego innych. Nawet bardzo rozbudowane procedury kontroli mogą w niektórych przypadkach nie ujawnić nieuczciwości ankietera i/lub uczestnika. 0 ile na prawdomówność uczestnika badacz nie ma żadnego wpływu, o tyle chyba jedynym sposobem na wzrost rzetelności selekcji ze strony ankieterów-rekruterów jest (poza procedurami kontrolnymi) ciągłe staranie się ze strony badacza, aby wykształcić w nich świadomość wagi tej sprawy dla sukcesu całego przedsięwzięcia. Jaki zaś powód zafałszowania parametru może wystąpić u potencjalnego uczestnika? Jedną z najprostszych odpowiedzi jest chęć wzięcia udziału w badaniu i uzyskania gratyfikacji. Jest to zjawisko szczególnie dobrze znane badaczom marketingowym (Lisek-Michalska, 2007, s. 311-327).

Opisane wyżej postępowanie ankieterów-selekcjonerów z pewnością nie zasługuje na określenie „etyczne”. Jednak jest także druga strona tego medalu, mianowicie realne trudności ze zrekrutowaniem ludzi do udziału w badaniach fokusowych, szczególnie w tych projektach badawczych, których budżet nie umożliwia wypłacania uczestnikom wysokich gratyfikacji (czyli głównie badania w obszarze pomocy społecznej, pracy socjalnej i in.).

Od kilkunastu lat obserwować można w Polsce dwie na pozór sprzeczne tendencje $-\mathrm{z}$ jednej strony lawinowo rośnie liczba realizowanych badań różnego rodzaju (badania marketingowe, polityczne, opinii publicznej, społeczne), a z drugiej strony wzrasta odsetek niedostępności respondentów w badaniach surveyowych (będący nie tylko rezultatem odmów) (Grzeszkiewicz-Radulska, 2009, s. 175-202). Można zasadnie spodziewać się, że te prawidłowości dotyczą także badań fokusowych, przynajmniej tych z obszaru badań społecznych.

Paweł Daniłowicz (2004) szukał powodów trudności ze zrekrutowaniem uczestników do naukowych badań fokusowych w niskim poziomie akulturacji tego sposobu zdobywania informacji (zob. też Przybyłowska I., 1996), badań społecznych w Polsce: „Mówiąc o akulturacji, należy zwrócić uwagę na to, że przebiega ona w dwu płaszczyznach:

1) jednostkowej,

2) ogólnej.

Akulturacja realizowana w płaszczyźnie jednostkowej oznacza naturalizację określonej metody zbierania informacji, czyli mówiąc w dużym uproszczeniu do upodobnienia naukowego sposobu gromadzenia danych do potocznych zachowań, których celem jest pozyskiwanie informacji. W tym też sensie mówi się na przykład o akulturacji badań surveyowych czy sondaży realizowanych przy użyciu wywiadu kwestionariuszowego. Językowym wyrażeniem takiego postępowania adaptacyjnego jest nazywanie 
tego sposobu porozumiewania się rozmową. Naturalizacja metody polega, ogólnie rzecz ujmując, na minimalizacji sztuczności nienaturalności sposobu uzyskiwania informacji. Należy tu zwrócić uwagę na fakt, który akcentuje wyraźnie Gostkowski mówiąc, że chodzi tu nie tyle o rzadkość występowania zachowań towarzyszących zdobywaniu danych, ile o anomii, nieokreśloność sytuacji społecznej, w której ono zachodzi.

Akulturacja w płaszczyźnie ogólnej oznacza zaś to, co Gostkowski (1966) nazywa społeczną lokalizacją badania, a więc stopień w jakim w danym społeczeństwie znana jest idea badań, stopień zinstytucjonalizowania badań czy zintegrowanie ich z ideologią i kulturą badanego społeczeństwa. Chodzi tu zatem głównie o stopień akceptacji społecznej dla informacji z badań o nim samym.

Akulturacja ogólna w znacznym stopniu związana jest $\mathrm{z}$ akulturacją szczegółową. Jeśli bowiem idea badań jest społecznie akceptowana ma swojego instytucjonalnego nadawcę, czy instytucjonalnych nadawców i powszechnego adresata, przenika do kultury danego społeczeństwa i staje się elementem jego codziennej rzeczywistości. Stwarza przez to podatny grunt dla stosowania coraz to nowych sposobów uzyskiwania informacji. Nie oznacza to jednak społecznego przyzwolenia na każdy dowolny sposób uzyskiwania informacji, a ponadto nie eliminuje problemu wartości informacji otrzymywanych przez stosowanie konkretnych metod. Innymi słowy akulturacja w płaszczyźnie jednostkowej przebiega do pewnego stopnia niezależnie od akulturacji w płaszczyźnie ogólnej chociaż wzajemnie się przenikają. (...) Być może zatem jest tak, że jako społeczeństwo chcielibyśmy o sobie wiedzieć coraz więcej, chociaż nie koniecznie jesteśmy gotowi, $\mathrm{z}$ różnych zresztą względów, być źródłem tych informacji. W płaszczyźnie ogólnej akulturacja metody wywiadu zogniskowanego związana jest $\mathrm{z}$ takimi aspektami jak powszechność stosowania metody, czy też zgodność formy kontaktu z ze społeczną praktyką komunikowania się."

W przeprowadzanych badaniach metodologicznych ${ }^{89}$ poddano m.in. sprawdzeniu gotowość ludzi do uczestnictwa w badaniach fokusowych (Daniłowicz, 2004). W pierwszym etapie przy użyciu wywiadu kwestionariuszowego, po przekazaniu 269 respondentom wyczerpującego opisu badania fokusowego, nieco ponad $1 / 3(35,9 \%)$ wyraziło wstępną gotowość do udziału w takim przedsięwzięciu (prawie 60\% nie zgodziło się, a niespełna 5\% nie miało zdania). Po dołączeniu informacji, że sesja ma dotyczyć zagadnień korupcyjnych, jeszcze zwiększył się odsetek odmów (30,9\% badanych wyraziło zgodę, odmówiło - 58,3\%, a 10,8\% nie miało zdania). Po kilku dniach nawiązano ponownie kontakt z tymi osobami, które wstępnie wyraziły zainteresowanie

89 „Zogniskowany wywiad grupowy. Studia nad metodą” (Grant KBN), kierownik: Jolanta LisekMichalska. 
uczestnictwem w sesji fokusowej, by ustalić dogodny dla nich czas na jej zorganizowanie. Spośród 48 osób, z którymi skontaktowali się ankieterzy dokładnie połowa, 24 osoby, odmówiły przyjścia na spotkanie. Jak precyzyjnie wylicza to Daniłowicz: „(...) zaproszeniami objęto więc w sumie 72 osoby, z których $32-$ odmówiły udziału w badaniu, 40 osób przyjęło zaproszenie, a na wszystkich czterech sesjach pojawiły się łącznie 24 osoby."

W obliczu takich katastrofalnych rezultatów staje się bardziej zrozumiała skłonność ankieterów-selekcjonerów do „upraszczania” sobie życia. Odsetek osób rezygnujących z udziału w badaniach, mimo wstępnej akceptacji, dowodzi stopnia trudności, z jakimi muszą zmierzyć się „łapacze”.

Problem zachowania etyki w procedurze rekrutacji nie zawsze leży po stronie ankietera-selekcjonera lub samego badanego. W praktyce badawczej zdarza się także jeszcze jeden rodzaj sytuacji związanej z doborem osób do badania, tylko, że w tym przypadku negatywnym bohaterem nie jest ankieter, ale przedstawiciele firm badawczych, współpracownicy badacza. Chodzi tu o takie okoliczności, kiedy w podglądowi na rozpoczęcie sesji czekają przedstawiciele zleceniodawcy, a nie ma wymaganej liczby uczestników. Reprezentant ośrodka badawczego, działając pod presją, świadomy, że spotkanie musi dojść do skutku (bo z jednej strony byłaby to bardzo niezręczna sytuacja wobec osób zgromadzonych za weneckim lustrem, a z drugiej strony dodatkowe koszty obciążające firmę realizującą badanie i ryzyko utraty pracy) decyduje się na zwerbowanie do badania osób zupełnie przypadkowych, przechodniów, pracowników zatrudnionych w miejscu realizacji badania, osób, które pod względem demograficznym, przynajmniej na podstawie obserwacji, odpowiadają kryteriom selekcyjnym, ale jednocześnie są to ludzie, o których zupełnie nie wiadomo, czy spełniają wymagania "merytoryczne”. W imię zasady show must go on sesje z taką strukturą uczestników odbywają się z oczywistymi konsekwencjami dla wartości zgromadzonych danych.

Wszystkie opisane wyżej przypadki można próbować eliminować poprzez rozmaite zabiegi nadzorcze. Jednak nawet najbardziej wyrafinowane metody kontroli nie pozwolą uzyskać takich rezultatów, jakie możliwe są do osiągnięcia wówczas, jeżeli postępowanie współpracowników badacza będzie regulowane przez uwewnętrznione w nich przekonanie o wartości zachowania w każdym etapie badania zasad etycznych. Zatem nie wystarczy, że badacz kierujący projektem będzie dbał o aspekty etyczne swojej działalności, ale konieczne jest, aby potrafił przekonać o ich znaczeniu także swoich współpracowników. Kolejny raz okazuje się, że względy etyczne znajdują bezpośrednie przełożenie na funkcjonowanie metody.

Inny problem pojawia się, kiedy na sesję zaprasza się większą liczbę uczestników, niż docelowo ma w niej uczestniczyć i okazuje się, że przycho- 
dzą wszyscy. Sytuacje takie są szczególnie częste w badaniach przeprowadzanych na wsiach i w małych miasteczkach ${ }^{90}$. Zapraszanie nadprogramowej liczby osób w nieznanym badaczowi środowisku, w którym wcześniej nie prowadził żadnych badań jest działaniem ze wszech miar słusznym ze względów organizacyjnych i finansowych. Jednak badacz musi także wypracować strategie etycznego postępowania wobec tych, z których udziału zrezygnuje. Wbrew pozorom nie jest to łatwe zadanie. Organizator spotkania musi wówczas zmierzyć się z wieloma trudnościami. Czasem ludzie nie potrafią zrozumieć, dlaczego do udziału w sesji zaprasza się jednych, a innym dziękuje za przybycie i nie chcą opuścić pomieszczenia, mimo że ankieterzyselekcjonerzy mieli obowiązek powiadomić ich w trakcie rekrutacji o fakcie zapraszania osób „zapasowych”. Dobrze jest, jeśli na takich wyjazdowych badaniach moderatorowi towarzyszy inny członek zespołu badawczego, który może wziąć na siebie rozwiązanie tej sytuacji, podczas gdy moderator rozpoczyna sesję w innym pomieszczeniu. I naprawdę nie zawsze załatwia sprawę zapłacenie tym nadprogramowym osobom połowy wynagrodzenia uczestnika, ponieważ one po prostu czują się zawiedzione. A jeśli planuje się w tej miejscowości przeprowadzenie jeszcze kilku sesji, to wiadomość o ich niewłaściwym potraktowaniu z pewnością dotrze do następnych potencjalnych uczestników i może zaważyć na ich stosunku do badania. Dlatego tym, z których udziału badacz rezygnuje, warto poświęcić czas i uwagę i zrobić wszystko, aby złagodzić ich rozczarowanie. Oczywiście, może być także sytuacja odwrotna - pomimo zaproszenia większej liczby uczestników, nie zjawia się nawet minimalna ich liczba konieczna do poprowadzenia sesji.

Sytuacja taka miała na przykład miejsce w (opisanym bardziej szczegółowo rozdziale IV) badaniu z dziećmi i młodzieżą, dotyczącym ich bezpieczeństwa. Uczestnicy rekrutowali się ze szkół, w których stwierdzono w oparciu o badania ilościowe - najwyższy poziom zagrożenia bezpieczeństwa uczniów. Na każdą sesję zaproszono większą liczbę dzieci, niż ustalone przez badaczy minimum, co okazało się zabiegiem słusznym, gdyż na żadne spotkanie nie stawił się komplet zaproszonych gości. Warto również zaznaczyć, że nie doszła do skutku w pierwszym terminie sesja z uczniami ponadgimnazjalnych szkół zawodowych, ponieważ z zaproszonych dziesięciorga osób, które dzień wcześniej potwierdziły swoje przyjście telefonicznie, przybyły zaledwie trzy. Z zebranych nieformalnie informacji wynikało, że potencjalni uczestnicy umówili się ze sobą i postanowili zrezygnować $\mathrm{z}$ udziału $\mathrm{w}$ badaniu, bez poinformowania o tym orga-

${ }^{90}$ Spośród wielu takich sytuacji Autorce najbardziej zapadła w pamięć sesja, na którą zrekrutowany do spotkania czterdziestoletni mężczyzna nie mógł przyjść na badanie i w zastępstwie przysłał swojego 78-letniego ojca. 
nizatora. Ale przecież należało jakoś postąpić wobec tych, którzy jednak przyszli i nakłonić ich do powtórnego przyjazdu do pracowni fokusowej. W tym przypadku było to szczególnie trudne, ponieważ uczestnikom nie rekompensowano finansowo udziału w badaniach, przygotowano dla nich jedynie prezenty rzeczowe (drobne akcesoria komputerowe: myszki bezprzewodowe, pen-drive'y i in.), zatem nie można było odwołać się do motywacji finansowej. W rezultacie udało się zorganizować sesję w innym terminie, ale to doświadczenie pokazuje, że badacz w społecznych projektach fokusowych powinien przewidzieć także strategie postępowania wobec tych słownych uczestników, którym trzeba wytłumaczyć zaistniałe okoliczności i skłonić ich do powtórnego przybycia.

Jest jeszcze jeden moment poprzedzający sesję, wart uwagi badacza. Chodzi tu o czas, jaki potencjalni uczestnicy spędzają w swoim towarzystwie tuż przed rozpoczęciem sesji. Dobrze jest, z punktu widzenia zadbania o tych ludzi, aby organizatorzy mieli do dyspozycji pomieszczenie spełniające funkcję poczekalni, w której przybyłe osoby mogą się rozebrać, w razie potrzeby ogrzać, napić w zależności od pogody czegoś ciepłego lub zimnego. Z doświadczeń badawczych wynika bowiem, że szczególnie na wsiach i w małych miejscowościach zaproszeni uczestnicy przychodzą znacznie wcześniej, czasem nawet ponad pół godziny przed wskazanym w zaproszeniu terminem. Organizator badania powinien być przygotowany na taką możliwość i zaplanować właściwie warunki, w jakich będą oczekiwać na początek badania. Ten drobny zabieg logistyczny zwiększa prawdopodobieństwo życzliwego nastawienia badanych do całego przedsięwzięcia - do badacza/moderatora, do siebie nawzajem i sprzyja koncentracji na temacie sesji.

\section{Relacja moderator - badacz, moderator - zleceniodawca}

We wcześniejszych fragmentach rozdziału poświęcono już sporo uwagi osobie prowadzącej sesje, choć to nie ona (jako, że jest współpracownikiem badacza, albo samym badaczem) jest głównym podmiotem etycznych reguł obowiązujących w badaniach społecznych. Warto jednak jeszcze wrócić do moderatora i ukazać związane z jego rolą problemy etyczne innego rodzaju, mianowicie takie, które pojawiają się na linii moderator — badacz, moderator - sponsor.

Moderator to osoba, której postępowanie jest oceniane przez wielu ludzi. Przede wszystkim obserwują go i oceniają uczestnicy sesji. Niezwykle uważnie przyglądają się jego poczynaniom osoby zgromadzone w podglądowi. Warto pamiętać, że często oprócz przedstawicieli zleceniodawcy są wśród nich także członkowie zespołu badawczego. Proces oceny jego działalności nie kończy się wraz z zakończeniem sesji. Zapis DVD spotkania następnie trafia do osób, które dokonują transkrypcji. Nagrania będące własnością zleceniodawcy są w przypadku badań marketingowych prezentowane często na 
spotkaniach zespołu pracowników i szczegółowo analizowane, także pod kątem zachowania moderatora. Podobnie zresztą dzieje się w przypadku badań społecznych. Gotowe transkrypcje przejmuje do analizy badacz, który na ich podstawie opracowuje raport końcowy. Zatem zarówno powodów, jak i kryteriów do oceny pracy prowadzącego sesje jest bardzo wiele. Moderator zdaje sobie z tego sprawę, wie, że ciąży na nim odpowiedzialność reprezentowania badacza wobec uczestników, że stanowi wizytówkę badacza i ośrodka wobec zleceniodawców, że jednocześnie reprezentuje siebie jako człowieka wobec wszystkich wspomnianych podmiotów: uczestników, zespołu badawczego i zleceniodawcy. Z pewnością nie jest to komfortowa sytuacja nawet dla doświadczonego moderatora. Od każdego z tych odbiorców może spodziewać się mniej lub bardziej jawnych i krytycznych komentarzy. Jest to element jego roli zawodowej, jednak należy dążyć do tego, aby uwagi krytyczne pochodziły przede wszystkim od badacza-kierownika projektu i były traktowane jako inspiracja do podnoszenia kwalifikacji moderatora, a nie jako przejaw potępienia i negacji jego pracy. Zawodowi moderatorzy powinni być poddawani jakiemuś rodzajowi cyklicznego audytu, którego wyniki byłyby wykorzystane nie tylko do poprawy pracy osoby prowadzącej sesje, ale także mogłyby służyć jako forma terapii dla rozładowania napięć zawodowych. Brak dbałości badacza o etycznie właściwe postępowanie wobec moderatora może stać się źródłem wielu problemów, w tym także może przełożyć się na poziom jego zaangażowania w wykonywaną pracę i w rezultacie na wartości uzyskiwanych danych.

Jednym z problemów etycznych, jakie może napotkać badacz w kontaktach ze zleceniodawcą badania, jest zainteresowanie sponsora uzyskaniem informacji na temat tożsamości uczestników. Jest ono tym silniejsze, im bardziej krytyczne uwagi pod adresem sponsora pojawiły się w wypowiedziach uczestników. Jeżeli relacje pomiędzy sponsorem a osobami badanymi mają być kontynuowane po badaniu, istnieje ryzyko, że ujawnienie informacji dotyczących osób badanych, może zaciążyć na tych relacjach. Chęć poznania i skonfrontowania się ze swoim krytykiem można uznać za naturalną. Ale przecież nie może temu służyć badanie. Każdy badacz $\mathrm{z}$ wieloletnim doświadczeniem spotkał się z wściekłym zleceniodawcą, który właśnie zapoznał się z raportem i domaga się informacji, o tym, który uczestnik wystawił mu taką negatywną ocenę ${ }^{91}$.

\footnotetext{
91 Dr Krzysztof Brocławik, moderator w wieloletnim stażem, zapytany o swoje najgorsze doświadczenie $w$ badaniach fokusowych opowiedział historię o sponsorze, który wybiegł zza weneckiego lustra w trakcie sesji i zaczął pouczać uczestników, jak bardzo się mylą w ocenie jego firmy i oferowanych przez nią usług.
} 
Szczególna sytuacja dotyczy badań biznesowych, kiedy głównym celem zleceniodawcy jest uzyskanie informacji po to, aby wykorzystać je przeciwko uczestnikom lub konkurencji. Próba uzyskania danych, które inni chcieliby w swoim interesie zachować w tajemnicy, jest formą szpiegostwa przemysłowego. Udział w takim projekcie może narazić badacza na konsekwencje z obszaru prawa karnego i cywilnego. Na przykład w badaniu ${ }^{92}$ realizowanym na zlecenie zarządu wielkiej elektrociepłowni, dotyczącym pozycji załogi w radach nadzorczych spółek, jeden z modułów dotyczył rekonstrukcji faktycznej roli, jaką odgrywają przedstawiciele załogi w radzie nadzorczej. Badani stwierdzili, że ich propozycje co prawda nie są zupełnie ignorowane, ale najczęściej sprawa sprowadza się do tego, że są jedynie wysłuchane przez pozostałych członków rady. Przedstawiciele załogi w radzie ich zdaniem nie mają żadnego wpływu na podejmowane decyzje, a szkoda, bowiem ich wiedza techniczna i doskonała znajomość przedsiębiorstwa są wielkimi i niewykorzystanymi atutami, gdyż pozostali członkowie rady takich kompetencji nie posiadają. Przedstawicielom załogi współpracę z innymi członkami rady utrudnia zaangażowanie tych ostatnich w działalność w innych radach nadzorczych. Po zapoznaniu się z transkrypcjami, zleceniodawca niezwykle stanowczo domagał się od badacza identyfikacji osób, które wyraziły najbardziej krytyczne opinie. W atmosferze awantury na szczęście jednak udało się uniknąć ujawnienia tożsamości osób badanych. Można było odnieść wrażenie, że zasadniczym, nieujawnionym badaczowi celem inicjatywy badawczej zleceniodawcy było odkrycie w przedsiębiorstwie pracowników negatywnie postrzegających pracę zarządu i rady nadzorczej.

W praktyce współpraca ze sponsorem w tej kwestii oznacza uzyskanie wyraźnego porozumienia przed rozpoczęciem badania na temat ochrony prywatności badanych i warunków ujawnienia danych o uczestnikach, jakie sponsor uzyska. Należy dokładnie doprecyzować, czy sponsor:

- będzie obserwował przebieg sesji,

- będzie oglądał nagrania z przebiegu sesji,

- uzyska listę imienną uczestników,

- uzyska transkrypcję z przebiegu sesji z nazwiskami.

W zależności od odpowiedzi na powyższe pytania, badacz jest zobowiązany do adekwatnego do sytuacji postępowania; jeśli nie uda mu się skłonić sponsora do rezygnacji $\mathrm{z}$ wglądu $\mathrm{w}$ materiały $\mathrm{z}$ badania, powinien bezwzględnie powiadomić o tym potencjalnych uczestników $\mathrm{w}$ fazie rekrutacji.

\footnotetext{
92 Badanie to Autorka prowadziła w ramach projektu realizowanego przez Ośrodek Naukowo-Badawczy Partycypacyjnych Form Zarządzania UŁ, pod kier. prof. Stanisława Rudolfa.
} 


\section{KONSEKWENCJE DLA OBIEKTU BADANIA}

Na zlecenie jednej ze stacji komercyjnej telewizji w Polsce przygotowano i zrealizowano projekt badawczy dotyczący wizerunku medialno-rynkowego aktorki NN, jako potencjalnej kandydatki do prowadzenia autorskiego „lifestylowego” magazynu telewizyjnego, a w późniejszym czasie również czasopisma o podobnym profilu. Pomysł tego magazynu zaczerpnięty został z amerykańskiego rynku medialnego, gdzie bardzo duży rynkowy i towarzyski sukces odniósł magazyn „Martha Stewart Living”. Zarówno program, jak i planowany magazyn miały inspirować kobiety przykładami i wzorami stylowego życia oraz pełnić funkcję poradnika. Oczekiwano, że obie te formy medialne powinny zostać zaakceptowane przez kobiety niezależne i lubiące „brać sprawy w swoje ręce”, a które równocześnie świadomie pragną budować życie swoje i całej rodziny w sposób „stylowy”. Planowano, że funkcja gospodyni programu zostanie powierzona znanej polskiej aktorce. Wstępne umowy zostały sporządzone i podpisane, aktorka wyraziła swoje zainteresowanie projektem. Stacji zależało na tym, aby w fokusach przetestować projekt obsadzenia NN w roli gospodyni/szefowej obu przedsięwzięć. W oparciu o materiał zgromadzony w trakcie czterech sesji fokusowych sporządzono raport zawierający m.in. następujące konkluzje ${ }^{93}$, „W wizerunku NN na pierwszy plan wysuwają się cechy widoczne $w$ jej postępowaniu i zachowaniu w konkretnych sytuacjach, głównie o charakterze zawodowym - konsekwencja w dążeniu do założonego celu, nerwowość, neurotyczność, skłonność do dominacji, silna osobowość, ogromny temperament, skłonność do koncentrowania uwagi na sobie. Dlatego trudno się dziwić, że NN przy całej swojej niekwestionowanej urodzie jest postrzegana jako »mało kobieca«, a bardziej »męska«. Mało tego, te cechy są na tyle widoczne, że czasem dominują nad odtwarzaną postacią/rolą, co niekorzystnie wpływa na ocenę poziomu aktorstwa NN. Stąd też oczywiste wydaje się postrzeganie NN jako osoby raczej skupionej na realizacji własnych celów i interesów, niż zajmującej się sprawami innych ludzi. W zasadzie nawet trudno ją sobie w takiej roli wyobrazić. NN — osoba prywatna jest mniej znana, stąd więcej w odniesieniu do tej kwestii domniemań, wyobrażeń i oczekiwań, niż wspierania się konkretnymi faktami. Ta ograniczona wiedza na temat »rodzinności« NN jest postrzegana tutaj jako wada, ponieważ aktorka wydaje się w tej mierze niezbyt kompetentną osobą, a tego rodzaju program kojarzony jest z wartościami rodzinnymi. Wiele kontrowersji wśród uczestników wzbudza ustalenie, czy jest osobą ciepłą emocjonalnie. W kontekście zawodowym nie jest to przecież cecha pierwszoplanowa. Dlatego nie może budzić zdziwienia, że nie jest ona kojarzona z typem powierniczki, przyjaciółki od serca,

93 Raport z badania autorstwa J. Lisek-Michalskiej; materiał własny. 
a tak producenci wyobrażali sobie gospodynię programu. Widoczne cechy jej zachowania wprost przekładają się na sposób jej odbioru; z tego powodu może zarażać energią i chęcią życia, ale także może nużyć i drażnić zbyt dużą dawką ekspresji. Sympatię, czasem graniczącą z podziwem, a nawet zazdrością, budzi jej szczerość, zdecydowanie, silna wola, stanowczość. Natomiast niechęć wywołuje nadmierna neurotyczność, pretensjonalność, zbyt żywa gestykulacja, brak opanowania, nadmierna pewność siebie. W rezultacie NN jawi się jako osoba wyniosła, ze skłonnością do dominacji nad innymi. W wyglądzie zewnętrznym na uznanie zasługuje jej gust. Nie jest to jednak jednoznaczne z tym, że jest postrzegana jako autorytet w kwestii wyglądu; po pierwsze, nad jej prezencją pracują inni specjaliści, a po drugie, może to być inspirujące tylko dla kobiet w określonym wieku i z określoną zasobnością portfela. Podobnie sprawa przedstawia się w kwestii postrzegania jej stylu życia; jest on prawdopodobnie atrakcyjny dla ściśle określonej kategorii osób - dla ludzi ceniących szybkie tempo życia, lubiących, aby ciągle coś się działo. Jej skłonność do dominacji nad rozmówcą stawia pod znakiem zapytania dobór i możliwości działania jej gości. Kwestionowanie jej sprawności w przekazywaniu własnych myśli, nadmierna ekspresyjność, która bywa denerwująca, skłaniają do zastanowienia, czy to rzeczywiście najlepszy pomysł. Tym bardziej, że przed zapoznaniem uczestniczek badania z koncepcją programu, NN zupełnie nie kojarzono z tego typu problematyką (i działalnościa). Jednocześnie duża uwaga, z jaką obserwuje się zachowanie i wygląd NN wywołuje obawę, że to na jej zachowaniu i wyglądzie będzie skupiała się uwaga widzów, natomiast drugorzędne znaczenie będzie miała treść programu. Istotne znaczenie ma także precyzyjne określenie grupy docelowej odbiorców i wyraźne poinformowanie o tym widzów, żeby nie wywoływać frustracji w sytuacji, gdy rozwiązania proponowane $w$ kontekście promowanego stylu życia będą poza zasięgiem możliwości finansowych przeciętnego zjadacza chleba. Generalnie zatem postrzega się program z jej udziałem jako przeznaczony dla dość konkretnego typu odbiorcy, bo i ona z pewnym poziomem i stylem życia jest kojarzona. Jest to świat obcy dla zwyczajnych ludzi."

Autor raportu z badania fokusowego miał świadomość, że powyższe stwierdzenia stawiają pod znakiem zapytania sensowność obsadzenia aktorki we wspomnianej roli. I rzeczywiście, odstąpiono od umów przedwstępnych, wypłacono tej aktorce jakieś kwoty w ramach kar umownych i nigdy nie zrealizowano tego programu. Podobnie jak wszyscy polscy widzowie telewizyjni, autor raportu znał tę aktorkę i formułowanie wniosków, które stały się przyczyną rezygnacji stacji telewizyjnej z podpisania z nią wieloletniego kontraktu było dla niego ogromnym przeżyciem i dylematem etycznym. Wiązało się także z dużą odpowiedzialnością, obawą przed niewłaściwą interpretacją zebranego materiału, dlatego autor raportu konsultował swój punkt widzenia z kolegami badaczami w obawie, że może jakieś wewnętrzne przekonania ciążą nad pro- 
wadzoną analizą materiałów z fokusów. Tego typu przedsięwzięcie badawcze pozwala odczuć różnicę między badaniami, które dotyczą zjawisk, nawet trudnych, ale powszechnych, gdzie obiektem dyskusji są na przykład instytucje, nie kojarzone z konkretnym człowiekiem, a takimi, których rezultaty przekładają się na życie konkretnej osoby.

Jak widać, problemy etyczne w badaniach fokusowych nie zaczynają się i nie kończą wraz z samą sesją i nie dotyczą one jedynie relacji z samymi badanymi, ale obejmują cały kontekst społeczny i wszystkie podmioty, które w badanie są uwikłane: badaczy, jego współpracowników, uczestników, zleceniodawców i obiekty badania.

\section{ETYKA FOKUSOWA W PRAKTYCE BADAWCZEJ}

W tej części zostaną zaprezentowane wybrane wyniki empiryczne, które ilustrują tylko jeden aspekt etyki fokusowej w praktyce badawczej - związany z sesją, a zatem dotyczący wszelkich form zadbania o uczestników i ich relacji $\mathrm{z}$ moderatorem.

Analizie poddano sesje fokusowe przeprowadzone w ramach projektu Partnerstwo na rzecz rozwoju kompetencji informatycznych $w$ Polsce (IT QUAL) ${ }^{94}$, na zlecenie Instytutu Pracy i Spraw Socjalnych. Badanie to objęło dwa typy respondentów reprezentujących sektor prywatny:

- pracodawców sektora małych i średnich przedsiębiorstw (zatrudniających do 250 osób) z terenu pięciu województw: mazowieckiego, łódzkiego, śląskiego, dolnośląskiego i małopolskiego,

- pracowników sektora małych i średnich przedsiębiorstw (zatrudniających do 250 osób) z terenu ww. województw, którzy ukończyli 40 lat.

Ogółem przeprowadzono 40 FGI: 20 z pracodawcami i 20 z pracownikami. W badaniach łącznie wzięło udział 212 pracodawców i 210 pracowników 95 .

Bardzo istotne dla interpretacji poniższych wyników jest podkreślenie, iż sesje były prowadzone przez siedmioro profesjonalnych moderatorów, wyspecjalizowanych w problematyce badań społecznych. Każde nagranie sesji zostało obejrzane przez dwóch niezależnych obserwatorów, którzy nie po-

\footnotetext{
94 Projekt nr F0030d1, kierownik: prof. Elżbieta Kryńska.

95 Niezwykle trudno jest uzyskać wgląd w nagrania sesji fokusowych prowadzonych przez moderatorów zatrudnionych w ośrodkach/firmach badawczych. Autorka wykorzystała dla przedstawionych tu analiz jedyny tak obfity materiał empiryczny, jakim dysponowała, bowiem sama opracowała w tym projekcie koncepcję badania, narzędzia i raport końcowy.
} 
rozumiewali się ze sobą $w$ kwestii wystawianych ocen. Ich zadaniem był ogląd nagrań pod kątem opracowanych kategorii analitycznych, przyjętych jako wskaźniki poziomu zachowania zasad etycznych w trakcie badania. Ocenie poddano następujące kryteria:

- warunki lokalowe, w jakich odbywała się sesja,

- etap wprowadzania uczestników do pracowni fokusowej,

- strategia wyrażania zgody,

- zakres informacji na temat badania przekazany uczestnikom przez moderatora na początku sesji,

- zachowanie prawa do prywatności

- wymiar emocjonalny sesji,

- wymiar zadaniowy sesji ${ }^{6}$.

Tabela 1. Ocena warunków lokalowych, w jakich odbywała się sesja

\begin{tabular}{|c|c|c|c|c|c|}
\hline \multicolumn{5}{|c|}{ CZĘŚĆ POPRZEDZAJĄA SESJE } \\
\hline LP & \multicolumn{2}{|c|}{ Jakie stworzono warunki lokalowe do prowadzenia spotkania? } \\
\hline PARAMETR/OCENA & $\begin{array}{c}\text { Zdecydo- } \\
\text { wanie tak } \\
\text { i raczej } \\
\text { tak } \\
\%\end{array}$ & $\begin{array}{c}\text { Raczej nie } \\
\text { i zdecydo- } \\
\text { wanie nie } \\
\%\end{array}$ & $\begin{array}{c}\text { Trudno } \\
\text { powiedzieć } \\
\%\end{array}$ & Razem \\
\hline 1. & $\begin{array}{l}\text { Czy w pracowni fokusowej panowała } \\
\text { cisza (brak zakłóceń z zewnątrz)? }\end{array}$ & 78 & 22 & 0 & 100 \\
\hline 2. & $\begin{array}{l}\text { Czy zapewniono wygodne miejsca sie- } \\
\text { dzące? }\end{array}$ & 78 & 10 & 12 & 100 \\
\hline 3. & $\begin{array}{l}\text { Czy zapewniono odpowiednią odległość } \\
\text { pomiędzy uczestnikami? }\end{array}$ & 66 & 34 & 0 & 100 \\
\hline 4. & $\begin{array}{l}\text { Czy w pracowni fokusowej panowała } \\
\text { odpowiednia temperatura? }\end{array}$ & 31 & 0 & 69 & 100 \\
\hline & $\begin{array}{l}\text { Czy został odpowiednio przygotowany } \\
\text { sprzęt rejestrujący przebieg spotkania } \\
\text { (odpowiednio, to znaczy, czy jego ob- } \\
\text { sługa i działanie nie absorbowały } \\
\text { uwagi uczestników i moderatora)? }\end{array}$ & 88 & 12 & 0 & 100 \\
\hline 6. & $\begin{array}{l}\text { Czy zadbano o odpowiednią ilość na- } \\
\text { pojów i naczyń? }\end{array}$ & 91 & 9 & 0 & 100 \\
\hline 7. & $\begin{array}{l}\text { Czy zadbano o odpowiednią liczbę po- } \\
\text { trzebnych materiałów (długopisy, pa- } \\
\text { pier, wizytówki)? }\end{array}$ & 96 & 4 & 0 & 100 \\
\hline
\end{tabular}

Źródło: opracowanie własne.

\footnotetext{
${ }^{96}$ Sposób operacjonalizacji poszczególnych kryteriów wskazują kategorie umieszczone w kolejnych wierszach tabel.
} 
Należy wyraźnie podkreślić, iż mimo wielokrotnego ustalania z obserwatorami (którymi byli studenci socjologii), w jaki sposób należy interpretować różne zjawiska na nagraniu, aby osiągnąć możliwie jednorodne kwalifikacje, uzyskane rezultaty są jednak obciążone dozą subiektywizmu obserwatora i raczej należy je postrzegać w kategoriach ilustracji pewnych prawidłowości, niż wysoko wystandaryzowanych materiałów.

Sądzić można (patrz Tabela 1), że w zdecydowanej większości sesji właściwie zadbano o warunki lokalowe, $w$ jakich przebiegało badanie. Najczęściej obserwatorzy negatywnie ocenili względną ciasnotę, czyli zbyt małe odległości pomiędzy uczestnikami, naruszające ich przestrzeń prywatną.

Tabela 2. Ocena etapu wprowadzania uczestników do pracowni fokusowej

\begin{tabular}{|c|c|c|c|c|c|}
\hline \multicolumn{6}{|c|}{ CZĘŚĆ POPRZEDZAJĄCA SESJĘ } \\
\hline \multicolumn{6}{|c|}{ Jak przebiegał etap wprowadzania uczestników do pracowni fokusowej? } \\
\hline LP & PARAMETR/OCENA & \begin{tabular}{|c|} 
Zdecydo- \\
wanie tak \\
i raczej tak \\
$\%$
\end{tabular} & $\begin{array}{l}\text { Raczej nie } \\
\text { i zdecy- } \\
\text { dowanie } \\
\text { nie } \%\end{array}$ & $\begin{array}{l}\text { Trudno } \\
\text { powie- } \\
\text { dzieć } \\
\%\end{array}$ & $\begin{array}{c}\text { Razem } \\
\%\end{array}$ \\
\hline 1. & $\begin{array}{l}\text { Czy był obecny moderator podczas } \\
\text { wprowadzania uczestników? }\end{array}$ & 19 & 9 & 72 & 100 \\
\hline 2. & $\begin{array}{l}\text { Czy moderator zachęcał do zajmowania } \\
\text { miejsc siedzących? }\end{array}$ & 5 & 8 & 87 & 100 \\
\hline 3. & $\begin{array}{l}\text { Czy moderator nawiązywał } \\
\text { z uczestnikami rozmowy podczas zaj- } \\
\text { mowania miejsc siedzących? }\end{array}$ & 0 & 14 & 86 & 100 \\
\hline 4. & $\begin{array}{l}\text { Czy uczestnicy wchodząc do pracowni } \\
\text { witali się z obecnymi tam osobami? }\end{array}$ & 0 & 14 & 86 & 100 \\
\hline 5. & Czy inicjowali rozmowy z moderatorem? & 4 & 21 & 75 & 100 \\
\hline 6. & $\begin{array}{l}\text { Czy można określić zachowanie uczest- } \\
\text { ników przed rozpoczęciem sesji jako } \\
\text { swobodne, zdystansowanie? }\end{array}$ & 26 & 18 & 56 & 100 \\
\hline 7. & $\begin{array}{l}\text { Czy można określić zachowanie uczest- } \\
\text { ników przed rozpoczęciem sesji jako nie- } \\
\text { spokojne, podenerwowanie? }\end{array}$ & 13 & 26 & 61 & 100 \\
\hline
\end{tabular}

Źródło: opracowanie własne.

Etap wprowadzania uczestników do pracowni fokusowej stosunkowo rzadko był zarejestrowany na nagraniu, stąd wynika tak duży odsetek odpowiedzi typu „trudno powiedzieć" (Tabela 2). Oceny wystawiono tylko tam, gdzie rozwój wypadków można było zobaczyć bezpośrednio lub pośrednio wydedukować na podstawie dalszych wydarzeń. Przy wszystkich trudnościach (i wątpliwościach) związanych z kwalifikowaniem zjawisk do właściwych wariantów kategorii analitycznych w tej obserwacji, na uwagę zasługuje stosunkowo rzadka obecność 
moderatora w chwili, gdy uczestnicy wchodzili do pomieszczenia, w którym miała odbywać się sesja. Mimo stosunkowo znacznego odsetka sesji, w których oceniono zachowanie badanych przed rozpoczęciem spotkania jako swobodne 26\%; obecność moderatora od samego początku wydaje się bardziej właściwa. Moderator pełni funkcję gospodarza i do jego rutynowych zachowań powinno należeć witanie kolejno przybywających uczestników. Poza tym czas bezpośrednio poprzedzający sesję stanowi doskonałą okazję z jednej strony do oswojenia badanych z prowadzącym, a z drugiej strony daje moderatorowi możliwość uzyskania pierwszych istotnych informacji o badanych.

Tabela 3. Ocena zakresu informacji na temat badania przekazanych uczestnikom przez moderatora na początku sesji

\begin{tabular}{|c|c|c|c|c|c|}
\hline \multicolumn{6}{|c|}{ SESJA FOKUSOWA } \\
\hline \multicolumn{6}{|c|}{ Jakie informacje na temat badania przekazał uczestnikom moderator na początku sesji? } \\
\hline LP & PARAMETR/OCENA & $\begin{array}{l}\text { Zdecydowa- } \\
\text { nie tak } \\
\text { i raczej tak } \\
\%\end{array}$ & $\begin{array}{l}\text { Raczej nie } \\
\text { i zdecydo- } \\
\text { wanie nie } \\
\quad \%\end{array}$ & $\begin{array}{c}\text { Trudno } \\
\text { powie- } \\
\text { dzieć } \\
\%\end{array}$ & $\begin{array}{c}\text { Razem } \\
\%\end{array}$ \\
\hline 1. & $\begin{array}{l}\text { Przedstawienie się moderatora imie- } \\
\text { niem i nazwiskiem }\end{array}$ & 70 & 30 & 0 & 100 \\
\hline 2. & $\begin{array}{l}\text { Przedstawienie instytucji realizującej } \\
\text { badania }\end{array}$ & 50 & 50 & 0 & 100 \\
\hline 3. & $\begin{array}{l}\text { Przedstawienie instytucji wykorzy- } \\
\text { stującej badania }\end{array}$ & 18 & 79 & 3 & 100 \\
\hline 4. & Przedstawienie samego tematu & 79 & 17 & 4 & 100 \\
\hline 5. & $\begin{array}{l}\text { Poinformowanie szerzej o tematyce } \\
\text { spotkania }\end{array}$ & 73 & 21 & 6 & 100 \\
\hline 6. & Pełne wyjaśnienie celu badania & 35 & 65 & 0 & 100 \\
\hline 7. & $\begin{array}{l}\text { Poinformowanie o przewidywanym } \\
\text { czasie trwania badania }\end{array}$ & 35 & 61 & 4 & 100 \\
\hline 8. & $\begin{array}{l}\text { Wyjaśnienie zasady doboru osób do } \\
\text { badania }\end{array}$ & 18 & 82 & 0 & 100 \\
\hline 9. & $\begin{array}{l}\text { Poinformowanie o fakcie rejestracji } \\
\text { za pomocą kamery }\end{array}$ & 74 & 26 & 0 & 100 \\
\hline 10. & $\begin{array}{l}\text { Zapewnienie o anonimowości bada- } \\
\text { nych** }\end{array}$ & 70 & 26 & 4 & 100 \\
\hline 11. & $\begin{array}{l}\text { Zapewnienie o poufności zebranych } \\
\text { materiałów*** }\end{array}$ & 66 & 30 & 4 & 100 \\
\hline 12. & $\begin{array}{l}\text { Wyjaśnienie zadania i zasad udziału } \\
\text { w dyskusji (dobrowolne uczestnictwo, } \\
\text { zabieranie głosu w wybranym przez } \\
\text { uczestnika momencie) }\end{array}$ & 65 & 30 & 5 & 100 \\
\hline 13. & $\begin{array}{l}\text { Poinformowanie o wysokości i formie } \\
\text { wynagrodzenia }\end{array}$ & 0 & 91 & 9 & 100 \\
\hline
\end{tabular}


Tabela 3. ciag dalszy

\begin{tabular}{|c|l|c|c|c|c|}
\hline LP & \multicolumn{1}{|c|}{ PARAMETR/OCENA } & $\begin{array}{c}\text { Zdecydo- } \\
\text { wanie tak } \\
\text { i raczej tak } \\
\%\end{array}$ & $\begin{array}{c}\text { Raczej nie } \\
\text { i zdecydo- } \\
\text { wanie nie } \\
\%\end{array}$ & $\begin{array}{c}\text { Trudno } \\
\text { powiedzieć } \\
\%\end{array}$ & $\begin{array}{c}\text { Razem } \\
\%\end{array}$ \\
\hline 14. & $\begin{array}{l}\text { Udzielenie odpowiedzi na wszyst- } \\
\text { kie pytania na temat procedury ba- } \\
\text { dania }\end{array}$ & 9 & 25 & $66^{*}$ & 100 \\
\hline 15. & $\begin{array}{l}\text { Upewnienie się, że uczestnicy posia- } \\
\text { dają wszystkie niezbędne z ich punk- } \\
\text { tu widzenia informacje }\end{array}$ & 5 & 74 & 21 & 100 \\
\hline 16. & $\begin{array}{l}\text { Poproszenie uczestników } \\
\text { o potwierdzenie zgody na udział } \\
\text { w badaniu }\end{array}$ & 0 & 82 & 18 & 100 \\
\hline 17. & $\begin{array}{l}\text { Poinformowanie o możliwości opusz- } \\
\text { czenia spotkania w dowolnym mo- } \\
\text { mencie, bez podawania przyczyn i bez } \\
\text { jakichkolwiek konsekwencji dla osób } \\
\text { badanych }\end{array}$ & 5 & 86 & 9 & 100 \\
\hline 18. & $\begin{array}{l}\text { Informacja o możliwości odmowy } \\
\text { udzielenia odpowiedzi na pytania } \\
\text { moderatora prowadzącego sesję }\end{array}$ & 0 & 86 & 14 & 100 \\
\hline
\end{tabular}

Źródło: opracowanie własne.

* Nie dotyczy, nie było pytań ze strony uczestników.

** Anonimowość —oddzielenie danych o tożsamości osób badanych od informacji, jakich one udzielają. Osoba badana jest uważana za osobę anonimową, jeśli badacz lub inne osoby nie potrafią powiązać konkretnych informacji z konkretnymi osobami badanymi - poza sesją. W przypadku badań fokusowych tak rozumiana anonimowość nie dotyczy samej sesji, lecz materiału upublicznionego przez badacza w postaci raportu.

*** Poufność - zapewnienie i zadbanie, aby informacje identyfikujące osoby badane nie były upubliczniane. Szczególnie istotne jest takie zapewnienie wówczas, gdy udzielane informacje niosą faktyczne zagrożenie dla osób badanych (np. nakaz sądowy), lub zagrożenie domniemane.

Moderatorzy dość powszechnie mają zwyczaj przedstawiać sięimieniem i nazwiskiem, przywoływać temat spotkania i fakt jego rejestrowania oraz gwarantują anonimowość i poufność uzyskanych informacji. Dbają też o wyjaśnienie zasad obowiązujących w trakcie dyskusji (Tabela 3). Znacznie bardziej są powściągliwi w kwestii informowania uczestników o sposobie doboru osób badanych i instytucji, która wykorzysta uzyskane informacje. Niestety, nie mają także zwyczaju wyraźnie informować uczestników o przysługującym im prawie do rezygnacji z udziału w sesji, nie upewniają się, że wszyscy zaproszeni posiadają wystarczający zestaw potrzebnych im informacji, nie proszą o potwierdzenie zgody na udział $w$ dyskusji oraz nie przypominają uczestni- 
kom, że mają oni prawo odmowy udzielenia odpowiedzi na pytania moderatora prowadzącego sesję. Jest to postawa jak najbardziej zrozumiała, bowiem reprezentuje interes badacza, którego są współpracownikami, jednak stoi ona w konflikcie z normą informowania badanych o ich wszystkich prawach.

Tabela 4. Ocena dbałości o prawo badanych do prywatności

\begin{tabular}{|l|l|c|c|c|c|}
\hline \multicolumn{6}{|c|}{ SESJA FOKUSOWA } \\
\hline \multicolumn{2}{|c|}{ LP } & \multicolumn{1}{|c|}{ PARAMETR/OCENA trakcie badania uszanowano prawo badanych do prywatności? } \\
\hline 1. & $\begin{array}{c}\text { Zdecydo- } \\
\text { wanie tak } \\
\text { i raczej tak } \\
\%\end{array}$ & $\begin{array}{c}\text { Raczej nie } \\
\text { i zdecydo- } \\
\text { wanie nie \% }\end{array}$ & $\begin{array}{c}\text { Trudno } \\
\text { powie- } \\
\text { dzieć } \\
\%\end{array}$ & $\begin{array}{c}\text { Razem } \\
\%\end{array}$ \\
\hline 2. & $\begin{array}{l}\text { Czy w trakcie badania uzyskiwano in- } \\
\text { formacje istotne na temat osób bada- } \\
\text { nych? }\end{array}$ & 33 & 67 & 0 & 100 \\
\hline $\begin{array}{l}\text { Czy w trakcie badania zadbano o jedno- } \\
\text { znaczne określenie charakteru otoczenia, } \\
\text { w jakim odbywało się badanie?97 }\end{array}$ & 50 & 34 & 16 & 100 \\
\hline 3. & $\begin{array}{l}\text { Czy w trakcie badania pojawiła się moż- } \\
\text { liwości identyfikowania danych perso- } \\
\text { nalnych i łączenia ich z odpowiedziami } \\
\text { udzielanymi przez osoby badane? }\end{array}$ & 4 & 96 & 0 & 100 \\
\hline
\end{tabular}

Źródło: opracowanie własne.

Bardzo pocieszające jest to, że powszechną cechą analizowanych sesji jest brak możliwości identyfikowania przez obserwatora danych personalnych badanych w połączeniu z ich wypowiedziami, mimo, że w 1/3 sesji wystąpiły informacje zakwalifikowane jako istotne z tego punktu widzenia ${ }^{98}$. Tylko w $4 \%$ sesji padały nazwiska osób wypowiadających się, natomiast w pozostałych przypadkach używano wyłącznie formy Pan/Pani lub imion z identyfikatorów.

Pomimo trudnego tematu (zachowania korupcyjne) należy uznać w oparciu o dane (Tabela 5), że moderatorzy wyraźnie wykazują dbałość o stworzenie przyjaznej, życzliwej atmosfery spotkania. Te starania przenoszą się

\footnotetext{
97 Otoczenie, w którym przeprowadza się badania - wyrazistość faktu, że badanie odbywa się w otoczeniu publicznym, a nie prywatnym, co powoduje, że badani inicjują zachowania o charakterze publicznym, a nie prywatnym.

98 Istotność informacji odnosi się tu do zakresu, w jakim informacje zbierane przez badacza mają charakter prywatny lub potencjalnie zagrażający osobie badanej. Wg Amerykańskiego Towarzystwa Psychologicznego „preferencje religijne, praktyki seksualne, dochody, uprzedzenia rasowe i inne właściwości jednostki, takie jak: inteligencja, uczciwość i odwaga to dane zdecydowanie bardziej osobiste, niż nazwisko, klasa społeczna, czy numer identyfikacyjny".
} 
także na wzajemne relacje uczestników - w $88 \%$ sesji okazywali sobie sympatię, a oznaki wrogości czy agresji nie wystąpiły w ogóle. W dyskusjach zagwarantowano badanym także możliwość pełnego wypowiedzenia się, a moderatorzy mają nawyk dziękowania respondentom za udział w sesji.

Tabela 5. Ocena dbałości o wymiar emocjonalny sesji

\begin{tabular}{|c|c|c|c|c|c|}
\hline \multicolumn{6}{|c|}{ SESJA FOKUSOWA } \\
\hline \multicolumn{6}{|c|}{ Wymiar emocjonalny } \\
\hline LP & PARAMETR/OCENA & $\begin{array}{c}\text { Zdecydo- } \\
\text { wanie tak } \\
\text { i raczej tak } \\
\%\end{array}$ & $\begin{array}{l}\text { Raczej nie } \\
\text { i zdecydo- } \\
\text { wanie nie \% }\end{array}$ & $\begin{array}{c}\text { Trudno } \\
\text { powiedzieć } \\
\%\end{array}$ & $\begin{array}{c}\text { Razem } \\
\%\end{array}$ \\
\hline 1. & $\begin{array}{l}\text { Czy moderator dbał o stworzenie } \\
\text { przyjaznej atmosfery? }\end{array}$ & 91 & 9 & 0 & 100 \\
\hline 2. & $\begin{array}{l}\text { Czy w trakcie sesji pojawiły się sy- } \\
\text { gnały świadczące o napięciu, zde- } \\
\text { nerwowaniu uczestników? }\end{array}$ & 13 & 87 & 0 & 100 \\
\hline 3. & $\begin{array}{l}\text { Jak zachowywali się uczestnicy } \\
\text { względem siebie-okazywali życzli- } \\
\text { wość, sympatię? }\end{array}$ & 88 & 12 & 0 & 100 \\
\hline 4. & $\begin{array}{l}\text { Jak zachowywali się uczestnicy } \\
\text { względem siebie-okazywali nie- } \\
\text { chęć, agresję? }\end{array}$ & 0 & 95 & 5 & 100 \\
\hline 5. & $\begin{array}{l}\text { Jak zachowywali się uczestnicy } \\
\text { względem siebie — okazywali neu- } \\
\text { tralność, dystans? }\end{array}$ & 39 & 48 & 13 & 100 \\
\hline 6. & $\begin{array}{l}\text { Czy uczestnicy mieli możliwość } \\
\text { pełnego wypowiedzenia się? }\end{array}$ & 94 & 6 & 0 & 100 \\
\hline 7. & $\begin{array}{l}\text { Czy występowały pytania drażliwe, } \\
\text { zagrażające, wywołujące widoczną } \\
\text { reakcję emocjonalną badanych? }\end{array}$ & 26 & 74 & 0 & 100 \\
\hline 8. & $\begin{array}{l}\text { Czy występowały sytuacje, } \\
\text { w których moderator wymuszał } \\
\text { odpowiedzi uczestników, mimo ich } \\
\text { niechęci do zabrania głosu? }\end{array}$ & 9 & 91 & 0 & 100 \\
\hline 9. & $\begin{array}{l}\text { Czy sesja zakończyła się w przewi- } \\
\text { dzianym czasie (o jakim uprzedził } \\
\text { moderator)? }\end{array}$ & 28 & 14 & 58 & 100 \\
\hline 10. & $\begin{array}{l}\text { Czy moderator podziękował } \\
\text { uczestnikom sesji? }\end{array}$ & 96 & 0 & 4 & 80 \\
\hline
\end{tabular}

Źródło: opracowanie własne.

Wysoką ocenę profesjonalizmu moderatorów potwierdzają dane dotyczące aspektu zadaniowego sesji (Tabela 6). Mimo dostrzeżonych przez obserwatorów sygnałów świadczących o trudności zadania stawianego bada- 
nym przez moderatora, osoby prowadzące dyskusję wyjaśniały wątpliwości, wzmacniały uczestników pozytywnymi sygnałami oraz w zdecydowanej większości przypadków potrafiły dostosować swój sposób mówienia do poziomu percepcji uczestników.

Mimo że analizą objęto aż 40 sesji fokusowych, w których łącznie uczestniczyły 422 osoby, to dane te stanowią jednie kroplę w morzu realizowanych w Polsce projektów wykorzystujących zogniskowany wywiad grupowy. Ponadto wszystkie te sesje były prowadzone przez moderatorów z wieloletnim stażem w realizacji badań społecznych, dlatego wyniki te nie mogą stanowić podstaw do wnioskowania o prawidłowościach w praktyce badawczej w ogóle.

Tabela 6. Ocena dbałości o wymiar zadaniowy sesji

\begin{tabular}{|l|l|c|c|c|c|}
\hline \multicolumn{5}{|c|}{ SESJA FOKUSOWA } \\
\hline LP & \multicolumn{1}{|c|}{ Wymiar zadania } \\
\hline 1. & $\begin{array}{c}\text { Zdecydowa- } \\
\text { nie tak } \\
\text { i raczej tak } \\
\%\end{array}$ & $\begin{array}{c}\text { Raczej nie } \\
\text { i zdecydo- } \\
\text { wanie nie } \\
\%\end{array}$ & $\begin{array}{c}\text { Trudno } \\
\text { powie- } \\
\text { dzieć } \\
\%\end{array}$ & $\begin{array}{c}\text { Razem } \\
\%\end{array}$ \\
\hline 2. & $\begin{array}{l}\text { Czy język używany przez moderatora } \\
\text { był zrozumiały dla uczestników? } \\
\text { przez uczestników lub dostrzeżone } \\
\text { przez siebie wątpliwości? }\end{array}$ & 71 & 29 & 0 & 100 \\
\hline 3. & $\begin{array}{l}\text { Czy pojawiły się sygnały świadczące } \\
\text { o trudności zadania stawianego bada- } \\
\text { nym przez moderatora? }\end{array}$ & 26 & 4 & 4 & 100 \\
\hline & $\begin{array}{l}\text { Czy moderator dbał o utrzymanie po- } \\
\text { zytywnej samooceny badanych, np. } \\
\text { poprzez wyjaśnianie, że nie ma odpo- } \\
\text { wiedzi dobrych lub złych, że wszystkie } \\
\text { są jednakowo cenne? }\end{array}$ & 79 & 17 & 4 & 100 \\
\hline
\end{tabular}

Źródło: opracowanie własne.

Odpowiedź na pytanie "Jak w polskiej praktyce badań fokusowych respektowane są zasady etyki?" wymagałaby przeprowadzenia analiz, które objęłyby wszystkie podmioty uwikłane w proces badawczy, czyli zleceniodawców, badaczy, moderatorów, ankieterów-rekruterów, wreszcie - samych uczestników oraz wglądu w materiały badawcze, do których dostęp często jest niemożliwy. Być może uda się w przyszłości taki projekt zrealizować. 


\section{Podsumowanie}

Metoda zogniskowanego wywiadu grupowego wymaga w procesie badawczym współudziału wielu osób - badanych, badaczy, zleceniodawców. Podmioty te wchodzą ze sobą w bardzo rozbudowane, wielowymiarowe relacje. Wszystkie relacje z kolei mają swój wymiar etyczny. Zarówno poszczególne elementy procedury badawczej: nagrywanie, podgląd, obecność innych uczestników, charakter badanego zagadnienia, treść i forma wypowiedzi rozmówców, narzędzie badawcze, jak i sposób realizacji roli moderatora, przebieg rekrutacji, stosunek zleceniodawcy do badania mogą stanowić potencjalne źródło etycznych zaniedbań, które z jednej strony przekształcają samą metodę, a z drugiej - prowadzą do uzyskania materiałów wątpliwej jakości. Przywołane przykłady empiryczne dowodzą ścisłego związku pomiędzy etyką a metodologią badań fokusowych. Decyzje podejmowane $w$ jednym z tych wymiarów (czy z jednej pespektywy) znajdują swoje odzwierciedlenie $\mathrm{w}$ drugim. Zaniedbania o charakterze etycznym wywołują konsekwencje metodologiczne i w rezultacie sprzyjają uzyskiwaniu mniej wartościowych materiałów badawczych. 



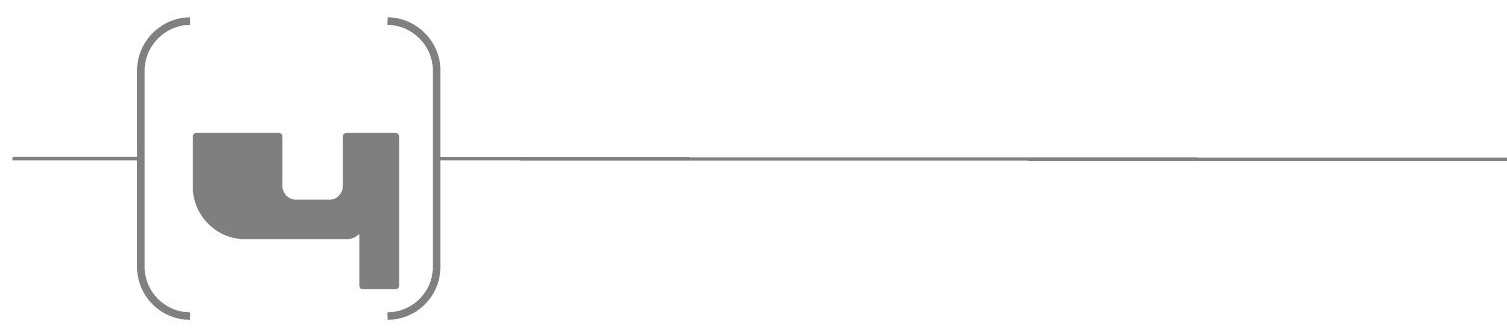

ETYCZNE ASPEKTY

BADAŃ FOKUSOWYCH

Z UDZIAEEM

DZIECI I MEODZIEŻY 



\section{WPROWADZENIE}

Rozdział zawiera przegląd zaleceń ujętych w kodeksach etycznych dotyczących postępowania wobec nieletnich uczestników badań, ze szczególnym uwzględnieniem procedury uzyskiwania świadomej zgody oraz zapewnienia poufności. Opisano także przykładowe dylematy etyczne, trudne do rozstrzygnięcia, mimo wsparcia w ustaleniach dekretowych oraz wskazano źródła zagrożeń o charakterze etycznym w badaniach z udziałem dzieci. W ostatniej części zamieszczono przykłady rozwiązywania problemów etycznych w badaniach fokusowych z udziałem dzieci w praktyce badawczej.

Zasady etyczne obowiązujące wobec dzieci w badaniach fokusowych w znacznej mierze dotyczą postępowania badacza z tą kategorią uczestników przy zastosowaniu dowolnej metody badawczej w obszarze badań socjologicznych i społecznych oraz marketingowych. Jednak specyfika fokusa powoduje, że niektóre spośród reguł ogólnych nabierają szczególnego znaczenia. Na przykład w praktyce badań surveyowych bardzo często przyjmuje się, że próba obejmuje osoby w wieku powyżej 15. roku życia. W przypadku zogniskowanego wywiadu grupowego decyzja o minimalnej granicy wiekowej uczestników nie jest taka oczywista. Z kolei badania marketingowe zazwyczaj nie wikłają badacza w konieczność rozstrzygania problemów etycznych związanych z charakterem informacji uzyskiwanych od niepełnoletnich uczestników.

Społeczne i socjologiczne badania fokusowe z udziałem niepełnoletnich szczególnie obfitują w elementy wrażliwe etycznie oraz znakomicie ilustrują silne powiązanie między stosowaną metodą a przyjętymi przez badacza zasadami etyki. 


\section{KODEKSY ETYCZNE}

Refleksja nad etyką postępowania z dziećmi ${ }^{99} \mathrm{w}$ różnych obszarach życia społecznego ma długą historię. Chociaż początki działalności na rzecz ich praw datuje się na wiek XIX, to dekretacja najważniejszych w tym zakresie aktów ustawowych przypada na drugą połowę XX wieku.

Szczególną rolę odegrały w tym procesie dylematy związane z udziałem dzieci w badaniach o charakterze medycznym. W tym kontekście sformułowano fundamentalne zasady obowiązujące $w$ traktowaniu dzieci jako obiekty badań. Autorzy Wytycznych do badań z udziałem dzieci (Research Involving Children) ${ }^{100}$, skupieni w University College London Research Ethics Committee, upatrują genezy obecnie obowiązujących zasad etycznych prowadzenia badań z dziećmi w ustaleniach procesu norymberskiego i wypracowanego na ich podstawie Kodeksu Norymberskiego, który reguluje moralne, etyczne i prawne zasady odnoszące się do badań z udziałem ludzi.

Niektóre podstawowe zasady sformułowane w opracowanej w 1964 roku (z późniejszymi zmianami) Deklaracji Helsińskiej stały się powszechne i stanowią jednocześnie podstawę do formułowania reguł postępowania wobec dzieci w badaniach społecznych. W przeciwieństwie do zapisów prawnych, żadna z tych reguł nie ma statusu bezwzględnie obowiązującej, chociaż zdaniem niektórych filozofów zasady etyczne są prima facie wiążące we wszystkich sytuacjach z wyjątkiem takich, w których popadają w konflikt z zasadami o równej lub większej wadze.

Istotne dla przebiegu dyskusji dotyczącej sposobu traktowania nieletnich jako uczestników badań było także przyjęcie w 1989 r. Konwencji ONZ o Prawach Dziecka. Konwencja ustanawia status dziecka oparty m.in. na następujących założeniach:

- dziecko jest samodzielnym podmiotem, ale ze względu na swoją niedojrzałość psychiczną i fizyczną wymaga szczególnej opieki i ochrony prawnej,

- dziecko jako istota ludzka wymaga poszanowania jego tożsamości, godności i prywatności.

\footnotetext{
${ }^{99}$ Stosowany tu termin „dzieci” i „młodzież” obejmuje niezwykle zróżnicowaną kategorię osób, które różnią się między sobą znacznie w poziomie kompetencji intelektualnych, psychologicznych, fizycznych i społecznych. Jednak dla potrzeb tych rozważań pominięto rozmaite sposoby definiowania tego, kim jest dziecko i przyjęto, że te określenia odnoszą się do osób, które w świetle polskiego prawa nie osiągnęły pełnoletniości. Ustawa z dnia 6 stycznia $2000 \mathrm{r}$. o Rzeczniku Praw Dziecka (Dz. U. z 2000 r. Nr 6, poz. 69, z późn. zm.).

100 Research Involving Children, http://ethics.grad. ucl.ac.uk/forms/guidance1.pdf
} 
Artykuł 12. tego dokumentu przyznaje dziecku, „(...) które jest zdolne do kształtowania swych własnych poglądów, prawo do swobodnego ich wyrażania we wszystkich sprawach dotyczących dziecka", a państwa obliguje do przyjmowania ich „(...) z należytą wagą, stosownie do wieku oraz dojrzałości dziecka." W art. 13. jest mowa o tym, że dzieci mają prawo do wyrażania swoich poglądów w sposób dla nich dogodny, a w konsekwencji zapis nakłada na badacza obowiązek zapewnienia warunków umożliwiających realizację tego prawa i ochronę przed wszelkimi formami wyzysku.

Równolegle do tych zmian, w dyskusji o etycznych aspektach badań społecznych wzrastało poszanowanie praw dzieci. Wiązało się to z szerszą zmianą sposobu myślenia o dzieciach - przyznano im przywilej posiadania własnej autonomii moralnej, czyli prawo do takiego postępowania, o którym decyduje wolna wola oparta na uznawanych przez nich rozumnych zasadach moralnych i uznano ich podmiotowość.

W kontekście analizowania kwestii dziecka jako uczestnika badania społecznego, szczególnie trafne wydaje się rozumienie podmiotowości zaproponowane przez M. Kondracką (2007): „Co to znaczy być podmiotem jakiejś sytuacji, zdarzenia, swego życia? To znaczy być źródłem przyczynowości. Znaczy to, że człowiek ma poczucie sprawstwa zdarzeń pochodnych od jego działania: to on ma możliwość dokonywania wyboru ról, zadań, partnerów, metod, sposobów pracy. Od niego jest zależny poziom jego aktywności wysoki albo jej zupełny brak. To on podejmuje decyzje, ma wpływ i kontrolę nad przebiegiem zadań związanych z jego działalnością oraz tego skutków, a co za tym idzie - czuje się odpowiedzialny za to, co robi. Nie wystarczy jednak, żeby tym podmiotem był - (...) musi się uważać za podmiot - za człowieka poznającego, działającego i przeżywającego. To wszystko nierozerwalnie łączy się z własnym »ja«. Konieczna jest świadomość swojego osobistego systemu wartości i budowanie na nim swoich podmiotowych działań, wywieranie wpływu na otaczające go sytuacje czy zdarzenia. (...) podmiot wie, że ma prawo do samorealizacji, inicjatywy, zadawania pytań, samodzielnego wykonywania czynności i poszukiwania sposobów rozwiązań, indywidualności, odrębności, niepowtarzalności, szacunku, życzliwości, własnego wysiłku i osiągnięcia celu, działań z własnej woli, samokontroli."

W latach 90. ubiegłego wieku nastąpił gwałtowny wzrost zainteresowania udziałem dzieci w badaniach społecznych, pojawiło się bowiem zapotrzebowanie na poznanie ich doświadczeń oraz dziecięcego punktu widzenia różnych problemów społecznych. Bardzo powszechne stało się przekonanie 
(wyrażone już w znacznie wcześniej, chociażby przez George Eliot ${ }^{101}$ ), że nie ma innego sposobu na poznanie dziecięcej perspektywy niż badanie samych dzieci. Dążenie do zrozumienia dziecięcych priorytetów i sposobu interpretowania tego, co stanowi ich codzienne doświadczenie powoli stawało się istotnym elementem studiów empirycznych. Towarzyszył temu rozwój metod stosowanych $\mathrm{w}$ badaniach $\mathrm{z}$ dziećmi i zmiana sposobu postrzegania ich roli jako uczestników badań. Także sposób widzenia rozwoju dziecięcych kompetencji zaczął ulegać wyraźnym zmianom (Woodhead, Faulkner 2008; Greig, Taylor, Mackay 2007), do czego w istotny sposób przyczyniły się wcześniejsze prace (Prout i James, 1997; Waksler, 1991). W tych i innych publikacjach postuluje się postrzeganie dzieci jako „niekompletnych dorosłych” (incomplete versions of adults) i traktowanie kompetencji dzieci jako inne, a nie mniejsze, czy gorsze.

Wyrazem wzrostu zainteresowania psychologów i socjologów dzieckiem jako uczestnikiem badań i jednocześnie dowodem zrozumienia, iż zapraszanie do badań dzieci niesie ze sobą pewne ryzyko narażenia ich na różne nadużycia, stały się kolejne opracowania regulujące ich udział w badaniach społecznych (Problemy etyczne..., 2007). I tak na przykład Komisja Badań Etyki UCL (University College London) stworzyła Wytyczne do badań z udziałem dzieci (Research Involving Children). Zgodnie z tym dokumentem, badania $z$ udziałem dzieci i młodzieży powinny być prowadzone wyłącznie wtedy, gdy:

1. Problematyka badań jest ważna dla zdrowia i dobrostanu dzieci. Przy czym nie oznacza to, że projekty, których bezpośrednim celem nie jest dobro dziecka, należy koniecznie traktować jako nielegalne lub nieetyczne. (Na przykład obserwacja i pomiar normalnego rozwoju przy uczestnictwie „zdrowych ochotników” w kontrolowanych eksperymentach.)

2. Udział dzieci jest niezbędny, ponieważ inne osoby nie są w stanie dostarczyć odpowiedzi na pytania postawione w stosunku do dzieci.

3. Metoda badania jest odpowiednia dla dzieci.

4. Okoliczności, w których będą prowadzone badania, zapewniają zachowanie fizycznego, emocjonalnego i psychologicznego bezpieczeństwa dziecka.

Także brytyjskie Narodowe Biuro do spraw Dzieci (National Children's Bureau) opracowało dokument, który reguluje udział dzieci w badaniach ( $\mathrm{Gu}$ idelines of Research, 1993). Ustalone w nim zasady i wartości zobowiązują do: słuchania i włączania perspektywy dzieci i młodzieży do badań, przyjęcia ho-

\footnotetext{
101 George Eliot pisała: „Czy jest gdzieś ktoś, kto potrafi odtworzyć doświadczenia z dzieciństwa, po prostu przypomnieć sobie, co robił, co się z nim działo, co lubił, a czego nie, i poprzez taki wewnętrzny wgląd uświadomić sobie, co czuł wtedy, kiedy jedno lato było tak bardzo odległe od drugiego." (Davis J. i in., 2006).
} 
listycznego sposobu postrzegania dzieciństwa i pracy ponad granicami: profesjonalnymi, instytucjonalnymi i między dziećmi a dorosłymi. Generalnie autorzy tego kodeksu akceptują wszystkie postanowienia Statement of Ethical Practice (2002) Brytyjskiego Towarzystwa Socjologicznego (BSA), ale w czterech obszarach wprowadzają bardziej szczegółowe ustalenia. Dotyczy to: uzyskiwania świadomej zgody od dzieci, gwarancji konfidencjonalności, ustalenia zasad wynagrodzenia dziecka za udział w badaniu i monitorowania skutków dla dzieci uczestnictwa w badaniu.

Sformułowany przez NCB (National Children's Bureau) postulat monitorowania skutków uczestniczenia w badaniu obejmuje nie tylko sam proces uzyskiwania informacji od dziecka, ale także okres po badaniu, gdyż skutki doświadczenia badawczego mogą ujawnić się po pewnym czasie. Badacze powinni być świadomi tej możliwości, zwłaszcza w przypadku badania dziecka lub nastolatka. Jest to zdaniem autorów szczególnie ważne wówczas, jeżeli dziecko omawia z badaczem jakieś swoje bolesne przeżycia. Przed przystąpieniem do takiego badania badacz powinien rozpoznać lokalne (dla dziecka) źródła pomocy i zadbać o ich udostępnienie oraz uznać ograniczenie własnych kompetencji i wesprzeć się pomocą innych profesjonalistów.

Zapewnienie w trakcie badania (i po nim) profesjonalnego wsparcia dla dzieci należy do podstawowych obowiązków badacza. Zaleca się także, aby pisemne informacje dotyczące badania badacz zawsze formułował $w$ wersji właściwej dla percepcji dzieci oraz aby zawsze załączyć numer telefonu dla tych uczestników, którzy chcieliby skontaktować się z badaczem.

W Guidelines of Research NCB jest także zapis mówiący o potrzebie rekompensowania uczestnikom czasu i wysiłku włożonego przez nich w badanie. Te wytyczne stosują się również do dzieci i młodzieży. Zwykle jest to jakiś skromny upominek bądź kupon zakupowy. Warto, aby informacja o tym znalazła się w piśmie przekazanym dzieciom przed podjęciem przez nie decyzji o uczestnictwie w badaniu. Przy czym, nie tyle chodzi o wykorzystanie tego elementu jako zachęty do przystąpienia do badania, ale o podkreślenie, że jest to forma uznania dla ich wysiłku.

Najbardziej szczegółowe dyrektywy regulujące postępowanie badawcze z dziećmi i nastolatkami to zapisy w Kodeksie ICC/ESOMAR wraz z wytycznymi zamieszczonymi w Esomar World Research Codes \& Guidelines.

W Kodeksie ICC/ESOMAR przyjmuje się, że dobro dziecka ma wartość nadrzędną i nie może ono zostać naruszone poprzez czynności badawcze. Rodzice lub opiekunowie dzieci uczestniczących w badaniu muszą uzyskać pewność, że bezpieczeństwo, prawa i interesy dziecka są w pełni zabezpieczone. Ankieterzy i inni badacze uczestniczący $\mathrm{w}$ projekcie muszą być chronieni przed wszelkimi nieporozumieniami lub możliwymi zarzutami dotyczącymi ich relacji z bada- 
nymi młodocianymi. Władze i społeczność muszą uzyskać pewność, że wszelkie badania realizowane zudziałem dzieci są przeprowadzane woparciu o najwyższe standardy etyczne i nie występuje ryzyko jakiegokolwiek ich wykorzystania czy nadużycia.

Przywołany tu Kodeks postuluje, aby ze względu na brak jednolitej międzynarodowej definicji dziecka i młodzieży (i trudności w sformułowaniu takiej definicji, wynikające chociażby z takich czynników, jak kompetencje poznawcze dziecka) zastosować rozwiązanie praktyczne. W badaniach realizowanych z udziałem dzieci i młodzieży do obowiązków badacza należy przestrzeganie zaleceń lokalnie obowiązującego kodeksu prawnego. Jeżeli jednak lokalnie nie ustalono jakichś innych obowiązujących kryteriów, to przyjmuje się, że dzieckiem jest osoba poniżej 14. roku życia, natomiast do młodzieży zalicza się badanych w wieku 1417 lat. Mimo że dziecku siedmio- i trzynastoletniem nie można sensownie zadawać takich samych pytań lub rozmawiać na identyczne tematy, to, według zapisów tego dokumentu, w większym stopniu jest to kwestia rozsądku i doświadczenia badawczego niż problem etyczny.

Badacz musi zachować czujność w sytuacjach, gdzie charakter albo okoliczności badania mogą być drażliwe i upewnić się, że podjęto wszelkie środki służące zadbaniu o młodocianych uczestników w każdej grupie wiekowej. Jeżeli rodzic lub inna osoba dorosła odpowiedzialna za dziecko, poinformowana o treści badania i jego okolicznościach nie uzna tego doświadczenia za przyczynę zdenerwowania dziecka lub za działanie zakłócające dobro dziecka, to należy przyjąć, że badanie jest adekwatne do danego dziecka. Ponadto, badania z udziałem dzieci muszą pod każdym względem respektować ogólne zasady określone przez zapisy Kodeksu ICC/ESOMAR oraz przepisy o ochronie danych i inne istotne oraz te, które przewidziane są w narodowych kodeksach praktyki badawczej. Gdy badany uczestnik ma mniej niż 14 lat, wytyczne zobowiązują badacza do przestrzegania następujących procedur:

1. W trakcie przeprowadzania wywiadów z dziećmi jest właściwe, aby dorosły opiekun dziecka pozostawał do dyspozycji. Ma to szczególne znaczenie w wywiadach realizowanych w mieszkaniu. Jednakże nie oznacza to, że ten dorosły opiekun dziecka przebywa w tym samym pomieszczeniu, w którym odbywa się wywiad. W niektórych przypadkach jego obecność może być niepożądana z przyczyn metodologicznych, np. może spowodować, że dziecko będzie udzielało stronniczych odpowiedzi (pkt 4).

2. Jeżeli dziecko jest proszone o testowanie jakiegoś produktu, osoba odpowiedzialna za nie musi mieć możliwość obserwowania tego procesu oraz — jeśli sobie zażyczy — wypróbowania tego produktu osobiście (pkt 5). 
Natomiast bez względu na wiek młodocianych uczestników badań w sprawach dotyczących testowania wszelkich produktów badacz jest zobowiązany do zachowania pełnej ostrożności i musi upewnić się, że:

- są bezpieczne do spożycia (np. produkty żywnościowe, wyroby cukiernicze) lub do obsługi (np. zabawki). Badacz musi uzyskać takie potwierdzenie (zazwyczaj na piśmie) od dostawcy danego produktu, który ponosi odpowiedzialność prawną w przypadku jakichkolwiek niepożądanych skutków wywołanych użyciem tego produktu;

- dziecko lub osoba młodociana nie cierpi na alergię związaną z jakimkolwiek składnikiem testowanego produktu (np. produkty zawierające orzechy);

- dzieci i młodzież nie zostaną zaangażowane do jakiegokolwiek nielegalnego działania (np. do spożycia produktu zawierającego alkohol);

- poglądy rodziców lub opiekunów na temat produktów, na których testowanie nie pozwalają dziecku, powinny zostać uwzględnione.

Badacz musi także brać pod uwagę stopień dojrzałości dziecka lub osoby niepełnoletniej, gdy rozważa, jakie zagadnienia mogą lub nie być bezpiecznie podjęte $w$ wywiadzie. Podczas gdy konieczne okaże się unikanie określonych tematów w wywiadach z dziećmi (np. gdy temat wywołuje strach), to samo zagadnienie może stać się przedmiotem rozmów z nastolatkami przy podjęciu odpowiednich środków ostrożności. Przykłady problemów, przy podejmowaniu których należy zachować szczególną ostrożność $\mathrm{w}$ trakcie badań $\mathrm{z}$ dziećmi lub młodzieżą, $\mathrm{w}$ takim samym stopniu wynikają zarówno z praktyki badawczej, jak i z zaleceń etycznych. Do zagadnień, którym należy poświęcić szczególną uwagę podczas wywiadów z dziećmi i młodzieżą, zalicza się wszystkie takie kwestie, które mogą zdenerwować lub zmartwić potencjalnych uczestników (na przykład ich relacje z innymi w grupie rówieśniczej) lub takie, które stwarzają ryzyko napięcia w relacjach pomiędzy nimi a ich rodzicami. Bywają jednak ważne powody (np. wynikające z celów polityki społecznej), kiedy trzeba podjąć i takie tematy. Należy wtedy zadbać o dwie kwestie: kompletne poinformowanie osoby dorosłej odpowiedzialnej za dziecko (zwłaszcza w przypadku młodszych dzieci, ale także - jeśli jest to możliwe - w odniesieniu do opiekunów nastolatków w wieku 14-17 lat) oraz uzyskanie zgody. Ponadto należy się upewnić, że podjęto wszelkie działania minimalizujące ryzyko zdezorientowania, wprowadzenia w błąd lub narażenia badanego na odczucie niepokoju na skutek zadawanych pytań.

Kodeks ICC/ESOMAR nie zalicza do koniecznych zaleceń angażowania specjalnych rodzajów ankieterów do badań z dziećmi i młodzieżą. Wielu spośród doświadczonych praktyków jest zupełnie odpowiednio przygotowa- 
nych do takiej pracy. Jednakże jest bardzo ważne, aby każda osoba, która ma zajmować się realizacją wywiadów z dziećmi, została szczegółowo sprawdzona pod kątem jej poczucia odpowiedzialności ze względu na rosnące obawy rodziców i ogółu społeczeństwa związane z ochroną młodych ludzi, a szczególnie dzieci. Sposób zachowania się przedstawicieli badacza $\mathrm{w}$ bezpośrednim kontakcie $\mathrm{z}$ dzieckiem musi wyraźnie wzbudzać zaufanie, a nie podejrzenia ze strony obserwatorów. Bez względu na to, czy ankieter pracuje w pełnym, czy niepełnym wymiarze czasu, powinien przejść specjalne przeszkolenie do takiego zajęcia, obejmujące w szczególności środki ostrożności, jakie powinny zostać podjęte, właściwe strategie uzyskiwania zgody, specjalne działania konieczne do wypracowania dobrego kontaktu $\mathrm{z}$ badanym itp. Ankieterzy muszą znać i respektować wymagania zarówno wytycznych Kodeksu ICC/ESOMAR, jak i wszelkich właściwych dla danego kraju przepisów postępowania w badaniach z dziećmi i młodzieżą. (Zalecenia te powinny być $w$ miarę możliwości przestrzegane także $w$ badaniach telefonicznych i internetowych.)

Mimo zmian w mentalności i praktyce badawczej wyrażających się chociażby w przytoczonych wyżej regulacjach etycznych, niektórzy badacze twierdzą, że nadal nader często prowadzi się raczej badania „nad” dziećmi, niż „z” dziećmi. Wielu autorów uważa, że ciągle w głównym nurcie psychologii rozwojowej postrzega się dziecko jako mniej odpowiedni obiekt do badań niż osoby dorosłe, co odzwierciedla kulturową tradycję traktowania dzieci mniej poważnie, aniżeli na to zasługują. Postawa taka nie wydaje się zaskakująca, zważywszy na utrwaloną kulturowo tendencję do bagatelizowania i dewaluowania pozycji nieletnich (Waksler 1991). Lansdown (1994) w odniesieniu do tego problemu użył sformułowania, iż dorośli po prostu „nie mają kultury słuchania dzieci”. Również polscy badacze zauważają, że „Postrzeganie dziecka jako podmiotu (...) nie jest w Polsce - delikatnie rzecz ujmując - postawą dominującą. W społeczeństwie powszechnie akceptowanej agresji wobec dzieci trudno oczekiwać, aby było inaczej. (...) W tym kontekście trudno, by rychło upowszechniło się podejście do dziecka jako do podmiotu, w tym podmiotu prawa. Czynienie podłości czy też pasywność wobec czynionego dzieciom zła jest po prostu łatwiejsze, jeśli ofiar nie będzie traktowało się jako podmiotów." (Brzezińska, Toeplitz 2007)

Warto zatem bliżej przyjrzeć się dwóm aspektom badań społecznych i socjologicznych o fundamentalnym znaczeniu etycznym, czyli uzyskiwaniu zgody na badanie oraz kwestii poufności uzyskanych informacji w kontekście badania osób niepełnoletnich. 


\section{ŚWIADOMA ZGODA}

Podczas gdy podstawowe kwestie etyczne (ochrona godności, szacunek dla autonomii, przysparzanie korzyści badanym, rzetelność i legalność procesów) pozostają takie same dla badań z udziałem dzieci i dorosłych, są jeszcze inne problemy do rozwiązania, gdy badania dotyczą dzieci. Na skutek zmiany sposobu postrzegania dziecka odstąpiono od wcześniejszej praktyki, w której zgoda na uczestnictwo dziecka w projekcie zależała wyłącznie od jego rodziców lub opiekunów prawnych. Takie nowe podejście sformułowano już w Deklaracji Helsińskiej (2008). Co prawda zasady zawarte w tym dokumencie dotyczą zarówno dzieci, jak i dorosłych uczestników badań (np. odpowiednie informacje muszą być dostarczone uczestnikom badań, udział $w$ badaniu ma charakter dobrowolny, uczestnik ma prawo w każdej chwili wycofać się i powinna być uzyskana deklaracja świadomej zgody - najlepiej na piśmie), jednak jeden zapis odnosi się wprost do badań z udziałem dzieci i mówi: „gdy obiekt badania jest niepełnoletni, oprócz jego zgody należy uzyskać zgodę jego opiekuna prawnego". Procedura uzyskiwania świadomej zgody w badaniach z udziałem dzieci zakłada, że dziecku przekazywany jest „komplet informacji na temat badania, gdyż tylko wówczas jego zgoda ma rzeczywiście świadomy charakter i może podjąć dobrowolnie decyzję. Należy zadbać o to, by dziecko wiedziało, iż może w każdej chwili się wycofać" (Deklaracja..., 2008).

Obecnie w praktyce badawczej (również w odniesieniu do badań medycznych) funkcjonują trzy powszechnie uznane modele uzyskiwania od osób niepełnoletnich zgody na uczestnictwo w badaniu. Po pierwsze, dzieci nazywane czasem "dojrzałymi nieletnimi” mogą podjąć całkowicie samodzielną decyzję. Po drugie, niektóre dzieci mogą wyrazić wstępną zgodę, która musi być zaakceptowana przez rodziców/opiekunów prawnych. I wreszcie po trzecie, jeszcze inne dzieci, ze względu na wiek lub stadium rozwoju nie mogą samodzielnie o sobie zadecydować i wówczas zgoda rodziców/opiekunów prawnych jest bezwzględnie konieczna. Takie podejście wydaje się najbardziej uwzględniać ewolucję stopnia autonomii jednostki, ale jednocześnie stawia wiele problemów przed badaczami-praktykami, chociażby dotyczących nierównomiernego rozwoju dzieci, ewoluowania ich kompetencji i tym samym zdolności do podejmowania decyzji na swój temat.

Standardy etyczne BSA (Brytyjskiego Towarzystwa Socjologicznego) zakładają, że badanie poprzedzone jest dobrowolnie złożonym oświadczeniem świadomej zgody uczestników, którego podstawę stanowi akceptacja informacji kompletnych i właściwie zrozumianych przez potencjalnego badanego. Szczególnej uważności wymaga to wówczas, gdy uczestnikami są dzieci. 
National Children's Bureau oczekuje, że badacz dostarczy dziecku wszystkich informacji na temat badania, które są potrzebne do udzielenia zgody o uczestnictwie. Taki kompletny zestaw powinien obejmować następujące informacje:

- o czym jest badanie,

- kto je realizuje,

- kto je finansuje,

- dokładny opis oczekiwań wobec uczestników - przykłady kwestionariuszy, liczba osób uczestnicząca w wywiadzie (grupowym),

- jak będą rejestrowane odpowiedzi - zapisywane, nagrywane audio/wideo,

- jak będą opracowywane materiały (włącznie z materiałami poufnymi),

- jaki jest zapewniony stopień anonimowości i konfidencjonalności,

- jak zostaną wykorzystane uzyskane informacje,

- kto zapozna się z rezultatami badania,

- jakie korzyści odniosą uczestnicy i/albo społeczeństwo z tych badań,

- o prawie do odmowy bez żadnych konsekwencji,

- o prawie do przerwania udziału z jakiegokolwiek powodu bez żadnych konsekwencji.

Zadaniem badacza jest upewnić się, czy dzieci zrozumiały otrzymane informacje, w szczególności, czy małe dzieci, dzieci z problemami szkolnymi, dzieci z problemami w porozumiewaniu się (komunikacyjnymi) zostały właściwie poinformowane i wyraziły zgodę, czy dzieci mają świadomość, że mogą się zgodzić lub nie bez żadnych negatywnych konsekwencji, czy badacz jest w stanie rozpoznać i właściwie zareagować na sygnał od dziecka, które nie potrafi wyraźnie odmówić.

Autorzy uważają, że dzieci same muszą wyrazić zgodę na udział, jednak zdają sobie sprawę, że może być konieczne zwrócenie się z prośbą o pozwolenie do rodziców lub opiekunów dziecka. Im także należy przedstawić kompletne informacje o planowanym przedsięwzięciu. Zdaniem twórców tego dokumentu bardzo istotne jest, aby po uzyskaniu zgody od opiekunów dzieci, starać się koniecznie uzyskać zgodę od samych zainteresowanych nieletnich. Nie należy zakładać, że zgoda dyrektora szkoły lub kierownika jednostki, w której badanie ma się odbyć, jest równoważna i zastępuje zgodę poszczególnych dzieci. Wszystkie dzieci, mające uczestniczyć w badaniu, powinny otrzymać na piśmie kompletne informacje sformułowane w sposób dla nich zrozumiały. Ponadto powinny dysponować numerem telefonicznym do badacza, gdyby potrzebowały odpowiedzi na dodatkowe pytania. Takie dane powinny być udostępnione dzieciom w celu podjęcia przez nie decyzji, czy chcą wziąć udział w projekcie.

Komisja Badań Etyki UCL zwraca uwagę, aby - gdy uczestnikiem jest dziecko - we właściwy sposób realizować w praktyce przyjęte zasady etycz- 
ne. Zatem informacje przedstawione dziecku i rodzicom powinny zawierać dokładny opis planowanego przebiegu przedsięwzięcia, w którym dziecko ma wziąć udział, powinny wyraźnie dawać dziecku wybór w kwestii jego uczestnictwa, powinny zapewnić brak jakichkolwiek negatywnych konsekwencji w przypadku odmowy dziecka lub $w$ razie jego wycofania się $\mathrm{z}$ badania $\mathrm{w}$ dowolnym momencie. Ponadto zaleca się $w$ tym dokumencie, aby wszystkie informacje były przekazane dziecku w taki sposób, aby było w stanie je właściwie zrozumieć, używając $w$ razie potrzeby na przykład pomocy wizualnych.

Zgodnie z ustaleniami autorów, młodzi ludzie w wieku 16-18 lat z właściwym dla tego wieku poziomem rozwoju są w stanie samodzielnie wyrazić zgodę na udział w badaniach, niezależnie od decyzji ich rodziców i opiekunów. Natomiast dzieci do lat 16 mogą podjąć samodzielną decyzję o uczestnictwie w badaniu, pod warunkiem, że mają wystarczające kompetencje do tego, by właściwie zrozumieć naturę, cel i prawdopodobny rezultat proponowanych badań. Zgoda rodziców jest wymagana, gdy dziecko nie jest w stanie zrozumieć implikacji udziału w badaniu lub gdy dziecko jest traktowane jako niezdolne do wyrażenia zgody samodzielnie. Chociaż wyrażenie zgody przez dziecko jest wskazane, prawo do decydowania w jego imieniu mają tylko jego prawni opiekunowie. Art. 4.6. postuluje, żeby, jeśli to możliwe, w takich sytuacjach uzyskać zgodę obojga rodziców/opiekunów prawnych. W przypadku braku zgody jednego z rodziców na udział w badaniu dziecka, które samodzielnie nie jest w stanie podjąć takiej decyzji, Komisja Etyki może uniemożliwić włączenie dziecka do badań.

Podobnie kwestię uzyskania zgody osoby niepełnoletniej na udział w badaniu ujmuje uchwalony 25 marca 2012 r. przez Walne Zgromadzenie Delegatów Polskiego Towarzystwa Socjologicznego Kodeks Etyki Socjologa, którego art. 16. mówi: „Szczególnej staranności wymagają badania z udziałem dzieci. Oprócz zgody rodziców lub opiekunów prawnych należy również starać się uzyskać zgodę dziecka (podkreślenie Autorki). Badacze powinni wykorzystać swoje umiejętności tak, by podawane informacje pozostawały dla dziecka zrozumiałe, oraz samemu osądzić, czy dziecko jest w stanie zrozumieć zadawane mu pytania. Jeżeli jest to wskazane, należy zasięgnąć porady specjalisty." Podkreślony fragment otwiera drogę do różnorodnych interpretacji. Zalecenie „starania się” nie jest jednoznaczne z dyrektywą domagającą się uzyskania zgody od dziecka. W tym aspekcie zasady sformułowane przez National Children's Bureau w znacznie większym stopniu uznaje podmiotowość dziecka i jego prawo do odejmowania decyzji o udziale w badaniu. 
Zarówno Kodeks Etyki Socjologa, jak i Kodeks ICC/ESOMAR (art. 8.) wymagają uzyskania zgody na badanie dziecka d jego rodzica/opiekuna prawnego.

Wytyczne do Kodeksu ICC/ESOMAR doprecyzowują ten zapis. W przypadku dzieci poniżej 14. roku życia:

1. Jeżeli badanie wykonywane jest $\mathrm{w}$ „środowisku chronionym” (protected environment), na przykład w szkole, czy w centrum zabawy, w którym konkretna dorosła osoba ponosi całkowitą odpowiedzialność za ochronę dziecka - to zgodę takiej osoby nadzorującej tę lokalizację (np. nauczyciela) należy uzyskać przed podjęciem jakichkolwiek rozmów z dzieckiem.

2. W innym środowisku - np. w domu, na ulicy, w innych miejscach publicznych zgodę rodzica lub opiekuna, któremu rodzic powierzył odpowiedzialność za dziecko (np. opiekunki, sąsiada) należy uzyskać przed przystąpieniem do wywiadu. W żadnym wypadku nie należy podejmować czynności badawczych wobec dziecka, któremu nie towarzyszy osoba dorosła.

Natomiast bez względu na wiek dziecka, gdy prosi się o zgodę na przeprowadzenie z nim wywiadu, należy osobie za nie odpowiedzialnej przedstawić wszelkie informacje potrzebne do podjęcia adekwatnej decyzji w kwestii tego pozwolenia. Jeżeli nie jest możliwe, aby ta osoba słyszała rzeczywiście zadawane dziecku pytania, należy przedstawić jej tematykę i ogólny charakter wywiadu, łącznie z wytłumaczeniem potencjalnie drażliwych lub mogących wywołać zażenowanie pytań. Dane personalne tej dorosłej osoby należy zanotować, ale nie jest konieczne, aby ta zgoda została udzielona pisemnie.

Zatem we współcześnie prowadzonych badaniach dziecko i jego opiekunowie przed wyrażeniem zgody na badanie powinni zostać szczegółowo i w zrozumiałej dla nich formie poinformowani o charakterze przedsięwzięcia badawczego, powinni mieć świadomość prawa do odmowy i wycofania się z badania, nie związanego z jakimikolwiek konsekwencjami dla dziecka czy rodziny. Praktyczna realizacja tych zasad wymaga konkretnych działań ze strony badacza, które wpływają na przebieg procedury badawczej ${ }^{102}$.

\section{POUFNOŚć}

Przed wyrażeniem świadomej zgody na udział w badaniach, wszystkie osoby, a w szczególności dzieci, powinny zrozumieć, w jakim stopniu badacz jest w stanie zapewnić im anonimowość i poufność. Autorzy Guidelines of Research uważają, że musi istnieć ograniczenie gwarancji poufności lub anoni-

\footnotetext{
102 Przykładowe oświadczenia świadomej zgody na udział w badaniu niepełnoletniego uczestnika i rodzica/opiekuna. (Aneks, Załącznik 3. i 4.)
} 
mowości w sytuacjach, w których chodzi o ochronę dziecka. W przypadku, gdy dziecko lub młody człowiek ujawniają, że oni sami lub inni w ich bezpośrednim otoczeniu społecznym są w stanie zagrożenia lub gdy badacz uzyskuje informacje o zdarzeniach, które mogą spowodować poważne szkody, badacz ma obowiązek podjąć kroki w celu ochrony dziecka lub innych dzieci. Ważne jest jednak, żeby badacz najpierw przeprowadził z dzieckiem rozmowę i uświadomił mu potencjalne konsekwencje ujawnionego stanu rzeczy. Jeśli, po dyskusji z dzieckiem, badacz decyduje, że należy poinformować innych - najlepiej za zgodą dziecka - musi on zapewnić dziecku wsparcie i dostęp do informacji o dalszym rozwoju wydarzeń. Dzieci i młodzież powinni być poinformowani, że jeśli tego typu informacja ujawni się w badaniu, badacz nie może zagwarantować im pełnej poufności. Najlepiej, gdy o tej zasadzie postępowania badacz poinformuje nieletnich uczestników na początku badania, a gdy to niezbędne - w trakcie wywiadu, gdy tego typu informacja wyłania się z wypowiedzi uczestników.

Paragraf 5. dokumentu pt: Research Involving Children także reguluje kwestie związane z poufnością — badacz jest zobowiązany do wyjaśnienia dzieciom w sposób dla nich zrozumiały, kto i w jakim celu będzie miał dostęp do uzyskanych od nich informacji. Powinien szczegółowo zapewnić je o braku możliwości identyfikacji autora konkretnej wypowiedzi (art. 5.2). Szczególnej uważności ze strony badacza i podjęcia działań w celu ochrony dziecka lub innych dzieci wymaga sytuacja, w której uważa się, że są one „narażone na szkodę”. Dziecko musi wiedzieć, jakie działania mogą zostać podjęte w przypadku, gdy ujawnia coś, co może zaszkodzić jemu lub innym.

\section{DYLEMATY ETYCZNE W BADANIACH Z UDZIAEEM DZIECI}

Wspomniane wyżej kodeksy postępowania w badaniach z udziałem dzieci to tylko przykładowe pozycje spośród bardzo licznych istniejących propozycji. Jednak mimo coraz bardziej szczegółowych opracowań kodyfikacyjnych, uczestnictwo dzieci w badaniach społecznych wciąż wzbudza wiele problemów etycznych. Niektóre spośród nich opisał Charles Manga Fombad (2005), opierając się na doświadczeniach zebranych w praktyce badawczej w Bostwanie, gdzie jak w soczewce skupiają się kwestie, które w badaniach europejskich lub amerykańskich są bardziej rozproszone, a przez to trudniejsze do uchwycenia, ale z pewnością także występują. Autor ten uważa, że badacz społeczny w kontakcie z osobami niepełnoletnimi może stanąć wobec dylematów, jakich się nie spodziewał, i dla rozwiązania których dotychczasowe regulacje prawno-etyczne są niewystarczające. Jego zdaniem 
brakuje dowodów na to, by na szczeblu międzynarodowym zagadnienie praw dziecka zostało potraktowane odpowiednio poważnie i wnikliwie.

Fombad zaobserwował dynamiczny rozwój badań z udziałem dzieci w obszarze problemów niezwykle trudnych, takich jak na przykład wykorzystywanie seksualne nieletnich, działalność młodocianych gangów, uzależnienie od substancji psychoaktywnych, narażenie dzieci na zakażenie HIV/AIDS. W tego typu projektach badacze stają wobec konieczności podjęcia decyzji nie tylko dotyczących dzieci bezpośrednio zaangażowanych w przedsięwzięcie, lecz także ich otoczenia społecznego - rodziców, opiekunów społecznych, szkoły i środowiska rówieśniczego. Potrzebna jest odpowiedź na przykład na następujące pytania: czy badacz planujący przeprowadzić badanie wśród studentów pierwszego roku studiów prawniczych na temat ich orientacji seksualnej ma prawo do opierania się wyłącznie na decyzji kierownictwa wydziału, bez uzyskania zgody od każdego pojedynczego studenta? Jak powinien zachować się badacz, który w trakcie badań z szesnastolatkami dowiaduje się o codziennym, powszechnym stosowaniu przez nich kokainy, marihuany i alkoholu? Czy jest on zobowiązany do ujawnienia tej informacji rodzicom i/lub władzom szkoły? Czy badacz ma etyczne prawo do objęcia dzieci badaniem na temat zagrożenia HIV/AIDS bez ubiegania się o zgodę ich rodziców/opiekunów w sytuacji, kiedy zdaje sobie sprawę ze skali ryzyka, na jakie są narażone dzieci i z niechętnego stosunku rodziców do badań społecznych? Przecież badacz musi dążyć do zachowania równowagi pomiędzy poszanowaniem praw rodziców i opiekunów oraz ochroną interesów dziecka...

Podobne wątpliwości zgłaszają polscy badacze, szczególnie psychologowie, którzy twierdzą, że poziom złożoności problemów, jakich doświadczają współczesne dzieci sprawia, iż pytania o zgodę dziecka i jego opiekunów prawnych na udział w badaniu, kwestia zadbania o poufność uzyskanych danych należą już do klasyki zagadnień etycznych w postępowaniu badawczym wobec dzieci. Natomiast pojawiło się wiele wyzwań „(...) o charakterze wręcz dylematów etycznych, kiedy to nie ma możliwości podjęcia dobrej decyzji dobrej w danym momencie dla wszystkich zaangażowanych w proces jej podejmowania stron" (Brzezińska, Toeplitz, 2007).

Warto również zwrócić uwagę na fakt, iż znacznie częściej finansowane są $\mathrm{w}$ ramach polityki społecznej takie badania z udziałem dzieci, które nastawione są na poznawanie „dzieci z problemami”, a zatem już na etapie konceptualizacji dzieci postrzegane są jako słabe, podatne na nadużycia. Badania często koncentrują się na dzieciach doświadczonych przez los, pochodzących z trudnych, czasem patologicznych środowisk. Podejmowane zagadnienia badawcze dotyczące dzieci traktują często o przemocy, uzależnieniach, agresji, biedzie. Wielu autorów podkreśla, że nadal zbyt często są to badania 
z problemowymi dziećmi, a nie badania problemów dzieci (problem children not children's problems). Dzieci te, poza powszechnymi wśród nieletnich obawami, często mają dodatkowo niezwykle silny lęk przed oceną, przekonanie o niskim poziomie własnych kompetencji, cechuje je brak zaufania do dorosłych (w tym rozmaitych specjalistów) oraz brak gotowości do współpracy. Taka kategoria uczestników w sposób nieuchronny nasuwa mnóstwo problemów o charakterze etycznym, ponieważ ich szczególnie należy chronić przed dalszym krzywdzeniem, także związanym z koniecznością ujawniania drażliwych spraw w trakcie badania.

Również w Polsce, poza badaniami o charakterze marketingowym, nadal zbyt mało jest badań $\mathrm{z}$ „normalnymi” dziećmi i nastolatkami. Zjawisko to wzmacniane jest często przez nadopiekuńczą postawę rodziców dbających o dobro własnego dziecka, która przejawia się w nakłanianiu dzieci do odmowy i w rezultacie wpływa na zmniejszenie udziału dzieci w badaniach ${ }^{103}$.

Do zagadnień o charakterze etycznym należy także sposób wykorzystania rezultatów badań z udziałem dzieci w praktyce społecznej. Ta kwestia pozostaje w znacznym stopniu poza obszarem zainteresowania badaczy, którzy stali się jedynie diagnostami - nie ma bezpośredniego związku pomiędzy procesem uzyskiwania danych a ewentualnymi praktykami naprawczymi, jak było to chociażby w działalności badaczy społecznego ruchu surveyowego o celach reformatorskich.

\section{Przyczyny zagrożeń o Charakterze etyCznym W BADANIACH Z UDZIALEM DZIECI}

Dylematy związane ze specyfiką zasad etyki badawczej w przypadku badań z udziałem nieletnich w znacznym stopniu wynikają z próby ustalenia, w jakim zakresie i w jakim stopniu dzieci są uważane za podobne lub różne od dorosłych. W takim kontekście na pierwszy plan wysuwa się kwestia ich fizycznej słabości, relatywnie niskiego poziomu kompetencji (w tym brak umiejętności oddzielenia prawdy od fikcji), wysokiego poziomu wrażliwości i uzależnienia od osób dorosłych. Przekonanie o braku odpowiednich kompetencji do samodzielnego podejmowania przez dzieci decyzji o uczestnictwie w badaniu oraz powątpiewanie w wartość uzyskanych od takich uczestników informacji czasem przyjmuje skrajną postać. Na przykład Fine i Sandstrom (1988) zdają się postrzegać dzieci jako bardzo różniące się od osób dorosłych, gdy sugerują, że: „Odkrywanie tego, co dzieci naprawdę wiedzą, może

103 Warto zapoznać się z dziecięcą perspektywą uczestnictwa w badaniach (Edwards, Edwards, 2012). 
być prawie tak trudne, jak odtworzenie wiedzy domowego kotka na podstawie wydawanych przez niego dźwięków" (Lansdown, 1994). Zdaniem tych autorów jedyną właściwą metodą poznawania świata dzieci jest obserwacja ich zachowań. Ale na szczęście tak radykalne stanowisko prezentują jedynie nieliczni badacze. Inni wskazują, że większość aspektów trudnych występujących przy badaniach z dziećmi może pojawić się także w badaniu z osobami dorosłymi, a rozwiązaniem jest znalezienia właściwego sposobu interpretacji zebranego materiału (Waksler, 1991; Mayall, 2008; Woodhead, Faulkner, 2008). Przywołany wcześniej Charles Manga Fombad na przykład prezentuje stanowisko, zgodnie z którym nie można po prostu traktować dzieci jak dorosłych, bo one nie są dorosłe. Trzeba je traktować jak dzieci, ale w sposób, w jaki normalnie dorośli nie traktują dzieci - jako osoby z uprawnieniami, a nie tylko jako obiekty niepokoju.

Dzieci są pozbawione praw politycznych i obywatelskich, co ma swoje źródło w historycznych postawach i założeniach na temat natury dzieciństwa. Te okoliczności powodują, że dzieci stają się bardziej niż dorośli podatne na rozmaite zagrożenia (Lansdow, 1994). Można mówić o co najmniej czterech okolicznościach, które generują większy poziom zagrożenia wtedy, gdy uczestnikiem badania jest dziecko (Fombad, 2005).

Po pierwsze, ze względu na ograniczone kompetencje i doświadczenia życiowe, dzieci mogą mieć większe trudności niż dorośli ze zrozumieniem specyfiki procesu badawczego. Abstrahując od indywidualnych różnic rozwojowych, można przyjąć, że im młodsze dziecko, tym bardziej abstrakcyjnym przedsięwzięciem jest dla niego badanie społeczne. Tym samym ich zdolność do właściwego zrozumienia procedury świadomej zgody, prawa do rezygnacji z udziału $w$ badaniu oraz prawa do zachowania prywatności są mocno ograniczone. Z tych powodów dzieci zwykle mają niewielką kontrolę nad wieloma kluczowymi aspektami ich udziału w badaniach, które są gwarantowane dorosłym uczestnikom.

Po drugie, osoby niepełnoletnie są zdecydowanie bardziej niż dorośli podatne na wpływy zewnętrzne. Ich doświadczenia życiowe w wielkim stopniu mają charakter zinstytucjonalizowany (rodzina, szkoła), co znacznie wpływa na ograniczenie ich prawa do samodzielnej decyzji w kwestii uczestnictwa w badaniach. Mimo odczuwanej niechęci do udziału w badaniu, jeśli zgodę w tej sprawie podjęli rodzice lub nauczyciele, dziecku jest trudno odmówić.

Po trzecie, dzieci jako uczestnicy badania mają podwójny status prawny — z jednej strony bowiem zaleca się ich szczególną ochronę, a z drugiej strony - posiadają ograniczone prawa. Z tego powodu odpowiedzialni za nie dorośli mają tendencję do podejmowania w imieniu dzieci decyzji nie tylko dotyczących ich uczestnictwa w badaniach, lecz także w takich kwe- 
stiach, jak upublicznianie materiałów badawczych i uzyskiwanie bezpośrednich korzyści z udziału w badaniach. Zakłada się, że rodzice podejmują działania najlepsze z punktu widzenia interesów ich dzieci, ale przecież nie zawsze tak jest. Czasem kierują się egoistycznymi motywacjami (na jednym $\mathrm{z}$ amerykańskich forów internetowych zamieszczone są wpisy rodziców uszczęśliwionych faktem udziału ich dzieci w badaniach fokusowych dzieci za udział w sesji zarobią 75 dolarów, a rodzice mają 3 godziny darmowej opieki nad dzieckiem i czas na zakupy).

I wreszcie po czwarte, udział w niektórych typach badań wiąże się z narażeniem uczestnika na naruszenie jego autonomii, na stres i inne niekorzystne konsekwencje, które w przypadku, gdy uczestnikami są niedojrzałe dzieci, mogą być znacznie poważniejsze. (Przyjmuje się, że wrażliwość dziecka i podatność na skrzywdzenie zmniejsza się wraz z wiekiem, ale nie jest to reguła, gdyż czasem może być odwrotnie, na przykład zapytanie słabego ucznia-nastolatka o jego szkolne osiągnięcia niesie większe zagrożenie dla jego własnego wizerunku, niż gdyby takie pytanie zadać kilkuletniemu dziecku, które dopiero zaczyna naukę w szkole).

Uwzględniając powyższe zagrożenia, należy zgodzić się ze stanowiskiem Grodina i Glantza (1994), którzy wskazują, że zaangażowanie dzieci do badań społecznych wywołuje napięcie pomiędzy dwoma czasami sprzecznymi celami: z jednej strony jest ochrona dziecka przed ewentualną krzywdą i eksploatacją wynikającą z jego udziału w badaniu, ale z drugiej strony uzyskane od nich informacje zwiększają zasób wiedzy na temat dzieci i pozwalają projektować adekwatne medyczne, psychologiczne i społeczne strategie interwencyjne.

\section{ROZWIAZZYWANIE W PRAKTYCE BADAWCZEJ PROBLEMÓW ETYCZNYCH W BADANIACH FOKUSOWYCH Z UDZIALEM DZIECI}

Zainteresowanie udziałem dzieci w badaniach na świecie stało się w ostatnich kilkunastu latach widoczne także w projektach wykorzystujących zogniskowany wywiad grupowy. Dotyczy to zarówno obszaru polityki społecznej, socjologii, psychologii, jak i medycyny (Gibson, 2007) oraz rynku. Fokusy $\mathrm{z}$ udziałem dzieci są stosowane na każdym etapie badania, poczynając od fazy eksploracyjnej, na wsparciu w interpretacji wyników kończąc.

Liczni autorzy podkreślają zalety tej metody pozyskiwania informacji o dzieciach i od dzieci. Stwierdzają, że fokus pozwala na uzyskanie danych, jakie nigdy nie ujrzałyby światła dziennego przy zastosowaniu metod standaryzowanych (Kennedy, Kools, Krueger, 2001). Zdaniem badaczy praktyków uniknięcie wielu problemów etycznych oraz poprawa rzetelności i trafności rezultatów uzyskanych w badaniach z dziećmi mają miejsce wówczas, 
gdy zastosowana metoda badawcza daje dzieciom kontrolę nad procesem badań i pozostaje w zgodzie z dziecięcym sposobem postrzegania świata (Thomas, O'Kane, 1998).

Właśnie fokus bywa nazywany techniką przyjazną dzieciom (child-friendly technique) (Morgan i in., 2002). Dzieci w grupie czują się bezpieczniej, łatwiej jest im mówić o sprawach trudnych i złożonych. Dane uzyskiwane od dzieci w trakcie sesji nie są w żaden sposób filtrowane przez dorosłych i dlatego ich wartość dla badacza jest bardzo duża. Fokus nie wymaga od uczestnika jakiś specjalnych kompetencji, co jest jego ogromną zaletą, gdy badanymi są dzieci. Jeżeli zogniskowany wywiad grupowy realizowany jest z udziałem osób dorosłych, to w każdej sesji spotyka się od 6 do 12 osób, które dyskutują ze sobą około dwóch godzin. Zwykle uczestnicy nie znają się nawzajem. W sytuacji, gdy projekt jest realizowany z udziałem dzieci, przyjmuje się, że grupa powinna składać się nie więcej niż z sześciorga dzieci, a czas dyskusji dla dzieci najmłodszych w wieku 6-12 lat (z doświadczeń badawczych wynika, że dzieci poniżej szóstego roku życia nie radzą sobie w tego typu sytuacjach) nie powinien przekraczać $45 \mathrm{~min}$., 60 do 75 minut dla uczniów gimnazjum i 90 minut dla uczniów szkół średnich, pod warunkiem, że temat spotkania jest dla nich na tyle interesujący, że uda się tak długo utrzymać ich koncentrację. Pytania muszą być dostosowane do poziomu percepcji dzieci. Uczestnicy sesji mogą się znać pomiędzy sobą, czasem nawet zaleca się, aby tak było, ponieważ zwiększa to poczucie bezpieczeństwa małoletnich uczestników badania. Wskazane jest, aby dzieci były w możliwie zbliżonym wieku, żeby różnice poziomu kompetencji nie zaciążyły na przebiegu spotkania i samopoczuciu uczestników. Dzieci potrafią wiele wyrazić rysując, wycinając, sortując obrazki, odgrywając role, dotykając przedmiotów, bawiąc się nimi. Takie działania mają na celu uruchomienie wszystkich zmysłów i umożliwienie dzieciom wyrażenie opinii w inny niż werbalny sposób.

Moderatorem powinna być osoba, która ma doświadczenie w pracy z dziećmi. Musi potrafić okazać dzieciom szacunek, tolerancję, chęć słuchania. Powinno cechować go poczucie humoru, swoboda zachowania, spontaniczność, naturalność, pogodne usposobienie. Bardzo przydaje się także kreatywność, która pozwala na bieżąco modyfikować strategie przewidziane w scenariuszu, które nie sprawdzają się w bezpośrednim kontakcie z dziećmi. W takich sytuacjach dobrze radzą sobie młodzi nauczyciele nauczania początkowego pod warunkiem, że zostaną odpowiednio przeszkoleni i przygotowani. Jenny Schade, prezes Consulting JRS104, stwierdził w jednym $\mathrm{z}$ wywiadów, że moderowanie grup fokusowych z udziałem dzieci jest najbardziej zbliżone do prowadzenia teleturnieju. Do kontrolowania

104 Dostęp online: http://www.jrsconsulting.net/index.html 
i modyfikowania dynamiki grupy moderator powinien używać głównie języka ciała - uśmiechu, mimiki, zamiast krytycznego strofowania zachowania niesfornych dzieci.

Ważne jest właściwe przygotowanie pomieszczenia, w którym mają spotkać się dzieci - powinno być tak zaaranżowane, aby dzieci czuły się w nim bezpiecznie. Atmosfera spotkania powinna być możliwie nieformalna. Dzieci potrzebują trochę więcej czasu niż dorośli na zaakceptowanie sytuacji i zrozumienie jej specyfiki, zatem należy zaplanować wydłużoną fazę aranżacyjną (wstępną). Bardzo przydatne są w takich badaniach rozmaite techniki dodatkowe, stosowane wobec dzieci w innych niebadawczych sytuacjach. Można na przykład wprowadzić zasadę, że głos zabiera ta osoba, która złapała piłkę rzuconą przez moderatora. Takie zabiegi dobrze organizują formułę spotkania, a jednocześnie angażują uczestników i utrzymują ich koncentrację. Oczywiście pod warunkiem, że są właściwie dobrane ze względu na wiek i poziom rozwoju uczestników. Wielu problemów etycznych w badaniach fokusowych z udziałem dzieci można uniknąć lub przynajmmniej osłabić ich negatywne rezultaty poprzez stosunkowo proste zabiegi metodyczne. W bardzo wyjątkowym (ze względu na rozmiar, zakres problemowy i wagę uzyskanych wyników) projekcie pt.: Bezpieczeństwo dzieci w szkole i w rodzinie $w$ Łodzi ${ }^{105}$ celem było zebranie informacji od przedstawicieli szkół, których uczniowie w badaniach ilościowych najbardziej wyraźnie dali wyraz braku poczucia bezpieczeństwa (Lisek-Michalska, 2010a, Michałowska i in., 2008). Zamierzano głębiej spenetrować to środowisko i poznać ich opinie i odczucia w celu znalezienia odpowiedzi na pytania badawcze. Zatem już na wstępie było oczywiste, że uczestników sesji będzie się poszukiwać w środowiskach „trudnych" pod względem wychowawczym. Badania fokusowe zostały zaplanowane w okresie, w którym w łódzkiej prasie lokalnej opublikowano wyniki badania ilościowego. Zamieszczony tam ranking łódzkich szkół pod względem poziomu subiektywnie przez uczniów odczuwanego braku bezpieczeństwa wywołał liczne komentarze krytyczne ze strony środowiska nauczycielskiego. Ponieważ badacze nie uzyskali zgody na wgląd w listy adresowe uczniów interesujących szkół, zrealizowano rekrutację w następujący sposób: we wszystkich istotnych z badawczego punktu widzenia szkołach przeprowadzono ankietę złożoną z zaledwie czterech pytań.

Warto w tym miejscu zwrócić uwagę na jeden szczegół tego kwestionariusza ankiety (dlatego zamieszczono go tutaj w całości). Okazało się bowiem, że błędna była konstrukcja ostatniego pytania. Jeśli badaczom zależało na tym, aby ani koledzy uczniów, ani tym bardziej nauczyciele nie zorien-

105 Grant Prezydenta Miasta Łodzi, kierownik: prof. Elżbieta Michałowska; scenariusz, realizacja i opracowanie badania fokusowego: Jolanta Lisek-Michalska. 
towali się, kto zgłasza się do udziału w sesjach, należało przy odpowiedzi 2. Nie w pytaniu nr 4. poprosić o uzasadnienie odpowiedzi - Dlaczego nie? Tylko wtedy każdy respondent bez względu na swoją decyzję, musiałby poświęcić podobną ilość czasu i napisać podobną liczbę wyrazów w odpowiedzi na to czwarte pytanie. Przy budowie pytania, którą zastosowano, na uczniów wypisujących coś w końcowej części kwestionariusza (a nie ograniczających się do zakreślenia odpowiedzi $\mathrm{Nie}$ ) patrzono podejrzliwie i to niedopatrzenie mogło ich narazić na kłopoty ze strony nauczycieli lub kolegów przeciwnych badaniu.

\section{ANKIETA}

Zaznacz wybrane przez siebie odpowiedzi, otaczając kółeczkiem jej numer.

1. CZY WYPEŁNIAŁAŚ/WYPEŁNIAŁEŚ ANKIETE, DOTYCZĄCĄ TWOJEGO SAMOPOCZUCIA W SZKOLE I POZA SZKOŁĄ?

1. Tak.

2. Nie.

2. JAK SĄDZISZ, CZY PRZEPROWADZANIE TAKICH ANKIET WŚRÓD MŁODZIEŻY JEST POTRZEBNE?

1. Tak.

2. Nie.

3. UWAŻASZ, ŻE TWOI RÓWIEŚNICY ODPOWIEDZIELI NA PYTANIA ANKIETY:

1. Szczerze.

2. Nieszczerze.

4. CZY CHCIAŁABYŚ/CHCIAŁBYŚ WZIĄĆ UDZIAŁ W SPECJALNEJ ROZMOWIE O SPRAWACH PODOBNYCH DO TYCH, KTÓRYCH DOTYCZYŁY PYTANIA W ANKIECIE, CZYLI PRZEDE WSZYSTKIM O SAMOPOCZUCIU TWOIM I TWOICH RÓWIEŚNIKÓW?

1. Tak.

Wpisz swoje imię:

numer telefonu do Ciebie lub do Twoich Rodziców:

2. Nie.

DZIĘKUJEMY CI ZA WYPEŁNIENIE ANKIETY.

Uczniowie zainteresowani uczestniczeniem w sesji fokusowej podawali swoje dane ( $\mathrm{nr}$ telefonu). Następnie ankieterki kontaktowały się z potencjalnymi uczestnikami telefonicznie, potwierdzając ich udział w spotkaniu i uzyskując wstępną aprobatę rodziców/opiekunów. Uczniowie na spotkanie zobowiązani byli dostarczyć pisemne oświadczenia zgody rodziców/opiekunów na udział 
swoich niepełnoletnich dzieci w badaniu. Druk takiego oświadczenia dostarczały ankieterki tym dzieciom/nastolatkom, które w rozmowie telefonicznej potwierdziły swoją decyzję o uczestnictwie w badaniu.

Na każdą sesję zaproszono większą liczbę dzieci niż ustalone przez badaczy minimum, co okazało się zabiegiem słusznym, gdyż na żadne spotkanie nie stawił się komplet zaproszonych gości.

Uczestnikami każdego spotkania byli uczniowie jednego typu szkoły, czyli odbyły się sesje z uczniami szkół podstawowych, gimnazjów, szkół zawodowych ponadgimnazjalnych i liceów ogólnokształcących. W każdej sesji spotkali się uczniowie przynajmniej dwóch szkół z danego poziomu, szkół, które zajęły ostatnie miejsca $w$ rankingu tych placówek pod względem bezpieczeństwa. Badanie dotyczyło spraw bardzo trudnych. (Aneks, Załącznik 6.) Miało na celu m.in. sprawdzenie hipotezy o marginalizacji roli ojca w procesie wychowania dzieci i młodzieży i o zdominowaniu funkcji wychowawczych przez matkę. W celu odtworzenia sposobu, w jaki uczestnicy postrzegali rolę ojca i matki w procesie wychowania posłużono się techniką projekcyjną, techniką chińskiego portretu, wychodząc z założenia, że taka formuła pytania nie tylko będzie bardziej dostosowana do poziomu kompetencji uczestników, lecz także osłabi nieco spodziewane przykre emocje. Poproszono zatem uczestników o podanie pierwszych skojarzeń w reakcji na bodziec: Gdyby mama była zwierzęciem, jakim zwierzęciem by była? Dlaczego?

I tak na przykład, skojarzenia uczniów szkół gimnazjalnych były następujące: mama to zwierzę agresywne (...) No moja mama umie walczyć o swoje, lew (...) Dba i walczy, (...) jest opiekuńcza, hiena (...) Bardzo lubi się śmiać, czasami jest jak chłopak, czasami, jak i dziewczyna. Hieny sq czasem zalatane, a czasem sq leniwe, sarna (...) łagodna, mała jest, delikatna, i koń (...) Lubi się śmiać i biegać. Dla największej liczby uczestników ze szkół ponad gimnazjalnych mama to lew, ponieważ (...) jest władcza, (...) dominujqca, opiekuńcza też bardzo, (...) pilnuje porzqdku w domu, (...) jest osobq dumnq i szlachetnq, (...) Jest osobq opiekuńczq, o silnym charakterze. Umie postawić na swoim. (...) Jest choleryczką. Jest władcza. Mama może kojarzyć się także z psem, ponieważ (...) jest najlepszym przyjacielem, osłem (...) jest uparta i zawsze stawia na swoim. Licealiści skojarzyli mamę z psem, kotem i wężem. Psem jest dlatego, że (...) Wszystko musi wywęszyć, [pies jest] (...) Wdzięczny, (...) No, że zawsze jest przy mnie, (...) Na pewno psy sq bardziej otwarte, z psem utrzymuje się (...) Stosunki przyjacielskie.

Zatem, uogólniając, mama postrzegana jest przez uczestników badania przede wszystkim jako postać silna, stanowcza, niezależna, dominująca, opiekuńcza, zaradna, cechuje ją silny charakter, potrafi obronić siebie i swoich bliskich, jest wymagająca, konsekwentna, daje oparcie, jest przyjacielem. 
W drugiej części tego zadania uczniowie podawali skojarzenia w reakcji na bodziec: Gdyby tata był zwierzęciem, jakim zwierzęciem by był? Dlaczego?

I tak na przykład dla uczniów szkół podstawowych, gdyby tata był zwierzęciem, byłby psem, ponieważ jest (...) Silny, (...) Mądry trochę, (...) Da się wychować, (...) Jest miły. Tata to także żyrafa (...) No, bo jest duży, lub sowa (...) No, bo np. jak zacznę o czymś mówić, to już taki rozmowny i mądraliński się robi. Gimnazjalistom ojciec kojarzy się z bykiem, bo jest (...) Stanowczy, (...) Również lubi postawić na swoim, misiem (...) Mis duży pluszowy. Bo można się do niego przytulić zawsze. Pocieszy, niedźwiedziem, (...) Bo też jest duży i można się przytulić, ale też potrafi nakrzyczeć, jak trzeba i lisem (...) No tak. Jest przebiegły. Skojarzenia uczestników ze szkół zawodowych ponadgimnazjalnych zwracają uwagę na siłę, funkcje obronne oraz przebiegłość i egoizm ojców. Zatem tata to: lampart, bo (...) tata też stawia na swoim cały czas i potrafi mnie zawsze podejść. I przekabacić na swojq stronę, że wyjdzie na jego, lew (...) po prostu dominuje, tylko tyle, lis (...) przebiegły, podstępny i dba tylko o siebie, wąż (...) zdradziecki, namieszał w moim życiu, rozbił rodzinę, (...) Suset, bo też cały czas śpi, pies (...) Pies, tak ogólnie pies to zwierzę, które przywiqzuje się do człowieka bliskiego, natomiast do obcych, jeśli stwarzajq zagrożenie, jest agresywny i broni. Mój tata jest właśnie wcieleniem takiej osoby. Umie pokazać zęby jak trzeba. Licealistom ojciec skojarzył się np. ze szczurem (...) Mama mi się kojarzy z kotem, a tata ze szczurem. Szczur jest... takie małe, jak złapiesz przyciśniesz, to... zrobi, no tak, tata taki jest, jak my coś chcemy, to złapiesz za ogon i nic ci nie zrobi. (...) tagodny jest jak baranek, siedzi u mamy pod pantoflem strasznie, na wszystko się zgadza.; lisem, (...) bo mój tata jest strasznie przebiegły. Znaczy ogólnie, ja np. jak robię naleśniki w kuchni, to już zrób więcej, czy nawet...(...) Tzn. chytry nie jest, ale cwany potrafi być. (...) Tak zadziała, aby było po jego myśli, nie? lub lwem (...) Z jednej strony groźny, z drugiej bardzo rodzinny, Lew jest władczy...(...) No [tata] chciałby, ale mu się nie udaje.

Wizerunek ojca, jaki można wyinterpretować z tych wypowiedzi, różni się wyraźnie od obrazu matki. Uczestnicy akcentują przede wszystkim rozmiary i siłę fizyczną ojców, ale jednocześnie ich skłonność do podporządkowania się, uległość, mimo pozorów niezależności i stanowczości, egoizm, relatywnie małą dynamiczność życiową, spełnianie funkcji obronnych wobec rodziny.

Reakcja badanych osób na zastosowane pytanie projekcyjne była bardzo pozytywna. Zaskoczenie rodzajem zadania skutecznie „ukryło” jego bezpośrednie intencje. Wyzwoliło w nich jednocześnie zainteresowanie i ułatwiło mówienie o sprawach nie zawsze przyjemnych. 
Zdjęcie 10. Dwunastoletni uczestnicy sesji fokusowej; projekt Speak Up!

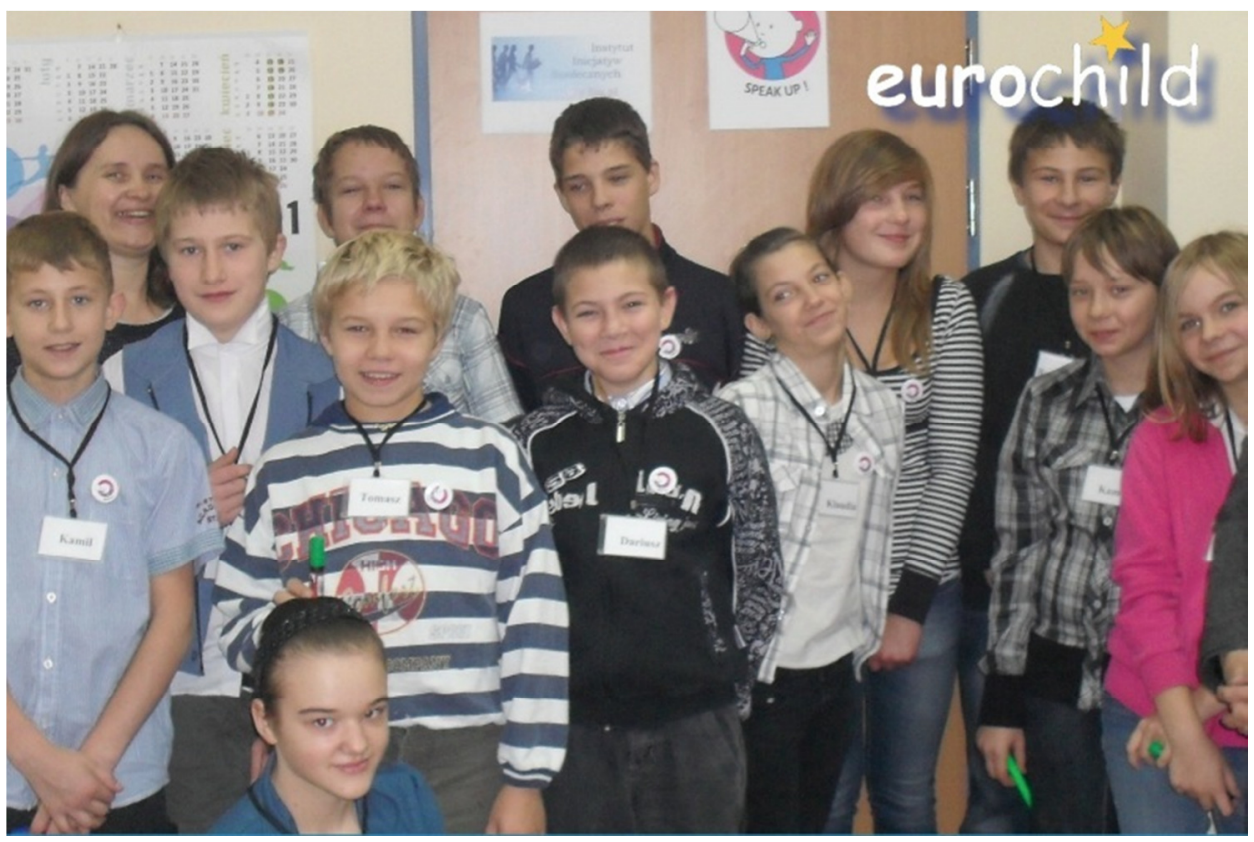

Źródło: http://www.eurochild.org/fileadmin/Projects/Speak\%20Up/triptych_final.pdf

Informacje o proporcjach udziału rodziców w procesie wychowania badanych dzieci i nastolatków uzyskano także przy zastosowaniu techniki projekcyjnej, tym razem wizualnej. Każdy uczestnik otrzymał rysunki dwóch identycznych pustych kwadratów. Używając dwóch kolorów kredek mieli za zadanie w pierwszym kwadracie zamalować właściwym kolorem (odpowiadającym matce lub/i ojcu) taki jego fragment, który ilustruje, w jakiej części ich własnych spraw uczestniczy matka, a w jakiej ojciec. Korzystając z tych samych kolorów, w drugim kwadracie mieli zakreślić taką jego powierzchnię, która odpowiadałaby ich potrzebom w tym zakresie. Zmierzenie i policzenie powierzchni kwadratów zamalowanych poszczególnymi kolorami pozwoliło wysnuć wniosek, że najbardziej ojca brakuje uczestnikom ze szkół gimnazjalnych; w pięciu na sześć przypadków, powierzchnia dolnego kwadratu, który miał ilustrować pożądany stopień uczestnictwa ojca w życiu badanych, była wyraźnie większa, niż ta zamalowana w pierwszym kwadracie. Relatywnie na Drugi projekt, realizowany w 2011 i wiosną 2012 roku, miał zupełnie inny charakter. Sieć Eurochild ${ }^{106}$ była koordynatorem między-

106 Eurochild jest siecią organizacji i osób pracujących w krajach europejskich na rzecz poprawy jakości życia dzieci i młodzieży; http://www.eurochild.org. 
narodowego projektu pod nazwą Speak up!107 dotyczącego, ogólnie mówiąc, praw dziecka. Podstawowym celem przedsięwzięcia było ustalenie, w jakim stopniu dzieci dorastające w trudnych warunkach życiowych są świadome praw przysługujących dzieciom, jaką mają wiedzę w tym zakresie, jak oceniają przestrzeganie tych praw. W Bułgarii i Grecji obiektem zainteresowania były dzieci romskie, w Irlandii - dzieci ze zmarginalizowanej grupy etnicznej wywodzącej się z nomadów (Irish Travellers), na Węgrzech - dzieci z domów dziecka, w Szwecji - dzieci głuche i niedosłyszące, w Anglii dzieci, które miały kontakt $\mathrm{z}$ wymiarem sprawiedliwości dla nieletnich, zaś w Holandii - dzieci rodziców ubiegających się o azyl. W Polsce natomiast uczestnikami były dzieci z wielkomiejskich enklaw biedy108. W każdym kraju, także w Polsce, sesja z wybraną kategorią badanych została poprzedzona spotkaniem z grupami kontrolnymi złożonymi z dzieci zdefiniowanych jako niezagrożone społecznie

Celem tego zabiegu było nie tylko uzyskanie materiału porównawczego, lecz także sprawdzenie, wjaki sposób funkcjonuje narzędzie badawcze i opracowana strategia badania. Było to bardzo istotne, gdyż w sesji uczestniczyły dzieci zaledwie dwunastoletnie i należało dążyć do wyeliminowania wszelkich potencjalnie niewłaściwych elementów zasadniczego spotkania. Zabieg ten okazał się ze wszech miar pożądany, gdyż ujawnił pytania/zadania sprawiające kłopoty. Dostrzeżenie tych trudności i zidentyfikowanie ich przyczyn pozwoliło na zmodyfikowanie scenariusza przed właściwą sesją z dziećmi dorastającymi w trudnych warunkach.

Narzędzie do badania (Aneks, Załącznik 5.) zostało przygotowane w oparciu o niezwykle szczegółowe dyrektywy metodologiczne sformułowane przez zespół projektowy Eurochild. Wskazówki zawarte w tym dokumencie dotyczyły podstawowych zasad, jakich zobowiązany był przestrzegać każdy dorosły członek zespołu badawczego podczas konsultowania się z badanymi dziećmi. Reguły te obligowały do: zagwarantowania dzieciom możliwości wypowiadania się własnymi słowami i mimiką; zapewnienia wszystkim dzieciom bez względu na wiek, płeć, poziom kompetencji, pochodzenie społeczne, pochodzenie etniczne itd. jednakowej

\footnotetext{
107 Projekt Speak up! Giving a voice to Europe's most vulnerable children, był współfinansowany przez Komisję Europejską, Directorate-General Justice (nr projektu 30-CE-0377147/00-75-1240) 108 Partnerem polskim w projekcie była Fundacja Instytut Inicjatyw Społecznych w Łodzi, która zrealizowała badanie z udziałem pracowników UŁ: Grażyny Mikołajczyk-Lerman, Kamila Kruszyńskiego i Autorki; pod kierownictwem prof. W. Warzywody-Kruszyńskiej. J. Lisek-Michalska opracowała scenariusz fokusa na podstawie wytycznych Eurochild (zob. http://www.euro child.org/fileadmin/Projects/Speak\%20Up/Methodology_Speak_Up_Final.pdf) i moderowała FGI, we współpracy z G. Mikołajczyk-Lerman, reprezentującą polski zespół wśród metodologów opracowujących wytyczne do projektu.
} 
szansy uczestniczenia w grupach fokusowych. Osoby dorosłe zobowiązano do całkowitej szczerości wobec dzieci i do formułowania czytelnych dla uczestników informacji zwrotnych oraz do powstrzymywania się od traktowania dzieci w kategoriach ofiar lub jednostek słabych, do unikania artykułowania stereotypów płciowych oraz sytuacji, które mogłyby takie stereotypy tworzyć, a także do dokładnego upewnienia się, czy wszystkie uzyskane informacje zostały przez badaczy właściwie (zgodnie z intencją dzieci) zrozumiane.

Zdjęcie 11. Dwunastoletni uczestnicy sesji fokusowej w trakcie realizacji techniki projekcyjnej; projekt Speak Up!

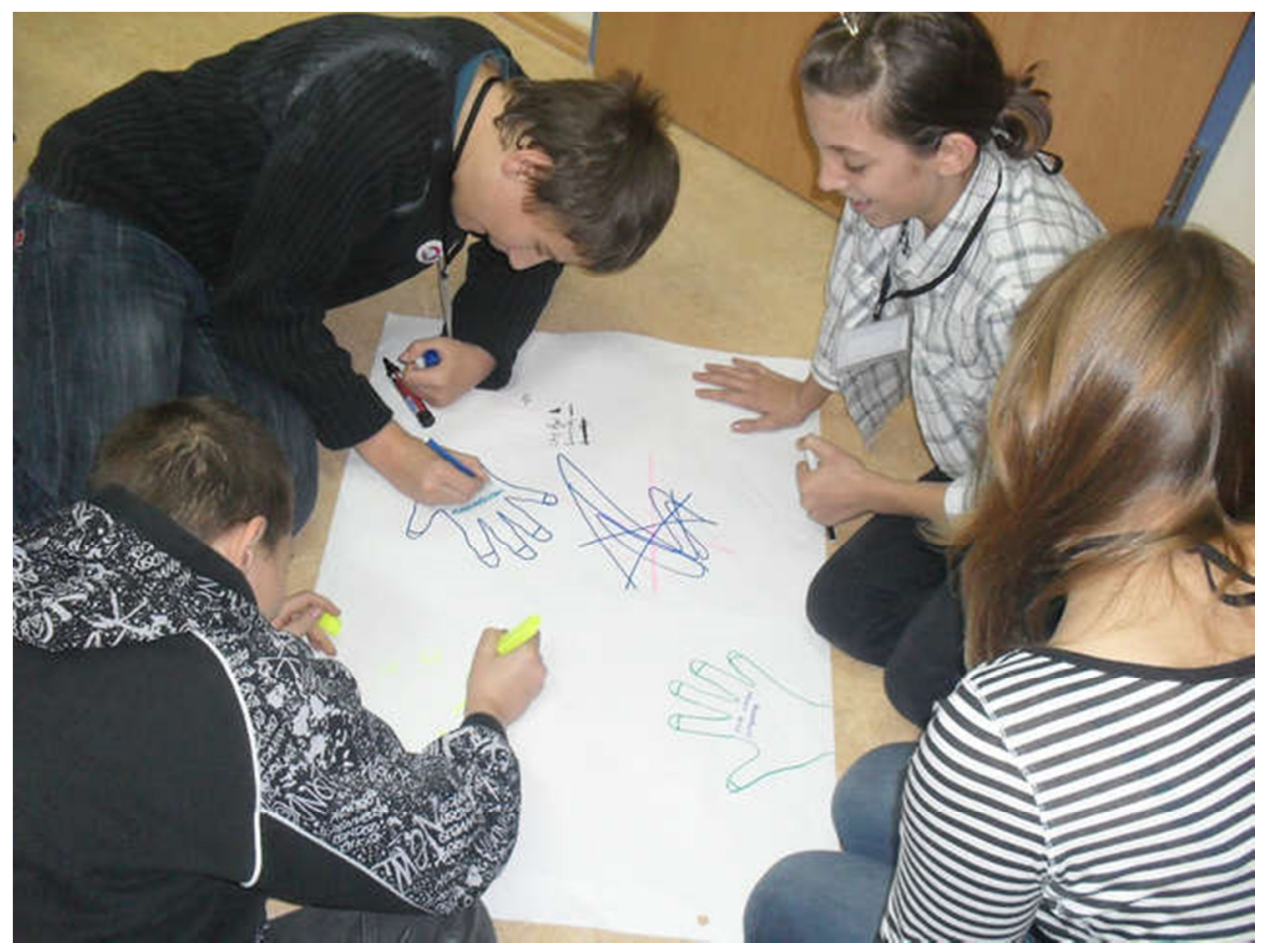

Źródło: http://www.sp111.edu.lodz.pl/SDC15786.jpg

Od moderatora prowadzącego sesje oczekiwano, iż będzie uwzględniał w trakcie dyskusji zarówno indywidualne idee, jak i hierarchię, jaką poszczególnym problemom nadadzą same dzieci, że będzie traktował uczestników jak ekspertów własnego życia, jak jednostki mądre i kreatywne oraz że zapewni jednakowy udział w dyskusji wszystkim dzieciom, zadba o ich pełne bezpieczeństwo i zapewni jednocześnie dobrą zabawę. W celu zadba- 
nia o dobre samopoczucie uczestników od moderatora oczekiwano różnorodnych kompetencji i zachowań komunikacyjnych, takich jak utrzymywanie stałego kontaktu wzrokowego z dziećmi, częste uśmiechanie się do dzieci, współpracowanie z nimi podczas wykonywania zadań, wyrażanie zrozumienia wypowiadanych treści, prezentowanie spokoju i pewności siebie. W obszarze komunikacji werbalnej moderator zobowiązany został do uważnego słuchania i reagowania na wypowiedzi dzieci, do wyraźnego i czytelnego formułowania pytań i zadań, do aktywnego wspierania tych uczestników, którzy potrzebują różnorodnej pomocy, do wyrozumiałości i umiejętności utrzymania przyjaznej atmosfery. Sugestie zawarte w wytycznych metodologicznych dotyczyły także odpowiednich rozmiarów i wyposażenia pomieszczenia, w którym przeprowadzano sesje.

Szczególnie wiele uwagi poświęcono licznym środkom ochrony dzieci uczestniczących w badaniu fokusowym. Obejmowały one między innymi: precyzyjne sformułowanie obowiązków wszystkich osób dorosłych zaangażowanych w realizację projektu, uzyskanie zgody dzieci i ich rodziców/opiekunów prawnych, zagwarantowanie dzieciom dobrowolności uczestnictwa, zapewnienie im konfidencjalności, czyli niewskazywanie wopracowaniu końcowym tożsamości autorów poszczególnych wypowiedzi.

Warto zwrócić uwagę na niektóre elementy scenariusza, który starano się opracować (i realizować) zgodnie z wytycznymi metodologicznymi projektu Speak up!, uwzględniającymi zasady etyki badawczej wobec dzieci oraz ich możliwości intelektualne, a także ze świadomością ich potrzeby zabawy, ruchu, trudności w utrzymaniu koncentracji.

$\mathrm{Na}$ wstępie moderator prowadzący sesję przedstawił się, proponując, aby uczestnicy sami zapytali go o to, co jeszcze na jego temat chcieliby wiedzieć. Do prezentacji uczestników zastosowano następującą technikę: każde dziecko losowało jedno spośród przygotowanych wcześniej haseł, które stanowiło oś jego własnej autoprezentacji np.: Ulubiony film - jaki, dlaczego?, Ulubiony przedmiot szkolny - jaki, dlaczego?, Ulubione zwierzęjakie, dlaczego?, Ulubiona potrawa - jaka, dlaczego?, Ulubiona pora roku jaka, dlaczego? W trakcie opisywania projektu Speak up! poinformowano uczestników, że wszystkie dzieci, które biorą udział w przedsięwzięciu badawczym, mogą ze sobą korespondować i wymieniać doświadczenia na Facebooku. Następnie dzieci wyszukiwały i oznaczały na zamocowanej na ścianie pracowni mapie kraje, z których dzieci uczestniczyły w projekcie. Zadanie to miało na celu uświadomienie dzieciom zakresu wydarzenia, w którym partycypują. Zasady uczestnictwa zostały kolejno odczytane, a dalej ustalano, czy dzieci je rozumieją oraz akceptują. Po upewnieniu się, że porozumienie zostało osiągnięte, kolejne plansze z wydrukowanymi 
regułami wzajemnego postępowania były mocowane na ścianie pracowni fokusowej. W wersji dla dzieci, zasady te sformułowano następująco:

- Każdy słucha uważnie, gdy ktoś mówi, nie przerywa innej osobie w trakcie jej wypowiedzi.

- Każdy ma prawo nie uczestniczyć w dyskusji, gdy nie czuje się gotowy.

- Każda wypowiedź jest jednakowo ważna.

- Każda wypowiedź jest jednakowo dobra. Nie ma złych odpowiedzi.

- Każdy ma prawo do własnych opinii.

- Każdy uczestnik wyłącza swój telefon na czas trwania spotkania.

- Każdy ma prawo zapytać, jeśli czegoś nie rozumie lub nie usłyszy.

- Każdy szanuje opinie innych, nawet jeśli się z nimi nie zgadza.

- Każdy stara się jak najlepiej uczestniczyć w spotkaniu.

- Nikt nie używa wulgarnych słów.

- Nikt nie narzuca swojego zdania innym uczestnikom spotkania.

- Nikt, a w szczególności rodzice, nauczyciele i koledzy ze szkoły nie dowiedzą się od organizatorów o tym, co zostanie powiedziane podczas spotkania.

Uczestnicy zostali poinformowani także o planowanym nagraniu krótkiego filmu ze spotkania i o zamiarze umieszczenia go na stronie internetowej organizacji Eurochild. Dopiero w tym momencie dzieci zostały poproszone o pisemne wyrażenie zgody na udział w badaniu i upublicznienie ich wizerunku (fotografie i filmy) w opracowaniach dotyczących projektu Speak up! zgodnie z przyjętymi zasadami. Otrzymały do przeczytania i podpisania przygotowane wcześniej formularze. Zgoda rodziców na udział dzieci w badaniu została uzyskana za pośrednictwem szkoły, z której uczniowie byli rekrutowani do uczestnictwa w projekcie, przy współudziale nauczycieli.

Wzmocnieniu podmiotowości badanych i ich pewności siebie służyły różne zabiegi, miedzy innymi informacja o tym, że „kilka dni wcześniej świat oczekiwał narodzin siedmiomiliardowego mieszkańca Ziemi. Wśród tych 7 mld ludzi jest około 2 miliardy dzieci poniżej 15. roku życia. Czyli mniej więcej co trzeci mieszkaniec Ziemi jest dzieckiem, które nie ukończyło jeszcze 15 lat! W Polsce żyje około 40 milionów ludzi. Gdyby wszyscy mieszkańcy Polski byli dziećmi, to musiałoby być takich państw 50 , żeby pomieścić wszystkie dzieci świata!!!”

W module wprowadzającym w problematykę praw dziecka uczestnicy zostali poinformowani, że każde dziecko ma określone prawa. Zarówno chłopiec, jak i dziewczynka w wieku poniżej 18 lat dysponuje pewnymi szczególnymi uprawnieniami. Lista tych praw, jak również działania, które rządy muszą podjąć, aby pomóc w korzystaniu z nich, są określone w Kon- 
wencji Narodów Zjednoczonych o Prawach Dziecka. Konwencja (KPD) jest traktatem międzynarodowym, czyli umową między państwami. Prawie wszystkie kraje na świecie, w tym wszystkie kraje Europy, przyjęły Konwencję. Państwa - strony Konwencji są zobowiązane przestrzegać zasad ustanowionych w traktacie, a także są zachęcane do podejmowania środków, które byłyby jeszcze bardziej korzystne dla dzieci niż przepisy Konwencji. KPD jest zatem bardzo ważnym traktatem dla dzieci na całym świecie. Konwencja zajmuje się różnego rodzaju zagadnieniami mającymi związek z życiem dzieci i młodzieży. Wszystkie prawa są ze sobą ściśle powiązane i są równie ważne. Czasami prawa opisują, co jest najlepsze dla dzieci w danej sytuacji, lub co ma decydujące znaczenie dla życia dzieci i chroni je przed krzywdą.

Zdjęcie 12. Rezultaty wizualnej techniki projekcyjnej ${ }^{109}$.

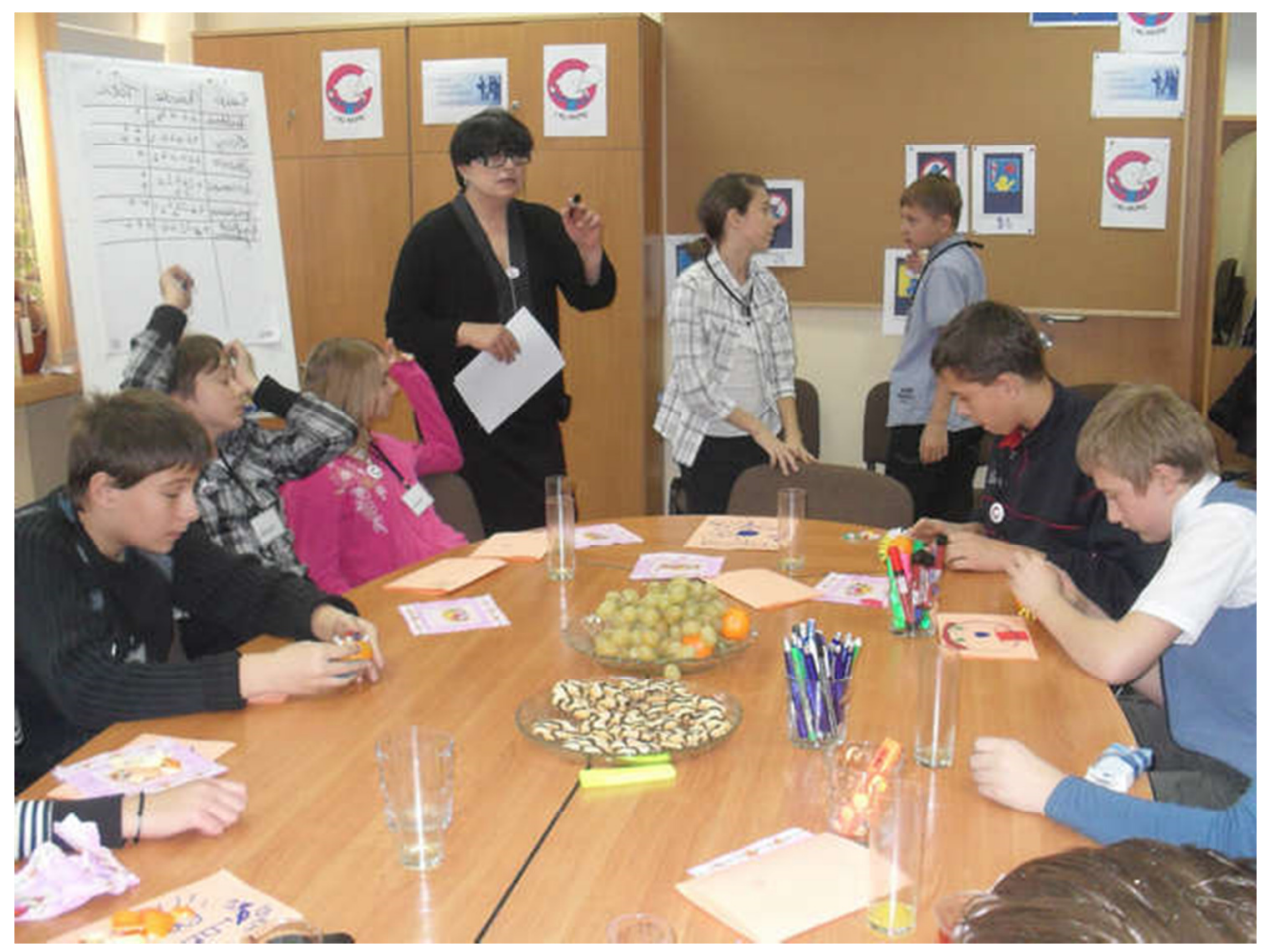

Źródło: http://www.sp111.edu.lodz.pl/SDC15808.jpg

${ }^{109}$ Sesja moderowana przez Autorkę. 
$(221) \quad$ Rozwiązywanie problemów

Dopiero po takim wprowadzeniu dzieci były proszone o dokonanie selekcji zilustrowanych praw na prawa zawarte w KPD i takie, które nie są prawami dzieci w rozumieniu KPD. Wszystkie prawa zostały umieszczone na niewidocznej wcześniej dla uczestników tablicy. Spośród wybranych i pozostawionych 14 prawdziwych praw dzieci miały za zadanie wybrać 4 prawa najważniejsze z ich punktu widzenia. Zrealizowały cel przy pomocy selekcji negatywnej, odrzucając (i uzasadniając swoje decyzje) kolejno prawa mniej ważne.

Zdjęcie 13. Sesja moderowana przez Autorkę w projekcie Speak Up!

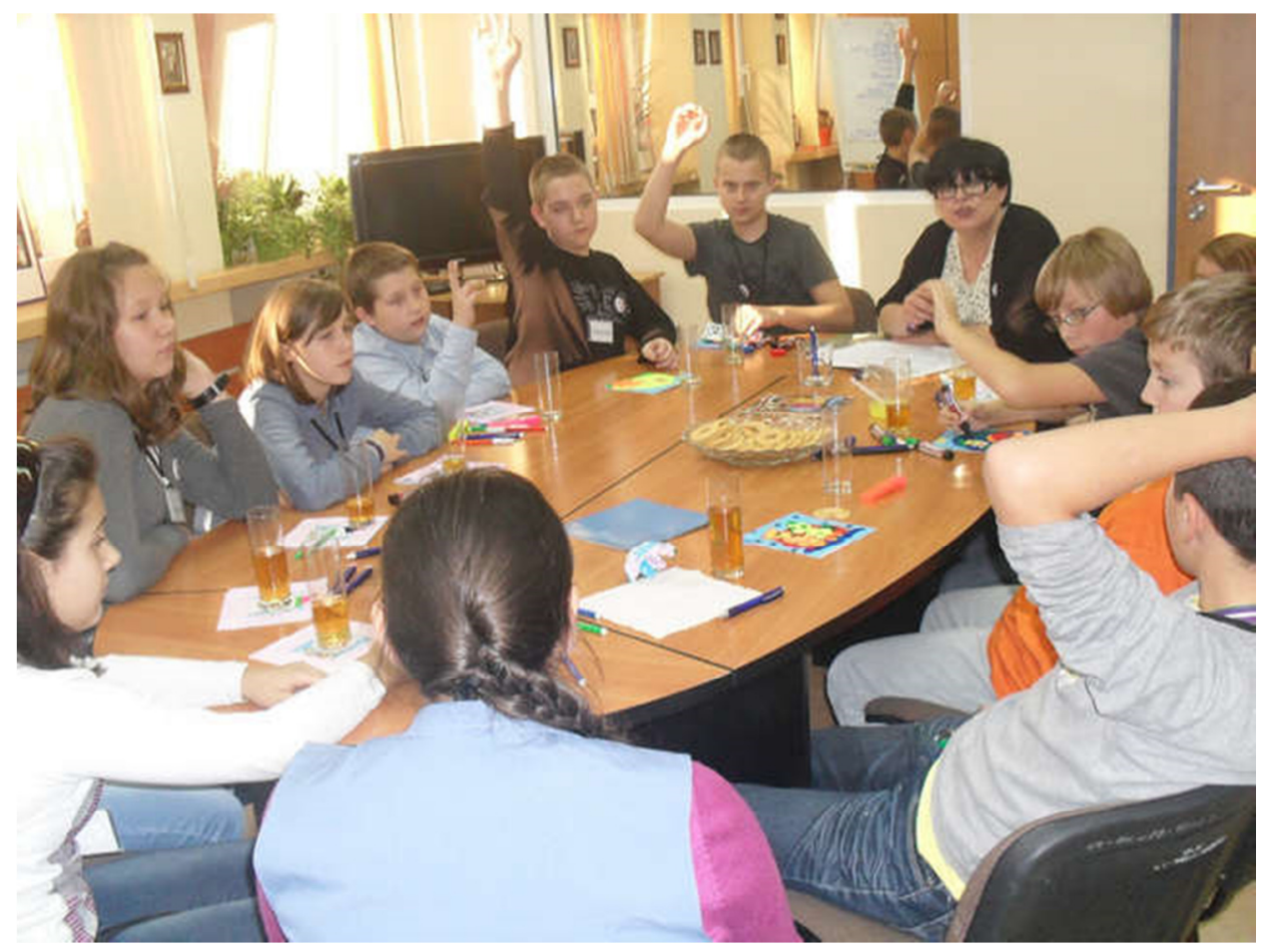

Źródło: http://www.sp111.edu.lodz.pl/SDC15735.jpg

Po podsumowaniu dyskusji i ustaleniu, czy dzieci akceptują uzyskane wnioski, poproszono je o dokonanie oceny spotkania, w którym brały udział. Uczestnicy opiniowali sesję w poniższych wymiarach, używając do tego skali ocen szkolnych od 1 (niedostateczny) do 5 (wzorowy).

- Jak oceniasz udział innych dzieci w tym spotkaniu? Czy pracowały aktywnie?

- Jak oceniasz atmosferę tego spotkania? Czy było ci tutaj miło, czy też nie? 
- Jak oceniasz wnioski z tego spotkania? Czy są ważne, czy też nie?

- Jak oceniasz osoby prowadzące to spotkanie?

- Jak oceniasz przebieg tego spotkania? Czy było ono dla ciebie ciekawe, czy też nie?

Każde dziecko wystawiało flamastrem ocenę na planszy umieszczonej na ścianie pracowni.

Na zakończenie wyjaśniono dodatkowo, że takie konsultacje z dziećmi są prowadzone po to, aby rządy państw mogły lepiej zatroszczyć się o dzieci, aby ci, którzy podejmują decyzje, zdawali sobie sprawę z tego, co jest dla dzieci ważne, na co powinni zwrócić uwagę w swojej działalności. Poinformowano uczestników także o tym, że Eurochild (na swojej stronie internetowej), dla dzieci uczestniczących w takich spotkaniach, planuje uruchomić sieć kontaktową za pomocą Facebooka i Twittera. Wreszcie podziękowano dzieciom za ich wysiłek i wręczono im drobne upominki.

W przypadku obu przedstawionych wyżej przedsięwzięć badawczych z udziałem niepełnoletnich uczestników z uwagi na szczególne okoliczności (w pierwszym przypadku - drażliwość tematyki, w drugim - trudna sytuacja życiowa badanych dzieci), opracowanie metod badawczych w jednakowym stopniu uwzględniało cele merytoryczne projektów oraz aspekty etyki postępowania wobec dzieci w kontekście badawczym. Przyjęcie przez realizatorów innych zasad etyki badawczej, niż miało to miejsce we wspomnianych projektach z pewnością zaowocowałoby wypracowaniem odmiennych metod badawczych. 


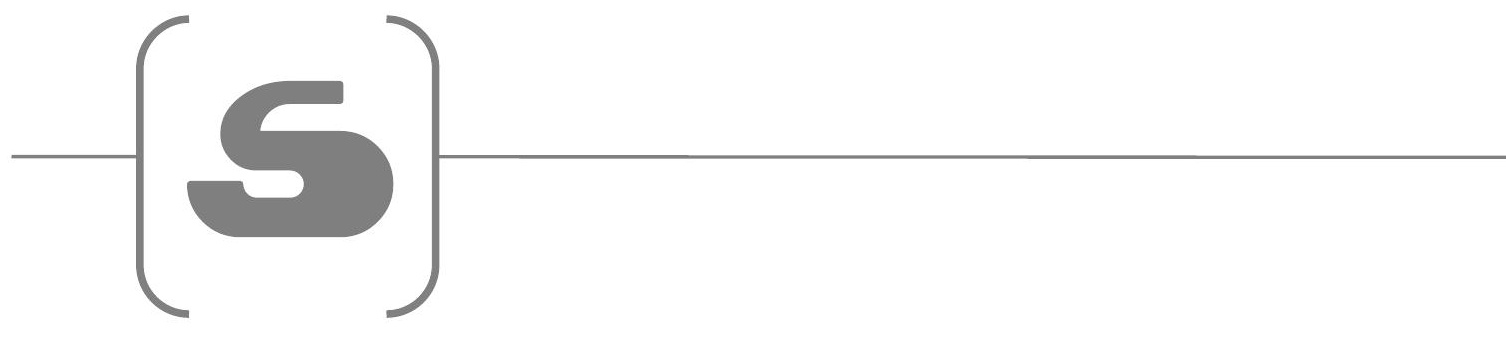

ZASTOSOWANIE

METODY FGI

DO ROZWOJU

METODOLOGII BADAŃ

OSÓB STARSZYCH 



\section{WPROWADZENIE}

Obserwacja projektów badawczych, realizowanych w ostatnim dwudziestoleciu w różnych dziedzinach nauk społecznych, skłania do stwierdzenia, iż badacze społeczni nie weryfikują swojego podejścia badawczego ani nie modyfikują narzędzi ze względu na obecność w badanej próbie osób w wieku 65+. Badani $\mathrm{w}$ wieku mocno podeszłym traktowani są w sposób identyczny, jak młodsze kategorie wiekowe. Badacze zdają się lekceważyć związane z wiekiem zmiany percepcyjne, ograniczenia komunikacyjne oraz wiele innych cech osób w zaawansowanym wieku, które to cechy mogą w znacznym stopniu zakłócić przebieg procesu uzyskiwania materiału empirycznego. Efektem takiego podejścia staje się atrefaktualność raportowanych materiałów empirycznych. Wydaje się, że największe zagrożenie dotyczy technik wysoko zestandaryzowanych oraz badań z wykorzystaniem nowoczesnej technologii (CAPI, CATI, CAWI), choć z pewnością ten rodzaj problemów może wystąpić także w bardziej „miękkich” sposobach uzyskiwania informacji. Taka postawa badaczy sprzyja pogłębianiu (będącej często przedmiotem zainteresowań badawczych!) marginalizacji tego pokolenia poprzez formułowanie diagnoz opartych na danych o niewielkiej czy trudnej do oszacowania wartości.

Celem tego rozdziału jest zainteresowanie badaczy społecznych problematyką dostosowania metod badawczych do badania silver generation. $\mathrm{Z}$ uwagi na dynamiczne zmiany struktury społecznej, polegające na stałym wzroście w społeczeństwie polskim odsetka osób w wieku 65+ (Szukalski 2006) i tym samym zwiększeniu udziału tej kategorii wiekowej w próbach losowanych/dobieranych w badaniach, należałoby bardzo poważnie zastanowić się nad możliwymi metodologicznymi i etycznymi skutkami tego procesu dla badań społecznych. Sprawa wydaje się nagląca, gdyż wyraźnie wzrosła średnia długość życia, osiągając w Polsce dla kobiet 79 lat, dla mężczyzn - 71, a prognozy demograficzne każą spodziewać się, że już w 2020 roku co czwarty Polak przekroczy 75. rok życia (Szukalski, Kowaleski, 2008). Nie uda się właściwie rozpoznawać problemów tej społeczności bez wypracowania adekwatnych taktyk porozumiewania się pomiędzy jej przedstawicielami a badaczami. 


\section{CECHY WIEKU PODESZtEGO W KONTEKŚCIE METOD BADAŃ SPOtECZNYCH}

Osiąganie zaawansowanego wieku biologicznego wiąże się ze zmianami w funkcjonowaniu wielu narządów wewnętrznych człowieka i tym samym skutkuje obniżeniem jego sprawności psychofizycznej. Zmiany obejmują wszystkie sfery aktywności człowieka (Giddens, 2004). Tutaj zostaną zasygnalizowane jedynie te spośród nich, które wsposób bezpośredni mają znaczenie dla przebiegu procesu badawczego o charakterze interrogacyjnym.

Planując badania z udziałem osób w wieku $65+$, warto pamiętać, że w ich obszarze percepcji następuje ograniczenie zdolności widzenia (u bez mała 75\% osób pomiędzy 65. a 70. rokiem życia występuje dalekowzroczność, a prawie co druga osoba powyżej 60. roku życia cierpi na kataraktę) (Stuart-Hamilton, 2006). Oczy osób starszych widzą inaczej, co powinno być brane pod uwagę szczególnie w badaniach ankietowych. Spadek wrażliwości wizualnej następuje także u osób z pozornie nieuszkodzonym wzrokiem.

Ulega także wyraźnemu pogorszeniu słuch (Stuart-Hamilton 2006); z badań wynika, że problem niedosłuchu czy, inaczej mówiąc, głuchoty starczej, dotyka co piątą osobę powyżej 55. roku życia, co czwartą w wieku ponad 65. lat, oraz 33\% tych, którzy skończyli 75. rok życia.

Obie te dysfunkcje prowadzą w sposób nieuchronny do wydłużenia czasu reakcji na bodźce; są także jedną z przyczyn trudności w osiąganiu i utrzymaniu koncentracji. Warto wziąć to pod uwagę już w fazie konceptualnej projektu badawczego.

Przy formułowaniu problematyki badania oraz konstrukcji narzędzia badawczego koniecznie należy uwzględnić powszechne przekształcenia w obszarze pamięci osób 65+. Kosztem pamięci krótkotrwałej relatywnie dobrze funkcjonuje pamięć długotrwała. Relatywnie, gdyż także pamięć całościowa ulega pogorszeniu na skutek zakłócenia transferu zmagazynowanych danych (trudniej je wydobyć, przywołać). Generalnie z badań wynika, że charakter pamięci ludzi starych jest jakościowo różny od specyfiki pamięci ludzi młodych.

U ludzi po 60. roku życia obserwuje się także wzmożone problemy w zakresie umiejętności kojarzenia, myślenia logicznego ${ }^{111}$. Również możliwości dokonywania analiz i syntez ulegają ograniczeniu, pojawiają się problemy z podjęciem decyzji i z jej wyrażeniem - trudniej znaleźć odpowiednie słowa. Zmniejsza się wyraźnie zdolność uczenia się, przyswajania nowych

\footnotetext{
111 „Na podstawie przesiewowego testu MMSE w reprezentatywnej dla populacji polskiej grupie osób po 65. roku użycia wysunięto podejrzenie otępienia u ok.1/3 badanych. Wykazano wyraźne wzrastanie częstości i stopnia nieprawidłowości w zakresie funkcji poznawczych wraz z wiekiem oraz u badanych gorzej wykształconych." (Klich-Rączka i in., 2012, s. 119)
} 
treści i ich zapamiętywania, natomiast wzrasta podatność na działanie bodźców rozpraszających (Klich-Rączka i in., 2012). Generalnie wszelkie procesy myślowe przebiegają w zwolnionym tempie, co często wyraźnie daje się zaobserwować w bezpośredniej rozmowie. [np.: geragogika przyjmuje założenie o tak wyraźnej odmienności struktur poznawczych ludzi starych, że różnice te uzasadniają konieczność sformułowania odrębnej teorii edukacji w starości. (Halicki, 2003, s. 29-30)]

Wymienione tu w zarysie prawidłowości oczywiście występują w różnym nasileniu u poszczególnych przedstawicieli silver generation. Stopień natężenia tych niekorzystnych objawów uzależniony jest od osobowości konkretnego człowieka, a w tym także od czynników ją kształtujących takich jak poziom i rodzaj wykształcenia, subiektywnie postrzegany status społeczny, charakter wykonywanej w przeszłości pracy zawodowej, stan zdrowia, relacje z najbliższą rodziną czy wreszcie kondycja ekonomiczna.

Osoby w zaawansowanym wieku przybierają także bardzo różne postawy wobec własnej starości. Rozmaite teorie adaptacji do starości próbują je wyjaśnić $\mathrm{z}$ różnych perspektyw, koncentrując się na aspektach jednostkowych, indywidualnych (np. teoria ról - Cottrell, 1942; Rosow, 1985; teoria aktywności - Lemon, Bengtson, Peterson, 1981; teoria wycofania - Cumming, Henry, 1961; Havighurst, Neugarten, Tobin, 1968; Rembowski, 1984; teoria opanowywania trwogi TMT - Greenberg, Pyszczyński, Solomon, Simon, Breus, 1994), na relacjach społecznych (np. teoria stratyfikacji wieku Rileya, Johnsona i Fonnera, teoria modernizacji —Cowgill, 1974), lub, jak te najnowsze, na przykład podkreślając rolę płci w procesie starzenia (gerontologia feministyczna - Garner, 1999). Wiele interesujących propozycji analizy procesu starzenia się dostarczają współczesne koncepcje wywodzące się z badań genetycznych, na przykład teoria zegara molekularnego (Fossel, 1999; Medina, 2001) czy teoria szybkości życia (Hayflick, 1998). Przedstawicielka nurtu biograficznego, Ch. Bühler (1999), w oparciu $\mathrm{o}$ analizę biografii, zwraca z kolei uwagę na znaczenie poczucia spełnienia i bilansu życiowego, jakiego dokonują seniorzy, a według najbardziej chyba popularnej wśród przedstawicieli nauk społecznych koncepcji E. Eriksona (Sękowska, 2000; Erikson, Erikson, 2012), starość przypada na ósme stadium rozwoju. Ludzie starzy mają za zadanie uporanie się z ostatnim już, ale wcale nie najmniej istotnym kryzysem rozwojowym, w którym lokują się pomiędzy integracją (poczuciem harmonii i sensu własnego życia) a rozpaczą związaną $\mathrm{z}$ lękiem przed śmiercią.

Bez względu na to, jak w poszczególnych koncepcjach rozłożone są akcenty, zawsze uwzględniają one zmiany zachodzące w osobowości ludzi starych (Susułowska 1989), polegające między innymi na wyższym niż u ludzi młodych poziomie lęku, wzrastającym poczuciu uzależnienia od otoczenia, większym zapotrzebowaniem na odczuwanie bezpieczeństwa (Straś-Roma- 
nowska, 2007). Często doświadczają poczucia bezradności, zagubienia, niemocy (Pankowski, 1999; Wciórka, 2000; Grudniewicz, 2001).

Powyższy, bardzo powierzchowny przegląd koncepcji starzenia się i starości pokazuje, jak ogromny dorobek wielu dyscyplin mogą wykorzystać badacze społeczni do modyfikacji podejścia badawczego wobec ludzi starych. Wymienione tu propozycje sugerują także kierunki użytecznych analiz, na przykład nie tylko konieczność dostosowania formy komunikacji (empatia, cierpliwość), lecz także uważności w doborze jej treści ze względu na przemodelowanie systemu wartości ludzi starych (Cibor, 2008). Przekształcenia w systemie wartości seniorów prowadzą bowiem do wyłonienia się obszarów drażliwych, jakościowo odmiennych niż uludzi młodszych. Konstatacja ta powinna być szczegółowo rozpoznana i uwzględniana w projektowaniu badań z udziałem ludzi starszych co najmniej na równi zuwzględnieniem ich zmienionych możliwości w sferze percepcji.

Formułując wykaz analiz, jakie wydają się użyteczne dla dostosowania metodologii badań społecznych do starszych uczestników badań, można jako punkt wyjścia wykorzystać zadania postawione geragogom ${ }^{112}$ i pedagogice starzenia się i starości. Do najważniejszych problemów w zakresie badań podstawowych i badań zalicza się tutaj między innymi następujące zagadnienia:

- poznanie starzenia się jako procesu, a równocześnie fazy życia ludzkiego,

- diagnozę sytuacji życiowej ludzi w podeszłym wieku (m.in. określenie stanu zdrowia i zaradności życiowej, systemu wartości uznawanych przez ludzi starszych, aktywności w czasie wolnym, a także rozpoznanie sytuacji ekonomicznej i społecznej ludzi starych) w różnych krajach i grupach kulturowych bądź etnicznych (geragogika porównawcza), - określenie podstawowych czynników warunkujących proces starzenia się.

\footnotetext{
112 „Geragogika to nauka pedagogiczna, w centrum zainteresowań której mieszczą się pedagogiczne aspekty związane ze starością jako specyficznym etapem ludzkiego życia oraz ze starzeniem się jako naturalnym procesem, któremu podlegają wszystkie istoty ludzkie. Podmiotem zainteresowania geragogiki jest człowiek starszy, postrzegany z perspektywy szeroko rozumianej edukacji, trwającej przez całe życie. Ponadto jest nim również ogół społeczeństwa, $\mathrm{z}$ uwagi na akcentowany $\mathrm{w}$ geragogice postulat wychowania do starości, w starości i przez starość. Należy jednak podkreślić, iż w prezentowanym rozumieniu pedagogika starości jest ujmowana szerzej niż gerontologia edukacyjna (określana jako uczenie się w późniejszych latach życia) i edukacja gerontologiczna (tj. nauczanie gerontologii, edukowanie do starości). Głównym przedmiotem zainteresowań pedagogiki starości jest wychowanie człowieka starszego rozumiane jako wspomaganie jego rozwoju (fizycznego, umysłowego, społecznego, kulturalnego, duchowego). Przy czym wspomaganie rozwoju oznacza tu niedyrektywne kierowanie rozwojem, w którym wychowawca pełni głównie funkcję animatora, doradcy, mediatora lub organizatora, zachowując podmiotowy charakter relacji. W praktyce wspomaganie to obejmuje działania o charakterze pomocowym, opiekuńczym lub kompensacyjnym, w jakich odnaleźć można szeroko pojęty aspekt edukacyjny." (Leszczyńska-Rejchert, 2009, s. 227)
} 
Dla opracowania metodologii badania ludzi w podeszłym wieku konieczne jest naturalnie rozbudowanie tej listy poprzez dokładną analizę zmian psychologicznych, w tym szczególnie mechanizmów percepcyjnych. W tym obszarze widoczna jest potrzeba współpracy psychologów, pedagogów, geriatrów (zob. Ograniczenia poznawcze..., 2006).

\section{BADANIE PERCEPCJI TECHNIK OTRZYMYWANIA MATERIAtU - PRZYCZYNEK DO BADANIA METODOLOGII I ETYKI BADAŃ SPOLECZNYCH Z UDZIALEM SILVER GENERATION}

Uwzględnienie zmiennej wieku w jej najwyższych wartościach powinno dotyczyć wszelkich technik otrzymywania informacji w socjologii i badaniach społecznych. Kilka powodów zostało sformułowanych wyżej. Nie tylko najbardziej oczywiste ograniczenia percepcyjne powinny być brane pod uwagę. Źródłem problemów badawczych może bowiem stać się korzystanie $\mathrm{w}$ kontakcie $\mathrm{z}$ badanym seniorem $\mathrm{z}$ laptopa, nieumiejętność wzbudzenia koniecznego zaufania, niedostosowanie języka, brak cierpliwości badaczy (ankieterów), zbyt szybkie tempo rozmowy, fakt jej nagrywania i mnóstwo innych okoliczności. Równie istotne niebezpieczeństwo może wiązać się z, mającą swoje źródło w powszechnych stereotypach, skłonnością ankieterów do infantylizacji rozmowy i przyjmowania postawy paternalistycznej wobec seniorów.

Mając jeszcze niepełną świadomość wyzwań, jakie stoją przed metodologami, którzy podejmą się dostosowania poszczególnych podejść badawczych do możliwości i cech ludzi starszych, w Katedrze Metod i Technik Badań Społecznych Instytutu Socjologii UŁ podjęto pierwsze próby badawcze zmierzające do ustalenia, czy i jakie problemy wiążą się ze stosowaniem popularnych technik badawczych w odniesieniu do osób powyżej 65 . roku życia. Schemat postępowania badawczego przewidywał uczestnictwo seniorów w sesji fokusowej oraz przeprowadzenie z nimi, bezpośrednio po jej zakończeniu, wywiadu swobodnego z modułem w formie wywiadu kwestionariuszowego. Ankieterzy zobowiązani zostali do zarejestrowania reakcji respondentów na wszystkie typy kontaktu badawczego. Rezultaty zostały omówione w trakcie dyskusji, w której uczestniczyli wszyscy ankieterzy i moderatorzy sesji.

Ankieterami rekrutującymi uczestników byli studenci studiów magisterskich na kierunku Socjologia. Każdy z nich zaprosił jednego uczestnika sesji FGI i z nim także przeprowadzał wywiad oraz obserwował jego zachowanie w trakcie spotkania przez lustro weneckie. Dodać należy, że wielu ankieterów zaprosiło do udziału w badaniu osoby z własnej rodziny lub znajome. 
Decyzja o takim trybie rekrutacji wynikała ze względów metodologicznych - dobra znajomość uczestnika badania dawała duże szanse na dostrzeżenie przez ankietera/obserwatora nieczytelnych dla innych osób sygnałów wskazujących na określone stany emocjonalne badanego.

W styczniu 2013 roku przeprowadzono dwie pierwsze w tym projekcie sesje fokusowe, w których łącznie wzięło udział 16 badanych. Kolejne cztery sesje odbyły się wiosną 2013 roku (27 uczestników). Wszyscy badani przekroczyli 65. rok życia, niektórzy nawet dość dawno (przeważali uczestnicy w wieku 70 i więcej lat). Problemy poruszone w wywiadzie swobodnym dotyczyły opinii badanych na temat sesji fokusowej, w której brali udział i ich oceny wymiaru emocjonalnego, intelektualnego (poznawczego) i etycznego sesji. Następny blok pytań (w postaci zestandaryzowanej) koncentrował się wokół opinii na temat samej metody FGI. Na koniec pytano respondentów o ich wcześniejsze doświadczenia badawcze i poglądy na temat badań socjologicznych.

Badanie traktowano jako etap wstępny, pilotażowy, dlatego przytoczone niżej dane empiryczne należy traktować w kategoriach przyczynkowych, a nie ostatecznych wniosków badawczych. Pamiętać też należy, że sytuacja respondentów była wyjątkowa - byli pytani przez swoich własnych dwudziestokilkuletnich wnuków, z którymi utrzymują dobre relacje, czego dowodem jest chociażby zgoda na udział w zaproponowanym przedsięwzięciu.

Uzyskany materiał empiryczny okazał się niezwykle interesujący w kontekście metodologicznego celu projektu. Dostarczył wielu inspirujących sygnałów wskazujących na potrzebę kontynuowania badań w tym zakresie. Wiele spośród opisanych w literaturze przedmiotu ograniczeń percepcyjnych seniorów i niektóre istotne cechy osobowości ludzi starych znalazło potwierdzenie w zgromadzonych danych:

1. Respondenci w wywiadach swobodnych mieli często problemy ze zrozumieniem (usłyszeniem?) zadawanych im pytań.

Przykład 1.

A: A co do twoich poglądów na różne tematy, to czy się jakoś zmieniło? À propos poruszanych tam tematów.

R: Czy zmieniły się czasy, czy zmieniły się?

A: Twoje poglądy.

R: Moje poglądy. No teraz jest o tyle lepiej, że jest wszystko, a kłopot z pieniędzmi, w tamtych czasach były pieniądze, a był kłopot, co kupić, bo półki były puste, nie było towaru, tak. Niektóre artykuły to były nie do zdobycia w ogóle. Jeżeli się gdzieś ukazały, to były kolejki, zapisy i wiele innych czynników, z których trzeba było korzystać i czekać nieraz pół roku czy rok na zakup jakiegoś produkt. 
Przykład 2.

A: Co czułeś, wchodząc do sali w której odbywała się sesja? Czy obawiałeś się czegoś może?

R: Zaraz, zaraz, bo nie mogę cię zrozumieć?

A: Co czułeś wchodząc do sali w której odbywała się sesja? Czy obawiałeś się czegoś może?

R: Nieeee, niczego, no cóż przecież. (...)

Przykład 3.

A: A czy były jakieś fragmenty trudne dla babci podczas całego badania?

R: Nie, nie było żadnych trudnych. Żadnych trudnych nie było. To tylko, ja też się zacięłam z tą pracą, bo ta kobieta, która siedziała obok mnie i ta druga, ja nie dosłyszałam, co one powiedziały. Jak ja powiedziałam, że jak ja pracowałam w księgowości, no to one zaczęły, tamta jedna zaczęła się uśmiechać, a ta druga coś przeglądała, tylko, że ja nie zrozumiałam co, a później mnie wprost zapytała, co w tej księgowości robiłam.

Przykład 4.

A: Jakie uczucia ci towarzyszyły w trakcie części wstępnej badania, czy one uległy zmianie w którymś momencie?

R: Ale to co?

A: No, jakie uczucia, czy jakoś bałeś się, albo oczekiwałeś czegoś?

R: Niczego się nie bałem, bo przecież na tyle jeszcze pamięć mam dobrą, że mogę sobie na tyle niektóre sprawy przypomnieć, jak było to kiedyś.

2. Dali także dowody kłopotów z pamięcią:

Przykład 1.

A: A czy w takim razie było coś, co ci się w tym wszystkim nie podobało?

R: Nie, nie. Nie o to chodzi. Tylko nie wszystko pamiętałam na pewno i trochę byłam sprężona, bo tak, jak ci mówię, nie miałam takiego doświadczenia wielkiego w mojej pierwszej pracy, bo już później po tych czternastu latach, jak już później zaczęłam pracować, bo przecież zachorowałam bardzo ciężko, więc zaczęłam jak gdyby zupełnie to od nowa, z powrotem. Także to takie podobne przeżycie było dwukrotnie.

Przykład 2.

A: (...) Ogólnie podczas tej sesji, sama zauważyłaś, że było mnóstwo dyskusji pomiędzy wami wszystkimi. Czy pod wpływem tych wszystkich dyskusji, pod wpływem tego, co usłyszałaś, czy były coś, co cię wyjątkowo zaciekawiło, na takiej zasadzie, że dowiedziałaś się czegoś nowego, czegoś niezwykłego, albo 
czy ktoś zwyczajnie sprawił, że zmieniłaś jakoś zadanie na jakiś temat? Czy były takie rzeczy?

R: No wiesz co, na pewno były. Ale ja wiem, teraz w tej chwili, czy ja bym umiała powtórzyć?... Były na pewno takie sprawy... Maciuś, wiesz co, ciężko mi jest mówić na ten temat. Naprawdę.

A: Czyli rozumiem, że niestety nie pamiętasz dokładnie.

R: Nie wiem, nie. Specjalnie nie pamiętam, ale wiem, że były takie sprawy, że... <cisza $>$

3. Respondenci mieli problemy z wyrażaniem własnych poglądów. Przykład 1.

A: A czy wyobrażała sobie babcia jakoś to spotkanie, czy zastanawiała się, jak będzie przebiegało?

R: No, jak sobie wyobrażałam? No po prostu pierwszy raz na takim spotkaniu byłam, więc, no i wyobrażałam sobie, na rożnych spotkaniach byłam, ale nie na takim $i$, ja wiem no, jak to powiedzieć... no, nie umiem powiedzieć.

Przykład 2.

R: Trudno mi było w zasadzie tak dokładnie przekazać to wszystko, co ja odczuwałam i jak to się zaczęło.

A: Czyli ogólnie, rozumiem, że byłaś taka podenerwowana na samym począt$\mathrm{ku}$ ?

R: I w zasadzie do końca byłam zdenerwowana, bo się bałam, że wiesz, że... no, że może nie będę umieć, nie będę potrafiła tego wszystkiego przekazać, o co, na co oczekuje pan Dawid który prowadził. Z resztą bardzo, bardzo miło prowadził.

4. Ujawniły się problemy związane ze spełnieniem poleceń moderatora. Przykład 1.

A: A jak ocenia babcia przydatność i kompletność informacji udzielonych przez tę osobę prowadzącą, na początku, która mówiła o tym, jak to będzie wyglądało i cały wstęp?

R: No widzisz, akurat myśmy były na korytarzu i ja jak weszłam z tobą do pokoju to byłam niezorientowana, te kartki które tam były, to myślałam, że trzeba napisać imię, nazwisko, prawda, gdzie się mieszka, bo myślałam, że to będzie potrzebne promotorowi, a to się okazało, że trzeba było wielkimi drukowanymi literami napisać swoje imię, żeby promotora, prawda, po imieniu każdego poprosiła o odpowiedzi, oni, byłam dlatego jakaś spięta, że nie udało mi się to. Bo weszłam i jakaś taka byłam zdezorientowana, można tak powiedzieć. 
5. Sama perspektywa uczestniczenia w badaniu okazała się silnym bodźcem emocjonalnym.

Przykład 1.

A: Chciałbym się od ciebie dowiedzieć przede wszystkim, jakie ty miałaś na początku oczekiwania na temat tej sesji, czego się spodziewałaś i jak sobie wyobrażałaś, że będzie wyglądało to spotkanie. Jeszcze zanim tam poszłaś. W ogóle, czy się zastanawiałaś, jak to będzie wyglądało, jak to będzie przebiegało i czy z kimś rozmawiałaś na ten temat. Jeśli tak, to z kim?

R: Nie. W zasadzie nie myślałam o tym, jak to będzie. Po prostu, myślałam, że to będzie zwykłe spotkanie, jakieś pytania będą zadawane, no i że trzeba będzie odpowiedzieć, ale na ten temat z nikim nie rozmawiałam, ani sobie nie wyobrażałam specjalnie, jak to może wyglądać. No, ale tak mniej więcej wiedziałam o co chodzi, że będą zadawane pytania, że będę musiała na nie odpowiadać, czy ewentualnie zabierać głos, no i tak to wyglądało. Ale powiem $\mathrm{Ci}$, że bardzo się denerwowałam. Strasznie się denerwowałam. Ale potem się okazało, że zupełnie nie... bezpodstawnie, bo było bardzo miło.

Przykład 2.

A: Czy rozmawiałaś na temat tego udziału z kimś wcześniej?

R: W domu mówiłam córce, no i mówiłam... Nawet przez telefon się pochwaliłam siostrze, że idę na spotkanie.

A: Czyli byłaś podekscytowana?

R: No byłam, oczywiście. Mówiłam, gdzie idę. Tak że to przeżyłam, to nie da się ukryć.

6. Niektórych uczestników uczucie napięcia i zdenerwowania nie opuściło do końca sesji.

Przykład 1.

A: (...) Mówiłaś na początku, że tam się bałaś, że trochę się stresowałaś. A czy w momencie, jak już weszłaś do tej sali, jak już Dawid przedstawił te wszystkie podstawy, czy twoje odczucia się jakoś zmieniły, czy trochę się rozluźniłaś?

R: No powiem ci, że nie za bardzo. Ja jestem nerwus i ja jestem, należę do tych osób, które tak nie potrafią się, wiesz, jakoś tak otworzyć bardzo. I w dalszym ciągu byłam zestresowana. $\mathrm{W}$ dalszym ciągu byłam zdenerwowana. Chociaż, no, na pewno nie było podstaw do tego, no i jakoś tak bardziej na luzie ludzie wypowiadali się, a ja jednak byłam spięta. 
7. Pojawiły się sygnały niepokoju o odbiór własnej osoby przez pozostałych uczestników sesji.

Przykład 1.

A: W sensie, że chciałaś coś powiedzieć, ale jednak się powstrzymałaś $\mathrm{z}$ jakiegoś powodu.

R: No, na pewno tak. Na pewno były takie momenty, że się powstrzymywałam. Bo tak jak ci mówiłam, ja nie lubię tak wyjawiać wszystko to, co tam gdzieś we mnie siedzi. Także były takie momenty, że nie chciałabym, o tym mówić po prostu.

A: Czyli ogólnie wolałaś, <cisza> bo się, no nie wiem, wstydziłaś, czy coś takiego?

R: No, bałam się, że może to coś, co bym powiedziała, że to by było takie śmieszne i nieciekawe, że mogłabym się narazić na jakąś śmieszność.

A: A kiedy były takie momenty? Przypominasz sobie?

R: No, w zasadzie to było wszystko na temat pracy, więc takie jakieś tam zdarzenia, jakie były w pracy, no, nie wydawały mi się, że to będzie, że jakoś to, co ja bym powiedziała na ten temat, że to byłoby ciekawe dla kogoś tam innego.

Przykład 2.

A: Jakie były dla ciebie fragmenty atrakcyjne?

R: No to może opinia innych osób.

A: A dlaczego?

R: No, ja wiem, może bardziej śmieli są, lepiej się potrafią wypowiadać, więcej wiedzą.

A: I to cię zainteresowało?

R: Tak, tak.

Przykład 3.

A: Czy powstrzymałaś się od wypowiedzi w czasie trwania naszego spotkania? Kiedy i dlaczego?

R: No, wstrzymałam się dużo od odpowiedzi, dlatego że zdążyłam zauważyć, że są mądrzejsi ode mnie.

Przykład 4.

A: Dlaczego powstrzymywałaś się od odpowiedzi?

R: Ja bym mogła dużo powiedzieć, ale one sugerowały się tylko tym... a żadna z nich nie pracowała na produkcji i żadna nie wiedziała, co to znaczy produkcja.

A: Ale dlaczego nie chciałaś powiedzieć swojego zdania?

R: Tylko dlatego że uważałam, że za mało doświadczona jestem. 
Przykład 5.

A: A na początku tej rozmowy, jakie emocje jeszcze pani towarzyszyły? Może uczucie zdenerwowania, zamknięcie?

R: No, tak, tak myślę. Obce były w koło ludzie, to takie zdenerwowanie było i tego.

A: Czyli raczej takie nieprzyjemne odczucia na początku?

R: No, na początku, tak.

A: A czy w toku rozmowy te uczucia się zmieniły? W jaki sposób i w jakim momencie? Czy na przykład jakoś otworzyła się pani? Można tak powiedzieć? Że chętniej pani zabierała głos? Albo czy jakiekolwiek obawy ustąpiły?

R: Ja bym raczej powiedziała, że ja tam słuchałam, bo tam były panie, które bardziej się chciały wypowiadać. Te panie raczej, raczej je tam posłuchałam, bo one miały więcej do powiedzenia, więcej pracy miały.

Przykład 6.

Jedna z uczestniczek zadbała o swój odbiór przez pozostałych uczestników sesji w sposób szczególnie niezwykły, bowiem przedstawiła się nieprawdziwym imieniem; uznała, że inni seniorzy nazywają się ładniej, bardziej elegancko, niż ona i na czas sesji przyjęła imię Zofia...

8. Skłonność ludzi starych do wycofania społecznego, ograniczenia kontaktów.

Przykład 1.

A: No to się cieszę, że było bardzo miło. A już teraz, przechodząc do samego momentu, jak wchodziłaś do sali, to jak już tam wchodziłaś do tego pomieszczenia, to jak się czułaś? Czy może się czegoś obawiałaś, czy może miałaś dobre nastawienie? Jak to było?

R: No, byłam trochę spięta, jak zobaczyłam tyle osób i przecież nie znaliśmy się nawzajem. I też nie wiedziałam, co mogę oczekiwać od tego. Czy dam radę w ogóle. Czy podołam. Bo to takie, wiesz... w zasadzie to było takie moje pierwsze spotkanie po iluś tam latach. Bo nigdy w takich, bo jeszcze dzieci chodziły do szkoły, to brałam udział z resztą w takich spotkaniach klasowych, ale poza tym to później był, to w zasadzie była taka pustka i nic takiego się nie działo i dlatego miałam pewne obawy, na pewno. I tak, jak powiedziałam ci, że byłam bardzo spięta.

Przykład 2.

A: Ale czy jakoś w trakcie tego spotkania twoje uczucia się zmieniły? Poczułaś się może swobodniej? 
R: No, na pewno na drugim spotkaniu, bym była pewniejsza siebie. No, jak tak się siedzi cały czas w domu i ma się mało do czynienia z ludźmi, to jak to mówią, że podróże kształcą, to tak samo spotkania jakieś.

9. Wykazali ograniczoną zdolność do pełnego zrozumienia sytuacji badania.

Przykład 1.

A: Co czułaś, wchodząc do sali, w której odbywała się sesja? Jak przyszłyśmy na uczelnię i tam sobie usiadłaś i czekałaś?

R: Mogłabym powiedzieć, że byłam zaskoczona.

A: Zaskoczona? Ale czym?

R: Nakryciem stołu przede wszystkim, no i prowadzącą.

Przykład 2.

A: A widziałaś kamerę?

R: Tak, wsiała tam nad tobą.

A: Nie to był mikrofon.

R: Ach to był mikrofon?

A: Kamera stała obok, czyli w ogóle nie zwróciłaś na nią uwagi?

R: Nie.

Przykład 3.

A: A jaka była twoja reakcja na to, że to spotkanie było nagrywane?

R: To było nagrywane?

A: Tak. Ania mówiła na początku.

R: Nie.

A: Tak, mówiła.

R: Może mówiła. Tak, że tam mój głos będzie słychać? Powiedziała, że nie jest nic nagrywane. Aha... dobrze, nagrywane, tylko niepokazywane. 0 matko, to po co ten mój głos tam będzie. Nie załapałam, bo bym nic nie mówiła.

A: Ania na samym początku zaznaczała, że wszystkie informacje są poufne i one nigdzie dalej nie trafią i mówiła, że spotkanie będzie nagrywane, tylko w takim celu, żebyśmy nie musieli zapisywać wszystkich waszych odpowiedzi.

R: No, tak, już sobie przypominam, skleroza. Ona tak rzeczywiście mówiła. No, ale cóż, taki głos mam i taką wymowę, jaką mam.

Przytoczone fragmenty wywiadów swobodnych całkowicie potwierdzają opisane w literaturze ograniczenia poznawcze i komunikacyjne starszych respondentów. Ujawniły się one w takcie badania fokusowego, zatem w sytuacji stwarzającej znacznie lepsze warunki do porozumienia z osobą badaną niż w przypadku metod wystandaryzowanych. Zresztą z danych zgroma- 
dzonych przez ankieterów wynika, że najwięcej problemów stwarzał badanym seniorom wywiad kwestionariuszowy. Pytania okazały się często niezrozumiałe, alternatywy zaproponowane do wyboru niewłaściwe, zadania - trudne. Wywiad kwestionariuszowy wywoływał podenerwowanie, znużenie, badani dawali sygnały świadczące bardziej lub mniej wyraźnie o chęci zakończenia rozmowy. Relatywnie najmniej uwag krytycznych respondenci wygłosili pod adresem sesji fokusowej - dostrzegli w niej elementy atrakcyjne z własnego punktu widzenia, których inne formy kontaktu (wywiad swobodny i kwestionariuszowy) były pozbawione. Niestety jednak ten korzystny wniosek nie jest pozbawiony bardziej skomplikowanego kontekstu. Wielu uczestników sesji wyraziło zgodę na udział w badaniu FGI wyłącznie dlatego, że zostali o to poproszeni przez swoich wnuków. Odmówiliby, gdyby zachęcał ich do takiego doświadczenia ktoś obcy. Jest to dowód na wspomnianą wyżej skłonność seniorów do wycofania społecznego. Być może, rozwiązaniem mogłoby być organizowanie sesji w sposób, który nie wymagałby od seniorów podejmowania wysiłku dojazdu do pracowni badawczej, na przykład w sanatoriach, klubach, stołówkach. Wówczas to na badaczu spoczywałaby konieczność dotarcia do badanych i organizacji sesji w zastanych warunkach. Przytoczone wyżej dane empiryczne prowadzą z każdej strony do mało odkrywczej konstatacji, że realizacja badań socjologicznych $\mathrm{z}$ osobami starszymi jest znacznie trudniejsze niż z młodszymi uczestnikami. Jednak z drugiej strony ujawniają ta także ogromną potencję, jaka tkwi w zogniskowanym wywiadzie grupowym do analizowania tych problemów i do testowania alternatywnych strategii badawczych wobec respondentów seniorów.

Opisane tu doświadczenie badawcze pozwoliło także na sformułowanie pozornie banalnego zalecenia praktycznego dotyczącego badań z udziałem seniorów: bez względu na rodzaj techniki otrzymywania informacji, kontakt badawczy z osobami w podeszłym wieku powinien mieć miejsce najlepiej we wczesnych godzinach popołudniowych. Dla zdecydowanej większości uczestników referowanego tu przedsięwzięcia jest to czas ich największej mobilizacji i najlepszego samopoczucia. Wraz ze zbliżaniem się wieczoru odczuwają wyraźny spadek kondycji i łatwiej o rozdrażnienie, zmęczenie i zniecierpliwienie. 


\section{Podsumowanie}

Jak wspomniano wcześniej, wykorzystane tu materiały empiryczne pochodzą z niewielkiego badania próbnego. Sądzić jednak należy, że są na tyle interesujące, iż warto kontynuować na znacznie większą skalę prace nad metodologią i etyką badania ludzi starych w obszarze nauk społecznych. Metoda zogniskowanego wywiadu grupowego może być bardzo użyteczna w takim przedsięwzięciu, bowiem uzyskane dane wyraźnie wskazują na jej zdecydowanie większą akceptację przez badanych w wieku 65+, niż ma to miejsce w odniesieniu do wywiadu swobodnego i kwestionariuszowego. Projekt taki musiałby mieć charakter interdyscyplinarny, gdyż tylko połączone wysiłki socjologów, psychologów, gerontologów, geriatrów, pedagogów i przedstawicieli innych dyscyplin społecznych pozwolą na wypracowanie metod badawczych i etyki badawczej w postaci adekwatnej dla tej szczególnej kategorii badanych ${ }^{113}$. Jednocześnie wydaje się, iż jest to jedyny sposób na uzyskanie prawdziwie wartościowych danych (lub danych, których wartość będzie można określić), umożliwiających badaczom społecznym penetrowanie problemów tej coraz liczniejszej i zasługującej na odzyskanie należnej pozycji części społeczeństwa (Gałuszka, 2007).

$\mathrm{Z}$ aspektem metodologii badania silver generation ściśle wiąże się konieczność rewizji etycznych standardów postępowania badawczego, które powinny w sposób wyraźny formułować zalecenia dotyczące charakteru kontaktu badawczego z badanymi w zaawansowanym wieku. Przywołane $w$ rozdziale II kodeksy etyki badacza w dziedzinie nauk społecznych poza dyrektywą zachowania szczególnej ostrożności w badaniach z udziałem starych ludzi, nie formułują szczegółowych wskazówek w tym zakresie. I sądzić należy, że nie uda się sprawić, by zapisy kodeksowe były dostosowane do badania ludzi 65+ bez rozbudowanych i wielokierunkowych analiz uwzględniających specyfikę osób starszych - ich ograniczeń, cech i możliwości. Poza wypracowaniem adekwatnych strategii komunikowania się ze starszymi uczestnikami badań, konieczne jest także wnikliwe przyjrzenie się systemowi wartości tego pokolenia w kontekście problemu drażliwości i trudności pytań i tematów badawczych.

Wypracowanie standardów prawnych i badawczych w odniesieniu do niepełnoletnich uczestników badań społecznych zajęło kilkadziesiąt lat $\mathrm{w}$ przypadku silver generation proces ten powinien przebiegać znacznie bardziej dynamicznie, bowiem pomimo uwzględniania coraz większego odsetka tej kategorii w próbach badawczych, ze względu na niedostosowanie

113 Przedsięwzięcie takie mogłoby być pomyślane na wzór badania PolSenior. (zob. Mossakowska, Więcek, Błędowski, 2012) 
metod uzyskiwania danych, głos tego pokolenia nadal nie jest wystarczająco słyszalny. Zogniskowany wywiad grupowy jako swoiste laboratorium wydaje się szczególnie przydatny do testowania i weryfikowania modyfikowanych strategii badawczych wobec starszych respondentów. Stwarza jednocześnie doskonałe pole do wypracowania właściwych zasad etycznego postępowania z badanymi $65+$. 



\section{ZAKOŃCZENIE}

Metoda zogniskowanego wywiadu grupowego to konstrukcja złożona i wielowymiarowa. Przedstawiona $w$ tej książce relacja pomiędzy metodologią fokusa a jego etyką stanowi zaledwie jedną, choć sądzić należy, że bardzo istotną perspektywę analityczną. Mimo bowiem trwającego już od wielu lat publicznego dyskursu dotyczącego etyki badawczej, nadal wbrew oczekiwaniom wielu badaczy cechuje krytykowana przez Amsterdamskiego postawa sprowadzająca się do przekonania, że sformułowania: „moją etyką jest moja metodologia". (Amsterdamski, 1983, s. 134-135) Jednym z powodów tego stanu rzeczy jest z pewnością fakt, iż ta refleksja i towarzysząca jej debata, choć podkreślają aksjologię badanego, toczy się zazwyczaj na dość wysokim poziomie ogólności, jest niejako autonomiczna i związek pomiędzy takimi ustaleniami, a konkretną metodą badawczą nie zawsze jest oczywisty. Tutaj starano się te wzajemne powiązania wykazać na konkretnym przykładzie zogniskowanego wywiadu grupowego.

Zagadnienie etyki badań fokusowych w pierwotnym zamyśle miało być jedynie jednym z rozdziałów planowanej książki. Jednak w miarę pisania wątek ten tak się rozrastał, że przekształcił się ostatecznie w problem centralny. W ten sposób zostało $\mathrm{w}$ jakimś zakresie zrealizowane zapotrzebowanie sformułowane kilka lat temu: „W obrębie ilościowych technik badawczych kwestie deontologii stanowią przedmiot rozwiniętej refleksji teoretycznej, często wspartej rezultatami badań empirycznych. Fokus nie doczekał się dotąd takich analiz, a szkoda, ponieważ mogłyby one przyczynić się do ustalenia jasnych i klarownych zasad, regulujących relacje wzajemne pomiędzy uczestnikami, badaczami i zleceniodawcami badań metodą zogniskowanego wywiadu grupowego." (Lisek-Michalska, 2004, s. 48) Zaprezentowane tu podejście, łączące $\mathrm{z}$ jednej strony doświadczenia praktyczne, a z drugiej uwzględniające bogate zaplecze teoretyczne sprzyja bardziej całościowemu oglądowi problemów, które rozpatrywane tylko z jednej z tych perspektyw mogą wydawać się banalne. Nie oznacza to niestety, że całkowicie je rozwiązuje. Ale intencją tej pracy jest przede wszystkim zwrócenie uwagi na aspekty nie będące dotąd przedmiotem szczegółowych studiów. 
Proponowane w tej książce podejście czyni namysł etyczny wartością dodaną metody badania, pokazuje, iż związek pomiędzy metodologią a przyjętą przez badacza etyką ma charakter synergiczny. Konstatacja ta bynajmniej nie odnosi się jedynie do badań fokusowych. Za materiałem opracowywanym przez socjologa lub badacza społecznego zawsze mniej lub bardziej kryje się określony człowiek. Poszukiwaniu informacji o nim lub/i od niego przy pomocy dowolnych metod w sposób trwały powinna towarzyszyć głęboka refleksja etyczna. Jej zadaniem nie jest jednak dążenie do zniesienia czy zatarcia różnic pomiędzy badaczem a badanym i do ustanowienia dla obu partnerów identycznego katalogu praw i obowiązków. Pozycja badacza zawsze jest w pewien sposób uprzywilejowana, czego konsekwencją jest także i to, że jego zakres odpowiedzialności jest większy. I właśnie w ramach tego statusu i przyporządkowanym do niego możliwościom i powinnościom badacz podejmując decyzje metodologiczne aktywuje jednocześnie określone konsekwencje etyczne.

Zogniskowany wywiad grupowy jest metodą, która jak chyba żadna inna pozwala przyjrzeć się tak wielu aspektom badania wrażliwym ze względów etycznych. Dzięki swoim właściwościom może być bardzo przydatny jako laboratorium do rozwiązywania problemów metodologiczno-etycznych innych metod badawczych i badań z uczestnikami wymagającymi wyjątkowej dbałości (dziećmi, ludźmi w podeszłym wieku, chorymi). Jednocześnie jednak jest metodą szczególną. Fokus bowiem ma jeszcze jedną istotną z interesującego tu punktu widzenia cechę, mianowicie wrelatywnie szerokim zakresie w porównaniu do innych metod badawczych dopuszcza in statu nascendi możliwość modyfikacji zatwierdzonych wcześniej decyzji badawczych. Moderator może np. zmienić kolejność pytań, wprowadzić techniki dodatkowe, zareagować na relacje między uczestnikami itp., jeśli uzna, że naruszają one dobrostan badanych. W przypadku innych metod, szczególnie standaryzowanych, badacz nie ma możliwości reagować w tym aspekcie adekwatnie do konkretnych sytuacji, zatem wydaje się, że namysł nad etycznym wymiarem badania powinien być tym głębszy. Ta specyfika fokusa w połączeniu z dynamiką i mechanizmami funkcjonowania grupy sprawia, że granica pomiędzy światem metody, a światem codzienności badanych traci na ostrości, ulega zatarciu (chociaż nigdy nie jest zniesiona do końca). Sytuacja taka nie jest też bez znaczenia dla badacza-moderatora, bowiem daje mu pole do zachowań bez mała odruchowych, nawykowych. W zależności od reprezentowanej przez niego postawy etycznej czasem jest to z korzyścią dla wszystkich osób uwikłanych w proces badawczy, a czasem może być źródłem wielu zagrożeń etycznych. Sposobem na uniknięcie takiego ryzyka jest jednoczesne, łączne, postrzeganie metody i etyki badania. 
Zatrzymanie i ujęcie w słowach całego bogactwa zdarzeń mentalnych, werbalnych i emocjonalnych, jakie ma miejsce w badaniu fokusowym odbiera mu tę część, która bliższa jest magii lub sztuce, która sprawia, tak dla tak wielu badaczy stał się ich ulubioną metodą. Zajęcia warsztatowe prowadzone ze studentami, podczas których realizują oni sesje $\mathrm{z}$ autentycznymi respondentami dobranymi według przyjętych kryteriów stają się dla nich niezwykłą okazją do empirycznego odczucia znaczenia etycznych decyzji i wyborów. Konfrontacja z grupą nieznanych osób w celach badawczych uświadamia im sens dyrektyw, jakie poznają od strony teoretycznej na przedmiotach poświęconych wprost etycznym problemom badań. To w sesji fokusowej, jak w soczewce, skupiają się wszelkie możliwe niebezpieczeństwa naruszenia wobec uczestników zasad etyki badawczej. W takim natężeniu i rozmaitości nie pojawiają się one w indywidualnych technikach interrogacyjnych. Ci, którzy moderowali sesje często stwierdzają, że odtąd ich wywiady indywidualne zaczęły przebiegać zupełnie inaczej, że potrafią wreszcie koncentrować się jednocześnie na realizacji dyspozycji narzędzia i na tym, co mówi ich respondent. Zaczęli też słyszeć, jak to mówi- wreszcie zobaczyli przed sobą człowieka, a nie tylko źródło informacji. Poczuli to, o czym pisali Fontana i Frey (2009, s. 111), „(...) że większość tradycyjnych wywiadów pogłębionych jest prowadzona w sposób nieetyczny, czy to celowo, czy nieświadomie. Techniki i taktyki wywiadu (...) są tak naprawdę metodami manipulacji respondentami i jednocześnie traktowania ich przedmiotowo, zamiast widzieć w nich indywidualne jednostki". Siła emocji, jakie odczuwają młodzi socjologowie po dokonaniu tego odkrycia napełnia nadzieją, że podejmowanym przez nich w przyszłości samodzielnym wyborom metodologicznym zawsze będą równolegle towarzyszyć przemyślane decyzje etyczne.

Fenomen fokusa pełen jest jeszcze obszarów, które zasługują na wnikliwą analizę. Należą do nich rozmaite kwestie stricte metodologiczne, w tym przede wszystkim ocena wartości informacji uzyskiwanych od uczestników, problemy interpretacji materiału empirycznego, wybór i zasadność kryteriów rekrutacyjnych i wiele innych. W kontekście rozważań przedstawionych w tej książce uznać zatem należy, że pytanie, czy fokus jest sztuką, czy metodą (Lisek-Michalska, 2004), nadal pozostaje otwarte. 



\section{ANEKS}

\section{ZALACZNIK 1}

David B. Resnik, Kalendarium wydarzeń (od 1931 r. do teraz)

\section{ZAtACZNIK 2}

Badanie uczestników sesji fokusowych metodą wywiadów swobodnych. Dyspozycje do wywiadu.

\section{ZALACZNIK 3}

Formularz zgody rodzica/opiekuna prawnego

ZAtA̧CZNIK 4

Formularz zgody dziecka

ZALACZNIK 5

Projekt Speak Up! Scenariusz FGI

ZAtA̧CZNIK 6

Scenariusz zogniskowanego wywiadu grupowego do badania problematyki przemocy wśród dzieci i młodzieży. 

ZALACZNIK 1

\section{David B. Resnik ${ }^{114}$ \\ Kalendarium wydarzeń (od 1931 r. do teraz)}

\section{2-1972}

Studia nad chorymi na kiłę w Tuskegee, sponsorowane przez Departament Zdrowia. Badano wpływ nieleczonej kiły u 400 afrykańskich kobiet amerykańskich. Naukowcy powstrzymali się od leczenie nawet wówczas, gdy penicylina stała się powszechnie dostępna. Chore kobiety nie zostały powiadomione, że uczestniczą w eksperymencie medycznym.

\section{9-45}

Niemieccy naukowcy prowadzą badania na więźniach obozów koncentracyjnych.

\section{0}

Dwaj nazistowscy naukowcy, uchodźcy: Frisch i Peierls, ostrzegają rząd USA o niemieckim programie broni jądrowej.

\section{2-1945}

USA rozpoczyna Projekt Manhattan o wartości 2 mln dolarów, który ma na celu stworzenie bomby atomowej.

\section{4-1980}

Rząd USA sponsoruje tajne badania nad wpływem promieniowania na człowieka. Uczestnicy nie zostali powiadomieni, że biorą udział w eksperymencie. Badania zostały przeprowadzone na chorych na raka, kobietach ciężarnych i personelu wojskowym.

\section{5}

USA zrzuca dwie bomby atomowe na Japonię.

Z inicjatywy Prezydenta Eisenhowera i Roberta Oppenheimera uruchomiono program Atomy dla pokoju.

\section{5}

Vannevar Bush pisze dla Roosevelta raport naukowy Bez Granic (The endless frontier). Przekonuje w nim do znacznego wzrostu wydatków publicznych na naukę i broni ideału naukowej wspólnoty samorządowej wolnej od znaczącego nadzoru zewnętrznego. Promuje także inwestycje w dziedzinie nauki i technologii jako środek wspierania bezpieczeństwa narodowego i rozwoju gospodarczego.

114 http://www.niehs.nih.gov/research/resources/bioethics/whatis/ 


\section{7}

Przyjęcie Kodeksu Norymberskiego dotyczącego badań z udziałem ludzi. Na podstawie ustaleń Kodeksu, alianci w procesie norymberskim oskarżyli naukowców hitlerowskich o zbrodnie wojenne.

\section{8}

Alfred Kinsey wydaje książkę Zachowanie seksualne mężczyzn; książka Zachowanie seksualne kobiet ukazuje się w 1953 roku. Obie te książki wzbudziły wiele kontrowersji. Badania były sfinansowane przez Instytut Kinseya.

\section{9}

Związek Radziecki testuje bombę wodorową. Początek zimnej wojny.

\section{3}

James Watson i Francis Crick odkrywają struktury DNA, za co ostatecznie otrzymają Nobla w 1962 roku. Kluczowe dane uzyskali potajemnie bez wiedzy Rosalind Franklin, która prowadziła badania. Ona nie otrzymała Nagrody Nobla, ponieważ zmarła w 1953 na raka jajnika (w wieku lat 37), a nagroda Nobla nie jest przyznawana pośmiertnie.

\section{6-1980}

Saul Krugman, Joan Giles i inni naukowcy prowadzą eksperymenty na dzieciach $\mathrm{z}$ upośledzeniem umysłowym w szkole Willowbrook. Celowo zainfekowano dzieci chorobą i obserwowano jej naturalny rozwój. Eksperymenty zostały zaakceptowane przez Departament Zdrowia w Nowym Yorku.

\section{0-1963}

CIA rozpoczyna program badawczy kontroli umysłu, który obejmuje m.in. podawanie LSD nieświadomym tego osobom.

\section{7}

Związek Radziecki wysyła w kosmos pierwszego satelitę, co skłania rząd USA do zwiększenia inwestycji w dziedzinie nauki i technologii, aby uniknąć przegranej w wyścigu kosmicznym.

\section{0-}

Departament Obrony rozpoczyna łączenie swoich komputerów rozrzuconych na całym terenie USA na różnych uniwersytetach i laboratoriach badawczych w jeden system. Nastepuje rozwój ARPANET (1972), BITNET and USENET (1981), NSFNET (1985), the Internet (1988), and the World Wide Web (1995).

\section{1}

John F. Kennedy zobowiązuje USA do wprowadzenia człowieka na Księżyc przed końcem dekady

Rachel Carson publikuje książkę Milcząca wiosna (Silent spring), w której ostrzega ludzi przed szkodliwymi dla środowiska skutkami różnych toksyn i zanieczyszczeń, w tym DDT. Jej książka przyczynia się do powstania globalnego ruchu ekologicznego. 


\section{1-1962}

Stanley Milgram przeprowadza swoje eksperymenty z użyciem bodźca elektrycznego (electric shock), które dowiodły, że wiele osób jest w stanie zrobić rzeczy, które uznają za moralnie złe, jeżeli wykonują rozkazy kogoś, kogo uznają za autorytet. Publikuje książkę Posłuszeństwo wobec autorytetu (Obedience to Authority) w $1974 \mathrm{r}$.

\section{4}

Światowe Stowarzyszenie Lekarzy ogłasza Deklarację Helsińską. Zasady etyczne dotyczq̨e badań na ludziach. Deklaracja była kilkakrotnie modyfikowana, ostatnio - w 2001 roku.

Biuro amerykańskiego lekarza naczelnego wydaje swój pierwszy z kilku raportów na temat problemów zdrowotnych związanych z paleniem.

\section{6}

Henry Beecher publikuje artykuł w "The New England Journal of Medicine" przedstawiając 22 nieetyczne badania w biomedycynie, w tym badania w Tuskegee i badania WZW w Willowbrook.

\section{0/1970-1985}

Rozwija się ruch na rzecz praw zwierząt. Kongres akceptuje Animal Welfare Act $(1966,1970,1976,1985)$. Dokument nie obejmuje ptaków oraz gryzoni. Stany Zjednoczone Ameryki przyjmują przepisy prawne w zakresie dobrostanu zwierząt i wykorzystywaniu ich dla celów badań

\section{9}

USA - pierwszy człowiek ląduje na Księżycu.

\section{2}

Narodowe media i Kongres koncentrują się na nieetycznej praktyce $\mathrm{w}$ badaniach prowadzonych na ludziach, $\mathrm{w}$ tym badaniu Tuskegee.

\section{4}

Kongres przyjmuje National Research Act, który zobowiązuje agencje federalne do rozwijania przepisów dotyczących prowadzenia badań na ludziach, np. 45 CFR 46, 21 CFR 50,54,56.

\section{4}

William Summerlin przyznaje się do fabrykowania danych przy użyciu znacznika, aby stworzyć czarne plamy na białych myszach w Sloan Kettering Cancer Institute. Zajmował się rozwojem technik transplantacji skóry.

1974

Monsanto i Harvard wchodzą w porozumienie korporacyjne.

\section{5}

Naukowcy zbierają się w Asilomar (Kalifornia), aby omówić korzyści i ryzyko badań rekombinacji DNA; NIH powołuje Recombinant DNA Advisory Committee. 


\section{5}

Peter Singer publikuje Wyzwolenie Zwierząt (Animal Liberation).

\section{5}

E.O. Wilson publikuje Socjobiologię, która ponownie zapala debatę „natura vs wychowanie". Jego książka proponuje biologiczne i ewolucyjne wyjaśnienia ludzkiego zachowania i kultury.

\section{8}

Rodzi się pierwsze dziecko z próbówki - Louise Brown.

\section{9}

Komisja Krajowa przedstawia Raport Belmonta, który określa podstawowe zasady etyki badań klinicznych w USA. Raport staje się kluczowym dokumentem $w$ regulacjach etycznych badań z udziałem ludzi.

\section{0}

Kongres przyjmuje Bayh-Dole Act, która pozwala naukowcom opatentować wynalazki opracowane z funduszy rządowych, ustawę zmieniono na Technology Transfer Act w 1986 r.

\section{0}

W sprawie Diamond vs. Chakrabarty w USA przyjmuje się zasadę, że genetycznie zmodyfikowane bakterie mogą być objęte patentem, ponieważ są wytworem ludzkiej pomysłowości. Ten precedens jest istotny dla uzyskiwania patentów na inne formy życia i pomaga stworzyć solidne podstawy ochrony własności intelektualnej dla nowego przemysłu biotechnologicznego.

\section{1}

Whitehead Institute zawiera porozumienie z MIT (Massachusetts Institute of Technology), kolejną ważną prywatną inwestycją w szkolnictwie wyższym.

\section{1}

DHEW (Department of Health, Education and Welfare) wprowadza poważne korekty przepisów ochrony ludzi w badaniach na nich prowadzonych.

\section{1}

John Darsee, adiunkt na Uniwersytecie Harvarda, jest oskarżony o fabrykowanie danych.

\section{2}

William Broad i Nicholas Wade publikują książkę Zdrajcy Prawdy (Betrayers of Truth), w której twierdzą, że jest więcej wykroczeń w obszarze nauki, niż badacze gotowi są przyznać. Ich książka pomaga rozpocząć okres „krachu nadużyć finansowych" w nauce ("fraud busting" in science).

\section{4-1993}

Luc Montagnier oskarża Roberta Gallo o sprzeniewierzenie wyników badań wirusa HIV. Gallo przedstawia dowody swojej niewinności. Gallo i Montagnier toczą spór o to, kto powinien być uznawany za odkrywcę HIV i który 
z nich ma prawo do patentu. Amerykańskie i francuskie rządy osiągają porozumienie w tej kwestii.

\section{6}

Roger Boisjoly ostrzega NASA o możliwej awarii 0-ringu z powodu zimna w promie kosmicznym Challenger. NASA zdecyduje się jednak na jego uruchomienie i Challenger eksploduje przy starcie, zabijając całą załogę.

\section{7}

W trakcie debaty w NIMH (The National Institute of Mental Health) stwierdzono, że Steven Breuning sfabrykował i sfałszował dane w 24 referatach. Breuninga skazano za defraudację na szkodę rządu federalnego w $1988 \mathrm{r}$.

\section{7}

Martin Luther King oskarżony o plagiat rozprawy doktorskiej.

\section{7-1996}

Margot O'Toole, doktorant $w$ Whitehead Institute, poddaje w wątpliwość dane zawarte w publikacji autorstwa jego sześciu kolegów, zamieszczonej w czasopiśmie "Cell”. Zwraca się z prośbą o zbadanie danych w komputerze laboratoryjnym Thereza Imanishi-Kari, które wydają się niezgodne z opublikowanymi wynikami. Oskarża Imanishi-Kari o fabrykowanie lub fałszowanie danych. Rozpoczyna się dochodzenie prowadzone przez MIT, NIH oraz komisję pod przewodnictwem Jana Dingell. Laureat Nagrody Nobla David Baltimore jest jednym z współautorów spornego artykułu. Chociaż nie został oskarżony, złożył rezygnację ze stanowiska szefa Uniwersytetu Rockefellera. Opisał dochodzenie, które zostało określone przez New York Times jako "polowanie na czarownice". Ostatecznie Imanishi-Kari został uniewinniony, zganiono go jedynie za złe przechowywanie dokumentacji.

\section{8}

Harvard i Dow Chemical obejmują patentem genetyczne wykorzystanie myszy do badania nad rakiem.

\section{9}

PHS (The United States Public Health Service) tworzy dwie agencje: Office of Scientific Integrity i Office of Scientific Integrity Review do badania rzetelności naukowej oraz dostarczenie informacji i wspierania uniwersytetów. Zmienia również swoją definicję wykroczenia. Obie agencje przekształcono 1992 roku w Office of Research Integrity (ORI).

\section{9}

NIH (National Institutes of Health) nakłada na wszystkich studentów studiów podyplomowych, którzy otrzymują stypendia, obowiązek odbycia szkolenia w zakresie odpowiedzialnego prowadzenia badań.

\section{9}

Stanley Pons i Martin Fleischmann na konferencji prasowej na Uniwersytecie w Utah ogłaszają, że odkryli sposób wytwarzania syntezy jądrowej 
w temperaturze pokojowej. Kilkadziesiąt laboratoriów na całym świecie bezskutecznie próbuje powielić ich wyniki. Oskarżono ich o oszustwa i niechlujstwo.

\section{9}

NAS (The National Institute of Standards and Technology) publikuje krótką książkę Bycie naukowcem (On Being A Scientist) (zaktualizowaną w 1994) dla naukowców o etyce badawczej.

\section{0}

USA uruchamia Projekt poznania ludzkiego genomu (Human Genome Project) wart 20 bilionów dolarów. Projekt ma na celu stworzenie mapy i sekwencji ludzkich genomów.

\section{0}

W. French Anderson rozpoczyna pierwszą ludzką kliniczną terapię genową u pacjentów z niedoborem ADA - objaw choroby genetycznej, która wpływa na układ odpornościowy.

\section{0}

Sprawa Moore vs Uniwersytet Kalifornia. Sąd Kalifornii formułuje zasadę, że naukowcy mają prawa własności intelektualnej do komórek pobranych z tkanki Moore'a, ale Moore nie miał żadnych praw własności do własnej tkanki. Trybunał postanawia także, że naukowcy naruszyli prawo Moore'a do świadomej zgody nie ujawniając mu bezpośrednio swoich interesów komercyjnych dotyczących pobranej od niego tkanki.

\section{0}

Kongres bada konflikt interesów pomiędzy Pharmatec i University of Florida.

\section{0-obecnie}

Europejczycy sprzeciwiają się wprowadzeniu genetycznie modyfikowanych żywności i upraw. Konsumenci w USA są bardziej otwarci na genetycznie zmodyfikowane rośliny i zwierzęta. Europejczycy w końcu wyrazili zgodę, jednak wymagają, aby żywność GMO była oznaczona.

\section{1}

Weryfikacja/zjednoczenie przepisów na temat badań prowadzonych na ludziach. Wszystkie agencje rządu Stanów Zjednoczonych, oprócz EPA, przyjęły jedną podstawową ramę prawną, znaną jako "zasadę wspólną" CFR (Code of Federal Regulations).

\section{2}

NAS (American National Standard) publikuje Odpowiedzialna Nauka: zapewnienie integralności procesu badawczego (Responsible Science: Ensuring the Integrity of the Research Process). W książce wskazuje się występujące w praktyce naukowej uchybienia, omawia niektóre z przyczyn ich powstawania, proponuje definicję wykroczenia i zaleca pewne strategie zapobiegania nierzetelności. 
1993

W sprawie Daubert vs. Merrell Dow Pharmaceuticals sąd postanawia, że sędziowie pełnią rolę strażników w kwestii dopuszczenia naukowych świadectw $\mathbf{w}$ sądzie i że w związku z tym mogą korzystać z różnych kryteriów tego dopuszczania, w tym sprawdzalności, niezawodności, ocen $\mathbf{i}$ akceptacji.

1993

Naukowcy klonują z powodzeniem ludzkie embriony.

\section{4}

Richard Herrnstein i Charles Murray publikują kontrowersyjną książkę pt: Rozkład normalny (The Bell Curve), która ponownie rozpala debatę na temat biologii, rasy i inteligencji

\section{4}

Roger Poisson przyznaje się do wytwarzania i fałszowania danych pacjentów w badaniach klinicznych raka piersi w celu zakwalifikowania swoich pacjentów do udziału w badaniach i aby mieć dostęp do eksperymentalnych metod leczenia.

\section{4}

NIH (National Institutes of Health) występuje z wnioskiem o prawa patentowe do tysięcy fragmentów genów, aby zablokować prywatne starania zmierzające do objęcia patentem fragmentów genów. Urząd Patentowy odrzucił aplikację NIH.

\section{4-1995}

Komisja Ryana powołana przez NIH (National Institutes of Health) organizuje debatę na temat nierzetelności naukowej.

\section{4}

Administracja Clintona odtajnia informacje o tajnych eksperymentach radiacyjnych prowadzonych na ludziach w latach 1940-1980.

\section{4}

Dwóch naukowców, którzy pracowali w Philip Morris: Victor DeNobel i Paul Mele, zeznają przed Kongresem na temat tajnych badań nad właściwościami uzależniającymi nikotyny. Jeśli badania zostałyby podane do wiadomości publicznej, FDA lub Kongres mogłyby podjąć dodatkowe kroki w celu uznania, że tytoń jest narkotykiem. Wiele stanów i osób prywatnych wniosło spory wobec firm tytoniowych, które doprowadziły do wartej 206 miliardów dolarów ugody pomiędzy firmami tytoniowymi i 46 stanami. Naukowcy publikują także więcej danych na temat szkodliwości biernego palenia.

\section{5}

Boots Pharmaceuticals wywiera presję na Betty Dong, aby wycofała referat z publikacji w JAMA pokazujący, że ich lekarstwo - synthroid, nie jest bardziej skuteczny niż jego generyczny ekwiwalent w leczeniu niedoczynności tarczycy. 


\section{5-2003}

W czasopismach biomedycznych publikowane są dziesiątki artykułów, które dostarczają danych na temat relacji między źródłem finansowania badań naukowych i ich wynikami, finansowych interesów naukowców w naukach biomedycznych i ścisłym związku między badaczami akademickimi i przemysłem farmaceutycznym.

\section{5}

NIH (National Institutes of Health) i NSF (National Science Foundation) dokonują korekty swojej polityki wobec konfliktu interesu.

\section{5}

Japońska sekta religijna Aum Shinrikyo uwalnia gaz sarin w metrze w Tokio; zabito 12 osób, a 5500 skierowano do szpitali. Ponadto grupa próbowała (bezskutecznie) rozpylić zarodniki wąglika nad Tokio. W $1998 \mathrm{r}$. eksperci do spraw terroryzmu ostrzegali o użyciu broni biologicznej lub chemicznej przez Osamę bin Ladena i Saddama Husajna.

\section{5}

Ponad 200 przywódców religijnych, na czele z krytykiem biotechnologii Jeremy Rifkinem, protestowało w Waszyngtonie przeciwko obejmowania patentami roślin, zwierząt i części ciała człowieka.

\section{6}

Zostaje sklonowana pierwsza na świecie owca. Narodziny Dolly zostają ogłoszone w 1997 roku. Kilka europejskich krajów zakazuje klonowania ludzi. Kongres przyjmuje projekt ustawy o zakazie wszelkiego klonowania ludzi, ale zmienia zdanie na skutek argumentacji naukowców, że ustawa zaszkodzi badaniom biomedycznym.

\section{7}

International Committee of Medical Journal Editors, reprezentujący ponad 400 czasopism biomedycznych, aktualizuje swoje wytyczne na temat autorstwa tekstów i formatowania opisów bibliograficznych.

\section{7}

W artykule opublikowanym w "The New England Journal of Medicine", Peter Lurie i Sidney Wolfe oskarżają PZH, WHO, ONZ i CDC o prowadzenie nieetycznych badań dotyczących zapobiegania transmisji wirusa HIV matka dziecko w krajach rozwijających się. Spór przyczynia się do ponownego rozpoznania międzynarodowych kodeksów badań etycznych.

\section{8}

Naukowcy odkrywają idealne warunki do uprawy ludzkich embrionalnych komórek macierzystych. Niektóre kraje zakazują badań, inne chcą ją promować. 
1998

Craig Venter tworzy Celera Genomics i rozpoczyna prywatne starania do odczytania sekwencji ludzkiego genomu, wykorzystując dziesiątki automatów sekwencjonowania.

\section{8-1999}

Korporacja Apotex zmusza Nancy Olivieri, kliniczną badaczkę z Uniwersytetu Toronto, do wycofania publikacji, w której wykazuje zakres bezpieczeństwa deferypronu, leku który jest stosowany w leczeniu talasemii. Firma dyskredytuje Olivieri i ją zwalnia.

\section{9}

Jessie Gelsinger jako pierwsza osoba oficjalnie umiera podczas eksperymentalnej terapii genowej prowadzonej w Uniwersytecie w Pensylwanii. Zdarzenie wywołuje zwiększone kontrole w zakresie konfliktów interesów $\mathrm{w}$ badaniach $\mathrm{z}$ udziałem ludzi, w tym instytucjonalnych konfliktów interesów. Uniwersytet negocjuje ugodę z rodziną Gelsinger za nieujawnioną kwotę pieniędzy.

\section{9-obecnie}

Badania z udziałem ludzi wywołują dramatyczny wzrost ilości pozwów. Alan Milstein, z kancelarii Sherman, Silverstein, Kohl, Rose \& Podolski w Pensylwanii nakłania do złożenia 13 pozwów przeciwko badaczom naukowym, uczelniom, firmom farmaceutycznym i członkom Izby Rewizyjnej.

\section{9}

NIH (National Institutes of Health) i OHRP (Office for Human Research Protections) domagają się, aby wszystkie osoby prowadzące lub nadzorujące badania, w których podmiotem jest człowiek, mieli pewne doświadczenie w dziedzinie etyki badań.

\section{0}

Biuro Nauki i Polityki Technologicznej formułuje ostateczną federalną definicję nierzetelności jako „wytwarzanie, sfałszowanie lub plagiatowanie"; nie obejmuje ona "niezamierzonego błędu lub rozbieżności”. Zasady te wciąż nie są wystarczająco obecne w praktyce.

2000

ORI (The Office of Research Integrity) proponuje obowiązkowe szkolenie w zakresie odpowiedzialnego prowadzenia badań dla wszystkich naukowców uzyskujących stypendia PHS (United States Public Health Service), w tym studentów, badaczy i techników. Kilka stowarzyszeń naukowych i uniwersytetów sprzeciwia się uważając, że jest to niepotrzebne i nieopłacalne. Administracja Busha zawiesza propozycję w 2001 r. ze względu, na to, że agencja naruszyła odpowiednie procedury proponowania nowych regulacji rządowych. 


\section{1}

Celera Corporationi Human Genome Project wspólnie kompletują 99\% ludzkiego genomu i publikują swoje wyniki w Nature and Science.

\section{1-obecnie}

Debata na temat prawodawstwa dotyczącego klonowania człowieka.

\section{1}

Kilka czasopism, w tym Nature i JAMA, podejmuje eksperyment polegający na wymaganiu, aby autorzy w publikacji opisywali swoje metody naukowe.

\section{1}

Administracja Busha informuje, że NIH będzie finansować badania nad około 64 liniami embrionalnych komórek macierzystych, uzyskanych z resztek ludzkich embrionów.

\section{1}

Terroryści porywają 4 samoloty w dniu 11 września i zabijają w wyniku ataków ponad 5000 osób. Kilka tygodni później, nieznany terrorysta wysyła 4 listy zawierające wąglik, zabijając 5 osób i zarażając 23.

\section{2}

Przewodniczący Rady ds. Bioetyki zaleca, by w USA zakazano klonowania reprodukcyjnego i uchwalenia moratorium na klonowanie badawcze.

\section{2}

Historyk Stephen Ambrose jest oskarżony o plagiat.

\section{2}

Panel niezależnych badaczy stwierdza, że Jan Hendrick Schön, fizyk z Bell Labs, sfałszował dane w 17 pracach opublikowanych w Science, Nature i Physical Review.

\section{2}

Bell Labs ustala, że Jan Hendrick Schön, wschodząca gwiazda w fizyce materii skondensowanej i nanotechnologii, który opublikował dziesiątki artykułów w krótkim czasie w prestiżowych czasopismach, popełnił oszustwa. Dotychczasowych 28 referatów autorstwa Schöna wycofano.

\section{2}

NAS publikuje „Integrity in Scientific Research” w którym zaleca się, aby uniwersytety opracowały programy edukacji w zakresie odpowiedzialnego prowadzenia badań (RCR), jak również zasady i procedury, z jakimi ma się do czynienia w obszarze etyki badawczej.

\section{2}

Korea Północna przyznaje, że ma tajny program budowy broni jądrowej i ostrzega, że ma inną „mocniejszą" broń.

\section{2}

Naukowcy publikują kilka prac w czołowych czasopismach branżowych, które zawierają wskazówki mogące posłużyć bioterrorystom. Artykuł opu- 
blikowany w Journal of Virology opisywał metodę inżynierii genetycznej, dzięki której nowa forma wirusa mousepox jest znacznie bardziej śmiercionośna niż naturalnie występujący szczep. Artykuł opublikowany w Science wyjaśnia, jak zrobić wirusa polio przy pomocy elementów zamówionych w wysyłkowym sklepie. W 2003 roku American Society for Microbiology (ASM), the National Academy of Sciences i Center for Strategic and International Studies zorganizowały spotkanie w celu omówienia kwestii cenzury badań biologicznych, której brak stanowi zagrożenie dla bezpieczeństwa. Pisma zgadzają się na wprowadzenie autocenzury w odniesieniu do niektórych badań.

\section{3}

USA napada na Irak w celu wyeliminowania jej chemicznej, biologicznej i jądrowej broni. Jak dotąd USA znalazło dowody programów zbrojeniowych, ale nie znalazło broni.

\section{4}

EPA (Environmental Protection Agency) zawiesza badanie CHEERS (Children's Health Environmental Exposure Research Study) z powodu krytyki grup poparcia i członków Kongresu, którzy twierdzili, że badanie celowo naraża dzieci na pestycydy. W odpowiedzi EPA zmieniła swoje podmioty badania, obejmując mandatem zabezpieczenia dzieci i kobiety w ciąży lub karmiące piersią.

\section{4}

NIH i inne agencje przyjmują definicję nierzetelności OSTP (Office of Science and Technology Policy).

\section{4}

Ronald Reagan Jr. popiera federalne finansowanie badań nad komórkami macierzystymi na rzecz Konwencji Demokratów. Badania na komórkach macierzystych (i klonowanie terapeutyczne) stają się gorącą kwestią w wyborach prezydenckich w $2004 \mathrm{r}$.

\section{5}

W odpowiedzi na falę krytyki ze strony Kongresu, NIH dokonuje rewizji konfliktu interesów w badaniach. Naukowcy NIH nie mogą posiadać akcji w firmach farmaceutycznych i biotechnologicznych ani udzielać konsultacji tym firmom za wynagrodzeniem.

\section{5}

Woo Suk Hwang, badacz z Uniwesytetu w Seulu przyznaje się do fabrykowania danych w dwóch artykułach opublikowanych w czasopiśmie Science. W artykułach tych Hwang twierdził, że stosowanie techniki transferu pozwala rozwijać u pacjenta specyficzne ludzkie embrionalne komórki macierzyste. 


\section{5}

Badacz Eric Poehlman z University of Vermont przyznaje się do fabrykowania lub fałszowania danych w 15 federalnych dotacjach i 17 publikacjach.

\section{9}

Ktoś włamał się do serwera pocztowego na Uniwersytecie Wschodniej Anglii Climatic Research Unit i opublikował w intrenecie tysiące maili wymienianych między badaczami zmian klimatycznych CRU i naukowcami na całym świecie. Emaile wykazały, że naukowcy odmawiali współdzielenia się danymi ze sceptykami wobec zmian klimatycznych. Incydent nazwano „Climategate".

\section{9}

Administracja Obamy zapowiada znaczne rozszerzenie finansowania badań NIH nad ludzkimi embrionalnymi komórkami macierzystymi, które zostało ograniczone w okresie administracji Busha.

\section{0}

National Science Foundation (NSF), ogłasza zasady RCR (Responsible Conduct of Research) obowiązujące badaczy, studentów i stażystów. NIH rozszerza i wzmacnia wymagania szkoleniowe RCR.

\section{0}

Podczas analizowania badania Tuskegee, Susan Reverby, profesor Studiów Kobiecych w College Wellesly, odkryła dokumenty dotyczące nieetycznych eksperymentów naukowych na ludziach, prowadzonych przez rząd USA w Gwatemali w latach 1946-48. Zarażono celowo ponad 1300 pacjentów $\mathrm{z}$ chorobami wenerycznymi, aby sprawdzić skuteczność penicyliny. Tylko 700 badanym podano penicylinę, 83 osoby zmarły w wyniku eksperymentu. Badani nie zostali poinformowani, że brali udział w eksperymencie.

\section{1}

NIH i NSF dokonują rewizji swojego konfliktu interesów.

\section{1}

Office of Human Research Protections proponuje zmiany do powszechnej zasady Common Rule ${ }^{115}$ na rzecz lepszego zabezpieczenia ludzkiego podmiotu badania i zmniejszenia obciążenia badacza. Common Rule nie była zmieniana w sposób znaczący od 1981 roku.

\section{2}

W Science and Nature opublikowane zostają dwa kontrowersyjne referaty, które rozbudzają dyskusję na temat ich wpływu na bioterroryzm. Prace zgłoszone były przez zespół pracujący w Holandii, na czele z Ronem Fo-

\footnotetext{
115 Common Rule jest zasadą etyki dotyczącą badań biomedycznych i behawioralnych z udziałem ludzi w Stanach Zjednoczonych. Została ustanowiona w 1981; drobne zmiany wprowadzono w 1991 roku.
} 
uchier oraz zespół pracujący w University of Wisconsin, prowadzony przez Yoshihiro Kawaoka. Badacze byli w stanie zmodyfikować genetycznie wirus ptasiej grypy H5N1 tak, że może być przenoszony przez ssaki, w tym również ludzi. Obecnie ptasią grypą można się zarazić przez kontakt z ptakami. Wirus jest bardzo śmiertelny; wskaźnik śmiertelności wynosi $60 \%$. Ponad 300 osób zginęło od wirusa od 1997 roku. NSABB (National Science Advisory Board for Biosecurity) początkowo zaleciło opublikowanie referatów w zredagowanej formie, kluczowe dane miały być usunięte, i jedynie udostępniane odpowiednim naukowcom, więc terroryści lub inni nie mogliby wykorzystać z tych do stworzenia śmiercionośnej broni biologicznej. Jednak NSABB zmieniło zdanie i zaleciło pełną publikację dokumentów. 



\title{
ZAtACZNIK 2
}

\section{Badanie uczestników sesji fokusowych metodą wywiadów swobodnych. Dyspozycje do wywiadu}

\author{
Pytania problemowe
}

A. Jakie są opinie badanych na temat sesji fokusowej, w której brali udział? Jak badani oceniają wymiar emocjonalny, intelektualny (poznawczy) i etyczny sesji fokusowej?

B. Jakie są opinie badanych na temat metody zogniskowanego wywiadu grupowego?

C. Jakie mają doświadczenia badawcze? Jakie są ich opinie na temat badań socjologicznych?

\section{DYSPOZYCJE \\ DO WYWIADU SWOBODNEGO Z UCZESTNIKAMI SESJI FOKUSOWYCH WERSJA DLA UCZESTNIKÓW SESJI ZE SCENARIUSZEM ZAMKNIETTYM}

WPROWADZENIE

Ogólne wyjaśnienie metodologicznego celu wywiadu swobodnego.

Takie spotkania odbywają się często. Organizatorom zależy na uzyskaniu prawdziwych informacji na interesujące ich tematy. Pragniemy dowiedzieć się, co można zmienić, poprawić, aby uczestnicy czuli się dobrze, żeby chcieli wypowiadać się szczerze.

\section{A. OCENA PRZEBIEGU SESJI FOKUSOWEJ W KATEGORIACH EMOCJONALNYCH, ETYCZNYCH I INTELEKTUALNYCH (POZNAWCZYCH)}

\section{NASTAWIENIE DO SESJI FOKUSOWEJ PRZED BADANIEM}

1. Oczekiwania na temat sesji, czego się spodziewali, jak wyobrażali sobie to spotkanie, czy zastanawiali się, jak będzie przebiegało? Czy rozmawiali na temat swojego udziału w tym badaniu z jakimiś osobami? Z kim?

2. Co czuli, wchodząc do sali, w której odbywała się sesja? Czy obawiali się czegoś? Czego? 


\section{OGÓLNE WRAŻENIA Z PRZEBIEGU SESJI}

(Chodzi tu o spontaniczne reakcje, bez dopytywania ze strony ankietera.)

1. Wrażenia pozytywne - co się w spotkaniu podobało?

2. Wrażenia negatywne - co się nie podobało?

\section{REKONSTRUKCJA PRZEBIEGU SESJI \\ III 1.Wstęp}

III.1.1. Ocena kompletności i przydatności informacji udzielonych przez moderatora na wstępie badania na temat zasad udziału w sesji.

III.1.2.Reakcje na nagrywanie za pomocą kamery.

III.1.3.Reakcje na zapewnienie o konfidencjonalności badania.

III.1.4. Jakie uczucia towarzyszyły R. w trakcie części wstępnej? Czy ulegały zmianie? Jak się zmieniły? Kiedy, w którym momencie?

\section{2.Circept}

III 2.1.0cena wkładu pracy wszystkich uczestników.

III 2.2. Ocena stopnia trudności tego zadania.

III 2.3. Czy R. dowiedział/a się czegoś nowego w trakcie rozwiązywania tego zadania? Czy pojawiły się takie określenia, o których sam/a by nie pomyślał/a? III 2.4. jakie uczucia towarzyszyły $R$. w trakcie rozwiązywania tego zadania? Czy odczuwał/a napięcie, stres, obawę, czy odczuwał/a przymus zabrania głosu, czy raczej czuł/a się swobodnie, traktował/a to jako rodzaj zabawy?

III 2.5.Opinie na temat zastąpienia zadania grupowego zadaniem indywidualnym - część zadania rozwiązywali indywidualnie (wymyślanie określeń i wpisywanie na kartkach, a następnie wstawienie w wybrane miejsce wykresu), a część - grupowo (wybieranie par określeń przeciwstawnych). Czy R. lepiej się czuł/a, gdy rozwiązywał/a część zadanie indywidualnie, na kartkach, czy lepiej, gdy rozwiązywano kwestie grupowo? Dlaczego?

\section{3.Doświadczenia badanych związane z sytuacjami łapowniczymi}

III 3.1. Własna ocena drażliwości sytuacji - czy pytanie o osobiste doświadczenia korupcyjne wywołało jakiś rodzaj niepokoju? Czy R. wypowiadał/a się całkowicie szczerze, czy też cenzurował/a swoje wypowiedzi? Dlaczego?

III 3.2. Czy na wstępie tej części sesji, po usłyszeniu pytania zadanego przez moderatora, R. podjął/ęła decyzję, o czym będą mówić, a o czym nie? Czy ta decyzja uległa zmianie w trakcie trwania tego fragmentu sesji? Czy R. wbrew pierwotnym zamierzeniom przekazał/a więcej informacji, czy mniej? Dlaczego R. zmienił/a ta wstępną decyzje? Czy wpłynęło na to zachowanie innych uczestników sesji? W jaki sposób? Co jeszcze wpłynęło na ewentualną zmianę tej decyzji? III 3.3. Opinia na temat drażliwości sytuacji dla pozostałych uczestników badania — jak R. sądzi, czy dla pozostałych osób ta część sesji była drażliwa, to znaczy czy inni denerwowali się, obawiali się? Czy inni uczestnicy wypowiadali się szczerze? 
III 3.4. Opinie na temat zastąpienia rozmowy grupowej rozmową indywidualną - czy lepiej zdaniem R. byłoby, gdyby mógł/mogła o takich sprawach rozmawiać indywidualnie, bez obecności innych osób? Czy obecność innych pomagała, czy przeszkadzała R.?

III 3.5. Ocena stopnia trudności zadania polegającego na wymyśleniu tytułu do własnej historii łapowniczej.

III 3.6. Czy R. w trakcie tej części spotkania miał/a możliwość pełnego wypowiedzenia się? Czy też chciałby/aby uzupełnić swoją wypowiedź? Dlaczego nie wypowiedział/a w pełni w trakcie sesji?

\section{4. Ocena zjawiska korupcji}

III 4.1. Ocena wkładu pracy wszystkich uczestników.

III 4.2. Ocena stopnia trudności tego zadania.

III 4.3. Czy R. dowiedział/a się czegoś nowego w trakcie rozwiązywania tego zadania? Czy akceptował/a decyzje innych uczestników, czy też nie? Jak reagował/a na opinie odmienne od własnych? Czy pod wpływem wypowiedzi innych uczestników zmienił/a swoje pierwotne oceny, czy nie?

III 4.4. Jakie uczucia towarzyszyły R. w trakcie rozwiązywania tego zadania? Czy odczuwał/a napięcie, stres, obawę, czy odczuwał/a przymus zabrania głosu, czy raczej czuł/a się swobodnie, traktował/a to jako rodzaj zabawy?

III 4.5. Opinie na temat zastąpienia zadania grupowego zadaniem indywidualnym - czy R. lepiej by się czuł/a, gdyby rozwiązywał/a to zadanie indywidualnie, na kartkach?

III 4.6. Czy R. w trakcie tej części spotkania miał/a możliwość pełnego wypowiedzenia się? Czy też chciałby/aby uzupełnić swoją wypowiedź? Dlaczego nie wypowiedział/a w pełni w trakcie sesji?

\section{5. Opinie na temat jawności dyskusji na temat korupcji. Adekwat- ność metody FGI do badania zjawiska korupcji}

III 5.1. Czy R. w trakcie spotkania miał/a możliwość zaprezentowania swego poglądu na tę sprawę? Czy chciałby/chciałaby uzupełnić swoje wypowiedzi na ten temat? Jeśli tak - dlaczego nie powiedział/a tego na sesji?

III 5.2. Czy metoda FGI jest dobrym sposobem badania takich zjawisk jak korupcja? Czy R. posiada jakieś doświadczenia korupcyjne, o których na sesji nie wspomniał/a? Dlaczego tak się stało?

III 5.3. Propozycje zmiany warunków prowadzenia rozmowy - co powinno się zmienić, aby R. czuł/a się lepiej, bardziej komfortowo, aby bez obaw chciał/a wypowiadać swoje opinie na tematy trudne, nie tylko dotyczące korupcji, ale nawet bardziej dotykające sfery prywatności, intymności? 
IV OCENA POSZCZEGÓLNYCH FRAGMENTÓW SESJI

IV 1. Fragmenty trudne - jakie, dlaczego?

IV 2. Fragmenty atrakcyjne - jakie, dlaczego?

IV 3. Powstrzymywanie się od wypowiedzi - kiedy, dlaczego?

IV 4.Zmiana poglądów pod wpływem przebiegu sesji - jakie, dlaczego? Czy R. dowiedział/a się czegoś owego lub niezwykłego na temat korupcji, co zmieniło jej/jego spojrzenie na to zjawisko? Co to było?

IV 5.Reakcja na obecność innych osób - pomagali czy przeszkadzali?

IV 6.0pinie na temat moderatora - jego zachowania, kompetencji, sposobu traktowania uczestników, sposobu radzenia sobie z organizacją sesji, panowanie nad całością, tworzenie klimatu sesji, czy sprzyjał dobremu samopoczuciu badanych, czy raczej nie?

\section{UWAGA \\ ZMIENIAMY FORMUtE ROZMOWY. \\ DALEJ POSTȨPUJEMY JAK W STANDARYZOWANYM WYWIADZIE KWESTIONARIUSZOWYM \\ NR SESJI (01-12) / NR RESP. (0-8)}

\section{B. OPINIE O METODZIE FGI}

1. Dlaczego zgodził/a P. się wziąć udział w tym spotkaniu?

1. Możliwość poznania poglądów innych ludzi.

2. Możliwość spotkania, poznania nowych osób.

3. Możliwość znalezienia się w nowej, niecodziennej sytuacji.

4. Ciekawość.

5. Nadmiar wolnego czasu.

6. Chęć zarobienia pieniędzy.

7. Chęć przysłużenia się dobrej sprawie.

8. Poczucie obowiązku obywatelskiego.

9. Inne. Jakie?

3. Proszę powiedzieć - używając do tego określeń ze skali (wręczyć Kartę $n r$ 1) — jak P. sądzi, jak ważny był dla P. każdy z niżej wymienionych elementów przy podejmowaniu decyzji o uczestniczeniu w dzisiejszym spotkaniu?

Zaznacz kółkiem odp. R.:

1. Bardzo ważny.

2. Raczej ważny.

3. Raczej nieważny.

4. Zupełnie nieważny.

5. Trudno powiedzieć. 
1. Możliwość poznania nowych ludzi.
1
2
3
4
5

2. Możliwość uczestniczenia w nowej sytuacji.

1

2

3

4

5

3. Szansa na dobrą zabawę.

12

3

4

5

4. Możliwość rozmawiania, wymiany poglądów z innymi ludźmi.

1

23

45

5. Możliwość przedstawienia innym ludziom własnych poglądów.

$\begin{array}{lllll}\mathbf{1} & \mathbf{2} & \mathbf{3} & \mathbf{4} & \mathbf{5}\end{array}$

6. Możliwość poznania poglądów innych ludzi.
1
2
3
4
5

7. Możliwość uzyskania wynagrodzenia.

2

3

4

5

8. Możliwość przysłużenia się ważnej sprawie.

1

2

3

4

5

9. Inne. Jakie?

3. Czy zgodził/a/by się P. wziąć ponownie udział w takim spotkaniu, jak dzisiejsze?

1. Zdecydowanie tak

2. Raczej tak

3. Raczej nie

przejdź do pyt. 5.

4. Zdecydowanie nie

przejdź do pyt. 5.

5. Trudno powiedzieć

przejdź do pyt. 5.

\section{Dlaczego zgodził/a/by się $P$. wziąć udział $w$ takim spotkaniu?}

1. Interesują P. poglądy innych ludzi, lubi P.

2. Sprawia P. przyjemność rozmawianie, dyskutowanie z innymi ludźmi.

3. Poszedłby (poszłaby) P. tam z czystej ciekawości.

4. Chciał(a)by P. dostać jakiś upominek lub wynagrodzenie pieniężne.

5. Inne. Jakie?

6. Trudno powiedzieć.

\section{UWAGA}

Przejdź do pyt. nr 6 
5. Dlaczego nie wyraził/a/by P. zgody na udział $w$ takim spotkaniu?

Proszę wskazać wszystkie powody tej decyzji. (wręczyć Kartę $n r 2$ )

1. Ponieważ zupełnie mnie takie spotkania nie interesują.

2. Ponieważ nie mam zaufania do organizatorów takich spotkań.

3. Ponieważ nie mam zaufania do innych uczestników takich spotkań.

4. Ponieważ po prostu nie lubię uczestniczyć w takich spotkaniach.

5. Ponieważ nie nadaję się do udziału w takich dyskusjach.

6. Ponieważ nie mam możliwości (brak czasu, trudności z poruszaniem się, okoliczności życiowe, typu: opieka nad dzieckiem lub osobą chorą i in.)

7. Ponieważ nie podobają mi się cechy takiego spotkania, które?

- rejestrowanie cyfrowe

- obecność obcych ludzi

- konieczność zabierania głosu w dyskusji

- zbyt małe wynagrodzenie

- zbyt trudne zadania

- inne, jakie?

8. Ponieważ poruszane tam tematy nie są dla mnie interesujące.

9. Trudno powiedzieć.

6. Proszę powiedzieć - używając do tego tych określeń (wręczyć Kartę $n r$ 3) — jak ważny jest $\mathbf{z}$ P. punktu widzenia każdy z niżej wymienionych warunków, aby spotkanie takie było dla $P$. bardziej atrakcyjne, aby chętniej wyraził/a P. zgodę na udział $w$ takim spotkaniu?

(Pytamy także te osoby, które nie zgodziły się na powtórny udział w sesji.)

Zaznacz kótkiem odp. R.:

1. Bardzo ważny.

2. Raczej ważny.

3. Raczej nieważny.

4. Zupełnie nieważny.

5. Trudno powiedzieć.

1. Temat rozmowy musi być interesujący dla mnie.

$\begin{array}{lllll}1 & 2 & 3 & 4 & 5\end{array}$

2. Muszę mieć pewność, że dobrze znam się na sprawach, których dotyczyć ma dyskusja, że pytania nie będą dla mnie zbyt trudne.

$\begin{array}{lllll}1 & 2 & 3 & 4 & 5\end{array}$

3. Muszę wiedzieć coś na temat pozostałych uczestników spotkania, kim są ci ludzie.

$\begin{array}{lllll}1 & 2 & 3 & 4 & 5\end{array}$

4. Muszę mieć zaufanie do organizatorów takiego spotkania.

1

2

3

4

5 
5. Muszę wiedzieć, jakim celom służy takie spotkanie, kto i do czego wykorzysta uzyskane ode mnie informacje.
1
2
3
4
5

6. Musi odpowiadać mi termin i miejsce spotkania

1

2

3

4

5

7. Muszę otrzymać odpowiednie wynagrodzenie za udział $w$ takim spotkaniu
1
2
3
4
5

8. Inne. Jakie?

7. Z przygotowanej listy proszę wybrać tylko jeden rodzaj tematu, na który zdecydowanie najchętniej dyskutował/a/by P. na takim spotkaniu? (wręczyć Kartę nr 4)

1. Dotyczący polityki (np. działalności partii, polityków, wyborów).

2. Dotyczący gospodarki (np. budżetu, prywatyzacji, inwestycji).

3. Dotyczący spraw publicznych (np. funkcjonowania instytucji, reform szkolnictwa, służby zdrowia, przestępczości).

4. Dotyczący życia codziennego (np. dzieci, pracy, zdrowia, rodziny).

5. Dotyczący zainteresowań (hobby, sport, ksiq̨żki, ryby).

6. Dotyczący produktów i usług (np. reklam, konkretnych produktów).

7. Dotyczący mediów (prasy, radia, tv).

8. Dotyczący czegoś innego. Czego?

9. Temat dla mnie nie ma znaczenia, może być dowolny.

10. Trudno powiedzieć.

8. Co chciał/a/by P. wiedzieć przed spotkaniem na temat pozostałych uczestników, aby w trakcie rozmowy czuł/a/ się P. lepiej, bezpieczniej? Czy chciał/a/by P. znać ich:

(Zaznaczyć we właściwej kolumnie odp. R.)

\begin{tabular}{|rr|r|r|}
\cline { 2 - 4 } \multicolumn{1}{l|}{} & TAK & NIE \\
\hline 1. & Płeć & & \\
\hline 2. & Wiek & & \\
\hline 3. & Wykształcenie & & \\
\hline 4. & Zawód & & \\
\hline 5. & Miejsce pracy & & \\
\hline 6. & Stanowisko & & \\
\hline 7. & Sytuację rodzinną (stan cywilny, dzieci) & & \\
\hline 8. & Warunki materialne & & \\
\hline 9. & Zainteresowania & & \\
\hline 10 & Inne. Jakie? & & \\
\hline
\end{tabular}


9. Wypowiedzi osób zaproszonych na takie spotkania wykorzystywane są rozmaicie. Proszę sobie wyobrazić, że ma P. do wyboru jedno z następujących spotkań (wręczyć Kartę $n r$ 5). W którym z tych spotkań, różniących się sposobem wykorzystania wyników, zdecydowanie najchętniej wziąłby/wzięłaby $P$. udział?

1. Wyniki jednego spotkani zostaną wykorzystane dla rozwoju jakiejś dziedziny nauki (medycyny, ekonomii, nauk społecznych, ekologii itd.).

2. Wyniki drugiego spotkania posłużą usprawnieniu jakiejś konkretnej dziedziny życia społecznego (zmniejszenie przestępczości, bezrobocia, poprawa funkcjonowania służb publicznych itd.).

3. Wyniki trzeciego spotkania zostaną rozpowszechnione w mediach, żeby ludzie wiedzieli, co myślą inni ludzie na różne tematy.

4. Wyniki czwartego spotkania posłużą zmianie jakiegoś konkretnego produktu - np. wpłyną na poprawę kształtu i kolorów opakowań, mebli, samochodów.

5. Jest mi to obojętne, nie ma dla mnie znaczenia, w jaki sposób zostaną wykorzystane wyniki takiego spotkania.

6. Inne. Jakie?

7. Trudno powiedzieć.

10. Jakie wynagrodzenie powinni zaproponować $P$. organizatorzy, aby zechciał/a/ P. wziąć udział w trwającym około 2 godzin spotkaniu?

Wpisz kwotę:

1. Do $10 \mathrm{zf}$

2. $11-20 \mathrm{zł}$

3. $21-50 \mathrm{zt}$

4. $50-100 \mathrm{zł}$

5. ponad $100 \mathrm{zł}$

6. nie potrafię określić kwoty

7. obojętnie - wysokość wynagrodzenia nie ma dla mnie znaczenia

8. Trudno powiedzieć, bo to zależy (od różnych rzeczy):

- od tematu,

- od miejsca,

- od czasu trwania spotkania,

- inne. 


\section{DOŚWIADCZENIA BADAWCZE UCZESTNIKÓW SESJI FOKUSOWYCH. OPINIE NA TEMAT BADAŃ}

11. W prasie, radio i telewizji pojawiają się często komunikaty, w których mowa o tym, jak ludzie zamierzają głosować w najbliższych wyborach lub co myślą o różnych sprawach. Informacje takie powstają jako rezultat badań, polegających na przeprowadzaniu rozmów bezpośrednio z ludźmi. Czy spotkał się P. z takimi informacjami z badań?

1. Tak.

2. Nie.

3. Trudno powiedzieć.

12. Czy kiedykolwiek udzielał/a P. ustnie jakiś informacji dla potrzeb takich badań ?

1. Tak.

2. Nie.

4. Nie pamiętam.

5. Trudno powiedzieć.

13. Czy kiedykolwiek zdarzyło się, że wypełnił/a P. dobrowolnie jakąś ankietę (np. otrzymaną na ulicy, dołączoną do jakiegoś produktu, wydrukowaną $w$ prasie)?

1. Tak.

2. Nie.

3. Nie pamiętam.

14. Jak P. sądzi, jakie zastosowanie $w$ dzisiejszych czasach mają badania opinii publicznej, to znaczy dowiadywanie się, co ludzie myślą o różnych sprawach?

15. Czy uczestniczył/a/ P. kiedykolwiek w taki spotkaniu, jak dzisiejsze?

1. Tak.

2. Nie. (ZAKOŃCZ WYWIAD - przejdź do procedury zakończenia)

16. Ile razy uczestniczył/a P. $w$ takich spotkaniach?

1. 1 raz.

2. 2 razy.

3. 3 razy i więcej.

4. Nie pamiętam. 
17. Kiedy miało miejsce (dla osób, które uczestniczyły kilka razy dołączyć określenie: „ostatnie”) takie spotkanie?

1. W ostatnim miesiącu.

2. W ostatnim kwartale.

3. W ostatnim roku.

4. Ponad rok temu.

5. Nie pamiętam.

18. Czy pamięta P., kto był organizatorem tego spotkania?

1. Tak.

2 Nie. (przejdź do pytania 20.)

19. Kto (jaka instytucja, firma, organizacja) był organizatorem tego spotkania?

20. Proszę powiedzieć kto i w jaki sposób zaprosił P. na to spotkanie?

Czy został/a P. zaproszony/a na to spotkanie:

1. Przez kogoś znajomego, $\mathrm{w}$ bezpośredniej rozmowie.

2. Przez kogoś znajomego w rozmowie telefonicznej.

3. Przez zupełnie obcą osobę, w rozmowie bezpośredniej.

4. Przez zupełnie obcą osobę $w$ rozmowie telefonicznej.

5. Inaczej. Jak?

6. Nie pamiętam.

21. Ciekawi nas, jak przebiegało to spotkanie? Jak długo ono trwało?

1. Mniej niż 1 godzinę.

2. Nie więcej niż 2 godziny.

3. Ponad 2 godziny.

4. Nie pamiętam.

22. Ile osób w nim uczestniczyło?

1. 1-3.

2. 4-6.

3. $7-10$.

4. 11-20.

5. Więcej niż 20.

6. Nie pamiętam. 


\section{Gdzie ono się odbyło?}

1. W mieszkaniu prywatnym.

2. W lokalu publicznym (np. kawiarnia, sala konferencyjna, szkoła).

3. Nie pamiętam.

\section{Jakich spraw dotyczyła rozmowa?}

1. Prezentowano jakiś produkt (reklama połączona ze sprzedaża) (przejdź do pytania 26.)

2. Prezentowano jakąś usługę (reklama połączona ze sprzedażą) (przejdź do pytania 26.)

3. Rozmawiano na różne tematy.

4. Nie pamiętam.

\section{Jakie tematy poruszano w trakcie tego spotkania?}

26. Na czym polegało $P$. zadanie jako uczestnika tego spotkania ?

1. Był/a P. tylko widzem, prowadzący spotkanie nie zadawał P. żadnych pytań.

2. Brał/a P. aktywny udział w rozmowie (dyskutował/a P., zadawał/a P. pytania, odpowiadał/a na pytania prowadzącego).

3. Nie pamiętam.

\section{Co się P. podobało w tym spotkaniu?}

1. Ogólnie wszystko mi się podobało.

2. Nic mi się nie podobało.

3. Korzyści materialne uzyskane w trakcie tego spotkania (wynagrodzenie pieniężne, drobny prezent, poczęstunek).

4. Niektóre elementy tego spotkania. Jakie?

5. Trudno powiedzieć.

6. Nie pamiętam.

\section{A co się P. w tym spotkaniu nie podobało?}

1. Nic mi się nie podobało.

2. Niektóre cechy tego spotkania. Jakie?

3. Trudno powiedzieć.

4. Nie pamiętam. 


\section{PROCEDURA ZAKOŃCZENIA}

- WYJAŚNIJ PYTANIA I WĄTPLIWOŚCI R.

- POPROŚ O WYPEENIENIE TESTÓW.

- PODZIEZKUJZA ROZMOWĘ.

- POPROŚ O ZGŁOSZENIE SIĘ PO WYNAGRODZENIE.

- PODPISZ KASETE Z NAGRANIEM WYWIADU (DATA, NR SESJI/RESP., NAZWISKO ANKIETERA).

- WPISZ SYMBOL IDENTYFIKACYJNY R. NA KWESTIONARIUSZU WYWIADU.

- UWAGI ANKIETERA:

DATA

SESJA NR

IMIĘ I NAZWISKO ANKIETERA 


\section{ZALACZNIK 3}

\section{Formularz zgody rodzica/opiekuna prawnego}

\section{Wprowadzenie i cele}

Zwracamy się z prośbą o wyrażenie zgody, aby Pana/Pani dziecko wzięło udział w dyskusji grupowej z udziałem dzieci. Realizowany przez nas projekt badawczy jest finansowany przez

Celem organizowanego spotkania jest uzyskanie informacji dotyczących tego, jak z perspektywy dzieci postrzegana jest struktura czasu szkolnego, ze szczególnym uwzględnieniem ilości, długości i formy spędzania szkolnych przerw. Pragniemy zaprosić Pana/Pani dziecko, ponieważ jest ono w wieku 810 lat i już od trzech lat jest uczniem, a zatem ma ono ważny dla nas rodzaj doświadczenia i wiedzy.

\section{0 co prosimy Pana/Pani dziecko?}

Pana/Pani dziecko jest proszone o wzięcie udziału w dyskusji grupowej, w której oprócz niego będzie uczestniczyło jeszcze pięcioro dzieci w tym samym przedziale wiekowym. Spotkanie będzie prowadzone przez członka naszego zespołu badawczego, który ma duże doświadczenie wpracy $\mathrm{z}$ dziećmi. Osoba ta będzie zadawała dzieciom pytania dotyczące tego, jak spędzają czas na przerwach w szkole, czy wystarcza im czasu na przejście do właściwych pomieszczeń, czy i jakie mają warunki do zjedzenia drugiego śniadania itp.

Spotkanie odbędzie się w dniu

o godzinie

w miejscu

Rozmowa z dziećmi potrwa około 45 minut.

\section{Jakie są korzyści i zagrożenia dla Pana/Pani lub dziecka?}

Chcemy, aby szkoła stała się środowiskiem najbardziej przyjaznym Pana/Pani dziecku i wyniki realizowanego badania mogą poprawić strukturę zajęć szkolnych zgodnie z potrzebami dzieci. Nie dostrzegamy żadnego potencjalnego zagrożenia wynikającego z udziału dziecka w tym projekcie. 


\section{Co zrobimy z informacjami uzyskanymi od Pana/Pani dziecka?}

Informacje uzyskane od wszystkich dzieci na wszystkich spotkaniach grupowych zostaną opracowane łącznie w postaci raportu z badania. W tym tekście nie pojawi się nazwisko ani imię żadnego z uczestniczących w spotkaniach dzieci ani żadne inne informacje konkretne, które pozwoliłyby na zidentyfikowanie poszczególnych uczestników.

\section{Dobrowolne uczestnictwo}

Uczestnictwo Pana/Pani dziecka w tym projekcie jest całkowicie dobrowolne. Oznacza to, że dziecko ma prawo w dowolnym momencie opuścić pomieszczenie, w którym odbędzie się spotkanie. Może też odmówić odpowiedzi na pytania bez żadnych konsekwencji.

\section{Koszty}

Pan/Pani nie poniesie żadnych kosztów w związku z udziałem dziecka w spotkaniu. Każde dziecko bez względu na swój wkład w rozmowę otrzyma na zakończenie drobny upominek — puzzle.

Od Pana/Pani oczekujemy, że dziecko zostanie przyprowadzone na wyznaczone spotkanie przez osobę dorosłą, która w trakcie badania będzie przebywać w sąsiednim pomieszczeniu na wypadek, gdyby dziecko przerwało swój udział w dyskusji przed jej zakończeniem. Spodziewamy się również, że po zakończeniu spotkania przejmie Pan/Pani opiekę nad dzieckiem. Jako rekompensatę za poświęcony czas i ewentualne koszty dojazdu wypłacimy Panu/Pani kwotę zł.

Pieniądze te zostaną Panu/Pani wypłacone również w sytuacji, gdy dziecko wcześniej zakończy swój udział w dyskusji.

\section{Informacje, kontakt}

Na wszystkie pytania związane z badaniem udzielimy Panu/Pani możliwie wyczerpujących informacji.

Proszę w tym celu kontaktować się z 


\section{ZALACZNIK 4}

\section{Formularz zgody dziecka}

Imię i nazwisko dziecka

(Treść tego oświadczenia należy głośno, wolno i wyraźnie odczytać dziecku. Dziecko w wieku szkolnym należy poprosić na zakończenie o złożenie podpisu na dole dokumentu.)

Za kilka dni ja i moi koledzy organizujemy spotkanie, na które chcemy zaprosić dzieci takie jak ty. Chcemy od was dowiedzieć się, jak spędzacie szkolne przerwy, czym się na przerwach zajmujecie. Chcemy to wiedzieć po to, aby wasze przerwy były takie, jak byście sobie tego życzyli.

W tej rozmowie nie ma złych odpowiedzi. Chcemy tylko dowiedzieć się, co naprawdę myślisz o szkolnych przerwach, co ci się w nich podoba, a co nie. Po prostu powiesz to, co chcesz powiedzieć na ten temat.

Będziemy notować dokładnie to, co każde dziecko nam powie. Nigdzie nie powiemy ani nie napiszemy, co dokładnie powiedziało konkretne dziecko. Również nie poinformujemy twoich rodziców ani nauczycieli, co nam powiedziałeś/powiedziałaś. Zamiast tego będziemy mówić: „Grupa dzieci z tej szkoły uważa, że..."

Twój udział w spotkaniu nie jest obowiązkowy. Możesz odmówić i masz do tego pełne prawo. Również, jeśli zgodzisz się przyjść, nie musisz odpowiadać na pytanie, jeśli nie będziesz mieć ochoty.

To spotkanie będzie trwało około 45 minut, czyli mniej więcej tyle czasu, ile szkolna lekcja.

Czy masz jakieś pytania, czy chcesz się jeszcze czegoś dowiedzieć?

Wszystkie informacje zostały mi odczytane. Uzyskałem/am odpowiedzi na moje pytania. Chcę wziąć udział w tym spotkaniu.

Nazywam się:

Oświadczam, że wszystkie informacje zostały przeze mnie dziecku odczytane. Odpowiedziałem/am na wszystkie pytania dziecka. Uważam, że dziecko właściwie zrozumiało, czego się od niego/niej oczekuje.

Podpis osoby zapraszającej dziecko

Data 

ZAtACZNIK 5

\section{Projekt Speak Up! Scenariusz FGI}

\section{Faza wprowadzająca}

\section{Powitanie, podziękowanie za przybycie.}

2. Przedstawienie się moderatora - imię, nazwisko, stałe zajęcie, zainteresowania.

Co jeszcze chcielibyście wiedzieć na mój temat?

\section{Zapoznanie się dzieci.}

Elementy do autoprezentacji to:

- imię,

- zainteresowania,

- wylosowane hasło.

(Dzieci losujq kartki z hasłami, które mają być podstawą trzeciej części ich autoprezentacji. Każde dziecko losuje 1 kryterium/hasło.

Hasła do przedstawienia siebie.)

1. Ulubiony film - jaki? dlaczego?

2. Ulubiony przedmiot szkolny - jaki? dlaczego?

3. Ulubione zwierzę - jakie? dlaczego?

4. Ulubiona potrawa - jaka? dlaczego?

5. Ulubione zajęcie (co lubisz robić najbardziej) — jakie? dlaczego?

6. Ulubiony kolega, koleżanka - kto? dlaczego?

7. Ulubiona gra komputerowa - jaka? dlaczego?

8. Ulubione miejsce (gdzie najchętniej spędzasz czas, dokąd przeniósłbyś się z tej sali, gdyby było to możliwe) — jakie? dlaczego?

9. Ulubiony przedmiot, rzecz — jaki? dlaczego?

10. Ulubiony serial - jaki? dlaczego?

11. Ulubiona pora roku — jaka? dlaczego?

12. Ulubiony sport - jaki? dlaczego?

\section{Krótkie wprowadzenie do projektu Speak Up!}

Projekt Speak Up!, w którym uczestniczycie, jest prowadzony przez organizację Eurochild, która skupia instytucje zajmujące się problemami dzieci z 35 krajów świata. Jego celem jest pogłębienie wiedzy o dzieciach. Jest zaadresowany do 
dzieci; jego celem jest ustalenie, co same dzieci myślą o swoich prawach, jak ich zdaniem te prawa są przestrzegane oraz co należy zrobić w kraju i na świecie, żeby wszystkie dzieci miały zagwarantowane prawa.

Projekt ruszył wiosną 2011 i będzie trwał do końca 2012 roku.

Wszystkie dzieci, które uczestniczą w projekcie, mogą ze sobą korespondować i wymieniać doświadczenia na Facebooku.

W takich samych spotkaniach jak to dzisiejsze, uczestniczą wasi rówieśnicy w ośmiu krajach europejskich: Bułgaria, Grecja, Węgry, Irlandia, Szwecja, Anglia, Holandia.

(Znajdźcie na mapie kraje, w których dzieci uczestniczq w takich samych spotkaniach, jak to dzisiejsze. Zamalujcie flamastrem powierzchnie tych państw.)

\section{Przedstawienie zasad uczestnictwa.}

(Moderator odczytuje kolejno zasady, ustala, czy dzieci je rozumieja, czy dzieci je akceptują. Następnie mocuje kartkę $w$ widocznym miejscu.)

\section{Zasady}

- Każdy słucha uważnie, gdy inny mówi, nie przerywa komuś w trakcie wypowiedzi.

- Każdy ma prawo nie uczestniczyć w dyskusji, gdy nie czuje się gotowy.

- Każda wypowiedź jest jednakowo ważna.

- Każda wypowiedź jest jednakowo dobra. Nie ma złych odpowiedzi.

- Każdy ma prawo do własnych opinii.

- Każdy uczestnik wyłącza swój telefon na czas trwania spotkania.

- Każdy ma prawo zapytać, jeśli czegoś nie rozumie lub nie usłyszy.

- Każdy szanuje opinie innych, nawet jeśli się z nimi nie zgadza.

- Każdy stara się jak najlepiej uczestniczyć w spotkaniu.

- Nikt nie używa wulgarnych słów.

- Nikt nie narzuca swojego zdania innym uczestnikom spotkania.

- Nikt (a w szczególności rodzice, nauczyciele i koledzy ze szkoły) nie dowie się od organizatorów, co zostało powiedziane podczas spotkania.

Moderator przekazuje informację o nagrywaniu spotkania oraz o planowanym filmiku z ich udziałem. Takie filmiki z udziałem innych dzieci są już zamieszczone w Internecie.

6. Wypełnienie formularza - potwierdzenie zgody na przedstawione cele i zasady uczestnictwa. 


\section{Faza zasadnicza}

\section{1. Wiedza ogólna o prawach dziecka.}

W sobotę świat oczekiwał narodzin sześciomiliardowego mieszkańca Ziemi. Wśród tych 6 mld ludzi jest około 2 miliardy dzieci poniżej 15 roku życia. Czyli mniej więcej co trzeci mieszkaniec Ziemi jest dzieckiem, które nie ukończyło jeszcze 15 lat!

W Polsce żyje około 40 milionów ludzi. Gdyby wszyscy mieszkańcy Polski byli dziećmi, to musiałoby być takich państw 50 , żeby pomieścić wszystkie dzieci świata!!!

\section{Dyskusja}

- Czy dzieciom przysługują jakieś specjalne prawa, czy takie same, jak ludziom dorosłym?

- Jeśli dzieci mają swoje specjalne prawa, to dlaczego te prawa nie są takie same, jak dla ludzi dorosłych?

- Czy wy jako dzieci macie określone prawa?

- Czy możecie złożyć skargę jeżeli wasze prawa nie są respektowane?

- Kto ustala prawa dla dzieci?

- Czy znacie Konwencję o Prawach Dziecka lub czy kiedykolwiek o niej słyszeliście?

- Skąd wiecie (z jakich źródeł), że dzieci mają jakieś swoje prawa? Skąd jeszcze?

\section{Podsumowanie - wprowadzenie}

Każde dziecko ma określone prawa. Zarówno chłopiec, jak i dziewczynka w wieku poniżej 18 lat dysponuje pewnymi szczególnymi uprawnieniami. Lista tych praw, jak również działania, które rządy muszą podjąć, aby pomóc w korzystaniu z nich, są określone w Konwencji Narodów Zjednoczonych o Prawach Dziecka. Konwencja jest traktatem międzynarodowym czyli umową między państwami. Dlatego jej interpretacja nie jest łatwym zadaniem. Prawie wszystkie kraje na świecie, w tym wszystkie kraje Europy, przyjęły Konwencję. Państwa-strony konwencji są zobowiązane przestrzegać zasad ustanowionych w traktacie, a także są zachęcane do podejmowania środków, które byłyby jeszcze bardziej korzystne dla dzieci niż przepisy Konwencji. KPD jest zatem bardzo ważnym traktatem dla dzieci na całym świecie. Konwencja zajmuje się różnego rodzaju zagadnieniami mającymi związek z życiem dzieci i młodzieży. Wszystkie prawa są ze sobą ściśle powiązane i są równie ważne. Czasami prawa opisują co jest najlepsze dla dzieci w danej sytuacji, lub co ma decydujące znaczenie dla życia dzieci i chroni je przed krzywdą. 


\section{2. Odróżnienie prawdziwych i fałszywych praw dziecka.}

(Odsłonić tablicę z prawami dziecka.

Odczytać kolejno treść wszystkich zamieszczonych na tablicy praw, wskazując odpowiadająe im obrazki.

Poprosić, aby dzieci podeszły do tablicy i uważnie przyjrzały się prawom.

Dać im czas.

Następnie rozdać arkusze z listą wszystkich praw.

Poprosić, aby przy każdym z nich indywidualnie wstawili $\times$ w kolumnie „prawdziwe" lub "fałszywe".

Zebrać kartki.

Pomieszać kartki, żeby nie ujawnić dzieci, które udzieliły „niewłaściwych” odpowiedzi.

Na tablicy w sposób widoczny dla dzieci wpisać odpowiedni dla każdego prawa wynik w kategoriach prawdziwe/fałszywe.)

\section{Dyskusja}

(Kolejno omówić ogólnie każde prawo - dlaczego uznali je za prawdziwe/fałszywe - na podstawie uzyskanych wyników w tabeli.)

\section{Podsumowanie - wprowadzenie}

14 spośród przedstawionych na tablicy praw jest prawdziwych, są wpisane do Konwencji o Prawach dziecka.

Przede wszystkim są to podstawowe prawa, takie jak prawo do tego, by nie być dyskryminowanym, prawo do nazwy/własnej tożsamości i rejestracji po urodzeniu i prawo do praktykowania własnej kultury.

Następnie są prawa dotyczące ochrony dzieci, takie jak ochrona przed wykorzystywaniem seksualnym, prawo do szczególnej ochrony dzieci pozbawionych wolności.

Następnie są prawa dotyczące potrzeb dzieci: do nauki, ochrony zdrowia, zabawy i wolności słowa. Wreszcie są też prawa o szczególnej ochronie dzieci w trudnych sytuacjach: sierot, dzieci uchodźców, dzieci niepełnosprawnych.

(Pozostawienie na tablicy tylko 14 prawdziwych praw.)

\section{3. Wybór 4 prawdziwych praw, które są najbliższe sytuacji życiowej dzieci i ich doświadczeniom. \\ (Poprosić, aby dzieci podeszły do tablicy i uważnie przyjrzały się tym prawom.)}

Pomyślcie teraz o własnym życiu - o domu, szkole, kolegach, relacjach z dorosłymi, o ulicy i miejscach publicznych. 
Zastanówcie się, w jakich sytuacjach w waszym doświadczeniu, życiu, mają/powinny mieć zastosowanie te prawa?

Które z tych sytuacji są dla was najważniejsze? Które występują najczęściej? A które są najrzadsze albo najmniej ważne?

(Odczytać kolejno treść każdego z 14 prawdziwych praw, wskazać na rysunku na tablicy wraz z dodatkowym wyjaśnieniem. Omówić każde prawo po kolei. Zaklasyfikować je do grupy praw istotnych i nieistotnych. Oddzielić, usunać $z$ tablicy prawa najmniej istotne z punktu widzenia doświadczeń dzieci.)

1. Wszystkie dzieci są równe. (art. 2. Konwencji o prawach dziecka) Niniejszy artykuł zawiera jedno z czterech kluczowych zasad Konwencji o prawach dziecka, że wszelkie prawa dotyczą wszystkich dzieci bez wyjątku oraz obowiązek państwa do ochrony dzieci przed wszelkimi formami dyskryminacji/nierównego traktowania. Dzieci mogą być dyskryminowane ze względu na: rasę, kolor skóry, płeć, język, religię, pochodzenie etniczne lub społeczne, status majątkowy, niepełnosprawność itp. dziecka albo jego rodziców.

2. Dzieci niepełnosprawne mają prawo do specjalnej opieki. (art. 23. Konwencji)

Ten artykuł gwarantuje dzieciom niepełnosprawnym („dzieciom ze specjalnymi potrzebami") prawo do specjalnej opieki, edukacji i szkolenia, mające pomóc im osiągnięcie jak największej samodzielności oraz ułatwiające dziecku prowadzenie pełnego i aktywnego życia w społeczeństwie.

3. Wszystkie dzieci mają prawo do opieki zdrowotnej. (art. 24.) Ten artykuł gwarantuje dzieciom prawo do korzystania z najwyższego poziomu ochrony zdrowia, możliwości dostępu do usług zdrowotnych i medycznych, ze szczególnym uwzględnieniem podstawowej i profilaktycznej opieki zdrowotnej, edukacji publicznej zdrowia i zmniejszania śmiertelności niemowląt. Państwa mają obowiązek działać na rzecz zniesienia szkodliwych praktyk tradycyjnych.

4. Wszystkie dzieci mają prawo do nauki. (art. 28. i 29.)

Te dwa artykuły gwarantują prawo dziecka do edukacji i obowiązek państwa do zapewnienia, aby szkoła podstawowa była obowiązkowa i bezpłatna dla wszystkich. Edukacja powinna być skierowana na rozwój osobowości dziecka i jego talenty, przygotowuje dziecko do aktywnego dorosłego życia, promowanie poszanowania podstawowych praw człowieka i rozwijanie $\mathrm{w}$ dziecku szacunku dla własnych wartości kulturowych i narodowych i innych.

5. Dzieci w konflikcie z prawem mają prawo do szczególnej pomocy. (art. 40.)

Ten artykuł dotyczy praw dzieci, które stykają się z wymiarem sprawiedliwości dla nieletnich. Dzieci, które są domniemanymi sprawcami lub uznanymi za popełnienie przestępstwa mają prawo do traktowania ich w sposób sprzyjający 
godności w duchu szacunku dla praw człowieka. Wymiar sprawiedliwości musi być dostosowany do konkretnych praw dzieci i ich potrzeb. Dotyczy to w szczególności korzystania z wszystkich aspektów rzetelnego procesu sądowego, w tym prawnej lub innej pomocy w przygotowaniu i prezentowaniu swojej obrony. Zawiera on zasadę, że w miarę możliwości, należy unikać postępowania sądowego i praktyki instytucjonalnej w stosunku do dzieci.

6. Dzieci-uchodźcy mają prawo do szczególnej pomocy. (art. 22.). Ten artykuł zapewnia szczególną ochronę dla dzieci uważanych za uchodźcę lub dzieci ubiegających się o status uchodźcy, a to zobowiązuje państwa do współpracy z właściwymi organizacjami w celu zapewnienie ochrony i pomocy.

7. Dzieci mają prawo do wyrażania opinii. (art. 12.) Ten artykuł gwarantuje prawo dziecka do wyrażania opinii, a także do brania tej opinii pod uwagę w każdej sprawie. Dziecko ma prawo do wyrażania swoich poglądów swobodnie i prawo do traktowania ich poważnie. Każde dziecko, które jest zdolne do kształtowania swych poglądów ma prawo do wyrażania tych poglądów. Poglądy dziecka muszą być traktowane poważnie i muszą być brane pod uwagę w zależności od wieku i dojrzałości dziecka. Oznacza to również, że dzieci mają prawo do bycia wysłuchanym w postępowaniach sądowych i administracyjnych dotyczących dziecka.

8. Dzieci mają prawo do informacji. (art. 17.)

Ten artykuł zapewnia dzieciom prawo do dostępu do odpowiednich informacji. Rola mediów w rozpowszechnianiu informacji dla dzieci musi uwzględniać dobro dziecka w wymiarze społecznym, duchowym i moralnym oraz jego zdrowie fizyczne i psychiczne. Państwo musi podjąć środki, aby zachęcić do tego środki masowego przekazu i do ochrony dzieci przed szkodliwymi materiałami.

9. Wszystkie dzieci mają prawo do zabawy. (art. 31.)

Ten artykuł gwarantuje prawo dziecka do wypoczynku, rozrywki, zabawy i rekreacji, działalności artystycznej i kulturalnej w środowisku, które jest odpowiednie do jego wieku.

10. Dzieci bez rodzin mają prawo do specjalnej ochrony. (artykuł 20.) Ten artykuł zobowiązuje państwa do zapewnienia szczególnej ochrony dzieci pozbawionych środowiska rodzinnego i zapewnienia właściwej opieki rodzin zastępczej. Przy wyborze odpowiednich rozwiązań należy w sposób właściwy uwzględnić wskazania w zachowaniu ciągłości w wychowaniu dziecka oraz jego tożsamości etnicznej, religijnej, kulturowej i językowej.

\section{1. Żadne dziecko nie będzie wykorzystywane. (art. 19. i 34.)}

Artykuł 19. zobowiązuje państwa do ochrony dzieci przed wszelkimi formami nadużyć popełnianych przez rodziców lub inne osoby odpowiedzialne za opiekę nad nimi, i do podjęcia środków zapobiegawczych i tworzenia programów 
w tym zakresie. Artykuł 34. zobowiązuje państwa do ochrony dzieci przed seksualnym wykorzystywaniem, w tym prostytucji i udziału w pornografii.

12. Dzieci mają prawo do tożsamości. (art. 8.)

Artykuł 8. zobowiązuje państwa do przestrzegania prawa dzieci do nazwiska, obywatelstwa oraz więzi rodzinnych.

13. Dzieci mniejszości mają prawo do korzystania z własnej kultury. (art. 30.)

Artykuł 30. gwarantuje dzieciom prawo do nauki i używania języka i zwyczajów swojej rodziny, bez względu na to czy są one podzielane przez większość ludzi w kraju, czy też nie.

14. Dzieci muszą być chronione przed pozbawieniem wolności. (art. 37.) Artykuł 37. zobowiązuje państwa do zapewnienia, że dzieci, które łamią prawo nie są traktowane okrutnie. Nie powinny one być $w$ więzieniu $\mathrm{z}$ dorosłymi i powinny móc utrzymywać kontakt z ich rodzinami.

(Z pozostawionych praw istotnych wybrać tylko 4 najważniejsze dla ich życia. Pozostawić na tablicy rysunki z tymi 4 prawami.)

\section{Przerwa obiadowa}

\section{Faza zasadnicza cd}

II 4. Odtworzenie codziennej struktury zajęć/czynności, wypełniających życie uczestników.

Opowiedzcie, jak wygląda wasz dzień powszedni. Jakie zajęcia/ czynności wykonujecie w ciągu dnia? Jakie relacje nawiązujecie w ciągu dnia, z kim? A jak wygląda dzień wolny od nauki, dzień świąteczny?

(Pamiętać o szkole, nauce $w$ domu, zajęciach dodatkowych, zajęciach domowych, towarzyskich, kulturalnych, Internet, telewizja, sklepy, galerie, ulica, kontakty z nauczycielami, kolegami, rodzina. Wypisać na planszy kolejne propozycje.

Ustalić, jakie zajęcia zajmujq najwięcej czasu, jakie relacje maja miejsce najczęściej. Stworzyć ranking zajęć/czynności, które wypełniaja ich życie.

Pozostawić w widocznym miejscu.)

\section{5. Omówienie wybranych 4 praw dziecka według schematu:}

- świadomość dzieci i znajomość praw dziecka,

- specyficzne potrzeby dzieci i ograniczenia w realizacji ich praw, 
- propozycje polityk lub działań na rzecz dzieci na poziomie krajowym, regionalnym lub lokalnym Zabawa w premiera: Co dzieci zmieniłyby w ich społeczności, w kraju lub w Europie, gdyby były premierem? (Zabawa w wywiad - kamera.)

- propozycje polityk lub działań na rzecz dzieci na poziomie UE.

\section{6. Negocjacja rezultatów.}

Krótkie podsumowanie. Ustalenie, czy dzieci akceptują uzyskane wnioski.

\section{7. Nagranie filmu przedstawiającego dzieci biorące udział w spotkaniu.}

\section{Faza końcowa}

III 1. Ocena konsultacji w grupie fokusowej (skala 1-5):

Dzieci oceniają spotkanie w poniższych wymiarach, używając do tego ocen szkolnych od 1 - niedostateczny do 5 - wzorowy.

Każde dziecko wystawia flamastrem ocenę na oddzielnej planszy.

- Jak oceniasz udział innych dzieci w tym spotkaniu? Czy pracowały aktywnie?

- Jak oceniasz atmosferę tego spotkania? Czy było ci tutaj miło?

- Jak oceniasz wnioski z tego spotkania? Czy są ważne?

- Jak oceniasz osoby prowadzące to spotkanie?

- Jak oceniasz przebieg tego spotkania? Czy było ono dla ciebie ciekawe?

\section{2. Poinformowanie dzieci, co się stanie z wynikami spotkania.}

Wyjaśnienie, że takie konsultacje zdziećmi są prowadzone po to, aby rządy państw mogły lepiej zatroszczyć się o dzieci, aby ci, którzy podejmują decyzje, zdawali sobie sprawę z tego, co jest dla dzieci ważne, na co powinni zwrócić uwagę w swojej działalności.

Eurochild planuje uruchomić sieć dla dzieci uczestniczących w takich spotkaniach na swojej stronie internetowej, za pomocą Facebooka i Twittera. Wszystkie dzieci mogą skontaktować się ze sobą. Musicie pamiętać, że wiele dzieci uczestniczących $\mathrm{w}$ tym projekcie nie ma dostępu do komputerów i nie będą mogły spotkać się w sieci.

\section{3. Podziękowanie dzieciom za udział w spotkaniu.}

Wręczenie pamiątkowych gadżetów. 


\section{ZALACZNIK 6}

\section{Scenariusz zogniskowanego wywiadu grupowego do badania problematyki przemocy wśród dzieci i młodzieży}

\section{WPROWADZENIE (poinformowanie o zasadach spotkania)}

(Ten etap badania służy wytworzeniu przyjaznej, swobodnej atmosfery, dq̨ży do rozluźnienia atmosfery, obniżenia lęku i wzbudzenia zaufania, poczucia bezpieczeństwa uczestników.)

Witam was bardzo serdecznie, dziękuję, że przyjechaliście na to spotkanie. Nazywam się jestem pracownikiem Instytutu Socjologii Uniwersytetu Łódzkiego. Przewidziany czas naszego spotkania to około 1,5 godziny. Chcę zapytać o sprawy, które bezpośrednio Was dotyczą, w których jesteście specjalistami, nikt poza Wami nie wie o nich więcej. Dlatego nie chcę rozmawiać z nauczycielami czy rodzicami. Jednocześnie zapewniam Was o całkowitej poufności tego spotkania i tajności uzyskanych informacji. O Waszym udziale $\mathrm{w}$ tym spotkaniu wiecie tylko Wy i Wasi rodzice, jeżeli jakieś informacje dostaną się do nauczycieli lub waszych kolegów to tylko te, które sami zechcecie przekazać. Cały jego przebieg zostanie zarejestrowany przez kamerę, żeby nic mi nie umknęło, ponieważ wszystkie Wasze wypowiedzi mają dla mnie ogromną wartość. Gwarantuję, że nikt - ani Wasi koledzy, ani nauczyciele, ani rodzice nie będą mieli dostępu do nagrania. Bezpośrednio po zakończeniu spotkania wszystko, co zostanie tu powiedziane, przepiszę bez rozróżniania, które z Was, co powiedziało i nagranie zostanie zniszczone.

Liczy się każda opinia i uwaga, dlatego proszę Was o szczerość i otwartość, a także uszanowanie prawa innych do głosu, umożliwienie każdemu swobodnej wypowiedzi. Nie obowiązuje tu zasada jednomyślności, każdy może mieć swoje zdanie. W razie wątpliwości proszę Was o zadawanie pytań zarówno mnie, jak i pozostałym uczestnikom.

Do Waszej dyspozycji są napoje i przekąski, zatem gorąco Was zachęcam, abyście nie krępowali się i częstowali nimi. Spędzimy ze sobą najbliższe 90 minut, więc może zanim przejdziemy do następnej części spotkania, poproszę Was jeszcze o krótkie przedstawienie się innym uczestnikom, wpiszcie, proszę, swoje imiona na wizytówkach, które leżą przed Wami. 


\section{Część zasadnicza}

\section{PYTANIE PROBLEMOWE I}

\section{Skąd czerpią wzory, standardy; kto ich wychowuje. Który typ oddzia-} ływania jest ważniejszy?

\section{Co to jest wychowywanie dziecka? Na czym polega?}

(Wypisać na planszy wymieniane czynności i zachowania, zadbać o zróżnicowanie ze względu na znaczenie w procesie wychowania, czyli zarówno zachowania codzienne, jak i o znaczeniu strategicznym, jak np. wybór szkoły, reakcja na śmierć kogoś w rodzinie.)

2. Kto to robi? Kto was próbuje wychowywać?

(Wypisać podmioty na planszy; dojść do wskazania rodziców/domu, szkoły, rówieśników, mediów, kościoła.)

3. Różne osoby, nazwijmy ich wychowawcami, odnoszą się do tych samych spraw, np. (Połączyć zachowania z podmiotami.)

4. Czyj wpływ jest decydujący?

- Do każdej historyjki zaprezentować na planszy wcześniej przygotowane alternatywy zachowania.

- Poza tym przygotować planszę z wypisanymi „w główce” pięcioma podmiotami-środowiskami wychowawczymi; wpisywać argumentację i wybory we właściwe kolumny.

\section{Winieta 1.}

Wojtek w tym roku kończy szkołę (dostosować poziom szkoły do grupy fokusowej). Ma do wyboru kilka możliwości.

- Koledzy - kilku najbliższych kolegów wybiera się do tej samej szkoły, namawiają go, aby złożył dokumenty razem z nimi, ale tam nie ma klasy sportowej, którą Wojtek jest zainteresowany.

- Rodzice - chcą, aby syn kontynuował naukę w szkole blisko domu, do której kiedyś chodził ojciec Wojtka.

- Nauczyciel - namawia na kontynuowanie nauki w klasie/szkole sportowej.

- Media - publikują informacje o szkołach, z których wynika, że szkoła, do której wybierają się koledzy, jest raczej słabo notowana.

- Ksiądz - pozostawia wolną rękę, namawia do wyboru szkoły zgodnie ze swoimi zainteresowaniami.

Co zrobi Wojtek? Jaką wybierze szkołę? Dlaczego? 
(Wypisać wszystkie argumenty na tablicy, w kolumnach właściwych dla konkretnego podmiotu.)

\section{Winieta 2.}

Impreza całonocna w ostatki; duża liczba gości, z różnych szkół (zmienić godziny dla starszych uczestników).

- Koledzy - większość z nich wybiera się.

- Rodzice - nie pozwalają zostać na noc, każą wrócić do godz. 22.00.

- Nauczyciel - właśnie kilka dni temu na godzinie wychowawczej przestrzegał przed chodzeniem wieczorami lub nocą po mieście.

- Media - zachęcają do organizowania imprez na zakończenie karnawału.

- Ksiądz - przestrzegał przed przypadkowymi znajomościami, nie pochwala organizowania takich imprez.

Co zrobi Wojtek? Pójdzie na tą imprezę, czy nie? O której wróci do domu? Dlaczego?

(Wypisać wszystkie argumenty na tablicy, w kolumnach właściwych dla konkretnego podmiotu.)

\section{Winieta 3.}

Komputer

- Koledzy - umawiają się, że wieczorem spotkają się on-line i wspólnie zagrają w grę internetową; zapraszają tez Wojtka.

- Rodzice - nie pozwalają spędzić mu tyle czasu przy komputerze.

- Nauczyciel - na zajęciach z informatyki wypytywał chłopców o postępy w grze internetowej.

- Media - pełne są zachęt do grania, publikują wyniki najlepszych graczy, opisują strategie gry.

- Ksiądz - krytycznie odnosi się do gier internetowych.

Co zrobi Wojtek? Zagra wieczorem przez kilka godzin, czy nie? Dlaczego?

(Wypisać wszystkie argumenty na tablicy, w kolumnach właściwych dla konkretnego podmiotu.)

\section{PYTANIE PROBLEMOWE II}

\section{Czy dostrzegają brak ojca $w$ procesie wychowania? Maternalizacja w domu, szkole, $w$ wychowaniu.}

1. Technika projekcyjna.

Rozdać kartki, po zadaniu pytania poprosić o napisanie odpowiedziskojarzenia na kartce (żeby nie „ściągali” z siebie nawzajem. Dalej rozmowa.) 
- Gdyby mama była zwierzęciem, jakim zwierzęciem by była? Dlaczego?

- Gdyby tata był zwierzęciem, jakim zwierzęciem by była? Dlaczego? (Uzasadnienie - dopytać szczegółowo.)

2. Pomyślcie proszę o rodzinach własnych i rodzinach swoich kolegów. (Rozdać kartki z dwoma kwadratami i położyć dwa kolory kredek/mazaków.) Na tych kartkach macie narysowany kwadrat. Wyobraźcie sobie, że w tym kwadracie mieszczą się wszystkie sprawy dotyczące was, waszego życia, czyli na przykład sprawa ocen w szkole, pory pójścia spać, ilości czasu spędzanej przed telewizorem lub komputerem, książki, które czytacie, organizacja komunii świętej, wybór szkoły, wyjścia do miasta, kino, uprawianie sportu, wyjazdów na wakacje, odwiedzania dziadków i masa innych.

2a.W jakiej części tych spraw uczestniczy matka, a w jakiej ojciec?

Zamalujcie tę część kwadratu, która pokazuje uczestnictwo matki kolorem zielonym, a tę część, która ilustruje uczestnictwo ojca, kolorem czerwonym. W czym uczestniczą ojcowie w życiu waszych rówieśników? W jakich zajęciach? O czym decydują?

Dlaczego?

To dużo czy mało? Wystarczy, czy nie?

2b. A jak chcielibyście, żeby było? Zamalujcie tę część kwadratu, która pokazuje, jak dużo powinno być matki kolorem zielonym, a tę część, która ilustruje uczestnictwo ojca, kolorem czerwonym.

\section{Kto i dlaczego jest autorytetem?}

1. Skojarzenia.

- Prośba, aby napisali na kartkach 3 skojarzenia ze słowem „autorytet”. (Dla starszych)

- Jakie zwierzę kojarzy się wam ze słowem autorytet? Dlaczego? (Dla młodszych)

2. Jakie cechy powinna mieć osoba, byście uznali ją za swój autorytet? (Wypisać cechy na planszy.)

3. Czy jest taka osoba (prawdziwa/fikcyjna) w waszym życiu? Kto to jest?

Czy jest ktoś, kto stanowi dla was wzór do naśladowania? Czy chcielibyście być do kogoś podobni? W jakich sprawach? Jakie cechy tej osoby sprawiają, że staracie się ja naśladować? 
4. Konfrontacja z liderem rówieśniczym - ile lider ma cech autorytetu, jakie? Dlaczego jest liderem?

(Ponumerować na planszy cechy autorytetu, a na kartkach majq wpisać numery tych cech, które posiada lider.)

\section{Agresor, napastnik, osoba, z którą kojarzy się zagrożenie}

Kto/co to jest agresor napastnik, osoba, z którą kojarzy się zagrożenie? Wzór/wyobrażenie (jakie?) Czy konkret-ktoś znany, kogo się w miarę możliwości unika, jaki ma zestaw cech?

\section{Dyskusja}

Prośba o wypełnienie testu „20 stwierdzeń — kim jestem?”

\section{CZĘŚĆ KOŃCZĄCA}

Podziękowanie za udział i wypowiedzi, wyjaśnienie wątpliwości, przekazanie upominków. 



\section{Bibliografia}

Adams K., Galanes G.J., 2008, Komunikacja w grupach, Warszawa: Wydawnictwo Naukowe PWN.

Agar M., MacDonald J., 1995, Focus groups and ethnography, „Human Organization" 54(1):78-86.

Agazzi E., 1997, Dobro, zło inauka. Etyczny wymiar działalności naukowotechnicznej, tłum. Kałuszyńska E., Warszawa: Oficyna Akademicka.

Akert R.M., Aronson E., Wilson T.D., 2004, Psychologia społeczna, Poznań: Wydawnictwo Zysk i S-ka.

Amsterdamski S., 1983, Między historiq a metodą. Spory o racjonalność nauki, Warszawa: PIW.

Angrosino M., 2010, Badania etnograficzne i obserwacyjne, Warszawa: Wydawnictwo Naukowe PWN.

Aronson E., 2002, Człowiek - istota społeczna, Warszawa: Wydawnictwo Naukowe PWN.

Augustyn, 1953, O wolnej woli, [w:] Pisma filozoficzne, t. 3., Dialogi Filozoficzne, Warszawa: PAX.

Axelrod M.D., 1976, The dynamics of the group interview, [w:] Advances in consumer research, Anderson B. (red.), t. 3., Cincinatti, $\mathrm{OH}$ : Association for Consumer Research, s. 437-441.

Babbie E., 2003, Badania społeczne w praktyce, Warszawa: Wydawnictwo Naukowe PWN.

Bales R.F., 1970, Personality and interpersonal behavior, New York: Holt, Rinehart and Winston.

Bauman Z, 2007, Szanse etyki w zglobalizowanym świecie, Kraków: Znak.

Bauman Z., 1994, Moralne obowiązki, etyczne zasady, „Etyka” 27. 
Bauman Z., 1994a, Moralność bez etyki, [w:] tenże, Dwa szkice z moralności ponowoczesnej, Warszawa: Instytut Kultury.

Belbin R.M., 2003, Twoja rola w zespole, Gdańsk: Gdańskie Wydawnictwo Psychologiczne.

Bergen K.J., 1973, The codification of research ethics. Views of doubting Thomas. „American Psychologists”, 10(28), za: Neyman-Mascarou E., Socjolog i maski, [w:] O społeczeństwie i teorii społecznej. Księga poświęcona pamięci Stanisława Ossowskiego, 1985, Warszawa: Wydawnictwo Naukowe PWN, s. 78-107.

Berger P.L., 1999, Zaproszenie do socjologii, Warszawa: Wydawnictwo Naukowe PWN.

Bertcher H.J., Maple F.F., 1996, Creating groups, t. 2., London - New Delhi: Sage Publications, Thousand Oaks,

Bieliński J., Iwańska K., Rosińska-Kordasiewicz A., 2007, Analiza danych jakościowych przy użyciu programów komputerowych, „ASK” 16:89-114.

Billson J.M., 1989, Review "Focus groups: a practical guide for applied research" (R.A. Krueger), „Clinical Sociology Review” 7:232-239.

Bloor M., Frankland J., Thomas M., Robson K., 2001, Focus groups in social research, London: Sage.

Bogardus E.S., 1926, Social distance in the city, „Proceedings and Publications of the American Sociological Society" 20:40-46.

Bono de E., 1997, Sześć kapeluszy, czyli sześć sposobów myślenia, Warszawa: Wydawnictwo Medium.

Brenner M., 1978, Interviewing: the social phenomenology of a research instrument, [w:] The social contexts of method, Brenner M., Marsch P., Brenner M. (red.), London: Croom Helm.

Brzezińska A.I., Toeplitz Z. (red.), 2007, Problemy etyczne w badaniach i interwencji psychologicznej wobec dzieci i młodzieży, Warszawa: Wydawnictwo Szkoły Wyższej Psychologii Społecznej „Academica”.

Bühler Ch., 1999, Bieg życia ludzkiego, Warszawa: Wydawnictwo Naukowe PWN.

Campbell D.T., 1958, Common fate, similarity, and other indices of the status of aggregates of persons as social entities, „Behavioral Science” 3:14-25. 
Caruso T.E., 1976, Moderators focus on groups: Session yields 7 hypotheses covering technology trend, professionalism, training techniques, reports, „Marketing News” 10(5).

Catterall M., Maclaran P., 1997, Focus group data and qualitative analysis programs: coding the moving picture as well as the snapshots, „Sociological Research Online", http:/www.socresonline.org.uk/socresonline/2/1/6.html.

Cawtrigh D., Zander A. (red.), 1968, Group dynamics: Research and theory, New York: Harper and Row.

Chmielecka E., 2008, Kilka uwag o etosie i kodeksach akademickich, [w:] Społeczna odpowiedzialność uczelni, Leja K. (red.), Gdańsk: Instytut Społeczeństwa Wiedzy.

Chomczyński P., 2006, Wybrane problemy etyczne w badaniach. Obserwacja uczestniczqca ukryta, „Qualitative Sociology Review” 1(2):68-87, http://hdl.handle.net/11089/1049.

Chrsitians C.G., 2009, Etyka i polityka w badaniach jakościowych, [w:] Denzin N., Lincoln Y., Metody badań jakościowych, t. 1., Warszawa: Wydawnictwo Naukowe PWN.

Cibor R., 2008, Wartości życiowe i ich bilans u osób starszych, „Chowanna”, nr 1.

Cottrell L.S., 1942, The adjustment of the individual to his age and sex roles „American Sociological Review” 7:617-620.

Cowgill D.O., 1974, The aging of populations and societies, „The Annals of the American Academy of Political and Social Science" 415(1):1-18.

Cumming E., Henry W.E., 1961, Growing older: the process of disengagement, New York: Basic Books.

Cunningham-Burley S., Kerr, A., 1999, Defining the "social": towards an understanding of scientific and medical discourses on the social aspects of the new genetics, „Sociology of Health and Illness” 21:647-668.

Daniłowicz P., 1992, Podręcznik socjologicznych badań ankietowych: ankieter $w$ procesie badawczym, Warszawa: IFiS PAN.

Daniłowicz P., 2004, Problemy akulturacji wywiadu zogniskowanego [w:] Zogniskowany wywiad grupowy. Studia nad metodq, Lisek-Michalska J., Daniłowicz P. (red.), Łódź: Wydawnictwo Uniwersytetu Łódzkiego. 
Davis J., Hill M., Tisdall K., Prout A. (red.), 2006, Children, young people and social inclusion: participation for what?, Bristol: The Policy Press University of Bristol.

Declaration of Helsinki, 2008, World Health Association, http://www.wma.net/ en/30publications/10policies/b3/index.html

Denzin N.K., 1970, The research act. A theoretical introduction to sociological methods, Chicago, za: Neyman-Mascarou E., Socjolog i maski, [w:] O społeczeństwie i teorii społecznej. Księga poświęcona pamięci Stanisława Ossowskiego, 1985, Warszawa: Wydawnictwo Naukowe PWN.

Denzin N.K., Lincoln Y.S., 1994, Handbook of qualitative research, CA: Sage.

Denzin N.K., Lincoln Y.S., 2009, Przyszłość badań jakościowych, [w:] Denzin N.K., Lincoln Y.S. (red.), Metody badań jakościowych, Warszawa: PWN.

Denzin N.K., Lincoln Y.S., 2010, (red.), Metody badań jakościowych, t. 2., Warszawa: Wydawnictwo Naukowe PWN.

Dobre obyczaje w nauce. Zbiór zasad i wytycznych, 2001, Warszawa: Polska Akademia Nauk Komitet Etyki w Nauce.

Doktór K., 1961, O stosowalności obserwacji uczestniczącej jako metody badań socjologicznych w przemyśle „Studia Socjologiczne” 2:76-90.

Doktór K., 1964, Przedsiębiorstwo przemysłowe. Studium Socjologiczne Zakładów Przemysłu Metalowego „Cegielski”, Warszawa: Książka i Wiedza.

Durkheim E., 1957, Professional ethics and civilc morals, London, za: Koralewicz-Zębik J., 1969, Socjologiczne aspekty etyki zawodowej: zarys problematyki, „Etyka” 4:151-164.

Edwards F., Edwards J., 2012, The experience of taking part in a national survey: A child's perspective - Freja Edwards, aged 10 years, „Research Ethics" (8):165-168.

Erikson E.H., Erikson J.M., 2012, Główne etapy rozwoju psychospołecznego [w:] Erikson E.H., Erikson J.M., Dopełniony cykl życia, Warszawa: Wydawnictwo Helion.

Esomar World Research Codes and Guidelines,

http://www.esomar.org/uploads/public/knowledge-andstandards/codes-and-guidelines/ESOMAR_Codes-and-

Guidelines_Interviewing-Children-and-Young-People.pdf. 
Fern E.F., 1982, The use of focus groups for idea generation: The effects of group size, acquaintanceship and moderator on response quantity and quality, „Journal of Marketing Research” 1(19):1-13.

Fine G.A., Sandstrom K.L., 1988, Knowing children: Participant observation with minors Newbury Park, CA: Sage Publications.

Folch-Lyon E., Trost J.F. 1981, Conducting focus group sessions. „Studies in Family Planning" 12(12):443-449.

Fombad Ch.M., 2005, Protecting children's rights in social science research in Bostwana: some ethical and legal dilemmas, „International Journal of Law, Policy and the Family" 19:102-120.

Fossel M., 1999, Jak przedłużyć nasze życie, czyli o mechanizmach starzenia się, Warszawa: Książka i Wiedza.

Frankfort-Nachmias Ch., Nachmias D., 2001, Metody badawcze w naukach społecznych, Poznań: Zysk i S-ka.

Frankland J., Bloor M., 1999, Some issues arising in the systematic analysis of focus group material, [w:] Developing focus group research: politics, theory and practice, Barbour R., Kitzinger J. (red.), London: Sage.

Frączek A., 1979, Czynności agresywne jako przedmiot studiów eksperymentalnej psychologii społecznej, [w:] Studia nad psychologicznymi mechanizmami czynności agresywnych, Frączek A. (red.), Wrocław.

Frey J.H., Fontana A., 1991, The group interview in social research, „The Social Science Journal" 28:175-187.

Galewicz W., 2007, Pomiędzy sumieniem i prawem — w obronie kodeksów etyki lekarsiej, [w:] Filozoficzne i prawne aspekty kodeksów etyki lekarskiej, „Diametros”, http://www.diametros.iphils.uj.edu.pl/?l=1\&p=cnf4\&m=44 $\& \mathrm{jh}=1 \& \mathrm{ih}=70$

Galewicz W., 2009, O etyce badań naukowych, „Diametros” 19:48-57.

Gałuszka M., 2007, „Siwiejąca populacja”: ekonomiczna, społeczna i etyczna waloryzacja starości, „Annales. Etyka w życiu gospodarczym” 2(10):83-93.

Garfinkel H., 1967, Studies in ethnomethodology, New Jersey: Prentice-Hall, za: Bloor M., Frankland J., Thomas M., Robson K., 2001, Focus groups in social research, London: Sage.

Garner J.D., 1999, Fundamentals of feminist gerontology, Routledge. 
Gibson F., 2007, Conducting focus groups with children and young people: strategies for success, „Journal of research in nursing" 5(12):473-483.

Giddens A., 2004, Socjologia ciała - zdrowie, choroba i starzenie się [w:] Giddens A., Socjologia, Warszawa.

Goldman A.E., 1962, The group depth interview, ,Journal of Marketing”, s. 61-68.

Gollin A.E., 1990, Foreword ix, [w:] Merton R.K., Fiske M., Kendall P.L., The focused interview: a manual of problems and procedures, New York: The Free Press.

Good W.J., Hatt P.K., 1952, Methods in social research, New York: McGrawHill, za: Neyman-Mascarou E., Socjolog i maski, [w:] O społeczeństwie i teorii społecznej. Księga poświęcona pamięci Stanisława Ossowskiego, 1985, Warszawa: Wydawnictwo Naukowe PWN.

Goode E., 2002, Sexual involement and social research in a fat civil rights organization, New York: Routledge, za: Fontana A., Frey J.H., Wywiad. Od naturalności do politycznego zaangażowania, [w:] Metody badań jakościowych, Denzin N.K., Lincoln Z.S. (red.), t. 2., 2009, Warszawa: Wydawnictwo Naukowe PWN.

Gopal M.H., 1970, An introduction to research procedure, za: NeymanMascarou E., Socjolog i maski, [w:] O społeczeństwie i teorii społecznej. Księga poświęcona pamięci Stanisława Ossowskiego, 1985, Warszawa: Wydawnictwo Naukowe PWN.

Gostkowski Z., 1957, Kształtowanie i badanie opinii publicznej w Stanach Zjednoczonych Ameryki Północnej, „Kultura i Społeczeństwo” 1(1):111-150.

Gostkowski Z., 1960, Opinia publiczna jako zjawisko społeczne, maszynopis.

Gostkowski Z., 1966, O założeniach i potrzebie empirycznych badań nad technikami i procedurami badawczymi w socjologii, [w:] Analizy i próby technik badawczych w socjologii, Gostkowski Z. (red.), Wrocław: Ossolineum.

Gostkowski Z.,1961, Z zagadnień socjologii wywiadu, „Studia Socjologiczne”, nr 2.

Gostkowski Z., 1992, Respondent jako „pehny człowiek” w badaniach surveyowych, [w:] Analizy i próby technik badawczych w socjologii, Gostkowski Z. (red.), t. IX, Problemy humanizacji procesu badawczego, Warszawa: IFiS PAN.

Greenbaum T.L., 1997, Using focus groups to add depth to your focus on quality, „The Quality Observer", http://www.groupsplus.com/pages/quality.htm. 
Greenbaum T.L., 1998, The handbook for focus group research, London New Delhi: Sage Publications.

Greenberg J., Pyszczyński T., Solomon S., Simon L., Breus M, 1994, Role of consciousness and accessibility of death-related thoughts in mortality salience effects, ,Journal of Personality and Social Psychology”, 4(67):627-663.

Greenstein T.N., 1980, A comment on Duster, Matza and Wellman: protection of human subject in field research, „The American Sociologist” 2(15):113, za: Neyman-Mascarou E., Socjolog i maski, [w:] O społeczeństwie i teorii społecznej. Księga poświęcona pamięci Stanisława Ossowskiego, 1985, Warszawa: Wydawnictwo Naukowe PWN.

Greig A., Taylor J., MacKay T., 2007, Doing research with children, London: Sage.

Griffin R., 1996, Podstawy zarzq̨dzania organizacjami, Warszawa: Wydawnictwo Naukowe PWN.

Grodin A., Glantz L.H. (red.), 1994, Children as research subjects: science, ethics and law, New York: Oxford University Press.

Grudniewicz A., 2001, Emerytów portret własny, Komunikat z badań CBOS nr 6/13/01.

Grzeszkiewicz-Radulska K., 2009, Respondenci niedostępni w badaniach sondażowych, Łódź: Wydawnictwo Uniwersytetu Łódzkiego.

Guidelines for conducting a focus group, 2005, Eliot \& Associates http://www.dsamh.utah.gov/spf/pdf/how_to_conduct_a_focus_group.pdf.

Guidelines for research with children and young people, 2011, National Children's Bureau, http://www.ncb.org.uk.

Gustaw G., Brocławik K., 2008, Homeopatia Witkowskiego, „Psychologia Społeczna" 3-4(9):329-335

Guston D.H., 2000, Retiring the social contract for science, „Issues in Science and Technology" 4(16).

Guston D.H., Keniston K., 1994, Introduction: The social contract for science, [w:] The fragile contract: University science and the Federal Government, Guston D.H., Keniston K. (red.), Cambridge: MIT Press.

Halicki J., Geragogika, [w:] Encyklopedia Pedagogiczna XXI wieku, t.2, Warszawa, 2003, s. 29-30.

Hare P., 1976, Handbook of small group research, New York: The Free Press. 
Havighurst R.J., Neugarten B.L., Tobin S.S., 1968, Disengagement and patterns of aging, s. 161-172, [w:] Middle age and ageing, Neugarten B.L. (red.), Chicago: University of Chicago Press.

Hayflick L., 1998, Jak i dlaczego się starzejemy, Warszawa: Książka i Wiedza.

Hess J.M., 1968, Group Interviewing, [w:] New science of planning, King R.L. (red.), Chicago: American Marketing Association.

Hock R.R., 2003, 40 prac badawczych, które zmieniły oblicze psychologii, Gdańsk: Gdańskie Wydawnictwo Psychologiczne.

Hoffman R., 1959, Homogeneity of member personality and its effect on group problem-solving, ,Journal of Abnormal and Social Psychology” 58:321-327.

Hoffman R., Maier N.R.F., 1961, Quality and acceptance of problem solutions by members of homogeneous and heterogenous groups, „Journal of Abnormal and Social Psychology" 2(62):401-407.

Hogg K.B., 2007, Lesser or just different? Capturing children's voices in consumer research, Lancaster: The Department of Marketing University Management School.

Homans G.C., 1950, The human group, New York: Harcourt, Brace and World, za: Malinowski H., Badanie dynamiki grupy w fokusie, [w:] Zogniskowany wywiad grupowy. Studia nad metoda, Lisek-Michalska J., Daniłowicz P. (red.), 2004, Łódź: Wydawnictwo Uniwersytetu Łódzkiego.

Hryciuk R., 2009, od córki do profesjonalistki. Obserwacja uczestnicząca w antropologii: dylematy, ograniczenia, zaskoczenia na przykładzie badań terenowych w mieście Meksyk,

http://www.pia.org.pl/sites/default/files/R_Hryciuk_SAID_Od_corki_do_ profesjonalistki_redakcja.pdf.

Humphreys R.A.L., 1970, Tearoom trade: impersonal sex in public places, London: Duckworth.

Hyman H.H., Cobb W.J., 1975, Interviewing in social research, za: NeymanMascarou E., 1985, Socjolog i maski, [w:] O społeczeństwie i teorii społecznej. Księga poświęcona pamięci Stanisława Ossowskiego, Warszawa: Wydawnictwo Naukowe PWN.

Ingham A.G., Levinger G., Graves J., Peckham V., 1974, The Ringelmann effect: Studies of group size and group performance, "Journal of Experimental Social Psychology" 10:371-384. 
Janis I., 1972, Victims of groupthink: a psychological study of foreign-policy decisions and fiascoes. Boston: Houghton Mifflin, za: Akert R.M., Aronson E., Wilson T.D., 2004, Psychologia społeczna, Poznań: Zysk i S-ka.

Jawłowska A., 1994, Życie i kodeksy, „Etyka” 27.

Jedynak S., 1990, Słownik etyczny, za: Olech M., Lazari-Pawłowska I., W obronie etyki zawodowej, „Słupskie Studia Filozoficzne” 5(2005).

Johnson A., 1996, It's good to talk: The focus group and the sociological imagination. „The Sociological Review” 44:517-538.

Johnson A.G., 1995, The Blackwell dictinary of sociology: A user's guide to social language, Cambridge: Blackwell, za: Malinowski H., 2004, Badanie dynamiki grupy $w$ fokusie, [w:] Zogniskowany wywiad grupowy. Studia nad metodq, Lisek-Michalska J., Daniłowicz P. (red.), Łódź: Wydawnictwo Uniwersytetu Łódzkiego.

Kahn R.L., Cannell Ch.F., 1957, The dynamics of interviewing, New York - London: Wiley, za: Neyman-Mascarou E., Socjolog imaski, [w:] O społeczeństwie i teorii społecznej. Księga poświęcona pamięci Stanisława Ossowskiego, 1985, Warszawa: Wydawnictwo Naukowe PWN.

Kahn R.L., Cannell Ch.F., Interviewing, [w:] The handbook of social psychology, Lindzey G., Aronson E. (red.), t. 2., Meulo Park - London: Reading, Mass, s. 536-538, za: Neyman-Mascarou E., Socjolog i maski, [w:] O społeczeństwie i teorii społecznej. Księga poświęcona pamięci Stanisława Ossowskiego, 1985, Warszawa: Wydawnictwo Naukowe PWN.

Kamiński M.M., 2006, Gry więzienne. Tragikomiczny świat polskiego więzienia, Warszawa: Oficyna Naukowa.

Kamiński M.M., 1990, Badacz w instytucji totalnej, „Kultura i Społeczeństwo" 1:247-250.

Kamiński M.M., 1993, Subkultura aresztów śledczych, „Studia Socjologiczne” 3-4:115-138.

Karwowski M., 2003, Twórcze przewodzenie, Warszawa: Wydawnictwo Instytutu Przedsiębiorczości i Samorządności.

Kaufman L., 1997, Enough talk, „Newsweek” 130:48-49, za: Kidd P.S., Parshall M.B., 2000, Getting the focus and the group: Enhancing analytical rigor in focus group research "Qualitative Health Research" 3(10):293-308. 
Kennedy C., Kools S., Krueger R., 2001, Methodological considerations in children's focus groups, „Nursing Research” 50(3):184-7.

Kiciński K., 1994, Etyka zawodowa a kodeks, „Etyka” 27, za: Staniszewska J., Kodeks zawodowy - konieczność czy absurd, [w:] Brzeziński J., TeplitzWiniewska M. (red.), 2000, Etyczne dylematy psychologii, Warszawa.

Kidd P.S., Parshall M.B., 2000, Getting the focus and the group: Enhancing analytical rigor in focus group research, ,"Qualitative Health Research”, 3(10):293-308.

Kingry M., Tiedje L., Friedman L., 1990, Focus groups: A research technique for nursing. „Nursing Research” 90:124-125.

Kistelski K., 1985, Rola ankietera w wywiadzie kwestionariuszowym, „Acta Universitas Lodziensis, Folia Sociologica" 11.

Kitzinger J., 1994, The methodology of focus groups: The importance of interaction between research participants. ,Sociology of Health and Illness” 16:103-121.

Kitzinger J., 1994a, Focus groups: method or madness?, [w:] Challenge and innovation: Methodological advances in social research on HIV/ AIDS, Boulton M. (red.), London: Falmer Press.

Kitzinger J., 1995, Qualitative research. Introducing focus groups, „British Medical Journal" 311(7000):299-302.

Kleszcz I., 2004, Wykorzystanie ukrytej obserwacji uczestniczacej w badaniu stylu życia szarej strefy , „Kultura i Społeczeństwo” 2(48):189-202.

Klich-Rączka A. i in., 2012, Zaburzenia funkcji poznawczych u osób w starszym wieku, [w:] Aspekty medyczne, psychologiczne, socjologiczne i ekonomiczne starzenia się ludzi w Polsce, Mossakowska M., Więcek A., Błędowski P. (red.), Poznań: Termedia.

Kodeks etyczno-zawodowy psychologa, 1992, Warszawa: Polskie Towarzystwo Psychologiczne.

Kodeks etyki pracownika naukowego, 2012, http://www.instytucja.pan.pl/images/stories/pliki/Komisja_ds_Etyki_Na uce/dokumenty/Kodeks_etyki_pracownika_naukowego_31.12._2012.pdf.

Kodeks Etyki Socjologa, 2012, http://www.pts.org.pl/public/upload/kodeks.pdf.

Kołodziej I., 1980, Czym grzeszy wywiad, „Studia Socjologiczne” 1:326-327.

Komunikat CBOS $n r$ 4037, 20.01.2009, http://badanie.cbos.p/details.asp?q $=\mathrm{a} 1 \& \mathrm{id}=4073$ 
Kondracka M., 2007, Praktyczny aspekt podmiotowego podejścia do dziecka w procesie edukacji przedszkolnej, Publikacja nr 3546, www.publikacje.edu.pl.

Konwencja ONZ o Prawach Dziecka http://www.unicef.org/magic/resources/CRC_polish_language_version.pdf.

Koralewicz-Zębik J., 1969, Socjologiczne aspekty etyki zawodowej: zarys problematyki, „Etyka” 4:151-164.

Kowalski M.W., 2005, Czy w badaniach jakościowych wybory metodologiczne sq problemem etycznym? "Człowiek i Społeczeństwo” 24:211-220.

Krimsky S., 2006, Zmieniający się etos nauki akademickiej, [w:] tenże, Nauka skorumpowana? O nieczystych zwiqzzach nauki i biznesu, Warszawa: PIW.

Król G., Król D., Wieczorkowska G., 2002, Rola interakcji w wyjaśnianiu percepcji grup, [w:] Jednostka i społeczeństwo. Podejście psychologiczne, Lewicka M. (red.), Gdańsk: Gdańskie Wydawnictwo Psychologiczne.

Krueger R.A., 1988, Focus groups: A practical guide for applied research, Newbury Park, CA: Sage.

Krueger R.A., 1997, Moderating focus groups (Focus Group Kit 4.), Thousand Oaks, CA: Sage Publications.

Krueger R.A., 1997a, Analyzing and reporting focus group results (Focus Group Kit 6.), Thousand Oaks, CA: Sage.

Krueger R.A., 1997b, Developing questions for focus groups (Focus Group Kit 3.), Thousand Oaks, CA: Sage.

Krueger R.A., Casey M.A., 2000, Focus groups. A practical guide for applied research, Thousand Oaks, CA: Sage Publications.

Krueger R.A., King J.A., 1997, Involving community members in focus groups, Thousand Oaks, CA: Sage.

Kubiak A., Przybyłowska I., Rostocki W.A., 1992, Społeczna przestrzeń wywiadu kwestionariuszowego, [w:] Analizy i próby technik badawczych $w$ socjologii, Gostkowski Z. (red.), t. IX, Problemy humanizacji procesu badawczego, Warszawa: IFiS PAN.

Lam P., Lee J., McNaught C., 2012, Comparing information from focus-group interviews with that obtained by surveys in an ESL environment, „The European Journal of Education and Educational Psychology" 1(1). 
Lansdown G., 1994, Children's rights, [w:] Children's childhood: Observed and experienced, Mayall B. (red.), London: The Falmer Press.

Lazari-Pawłowska I., 1969, Etyka zawodowa, „Etyka” 4:58-80.

Lazari-Pawłowska I., 1971, Etyki zawodowe jako role społeczne, [w:] Etyka zawodowa, Sarapata A. (red.), Warszawa.

Lazari-Pawłowska I., 1994, Etyka zawodowa bez kodeksu, „Etyka” 27.

Lekka-Kowalik A., 2008, Epistemiczna i społeczna odpowiedzialność nauki, [w:] taż, Odkrywanie aksjologicznego wymiaru nauki, Lublin: RWKUL.

Lekka-Kowalik A., 2011, Etyka badań naukowych: jej status metodologiczny i formy instytucjonalne, [w:] Podstawy naukoznawstwa. Skrypt dla studentów studiów licencjackich, Kawalec P., Lipski P., Wodzisz R. (red.), t. 1., Lublin: KUL.

Lemon B.W., Bengtson V.L., Peterson J.A., 1981, An exploration of the activity theory of aging: Activity types and life satisfaction among in-movers to a retirement community, [w:] Aging in America: Readings in socialgerontology, Kart C.S., Manard B.B. (red.), Palo Alto, CA: Mayfield.

Lenk H., 1995, Etyczne problemy eksperymentowania na ludziach, [w:] tenże, Filozofia pragmatycznego interpretacjonizmu, „Terminus”, $\mathrm{nr} 4$.

Leszczyńska-Rejchert A., 2009, Geragogika jako subdyscyplina pedagogiczna — założenia i formy realizacji, [w:] Edukacja wobec starości - tradycja i współczesność, Stopińska-Pająk A. (red.), „Chowanna” 2(33):225-233.

Lewis A., 1992, Group child interviews as a research tool, „British Educational Research Journal", nr 18.

Lindlof T.R., Taylor B.C., 2002, Qualitative communication research methods, Thousand Oaks, CA: Sage Publications.

Lisek-Michalska J., 2004, Fokus - sztuka czy metoda? [w:] Zogniskowany wywiad grupowy. Studia nad metoda, Lisek-Michalska J., Daniłowicz P. (red.), Łódź: Wydawnictwo Uniwersytetu Łódzkiego.

Lisek-Michalska J., 2007, Techniki dodatkowe w badaniach fokusowych na przykładzie badań nad korupcja, [w:] Zogniskowany wywiad grupowy. Studia nad metoda, Lisek-Michalska J., Daniłowicz P. (red.), 2007, Łódź: Wydawnictwo Uniwersytetu Łódzkiego. 
Lisek-Michalska J., 2008: Problemy kobiet wiejskich z punktu widzenia władz lokalnych i lokalnych instytucji [w:] Diagnoza sytuacji społecznozawodowej kobiet wiejskich w Polsce, Krzyszkowski J. (red.), Ministerstwo Pracy i Polityki Społecznej.

Lisek-Michalska J., 2010, Rodzicielstwo zastępcze — raport z badania fokusowego, maszynopis.

Lisek-Michalska J., 2010a, Przywództwo w grupach rówieśniczych na podstawie badań fokusowych [w:] Biuletyn Informacyjny Wiadomości Społeczne, Krzyszkowski J. (red.), Łódź: PTPS.

Lisek-Michalska J., 2011, Funkcjonowanie podmiotów ekonomii społecznej oraz uwarunkowania ich działalności. Badanie technikq FGI, maszynopis. Raport końcowy w ramach projektu: Diagnoza sytuacji sektora ekonomii społecznej w województwie łódzkim, kierownik: Jerzy Krzyszkowski.

Lisek-Michalska J., Lipiec M., Olczyk A., 2012, Ocena metodologicznej i praktycznej jakości fokusa - propozycja procedury, „Przegląd Socjologiczny" 1:201-228.

Lutyńska K., 1978, Ankieterzy i badacze. Z badań nad wpływem ankieterskim, „Przegląd Socjologiczny” 30:143-175.

Lutyńska K., 1993, „Wpływ” i „efekt” ankieterski. Ich źródła, [w:] taż, Surveye $w$ Polsce. Spojrzenie socjologiczno-antropologiczne (Wybrane zagadnienia), Warszawa: IFiS PAN.

Lutyńska K., 1997, Wpływ ankieterski w pierwszej fazie badań kwestionariuszowych, „ASK”, 1-2:53-73.

Lutyńska K., 1998, Strategie i postawy współczesnych ankieterów a reakcje i nowe obawy respondentów, „ASK” 7:17-37.

Lutyńska K., 1999, Ankieterzy, respondenci i osoby trzecie. Kulturowospołeczne uwarunkowania zachowań i postaw uczestników wywiadów kwestionariuszowych, [w:] Spojrzenie na metodę. Studia z metodologii badań społecznych, Domański H., Lutyńska K., Rostocki W.A. (red.), Warszawa: IFiS PAN, s. 32-47.

Lutyńska K., 2000, Bieda w rodzinie. Psychologiczny, społeczny i kulturowy kontekst wywiadów z przedstawicielami trzech pokoleń, [w:] Zrozumieć biednego. O dawnej i obecnej biedzie w Polsce, Tarkowska E. (red.), Warszawa: Typografika. 
Łukaszewski W., 2000, Złudzenia co do kodeksów etycznych, [w:] Etyczne dylematy psychologii, Brzeziński J., Toeplitz-Winiewska M. (red.), Warszawa: SWPS.

Maison D., 2001, Zogniskowane wywiady grupowe. Jakościowa metoda badań marketingowych, Warszawa: Wydawnictwo Naukowe PWN.

Maison D., 2011, Katalog PTBRiO 2010/2011, edycja XV.

Malinowski B., 2002, Dziennik w ścisłym znaczeniu tego słowa, Kraków: Wydawnictwo Literackie.

Malinowski H., 2004, Badanie dynamiki grupy w fokusie, [w:] Zogniskowany wywiad grupowy. Studia nad metoda, Lisek-Michalska J., Daniłowicz P. (red.), Łódź: Wydawnictwo Uniwersytetu Łódzkiego.

Manson N.C., O'Neill O., 2007, Rethinking informed consent in bioethics, Cambridge: Cambridge University Press.

Marczewski K., 2007, Po co i komu kodeksy etyki, których nikt nie czyta? [w:] Filozoficzne i prawne aspekty kodeksów etyki lekarskiej, Diametros, http://www.diametros.iphils.uj.edu.pl/?l=1\&p=cnf4\&m=44\&jh=1\&ih=87.

Mayall B., 2008, Conversations with children: Working with generational issues, [w:] Research with Children. Perspectives and practies, Christensen P., James A. (red.), London: Routledge.

Mays V.M., i in., 1992, The language of Black gay men's sexual behavior: Implications for AIDS risk reduction, „The Journal of Sex Research”, 3(29):425-434.

McGrath J.E., 1984, Groups: Interaction and performance. Newbury Park: Sage Publications Ltd., za: Malinowski H., 2004, Badanie dynamiki grupy w fokusie, [w:] Zogniskowany wywiad grupowy. Studia nad metoda, Lisek-Michalska J., Daniłowicz P. (red.), Łódź: Wydawnictwo Uniwersytetu Łódzkiego.

McKeganey N.P., 1995, Quantitative and qualitative research in the addictions: an unhelpful divide, „Addiction”, 90:749-751.

Medina J.J., 2001, Zegar życia. Dlaczego się starzejemy? Czy można cofnać czas?, Warszawa: Prószyński i S-ka.

Merton R.E., 1987, The focused interview and focus groups: Continuities and discontinuities, „The Public Opinion Quarterly” 4(51):550-566.

Merton R.E., 2002, Teoria socjologiczna i struktura społeczna, Warszawa: Państwowe Wydawnictwo Naukowe. 
Merton R.E., Fiske M., Kendall P., 1956, The focused interview, Illinois: The Free Press, za: Fern, 1982, The use of focus groups for idea generation: The effects of group size, acquaintanceship and moderator on response quantity and quality, , Journal of Marketing Research" 19:1-13.

Merton R.E., Fiske M., Kendall P., 1990, The focused interview: A manual of problems and procedures. Glencoe: The Free Press.

Michałowska E., Daniłowicz P., Szymczak M., 2008, Bezpieczeństwo dzieci w szkole i rodzinie $w$ Łodzi, Łódź: Łódzkie Towarzystwo Naukowe.

Miszewski K., 2007, Kiedy badacz jest tajnym agentem. O postrzeganiu niejawnej obserwacji uczestniczacej jako etycznie problematycznej, metodach badań ilościowych i jakościowych, zakulisowych wymiarach życia społecznego i ich związku ze wszystkim tym, oczym przed chwila, „Przegląd Socjologii Jakościowej” 2(3), http:// www.qualita tivesociologyreview.org/PL/Volume4/PSJ_3_2_Miszewski.pdf.

Moczydłowski P., 1988, Drugie życie w instytucji totalnej, Warszawa: IPSiR UW.

Moczydłowski P., 1989, O sposobach wglądu w sekrety stosunków międzyludzkich. Przypadek instytucji totalnych, [w:] Poza granicami socjologii ankietowej, Sułek A., Nowak K., Wyka A. (red.), Warszawa.

Mokrzycki E., 1988, Uwagi o sprawach dla socjologii polskiej egzystencjalnych, [w:] Stan i perspektywy socjologii polskiej, Kwilecki A., Doktór K. (red.), Warszawa - Poznań: Wydawnictwo Naukowe PWN.

Morgan D.L., 1988, Focus groups as qualitative research, Newbury Park, CA: Sage Publications.

Morgan D.L., 1993, Successful focus groups: Advancing the state of the art, Newbury Park, CA: Sage.

Morgan D.L., 1995, Why things (sometimes) go wrong in focus groups, „Qualitative Health Research", 5:516-522.

Morgan D.L., 1997, The focus group guidebook (Focus Group. Kit 1.), Thousand Oaks, CA: Sage.

Morgan D.L., 1997a, Planning focus groups (Focus Group. Kit 2.), Thousand Oaks, CA: Sage.

Morgan D.L., Krueger R.A., 1993, When to use focus groups and why, [w:] Successful focus groups: Advancing the state of the art, Morgan D.L. (red.), Newbury Park, CA: Sage. 
Morgan M., Gibbs S., Maxwell K., Britten N., 2002, Hearing children's voices: methodological issues in conducting focus groups with children aged 711 years, „Qualitative Research” 1(2):5-20.

Mossakowska M., Więcek A., Błędowski P. (red.), 2012, Aspekty medyczne, psychologiczne, socjologiczne i ekonomiczne starzenia się ludzi w Polsce, Poznań: Termedia.

Munday J., 2006, Identity in focus: The use of focus groups to study the construction of collective identity, „Sociology” 1(40):89-105.

Myers D.G., 2003, Psychologia społeczna, Poznań: Wydawnictwo Zysk i S-ka.

Nawrocki J., 1996, Tolerancja z ograniczeniami. Raport z badań jakościowych, [w:] Inny - Obcy - Wróg, Nowicka E., Nawrocki J. (red.), Warszawa: Oficyna Naukowa.

Neyman-Mascarou E., 1985, Socjolog i maski, [w:] O społeczeństwie i teorii społecznej. Księga poświęcona pamięci Stanisława Ossowskiego, Warszawa: Wydawnictwo Naukowe PWN.

Nęcka E., 1994, TROP - twórcze rozwiq̨zywanie problemów, Kraków: Oficyna Wydawnicza „Impuls”.

Nęcka E., Brocławik K., 1984, O możliwościach wykorzystania synektyki w procesie rozwiazywania zadań wynalazczych, [w:] Zadania, metoda, rozwiq̨zanie. Techniki twórczego myślenia, Góralski A. (red.), z. 5, Warszawa: WNT.

Niedbalski J., Ślęzak I., 2012, Analiza danych jakościowych przy użyciu programu NVivo a zastosowanie procedur metodologii teorii ugruntowanej, „Przegląd Socjologii Jakościowej” 1(7), http://www.qualitativesociologyreview.org/PL/Volume18/PSJ_8_1_ Niedbalski_Slezak.pdf.

Nikodemska-Wołownik A.M., 1999, Jakościowe badania marketingowe, Warszawa: Polskie Wydawnictwo Ekonomiczne.

Oakley A., 1981, Interviewing women: a contradiction in terms, za: Fontana A., Frey J.H., Wywiad. Od neutralności do politycznego zaangażowania, [w:] Metody badań jakościowych, Denzin N.K, Lincoln Y.S. (red.), 2009, Warszawa: Wydawnictwo Naukowe PWN.

Ograniczenia poznawcze. Starzenie się i psychopatologia, 2006, Engle R.W., Sędek G., Hecker von U., McIntosh D.N. (red.), Warszawa: Wydawnictwo Naukowe PWN. 
Osborn A., 1959, Applied imagination. NY: Scribner's.

Ossowska M., 1985, Normy moralne. Próba systematyzacji, Warszawa: Wydawnictwo Naukowe PWN.

Ossowski S., 1962, O osobliwościach nauk społecznych, Warszawa: Wydawnictwo Naukowe PWN.

Oyster C.K., 2002, Grupy, Poznań: Wydawnictwo Zysk i S-ka.

Pankowski K., 1999, Polacy o starości. Komunikat z badań CBOS nr 1/14, http://www.cbos.pl.

Patton M.Q., 1997, Utilization - focused evaluation: the new century text, London: Sage Publications.

Payne M.S., 1976, Preparing for group interview, [w:] Advances in consumer research, Anderson B.(red.), t. 3., Cincinatti, OH: Association for Consumer Research, s. 434-436.

Piechowiak M., 2003, Tomasza z Akwinu egzystencjalna koncepcja osoby i jej godności, „Poznańskie Studia Teologiczne” 14:219-242.

Problemy etyczne w badaniach i interwencji psychologicznej wobec dzieci i młodzieży, 2007, Brzezińska A.I., Toeplitz Z. (red.), Warszawa: Wydawnictwo Szkoły Wyższej Psychologii Społecznej „Academica”.

Prout A., James A. (red.), 1997, Constructing and reconstructing childhood: contemporary issues in the sociological study of childhood, London New York: Falmer Press.

Przyłuska-Fiszer A., 2007, Etyka zawodowa - pomiędzy moralnością a prawem, [w:] Filozoficzne i prawne aspekty kodeksów etyki lekarskiej, Diametros, http://www.diametros.iphils.uj.edu.pl/?l=1\&p=cnf4\&m=44\&jh=1\&ih=75.

Rembowski J., 1984, Psychologiczne problemy starzenia się człowieka, Warszawa: Wydawnictwo Naukowe PWN.

Resnik D.B., 2011, What is ethics in research and why is it important?, National Institutes of Health U.S. Department of Health and Human Services, http://www.niehs.nih.gov/research/resources/bioethics/whatis/.

Ringelmann M., 1913, Research on animate sources of power: The work of man, „Annales de l'Institut National Agronomique” 12:1-40, za: Forsyth, D.R., 2009, Group dynamics, Pacific Grove, CA: Brooks/Cole. 
Rosow I., 1985, Status and role change through the life cycle, [w:] Binstock R., Shanas E. (red.), Handbook of aging and the social scences, New York: Van Nostrand Reinhold.

Rostocki W.A., 1992, Bezradny respondent. Trudność pytań w wywiadzie kwestionariuszowym, Łódź: Instytut Socjologii Uniwersytetu Łódzkiego.

Rostocki W.A., 1992a, Kłamstwo obronne w ujęciu M. Ossowskiej a etyczne problemy wywiadu kwestionariuszowego w socjologii [w:] Gostkowski Z. (red.), Analizy i próby technik badawczych w socjologii, tom IX Problemy humanizacji procesu badawczego, Warszawa: PAN.

Rushkoff D., 2005, Get back in the box : innovation from the inside out, New York: Collins.

Saint-Germain M.A., Longman A.J., 1993, Breast cancer screening among older Hispanic women: knowledge, attitudes and practices. „Health Education Quarterly" 4(20):539-553.

Sampson P., 1972, Qualitative research and motivation research, [w:] Worcester R.M. (red.), Consumer Market Research Handbook, London — New York: McGraw-Hill.

Schaw M.E., 1981, Group dynamics: The psychology of small group behavior, za: Malinowski H., 2004, Badanie dynamiki grupy w fokusie, [w:] Zogniskowany wywiad grupowy. Studia nad metodq, Lisek-Michalska J., Daniłowicz P. (red.), 2004, Łódź: Wydawnictwo Uniwersytetu Łódzkiego.

Schindler R.M., 1992, The real lesson of new Coke: The value of focus groups for predicting the effects of social influence. "Marketing Research” $4(4): 22-27$.

Schütz A., Luckmann T., 1974, Structure of the Life - World., za: Bloor M., Frankland J., Thomas M., Robson K., 2001, Focus groups in social research, Sage.

Schwandt T., 1997, Qualitative inquiry: A dictionary of terms, Thousand Oaks, CA: Sage, za: Fontana A., Frey J.H., Wywiad. Od naturalności do politycznego zaangażowania. [w:] Metody badań jakościowych, Denzin N.K., Lincoln Z.S. (red.), 2009, t. 2., Warszawa: PWN.

Sękowska M., 2000, Neopsychoanalityczna koncepcja rozwoju psychospołecznego Erika H. Eriksona, [w:] Duchowy rozwój człowieka, Socha P. (red.), Kraków: Wydawnictwo Uniwersytetu Jagiellońskiego. 
Shamoo A., Resnik D., 2009, Responsible Conduct of Research, New York: Oxford University Press.

Shaw C., Brady L.M., Davey C., 2011, Guidelines of research NCB, NCB Research Centre, http://www.nfer.ac.uk/nfer/schools/developingyoung-researchers/NCBguidelines.pdf.

Shaw M.E, 1981, Group dynamics: the psychology of small group behavior, New York: McGraw-Hill Book Company.

Sherif M., Sherif C.W., 1956, An outline of social psychology. New York: Harper \& Row.

Shils E.A., 1956, The torment of secrecy, the background and consequences of American security policies, Melbourne: Heinemann.

Silverman G., 2012, Marketing strategy secrets, http://mnav.com/focusgroup-center/cligd-htm/.

Singer E., 1978, Informed consent: Consequences for response rate and response quality in social surveys, „American Sociological Review” 43:144-162.

Skarga B., 1994, Usankcjonowanie niecnoty, „Etyka” 27:169-170.

Skawiński Z., Sztabiński P., Sztabiński F., 2000, Podręcznik ankietera, Warszawa: IFiS PAN.

Staniszewska J., 2000, Kodeks zawodowy - konieczność czy absurd?, [w:] Etyczne dylematy psychologii, Brzeziński J., Toeplitz-Winiewska M. (red.), Warszawa: SWPS.

Statement of ethical practice, 2002, British Sociological Association, http://www.britsoc.co.uk.

Stefanowska M., 1988, Odbiorcy kultury. Deklaracje i rzeczywistość, Warszawa: PWN.

Stewart D.W., Shamdasani P.N., 1990, Focus groups: theory and practice, Newbury Park, CA: Sage.

Stewart D.W., Shamdasani P.N., Rook D.W., 2007, Focus groups: Theory and practice, Thousand Oaks, CA: Sage.

Stoner J., 1961, A comparison of individual and group decisions involving risk, submitted to the school of industrial management, http://dspace. mit.edu/bitstream/handle/1721.1/11330/33120544.pdf. 
Straś-Romanowska M., 2007, Późna dorosłość. Wiek starzenia się, [w:] Psychologia rozwoju człowieka, Harwas-Napierała B., Trempała J. (red.), t. 2., Charakterystyka okresów życia człowieka, Warszawa: PWN.

Straw R.B., Marks K., 1995, Use of focus groups in program development, "Qualitative Health Research" 5:428-443.

Straw R.B., Smith M.W., 1995, Potential uses of focus groups in federal policy and evaluation studies, „Qualitative Health Research” 5:421-427.

Strelau J., 2000, Starzenie się, umieranie, koniec drogi życiowej. [w:] Psychologia: podręcznik akademicki, tenże (red.), Gdańsk: Gdańskie Wydawnictwo Psychologiczne.

Stuart-Hamilton I., 2006, Czym jest starzenie się, [w:] tenże, Psychologia starzenia się, Poznań: Zysk i S-ka.

Styczeń T., 1998, Czy istnieje etyka dla naukowca?, „Ethos” 4(44):75-83.

Supińska J., 2003, Zogniskowane wywiady grupowe z imigrantami, „Raporty Migracyjne", nr 2, www.ips.uw.edu.pl/doc_download/5-raportm2.html

Susułowska M., 1989, Starzenie się a osobowość, [w:] taż, Psychologia starzenia się i starości, Warszawa: PWN.

Szmatka J., 1989, Małe struktury społeczne. Wstęp do mikrosocjologii strukturalnej, Warszawa: Wydawnictwo Naukowe PWN.

Sztompka P., 2006, Socjologia. Analiza społeczeństwa, Kraków: Wydawnictwo Znak.

Szukalski P., 2006, Populacja osób bardzo starych w społeczeństwie polskim - stan obecny i perspektywy, [w:] Ludzie starzy w polskim społeczeństwie w pierwszych dekadach XXI wieku, Kowalski J. (red.), Łódź: Wydawnictwo Uniwersytetu Łódzkiego.

Szukalski P., Kowaleski J.T., 2008, Starzenie się ludności Polski - między demografią a gerontologia społeczna, Łódź: Wydawnictwo Uniwersytetu Łódzkiego.

Szymańska M., 2007, Życie ludzkie w świetle norm deontologicznych, [w:] Filozoficzne i prawne aspekty kodeksów etyki lekarskiej, „Diametros”, http://www.diametros.iphils.uj.edu.pl/?l=1\&p=cnf4\&m=44\&jh=1\&ih=86. 
Środa M., 1994, Argumenty za i przeciw etyce zawodowej, „Etyka” 7, za: Staniszewska J., Kodeks zawodowy - konieczność czy absurd?, [w:] Etyczne dylematy psychologii, Brzeziński J., Toeplitz-Winiewska M. (red.), 2000, Warszawa: SWPS.

Tarkowska E. (red.), 2000, Zrozumieć biednego. O dawnej i obecnej biedzie $w$ Polsce, Warszawa: Typografika.

Tarkowska E. i in., 1994, Życie codzienne w domach pomocy społecznej, Warszawa: Instytut Filozofii i Socjologii PAN.

Templeton J.F., 1987, Focus groups: A guide for marketing and advertising professionals. Chicago: Probus.

Thomas N., O'Kane C., 1998, The ethics of participatory research with children, „Children and Society” 12:336-348.

Trouble at the top special - People v Coke, 2003, North Sydney: BBC Education and Training, film dokumentalny.

UCL Research Ethics Committee, Research Involving Children, http://ethics. grad.ucl.ac.uk/forms/guidance1.pdf.

Waksler F.Ch. (red.), 1991, Studying the social worlds of children. Sociological readings, Children in an adult world, London: Falmer Press.

Wallach M.A., Kogan N., Bern, D.J., 1962, Group influence on individual risk taking. "Journal of Abnormal and Social Psychology”, 65:75-86. Przedruk: Group dynamics. Research and theory, 1968, Cartwrigh D., Zander A. (red.), London: Tavisstock Publication.

Ward V.M., Bertrand J.T., Brown L.F.,1991, The comparability of focus group and survey results: three case studies, „Evaluation Review” 2(15):266-283.

Warwick D.P., 1982, Types of harm in social research. [w:] Ethical issues in social science research, Beauchamp T.L., Faden R.R., Wallace Jr. R.J., Walters L. (red.), Baltimore: Johns Hopkins University Press.

Wciórka B., 2000, Polacy wobec ludzi starych i własnej starości. Komunikat z badań CBOS nr 172/2000.

Wells W.D., 1974, Group interviewing, [w:] Handbook of marketing research, Ferber R. (red.), New York: McGraw-Hill Book Co.

Wiles R., Heath S., Crow G., Charles V., 2005, Informed consent in social research: A literature review, http://www.socresonline.org.uk/12/2/wiles.html. 
Wilk K.M., 2001, Komputerowe wspomaganie jakościowej analizy danych, „ASK”, nr 10.

Williams M., 2003, Making sense of social research, Thousand Oaks, London - New Delhi: Sage Publications.

Wolff B., Knodel J., Sittitrai W., 1993, Focus groups and surveys as complementary research methods: a case example, [w:] Successful focus groups: advancing the state of the art, Morgan D.L. (red.), Newbury Park, CA: Sage, s. 119-136.

Woodhead M., Faulkner D., 2008, Subjects, objects or participants? Dilemmas of psychological research with children, [w:] Research with children. Perspectives and practices, Christensen P., James A. (red.), London: Routledge.

Wosińska M., 2010, Przypadek złotego zęba, [w:] Kaniowska K., Etyczne problemy badań antropologicznych, Łódź.

Wunderli J., 1977, Medizin in Widerspruch, za: Lenk H., 1995, Etyczne problemy eksperymentowania na ludziach, [w:] Filozofia pragmatycznego interpretacjonizmu, „Terminus”, nr 4, Warszawa: Oficyna Naukowa.

Wynne B., 1996, May the sheep safely graze? A reflexive view of the expert-lay knowledge divide, [w:] Risk, environment and modernity: towards a new ecology, Lash S., Szerszynski B., Wynne B. (red.), London: Sage.

Zarębska-Piotrowska D., 1999, Psychomanipulacja - Grupy psychomanipulacyjne. Przyczyny - Mechanizmy - Skutki. Wybrane zagadnienia, Ekspertyza opracowana na zlecenie Biura Studiów i Ekspertyz Kancelarii Sejmu, Kraków.

Zimbardo P., 2008, Efekt Lucyfera. Dlaczego dobrzy ludzie czyniq zło?, Warszawa: PWN.

Zybertowicz A., 1995, Przemoc i poznanie, Toruń: Wydawnictwo UMK. 


\section{SPIS TREŚCI}

WSTȨP

\section{ROZDZIAE 1}

ZOGNISKOWANY WYWIAD GRUPOWY - CHARAKTERYSTYKA METODY

WPROWADZENIE 13

FOKUS - GENEZA 14

FOKUS — DEFINICJA I RODZAJE ______ 16

Dobór uczestników ____________________________ 21

Grupa fokusowa ___________________________ 23

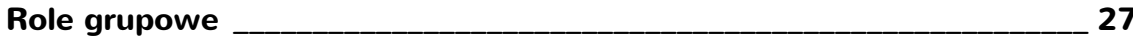

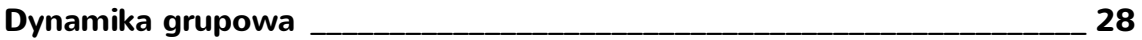

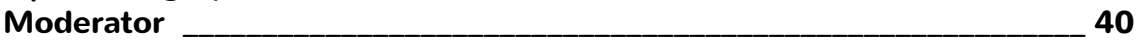

Sesja — organizacja ______ 43

Sesja — przebieg _______________________________ 44

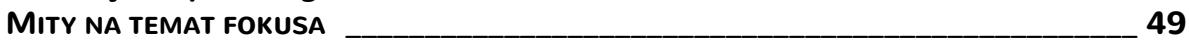

WADY I ZALETY BADAŃ FOKUSOWYCH ___________________________________ 53

FGI A SURVEYE _________________________________ 55

FOKUS A WYWIAD INDYWIDUALNY __________________________ 64

PODSUMOWANIE ___________________________________________

Rozdziat 2

ETYKA W NAUCE I BADANIACH SPOLECZNYCH

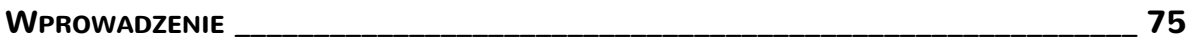

KODEKSY ZAWODOWE — ZA I PRZECIW ___

ETOS NAUKI — ETYKA BADAŃ NAUKOWYCH _________________________ 85

ETYKA W BADANIACH SPOLECZNYCH ___ 98

Problemy etyczne W technikach badawCzych ____________ 105

PodsumoWanie _____________________________ 109

\section{ROZDZIAE 3}

ETYKA BADAŃ FOKUSOWYCH W KONTEKŚCIE ELEMENTÓW METODY BADAWCZEJ WPROWADZENIE

Problemy Wy Wikajace Z elementów Procedury ______ 114

Lokalizacja badania

Rejestracja przebiegu sesji

Informacje przekazywane badanym $w$ fazie rekrutacji

a ich wyobrażenia o przebiegu sesji

Świadoma zgoda na udział w badaniu 
Rejestracja i podgląd przebiegu sesji

Obecność innych uczestników badania

Czas trwania sesji

Tematyka badania (drażliwość, trudność, kontrowersyjność)

Treść wypowiedzi uczestników: możliwość modyfikacji opinii

innych uczestników, konsekwencje dla samooceny badanych

Charakter narzędzia (SCEnARIUSZ MOderatora) - rodzaJ PYTAŃ I Zadañ STAWIANYCH UCZESTNIKOM, TECHNIKI PROJEKCYJNE

RELACJE MIȨDZY UCZESTNIKAMI

I POMIȨDZY UCZESTNIKAMI A MODERATOREM

Porównanie pod kątem zagadnień etycznych kontaktu

ankieter - respondent w wywiadzie kwestionariuszowym

i uczestnicy - moderator $w$ fokusie

Problemy etyczne zWiazane Z rola moderatora _____________ 167

Problemy etyczne realizatora badań ___ 170

Selekcja/rekrutacja uczestników sesji ___ 170

Relacja moderator — badacz, moderator — zleceniodawca ____ 176

KONSEKWENCJE DLA OBIEKTU BADANIA ___ 179

ETYKA FOKUSOWA W PRAKTYCE BADAWCZEJ ___

PODSUMOWANIE ___________________________________ 189

RozDZIAt 4

ETYCZNE ASPEKTY BADAŃ FOKUSOWYCH Z UDZIALEM DZIECI I MtODZIEŻY

WPROWADZENIE

KODEKSY ETYCZNE

ŚWIADOMA ZGODA

201

POUFNOŚĆ 204

DYLEMATY ETYCZNE W BADANIACH Z UDZIALEM DZIECI 205

Przyczyny zagrożeń O CHARAKTERZe etyCZNYM W BADANIACH

$Z$ UDZIALEM DZIECI

ROZWIAZYWANIE W PRAKTYCE BADAWCZEJ PROBLEMÓW ETYCZNYCH W BADANIACH

FOKUSOWYCH Z UDZIALEM DZIECI

Podsumowanie

RozDZIAt 5

ZASTOSOWANIE METODY FGI DO ROZWOJU METODOLOGII BADAŃ OSÓB STARSZYCH

WPROWADZENIE

CeChy WIEKU PODESZtego W KONTEKŚCie

METOD BADAŃ SPOLECZNYCH

BADANIE PERCEPCJI TECHNIK OTRZYMYWANIA MATERIALU — PRZYCZYNEK DO BADANIA

METODOLOGII I ETYKI BADAŃ SPOLECZNYCH Z UDZIALEM SILVER GENERATION

Podsumowanie 
ANEKS

ZALACZNIK 1

David B. Resnik, Kalendarium wydarzeń (od 1931 r. do teraz) 247

ZAtACZNIK 2

Badanie uczestników sesji fokusowych metodą

wywiadów swobodnych. Dyspozycje do wywiadu

ZAtACZNIK 3

Formularz zgody rodzica/opiekuna prawnego

ZAtACZNIK 4

Formularz zgody dziecka

ZAtACZNIK 5

Projekt Speak Up! Scenariusz FGI

ZALACZNIK 6

Scenariusz zogniskowanego wywiadu grupowego

do badania problematyki przemocy wśród dzieci i młodzieży 285

Bibliografia 